\title{
Radial Leste, Brás e Mooca: diretrizes para requalificação urbana
}

Maria Elizabet Paez Rodriguez

FAU $\bullet U S P$

São Paulo 2006 



\section{Radial Leste, Brás e Mooca: diretrizes para requalificação urbana}

Maria Elizabet Paez Rodriguez

Dissertação de Mestrado

Planejamento Urbano e Regional

$$
\text { FAU } \bullet U S P
$$

Orientadora: Prof ${ }^{a}$ Dra Marly Namur

São Paulo• 2006 
É proibida a reprodução total ou parcial sem autorização por escrito da autora.

Projeto gráfico:

Maria Elizabet Paez Rodriguez

Caroline Gabriel Pedro

Produção gráfica:

Caroline Gabriel Pedro

Tratamento de imagens:

Lenita Pimentel

Caroline Gabriel Pedro

Gustavo Yuji Honda

Computação gráfica:

Lenita Pimentel

Gustavo Yuji Honda

Revisão:

Sarah Garcia Rodriguez

Caroline Gabriel Pedro 
Para Raphael e Isabel 



\title{
Agradecimentos
}

\author{
À Professora Marly Namur \\ e a todos os dedicados professores da Pós Graduação da \\ Faculdade de Arquitetura e Urbanismo da Universidade de São Paulo \\ por dividirem conosco o seu precioso conhecimento \\ Aos caros Professores Adilson Macedo e Cândido Malta Campos Filho \\ pelas valiosas sugestões durante a fase final do trabalho \\ Ao Luisão, \\ primeiro e incansável voluntário, sob chuva ou sol \\ À Caroline, Lenita, Gustavo e Aninha \\ pelo coleguismo e pelo esmero e qualidade aplicados neste trabalho \\ À Sarah \\ pela atenta revisão final \\ À Íris \\ pela grata ajuda-surpresa
}

Aos funcionários da CDHU, da Prefeitura Municipal de São Paulo, das Subprefeituras Sé e Mooca, Secretaria da Saúde, do IBGE, ao Adriano e Wayne do Primeiro Cartório de Registro de Imóveis de São Paulo, ao Marcos do Quinto Cartório de Registro de Imóveis de São Paulo e a tantos outros pela pronta e simpática ajuda

Aos funcionários da secretaria, da biblioteca e de apoio da Pós-Graduação da FAU por toda atenção que me dedicaram durante todos os anos que com eles convivi

À minha família e aos amigos por esperarem pacientemente por mim. 



\section{Resumo}

Esta dissertação trata da problemática que envolve a requalificação urbana de áreas centrais consolidadas e industrializadas em processo de degradação urbana e ambiental que perderam parte de sua população residente, mas que dispõem de infra-estrutura urbana básica instalada suficiente para suportar readensamento populacional controlado na reorganização da cidade. A requalificação urbana dessas áreas, aliada à sua localização estratégica próxima aos centros históricos ou novos das grandes metrópoles completos por sua diversidade de oferta de comércio, serviços, cultura e lazer, são um trunfo para o planejamento urbano na solução de problemas causados pelo constante deslocamento das populações entre seu local de moradia, local de trabalho, consumo, educação, cultura, esporte e lazer. Esta dissertação partiu da análise histórica do desenvolvimento urbano de dois bairros centrais e industrializados: os bairros históricos Brás e Mooca, localizados na metrópole de São Paulo, passando pela análise do tecido urbano, por um diagnóstico geral e finalizando com a proposição de um conjunto de diretrizes gerais e pontuais para a requalificação urbana da área-objeto de estudo.

Palavras-chave: desenvolvimento urbano, tecido urbano, requalificação urbana. 



\begin{abstract}
The following dissertation discusses the problems involved in the urban requalification of consolidated and industrial central areas under urban and environmental degradation processes - also known as brownfields. It outlines areas that have lost part of their original inhabitants, but which still possess the basic installed infrastructure necessary to endure controlled repopulation upon city reorganization. The urban requalification of these areas, together with their strategic placing within the city - near historical and newly formed centers, which are made complete by the wide diversity of commerce, services, culture and entertainment constitutes a great advantage in the context of urban planning and problem solving regarding commuters and other shopping, education, culture, sport and leisure journeys. This paper begins with the historical analysis of the urban development of two central and industrialized neighborhoods - the historical neighborhoods of Brás and Mooca, located at the city of São Paulo - going through the analysis of the urban network via a general diagnosis, and summing up with the proposition of a set of general directives, both general and specific, for the urban requalification of the area under study.
\end{abstract}

Keywords: urban development, urban tissue, urban requalification 



\section{Resumen}

Esta disertación trata de la problemática que envuelve la recalificación urbana de áreas centrales consolidadas y industrializadas en proceso de degradación urbana y ambiental, que perdieron parte de su población residente pero que disponen de infraestructura urbana básica instalada suficiente para soportar un incremento en el número de habitantes de forma controlada en la reorganización de la ciudad. La recalificación urbana de esas áreas, aliada a su ubicación estratégica próxima a los centros históricos o nuevos de las grandes metrópolis, completos por su diversidad de oferta de comercio, servicios, cultura y entretenimiento, son una solución para la planificación urbana en la solución de problemas causados por la constante dislocación de las poblaciones entre su local de morada, local de trabajo, consumo, educación, cultura, deporte y entretenimiento. Esta disertación partió de la análisis histórica del desarrollo urbano de dos barrios centrales y industrializados: los barrios históricos Brás y Mooca, ubicados en la metrópoli de São Paulo, pasando por el análisis del tejido urbano, por un diagnóstico general y finalizando con la proposición de un conjunto de directrices generales y puntuales para la recalificación urbana de esta área-objeto de estudio.

Palavras-clave: desarrollo urbano, tejido urbano, recalificación urbana 



\section{Índice}

$\begin{array}{rr}\text { Introdução } & \text { । } \\ \text { Problemática } & 2 \\ \text { Área-objeto do estudo } & 5 \\ \text { Objetivos } & 6 \\ \text { Hipóteses } & 6 \\ \text { Metodologia } & 9 \\ \text { Terminologias para projetos de requalificação urbana } & 11\end{array}$

Capítulo I: referencial teórico

- 12

I. A industrialização no Brasil

2. A produção do espaço urbano $\quad 14$

2.1. As formas de produção do espaço urbano 15

3. Breve histórico do planejamento urbano em São Paulo $\quad 19$

4. Metodologia para análise do Tecido Urbano 21

4.I. As tipologias do tecido urbano 22

Capítulo Il: a evolução urbana do Brás e Mooca • 24

I. Breve histórico do crescimento urbano de São Paulo: do século 17 ao início do século 20

2. Brás e Mooca na formação da cidade de São Paulo

2.I Das Chácaras ao fim do século 19

2.2 Do fim do século 19 ao início do século 21

2.3 Evolução populacional no Brás e Mooca 49

2.4 Indicadores sociais no Brás e Mooca 51

3. As formas de produção do espaço no Brás e Mooca 52

3.I A produção capitalista do espaço urbano no Brás e Mooca 61

3.2 A produção estatal do espaço urbano na Mooca e Brás 63

4. A legislação urbana no Brás e Mooca 66

5. A estruturação viária no Brás e Mooca $\quad 70$

5.I As ferrovias Santos-Jundiaí e Estrada de Ferro Central do Brasil 70

5.2 A Avenida Radial Leste e as outras vias estruturadoras $\quad 72$

5.3 A Linha Leste do Metrô de São Paulo 75

5.4 O Expresso Tiradentes: VLP - Veículo Leve sobre Pneus 76

5.5 Os fluxos de pedestres e veículos $\quad 77$

5.6 Transporte público $\quad 79$

6. Equipamentos urbanos públicos e áreas verdes 81

6.1 Unidades de ensino público 81

6.2 Saúde pública 83

6.3 Referências culturais 83

6.4 Áreas verdes 83 
Capítulo III: o tecido urbano do Brás e Mooca

I. Delimitação da área-objeto de estudo 84

2. Categorias de uso e ocupação do solo no Brás e Mooca 88

2.1. Análise dos usos do solo no Brás e Mooca 89

3. A morfologia urbana 93

3. I. A topografia 93

3.2. O traçado viário 93

3.3. Os vazios urbanos 101

3.4. Os marcos referenciais e o Patrimônio Histórico $\quad 103$

4. As tipologias arquitetônicas predominantes $\quad 105$

4. I. As vilas operárias $\quad 106$

4.2. Os galpões industriais $\quad 107$

4.3. As estações Brás e Bresser da Linha Leste do Metrô $\quad 107$

5. Conclusão do Capítulo III 109

Capítulo IV: diagnóstico • I | 4

I. Aspectos urbanos positivos $\quad 114$

2. Aspectos urbanos negativos $\quad 115$

3. A estruturação viária fragmentadora do espaço $\quad 118$

4. Educação e saúde pública 121

5. Áreas verdes, praças e espaços para lazer $\quad 125$

6. Qualidade ambiental e urbana no Brás e Mooca 126

6.I Início da degradação urbana $\quad 128$

6.2 O perfil sócio-ambiental $\quad 132$

7. Recuperação e tombamento de imóveis $\quad 133$

Capítulo V: experiências em requalificação urbana ocorridas pelo mundo $\quad 135$

I. Battery Park City - Nova lorque 136

2. London Docklands 137

3. Vila Olímpica de Barcelona $\quad 143$

4. Bairro do Chiado, Lisboa $\quad 145$

5. Antíguo Puerto Madero, Buenos Aires $\quad 146$

6. Análise comparativa do estudo de experiências ocorridas
em relação à área-objeto deste estudo $\quad 150$

Capítulo VI: Subprefeituras Sé e Mooca: análise comparativa dos Planos Regionais

152

I. Situação político-administrativa da área-objeto de estudo

2. Análise comparativa dos Planos Diretores Regionais das Subprefeituras Mooca e Sé: diretrizes e propostas 2.1. Propostas e solicitações das comunidades

2.2. Uso e ocupação do solo 2.3. Habitação

3. As Operações Urbanas no Brás e Mooca 
Capítulo VII: Radial Leste, Brás e Mooca: diretrizes para a requalificação urbana

I. Diretrizes gerais para a requalificação urbana do Brás e Mooca $\quad 165$

2. Uso e ocupação do solo $\quad 166$

2.I. Uso residencial $\quad 166$

2.2. Uso comercial e uso serviços $\quad 170$

2.3. Uso institucional $\quad 171$

2.4. Uso misto $\quad 178$

2.5. Uso industrial $\quad 178$

3. Reestruturação Viária no Brás e Mooca $\quad 178$

3. I. Transporte público $\quad 179$

3.2. Vias estruturais $\quad 180$

4. Qualidade ambiental |81

5. O patrimônio histórico do Brás e Mooca | 181

6. Conclusão 182

Bibliografia • 187

Referências da legislação consultada $\quad 190$

Órgãos para pesquisa de dados oficiais |91

Referências cartográficas 192

Anexo I: glossário • 197

Anexo 2: compilação dos Planos Regionais Estratégicos

das Subprefeituras Mooca e Sé • 201 



\section{Introdução}

A leitura básica da metrópole de São Paulo, através da ótica urbanista, mostra uma grande mancha urbana por demais espraiada, com populações de baixa renda alijadas de serviços de qualidade e fadadas a perder horas de trabalho ou "não trabalho", a caminho dos destinos de trabalho, estudo ou consumo. Por outro lado, têm-se áreas centrais esvaziadas de seus habitantes ao longo do tempo. O espraiamento ou horizontalização do munícipio de São Paulo teve seu auge na década de 1960 quando se iniciou o deslocamento de populações de baixa renda para áreas mais longínquas em busca de aluguéis mais baixos ou para ocupação de áreas loteadas muitas vezes clandestinamente, o que perdurou até a década de 1990. Em I97I, quando São Paulo já alcançara seis milhões de habitantes aproximadamente, Langenbuch atribuiu o termo "macrópole" à cidade, resultado de um "processo de crescimento caótico e com vários milhões de habitantes e de tamanho além do ideal” (|97|, p.0 I).

Atualmente, impulsionadas pelo surgimento do Estatuto da Cidade ${ }^{2}$, instrumento sob a forma de lei federal que visa ordenar as cidades brasileiras e seu crescimento, surgem políticas públicas voltadas à requalificação urbana, tecnicamente conhecidas como Operações Urbanas. As operações urbanas são partes integrantes do Plano Diretor Estratégico de São Paulo e seus desdobramentos, os Planos Diretores Regionais de cada uma das trinta e uma subprefeituras dentro do município de São Paulo3.

O município de São Paulo passa atualmente por importante momento em seu panorama urbanístico quando, em paridade com outras cidades pelo mundo, alguns bairros e distritos começam a ser repensados e requalificados, como por exemplo, os distritos Sé e República, focos da Operação Urbana Centro e os distritos abrangidos pela Operação Urbana Diagonal Sul: Cambuci, parte do distrito do Brás, parte do distrito da Mooca, o distrito do Ipiranga até a divisa com o município de São Caetano, além de distritos da zona norte como Pari e outros ${ }^{4}$.

A requalificação urbana aqui pretendida não considera a implantação de projetos gigantescos, que afetam por demais a rotina de comunidades e que oneram exageradamente o orçamento da administração pública.

Propuseram-se aqui diretrizes que norteiem uma requalificação urbana com a criação de áreas abertas e praças apesar da pouca disponibilidade de vazios urbanos públicos, tendo sido necessário lançar mão de algumas desapropriações em pontos onde, a implantação dessas áreas públicas para lazer e outros equipamentos, para educação e saúde, seja estratégica para atender às demandas dos dois bairros.

patrimônio arquitetônico desses dois bairros vem sendo desconfigurado a cada dia com alterações de uso inadequadas, como por exemplo, a demolição do Cotonifício Crespi em 2005, para a instalação mais um hipermercado na cidade, localizado na Mooca e cujo lento processo de tombamento não foi concluído a tempo de evitar a sua demolição. Em vez disso, propôs-se nesta dissertação requalificar edificações existentes obtendo-se delas funções que colaborem com a inclusão social numa área tão desprovida de equipamentos públicos para diversas atividades.

O empenho pela permanência dos atuais moradores e a preservação do patrimônio histórico e arquitetônico tem grande importância para manter viva a memória cultural de suas populações.
I "Não trabalho" é termo retirado do texto de autoria do sociólogo Francisco de Oliveira: O Ornitorrinco.

${ }^{2}$ Estatuto da Cidade - Lei Federal $n^{\circ} 10.257$, de 10 de julho de 2001 .

3 Plano Diretor Estratégico do Município de São Paulo - Lei n 13.430, de 13 de setembro de 2002.

${ }^{4}$ Apesar do município de São Paulo ser oficialmente dividido em distritos, adotou-se para esta dissertação, na grande maioria das vezes, o uso do termo bairro, em virtude desta dissertação contemplar parte dos distritos do Brás e Mooca para o estudo e a criação de diretrizes e não a totalidade de sua área. 


\section{Problemática}

Durante a industrialização da cidade de São Paulo, no fim do século 19 até meados do século 20, muitos bairros do município tiveram seu crescimento estimulado pela instalação de indústrias ao longo de duas ferrovias existentes na cidade ou próximas a elas: A São Paulo Railway, posteriormente Santos-Jundiaí e a Estrada de Ferro Central do Brasil, ligando São Paulo ao Rio de Janeiro 5 . Bairros operários foram se formando próximos às indústrias, com vilas operárias de casas geminadas que surgiram intercaladas com os terrenos onde se construíram galpões industriais. Em 1932, no auge da industrialização, a população do município de São Paulo já era de um milhão de pessoas (Marcilio, 2004, p.266).

A problemática deste trabalho está fundamentada na reorganização da cidade a partir do adensamento populacional em áreas centrais com infra-estrutura básica instalada suficiente para suportar esse adensamento e no combate à degradação e obsolescência urbana que ocorrem sistematicamente em bairros industrializados de grandes metrópoles que se desenvolveram e cresceram de forma caótica, em maior ou menor grau, no Brasil e no mundo. Essa degradação urbana e ambiental em áreas industrializadas tem vários fatores como seus principais causadores. São exemplos disso o descaso dos governos, a queda na qualidade de vida em virtude da contaminação dos solos e da poluição do ar, a saída das indústrias e as conseqüentes quedas na oferta de empregos. Esses fatores podem ser provocadores da diminuição do número de habitantes. Um bairro com menos habitantes do que pode comportar perde também parte dos "olhos do bairro" que vigiam e podem ajudar a interromper desde o início um dos maiores problemas dentro do processo de degradação ou deterioração urbana: a instalação da violência (Jacobs, 2003, p.35). Áreas centrais de grandes metrópoles comumente apresentam uso do solo misto com predominância de comércio e serviços e poucos moradores fixos, o que os transforma em "bairros-fantasma" nos fins de semana, com pouca ou nenhuma vida nas ruas.

Mooca e Brás, localizados ao leste do Centro Histórico da cidade e dentro do centro expandido, foram bairros fundamentais para a cidade de São Paulo durante o processo de industrialização, onde inúmeras indústrias se instalaram nos terrenos ao longo das estradas de ferro já mencionadas: São Paulo Railway e Central do Brasil. Em conseqüência da industrialização do início do século 20, alguns bairros predominantemente residenciais como a Mooca ou bairros com pequenas e elegantes centralidades comerciais freqüentadas pela população de alta renda da cidade, como o Brás, passaram a ser bairros operários. Os bairros históricos do Brás e Mooca representam hoje a problemática que se deseja aqui estudar e por isso foram escolhidos como objeto de estudo desta dissertação.

Atualmente estes bairros estão inseridos em distritos centrais com potencial para adensamento populacional, pois tiveram suas populações diminuídas ao longo das duas últimas décadas e dispõem de infra-estrutura urbana básica completa. Ambos os bairros apresentam grande potencial de estudo para o conhecimento da história e do processo da industrialização do Município de São Paulo, ocorrido a partir do início do século 20. Por esses motivos fazem parte da Macrozona de Estruturação e Qualificação Urbana, segundo o Plano Diretor Estra-

5 Estradas de ferro São Paulo Railway, implantada em 1867, que passou a chamar-se Estrada de Ferro Santos Jundiaí (EFSJ), em 1946, hoje pertencente à CPTM e, a Estrada de Ferro D. Pedro II, que em 15 de novembro de 1889 passou a denominar-se Estrada de Ferro Central do Brasil, cujo trecho paulista também pertencente atualmente à CPTM. tégico de São Paulo:

\footnotetext{
A Macroárea de Estruturação e Qualificação Urbana inclui o centro metropolitano, a orla ferroviária, antigos distritos industriais e áreas no entorno das marginais e de grandes equipamentos a serem desativados, foi urbanizada e consolidada há mais de meio século, período em que desempenhou adequadamente atividades secundárias e terciárias, e passa atualmente por processos de esvaziamento populacional e desocupação de imóveis, embora seja bem dotada de infra-estrutura e acessibilidade e apresenta alta taxa de emprego (PDE de São Paulo, Capítulo II Seção II, Subseção III, Art. I55).
} 
Os bairros históricos do Brás e Mooca não podem ainda ser plenamente classificados como bairros degradados, pois por hora, apresentam somente alguns elementos que compõem focos de início de degradação urbana e de forma não crônica: diminuição gradativa da população residente, pessoas em situação de rua, violência urbana, contaminação de solos, existência de cortiços etc.

Um importante fato que complementa a problemática abordada nesta dissertação é o fracionamento de áreas urbanas por vias de circulação de veículos de ligação regional e sistemas de transporte público de massa e o conseqüente comprometimento da mobilidade intra-urbana ${ }^{6}$. Os dois bairros em questão sofreram a inserção dos principais sistemas viários regionais ali implantados após a consolidação do tecido urbano: a Avenida Alcântara Machado, em fins da década de 1960, também conhecida como Radial Leste e a Linha Leste do Metrô, implantada a partir de 1979. Antes da consolidação do tecido urbano, em fins do século 19, em meio às chácaras que formavam o entorno da cidade histórica, foram implantadas na região as duas ferrovias mencionadas anteriormente. Quando finalizados e em conjunto, esses sistemas viários passaram a dificultar a mobilidade de pedestres e até mesmo de veículos, criando vários bairros dentro de um:

- $\quad$ O bairro do Brás está dividido em três segmentos em virtude das ferrovias da CPTM: a área do Brás onde existe forte comércio de máquinas, couros e plásticos e situa-se a oeste da ferrovia Santos-Jundiaí e ao norte da Radial Leste, limitada pela Rua do Gasômetro; a área do Brás onde existe um forte comércio de confecções e produtos alimentícios, localizada ao leste da Santos-Jundiaí, entre Radial Leste e a antiga Ferrovia Central do Brasil e por fim, a área do Brás localizada entre a Ferrovia Santos-Jundiaí, a Rua Bresser, a Radial Leste e a Ferrovia Santos-Jundiaí, onde o uso residencial é mais presente, mas que também apresenta forte comércio local e diversificado.

- $\quad$ O bairro da Mooca está dividido em duas distintas partes: a Mooca baixa, entre Avenida do Estado, Radial Leste e Ferrovia Santos-Jundiaí e, o restante da Mooca, ao leste desta ferrovia e ao sul da Radial Leste. A Mooca baixa é visivelmente o trecho menos desenvolvido de todo o distrito da Mooca, composto também por Alto da Mooca e Parque da Mooca.

Poucos que circulam pela Radial Leste, via de ligação regional, vivem nesses bairros de classe média baixa, de cortiços, de vilas antigas. A grande maioria apenas se serve dela como ligação regional para chegar a seus destinos através da rede de linhas de ônibus metropolitanos regionais que se utilizam dessa via, principal opção de transporte em função da pequena rede municipal de linhas de metrô, aquém das necessidades da megalópole São Paulo. Esta avenida, com seu tráfego intenso de automóveis e a conseqüente dificuldade para sua transposição, forma significativa barreira urbana aos moradores que querem ou precisam ir de um bairro a outro, seja caminhando ou de automóvel ${ }^{7}$.

Diferentemente do que ocorre nas cidades do primeiro mundo, os distritos Brás e Mooca, localizados muito próximos do centro histórico da cidade e que têm parte deles às margens do Rio Tamanduateí - hoje canalizado naquele trecho - não são bairros valorizados por essa proximidade, a despeito da infra-estrutura urbana instalada, principalmente de transporte público e saneamento básico, presentes na região desde o final do século 19 e início do século 20, respectivamente.

Esses bairros dispõem de patrimônio arquitetônico que deve ser preservado como parte importante da memória paulistana e demandam intervenções urbanísticas urgentes. Essas intervenções podem ajudar a solucionar parte de problemas urbanos crônicos como a provisão de habitação para o mercado popular (HMP), e qualidade de vida dessa população, já que vivendo em bairros centrais, os moradores ficarão muito próximos ao Centro Histórico da cidade, foco de emprego, lazer, cultura e serviços locais e diversificados.
6 "Espaço intra-urbano" é expressão adotada por Flávio Villaça em O espaço intra-urbano (1998, p. 18). Apesar de considerar que a expressão "espaço urbano" é satisfatória, seu apelo regional leva à utilização da expressão "espaço intra-urbano" nas referências ao arranjo interno dos espaços urbanos.

${ }^{7}$ Apesar do município de São Paulo ser oficialmente dividido em distritos, adotou-se para esta dissertação, na grande maioria das vezes, o uso do termo bairro, em virtude desta dissertação contemplar parte dos distritos do Brás e Mooca para o estudo e a criação de diretrizes e não a totalidade de sua área. 


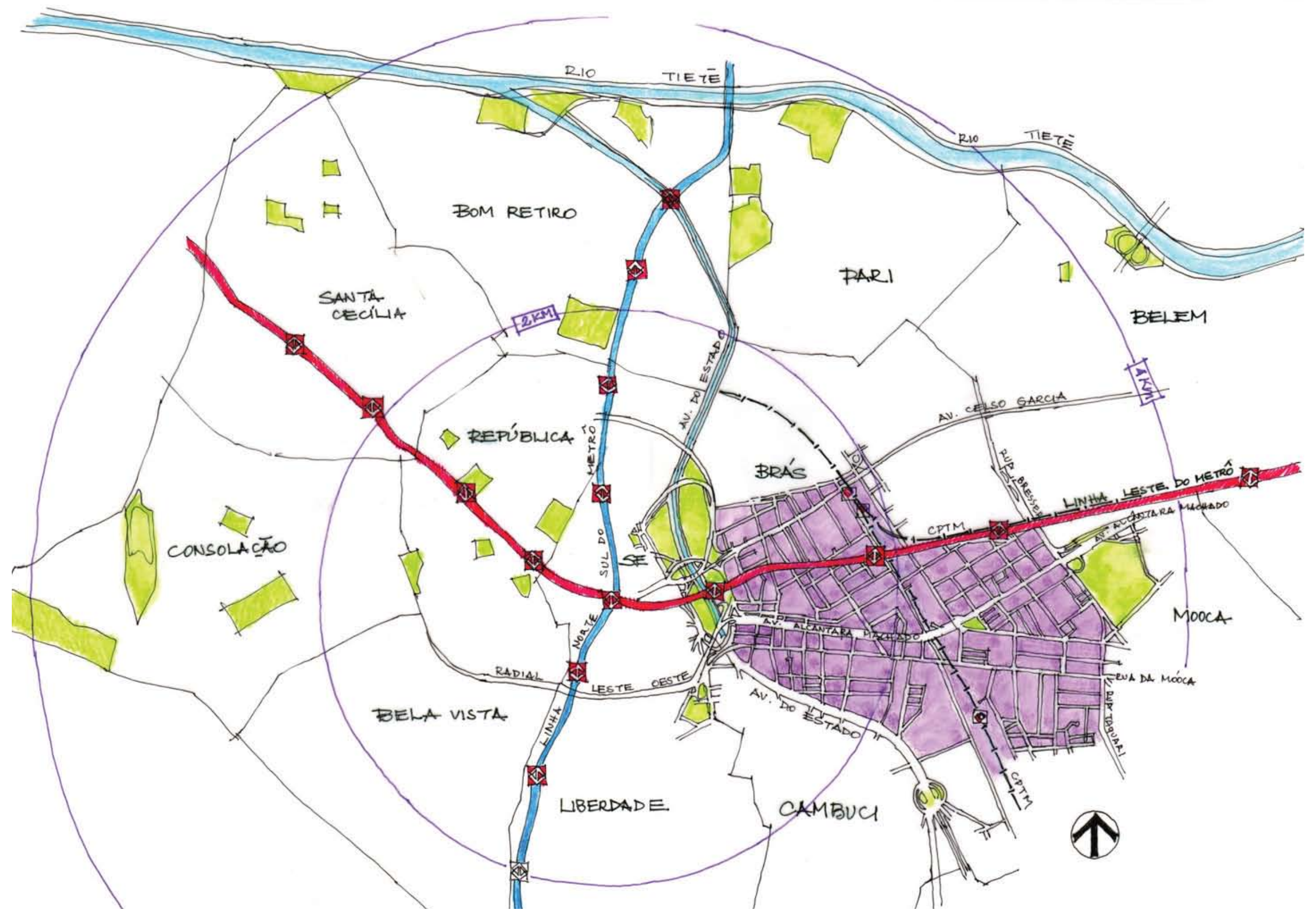

Figura 1

Localização da área-objeto de estudo:

trechos históricos do Brás e Mooca.

Croquis da autora. 
Neste trabalho propõe-se o adensamento de áreas centrais que já possuem infra-estrutura básica de qualidade e a ocupação de áreas subutilizadas que podem acomodar novas moradias para habitantes de baixa e média renda e novos equipamentos urbanos públicos. Num movimento inverso do que foi tão marcante nas décadas de 1960 a 1990, quando um contingente de população de baixa renda se acomodou nas periferias, pretende-se possibilitar a volta de um número considerável de habitantes de baixa renda hoje moradores de periferias com aluguel baixo e sem qualidade urbana, para áreas mais centrais, com aluguel também baixo atrelado ao fácil acesso a pólos de emprego, com qualidade urbana e ambiental.

\section{Área-objeto do estudo}

São objetos de estudo desta dissertação a Avenida Alcântara Machado, mais conhecida como Radial Leste, mais precisamente o trecho localizado entre a Avenida do Estado e o Viaduto Bresser e seu entorno próximo, as áreas históricas dos bairros Brás e Mooca aqui batizada de Mooca baixa. Esse conjunto, denominado área-objeto de estudo está localizado entre o centro histórico e o início da Zona Leste do Município de São Paulo. A área-objeto de estudo está localizada a 2 km em média do Centro Histórico do município de São Paulo. Brás e Mooca foram escolhidos como objeto de estudo por representarem a problemática que se pretende aqui estudar.

A Avenida Alcântara Machado inicia seu percurso em direção ao leste da cidade a partir da Avenida do Estado, localizada na região central, e faz parte do complexo viário Radial Leste-Oeste proposto no Plano de Avenidas de Francisco Prestes Maia ${ }^{8}$. Esse sistema viário atende primordialmente aos veículos automotivos, permite grande volume de tráfego diário e como todo o complexo em si, a Avenida Alcântara Machado teve um forte impacto sobre o tecido urbano consolidado existente na região por ocasião da construção de seu primeiro trecho, entre a Avenida do Estado e a Rua Piratininga, no fim da segunda metade da década de 1950.

A área analisada é limitada a oeste pelo Rio Tamanduateí, cuja imagem naquele trecho é de um rio canalizado de forma bruta, suportando uma linha de ônibus-trem em fase de lenta implantação, o que não contribui em nada com a imagem paradiśaca do desejo de qualquer cidadão habitante de uma metrópole: ter um rio limpo com margens ajardinadas ladeando seu bairro, ou até mesmo um rio canalizado de forma mais coerente, aberto, com águas limpas. Não cabe aqui avaliar até que ponto a municipalidade poderia investir para trazer de volta à vida esse rio que, mesmo continuando a ser barreira física de difícil transposição pelo pedestre, poderia contribuir com a qualidade de vida do morador da região e da cidade de forma geral. Ao leste, a área é delimitada pela Rua e Viaduto Bresser, Rua Taquari e Avenida Paes de Barros. Ao norte, a área está delimitada pela Rua do Gasômetro e pelas ferrovias da CPTM. Ao sul está delimitada pela Rua Serra de Paracaima, Rua Guaratinguetá, Canuto Saraiva e Rua Curupacê. Mais detalhes sobre a metodologia utilizada para definição do recorte da área-objeto deste estudo estão descritos no item I do Capítulo III.

\footnotetext{
${ }^{8}$ Francisco Prestes Maia. O Estudo de um Plano de Avenidas para a Cidade de São Paulo. São Paulo: Companhia Melhoramentos, 1930.
} 


\section{Objetivos}

O objetivo geral desta dissertação é traçar um plano de diretrizes para a requalificação urbana da Avenida Alcântara Machado ou Radial Leste e dos bairros históricos do Brás e Mooca, estes partes dos distritos do Brás e Mooca, tendo como focos principais o adensamento populacional, a melhoria da qualidade de vida, a manutenção das pequenas e médias indústrias não-poluentes existentes e a recuperaçãa e conservação de seu patrimônio histórico e arquitetônico. Para atingir esse objetivo buscou-se:

- - Conhecer a fundo a evolução urbana histórica da região, estudando o processo de produção do espaço construído da área, determinando dentre as quatro formas de produção do espaço urbano quais foram as mais predominantes, conhecendo seus problemas e os atores que intervieram nesse espaço;

- Conhecer as dinâmicas urbanas para determinar os agentes que levam ao esvaziamento populacional e à degradação de áreas ou bairros de grandes metrópoles;

- Estudar e conhecer projetos de requalificação urbana ocorridos em outras cidades no exterior com o objetivo de detectar similaridades com a área em estudo e apreender soluções ou críticas aplicáveis a este estudo;

- Conhecer e analisar os Planos Estratégicos Regionais das Subprefeituras Sé e Mooca, adotando as diretrizes propostas por esses planos para elevar a qualidade de vida da população da região, particularmente no que se referem à saúde, à educação, à cultura, às condições habitacionais, à infra-estrutura e aos serviços públicos e "racionalizar o uso da infra-estrutura instalada, em particular a do sistema viário e de transportes, evitando sua sobrecarga ou ociosidade"

${ }^{9}$ Plano Diretor Estratégico de São Paulo, Capítulo III, artigo 9, item II.

${ }^{10}$ Fonte: Secretaria da Habitação/PMSP, 1999 in Jornal A Folha de São Paulo, Caderno Cotidiano, 16/10/2001.

"Nos últimos 20 anos, o crescimento intra-urbano ocorreu de forma diferenciada: as áreas mais centrais, de ocupação já consolidada, apresentaram taxas negativas de crescimento, ou seja, contínua perda de população residente, enquanto as regiões periféricas continuaram a receber novos habitantes algumas delas com elevadas taxas de crescimento. Em outras palavras, se a aglomeração urbana continua a crescer em seu conjunto, isto se deve ao crescimento das áreas periféricas do Município de São Paulo e ao de grande parte dos demais municípios da Região Metropolitana. in www. prefeitura.sp.gov.br/ secretarias/sempla. I I.ago.2006.

${ }^{12}$ Lei Municipal $n^{\circ} 13.430$ de 13/09/2002, Capítulo III, artigo

79, cláusulas II, VIII, X; artigo

80, cláusulas I, VI, X, XIX.

\section{Hipóteses}

Para melhor conhecer as demandas urbanas do Brás e Mooca na proposição de um conjunto de diretrizes que as atendam, procurou-se responder as questões abaixo:

- Por que promover a requalificação urbana da Radial Leste, Brás e Mooca?

Primeiramente, deve-se promover a requalificação urbana dessa área para viabilizar o readensamento de bairros centrais a partir da provisão de moradia para as classes de baixa renda, mercado popular e classe média, tanto pelo Estado como pela iniciativa privada. A proximidade ao centro histórico, pólo de empregos e a oferta de transporte público para o restante do município, aliados à infra-estrutura urbana instalada possibilitam e justificam esse adensamento. A cidade de São Paulo contava no fim do século 20 com um déficit habitacional acima de 400 mil moradias ou mais de cinco milhões de pessoas ${ }^{10}$.

Nos últimos 20 anos esses bairros tiveram uma sensível queda no número de habitantes, o que pode demonstrar possivelmente o processo de expulsão, provocado não pela valorização e especulação imobiliária que não ocorreram, mas sim pela queda na qualidade de vida, na qualidade ambiental e no aumento da violência".

Na proposta de diretrizes para a requalificação urbana do Brás e Mooca, contida no Capítulo VII, propôs-se o adensamento populacional que pode viabilizar a recuperação de parte de seus habitantes, aliando-se a existência de vários terrenos vazios e edifícios industriais desocupados, às premissas do novo Plano Diretor Estratégico para São Paulo, que recomenda esse adensamento nas áreas com infra-estrutura urbana básica capaz de suportá-lo. Para isso, incentivos fiscais municipais podem motivar a iniciativa privada a prover esse tipo de moradia' ${ }^{12}$. 
A importância dessas áreas urbanas centrais não é apenas cultural, mas também, e de forma relevante, econômica. De fato, além da excelente qualificação de suas infra-estruturas, esse patrimônio construído constitui um enorme capital imobilizado, sujeito a processos contínuos de valorização e desvalorização - como ele próprio, socialmente produzidos por mecanismos normais de mercado na cidade capitalista. O binômio desvalorização-degradação dessas áreas constitui-se em desperdício inaceitável para as cidades, particularmente aquelas em países em desenvolvimento, com notórias carências urbanas (Farret in Vargas, 2006, p.IX).

A segunda justificativa, conforme nos mostra Farret, se fundamenta no importante parque econômico existente no Brás, na forma do forte comércio de abrangência regional, gerador de empregos locais. A terceira justificativa para a requalificação urbana do Brás e da Mooca é que bairros consolidados próximos ao centro, com valor histórico e infra-estrutura urbana instalada, podem ter seus imóveis que hoje se encontram desocupados ou abandonados, requalificados para outros usos como centros de convívio, centros culturais ou profissionalizantes.

- A infra-estrutura urbana instalada comporta o adensamento populacional?

A região apresenta infra-estrutura básica instalada completa. Na área educacional pública e na área da saúde pode haver expansões conforme a demanda. $\mathrm{Na}$ área de transporte público, como dito anteriormente, os bairros são muito bem atendidos pelas diversas linhas de ônibus e pela Linha Leste do Metrô. O comércio de âmbito local, hoje existente, mas muito disperso, se expandirá naturalmente conforme a expansão da demanda. $\bigcirc$ saneamento básico existe nos dois bairros desde o início do século 20 e hoje 100\% de seus territórios tem fornecimento de água, esgoto e iluminação pública'3.

O Estatuto da Cidade, lei federal sancionada em 200 I, estabelece novas regras para o controle da expansão urbana das cidades brasileiras e para o adensamento das grandes cidades, com o objetivo de eliminar os chamados "vazios urbanos" e os imóveis subutilizados ou abandonados e minimizar os custos com implantação e manutenção de infra-estrutura, com diretrizes gerais que garantem que o planejamento do desenvolvimento das cidades seja mais criterioso, estendendo os benefícios do processo de urbanização a todos os cidadãos ${ }^{14}$.

- Os bairros do Brás e Mooca apresentam focos de degradação urbana?

Segundo Vargas, intervir em centros urbanos pressupõe identificar processos claros de deterioração ou degradação urbana, conceitos freqüentemente associados à perda de sua função, ao dano ou à ruína as estruturas físicas, ou ao rebaixamento do nível do valor imobiliário desses centros. Deteriorar equivale a estragar, piorar e inferiorizar. Degradação significa aviltamento, rebaixamento e desmoronamento (Castilho in Vargas, 2006, p.3) e também a degradação de seus grupos sociais: empobrecimento, marginalização e destruição das bases da solidariedade entre os indivíduos e o descrédito na noção de bem comum (Gutierrez in Vargas, 2006, p.4).

Os principais fatores que podem levar à conclusão de que existem focos de deterioração e degradação urbana em curso nos dois bairros em estudo são: a perda e o empobrecimento da população residente, o que vem ocorrendo desde a sua desindustrialização; a perda de qualidade ambiental composta principalmente pela poluição do ar, a contaminação de solos pelas indústrias locais e a proliferação de cortiços - moradias insalubres de baixíssima qualidade através da subdivisão de imóveis - a fragmentação do espaço pelos sistemas viários de ligação regional e altos índices de violência urbana. Pessoas em situação de rua, catadores de lixo, imóveis abandonados ou subutilizados são elementos cada vez mais freqüentes. Apesar dos fatos mencionados e do intenso comércio especializado no Brás, tanto este como a Mooca são bairros com potencial para uso residencial com possibilidades para adensamento populacional e bem localizados em relação ao Centro Histórico da cidade.
13 Os bairros do Brás e Mooca dispunham de uma cobertura de área urbana com iluminação pública de $50 \%$ em 1900 e de $100 \%$ de cobertura para água e esgoto no Brás e de $80 \%$ para água e esgoto na Mooca, em I928 (Rolnik, p. I3I e |47).

${ }^{14}$ Lei n 0.257, de 10/07/200 I. Ver principalmente os artigos: Art. $2^{\circ}$, inciso IV, $\mathrm{V}, \mathrm{VI}, \mathrm{XII} \mathrm{e}$ XIV; Art. 25, parágrafos Io e 2०; Art. 26, incisos II, V e VI. 
- Quais são os elementos que provocam ou permitem a fragmentação do espaço de centros ou áreas urbanas nas grandes metrópoles? Foram as barreiras urbanas formadas pelas estradas de ferro e pela Linha Leste do Metrô, as principais causas da fragmentação do espaço do Brás e Mooca?

Uma das hipóteses é que a implantação de sistemas viários para transporte urbano sobre rodas ou trilhos, como vias expressas, ferrovias e trens metropolitanos, podem tornar-se "barreiras urbanas à acessibilidade e mobilidade intra-urbana", pois à medida que esses tipos de sistema são implantados interrompem fluxos locais de pedestres ou veículos, atuais ou anteriores à sua implantação, separando bairros ou isolando-os e dificultando o deslocamento da população e seu acesso a atividades mais diversificadas, como lazer, educação, comércio e serviços.

Por serem os sistemas viários ali implantados entre as décadas de 1960 e 1980 os projetos urbanos mais importantes ocorridos nessa região durante esse período são considerados aqui grandes projetos urbanos, com resultados finais de grande impacto na mobilidade e acessibilidade local: a Avenida Alcântara Machado e a Linha Leste do Metrô de São Paulo.

O primeiro grande projeto ali implantado foi a construção do trecho inicial da Avenida Alcântara Machado, mais conhecida como Radial Leste, que teve importante papel na transformação de seu entorno próximo, os bairros do Brás e Mooca baixa, localizados entre o centro e o início da Zona Leste da Cidade de São Paulo. O segundo grande projeto foi a implantação da Linha Leste do Metrô, tratando-se de linha aérea de metrô - linha aérea elevada da Estação Dom Pedro até a Estação Brás e que passa a linha de superfície descendo ao nível do solo, emparelhando-se aos trilhos da ferrovia anteriormente existente Estrada de Ferro Central do Brasil (hoje pertencente à CPTM). Isto aumenta a dificuldade de transposição desses sistemas viários, principalmente em relação à escala humana.

- Por que a implantação de linhas de trens metropolitanos em alguns casos valoriza e em outros casos desvaloriza uma região urbana consolidada?

Essa pergunta foi feita a vários profissionais ligados às áreas de transporte e urbanismo, que numa análise superficial condicionam a não valorização das áreas urbanas em torno das estações de metrô no bairro do Brás ao fato dessa linha do Metrô de São Paulo ser de superfície ao invés de subterrânea. Diferentemente da linha subterrânea, a população fica mais exposta aos ruídos e outros elementos que podem comprometer a qualidade ambiental e estética de seu entorno ${ }^{15}$.

${ }^{15}$ Após a implantação da Linha NorteSul do Metrô, foram comparados pela Companhia do Metrô de São Paulo, dois bairros do município com as mesmas características antes da construção desse sistema viário: Pinheiros, que não dispunha de metrô e Vila Mariana, já com a linha subterrânea implantada. A pesquisa concluiu que houvera uma valorização imobiliária na Vila Mariana em torno de $30 \%$ em relação a Pinheiros. Andreína Nigriello. Notas de palestra apresentada como convidada na disciplina AUP5727 - Atelier de Projeto Urbano II, ministrada pelo Prof. Dr. Bruno Padovano, PG-FAUUSP, 2003.
- Os bairros do Brás e da Mooca, que até o fim da década de 1950 tinham o traçado viário contínuo podem vir a ser reunificados novamente, com a desobstrução de suas ruas?

A requalificação urbana de uma área ou região deve estar vinculada a uma reestruturação viária consciente, que considere os fluxos de veículos e principalmente de pedestres, devolvendo vida às ruas, sem optar por obras faraônicas que priorizem ou estimulem somente o uso do automóvel. A Avenida Alcântara Machado representa uma importante ligação regional implantada numa cidade onde os veículos automotores têm prioridade desde a década de 1930 e que suporta um imenso fluxo de veículos diariamente. Uma interferência num sistema viário desse porte representa um investimento público de alto valor e que por isso deve estar embasado em solução técnica de baixo risco, buscando-se o equilíbrio entre as reais necessidades da população local e a disponibilidade de verbas públicas, evitando-se mau uso das mesmas.

- Como viabilizar a requalificação urbana do Brás e Mooca?

Farret responde a essa questão:

O enfrentamento desses processos extremamente perversos implica em investimentos públicos 
e privados, seja para a conservação, recuperação, reconversão-requalificação de novos usos desse valioso patrimônio construído. Contrariamente ao movimento moderno a partir dos $\mathrm{CIAM}^{16}$, que negam as morfologias passadas e crêem em começos absolutos e sem ter como objetivo somente um processo de maquiagem, a intervenção nessas áreas urbanas centrais demanda a consideração de importantes instrumentos econômicos, sociais, jurídicos e institucionais, que delineiam os contornos do processo de reconversão-requalificação urbana, buscando a conciliação entre conceitos dicotômicos, por exemplo, valor de uso e valor de troca, ganhos imobiliários e recuperação da mais-valia imobiliária, parceria público-privada, uso para o saber/lazer/morar e consumo supérfluo, inclusive de bens e serviços ditos culturais, articulação inter e intragovernamental e participação comunitária (Farret in Vargas, 2006, pp.IX-X).

\section{Metodologia}

A metodologia adotada para reunir todas as informações e dados oficiais necessários para a abordagem dos problemas que levam bairros industrializados à degradação e à fragmentação do espaço e para a análise, o diagnóstico e a proposição de diretrizes para requalificação urbana, foi conhecer detalhadamente a área a partir da evolução urbana e da análise de sua morfologia urbana, suas peculiaridades e necessidades.

No Capítulo I apresenta-se a referência teórica obtida com a bibliografia reunida e selecionada que orientou o desenvolvimento da dissertação, considerando os textos e as teorias de diversos autores - sociólogos, economistas e urbanistas - como Bresser Pereira, Paul Singer e outros, cujos argumentos são importantes no entendimento dos processos de urbanização de grandes cidades como São Paulo, onde a industrialização marcou definitivamente o tecido urbano e o crescimento das cidades e, no entendimento dos elementos que levaram à sua degradação ambiental durante o desenvolver desta dissertação e que deram sustentação às hipóteses levantadas. Com os textos de Samuel Jaramillo e Michael Ball, foi possível entender as formas da produção do espaço e as relações sociais envolvidas nessa produção do espaço urbano, principalmente na provisão de moradias operárias durante a industrialização.

Ainda neste capítulo são temas abordados o planejamento urbano e a metodologia de análise de tecidos urbanos desenvolvida pelo urbanista Cândido Malta Campos Filho.

O Capítulo II apresenta um breve relato sobre a evolução urbana do município de São Paulo a partir do século 17 até o início do século 20 passando posteriormente à análise histórica da evolução urbana dos distritos do Brás e Mooca, destacando-se a área-objeto de estudo contida dentro desses dois distritos, a partir do início do século 19 até a atual morfologia urbana e estruturação viária.

Para melhor analisar a evolução urbana da área objeto de estudo foram estudados diversos documentos como plantas cartográficas e mapas históricos da cidade, elaborados por engenheiros encarregados para isso pela municipalidade como J. Rufino e C.A.Bresser. Foram a base para a observação do crescimento da cidade de São Paulo e dos bairros em estudo neste trabalho - Brás e Mooca. Esses documentos têm sua elaboração datada entre início do século 19 e o ano de 1972, ano da elaboração do Mapa GEGRAN, fornecido pela EMPLASA - Empresa Paulista de Planejamento Metropolitano S/A. A partir dessa data foram utilizadas fotos aéreas fornecidas pela Secretaria de Planejamento da Prefeitura Municipal de São Paulo - SEMPLA, como material de observação do desenvolvimento urbano da área-objeto de estudo. Outros mapas e documentos históricos oficiais foram encontrados em arquivos da Prefeitura Municipal, como o CASE 3, RESOLO e nos arquivos da COHAB - Companhia de Habitação, nos arquivos da Fundação Energia e Saneamento e da Biblioteca Mário de Andrade. O traçado viário atual foi obtido no Mapa Digital da Cidade de São Paulo.

Com o objetivo de conseguir um encadeamento de acontecimentos na época de produção de cada documento-base da análise histórica da evolução urbana, foram estabelecidos

${ }^{16}$ Congressos Internacionais de Arquitetura Moderna. 
parâmetros de comparação obtendo assim uma metodologia de reunião de informações necessárias para ilustrar as circunstâncias econômicas e políticas à época de cada documento utilizado para a leitura da evolução urbana. São eles: o traçado viário, a tipologia das construções, a topografia, as configurações produtivas envolvidas na produção do espaço, os equipamentos urbano, os marcos referenciais, o prefeito ou intendente, o momento econômico e o perfil dos habitantes e suas relações sociais. A leitura de publicações de autores como J. Langenbuch, Aroldo de Azevedo, Benedito Lima de Toledo, Raquel Rolnik e outros em muito contribuiu para a localização de muitas dessas informações. Na seqüência, apresenta-se a evolução populacional dos distritos Brás, Mooca e Cambuci a partir dos Censos Demográficos de 1950 a 2000 até chegar-se à população efetiva, total e totais por faixa etária da área-objeto de estudo. Para isso foram utilizados os setores censitários do IBGE - Instituto Brasileiro de Geografia e Estatística. A produção do espaço urbano tem lugar neste capitulo com o objetivo de complementar a análise da evolução urbana da área-objeto de estudo e conhecer esse desenvolvimento. Durante a análise da produção do espaço urbano no Brás e Mooca foi possível conhecer alguns dos grandes loteadores da região e como essas áreas foram sendo desmembradas. Também foi possível conhecer a produção estatal de moradias, de infra-estrutura e mesmo de instrumentos urbanísticos que colaboraram para o delineamento urbano da área. Ainda neste capitulo achou-se por bem destaca a estruturação viária desses dos bairros, por considerá-la o segundo mais importante elemento transformador do tecido urbano depois da histórica industrialização. Pó fim, faz-se um levantamento da qualidade ambiental e da disponibilidade de equipamentos públicos para as áreas de educação, saúde e cultura.

No Capítulo III, inicialmente, faz-se uma descrição do processo pelo qual se definiu a área ideal a ser estudada e que conteria toda a problemática a ser analisada. $\bigcirc$ principal objetivo deste capítulo é fazer uma análise do tecido urbano, do conjunto de elementos que compõem a morfologia e outros dados do tecido urbano, como o tipo de traçado viário, a tipologia das construções, o tamanho das quadras e lotes, as reais categorias de uso e ocupação do solo e a topografia, características efetivamente encontrados numa determinada área urbanizada. Como ponto de partida fez-se um levantamento in loco, lote a lote, do atual uso e ocupação do solo, do gabarito das edificações e do parcelamento do solo existentes nesses dois bairros. Com esse levantamento foi possível conhecer o grau de adensamento urbano e de verticalização existentes na região. Esse adensamento e verticalização estão demonstrados nas imagens elaboradas por computação gráfica e que também apresentam os usos atuais das construções. Através da análise do tecido urbano foi possível localizar áreas adensáveis e áreas remanescentes das obras de implantação da Linha Leste do Metrô, que podem receber equipamentos públicos, principalmente para lazer, o grande déficit da região. Neste capítulo são também apresentados indicadores sócio-econômicos e ambientais básicos mas suficientes para traçar-se o perfil dos bairros e assim conhecer e entender a problemática urbana da área e abordada nesta dissertação.

O Capítulo IV, na seqüência, fez-se um diagnóstico geral do panorama urbano atual em que se encontra a região, considerando-se os aspectos positivos e os negativos que deverão ser considerados na proposição das diretrizes. Por ser um importante fator transformador de tecidos urbanos consolidados, a estruturação viária foi tratada à parte, bem como a qualidade ambiental da área-objeto de estudo, mostrando os focos de degradação urbana e tratando de questões como a cobertura vegetal e a temperatura locais.

$\bigcirc$ Capítulo $\mathrm{V}$ apresenta um estudo de experiências de requalificação urbana ocorridas em áreas degradadas ou industrializadas em outros países e os resultados obtidos nessas requalificações. Foram estudados os casos de Battery Park City, na cidade de Nova lorque; London Docklands, em Londres; a Vila Olímpica de Barcelona; a recuperação da área portuária de Puerto Madero, na cidade de Buenos Aires e finalmente, a reconstrução do bairro do Chiado 
em Lisboa. Em cada um desses casos foram encontrados elementos que compõem o cenário foco de cada uma dessas requalificações urbanas e que apresentam alguma similaridade com o objeto de estudo desta dissertação - as áreas históricas do Brás e Mooca.

No Capítulo VI são comparadas e compiladas as diretrizes dos Planos Estratégicos Regionais das duas subprefeituras que detém a administração da área em estudo - Subprefeitura Sé e Subprefeitura Mooca - através de uma fusão dos dois planos com o objetivo de agrupar as similaridades e as particularidades das diretrizes reservadas para cada um dos dois trechos que compõem a área-objeto de estudo desta dissertação. A compilação resultante apresentase na íntegra no Anexo 2 desta dissertação.

Finalmente, no Capítulo VII são propostas as diretrizes para a Requalificação Urbana das áreas históricas do Brás e Mooca e da Avenida Alcântara Machado. Esta dissertação adota e complementa parte das diretrizes, como no caso da preservação de edifícios históricos e a criação de áreas verdes - estas reivindicadas pelas comunidades locais - já propostas pelas subprefeituras em seus planos estratégicos regionais, altera outras, como no caso dos perímetros delimitados para as ZEIS 3 e propõe novas diretrizes, de acordo com as necessidades e demandas levantadas durante a análise e descritas no diagnóstico geral.

\section{Terminologias para projetos de requalificação urbana}

Durante o desenvolvimento da pesquisa, foram encontrados vários termos utilizados na descrição dos resultados de um projeto urbano em áreas degradadas nos textos da bibliografia analisada: reurbanização urbana; recuperação urbana, requalificação urbana, revitalização urbana e renovação urbana. Com o objetivo de identificar o melhor termo a ser aplicado e de obter melhor entendimento nos textos a serem desenvolvidos para esta dissertação, comparou-se a forma de utilização de cada um nos textos contidos na bibliografia utilizada para o seu desenvolvimento, sempre dentro do contexto do planejamento urbano na recuperação de áreas degradadas ou desativadas. Verificou-se que os diversos autores utilizam um ou mais dos termos citados acima, de acordo com o foco ou a escala de intervenção no objeto descrito. No caso desta dissertação definiu-se por bem adotar o termo requalificação urbana, como sendo o que tem maior abrangência e melhor define o objetivo das diretrizes a serem propostas na parte final deste trabalho: re-atribuir qualidades de modo geral a bairros consolidados e com infra-estrutura urbana básica instalada, mas que perderam a qualidade ambiental ao longo das últimas décadas.

O significado de cada um dos cinco termos acima mencionados se encontra no glossário do Anexo I desta dissertação, bem como outros termos recorrentes tanto em textos de planejamento urbano quanto neste trabalho. 


\section{Capítulo 1 \\ Referencial teórico}

O primeiro objetivo deste capítulo é apresentar um breve histórico sobre o processo de industrialização capitalista atrelado à urbanização das cidades para que a classe operária pudesse ter nível produtivo mais alto, morando próximo ao seu local de trabalho.

O segundo objetivo deste capítulo é fundamentar as hipóteses levantadas para abordar e explicar o processo de degradação urbana que pode atingir bairros industriais em metrópoles de países capitalistas em desenvolvimento.

Em virtude da urbanização das cidades em processo de industrialização estar diretamente ligada a novas demandas por moradias nas cidades em desenvolvimento, foi necessário conhecer como se deu e se dá o processo de provisão de moradias para essa classe operária em movimento do campo para as cidades. Através de textos como os de Samuel Jaramillo e Michael Ball, foi possível conhecer os tipos de produção de espaço e suas principais características desde o fim do século 18 e durante o processo de industrialização em cidades como Londres e Bogotá, podendo-se estabelecer um comparativo com a produção do espaço na cidade de São Paulo.

Cândido Malta Campos Filho empresta a metodologia de análise utilizada para conhecimento do crescimento do tecido urbano e as conseqüentes tipologias de tecido e traçado viário decorrentes das diferentes formas de produção do espaço e também colabora com um breve histórico do Planejamento Urbano.

\section{A industrialização no Brasil}

Nos países centrais, o capitalismo desenvolveu-se em quatro fases: capitalismo mercantil (apropriação do excedente nos quadros da acumulação primitiva), capitalismo industrial competitivo (com a apropriação da mais-valia), capitalismo monopolista (concentração e centralização do capital) e capitalismo monopolista estatal (Estado-produtor) (Pereira, 1998, p.6I). O Brasil, por sua vez, não passou por um período pré-capitalista ou feudal mas sim por um período do capital mercantil, até 1930, e pelo período do capital industrial, de 1930 em diante (Pereira, 1998, p.21).

No século 19, com o fim da escravidão e a disseminação do trabalho livre, houve um surto industrial no Brasil, principalmente em São Paulo. No final do século 19, o Brasil encontrava-se sob fortes incentivos fiscais governamentais para implementar a industrialização e a oligarquia agrário-mercantil por questões étnicas e sociais. O país comportava-se externamente como capitalista, pois entendia como mercadorias apenas os produtos destinados à exportação e internamente como feudalista, produzindo apenas para consumo próprio. A partir dos anos 1930, as mercadorias começam a se diversificar para o consumo interno, época também em que se consagra o trabalho assalariado, característica histórica essencial do capitalismo (Pereira, 1998, pp.4 I-43).

No período de 1930 a 1950 deu-se a nossa revolução industrial substitutiva das importações. Suas causas gerais foram a crise do sistema capitalista internacional e a decadência política da burguesia mercantil. O pacto entre o imperialismo e a oligarquia local entra em colapso, abrindo espaço para o desenvolvimento do capital. A revolução de 30 foi o primeiro capítulo desse processo. Como resultado, ocorreu a transformação do Brasil em um país no qual o modo capitalista de produção tornou-se dominante, mas a industrialização de então 
era inteiramente dependente de nossas importações. Limitava-se a alguns bens de consumo e não possuía qualquer grau de integração vertical e de autonomia. A verdadeira industrialização brasileira só ocorreu a partir de 1930 (Pereira, 1998, pp.4I-5I).

Nos anos 50 e 60 acelera-se esse processo no sul do país e, na década de 1980, ainda há no nordeste do país resquícios da produção para consumo próprio (Pereira, 1998, p.43).

Na metade dos anos 40, após a Segunda Guerra, estimulou-se a industrialização brasileira com o Estado intervindo cada vez mais, transferindo o capital de exportação de café, cujo preço estava acima do seu "valor-trabalho" 17, para a indústria (1945-1960). Através do confisco cambial, cobrava-se um imposto disfarçado dos exportadores, alterando a cotação do dólar e transferindo a diferença para que os industriais pudessem importar máquinas e matérias primas (Pereira, 1998, p.52).

O grande impulso industrial se deve a dois fatores: a depressão mundial e conseqüente elevação dos preços no cenário mundial - tornando viável a produção nacional - e a manutenção da demanda agregada interna (keynesianismo), graças às compras, pelo Estado, de café para ser estocado e depois queimado.

A industrialização substitutiva de importações foi realizada exclusivamente por empresários locais. No período de 1930 até a década de 1940, as indústrias multinacionais e estatais eram secundárias, mudando a partir de 1950 o padrão de acumulação de capital. Nos anos 50, a indústria automobilística ainda estava por se implantar, mas já havia uma indústria leve nacional de bens de consumo (Pereira, 1998, p.54).

As empresas multinacionais instalaram-se no Brasil nos anos 1950. Essas empresas internacionais dedicavam-se ao comércio e exploração de matérias primas minerais e algumas culturas tropicais, sempre voltadas para a exportação. Interessavam-se pelos transportes coletivos como ferrovias e portos, serviços públicos e bancários, com a atenção voltada para o comércio internacional (Pereira, 1998, p.57).

Entre as décadas de 1960 e 1980, o Brasil viveu um quadro de desenvolvimento industrial e subdesenvolvimento social, paralelamente ao regime militar, com grande concentração de renda e o endividamento interno, culminando numa grande crise econômica nos anos 1980. Os países centrais desenvolvidos começam a aplicar suas políticas neoliberais na expansão de suas cidades e na recuperação das áreas desindustrializadas e subutilizadas, acomodando o setor terciário e habitações para a classe média alta.

Tanto nos países com industrialização precoce como tardia, a urbanização das cidades está diretamente ligada à época de sua industrialização, quando os trabalhadores rurais passam a viver nas cidades, próximos às fábricas onde sua mão-de-obra era requisitada. No município de São Paulo, colonos vindos em enormes surtos migratórios, com a crise na cafeicultura, transformam-se em operários e vão viver em cortiços nas áreas centrais, palco do processo de industrialização.

A industrialização-urbanização nos países desenvolvidos foi tão heterogênea quanto nos países subdesenvolvidos, mas acompanhada por lenta implantação de inovações tecnológicas e com população integrada à economia, enquanto nos subdesenvolvidos, a implantação de ramos inteiros de produção, a economia de subsistência foi exposta a choques maiores (Campos Filho, 1989, p.29)

Após a urbanização em função da industrialização, o próximo fator importante que passa a afetar a urbanização das cidades industrializadas é a desindustrialização. Uma das causas da desindustrialização de metrópoles é a "deseconomia de aglomeração", termo utilizado para definir um conjunto de variáveis, destacando-se maiores custos de transporte de carga, de terrenos, serviços e infra-estrutura urbana, poder sindical, questões ambientais e queda na produção, que levaram ao espraiamento da atividade industrial (Negri in Grillo, 1997, p.6).
17 Valor-trabalho: quantidade de trabalho incorporado no valor do bem (Pereira, 1998, p.43) 
$\bigcirc$ processo de desindustrialização ou desconcentração industrial do município de São Paulo acontece entre as décadas de 1970 e 1990 e o governo municipal cria a Lei de Uso e Ocupação do Solo (LUOS) em 1972. O perfil da indústria dos anos 90 é ditado por pequenas e médias indústrias de planta mais enxuta, voltados a ramos mais dinâmicos como a indústria alimentícia, eletrônica, gráfica e têxtil (Grillo, 1997, p.3). Esse processo ocorreu em inúmeras cidades industrializadas pelo mundo e pelas mesmas razões: a obsolescência de equipamentos, o controle ambiental e o adensamento das cidades no entorno das áreas industriais com conseqüente dificuldade no escoamento de mercadorias. A cidade sufoca as indústrias que sufocam a cidade. Áreas portuárias tiveram sua obsolescência determinada também pela conteinerização do transporte de mercadorias e geraram grandes áreas abandonadas e subutilizadas, dependentes de projetos de requalificação urbana para serem novamente inseridas na cidade.

\section{A produção do espaço urbano}

No Brasil, a Lei de Terras de 1850 ou Lei Imperial n 60 transformou os ocupantes de sesmarias em ricos, da noite para o dia, bastando que seus títulos de posse estivessem registrados ou que provassem ter executado bem-feitorias nas terras para conseguir registro. Foram concedidos prazos para se buscar a legitimação de títulos e, a partir daí, todas as terras devolutas do Império e as sesmarias que não se enquadravam nas condições legais passariam a ser vendidas (Rolnik, 2003, pp. I6-23).

A especulação imobiliária é a principal forma de lucro aqui discutida, por ter sido elemento de grande interferência na urbanização brasileira desde o seu início, nas Capitanias Hereditárias com a usurpação das terras, até os dias de hoje, quando a cidade de São Paulo ainda é palco do domínio da terra e da renda fundiária por parte de grupos investidores e outros agentes imobiliários - até mesmo na condução de reformas da legislação, quando estes tratam de defender seus interesses junto ao governo.

Os países latinos são os países que mais detém a propriedade privada da terra e os países ao norte da Europa são os que mais terras públicas têm. Na Suécia, nas áreas de expansão das cidades, o Estado permanece proprietário de terras públicas, que são cedidas na forma de concessão por prazo determinado e prorrogável a empresas ou construtores que queiram ali construir ou instalar suas empresas ${ }^{18}$.

Dentre todos os segmentos de produção, a construção foi o que mais dificuldades apresentou para deixar-se dominar pelo capitalismo, sendo um dos últimos a ser incorporado ao processo de acumulação de capital. $\bigcirc$ processo de introdução do capitalismo na produção do espaço urbano está muito ligado às características de cada cidade e de sua formação social. ○ autor coloca como barreiras ao capitalismo apresentadas pelo segmento da construção: o grande período de giro de capital com comprometimento do retorno esperado para o capital investido; relação de dependência do espaço construído com o solo urbano, que leva o proprietário de terras a ter certo controle, em forma de renda, sobre essa produção; oscilações das condições de produção e circulação de capital mais freqüentes, aumentando o risco e desestimulando o investimento nesse segmento e a falta de demanda de consumo crescente que viabilize os investimentos, a longo prazo (Jaramillo, 1982, pp. | 53- |6 I).

Jaramillo apresenta o modelo de acumulação colombiano e a urbanização na capital Bogotá, onde facilmente se reconhece a similaridade com o processo de urbanização da cidade de São Paulo. Este tipo de urbanização onde imperou o regime de acumulação capitalista de-

${ }^{18}$ Cândido Malta CAMpos FILHo. Notas tomadas durante aula ministrada na disciplina AUP572I - Atelier de projeto urbano, PG-FAUUSP, 2003. pendente de substituição de importações, tendo como conseqüências a "formação de centros urbanos com diferentes atividades e grandes reservas de mão-de-obra, que deram base à indústria, o crescimento demográfico acelerado por causa da geração de emprego na indústria, 
crescimento vegetativo rápido e migração do campo para a cidade e, o empobrecimento da população e aguda segregação sócio-espacial" (Jaramillo, 1982, p. 162 ).

A produção do espaço na Colômbia, mais precisamente em Bogotá, acontece cronologicamente, tecnologicamente e com formas de circulação de capital muito semelhantes às ocorridas na cidade de São Paulo. A grande diferença entre as duas cidades é que em São Paulo, ao contrário de Bogotá, houve um forte desenvolvimento do parque industrial local.

\subsection{As formas de produção do espaço urbano}

Segundo Jaramillo, analisando-se o tecido urbano de uma cidade, encontram-se basicamente quatro formas de produção do espaço urbano, que ele classifica em produção por encomenda, autoconstrução, produção capitalista e "produção estatal capitalista desvalorizada" ( 1982, p.202). Em cada uma dessas formas de produção imobiliária podem-se encontrar características de outra, pois elementos de um processo podem fazer parte do processo de produção do outro. Exemplo: a autoconstrução utiliza, por vezes, mão-de-obra contratada de conhecidos ou pequenos empreiteiros assalariados, característica da produção por encomenda.

Jaramillo classifica a forma de produção estatal como "produção capitalista desvalorizada por parte de estado", que representa o fornecimento de imóveis públicos para acomodar as atividades administrativas do Estado e a provisão de moradias. Ele a classificada de produção desvalorizada por que, apesar de ser esta uma produção capitalista baseada na relação capitaltrabalho assalariado e por respeitar a circulação de capital, apresenta uma peculiaridade que a distingue da produção capitalista pura: as taxas de lucro são inferiores em relação às taxas médias normais (1982, p.203).

Para Topalov, que destaca a produção de moradias em relação aos outros tipos de produto (1979, p. 139), são três os principais sistemas de produção de habitações:

- O sistema da produção não mercantilizada, onde o usuário constrói para si mesmo ou, no máximo contrata uma empresa de construção para fazer isso por ele; neste caso não há renda do solo;

- O sistema da valorização da propriedade do solo, onde coexistem três agentes: o proprietário do solo capitalista imobiliário-proprietário da terra, a empresa construtora e o usuário que busca sua moradia como mercadoria; neste caso há o controle da propriedade do solo;

- O sistema da promoção imobiliária, onde também coexistem três agentes: o proprietário do solo e o capitalista imobiliário são agora distintos; a própria produção de moradias pode ser realizada pelo promotor imobiliário que passa a ser também o construtor ou pode ser realizada por uma empresa que faz somente o papel de construtora; por último temos o usuário - comprador ou arrendatário da moradia, papel que não muda em relação ao sistema anterior; neste caso, a renda se forma sob o controle do capital de promoção.

Ainda para ele, são quatro atividades capitalistas ou agentes imobiliários envolvidos na produção do espaço: a indústria da construção, os promotores imobiliários, os rentistas imobiliários e o crédito imobiliário. "O nascimento do crédito imobiliário é contemporâneo à aparição das primeiras formas de produção capitalista de moradias e constitui, desde sua origem, um circuito financeiro específico, especializado, o crédito hipotecário" (1979, p. 109 e 126).

Assim como Jaramillo, Topalov também classifica a produção estatal da moradia como desvalorizada, pois é financiada por um "sistema de crédito imobiliário instalado graças ao capital de empréstimo público desvalorizado" (1979, p. I 58). No Brasil, esse sistema pode ser comparado ao crédito imobiliário brasileiro subsidiado pelos institutos Caderneta de Poupança e FGTS, salvaguardando-se as diferenças de taxas anuais aplicadas ao usuário final entre Brasil e países europeus, onde estas são mais baixas ${ }^{19}$.
${ }^{19}$ O FGTS - Fundo de Garantia por Tempo de Serviço foi instituído pela Lei no 5.107 , de 13/09/66, regulamentada pelo Decreto no 59.820 , de 20/I2/66. Os recursos do FGTS são distribuídos em: Habitação Popular 60\%; Saneamento Básico e Infra-Estrutura Urbana 30\%; Operações Especiais 10\% (operações de crédito entre os Agentes Financeiros e entre os Agentes Financeiros e os mutuários finais). 
${ }^{20}$ IAP - Institutos de Aposentadorias e Pensões;

COHAB - Companhia Metropolitana de Habitação de São Paulo, sociedade anônima de economia mista, foi criada sob a Lei n 6738 de 16/I I/1965 e tem a Prefeitura do Município de São Paulo como sócia-majoritária, com 99\% das ações;

CDHU - Companhia de Desenvolvimento Habitacional e Urbano do Estado de São Paulo, foi fundada em 1949 com o nome de CECAP - Companhia Estadual de Casas Populares; passou a CODESPAULO - Companhia de Desenvolvimento Habitacional de São Paulo em 1981; em 1984 passa a ser chamada de $\mathrm{CDH}$ - Companhia de Desenvolvimento Habitacional de São Paulo e em 1989 recebe o seu atual nome. A nova estatal absorve o DOP - Departamento de Obras Públicas e a CONESP - Companhia de Construções Escolares.

${ }^{21}$ Cândido Malta CAmpos FILHo. Notas tomadas durante aula ministrada na disciplina AUP572I - Atelier de projeto urbano, PG-FAUUSP, 2003.
Baseado na teoria de Topalov, o urbanista e estudioso das formas de produção do espaço, Professor Cândido Malta Campos Filho, classifica as formas de produção do espaço, preferindo o termo configurações produtivas do espaço urbano, como sendo:

- Rentismo: praticado por empresas ou pessoas que posteriormente dão origem ao incorporador;

- Produção pública de moradias: sua existência é justificada pela limitação da iniciativa privada na produção do espaço; organizou-se na forma de IAPs, COHAB e $\mathrm{CDHU}^{20}$;

- Autoconstrução popular: na forma de mutirão de amigos;

- Encomenda dos ricos: primeiramente com valor de uso, tem como aliado, o prestígio ${ }^{21}$.

\section{I.I. Produção por encomenda}

É a encomenda feita pelas camadas da população de alta renda, na forma de moradias, cujo resultado ou produto tem inicialmente valor de uso até o momento que passa a ter valor de troca, quando este é colocado no mercado. Compra-se o terreno, contrata-se o arquiteto e o construtor. Bons exemplos de produção do espaço construído por encomenda são as mansões dos barões do café do começo do século 20, em São Paulo e as atuais residências de classe média. Edifícios industriais ou para serviços também são exemplos de produção por encomenda. Como colocado por Jaramillo, a produção por encomenda da mesma forma que a autoconstrução, também encerra processos de produção industrial capitalistas, na forma de materiais de construção industrializados e mão-de-obra assalariada.

\footnotetext{
Esta forma de produção é caracterizada pelo fato de que quem exerce o controle econômico direto de produção é o próprio 'usuário final', enquanto que quem detém o controle técnico é um agente distinto o qual denominaremos 'construtor', quem opera à base de explorar o trabalho assalariado (Jaramillo, 1982, p. I77).
}

Segundo Topalov, existe uma "renda do solo determinada pelos usos capitalistas potenciais do solo: a produção direta da moradia como valor de uso, que está à margem do sistema, mas que terá, no entanto, que pagar seu tributo ao mercado capitalista do solo urbano" (1979, p. 143).

Pode-se observar que a produção por encomenda, enquanto valor de uso, também é uma produção doméstica, de padrão mais alto. Segundo Topalov, "a produção não mercantilizada" descansa sobre a relação direta de uso pelo consumidor do produto-moradia com valor de uso e não como mercadoria. Essa produção não mercantilizada pode apresentar duas formas: a autoconstrução individual ou coletiva onde o futuro morador constrói sobre o terreno de sua propriedade e, na segunda forma, quando há a contratação pelo proprietário do terreno para que este construa a sua moradia (Topalov, 1979, p. 137).

\subsubsection{A autoconstrução e a produção urbana marginal}

A autoconstrução ou produção doméstica é uma forma de produção do espaço, principalmente de moradias, dentro de uma economia de subsistência, quando o proprietário ou arrendatário do lote constrói sua casa, seja com as próprias mãos, seja na forma de mutirão de amigos ou com pequenas contratações de conhecidos na execução de alguns serviços específicos. A autoconstrução apresenta características capitalistas de produção, pois utiliza materiais produzidos industrialmente, utilizando mão-de-obra assalariada. 
Nos países desenvolvidos a autoconstrução atinge uma pequena camada da população como camponeses, os trabalhadores da obra e a população urbana mais pobre, principalmente os trabalhadores estrangeiros. No entanto pode acontecer com mais intensidade nos períodos de crescimento urbano acelerado e na falta de produção pública ou privada (Topalov, 1979, p. 142)

Ainda segundo Topalov, no fim da década de 1970, alguns países europeus dependentes de periferias apresentavam uma produção clandestina, nome dado à produção urbana marginal, era também realizada por promotores imobiliários (1979, p. 142).

Colocando o Brasil no contexto apresentado por Topalov na década de 1970, a autoconstrução da moradia teve e tem papel mais importante no panorama brasileiro que nos países de primeiro mundo, em virtude da periferização da cidade, a partir da década de 1960, quando o trabalhador de baixa renda, em virtude do encarecimento dos aluguéis nas áreas centrais e da omissão do Estado na provisão de moradia busca lotes mais baratos ainda que mais distantes, para construir sua moradia com as próprias mãos.

Solà-Morales diferencia a produção urbana marginal da suburbanização:

\begin{abstract}
A urbanização ou produção urbana marginal é uma forma de crescimento urbano baseado no parcelamento ou fracionamento do solo e a venda de lotes de solo natural fora das exigências legais, onde o comprador constrói com o tempo, a sua moradia. $\bigcirc$ tipo de edificação resultante é autoconstruída, econômica e adaptável à medida que a capacidade econômica de seus usuários cresce. A produção marginal é diferente do crescimento suburbano, porque este último está baseado na conexão direta com a infra-estrutura e é a partir dela que nasce esse tipo de urbanização. As favelas são resultantes desse tipo de crescimento, onde o elemento fundamental é a própria construção dos barracos, sem que exista praticamente nenhum plano prévio de urbanização ou parcelamento do solo. As causas da produção marginal são: a importância desses bairros na formação de mais-valia na cidade e o próprio processo de autoconstrução das casas e sua melhora progressiva que, apesar da ilegalidade, permite ajuste entre os recursos disponíveis e o espaço residencial (Solà-Morales, 1997, p. 166 e 169).
\end{abstract}

Pode-se, portanto, classificar o processo da autoconstrução no Brasil como uma forma de produção urbana marginal onde, além da privação da qualidade ambiental e do fácil acesso a serviços oferecidos pela cidade, este processo se apropria de elemento muito importante na vida do operário e sua família: as suas horas de lazer ou descanso.

\title{
2.I.3. Produção capitalista do espaço urbano
}

A produção imobiliária capitalista surge a partir do rentismo, quando este deixa de ser lucrativo aos investidores, dando origem aos incorporadores e promotores imobiliários. As empresas de incorporação inserem-se dentro do capitalismo competitivo, pois a competitividade entre empresas pode resultar em produtos mais baratos e de melhor qualidade. O capitalismo competitivo surge na Inglaterra entre o final do século 18 e início do século 1922.

A primeira condição da produção imobiliária capitalista é a transformação da moradia em mercadoria. A promoção imobiliária é o sistema capitalista mais desenvolvido, com duas condições estruturais essenciais: por um lado a transformação da moradia em mercadoria e por outro a transformação do solo em mercadoria. A promoção imobiliária pressupõe a destruição ou marginalização de sistemas anteriores de produção, porque se destruíram as relações sociais fundamentais que caracterizavam cada um deles (Topalov, 1979, p. I37).

Segundo Ball, que analisa a provisão de moradias na Inglaterra na Idade Média, no feudalismo os edifícios não eram mercadoria e tinham apenas valor de uso para quem os encomendava, o que não implicava na existência de produção capitalista de moradia, para o qual seria necessário o consumo em grande escala, o que veio com a separação entre mora- 
dia e local de trabalho (os trabalhadores urbanos inicialmente moravam nas oficinas em que trabalhavam). Os primeiros consumidores de moradias produzidas na forma capitalista foram os pobres urbanos, em função do desemprego ou trabalhos temporários e os nobres ricos e posteriormente, os próprios capitalistas ${ }^{23}$ (Ball, | 99 |, p. |4).

A produção capitalista de moradias ou produção para o mercado, para venda e rentismo, no Brasil, começa com a construção de moradias formais e cortiços para acomodar os imigrantes, principalmente italianos, trazidos para trabalhar nas lavouras de café e que posteriormente se voltaram ao trabalho nas fábricas que surgiam no início do século 20. Quando Jaramillo cita a superposição entre as formas de produção, ou seja, a produção por encomenda dependente da produção capitalista de materiais, que também abastece a autoconstrução e que por sua vez emprega mão-de-obra de forma capitalista, pode-se considerar que a construção de cortiços, apesar de ser um tipo de construção ou habitação precária, se trata de forma capitalista de provisão de moradia para o mercado de baixa renda ou para a classe trabalhadora.

A cidade de São Paulo, por ser o principal centro industrial brasileiro no processo de industrialização, teve grande parte de sua área urbanizada pela construção de inúmeras vilas operárias formadas por casas de dois pavimentos agrupadas, em bairros como Lapa, Brás e Mooca, dentre outros. Muitos industriais vislumbraram na construção dessas moradias, diversificação para seus investimentos, construindo-as ao lado ou próximas a suas indústrias e alugando-as aos próprios operários.

\subsubsection{Produção do espaço urbano pelo Estado}

A produção estatal ou produção pública deve entrar em ação quando a iniciativa privada não dá conta de suprir moradias a preços compatíveis com os rendimentos da população assalariada e para produzir edifícios governamentais ou equipamentos urbanos públicos.

País de industrialização tardia, a Holanda tem seus bancos reconhecidos como instituições bancárias a partir do início do século 20. Em virtude das condições de vida difíceis nas grandes cidades, o governo desse país agiu como financiador e estimulador da produção privada de moradias e cria a Lei Woningwet, em 1901. Esta lei fixa o valor dos aluguéis não em relação ao valor do investimento, mas em relação ao valor social da habitação. $\bigcirc$ Estado produz por vias indiretas, através de sociedades sem fins lucrativos criadas por industriais que constroem habitações operárias anexas a suas fábricas. Durante 30 a 40 anos, essa lei foi um paradigma na Europa, pois teve conseqüências extremamente benéficas, como o planejamento de longo prazo do território da cidade e a criação de planos diretores ${ }^{24}$.

A partir da década de 20, os investidores privados se desinteressaram da construção de cidades no Brasil, seja na infra-estrutura urbana, seja em vilas operárias, em virtude da fome de capitais na industrialização em ascensão. Pouco a pouco o Estado passou a assumir parcelas dos investimentos urbanos, criando condições gerais exigidas pela industrialização, principalmente o transporte ferroviário, essencial para os trabalhadores pobres e o transporte urbano por ônibus (década de 40). Essa crescente estatização dos meios coletivos de produção e consumo foi provocada pelo interesse do capital em aumentar seus lucros e manter os salá-

23 Publicado originalmente na revista IJUR Internacional Journal of Urban and Reserch, n० 5, 1991 in Revista Espaço e Debates, 1992, n³6, p.II.

24 Paulo Bruna. Anotações durante aula da disciplina AUH58I9 - História Social da Arquitetura e do Urbanismo Modernos, PG-FAUUSP, 2004. rios dos trabalhadores achatados, o que deixava os trabalhadores sem condições de comprar serviços urbanos produzidos pela iniciativa privada, o que exigia o subsídio estatal (Campos Fillho, 1989, p.32)

Durante a industrialização da cidade de São Paulo não houve por parte do Estado nenhum movimento em direção à provisão de moradias para operários ou seu subsídio. "Até o início da década de 1930, a luta dos operários, principalmente, era por salário, ou seja, não havia uma discussão clara sobre a questão de habitação e sua vinculação com o Estado" (Maria F. S. Farah, 1983 in Gawryszewski, 1996, p. 130). 
Os IAP's foram criados na década de 1930 para controlar as ações do Estado voltadas a setores mais organizados de funcionários públicos como bancários, marítimos e outros. Em função da pressão por moradias subsidiadas, o próprio Estado cria então o IAPI - Instituto de Aposentadorias e Pensões dos Industriários, em 1936. Até o final dos anos 50 e meados dos 60, eram os antigos IAPs (IAPC, IAPB, IAPI, IAPTEC, IAPM, Ipase) que movimentavam fabulosas somas na produção de moradias para funcionários públicos. (Maria F. S. Farah, 1983, in Gawryszewski, 1996, p. 129).

Foi através da criação do BNH - Banco Nacional da Habitação, e do SFH - Sistema Financeiro da Habitação, que financiavam a aquisição de imóveis residenciais com capital privado, que o Estado, em 1964, passa a produzir conjuntos residenciais para funcionários públicos. A produção estatal de moradias foi se organizando ao longo do tempo através dos IAP's, $\mathrm{COHAB}, \mathrm{CDHU}$ e outros programas de atendimento às classes menos privilegiadas.

Jaramillo adverte que as formas de produção do espaço apresentadas podem ocorrer um pouco modificadas quando se passa do plano da abstração para o plano concreto, ou seja, as formas de produção do espaço raras vezes se apresentam em seu estado puro. $O$ autor faz uma síntese dessas formas de produção do espaço e a inter-relação de seus elementos conforme o quadro a seguir.

Quadro 1 - Formas de produção do espaço construído Fonte: Jaramillo, 1982, p.211

\begin{tabular}{|c|c|c|c|c|}
\hline $\begin{array}{l}\text { Formas de } \\
\text { produção }\end{array}$ & Autoconstrução & $\begin{array}{l}\text { Produção por } \\
\text { encomenda }\end{array}$ & $\begin{array}{l}\text { Promoção } \\
\text { capitalista }\end{array}$ & $\begin{array}{c}\text { Produção estatal } \\
\text { capitalista desvalorizada }\end{array}$ \\
\hline $\begin{array}{l}\text { Controle técnico } \\
\text { da produção }\end{array}$ & Usuário final & $\begin{array}{l}\text { Trabalhador } \\
\text { assalariado }\end{array}$ & Trabalhador assalariado & Trabalhador assalariado \\
\hline $\begin{array}{l}\text { Controle técnico } \\
\text { da produção }\end{array}$ & Usuário final & Prestador de serviços & $\begin{array}{l}\text { Capital ou seu agente } \\
\text { subordinado }\end{array}$ & $\begin{array}{c}\text { Capital estatal desvalorizado } \\
\text { ou capital privado }\end{array}$ \\
\hline $\begin{array}{l}\text { Valor da } \\
\text { produção }\end{array}$ & $\begin{array}{l}\text { Autoprovisão de um } \\
\text { valor de uso } \\
\text { Valorização de } \\
\text { força de trabalho }\end{array}$ & $\begin{array}{l}\text { Autoprovisão de } \\
\text { um valor de uso }\end{array}$ & Acumulação de capital & $\begin{array}{l}\text { Produção da força trabalho- } \\
\text { acumulação } \\
\text { Acumulação de capital construtor } \\
\text { Reprodução geral de relação social }\end{array}$ \\
\hline $\begin{array}{l}\text { Controle } \\
\text { econômico } \\
\text { indireto }\end{array}$ & $\begin{array}{l}\text { Mercado do solo } \\
\text { Mercado de trabalho }\end{array}$ & $\begin{array}{l}\text { Mercado de solo } \\
\text { Loteador de terrenos } \\
\text { Planejadores }\end{array}$ & $\begin{array}{l}\text { Mecanismos financeiros } \\
\text { Planejamento } \\
\text { Mercado de solo } \\
\text { Loteadores de terrenos }\end{array}$ & $\begin{array}{l}\text { Mercado de terras } \\
\text { Aparato político }\end{array}$ \\
\hline $\begin{array}{l}\text { Formas de } \\
\text { circulação }\end{array}$ & Autoprovisão & Autoprovisão & Mercado livre & Atribuição mercantil \\
\hline
\end{tabular}

\section{Breve histórico do planejamento urbano em São Paulo}

No final do século 19, o urbanismo técnico-setorial teve visão técnica de necessidades como saneamento, transporte e habitação e trouxe no bojo uma visão de conjunto, priorizando as obras necessárias aos sistemas de abastecimento de água e viários, e produziram os primeiros códigos sanitários. Em seguida, tem lugar o urbanismo das intervenções pontuais que embelezava a cidade para a burguesia cafeeira, seguindo o modelo francês para o urbanismo e o modelo italiano para a arquitetura. No começo do século 20 surge o urbanismo sistêmico, com seu plano de avenidas e obras para grandes sistemas de distribuição de água e transportes. Ainda na primeira metade do século 20, o urbanismo crescentemente politizado do modelo Padre Lebret produz os primeiros planos diretores. Também tem lugar o movimento socializante das cidades-jardim, que preconizava o equilíbrio entre natureza e espaço construído, exemplificados pelos bairros-jardim da cidade de São Paulo. $\bigcirc$ urbanismo modernista propõe os sistemas de transporte elevados do chão e grandes espaços entre blocos. Brasília é um exemplo disso ${ }^{26}$.
${ }^{25}$ Criado em 1964, o BNH era um banco de segunda linha, ou seja, não operava diretamente com o público. Sua função era realizar operações de crédito e gerir o Fundo de Garantia do Tempo de Serviço, por intermédio de bancos privados ou públicos e de agentes promotores, como as companhias habitacionais e as companhias de água e esgoto. $\mathrm{O}$ BNH foi a principal instituição federal de desenvolvimento urbano da história brasileira, na qualidade de gestor do FGTS e da formulação e implementação do Sistema Financeiro da Habitação (SFH) e do Sistema Financeiro do Saneamento (SFS). Foi extinto, por decreto presidencial, em 1986. Marta T. S. ARRETCHE. www.mre.gov.br/cdbrasil/itamaraty/web/ port/economia/saneam/planasa/bnh/).

${ }^{26}$ Cândido Malta CAMpos FILHo. Notas tomadas nas aulas da disciplina AUP 5721 - Atelier de Projeto Urbano, PG-FAUUSP, 2003. 
27 Olavo Egídio Setúbal foi prefeito nomeado do Município de São Paulo no período de agosto de 1975 a julho de 1979.

${ }^{28}$ CODEVIN - Conselho de Desenvolvimento Urbano, um dos três Conselhos Inter-secretarias criados na COGEP pelo SecretárioCoordenador do Planejamento, Prof. Dr. Cândido Malta Campos Filho, na gestão municipal entre 1975 e 1979.

${ }^{29}$ O distrito do Brás passa de 67.950 habitantes em I950 para 63.97| habitantes em 1960 e registra-se um decréscimo na população do Brás em relação ao recenseamento anterior; em 1970, registra-se um novo processo de perda de população, passando para $51.25 \mathrm{I}$ habitantes; em 1980, o distrito registra uma população de 44.886 habitantes; em 1991 a população do Brás volta a diminuir para 33.536 e em 2000, a população do Brás é de 25. 158 habitantes.

Fonte: IBGE - Censos

Demográficos de 1950, 1960, 1970, 1980, 199| e 2000 .
Em 1970, Langenbuch afirma que a administração pública tem árduas tarefas: melhorar o que existe, corrigindo os erros ocasionados pela falta de planejamento, e planejar para o futuro, evitando erros. Segundo o autor, o administrador deve conhecer muito bem a realidade presente e estar a par das técnicas necessárias para atingir seus objetivos.

Para Campos Filho, não é simples o planejamento urbano e para os que o encaram assim, seriam necessárias para ordenar as cidades e resolver seus problemas apenas racionalidade e honestidade, numa abordagem técnico-científica. Ainda segundo o autor, é preciso também "reforçar os centros de pesquisa e os órgãos técnico-governamentais de decisão e implementação das políticas orientadoras de soluções dos problemas das cidades e excluir os desonestos do processo decisório" (Campos Filho, 1989, p.5).

A partir dos anos 1980, o chamado "planejamento estratégico" passou a figurar de maneira proeminente entre as políticas urbanas adotadas por municipalidades européias, tornando-se muitas vezes nada mais que o sinônimo de uma postura competitiva e empresarial preocupada com a atração de investimentos, eventos e turismo, com a imagem urbana e a reinserção otimizada de cada cidade no panorama europeu e mundial (Somekh e Campos, Anpur, 2005).

Em São Paulo, a implantação da Linha Leste do Metrô foi o resultado do conjunto de diretrizes criado a partir das políticas de aspectos global dentro do planejamento desenvolvido pela Prefeitura do Município de São Paulo e que foram reunidas em publicações. A série Políticas Setoriais apresenta elementos das políticas Institucionais, de Habitação e de Desenvolvimento da Área Central. A política de Controle e Uso do Solo da gestão de Olavo Egídio Setúbal ${ }^{27}$ tinha como objetivo, além da aplicação de forma coerente da Lei de Zoneamento do Município de São Paulo, aprovada em 1972 e finalmente consolidada em 1978, "direcionar o desenvolvimento urbano para áreas consideradas mais adequadas a receber maior contingente populacional e de atividades urbanas". Uma das áreas consideradas foi a Zona Leste e sua valorização, evitando o crescimento no vetor sul, fortemente acelerado a partir da implantação da área industrial de Santo Amaro e seus acessos pela ferrovia FEPASA e pela Marginal do Rio Pinheiros. Para isso foram adotadas medidas de zoneamento para atingir esse objetivo e ao mesmo tempo decidiu-se pelo prolongamento de vias em direção ao leste da cidade como Avenida Alcântara Machado e Marginal do Rio Tietê, além de outras vias (COGEP/PMSP, 1979, p.7). O projeto de prolongamento da Radial Leste foi desenvolvido pelo CODEVIN28 por um grupo de trabalho constituído por todos os órgãos municipais envolvidos, até mesmo órgãos estaduais (Campos Filho, 1979, p.7).

Além desse projeto, outro investimento público para desenvolvimento da Zona Leste foi decidido, o Metrô, "de maior poder gerador do redirecionamento desejado, cuja influência é decisiva sobre os níveis de acessibilidade à região Leste". A política de uso e ocupação do solo praticada pela COGEP considerava o adensamento máximo do entorno da linha do metrô em função da conjugação desse sistema de transporte de massa à Radial Leste e à Marginal do Rio Tietê, com atração de tráfego através de linhas de transporte público coletivo e transporte individual (Campos Filho, 1979, p.7).

Apesar do forte adensamento desejado pelo governo do município, na prática o Brás, que tem em seu território duas estações da Linha Leste do Metrô, teve um forte declínio de sua população urbana residente, registrado entre os Censos Demográficos de 1980 e 2000, realizados pelo IBGE - Instituto Brasileiro de Geografia e Estatística. Também a pouca verticalização atual de suas edificações e o grande parque comercial instalado na quase totalidade de suas quadras de uso misto, vem confirmar que até o início do século 21 essa localidade segue perdendo população, fato que teve início já na década de $1950^{29}$. 


\section{Metodologia para análise do Tecido Urbano}

O urbanista Cândido Malta Campos Filho coloca o ambiente de moradia como a âncora do cidadão no espaço urbano e o considera ponto de partida para a análise das questões urbanas, com foco na ótica do cidadão comum. Considera também que a ausência de quintais ou áreas privativas para lazer deve ser compensada com o uso do espaço coletivo das ruas ou praças. Segundo ele, devem-se conhecer os tipos de estruturação de bairros e como estes estão servidos de comércio, serviços e de equipamentos públicos para educação, saúde, lazer e cultura (2003, p. I5).

A metodologia de Campos Filho para a análise do tecido urbano de uma região aborda a organização da cidade sob o ponto de vista da relação entre a moradia e seu entorno imediato. $\mathrm{O}$ autor divide o uso comercial e serviços em 3 níveis, usando como parâmetro a freqüência de demanda (Campos Filho, 2003, p. I7):

- Comércio e serviços de uso local (freqüência diária ou semanal);

- Comércio e serviços diversificados (freqüência mensal ou semestral);

- Comércio e serviços de apoio a outras atividades urbanas, sofisticados e muitíssimo diversificados (freqüência esporádica, semestral, anual ou maior).

Com essa classificação e abordagem, o autor considera que a qualidade de vida para o morador também está baseada nas distâncias a percorrer para consumir produtos e serviços, maiores ou menores, em função da freqüência da necessidade.

...para o morador interessa que, quanto maior for a freqüência da demanda, mais fácil deve ser o acesso a esse comércio ou serviço. Isto é, o 'local' deve estar o mais perto possível de sua casa; o 'diversificado' pode estar um pouco mais longe, e o 'sofisticado' mais longe ainda. Não que tenha que ficar mais longe; tê-los por perto significa, como veremos, aceitar viver em bairros centrais com certos inconvenientes e qualidades próprias (Campos Filho, 2003, p. 18).

Ainda segundo o autor, pode-se raciocinar da mesma maneira em relação a "equipamentos de educação e saúde de uso mais ou menos freqüente", onde a distância máxima a se percorrer a pé com conforto é de 800 metros (Campos Filho, 2003, pp. 18 20). A figura 2 mostra o esquema de quadras de ruas locais, desenhado por Campos Filho.

Como diretriz para o desenho ou reformulação de bairros, Campos Filho introduz o conceito de Unidade Ambiental de Moradia, unidade territorial onde a recomposição das energias gastas no trabalho é feita pela tranqüilidade oferecida pelo local onde se mora, "ilhas de tranqüilidade com ruas internas de tráfego apenas local, com pouco ou nenhum tráfego de passagem, com seu aumento controlado" com o espaço de morar espraiado "para o espaço de uso coletivo da rua, da praça (...) e dos parques", que hoje entram em conflito com o uso cada vez mais intenso do automóvel, que provocam a degradação ambiental do espaço de uso coletivo (2003, pp.23-24).

Segundo Campos Filho, para a redução do uso de automóvel, deve-se propor transporte coletivo multidirecional através de microônibus e de malhas cerradas de metrô.

$\mathrm{Na}$ análise do tecido urbano é possível identificar uma gradação de níveis de tranqüilidade no espaço de uma cidade, desde o mais tranqüilo com ruas com apenas moradias até outros mais barulhentos com casas de shows, bares e restaurantes (Campos Filho, 2003, p.25). Para isso, deve-se considerar o nível de ruído gerado pelo tráfego e tipo de
Figura 2

$O$ conceito de unidade ambiental de moradia.

Fonte: Cândido Malta Campos FILHO. Reinvente seu bairro. São Paulo: Editora 34, 2003, p.23. 
mobilidade das pessoas, por onde passam e por quais vias tendem a transitar e quais meios de transporte tendem a usar, mudando seus meios atuais. $\bigcirc$ zoneamento deve nascer desses cálculos no que se refere à intensidade do uso do solo, pois não se pode permitir instalação de atividades que exigirão maior capacidade de circulação do que se consegue implantar. Deve-se saber utilizar melhor os meios de circulação para melhorarmos a qualidade de vida na cidade de São Paulo (Campos Filho, 2003, pp.25-33). Para isso, Campos Filho defende o desenvolvimento de um Plano de Circulação e Transporte associado a um Plano de Uso do Solo e um de Habitação, como previstos pelo Plano diretor Estratégico para São Paulo, de 2002. Essa relação entre Circulação e Densidade de Uso do Solo deverá levar em consideração o tipo modal de circulação utilizado pelo cidadão, pois quanto maior for a proporção da modalidade transporte coletivo, maior poderá ser a Densidade de Uso do solo e vice-versa (2003, p.4I).

\section{I As tipologias do tecido urbano}

Segundo Campos Filho, "há diversos modos de organização das densidades maiores ou menores com qualidades ambientais específicas, cada densidade definindo tecidos urbanos de caras diferentes" (2003, p.54). Conforme ele nos aponta, existem diversos tipos de tecido urbano como a cidade-jardim horizontal ou semi-horizontal com edifícios de poucos pavimentos ou as cidades-jardim vertical com edifícios-torre de 10 pavimentos ou sem limite de altura, ou com edifícios de gabarito heterogêneo ou até zonas com usos diversificados próximos e densidade demográfica local alta ou zona mista com densidade demográfica baixa mas com grande extensão (2003, p.57).

Segundo esse urbanista e estudioso das tipologias urbanas, os tipos básicos de tecido urbano são quatro (2003, p.60):

\footnotetext{
30 As figuras retiradas do livro de CAmpos FILHo, Reinvente seu bairro, são aqui numeradas de 3 a 6 para evitar descontinuidades pois, no original, são desenhos numerados de 24 a 27.
} 
Tipo I: bairro nascendo e se desenvolvendo isoladamente, usualmente na periferia do espaço urbano da época em que é iniciado.

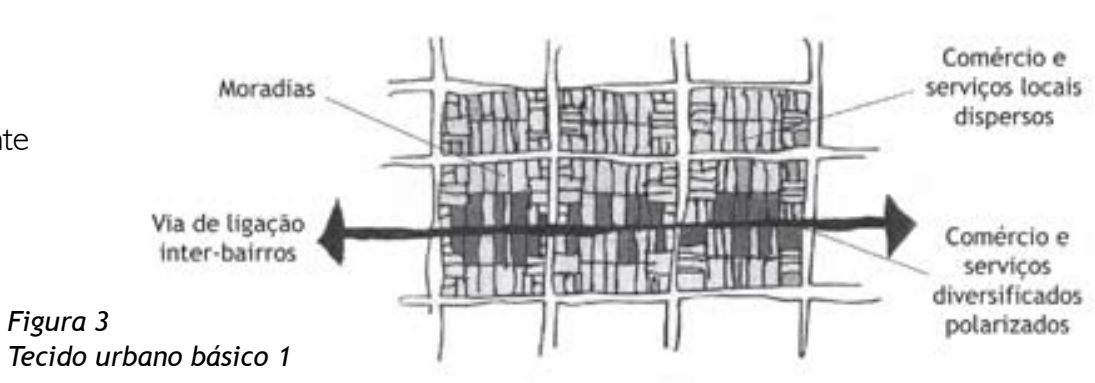

Tipo 2: bairro se relacionando a bairros vizinhos formando uma malha de bairros, conforme o território urbano vai se expandindo.

Figura 4

Tecido urbano básico 2

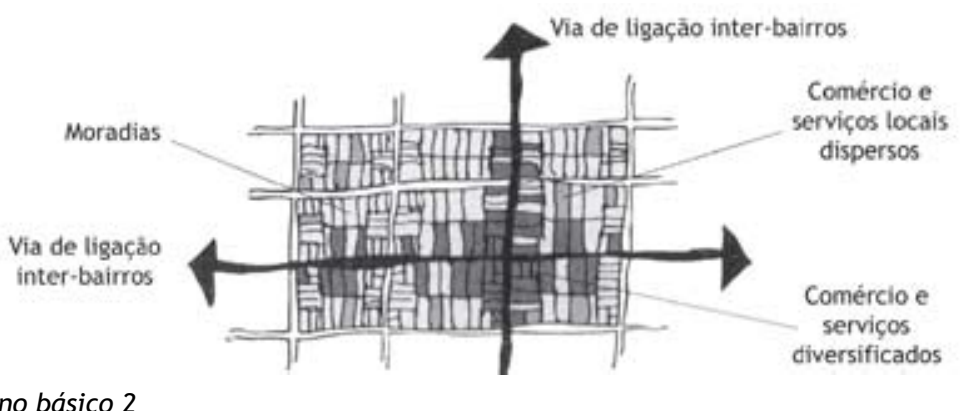

Tipo 3: bairro planejado tipo 'jardim', que nasce usualmente nas periferias urbanas da época em que são implantados e depois podem ir ficando centrais.

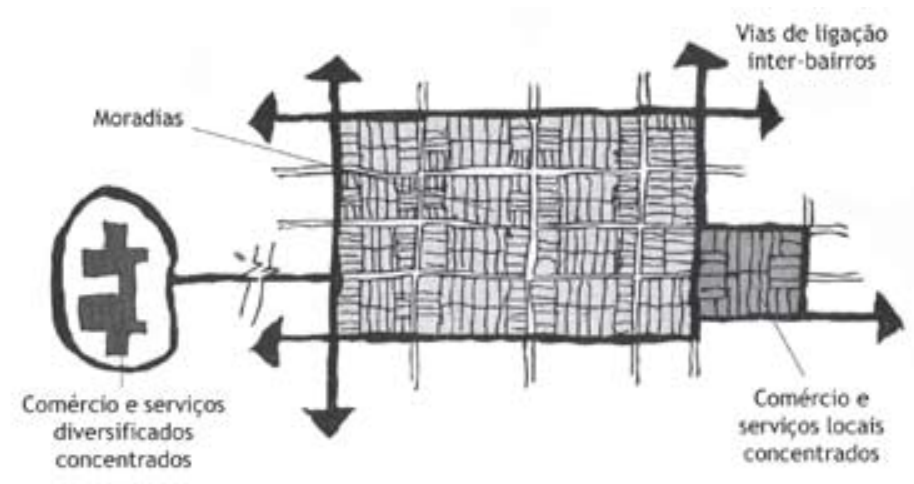

Figura 5

Tecido urbano básico 3

Tipo 4: bairro que se transformou em central na estrutura urbana devido a expansão do território da cidade.

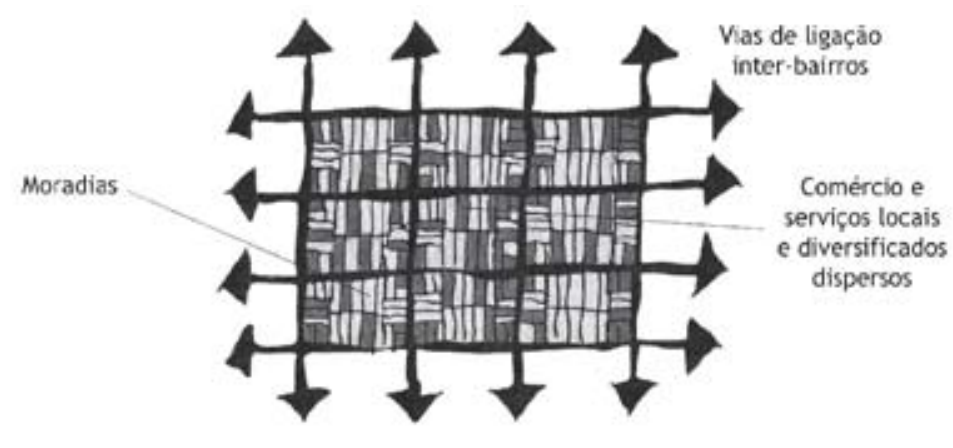

Figura 6

Tecido urbano básico 4 


\section{Capítulo II \\ A evolução urbana do Brás e Mooca}

Para traçar diretrizes para a requalificação urbana de distritos ou áreas industrializadas em processo de degradação ambiental ou que apresentem potencial para adensamento populacional como Brás, Mooca e Avenida Radial Leste - objetos de estudo desta dissertação - é imperativo conhecer e entender primeiramente todo o processo de seu desenvolvimento urbano. Para isso, fez-se um levantamento detalhado do histórico do crescimento urbano da área através da leitura e análise de mapas oficiais da cidade, a partir do século 19. Antes disso, apresenta-se um breve relato sobre o crescimento urbano da cidade de São Paulo com o objetivo de inserir esses dois bairros no contexto da cidade como um todo. A análise dos mapas e cartas históricos produzidos entre 1810 e 1972 levou a uma rápida análise da evolução do traçado viário e da mancha urbana da cidade e da área-objeto de estudo desta dissertação.

O período estudado foi delimitado pelo início do século 19, passando pela fase de parcelamento das chácaras que contornavam o centro histórico de São Paulo - ocorrido com maior intensidade a partir da segunda metade do século 19 - até o ano 2005.

O conhecimento dos primeiros loteadores - alguns dos agentes indutores do desenvolvimento urbano da área - permitiu também a localização de algumas das configurações produtivas do espaço como a produção capitalista de moradias operárias durante a fase da industrialização de São Paulo.

\section{Breve histórico do crescimento urbano de São Paulo: do século 17 ao início do século 20}

Em I530, D. João III, Rei de Portugal, passa a Martim Afonso de Souza a "carta para o capitãomor dar terras de sesmaria" permitindo a este conceder terras e criar vilas, com a obrigatoriedade de ocupação com cultivo, desbravamento da terra e o pagamento de dízimo sobre a produção à Ordem de Cristo. As sesmarias tinham uma légua de frente por uma de fundo e normalmente se estabelecia a frente utilizando-se as margens de um rio ou a linha costeira, ficando o fundo indefinido ou marcado por acidentes geográficos identificáveis (Rolnik, 1997, p.21).

Segundo relato de Paul Singer, em 168 I São Paulo era uma vila, sede da Capitania Hereditária de São Vicente, com 200 habitantes, passando à condição de cidade em 171 I. Em 1745 passou a sede de Bispado em virtude da localização estratégica entre o interior e o porto de Santos. Era a cidade do planalto mais próxima de São Vicente, onde estava a riqueza (minérios e índios), e por isso cidade-entreposto comercial entre regiões do país, com população rural maior que a urbana e economia colonial de subsistência (1966, p.24). "No começo do século XVII havia em São Paulo apenas 200 habitantes, em cerca de 100 casas, uma igreja paroquial, um convento" (Auguste de Saint-Hilaire in Marcílio, 2004, p.25I).

Em 1748, quando Portugal redesenhou as capitanias do Sul, São Paulo passou para a jurisdição da Capitania do Rio de Janeiro, perdendo sua condição de capital regional. Em I765, quando a região paulista recuperava sua autonomia, a população já atingira 20.832 habitantes (Marcílio, 2004, p.253). 


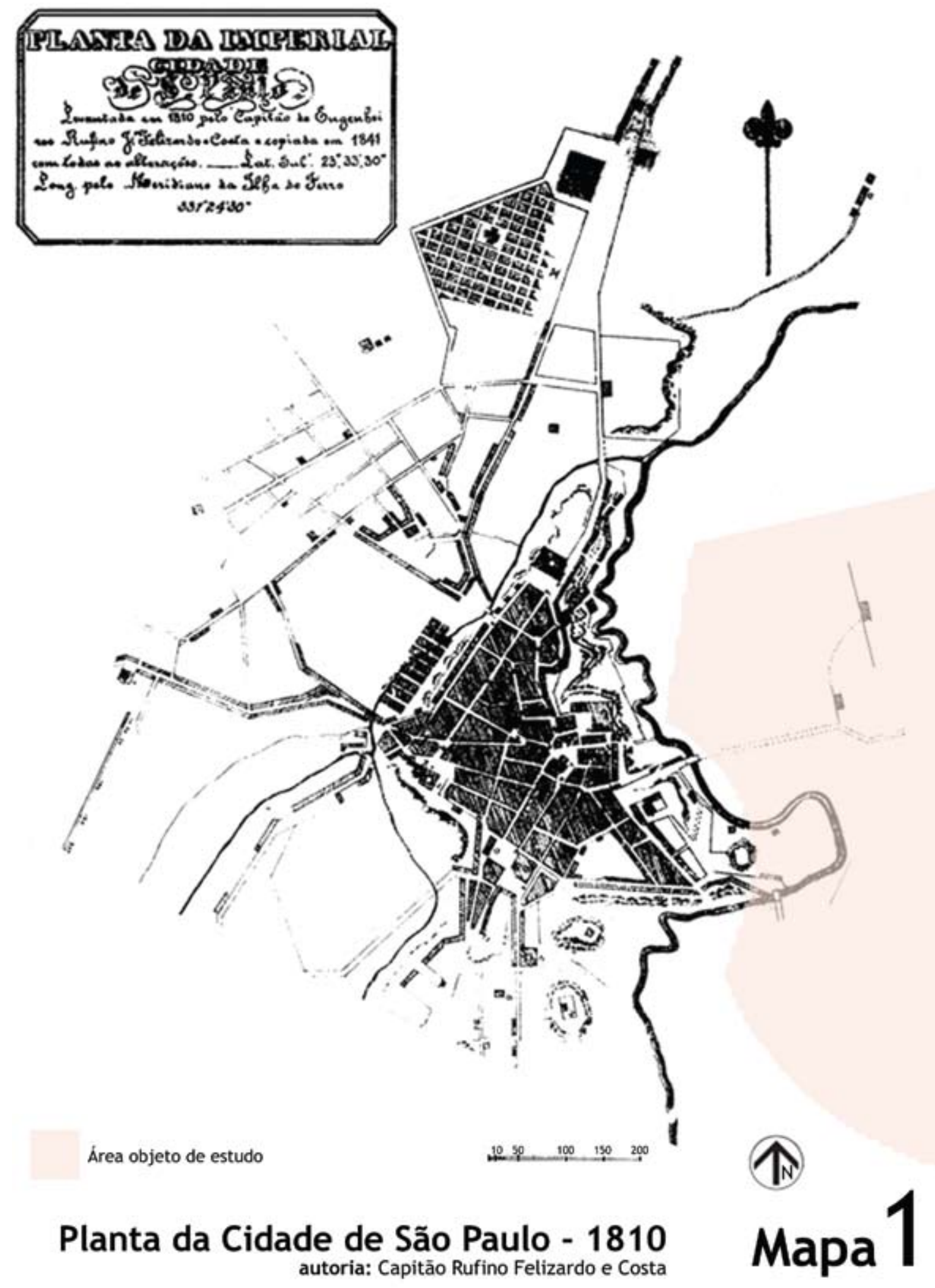


Falando um pouco da cidade de São Paulo e de suas "transformações urbanas nos séculos XVII e XVIII", segundo Aroldo de Azevedo (1958, p.38):

\begin{abstract}
Sem pretender fixar, dentro de exatos limites, a área ocupada pela vila e cidade paulistana, na era colonial - tarefa impossível, à falta de documentação precisa - pode-se dizer que essa área pouco se estendeu, desde o estabelecimento do primitivo núcleo quinhentista até os fins do século XVIII. O centro urbanizado da cidade estava confinado na área aproximadamente triangular, delimitada pelos cursos do Tamanduateí e do seu afluente Anhangabaú, sem atingir ao Norte a confluência destes dois cursos de água.
\end{abstract}

Segundo Azevedo (1958, p.49), a planta da cidade de São Paulo de 1810 - aqui apresentada no o Mapa I - de autoria de Rufino F. e Costa, "é fonte segura para o conhecimento da evolução urbana da cidade e faz parte do conjunto das duas plantas mais antigas da cidade, ao lado da planta de C.A. Bresser, engenheiro civil". Segundo Azevedo, são escassos os documentos disponíveis para coleta de informações sobre a cidade de São Paulo até o fim da primeira metade do século |8. Este mapa mostra o adensamento do centro histórico da cidade, contornado ao leste pelos meandros do Rio Tamanduateí encontrando-se, depois do rio, as propriedades rurais que formavam o Cinturão das Chácaras (Langenbuch, 1971, p.9). Ao oeste, o núcleo urbano da cidade estava limitado pelo Rio Anhangabaú. A população do município (urbana e rural) era então de 25.486 habitantes (Marcílio, 2004, p.253).

Pode-se observar através da leitura desse mapa que o curso do Tamanduateí estava ainda em seu traçado natural, antes de sua retificação. A Estrada do Brás ou Caminho para a Corte atravessava a grande várzea suscetível às cheias desse rio, em direção ao leste.

Das 10 freguesias que constituíam o termo da cidade, apenas três correspondiam ao centro urbano: Sé, Santa Ifigênia e Brás (Azevedo, 1958, p.55). O centro histórico, expandido e situado entre os Rios Tamanduateí e Anhangabaú, era formado nessa época por aproximadamente 30 quadras, contidas num traçado viário irregular que se expandia em direção norte e noroeste com algumas ortogonalidades, e outras tantas quadras, ainda desconectadas do conjunto maior. Além do centro histórico, chácaras ou grandes glebas compunham a área rural em torno do centro da cidade de São Paulo, no período entre o século 17 até meados do século 19, quando começou o processo de parcelamento dessas glebas e chácaras.

O "cinturão das chácaras" apresentava propriedades menores que o "cinturão caipira", onde ainda era comum uma certa indefinição fundiária, sendo freqüentes os litígios e as invasões, estas eventualmente relacionadas com a prática da rotação de terras pelo sistema de "roça", outras vezes à antiga estrutura ligada aos jesuítas e aos aldeamentos (Langenbuch, 1971, p.74).

A principal função econômica da cidade era o comércio diversificado do centro. Os camponeses habitantes da área de várzea, entre os rios Tamanduateí e Tietê, produziam e vendiam suas mercadorias agrícolas aos comerciantes da cidade, situados na Rua das Casinhas, hoje Rua do Tesouro, que as revendiam aos consumidores finais (Azevedo, 1958, p.6I). Segundo escritos de Saint-Hilaire (in Azevedo, 1958, p.61), as mercadorias produzidas nas propriedades rurais eram levadas por roceiros, negros e arrieiros com animais de carga.

O Mapa 2, das Chácaras, apresenta a divisão do território da cidade em grandes glebas e chácaras. Cada uma dessas propriedades apresenta uma data provável de sua aquisição. São datas diversas dentro de um período de quase 100 anos, dificultando estabelecer uma concomitância cronológica do parcelamento das terras. O Mapa das Chácaras, no entanto, representa uma conformaçã̃o de propriedades anterior à implantação da São Paulo Railway em 1867, conhecida como Ingleza, por ter sido construída por investidores ingleses e que não está ali graficamente representada. 


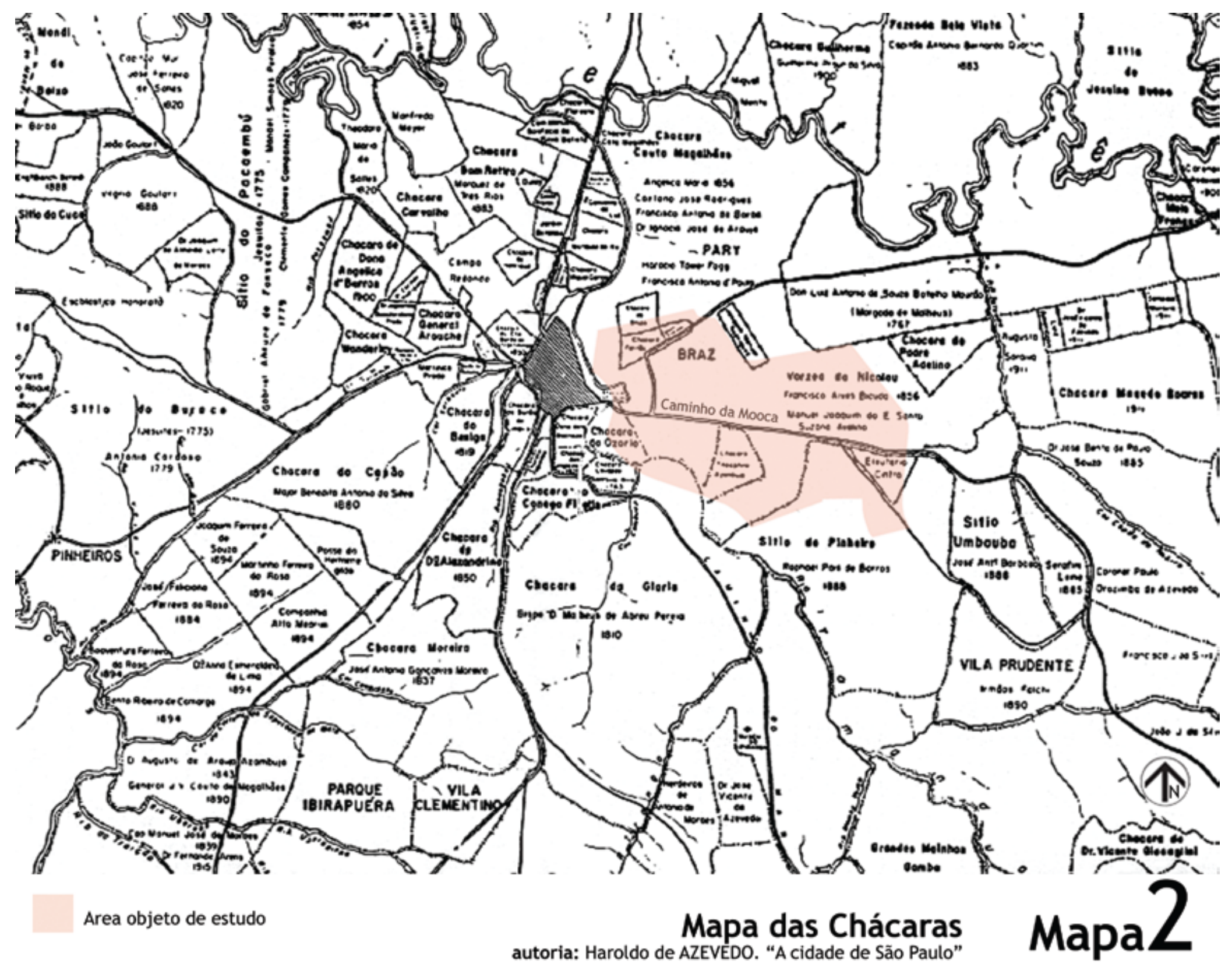




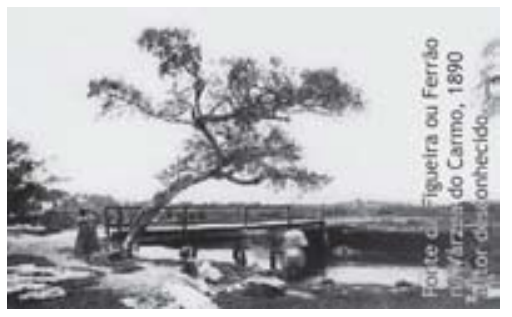

O bairro do Brás surgiu dentro de uma grande gleba de terras, chamada "Várzea do Nicolau", de propriedade de Francisco Alves Bicudo e Manoel Joaquim do Espírito Santo até pelo menos 1856, conforme a planta organizada por J. Rufino. Essa gleba estava delimitada ao oeste pelo rio Tamanduateí, ao leste por um córrego, ao sul pelo caminho da Mooca e, ao norte, pela Chácara do Padre Adelino (onde hoje fica parte do Tatuapé), pela grande gleba de propriedade de Don Luiz Antonio de Souza Botelho Mourão, o Morgado de Matheus e, finalmente, pelo Caminho para a Corte ou Caminho do Brás.

A área onde posteriormente se desenvolveu o bairro da Mooca localizava-se, em parte, no Sítio do Pinheiro, grande gleba de propriedade de Raphael Agenor Paes de Barros, por volta de 1888 , delimitada ao sudoeste pelo rio Tamanduateí, ao sudeste pela Vila Prudente, ao norte pelo caminho da Mooca e ao oeste por outra pequena propriedade. Era uma grande área plana, de várzea, suscetível às cheias do Rio Tamanduateí. A área da Mooca baixa, localizada no vértice formado pela Rua da Mooca e Avenida do Estado e limitada ao leste pela Ferrovia Santos-Jundiaí, era formada pela Chácara do Ozório e por parte da Chácara da Glória, quando seu proprietário era Abreu Pereira ainda na primeira metade do século 19.

O traçado viário na área-objeto de estudo era formado pelo Caminho do Brás ou Caminho para a Corte (à época localizada no Rio de Janeiro), que posteriormente deu origem à Avenida Rangel Pestana e ao Caminho da Mooca, atualmente Rua da Mooca. Esse conjunto de estradas levava os habitantes do centro urbano da cidade de São Paulo às propriedades e chácaras ao leste. Umas das pontes usadas para transpor o Rio Tamanduateí era a Ponte do Carmo.

Casas de fazenda e chácaras para lazer ou moradia fixa, construídas com taipa, representavam a tipologia das construções à época. Essas residências foram construídas provavelmente por encomenda utilizando-se mão-de-obra escrava. Eram habitadas por pequenos agricultores e por representantes da elite paulistana e seus empregados.

A criação da Faculdade de Direito em São Paulo se dá no ano de 1832. A cidade de São Paulo foi escolhida para sediar essa escola por ter custo de vida mais baixo que o Rio de Janeiro e Recife e porque, após a instauração da República, os ricos não mais podiam mandar os filhos para Coimbra.

Em 1836, a cidade de São Paulo tinha 9.291 habitantes urbanos dentro de um total de 21.933 habitantes no município (Singer, 1966, p. 19) e três freguesias (extensas áreas rurais - arrabaldes - com chácaras): Brás, Sé e Santa Ifigênia. A freguesia do Brás contava nesse ano com 659 habitantes, sendo que metade da população do Brás era composta por brancos e a outra metade composta por pardos e pretos em proporção de mesma expressão (Langenbuch, 1971 , p.9; Azevedo, 1958, p.55). A população da Mooca era ainda essencialmente rural.

"Zaluar, referindo-se especificamente às chácaras do Brás, escreve: 'É um dos arrabaldes mais belos e concorridos da cidade, já notável pelas elegantes casas de campo e deliciosas chácaras onde residem muitas famílias abastadas'”31.

Até meados do século 19, a cidade de São Paulo já apresentava economia de mercado

${ }^{31}$ Emílio Zaluar Augusto. Peregrinação pela província de São Paulo, p. 123 in Langenbuch, 1971, p. 10. externo com modesto setor de produção e exportação da cana-de-açúcar e população rural equivalente à urbana. Com um acanhado núcleo urbano, com áreas rurais mescladas a áreas urbanas, passa a Capital da Província (Singer, 1974, p.25).

Várzea do Carmo, nas imediações da Rua da Mooca, 1862

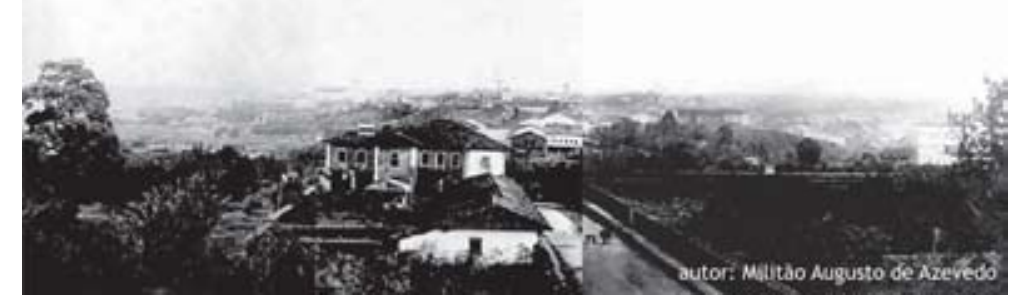


Segundo Langenbuch, no fim da primeira metade do século 19, São Paulo "já gozava de invejável posição de centro irradiador do sistema de circulação da província". Além das grandes estradas radiais ${ }^{32}$, várias correntes de circulação cruzavam os arredores paulistanos: circulação local, circulação entre os arredores e a cidade de São Paulo e entre a cidade e áreas mais afastadas (Interior). As correntes de circulação entre os arredores e a cidade tinham grande importância para o transporte de gêneros alimentícios, material de construção e artesanatos produzidos nos arredores paulistanos. Havia também grande circulação entre a cidade e os arredores pelos abastados paulistanos que residiam nas chácaras e pela população citadina em direção à periferia (Langenbuch, 197|, pp.31-32).

O relativo crescimento econômico da capital paulista, com o deslocamento do café para o oeste paulista e a construção da primeira ferrovia, a São Paulo Railway, em I867, que ligou a Capital ao porto, foram fatores que aceleraram a urbanização de São Paulo (Marcílio, 2004, p.263).

Na segunda metade do século 19, as primeiras chácaras da cidade começaram a ser loteadas, sendo que ao leste lotearam-se primeiramente a Chácara da Figueira e a Chácara do Ferrão (Toledo, 1981, p.78).

\begin{abstract}
O grande crescimento de São Paulo determinou, como é natural, uma expansão do espaço urbano sobre as áreas rurais contíguas, que passaram assim a integrar a cidade. Trata-se do processo de "extensão urbana por aglutinação"33, que afetou, sobretudo, o "cinturão das chácaras", cujo loteamento originava os novos bairros que surgiam (Langenbuch, 1971, p.79).
\end{abstract}

Em I868, o Engenheiro Carlos Roth prepara a Planta da Cidade de São Paulo (Mapa 3), que já apresentava um significativo conjunto viário no Brás ligado ao centro da cidade pela Rua do Brás, atual Avenida Rangel Pestana, e pela ponte do Carmo sobre o Rio Tamanduateí.

Enquanto a cidade de São Paulo já apresentava expansão urbana num vetor noroeste a partir do centro histórico, a ferrovia The São Paulo Railway, implantada em I867, começava a impor a geometria que conduziria o futuro traçado da área.

É o caso das terras à margem da Estrada de Ferro Central do Brasil, onde em cada "parada" surge um loteamento, ou da Vila Prudente, contida entre a Estrada da Mooca e o Rio da Mooca, ou do Ipiranga, limitado pelo riacho do mesmo nome e o Tamanduateí (Toledo, 1981, p.78).

O Mapa 3, de 1868, nos mostra já o traçado forte da Rua do Brás, futura Avenida Rangel Pestana, o traçado do Caminho da Mooca, futura Rua da Mooca, e a Rua Piratininga.O polígono é fechado ao oeste pelo Rio Tamanduateí em seu curso natural e, dentro daquele, o mapa mostra o território dividido ainda em pequenas e médias propriedades rurais. Ao sul da Rua da Mooca, estavam ainda as propriedades rurais ou chácaras. A cidade de taipa vai aos poucos sendo substituída pela cidade de alvenaria.

Depois da Guerra do Paraguai e da Lei do Ventre Livre (I87|), a população da cidade é afetada pela urbanização dos fazendeiros de café, que se transferiram para a Capital e que, a princípio, compraram terras e formaram as chácaras urbanas ao redor do centro urbano, dos fazendeiros mais ricos. Vieram depois as chácaras mais distantes, nos arredores da cidade, no espigão da Paulista, Pacaembu, Bela Vista, Consolação, Mooca e Vila Buarque (Marcílio, 2004, p.265).

As primeiras grandes transformações urbanas ocorreram durante a gestão do presidente Dr. João Teodoro Xavier, que governou o município entre 1872 e 1879. Foi o primeiro interessado em leis do urbanismo, ligando a Sé ao Brás (Toledo, 1981, p.80). O "cinturão das chácaras" além de ser penetrado pela expansão da cidade e pela instalação das fábricas, também passa a ser escolhido para abrigar estabelecimentos de grande porte que não mais
32 Estrada de Bragança, para o Sul de Minas; Estrada da Côrte, para o Rio de Janeiro, passando pelas freguesias do Brás, Penha e Vila de Mogi das Cruzes; Estrada de Santos, passando pela freguesia de São Bernardo; "Caminho do Carro" de Santo Amaro; Estrada do Sul, passando pela povoação de Pinheiros; Estrada de Itu via margem esquerda do Rio Tietê; Estrada de Itu via Parnaíba e Pirapora, que cruzava a Estrada de Goiás, passando por Jundiaí, a mais importante estrada de penetração in Langenbuch, 1971, p.30.

33 Georges Chaвот. Traité de Geographie Urbaine in Langenbuch, 1971, p.79. 


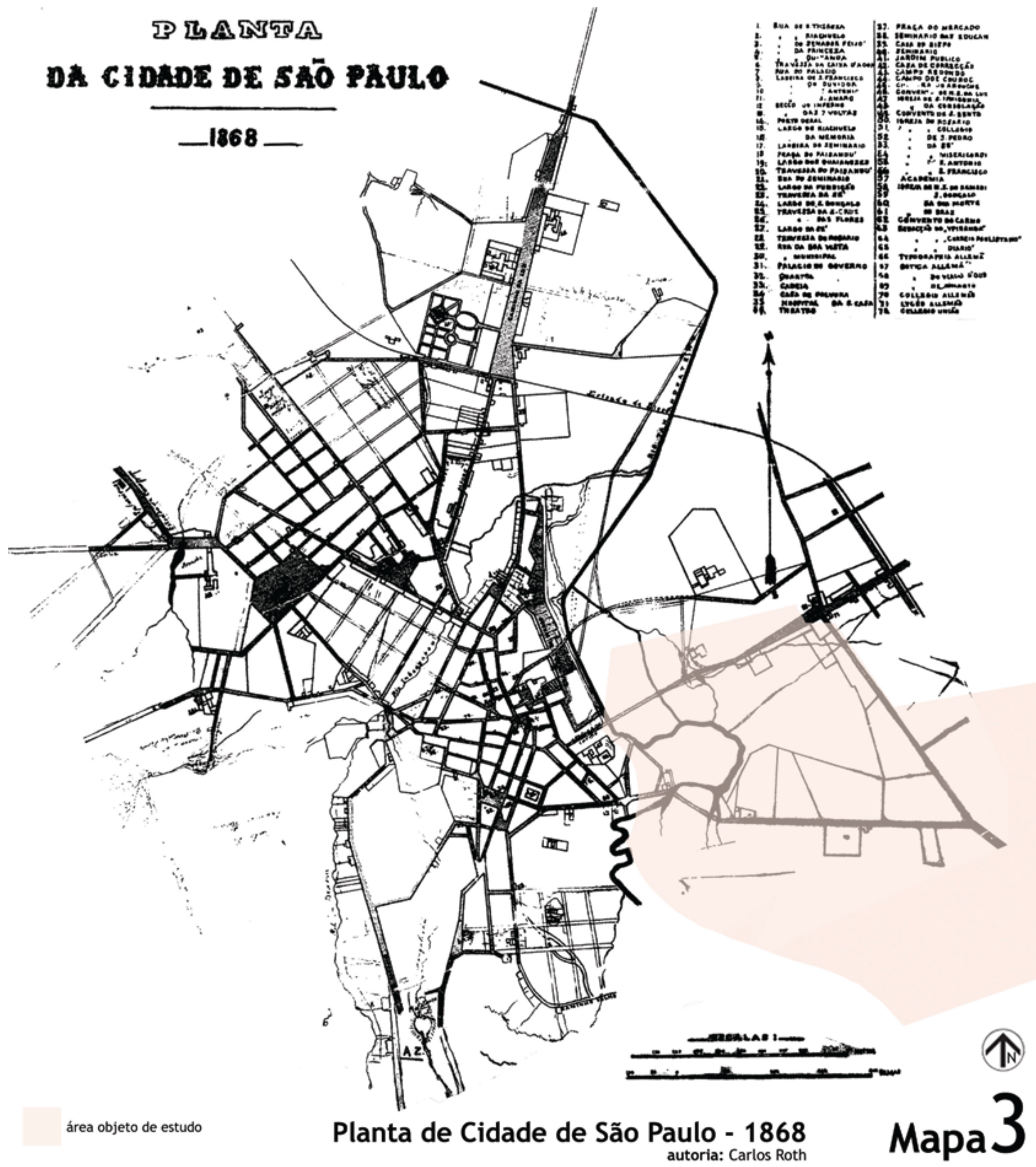


encontravam espaço na cidade já adensada, como o Hipódromo da Mooca, inaugurado em 1876, e a Hospedaria dos Imigrantes, inaugurada entre 1886 e 1888, às margens da São Paulo Railway, entre as estações do Brás e Mooca. Algumas chácaras ainda persistem com suas características originais (Langenbuch, 1971, p.81).

Em 1886, são proibidas as construções de cortiços na capital através das normas do Padrão Municipal dentro do perímetro urbano ${ }^{34}$. Os mesmos poderiam ser construídos em outras áreas da cidade, desde que obedecendo a uma série de critérios muito rigorosos, acima da realidade desse tipo de construção coletiva de aluguel. $\bigcirc$ Brás, que estava incluído no perímetro urbano da cidade, passa a ser considerado subúrbio em função da alteração do perímetro urbano para que pudesse receber construções de cortiços, necessárias para acomodar a classe operária.

A construção das demais ferrovias, na década de 1870, confirmou a vocação de São Paulo como entroncamento de estradas e como pólo comercial. Pequenas indústrias se desenvolveram na cidade, abrindo novas frentes de trabalho e de atração demográfica. A cidade registra a forte presença de imigrantes europeus, principalmente italianos, mas também de espanhóis, alemães, ingleses e outros que contribuíram para a expansão do comércio, indústria, artes, letras e ensino (Firmo de A. Diniz Junius in Marcílio, 2004, p.263).

Em I88I, a mancha urbana do Brás já havia ultrapassado as estações das ferrovias do Norte (posteriormente estação da Central do Brasil) e da ferrovia Santos-Jundiaí (estação do Brás) (Langenbuch, 197।, p.79). A cidade já tinha então uma população de mais de 120.000 habitantes (Rolnik, 1997, p.73).

A cidade, que até 1890 se expandira dentro de um bloco mais ou menos contínuo, passava agora a crescer lançando arruamentos isolados do bloco adensado, mas a eles ligados por estradas que atravessavam grandes extensões de terras vazias (Kawai, 2000, p. I 6) (o Mapa 4 ilustra a situação descrita por Kawai)

No fim do século 19, concomitantemente ao declínio da cafeicultura, a cidade era um grande entreposto comercial e já possuia parque industrial leve e serviços em expansão. Também já se tornara importante centro financeiro com duas agências bancárias e possuía uma elite consumista. A população atingira 64.934 habitantes em 1890 (Marcílio, 2004, p.266).

As áreas de várzea começaram a ser aterradas e as propriedades rurais deram lugar aos loteamentos de traçado ortogonal paralelos à linha férrea inglesa e a partir do traçado do caminho da Mooca, hoje Rua da Mooca. Outros bairros iam se formando com traçado ortogonal regular como Tatuapé e Penha, mas desconectados da mancha urbana da cidade, interligados a ela pelas vias anteriores a essa urbanização em focos, fenômeno descrito por Toledo:

Qualquer mapa de São Paulo de fins do século passado [19] ou início do presente [20] nos dá a impressão de inacabado. Vemos a área central já tomada pelos loteamentos, dela saindo caminhos ao longo dos quais vão surgindo outros loteamentos, deixando entre si largos espaços vazios. A configuração desses loteamentos é semelhante, seu perímetro exterior é irregular, formado por uma estrada, um rio, ribeirão ou outro acidente natural, como terrenos baixos e alagadiços. Dentro desses limites, o reticulado simplório, tendo uma das direções das ruas perpendiculares à via principal. É o caso das terras à margem da Estrada de Ferro Central do Brasil, onde em cada "parada" surge um loteamento, ou da Vila Prudente, contida entre a Estrada da Mooca e o Rio da Mooca, ou do Ipiranga, limitado pelo riacho do mesmo nome e o Tamanduateí (Toledo, 1981, p.79).

Segundo Langenbuch, "o início do último quartel do século passado [século 19] abre realmente uma nova fase na evolução da cidade de São Paulo". Entre 1890 e 1900 a cidade de São Paulo teve seu maior impulso evolutivo, passando de 64.934 habitantes em 1890 para

\footnotetext{
34 "No Padrão Municipal os cortiços inauguraram um capítulo à parte intitulado 'Cortiços, casas de operários e cubículos'. O efeito dessas regulamentações foi a demarcação de um zoneamento urbano correspondente à área central da cidade, onde a construção de cortiços era proibida" (Rolnik, 1997, p.35-36).
} 


\section{PLANTA}

DA

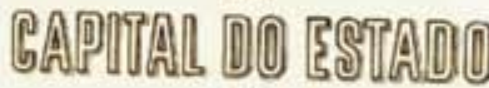

S. PAULD

c seva amabaidea

JULES MARTIN

1890

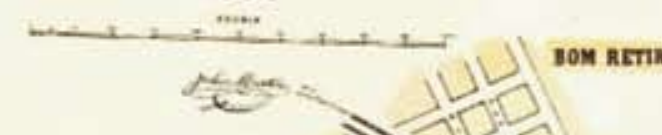

canpos errseos
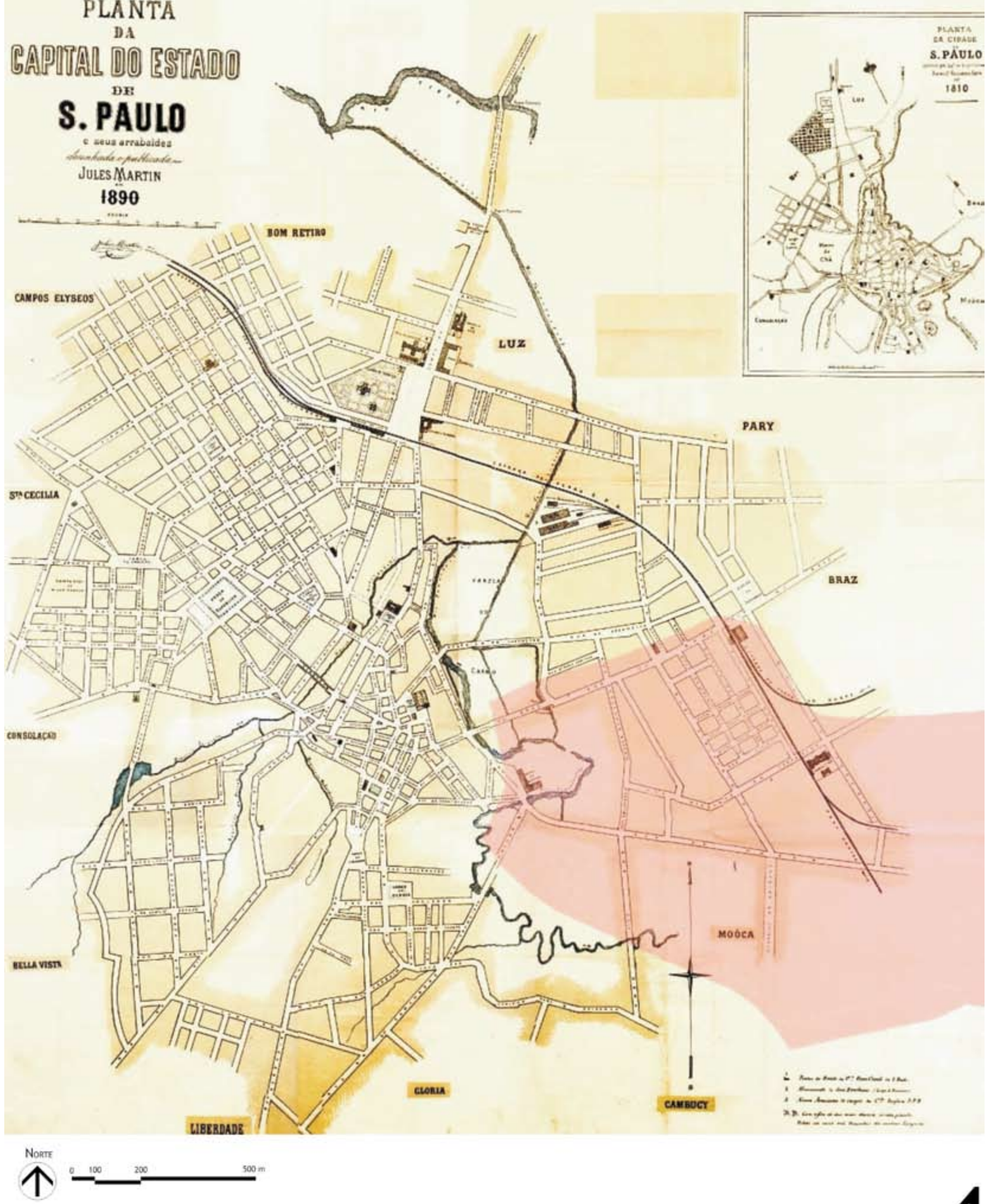
239.820 habitantes em 1900. "Constatamos que falta pouco para que o 'cinturão das chácaras' seja inteiramente absorvido pela cidade" (197|, p.82).

Nos primeiros anos do século 20, a municipalidade destinava mais de 10 vezes o valor gasto em obras viárias na área central da cidade que em bairros operários - em 1902, foram investidos 690 contos de réis no centro, 234 contos de réis na Consolação, 170 contos de réis nos Campos Elísios e 100 contos de réis no Brás e Mooca juntos (Rolnik, 2000, p. I I 3). O Mapa 6 ilustra a mancha urbana formada pela expansão das vias entre |88| e |9|4.

\section{Brás e Mooca na formação da cidade de São Paulo}

\section{I Das Chácaras ao fim do século 19}

O bairro do Brás foi elevado à categoria de freguesia em 1818 e tem sua história diretamente relacionada com a estrada São Paulo - Rio de Janeiro, onde já se havia estabelecido, em 1730, o português José Braz, com sua casa de comércio e albergue para tropeiros. Passou a Rua do Braz (atual Avenida Rangel Pestana) quando comerciantes de outros ramos começaram a se estabelecer à margem dessa estrada, que passava a assumir feições de rua (Langenbuch, 1971, p.4I).

Assim como o resto da cidade, do fim do século 18 até meados do século 19, Brás e Mooca eram basicamente bairros rurais compostos por terras de várzea, muito procuradas para a instalação de chácaras residenciais ou para lazer que tinham como moradores paulistanos abastados e aristocráticos. O Brás já dispunha nessa época, de um pequeno núcleo urbano, ao longo da Rua do Braz.

Ainda no século 18, segundo Azevedo, o acesso à várzea do Tamanduateí ficava prejudicado pela escarpa acentuada sujeita a desmoronamentos, da colina onde se situava o centro da cidade. Entre 1814 e 1828, obras viárias, como a construção da Ponte do Carmo, iniciam a ligação da cidade de São Paulo com a Corte, instalada na cidade do Rio de Janeiro. Projetada pelo urbanista Daniel Pedro Müller, essa obra viária é o primeiro trecho do que é hoje a Avenida Rangel Pestana, antiga Rua do Braz, por onde os tropeiros se dirigiam ao Rio de Janeiro. A ponte do Carmo era a principal ligação do Brás com o Centro Histórico.

"A cidade de São Paulo era circundada por um cinturão de chácaras que, além de fins agrícolas, encerravam importante função residencial. Muitos paulistanos ilustres residiam em suas chácaras", como Dr. Melo Franco, Mal. Arouche Toledo Rendon, Brigadeiro Jordão, Marquesa de Santos... (Langenbuch, 1971, pp.9-10).

O atual bairro do Brás fica onde em I 854 ficava a "Várzea do Nicolau", de propriedade de Francisco Alves Bicudo e Manoel Joaquim do Espírito Santo, que se estendia de onde hoje está a Rua Carneiro Leão até o Rio Aricanduva, afluente do Rio Tietê. $\bigcirc$ bairro da Mooca, no Sítio do Pinheiro, que em 1888 era propriedade de Raphael Agenor Paes de Barros. Essa propriedade estava localizada entre o Rio Tamanduateí e a Vila Prudente, já batizada naquela época com o nome de Mooca. Segundo Langenbuch, os aristocráticos proprietários de chácaras exerciam profissões urbanas e consumiam parte da produção agrícola de frutas e legumes produzidos nas pequenas propriedades rurais da região. No Brás, acomodavam-se "elegantes casas de campo e chácaras deliciosas junto a casebres e ranchos menos aristocráticos" (Zaluar in Langenbuch, pp. I0- I I).

Em meados do século 19, os trabalhadores, os pobres e os imigrantes foram destinados a fixar moradia do outro lado do Rio Tamanduateí em função das doenças que assolavam a classe operária e que induziram a legislação sanitarista a proibir a construção de novos cortiços no perímetro urbano da cidade. 


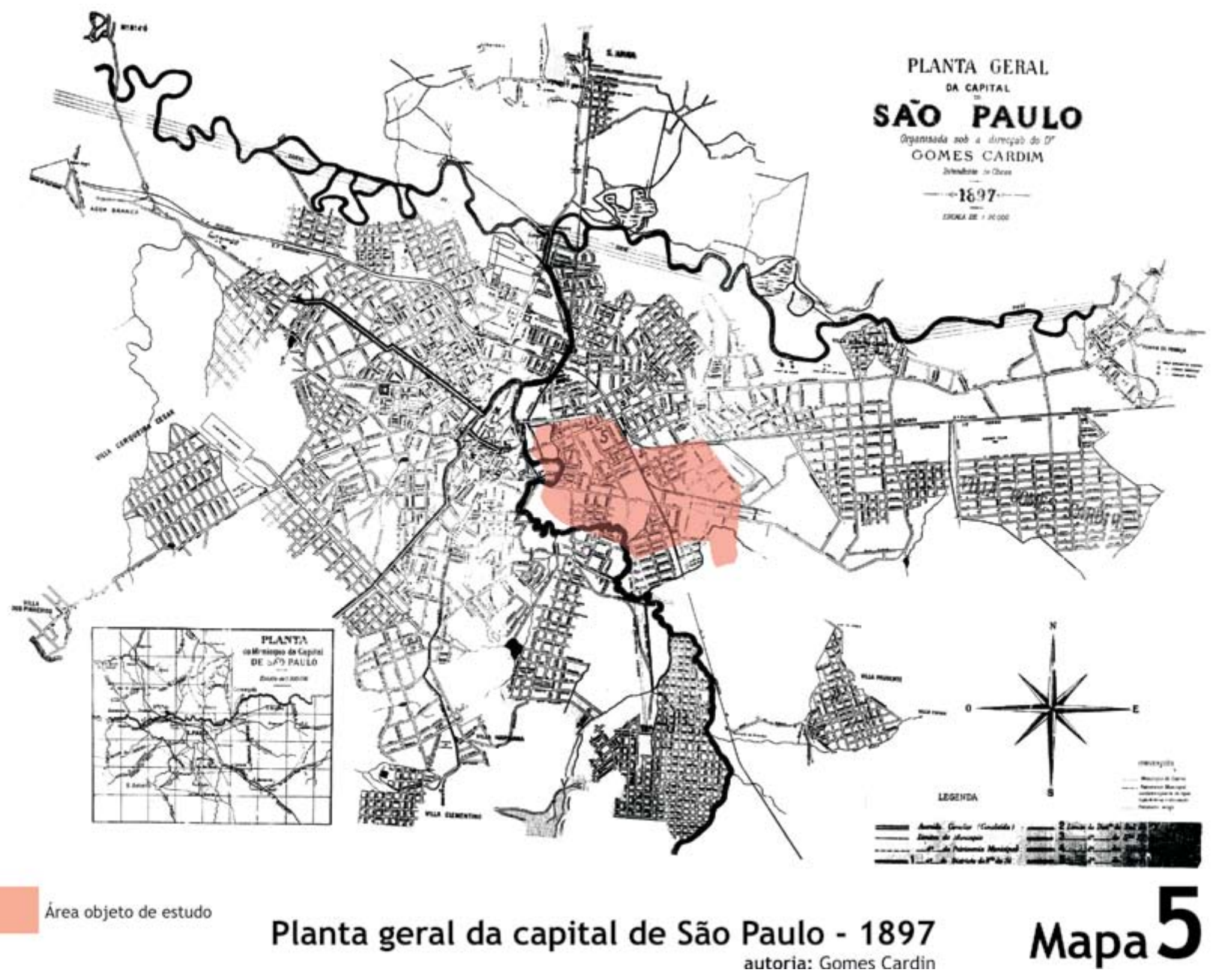



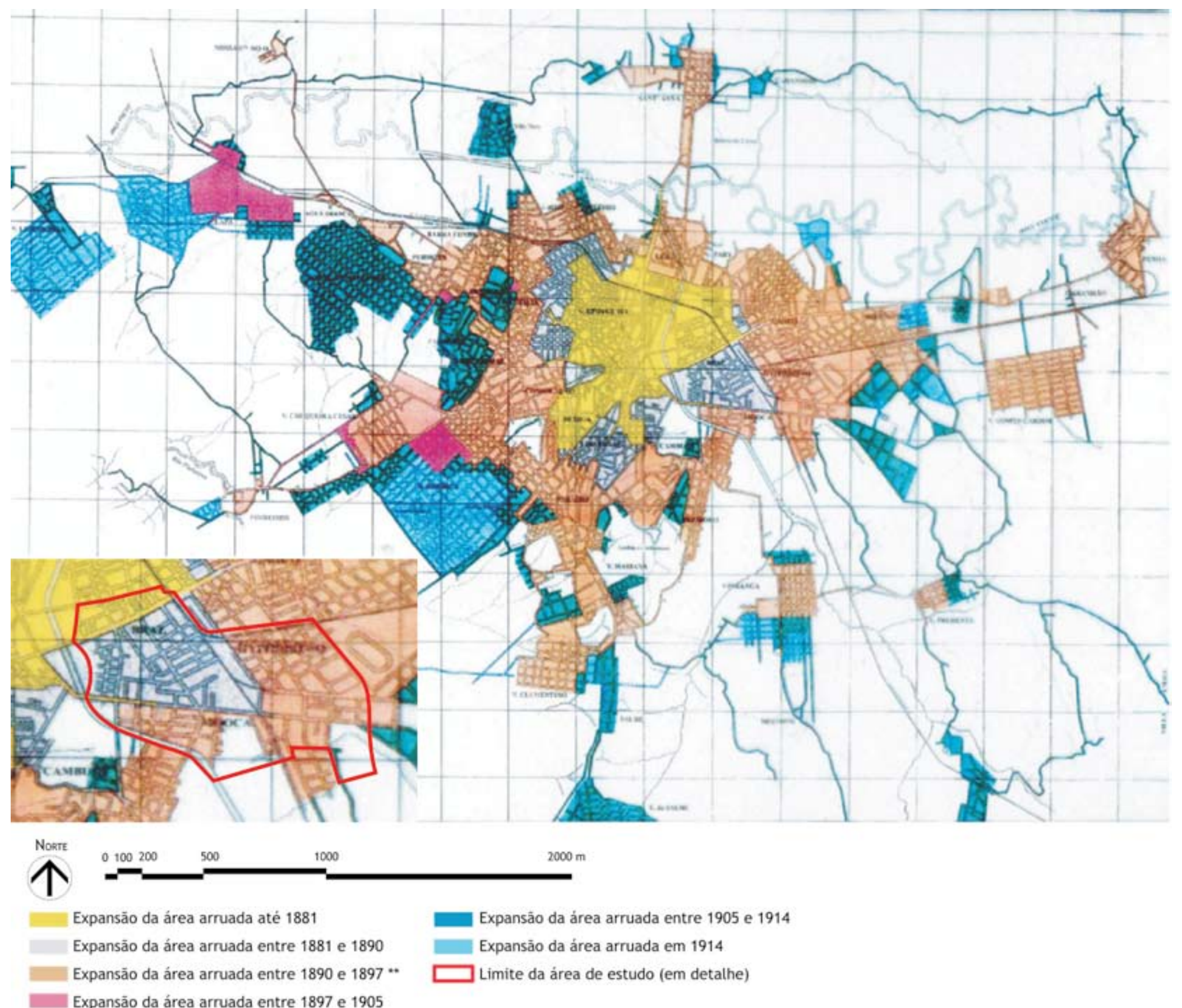

Mapa da expansão da área arruada da cidade de São Paulo entre 1881 e 1914 autoria: Mônica Silveira Brito sobre cópia esquemática da planta da cidade de São Paulo de 1914 

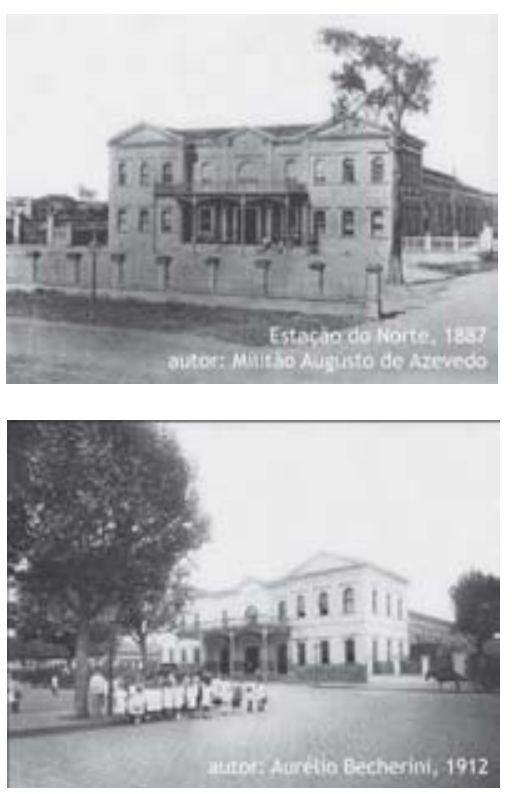

Estação do Norte acima, em 1887 abaixo, em 1912

O antigo "cinturão das chácaras" foi anexado pela cidade através de uma expansão urbana difusa, traduzida no desdobramento do espaço urbano, em bairros e loteamentos territorialmente isolados da cidade propriamente dita sendo que a ocupação urbana efetiva era pouco densa tanto nesta (em seu conjunto) quanto naquelas (Langenbuch, 1971, p. 128).

Imediatamente após as margens do rio Tamanduateí, que sofreu a primeira retificação em 1848, dois bairros se formaram, com a subdivisão das chácaras, originando os bairros Brás e Mooca, que logo se consolidaram sobre as áreas de várzeas aterradas.

\title{
2.2 Do fim do século 19 ao início do século 21
}

Em I874, quando a classificação urbana se dividia em ordem decrescente de importância em cidade, vila, freguesia e bairro, o Brás já estava classificado como freguesia e a Mooca era apenas uma localidade sem classificação oficial (Azevedo Marques, Apontamentos in Langenbuch, p.43). A cidade de São Paulo já tinha 40.6 I 4 habitantes e o Brás contava com 2.308 habitantes (Marcílio, 2004, p.262; Langenbuch, 197I, p.64). A população da Mooca, por ser essencialmente rural, ainda não aparecia contabilizada oficialmente.

\begin{abstract}
Era essencialmente um bairro rural, com pequenas manufaturas de vinho e cerveja, quando, em 1877, foi atravessado pela Estrada de Ferro do Norte ligação ferroviária de São Paulo a Rio de Janeiro. Já desde esse período teve início um processo de ocupação mais intensa do bairro, com o loteamento das chácaras para a implantação de indústrias e residências. O Brás tornou-se um dos primeiros subúrbios populares, onde se constituiu um forte e emergente mercado de imóveis para armazéns, manufaturas, casa de cômodos e de aluguel (Rolnik, 1997, p. I I 5).
\end{abstract}

A única praça do bairro do Brás era conhecida como Largo do Brás, junto à chácara de Dr. Inácio José de Araújo, que em 1865 passou a denominar-se Praça da Concórdia, hoje Largo da Concórdia (Torres, 1981, p.95).

Melhoramentos na Rua do Gasômetro e extensão do aterro do Gasômetro com o saneamento das várzeas alagáveis realizados pelo então Presidente Dr. João Teodoro Xavier, presidente de província entre 1872 e | 875, deram início à viabilização da implantação da Estrada de Ferro Central do Brasil em 1877 (Toledo, 1981, pp.44-48).

Em I88I, o município de São Paulo apresentava oficialmente como perímetro urbano uma área que não incluía os bairros Brás e Mooca, considerados suburbanos. O traçado viário do Brás já contava em I88I com a Rua do Braz, hoje Avenida Rangel Pestana, Rua do Gasômetro e Piratininga e as ferrovias São Paulo Railway e Central do Brasil.

\footnotetext{
No Bairro do Brás a urbanização já ultrapassara, em I88I, as estações do Brás (da Estrada de Ferro Santos-Jundiaí) e do Norte (Terminal da Estrada de Ferro do Norte, hoje Estação Roosevelt, da Central do Brasil). À Rua do Brás (hoje Avenida Rangel Pestana) se juntara em direção paralela, ao Norte, à Rua do Gasômetro, igualmente constituindo um eixo de urbanização linear. A Rua da Mooca e a Rua Piratininga já se achavam traçadas, mas ainda não atraíram o povoamento urbano a suas margens (Langenbuch, 197I, p.79).
}

Em I890, enquanto a Mooca, ainda formada por chácaras e outras propriedades rurais, só contava com o Caminho da Mooca, hoje Rua da Mooca - cortada pelas Ruas Piratininga e Carneiro Leão, esta última ligando a Mooca à Rua do Lavapés - o Brás já iniciava seu traçado viário de malha ortogonal paralela à ferrovia São Paulo Railway, hoje pertencente à CPTM - Companhia Paulista de Transportes Municipais. Ao oeste, Brás e Mooca eram limitados pelos meandros do Rio Tamanduateí, retificado alguns anos depois. Traçando-se uma 
linha vertical imaginária no Mapa 4 - e com isso dividindo-se a cidade ao meio - vê-se que a metade da mancha urbana de São Paulo à esquerda do Rio Tamanduateí já está bem mais adensada e parcelada que a metade à sua direita, seguindo o vetor de crescimento em direção ao noroeste e oeste, como verificado inicialmente no Mapa I. O Brás teve sua primeira grande área parcelada: I 5 quadras localizadas entre as ruas Domingos Paiva, Piratininga, Visconde de Parnaíba e Avenida Rangel Pestana. Outros polígonos já estavam delimitados entre ruas que permanecem com o mesmo traçado até hoje: Rua Carneiro Leão, Rua Caetano Pinto e Mem de Sá.

No fim do século 19, a grande maioria dos habitantes estrangeiros da cidade de São Paulo era de artesãos e uma significativa parte deles vivia e trabalhava no Brás e Mooca, como mencionado por Rolnik:

Em I 890 eram 14.303 estrangeiros para uma população total de 64.934 habitantes; em 1893 eram 71.468 para uma população de 120.755. De acordo com o censo de 1893 realizado na capital de São Paulo, os estrangeiros constituíam 54,6\% da população total e uma porcentagem ainda maior da força de trabalho. Dos 10.24I artesãos, 85,5\% eram estrangeiros, na manufatura 79\%, no comércio 71,2\% (Rolnik, 1997, p.73).

Em 1897, o Brás, que já exercia a função comercial que tem até hoje, já dispunha de um pequeno centro de compras, "considerado em 1900 como o mais elegante, embora menos concorrido do mercado paulistano" (Torres, 1981, p.96). Era formado por lojas pequenas, mas diversificadas, com produtos de alta qualidade produzidos por especialistas e artesãos, imigrantes ou seus descendentes, como luvarias, chapelarias, onde a elite paulistana fazia compras. Foi substituído pela construção da Estação Roosevelt da Ferrovia Central do Brasil.

Construído no Largo da Concórdia, consistia em "um edifício quadrangular, tendo no centro um pátio com chafariz e aos lados casas de negócios. Todo rodeado por duas galerias interiores, com o madeiramento em forma de xadrez, com quatro portas de entrada e quarenta e oito janelas", segundo o depoimento de Alfredo Moreira Pinto. Suprimido mais tarde, será substituído, numa tentativa para barateamento do custo de vida, pelos mercados livres, em 1914 (Torres, 1981, p.96).

Em 3 de junho de 1898 aprovou-se a lei número 355 que perpetuava a condição de exclusividade dos bairros residenciais tipo Garden-city, como os jardins e Higienópolis, elevando os preços das áreas localizadas na região da Avenida Angéllica, Paulista, bairros exclusivos de uso exclusivamente residencial o que garantia a sua valorização. $\bigcirc$ investimento da municipalidade nessas áreas era tão superior se comparado a outros bairros da cidade que os investimentos feitos no calçamento da Avenida Paulista eram similares aos gastos em todo um ano num bairro operário. Fatores como os bairros exclusivos e o loteamento das chácaras colaboraram com dois elementos importantes na urbanização da cidade: o deslocamento da elite que vivia nas chácaras para os bairros exclusivos e a transformação das áreas ao leste do Tamanduateí em bairros operários e industrializados (Rolnik, 1997, pp. I | 0 - | |4).

Em 1900, Brás e Mooca foram deixados fora do perímetro urbano e voltam a ser classificados como área urbana em 1916. Melhoramentos viários na cidade facilitam a ligação do centro histórico com as localidades ao leste do Tamanduateí, como a nova ponte do Carmo.

À época da produção do Mapa 7 (19|4), Brás e Mooca já tinham todo seu território subdivido em quadras. Pelo traçado viário é possível perceber que aproximadamente um terço delas ainda eram quadras abertas, ou seja, não estavam totalmente consolidadas, principalmente as que faziam limites com as ferrovias e o Rio Tamanduateí. $\bigcirc$ traçado viário da área-objeto de estudo já apresentava o mesmo desenho que permaneceu até o momento 
${ }^{36}$ Fonte: SPR - Memórias de uma ingleza, M. Lavander Jr. e P.A. Mendes, 2005, in www.estacoesferroviarias.com

37 "Wanshington Luís foi o último presidente da era PRP (Partido Republicano Paulista), de 1926 a 1929 e ficou conhecido por sua célebre expressão: 'a questão social é um caso de polícia', o que definia o tom conservador e repressivo do republicanismo paulista" (Rolnik, 2000, p. I 55).

\section{À esquerda}

Vista da ponte metálica sobre o Rio Tamanduateí, na Várzea do Carmo, no alinhamento ocupado depois pela Avenida Rangel Pestana, c. 1900

\section{Ao centro}

Obras do aterrado do Brás, futura Avenida Rangel Pestana, na Várzea do Carmo, c. 1905

\section{À direita}

A subestação da Mooca, c.1913 da implantação da Avenida Alcântara Machado, no fim da década de 1950. Este sistema viário alterou significativamente esse traçado viário e o tecido urbano como um todo. A grande área em forma de trapézio entre as a Avenida Presidente Wilson, cujo nome à época não foi possível conhecer, e a Rua Conselheiro João Alfredo, entre a Rua da Mooca e a futura Rua Serra de Paracaima, no limite sul da área objeto de estudo, sediaria posteriormente a planta industrial da Companhia Antárctica Paulista. Na área próxima à Ferrovia Santos-Jundiaí e acima da Rua da Mooca as quadras ainda estavam abertas nesse ano de 1914 , como mostra o mapa. $\bigcirc$ rio Tamanduateí já fora retificado naquele trecho. Em 1916, o Brás era oficialmente considerado pertencente à zona urbana da cidade, fazendo fronteira com o bairro do Belém, considerado zona suburbana (referência em relação ao Brás inteiro e não à área-objeto de estudo). A área sudeste do recorte objeto deste estudo era ainda uma grande área de terras que formariam a futura Chácara da Mooca, de propriedade da Companhia Chácara da Mooca S/A, sociedade anônima formada em 1912, com o objetivo de lotear uma área de mais de quatro milhões de metros quadrados. $\bigcirc$ Hipódromo da cidade não havia sido ampliado ainda sobre o Córrego Cassandoca, o que ocorreu em 1920, após forte vendaval que levou a uma reforma geral do local ${ }^{36}$.

No ano de 1914, Washington Luís toma posse como prefeito de São Paulo, permanecendo no cargo até 1919, quando passou a governador do estado em 192037.

Do início do século 20 até a década de 1930, a cidade se desenvolveu a partir do movimento exportador e da industrialização. $\bigcirc$ excedente de mão-de-obra qualificada e infraestrutura gerada para a cafeicultura - como as ferrovias para o escoamento da produção de café - migraram para a indústria, juntamente com os investimentos dos cafeicultores.

Em meados do século 19, São Paulo já contava com diversificado quadro de pequenas e médias indústrias instaladas em bairros industrializados da cidade como Lapa, Pari, Brás e Mooca.

Nas várzeas do Tamanduateí e Tietê, junto às estações ferroviárias, ao longo das estradas de ferro, desenvolveu-se em face do baixo preço dos terrenos e da facilidade de transporte dos produtos, o parque industrial paulistano, constituído principalmente por empresas de porte médio e pequenas oficinas, fabriquetas e ateliês, muitos deles de caráter doméstico. Assim Brás, Bom Retiro, Mooca, Água Branca, Lapa, Ipiranga foram loteados e cresceram rapidamente marcados por uma paisagem de fabriquetas, casebres, vilas e cortiços (Rolnik, 1997, p.78)

Mercê do grande surto industrial - intimamente relacionado como grande desenvolvimento da cidade - São Paulo já encerrava, em 1890, vários estabelecimentos fabris de certo porte. A maioria deles se implantara nos bairros novos em formação, mesmo além, em áreas compreendidas no "cinturão das chácaras", porém ainda não atingidas por uma urbanização mais ampla. A ferrovia já mostrava a tendência de atrair as indústrias às suas margens, tendência esta que se consolidaria, e que se revelara da máxima importância para a posterior estruturação do grande organismo urbano. No citado ano de 1890 já existia a importante fiação e tecelagem Anhaia, no Bom Retiro, e a Tecelagem Sant' Anna, no Brás, que fabricava sacos de aniagem para produtos agrícolas, e que possuía desvio ferroviário para expedir a mercadoria ao Interior (Langenbuch, 1971, p.80).

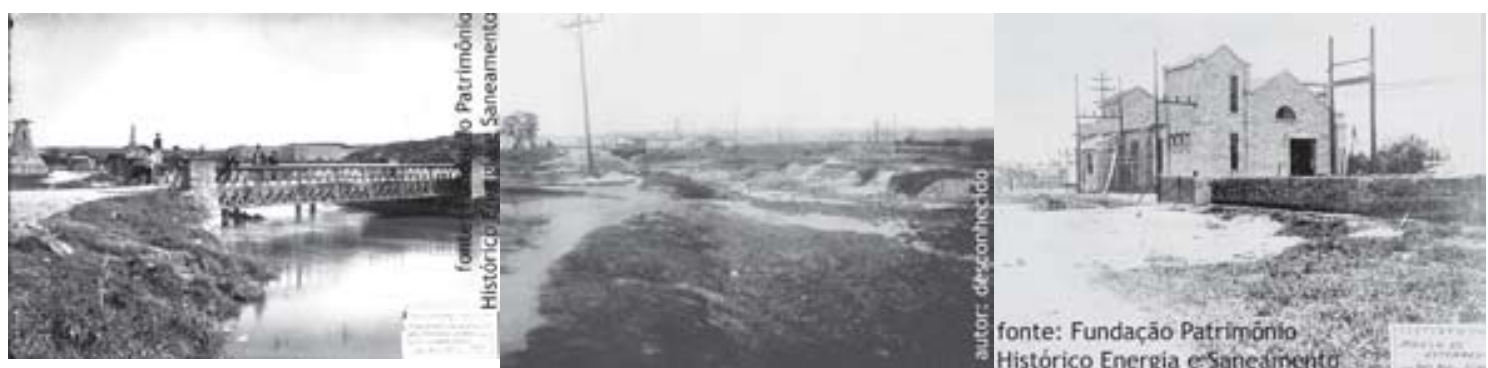




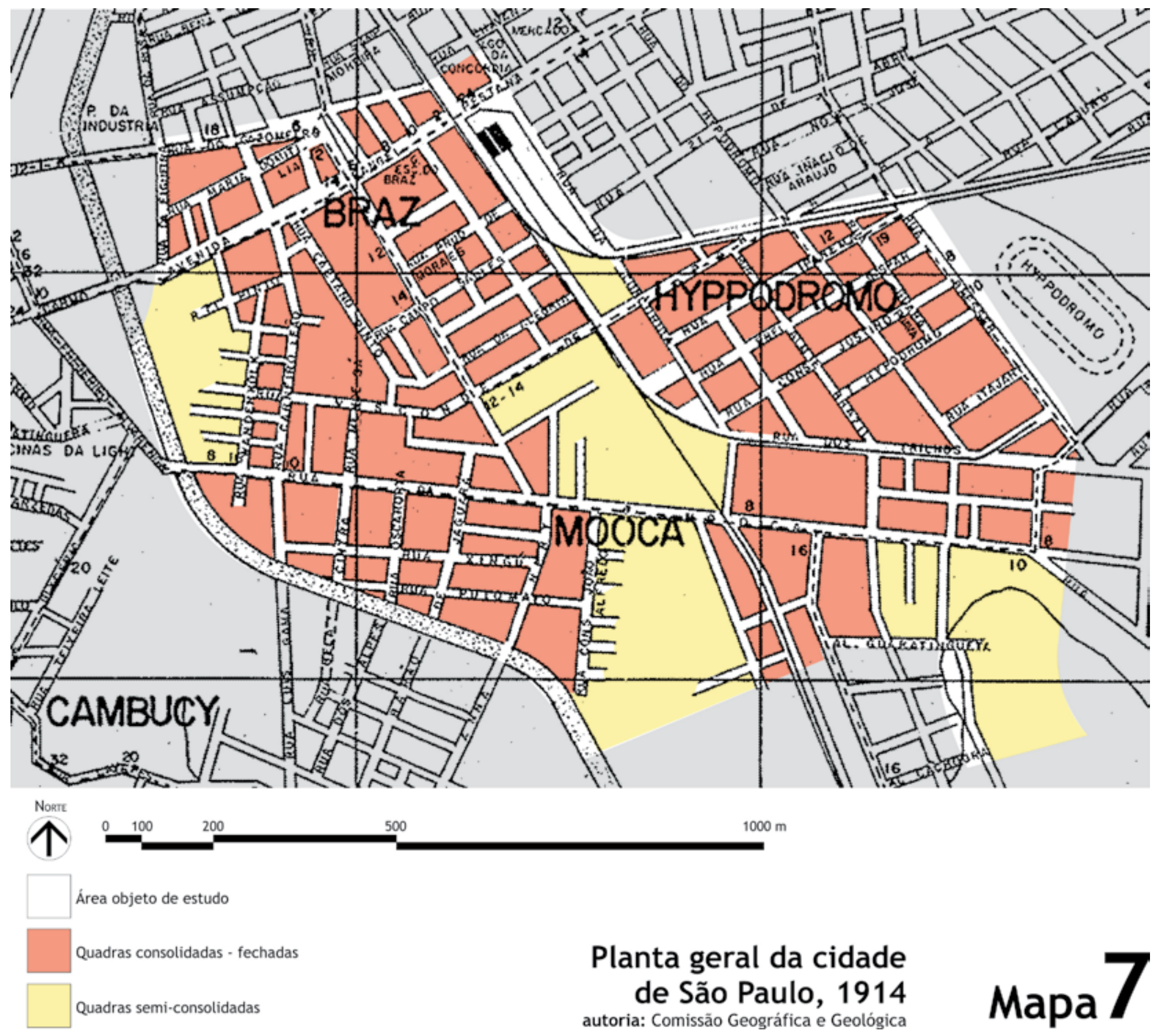


Figura 7

Planta de projeto original da Chácara da Mooca (não executado).

Fonte: Arquivo JMV in Célia Seri Kaway, 2000, p.123.

Figura 8

Planta Geral representando o projeto final do Parque da Mooca. Fonte: Célia Seri Kawai, 2000, p. 125.
O Mapa 8, elaborado em 19|4, pelo Engenheiro João Cardoso, apresenta a localização dos diversos tipos de indústrias existentes na região do Brás e Mooca, grandes concentradoras das indústrias paulistanas. Nele demonstra-se a localização das indústrias mais significativas por setor de atividade na área-objeto de estudo, na segunda década do século 20.

Em 1916 já circulavam bondes elétricos pela Avenida Intendência, hoje chamada de Avenida Celso Garcia, e na Avenida Rangel Pestana, no Brás. As linhas de bonde rapidamente atingiram o bairro da Mooca (Rolnik, 1997, p. I21).

Assim como acontecido em outros bairros da cidade de São Paulo, em 1919 a Mooca é contemplada com um projeto de loteamento nos moldes das cidades-jardim, com praças internas e traçado viário de forma orgânica, de projeto do engenheiro Macedo Vieira, que trabalhara na Companhia City até 1919 (Kawai, 2000, pp. I22-125).

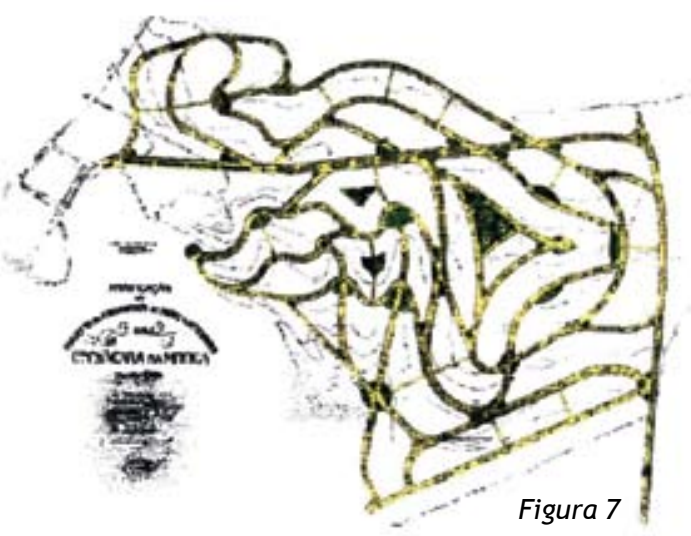

A Chácara da Mooca era propriedade da família Paes de Barros, que em 1912 constituiu a Companhia Chácaras da Mooca S.A. para proceder à urbanização de aproximadamente quatro milhões de metros quadrados de terras que possuía no Sítio das Pedrinhas, na zona leste da cidade. Em 1926 a Companhia teve seu nome alterado para Companhia Imobiliária Parque da Mooca. Ela deu origem a três bairros de São Paulo: Alto da Mooca, Parque da Mooca e parte da Vila Prudente. Em 1922 a Companhia contratou o escritório Wendel \& Vieira para fazer o projeto de parte de suas glebas, onde Macedo Vieira propôs um conjunto urbanístico composto de zona residencial localizada nas partes altas do terreno e um bairro industrial localizado na várzea, junto à linha de estrada de ferro da antiga São Paulo Railway, atual RFFSA-SP Rede Ferroviária Federal S/A - São Paulo (Kawai, p. I22).

$\bigcirc$ projeto (Figura 7, à esquerda) foi posteriormente modificado pelo próprio Vieira que eliminou os bolsões verdes internos às quadras, e manteve a proporção de áreas verdes previstas inicialmente para o loteamento, com a proposta convencional de parques e praças, destacados das quadras (Figura 8, à direita) (Kawai, 2000, p. I23).

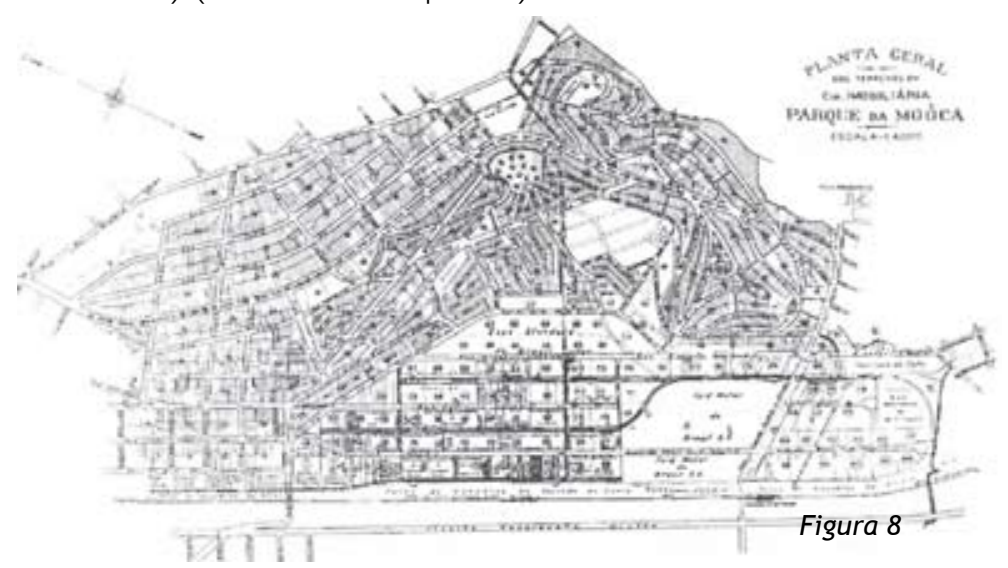

A área industrial fica localizada na parte mais baixa do terreno, ao longo da estrada de ferro. As quadras são paralelas à ferrovia e as avenidas que dão acesso aos lotes são retas e formam uma trama reticulada que se liga, de um lado, à avenida que contorna o loteamento residencial e que delimita as zonas residencial e industrial e, de outro, à avenida que faz ligação do Parque da Mooca à Vila Prudente. As quadras são organizadas de modo a alterar as avenidas com os desvios ferroviários que lhes são paralelos, de forma que as frentes dos lotes se abram para as avenidas e os fundos para o ramal ferroviário, fazendo com que cada lote tenha acesso às duas modalidades de transporte. Trata-se de esquema engenhoso que soluciona a questão do transporte de carga, fato essencial para sucesso de um empreendimento industrial (Kawai, 2000 p. I25).

38 Philip Gunn e Ricardo Toledo. Notas tomadas durante aula ministrada na disciplina AUH582I - Estado Capitalista e a Questão Urbana, PG-FAUUSP, I ${ }^{\circ}$ semestre de 2004.
Em 1920, Anhaia Mello defendia a regulamentação, por parte do Estado, dos serviços públicos de forma que sua distribuição tivesse uma função social| ${ }^{38}$. Apesar da média nacional 


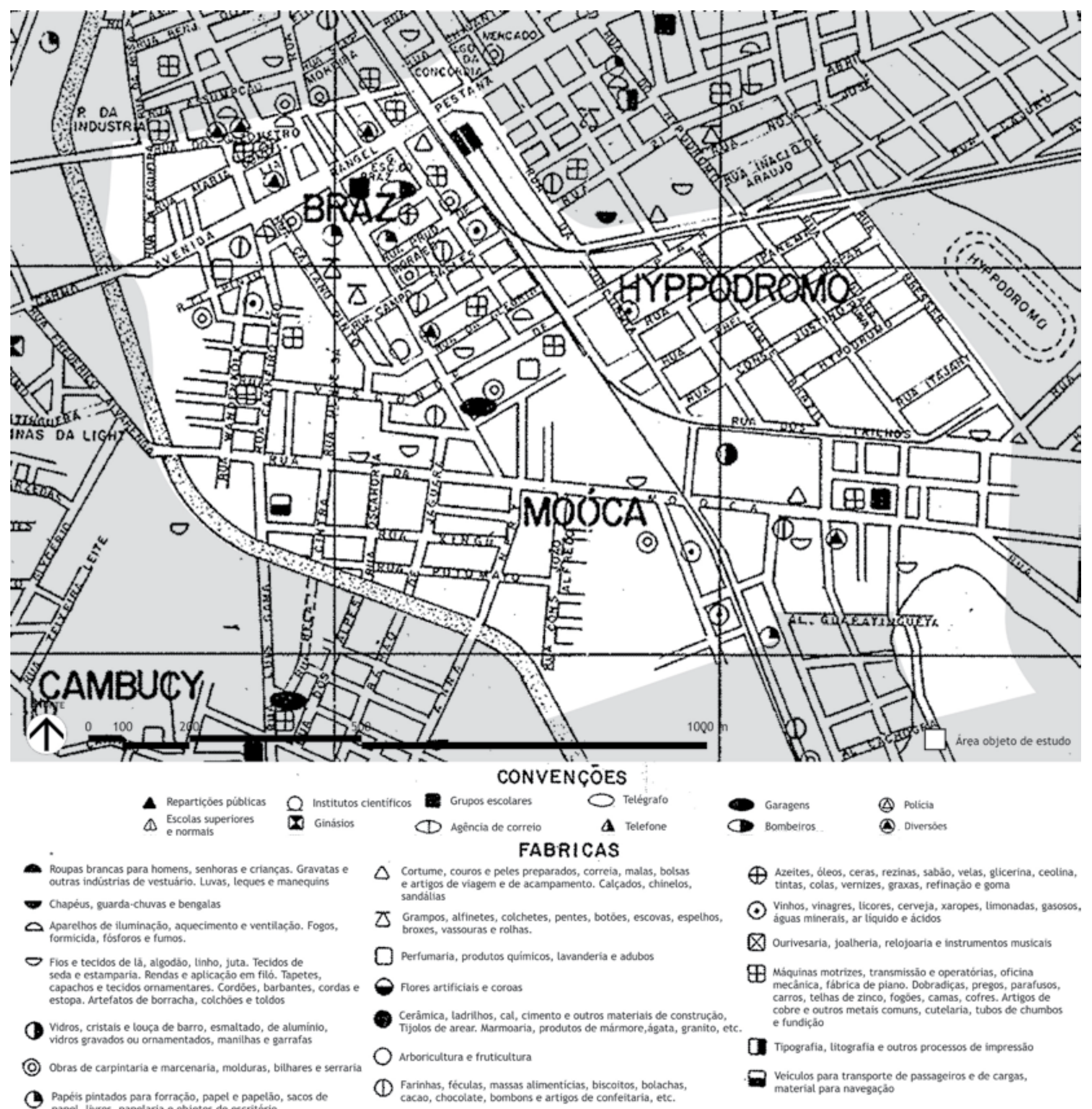

Trecho Brás e Mooca da Planta geral da cidade de São Paulo, 1914 - fábricas 

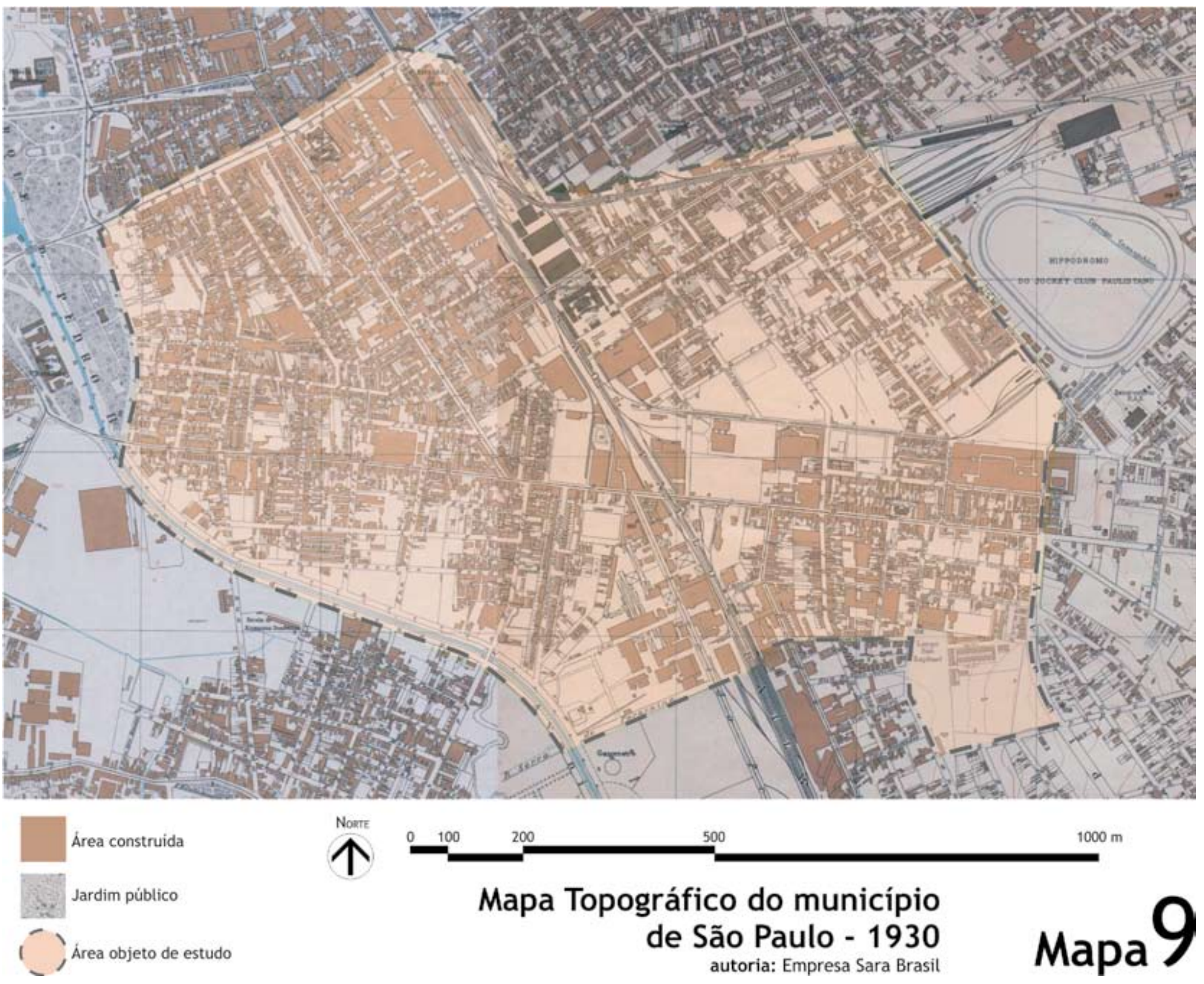

$1000 \mathrm{~m}$ 
nos anos 50, quando a cobertura de área urbana com saneamento básico era de $40 \%$ para água e $25 \%$ para esgoto, já em 1900, os bairros do Brás e Mooca dispunham de iluminação pública em 50\% de sua área urbana. Em 1928, a cobertura para água e esgoto no Brás era 100\% e 80\% na Mooca39. Em 1924, Brás e Mooca passam oficialmente a fazer parte do perímetro urbano.

Em 1930 os bairros Brás e Mooca já apresentavam tecido urbano em fins de consolidação, com pequena parte de seus terrenos ainda por construir e o restante ocupado por sobrados de alvenaria, vilas de casas em renque e galpões industriais de tijolos com cobertura tipo lanternin. $O$ traçado viário já tinha as características que mantém até hoje, incluindo as pequenas passagens onde se construíram as vilas operárias.

No auge da industrialização e segundo os documentos arquivados pela prefeitura, a produção de moradias ficava a cargo da iniciativa privada, na forma de casas unifamiliares em renque que seriam colocadas à disposição do mercado para aluguel ou venda.

O Hipódromo de São Paulo foi aberto ao público em março de 1875 e representava um marco referencial da cidade dentro da Mooca. Chamava-se Clube de Corridas Paulistano, depois Jockey Clube de São Paulo. Permaneceu na Mooca até 194I, localizado à Rua do Hipódromo, no quarteirão também limitado pela Rua Bresser, pela Ferrovia Central do Brasil e pela Rua dos Trilhos, quando foi transferido para o bairro paulistano de Cidade Jardim em função dos alagamentos que ocorriam por ser a pista de corridas cortada pelo córrego Cassandoca ${ }^{40}$. Levou junto o glamour peculiar a esse tipo de equipamento urbano. Em função da saída do Jockey Club da Mooca, o ramal dos trilhos de bondes que chegavam à Parada Hipódromo foi desativado. $\mathrm{Na}$ área deixada foi posteriormente construído o Centro Educacional Municipal da Mooca, complexo de equipamentos públicos com espaços para a prática de esportes, instituto de pesquisa na área de saúde e equipamentos públicos para saúde e para educação.

Energia elétrica e saneamento básico atendiam 100\% das moradias existentes na área histórica do Brás e Mooca (área-objeto de estudo desta dissertação) (Rolnik, 1997, mapas 18 e 19). Por ser a área muito industrializada, a indústria participava fortemente no consumo de energia e na utilização das duas ferrovias que escoavam a produção industrializada.

Em outubro de 1930, José Pires do Rio é eleito prefeito da cidade de São Paulo e permanece no cargo somente um dia, quando foi substituído por Joaquim José Cardoso de Melo Neto, prefeito nomeado dentro do período republicano ${ }^{41}$.

São Paulo vivia o auge de seu desenvolvimento econômico e de suas relações sociais entre operários, imigrantes, industriais e pequenos artesãos. Brás e Mooca estavam totalmente inseridos neste contexto urbanístico e econômico.

Em 1950, como se pode observar no Mapa 10, o traçado viário da área-objeto já apresentava seu desenho final antes da implantação da Avenida Radial Leste. Hippódromo era ainda o nome do trecho do bairro da Mooca onde anteriormente estivera instalado o Jockey Club de São Paulo. O tecido urbano totalmente consolidado apresentava variado leque de tipologias arquitetônicas, formado por vilas operárias, galpões industriais, pequenos prédios residenciais com andar térreo destinado a armazéns e pequenos comércios, construções que abrigavam as instalações ferroviárias e as instalações e equipamentos para fornecimento de gás e energia elétrica. Aos sobrados de alvenaria, às vilas de casa operárias em renque no estilo arquitetônico da década de 30 e à vila projetada por Gregori Warchavich ${ }^{42}$ começam a se juntar construções residenciais de traços modernistas. As áreas aterradas da várzea do rio Tamanduateí estavam ainda sujeitas às constantes inundações.

$\mathrm{Na}$ década de 50 começam a escassear os pedidos de aprovação de loteamentos, arruamentos e passagens junto à prefeitura da cidade, cujas obras eram financiadas pelos industriais que atuavam como promotores imobiliários na produção de moradias para a classe média e

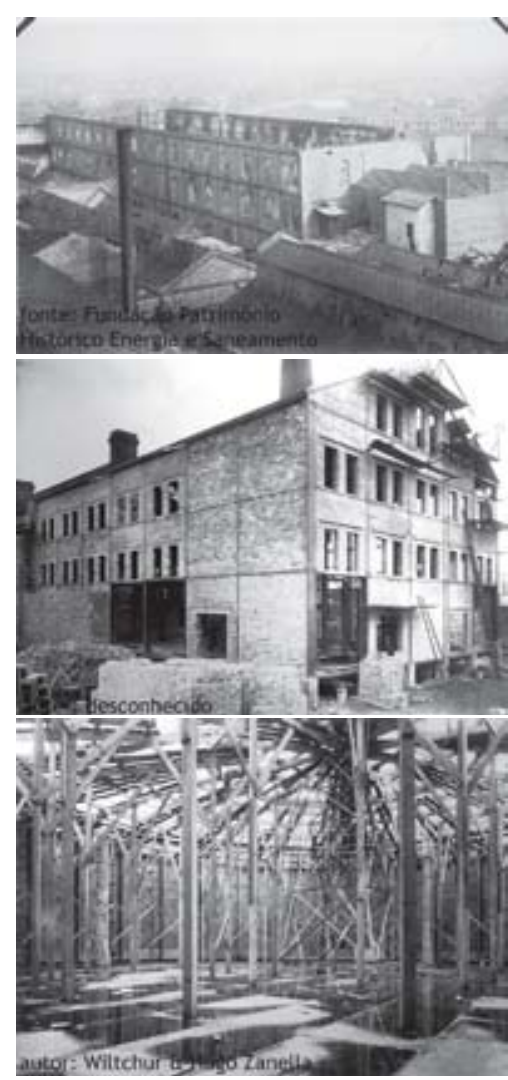

\section{Acima}

Cotonifício Crespi após o incêndio de 1924.

\section{Ao centro}

Ampliação da casa das Retortas, c. 1928

\section{Abaixo}

Construção do balão 4 do gasômetro, c. 1927

Fonte: Fundação Energia e Saneamento

${ }^{39}$ Raquel RoLNIK. 1997 Mapas 15, 16 e 17.

40 M. Lavander Jr. e P.A. Mendes. SPR - Memórias de uma ingleza, 2005 in www.estacoesferroviarias.com.

${ }^{41}$ Fonte: Prefeitos de São Paulo. Jornal A Folha de São Paulo, São Paulo, 3 I .mar.2006. Caderno Cotidiano, p.C4

${ }^{42}$ Gregori Warchavchik, arquiteto responsável por vários projetos importantes no Brasil, nasceu em Odessa, Ucrânia, em I896. Emigrou para o Brasil em 1923 onde viveu até seu falecimento em |97|. 

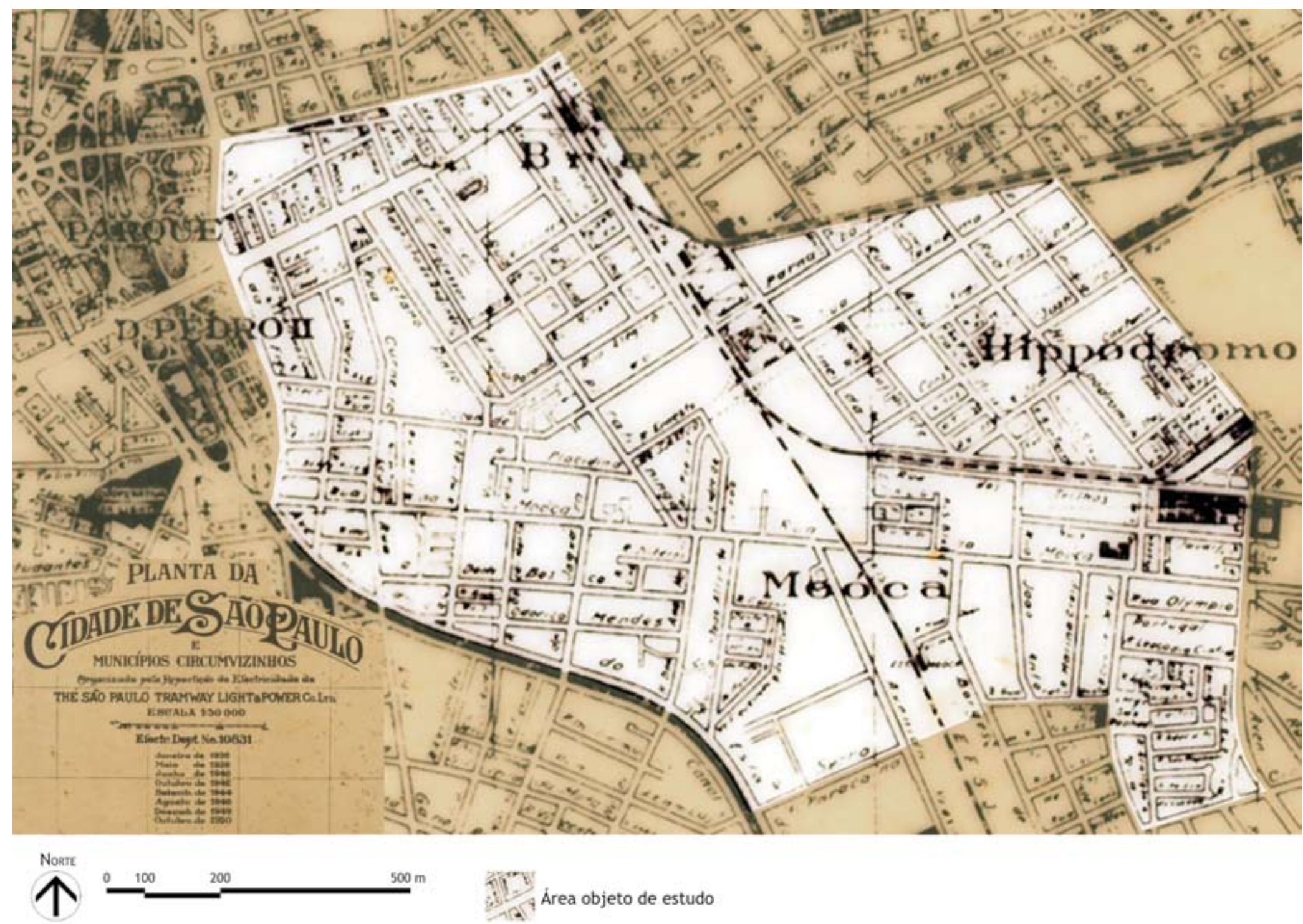

(1). Area objeto de estudo

\section{Planta da cidade de São Paulo e municípios circunvizinhos - 1950



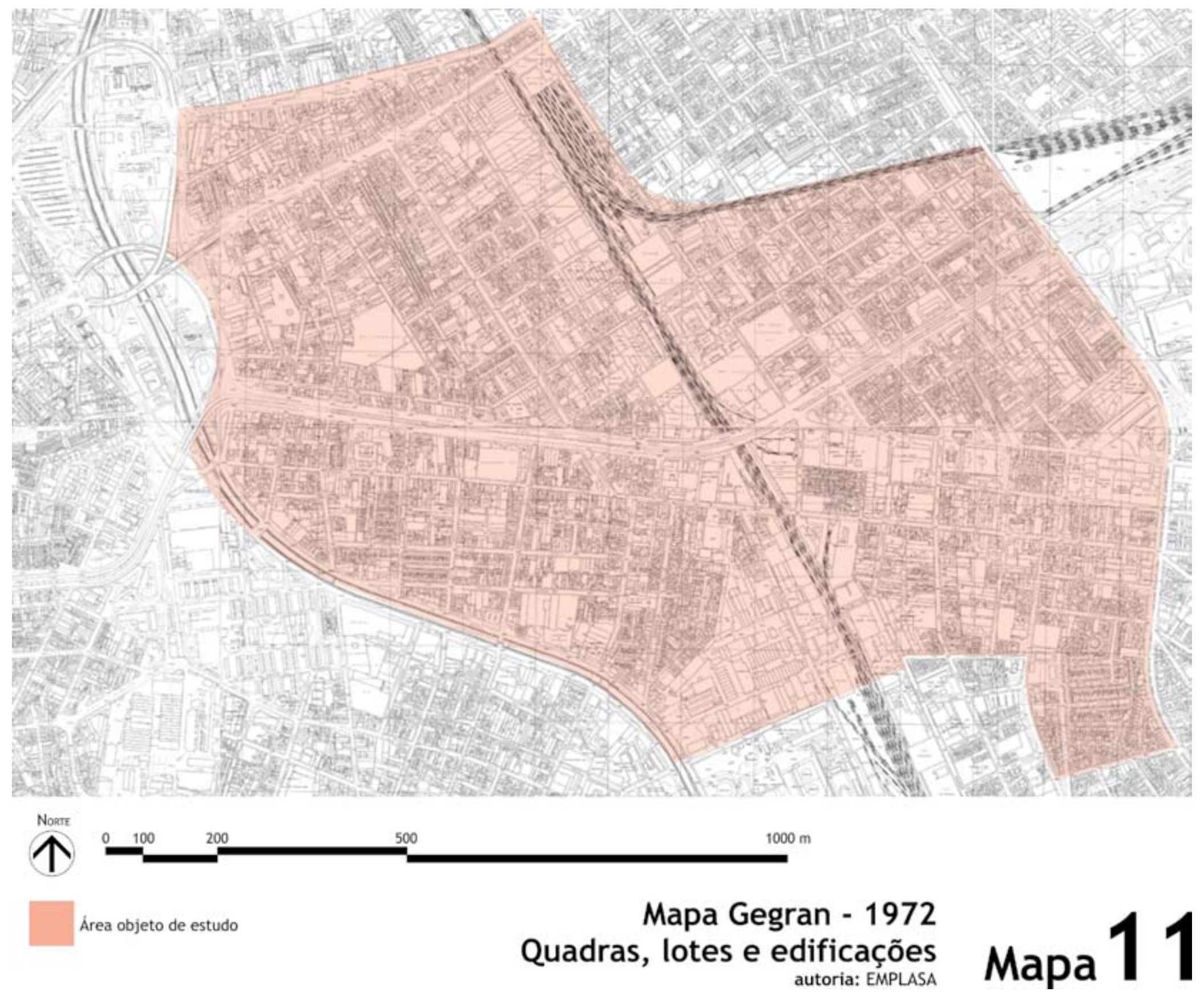


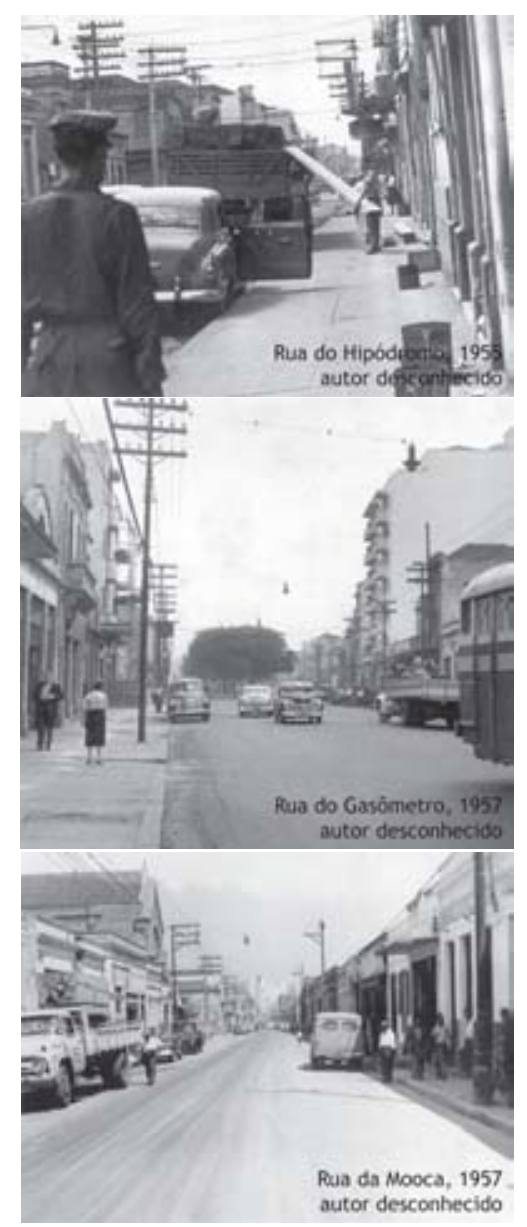

\section{Acima}

Rua do Hipódromo, 1955

\section{Ao centro}

Rua do Gasômetro, 1957

Abaixo

Rua da Mooca, 1957

Fonte: almanaque.folha.uol.com.br

${ }^{43}$ Fonte: Documentos do arquivo do CASE 3 - SEMPA - PMSP a classe operária ${ }^{43}$. Lineu Prestes, prefeito da cidade, fica no cargo entre fevereiro de 1950 e janeiro de 1951.

Toda a área já estava completamente atendida pelas redes de energia, saneamento básico e transporte público e a população dos distritos do Brás e Mooca era de 67.950 e 48. I 42, respectivamente, no Censo de 1950 do IBGE. No Censo Demográfico de 1960, a população urbana no distrito do Brás era de 63.97I e no distrito da Mooca, 42.792 habitantes.

No ano de 1972, o traçado viário e conseqüentemente o tecido urbano da região do Brás e Mooca foram fortemente alterados para dar lugar à construção da Avenida Alcântara Machado, trecho do conjunto Radial Leste, uma das artérias do Plano de Avenidas. Quarenta anos depois ela se tornou imprescindível para dar vazão ao grande número de veículos na direção centro-leste onde estão localizadas as populosas periferias de operários.

A Avenida Alcântara Machado ou Avenida Radial Leste inicia seu percurso rumo ao leste da cidade a partir da Avenida do Estado que está localizada na região central, ou seja, no coração da cidade. A Avenida Radial Leste surge a partir do Estudo para um Plano de Avenidas, publicado em 1930, feito pelo engenheiro formado pela Escola Politécnica da Universidade de São Paulo, Francisco Prestes Maia, projeto urbanístico viário que foi implantado somente em parte.

O traçado viário que era contínuo entre Brás e Mooca foi fortemente alterado pela construção do primeiro trecho da Radial Leste, pois as ruas foram por ela interrompidas e a mobilidade local, conseqüentemente, também.

As novas construções locais da década de 1970 basicamente apresentam linhas retas, sem refinamento, estando mais próximas à arquitetura modernista. A morfologia urbana foi modificada pela adição das alças de acesso ao sistema Radial Leste e Viaduto Leste-Oeste, que passaram a dificultar a mobilidade local de veículos e, principalmente, a dos pedestres. A produção urbana nessa década foi basicamente estatal, representada pela implantação da Avenida Radial Leste.

No início da década de 1970 e durante o governo de José Carlos Figueiredo Ferraz, a região já dispunha do grande elemento modificador de seu espaço urbano: parte inicial do conjunto Radial Leste-Oeste. O município de São Paulo contava com o Plano Diretor de 1971, introdutor da Lei de Uso e Ocupação do Solo, vigente até 2002, e o Brasil se encontrava em pleno Estado militar, com a indústria em pleno crescimento, mas com subdesenvolvimento econômico e social.

Langenbuch discorre sobre a compactação da cidade no início da década de 1970, quando publica A Estrutração da Grande São Paulo, mencionando acentuado crescimento vertical no centro e em bairros próximos e, em menor escala, em outros como o Brás, e até mesmo em bairros afastados.

Durante o levantamento de dados in loco efetuado para fundamentar esta dissertação, poucos edifícios foram localizados no bairro do Brás que tenham sido construídos antes da década de 1970. Essa verticalização foi iniciada e finalizada até o ano de 2000 pela produção estatal da COHAB, mencionada na página 20 , quando este órgão viabilizou a construção de 13 condomínios residenciais para população de média renda contendo de um a quatro blocos, cada um possuindo entre treze a vinte andares: os empreendimentos Brás I a I 0 e Bresser I a 3. Após a produção estatal da $\mathrm{COHAB}$, foram construídos também empreendimentos da $\mathrm{CDHU}$, com dois edifícios na área em estudo construídos no início da década de 2000. 0 autor se refere também à compactação ocorrida através da ocupação de loteamentos situados em pleno domínio urbano e entre os exemplos, destacamos o Parque da Mooca, onde a Avenida Paes de Barros, limite de nossa área objeto de estudo, sofreu acentuada verticalização a partir da década de 1970. A população dos distritos do Brás e Mooca, segundo o Censo Demográfico de 1970, era de 51.25I habitantes e 35. 172 habitantes, respectivamente. 
A foto aérea da área, produzida em 2000 e fornecida pela SEMPLA, mostra a segunda e importante interferência no tecido urbano: a implantação da Linha Leste do Metrô, transporte rápido de massa do tipo aéreo no trecho até o Brás e de superfície a partir da transposição da Ferrovia da CPTM até a Estação Bresser. A segunda linha de metrô do município de São Paulo não é do tipo subterrâneo, como seria mais adequado para preservar a qualidade ambiental da região, em virtude da diferença de custo entre o metrô de superfície e o subterrâneo. Durante a construção da Linha Leste do Metrô, Olavo Egídio Setúbal foi o prefeito nomeado que inaugurou as obras desse sistema viário. Nessa ocasião, a ocupação dos imóveis no município estava amparada pelo Plano Diretor de 197| e pela LUOS, Lei de Uso e Ocupação do Solo, vigente até a aprovação do Novo Plano Diretor Estratégico para São Paulo, em 2002.

A Tabela I demonstra a densidade demográfica dos distritos Brás, Mooca e Cambuci (incluído nesta tabela por abranger em seu território o trecho da Mooca baixa), a área de sua superfície e, o mais importante, a taxa de urbanização, com abrangência de 100\% de cobertura em saneamento básico, iluminação pública, calçamento e ruas asfaltadas.
Tabela 1 - Distritos Caracterização do Território Fonte: SEADE

\begin{tabular}{ccccc}
\hline & & 2002 & 2003 & 2004 \\
\hline \multirow{2}{*}{ Área $\left(\mathrm{km}^{2}\right)$} & Brás & 3,50 & 3,50 & 3,50 \\
& Cambuci & 3,90 & 3,90 & 3,90 \\
& Mooca & 7,70 & 7,70 & 7,70 \\
\cline { 2 - 5 } Densidade Demográfica & Brás & $6.884,29$ & $6.724,86$ & $6.567,43$ \\
(hab/km²) & Cambuci & $7.082,82$ & $6.934,36$ & $6.787,69$ \\
& Mooca & $8.041,30$ & $7.945,58$ & $7.848,96$ \\
\cline { 2 - 5 } Taxa de Urbanização (\%) & Brás & 100,00 & & \\
& Cambuci & 100,00 & & \\
& Mooca & 100,00 & & \\
\hline
\end{tabular}

Foto aérea da área-objeto de estudo, 2000. Fonte: SEMPLA.

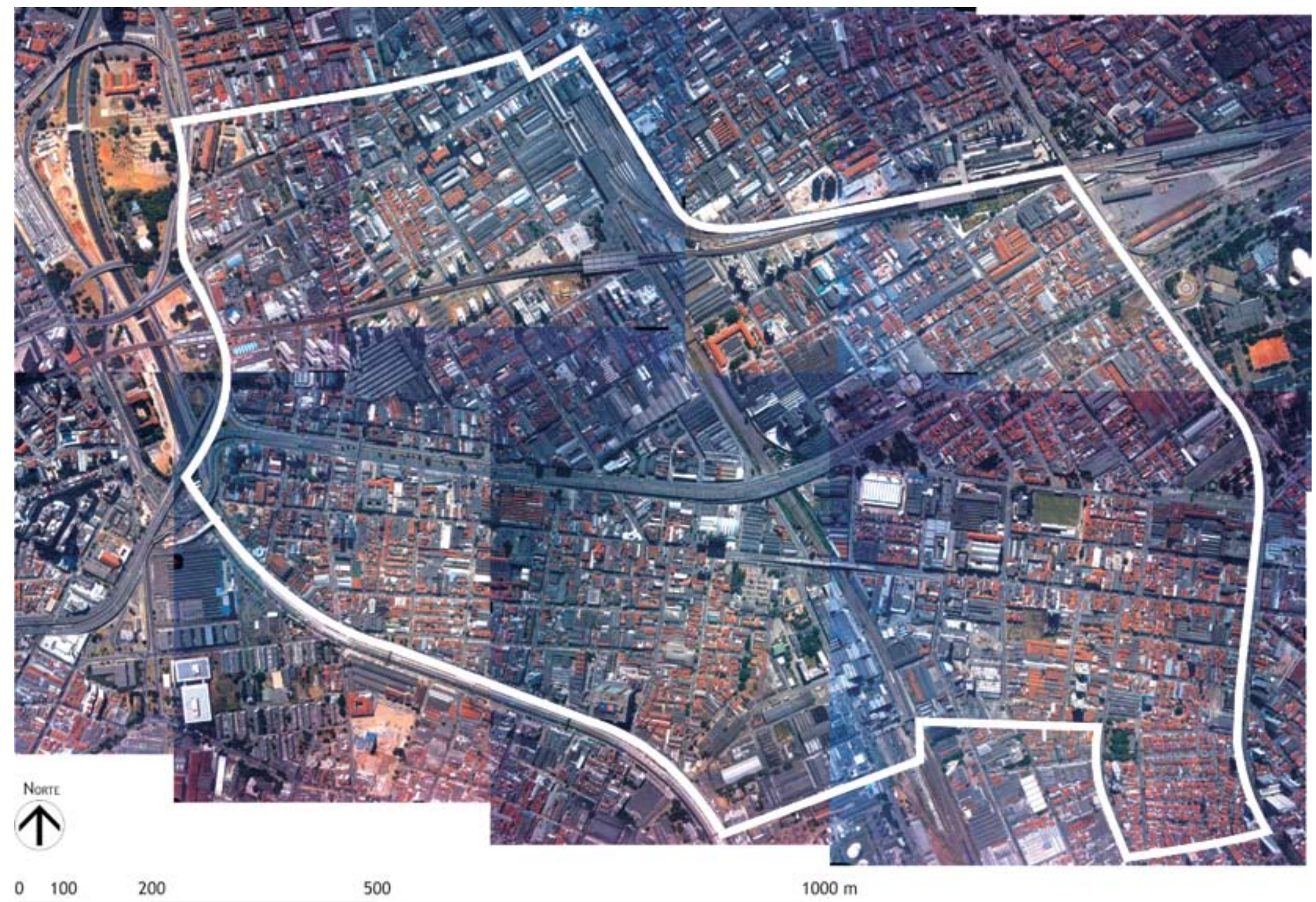


Figura 9

Área urbanizada em 1890. O Rio

Tamanduateí antes da retificação. Croquis da autora sobre base Planta da capital do Estado de São Paulo e seus arrabaldes, 1890, de Jules Martin

\section{Figura 10}

Area urbanizada em 1914.

Croquis da autora sobre base Planta geral da cidade de São Paulo, 1914, de João Pedro Cardoso.

Figura 11

Área urbanizada em 1930 sobre base Mapa topográfico do município de São Paulo, 1930, fonte Sara Brasil.

Figura 12

Área urbanizada em 1950 sobre base Planta da Cidade de São Paulo e Miunicípios Circunvizinhos, 1950, fonte The São Paulo Tramway Light \& Power Co. Ltd.

Figura 13

Área urbanizada em 1972 sobre base Gegran, 1972, fonte EMPLASA.

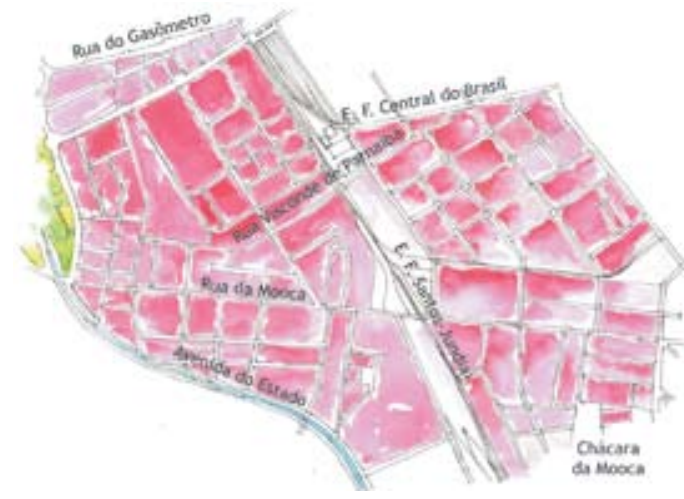

Figura 11
Resumidamente, a evolução do traçado viário e a consolidação urbana dos trechos do Brás e Mooca que fazem parte da área-objeto de estudo desta dissertação estão ilustrados da Figura 9 à Figura 13

Em 1890, o Brás já apresentava parte de seu território subdivido em quadras, cortado pela Rua Piratininga e a Rua Carneiro Leão, enquanto a Mooca ainda era formada por chácaras, áreas de várzea e a Rua da Mooca.

Em 19|4, o Brás já tinha todo o trecho em estudo subdivido em quadras. No trecho Mooca, aproximadamente $80 \%$ de sua área já tem o traçado definido. O Rio Tamanduateí já fora retificado.

Em 1930, Brás e Mooca já apresentam todo seu território subdivido em quadras numa evolução a partir do traçado viário inicial e a Rua dos Trilhos leva os bondes até o Hipódromo da Cidade, localizado à direita da Rua Bresser.

Em 1950, com o tecido totalmente consolidado, a área perdeu o Hipódromo para o bairro de Cidade Jardim, na zona oeste da cidade (em 194I).

Em 1972, Brás e Mooca já contavam com uma nova via, de alto tráfego: Avenida Alcântara Machado, cujo ${ }^{\circ}$ trecho foi construído no fim da década de 1950, entre a Avenida do Estado e a Rua Piratininga.

No fim da década de 1970, Brás já tem implantada a Linha Leste do Metrô, no trecho dentro da área-objeto de estudo, inaugurado entre 1979 e 1981, entre a Avenida do Estado e o Viaduto Bresser, onde existem duas estações: Brás e Bresser.
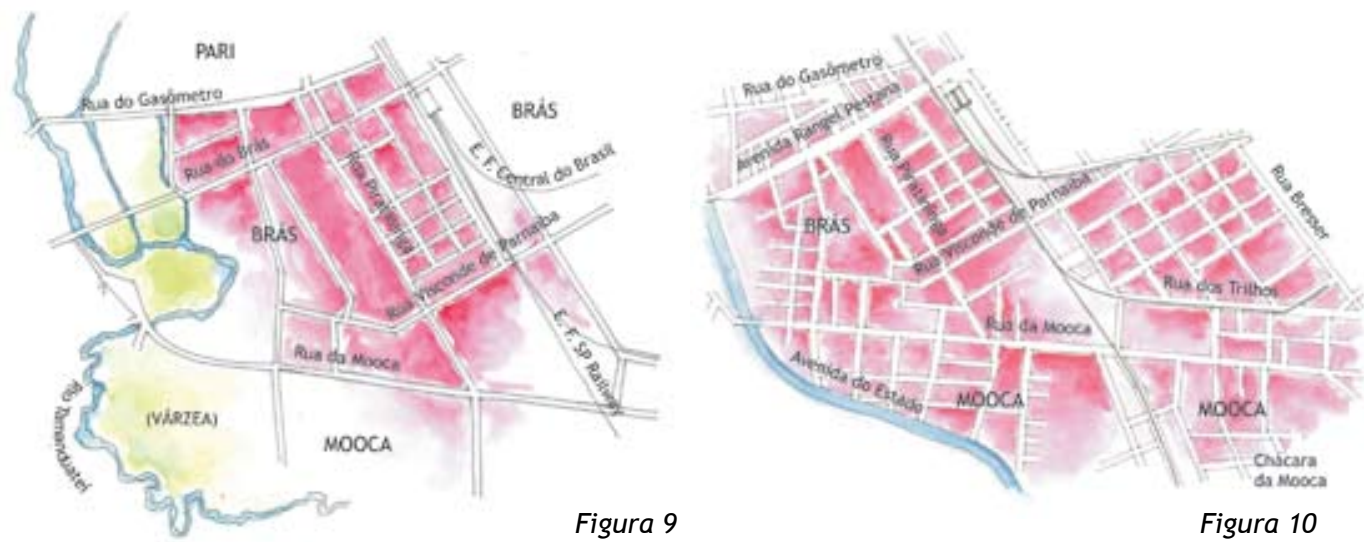

Figura 9

Figura 10
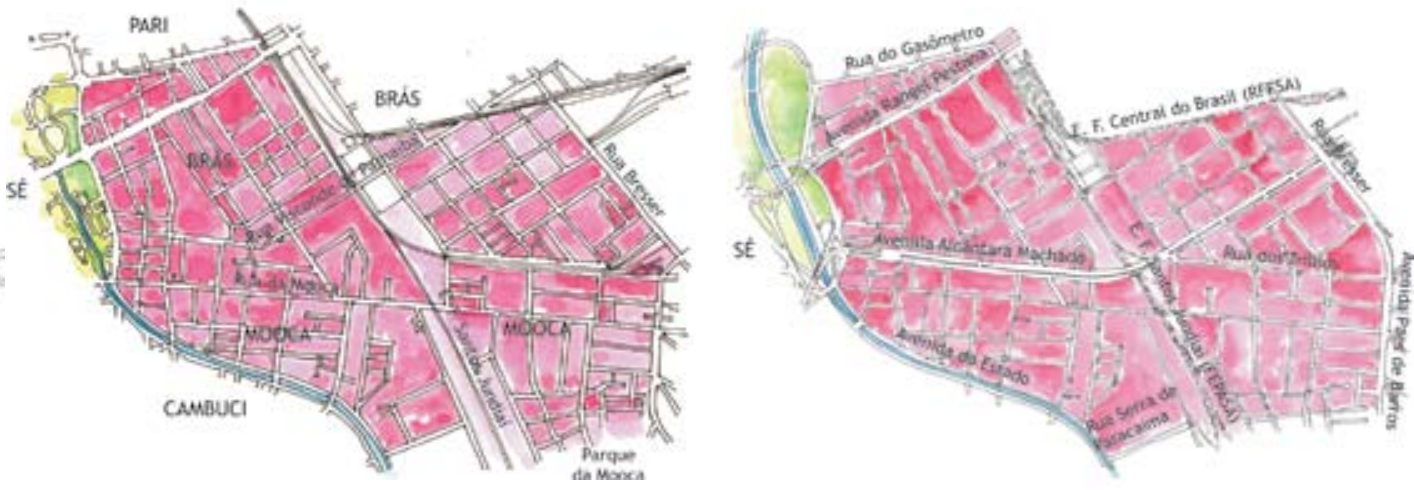

Figura 12

Figura 13 


\subsection{Evolução populacional no Brás e Mooca}

Amparado pelos dados demográficos coletados e apresentados por Langenbuch ( I 97 I, p. I70) e coletados no Instituto Brasileiro de Geografia e Estatística, a tabela 2 pretende demonstrar a evolução do crescimento populacional no Brás e Mooca.

Langenbuch frisa que, no período intercensitário de 1920 a 1940, ocorreu uma série de deslocamentos de divisas interdistritais (e intermunicipais), o que pode levar a uma nãocorrespondência entre territórios e número absoluto de habitantes ( $197 \mid$, p. 1 99).

Tabela 2 - População residente por distrito Fontes: IBGE (censos demográficos de 1950, 1960, 1970, 1980, 1991, 1996 e 2000) e SEMPLA/DINFO (Crescimento vegetativo da população para 2005)

\begin{tabular}{cccccccc}
\hline \multirow{2}{*}{ Distrito } & \multicolumn{7}{c}{ Ano } \\
\cline { 2 - 7 } & 1950 & 1960 & 1970 & 1980 & 1991 & 1996 & 2000 \\
\hline Brás & 67.950 & 63.971 & 51.251 & 38.630 & 33.536 & 26.665 & 25.158 \\
Mooca & 48.142 & 42.792 & 35.172 & 36.175 & 71.999 & 63.844 & 63.280 \\
Cambuci & Até 1992 a Mooca baixa não fazia parte do distrito do Cambuci & 32.089 & 28.717 \\
\hline
\end{tabular}

Analisando-se a tabela 2 vê-se que a população do Brás e Mooca já havia decrescido entre os censos de 1950 e 1960, na ordem de 5,9\% e II\%, respectivamente, provavelmente em função de ser esta a década da saída das indústrias para localizações ao longo das rodovias e para outras cidades da região metropolitana. Entre os Censos Demográficos de 1960 e 1970, a queda no número de habitantes é comum aos dois distritos, mas mais significativa no Brás: 19,9\%, contra 17,8\% na Mooca. Entre os Censos Demográficos de 1970, 1980, I99। e 2000, a população de ambos os bairros continua em queda, sendo que nos últimos 20 anos o distrito do Brás perdeu 34,9\% de sua população residente e o distrito da Mooca, 25,2\%. O distrito do Cambuci perdeu 10,5 \% de sua população entre os Censos de I99| e 2000. O IBGE, no Censo Demográfico de 1940, não levantou dados censitários por distrito, somente do município como um todo.

A tabela 3a apresenta a população total e a distribuição da população por faixa etária da área-objeto desta análise. A metodologia utilizada para chegar ao número de habitantes foi o levantamento de dados por Setor Censitário do Censo de 2000 do IBGE.

Tabela 3a - População residente por grupo de idades Fonte: IBGE. Censo Demográfico de 2000 (destacada a população total da área-objeto de estudo)

\begin{tabular}{|c|c|c|c|c|c|c|c|c|c|c|c|c|}
\hline \multirow[b]{2}{*}{ Grupos de idade } & \multicolumn{3}{|c|}{ Brás } & \multicolumn{3}{|c|}{ Cambuci } & \multicolumn{3}{|c|}{ Mooca } & \multicolumn{3}{|c|}{ Total } \\
\hline & Distrito & $\%$ & $\begin{array}{c}\text { Área } \\
\text { objeto }\end{array}$ & Distrito & $\%$ & $\begin{array}{c}\text { Área } \\
\text { objeto* }\end{array}$ & Distrito & $\%$ & $\begin{array}{c}\text { Área } \\
\text { objeto }\end{array}$ & Distritos & $\%$ & $\begin{array}{c}\text { Área } \\
\text { objeto }\end{array}$ \\
\hline 0 a 4 anos & 2.030 & 8,1 & 932 & 1.722 & 6 & 273 & 3.146 & 5 & 569 & 6.898 & 5,9 & 1.774 \\
\hline 5 a 9 anos & 1.752 & 7 & 804 & 1.520 & 5,3 & 241 & 3.213 & 5,1 & 581 & 6.485 & 5,5 & 1.627 \\
\hline 10 a 19 anos & 3.722 & 14,8 & 1.709 & 4.093 & 14,3 & 650 & 8.658 & 13,7 & 1.565 & 16.473 & 14,1 & 3.924 \\
\hline 20 a 29 anos & 4.893 & 19,4 & 2.247 & 4.885 & 17 & 776 & 9.932 & 15,7 & 1.795 & 19.710 & 16,8 & 4.818 \\
\hline 30 a 39 anos & 4.525 & 18 & 2.078 & 4.368 & 15,2 & 694 & 9.814 & 15,5 & 1.774 & 18.707 & 16 & 4.545 \\
\hline 40 a 49 anos & 3.556 & 14,1 & 1.633 & 4.002 & 13,9 & 635 & 9.182 & 15,5 & 1.660 & 16.740 & 14,3 & 3.928 \\
\hline 50 a 59 anos & 1.986 & 7,9 & 912 & 2.894 & 10,1 & 460 & 6.636 & 10,5 & 1.199 & 11.516 & 9,8 & $2.57 \mid$ \\
\hline 60 anos ou mais & 2.694 & 10,7 & 1.237 & 5.233 & 18,2 & 831 & 12.699 & 20,1 & 2.295 & 20.626 & 17,6 & 4.363 \\
\hline População total & 25.158 & 100 & 11.552 & 28.717 & 100 & 4.560 & 63.280 & 100 & 11.438 & 117.155 & 100 & 27.550 \\
\hline
\end{tabular}

* Trecho da área-objeto localizado no Cambuci corresponde à Mooca baixa 
${ }^{44}$ Fonte: IBGE - Instituto Brasileiro de Geografia e Estatística. Diretoria de Geociências. XI Recenseamento Geral do Brasil. Manual de Delimitação dos Setores Censitários de 2000.
* Trecho da área-objeto localizado no Cambuci corresponde à Mooca baixa

\begin{abstract}
A base setorial de 2000 foi concebida com uma divisão do espaço para fins de coleta censitária, cujas unidades servirão de base a todos os levantamentos por amostragem probabilística da próxima década. Permitirá, através de agregação de suas unidades básicas, chamadas setores censitários, a obtenção dos dados coletados por unidades territoriais de interesse do planejamento a nível local e nacional, possibilitando assim o atendimento da demanda de dados para áreas de nível geográfico menor que município ou distrito; a saber: bairros, povoados, favelas, comunidades indígenas, entre outros ${ }^{44}$.
\end{abstract}

Aplicando-se a planta com a área-objeto deste estudo sobre a planta de setores censitários do IBGE, foi possível chegar-se a um número de habitantes real com baixíssima margem de erro. As pessoas residentes na área objeto de estudo estão distribuídas em 1 I.552 habitantes no trecho-Brás, 4.560 habitantes no trecho Mooca baixa/Cambuci e I I .438 habitantes no trecho Mooca. A Tabela 3a apresenta também a população total urbana de cada um dos distritos, para comparação. $\bigcirc$ distrito do Cambuci foi considerado em função de ter sido a Mooca baixa rebatizada recentemente pela municipalidade como Cambuci.

Para determinar-se o número de habitantes dentro de uma determinada faixa etária e conseqüentemente vislumbrar as verdadeiras necessidades de cada grupo da população, a metodologia adotada foi o cálculo de um fator de proporcionalidade entre a população total de cada um dos três distritos e a população total da área-objeto de estudo para então aplicá-lo ao número de habitantes de cada faixa etária do distrito (dados oficiais) e encontrar respectivamente a população daquela faixa etária dentro da área de recorte. Agrupou-se as faixas etárias na Tabela 3 b de acordo com a similaridade de suas necessidades, como creches ( 0 a 4 anos), escolas (5 a 19 anos), empregabilidade (20 a 59 anos) e acessibilidade especial e lazer (60 anos ou mais). A tabela 3 b demonstra, portanto, que:

- A população na faixa etária de 0 a 4 anos é maior no trecho Brás da área-objeto de estudo, seguido pelo trecho Mooca e, finalmente, pelo trecho Mooca baixa (Cambuci);

- A população na faixa etária de 5 a 19 anos - que abrange as idades nas quais essa população deveria estar matriculada nos ensinos fundamental e médio - é maior no Brás;

- A população na faixa etária entre 20 e 59 anos compreende a população economicamente ativa, tem número praticamente igual no trecho Brás e no trecho Mooca, sendo bem menor no trecho Mooca baixa (Cambuci);

- A maior parte da população com 60 anos ou mais concentra-se no trecho Mooca, sendo que nos outros dois recortes sua expressividade é bem menor;

- Não há necessariamente uma correlação entre a porção territorial analisada e os números absolutos de cada faixa etária. Conclui-se, portanto, que proporcionalmente a população do Brás é mais jovem que a da Mooca.

Tabela 3b - População residente por grupo de idades Fonte: IBGE. Censo Demográfico de 2000 (destacada as maiores incidências em cadad faixa etária)

\begin{tabular}{|c|c|c|c|c|c|c|c|c|c|c|c|c|}
\hline \multirow[b]{2}{*}{ Grupos de idade } & \multicolumn{3}{|c|}{ Brás } & \multicolumn{3}{|c|}{ Cambuci } & \multicolumn{3}{|c|}{ Mooca } & \multicolumn{3}{|c|}{ Total } \\
\hline & Distrito & $\%$ & $\begin{array}{c}\text { Área } \\
\text { objeto }\end{array}$ & Distrito & $\%$ & $\begin{array}{c}\text { Área } \\
\text { objeto* }\end{array}$ & Distrito & $\%$ & $\begin{array}{c}\text { Área } \\
\text { objeto }\end{array}$ & Distritos & $\%$ & $\begin{array}{c}\text { Área } \\
\text { objeto }\end{array}$ \\
\hline 0 a 4 anos & 2.030 & 8,1 & 932 & 1.722 & 6 & 273 & 3.146 & 5 & 569 & 6.898 & 5,9 & 1.774 \\
\hline 5 a 9 anos & 1.752 & 7 & 804 & 1.520 & 5,3 & 241 & 3.213 & 5,1 & 581 & 6.485 & 5,5 & 1.627 \\
\hline 10 a 19 anos & 3.722 & 14,8 & 1.709 & 4.093 & 14,3 & 650 & 8.658 & 13,7 & 1.565 & 16.473 & $|4|$, & 3.924 \\
\hline 20 a 29 anos & 4.893 & 19,4 & 2.247 & 4.885 & 17 & 776 & 9.932 & 15,7 & 1.795 & 19. & 16,8 & 4.818 \\
\hline 30 a 39 anos & 4.525 & 18 & 2.078 & 4.368 & 15,2 & 694 & 9.814 & 15,5 & 1.774 & | 8.707 & 16 & 4.545 \\
\hline 40 a 49 anos & 3.556 & $|4|$, & 1.633 & 4.002 & 13,9 & 635 & 9.182 & 15,5 & 1.660 & 16.740 & 14,3 & 3.928 \\
\hline 50 a 59 anos & 1.986 & 7,9 & 912 & 2.894 & 10,1 & 460 & 6.636 & 10,5 & 1.199 & 11.516 & 9,8 & $2.57 \mid$ \\
\hline 60 anos ou mais & 2.694 & 10,7 & 1.237 & 5.233 & 18,2 & 831 & 12.699 & 20,1 & 2.295 & 20.626 & 17,6 & 4.363 \\
\hline População total & 25.158 & 100 & 11.552 & 28.717 & 100 & 4.560 & 63.280 & 100 & 11.438 & 117.155 & 100 & 27.550 \\
\hline
\end{tabular}




\subsection{Indicadores sociais no Brás e Mooca}

Para propor diretrizes para requalificação urbana de bairros ou distritos de grandes metrópoles é necessáio conhecer o perfil sócio-econmico de seus habitantes através de índies como renda, escolaridade, natalidade e mortalidade infantil. Esses dados foram obtidos em pesquisa junto à Fundação SEADE e estão demosntrados na tabela 4.

Tabela 4 - Indicadores sócio-econômicos Fonte: IBGE e SEADE

\begin{tabular}{|c|c|c|c|c|c|}
\hline & & Brás & Cambuci & Mooca & Municipio \\
\hline \multirow{15}{*}{ ষ্ণ } & População & & & & \\
\hline & População total & 21736 & 28790 & 56921 & 8727411 \\
\hline & População economicamente ativa (\%) & 68,83 & 56,09 & 62,48 & 53,1 \\
\hline & Índicadores de vida & & & & \\
\hline & Taxa de mortalidade infantil (\%o nascidos vivos) & 10,97 & 21,65 & 9,04 & 15,8 \\
\hline & Taxa de natalidade (\%o habitantes) & 28,89 & 17,65 & $12,2 \mid$ & 19,9 \\
\hline & Nível de escolaridade (\%) & & & & \\
\hline & Taxa de alfabetização (em \%) & 96,97 & 97,33 & 98,28 & 95,41 \\
\hline & Média de anos de estudo da população de 10 anos e mais (em \%) & 7,9 & 8,8 & 9,5 & 7,6 \\
\hline & Renda (em \%) & & & & \\
\hline & Responsáveis pelos domicílios com rendimento até 02 sal.min. & 15,14 & 11,45 & 9,71 & 17,88 \\
\hline & Responsáveis pelos domicílios com rendimento entre mais de 02 a 05 sal.min. & 30,03 & 24,22 & 20,22 & 29,67 \\
\hline & Responsáveis pelos domicílios com rendimento entre mais de 05 a 10 sal.min. & 27,21 & 27,52 & 24,72 & 20,95 \\
\hline & Responsáveis pelos domicílios com rendimento maior que 10 sal.min. & 23,12 & 30,98 & 40,23 & 21,07 \\
\hline & Responsáveis pelos domicílios sem rendimento & 4,52 & 5,83 & 5,12 & 10,43 \\
\hline \multirow{3}{*}{ ๙ } & Empregos & & & & \\
\hline & Estabelecimentos empregadores & 3882 & 1373 & 2673 & 179927 \\
\hline & Empregos & 32548 & 25566 & 37645 & 2222518 \\
\hline
\end{tabular}

O perfil sócio-econômico da população residente no Brás e Mooca foi adotado da pesquisa realizada pela CDHU, na implantação do PAC - Programa de Atuação em Cortiços (2004, p. 18):

O setor Brás apresenta uma população com predominância $(47,4 \%)$ de pessoas na faixa etária entre 20 e 39 anos. As famílias contam com a presença elevada de chefia feminina (20,2\%). Grande parte dos chefes de família apresenta escolaridade baixa: em $70 \%$ das famílias o chefe não completou o ensino fundamental enquanto $10 \%$ não completou o ensino médio. Os rendimentos dos chefes de família na faixa de um a três salários mínimos são maioria: 64,5\%.

Os chefes de família que declararam não dispor de renda foram da ordem de 6,5\%. A fonte de renda principal dos chefes de família é o trabalho autônomo (36\%), seguido pelos assalariados com registro em carteira profissional (29\%) e os assalariados sem registro (8,5\%). Há também uma proporção nada desprezível de famílias cujo chefe vive de pensões ou aposentadoria (I3\%). Quando se considera o rendimento familiar, a proporção de domicílios onde a renda atinge até três salários mínimos é de 54,4\%.

Importante salientar também os números da população vivendo em cortiços ou outras moradias precárias, segundo a pesquisa CDHU-2002:

A distribuição das famílias aponta a predominância de pessoas sozinhas (42,5\%). Os casais com filhos representam 18\% e os sem filhos representam 15,5\%. As outras categorias de famílias incluem as monoparentais (chefes com filhos) simples e ampliadas, que somam I4\%. Arranjos de tipo ampliado (com a presença de parentes ou não-parentes no mesmo domićlí) contam por 1 I,4\%. As mulheres chefe de família aparecem em 20,2\% dos domićlios (CDHU, Relatório PAC-Brás, 2004, p. 18). 
A região da Mooca apresenta alto índice de oferta de empregos com um total de 160.615 no ano de 1999, representando um percentual de mais de $7 \%(7,23)$ da totalidade dos empregos do município. Supõe-se que pela grande oferta de empregos, uma boa porcentagem deles seja ocupada por mão-de-obra oriunda de outras regiões, primordialmente a periferia da Zona Leste.

O Relatório de Subsídios Ambientais para os Planos Regionais, dados da SEMPLA de 1997, mostra que o distrito da Subprefeitura Mooca corresponde a 7,23\% dos empregos - se considerarmos o município como um todo - subdivididos em: Mooca ( I,69\%), Brás ( I ,46\%, ) Tatuapé ( I,42\%), Água Rasa (0,68\%), Pari (0,73\%), Belém ( $1,24 \%)$.

A maior oferta de empregos $(40,2 \%)$ encontra-se no setor de indústria de transformação com destaque para o setor têxtil e vestuário $(13,2 \%)$ seguindo-se o setor de serviços (31,3\%). Em terceiro lugar aparece o setor de comércio, com 24\%, sendo 14,2\% varejista e 9,8\% atacadista (SEMPLA/PMSP, 2002).

\section{As formas de produção do espaço no Brás e Mooca}

Quais foram as configurações produtivas ou as formas de produção do espaço durante o desenvolvimento urbano desses bairros? Para responder a essa questão analisou-se o processo de produção do espaço construído da área, determinando dentre as quatro formas de produção do espaço urbano apresentadas por Jaramillo e Campos Filho (autoconstrução, produção por encomenda, produção capitalista para o mercado e produção estatal desvalorizada) quais foram as predominantes, conhecendo seus problemas e os atores que intervieram na mesma. No Brás e Mooca existem e existiram todas as formas de produção urbana mencionadas no Capítulo I deste trabalho.

No Brasil, a propriedade de terras se fundamentou, até | 822, na concessão de domínio de sesmarias ${ }^{45}$, concedidas pelo Estado Absolutista português em 1375. Essa foi a forma de garantir ao Estado o poder sobre a terra. A Câmara zelava pelo cumprimento de condições de ocupação efetiva. O regime de sesmarias foi extinto em 1822 e em 1850 foi promulgada a Lei de Terras ${ }^{46}$. No período entre 1822 e 1850, houve um amplo apossamento de terras, ocupação pura e simples, transformada em regra (Rolnik, 1997, pp.21-22).

Com a Lei de Terras, as sesmarias com título de registro ou posses comprovadas com a efetiva ocupação com inclusão de benfeitorias, passaram a ser propriedade de seus ocupantes e passou a ser obrigatório o título de compra para obter o direito de ocupação de terras devolutas (Rolnik, 1997, p.23). As sesmarias foram posteriormente parceladas nas glebas e chácaras que compunham os arredores do centro urbano da cidade. As chácaras começaram a ser negociadas e seus compradores foram a classe dos primeiros loteadores de terras na cidade. Brás e Mooca tiveram suas chácaras negociadas a partir dos primeiros anos da década de 1880 e o parcelamento de porte mais recente, encontrado nos registros consultados, foi a grande gleba de terras pertencente ao espólio de Rafael Agenor Paes de Barros: 4.140.000 $\mathrm{m}^{2} \mathrm{em}$ 1912 que formariam a Chácara da Mooca, área do distrito da Mooca atualmente conhecida como Parque da Mooca.

Com o objetivo de conhecer detalhadamente o processo de parcelamento do solo

${ }^{45}$ Lote de terra inculto ou abandonado que os reis de Portugal cediam a sesmeiros que se dispusessem a cultivá-los in Novo Dicionário Básico de Língua Portuguesa Folha/Aurélio. São Paulo: Nova Fronteira, 1994

${ }^{46}$ Lei $n^{\circ} 601$ de 18 de setembro de 1850 a partir da subdivisão das chácaras até os proprietários atuais dos imóveis selecionados, formando uma amostragem que pudesse elucidar como esse processo ocorreu e quais foram os grandes loteadores da área, adotou-se como metodologia inicial uma busca na PMSP, no departamento CASE 3, por documentos e registros sobre os pedidos de aprovação de arruamentos e passagens na região em estudo.

Os documentos do primeiro pedido de aprovação de arruamento encontrados no CASE 3 datam de 1892. Trata-se do maior empreendimento encontrado, de propriedade 
do Barão de Arary e outros, e foi identificado como a esquina das Ruas dos Trilhos com Rua Taquari, onde até hoje se encontra um enorme galpão industrial, de tijolos à vista e três andares, com ruas internas que abrigavam até 2005 diversas pequenas fábricas ou depósitos, quando foi demolido para a implantação de um hipermercado, mantendo-se apenas uma das fachadas. O pedido de arruamento mais recente na Mooca data de 1955.

Segundo informações dadas pelos técnicos do CASE 3, os pedidos de aprovação de arruamentos tratavam de solicitar à prefeitura que aprovasse a abertura das ruas dos novos loteamentos. A aprovação dos lotes para venda cabia aos registradores de imóveis. A documentação apresentada para a aprovação de loteamentos conjunta com a aprovação da construção das casas na forma de vilas, que poderiam ter de 4 a 50 unidades aproximadamente, continha também as plantas de arquitetura assinadas por um engenheiro ou arquiteto. Esses pedidos tinham o objetivo de aprovar um determinado empreendimento antes de sua construção ou a regularização de obras realizadas.

Os loteamentos ou arruamentos - abertura de ruas em áreas particulares e as passagens - ruas mais estreitas com ou sem saída, dentro das vilas operárias - que constam dos registros, variavam de $1.500 \mathrm{~m}^{2}$ aproximadamente (Brás) a $28.000 \mathrm{~m}^{2}$ aproximadamente (Mooca). O número de lotes para venda por empreendimento variava de 30 a 57 unidades e apresentavam de 200 a $570 \mathrm{~m}^{2}$. Alguns empreendimentos eram compostos de pelo menos um lote destinado à construção de fábrica, o que mostra a intenção de vender ao investidor a idéia de construir casas operárias ao lado da fábrica.

O Mapa 12 apresenta a localização de cada pedido de aprovação de arruamento ou passagem na Mooca e Brás, área-objeto deste estudo.

Como resultado da pesquisa efetuada junto ao CASE 3, na Prefeitura Municipal de São Paulo foi possível uma visualização do período entre 1892 e 1955 no qual ocorreram os pedidos de alvará para o parcelamento de áreas menores e para a construção de algumas das vilas operárias que existem dentro da área-objeto de estudo. Foi possível montar a tabela 5 listando os arruamentos que tiveram aprovação da municipalidade para serem implantados juntamente com os nomes dos proprietários dos lotes, a data da aprovação e o tipo de empreendimento. São informações que se somam às visitas ao local e à análise do tecido para determinar as configurações produtivas na área, dentro do período mencionado. No caso da Mooca foram encontrados registros de dez arruamentos e sete passagens e no Brás, somente dois arruamentos e duas passagens.

No departamento RESOLO da Secretaria de Planejamento da Prefeitura Municipal, encontrou-se outro documento importante para esta análise: o de loteamentos irregulares.

Mesmo confrontando o Mapa 12 com o Mapa 13 ainda não é possível ter visibilidade de todos os loteamentos, regulares ou irregulares, que devem ter sido necessários para consolidar o tecido urbano da área. Estes mapas foram atualizados em 2003 no caso do Mapa do CASE 3, e diariamente no caso do RESOLO. Os arruamentos, loteamentos ou passagens que não constam dele podem ter sido realizados antes de qualquer legislação que implicasse na aprovação, ou à margem desta.

Observando-se o Mapa 13 verifica-se que na área-objeto de estudo os loteamentos irregulares ou não existiram ou provavelmente as áreas foram parceladas antes que qualquer lei reguladora fosse promulgada. $\mathrm{Na}$ área do Brás os arruamentos e passagens, com autorização da prefeitura para abertura das vias, aparecem na planta cedida pelo CASE 3 em número insignificante: quatro. No trecho Mooca deste estudo o número de pedidos é bem superior: catorze, de dimensões bem variadas no caso dos arruamentos. O registro n 197800040755 aponta como irregular todo o território onde fica o Parque da Mooca, loteamento produzido pela Cia. Chácara da Mooca S/A a partir do espólio de Rafael Agenor Paes de Barros, mas que consta regular no registro de cartórios consultados. Essa área é hoje verticalizada e de médio adensamento. 

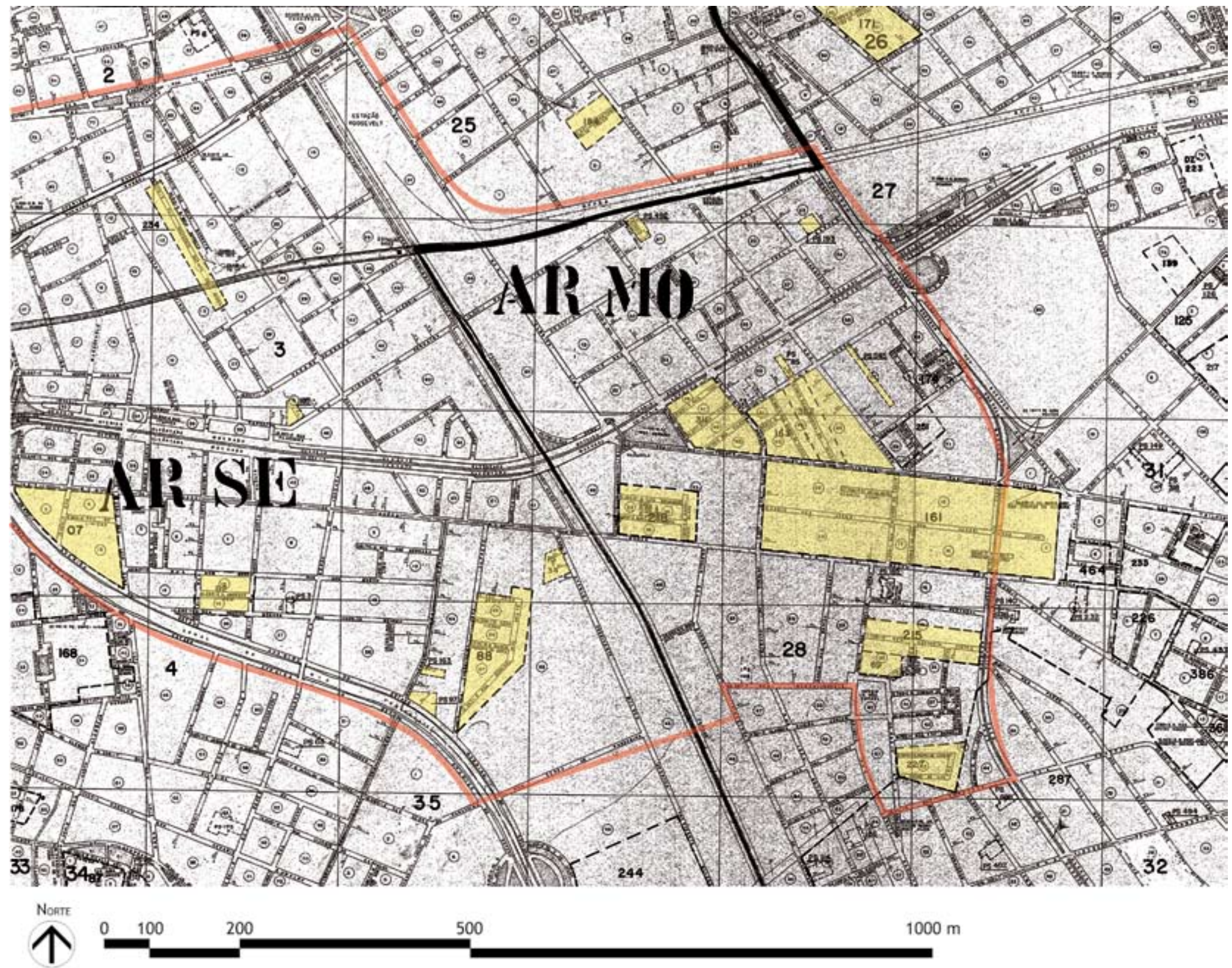

Arruamento (loteamento), passagem (vila) conjunto residencial

- - Arruamento (loteamento) urbanizado
Desdobramento de gleba

— Divisa de administraçăo regional
$1000 \mathrm{~m}$

Área objeto de estudo

Passagens e arruamentos aprovados na PMSP entre 1892 e 1955

Indicação de arruamentos e passagens aprovados entre 1892 e 1955

autoria: SEHAB-CASE3 sobre MOC 

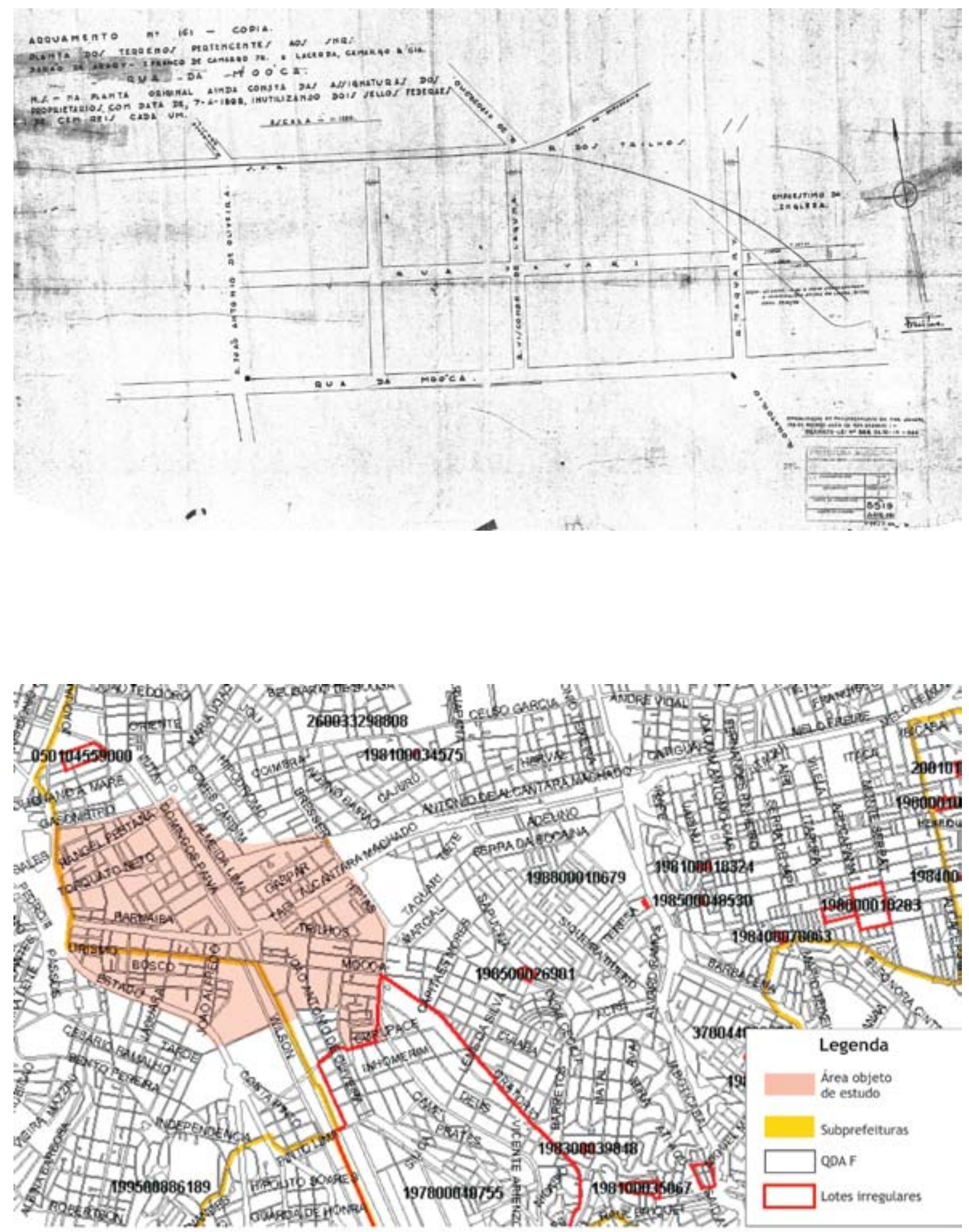

Nonts

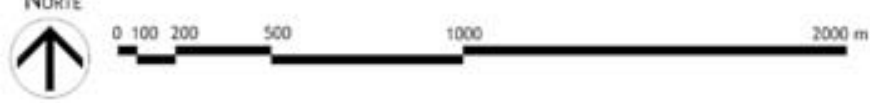

Loteamentos irregulares

na cidade de São Paulo autoria: RESOLO
Figura 14

Planta de aprovação de arruamento

na Mooca, datado de 1892, onde se

construiu o Contonifício Crespi. Nessa

mesma área está localizado o Clube Atlético Juventus. 
Tabela 5 - Loteadores e Produtores Imobiliários no Brás e Mooca - 1892 a 1955 Autoria: Maria Elizabet Paez Rodrigues. Fonte: documentos do CASE 3 - PMSP

\begin{tabular}{|c|c|c|c|c|c|c|c|c|c|c|}
\hline Item & Proprietário & Bairro & Localização & Tipo & $\begin{array}{l}\text { Ano de } \\
\text { aprovação }\end{array}$ & Ref. PMSP & Área Total & $\begin{array}{l}\text { Lotes } \\
\text { Industriais }\end{array}$ & $\begin{array}{l}\text { Lotes } \\
\text { Residenciais }\end{array}$ & Casas \\
\hline 1 & Cristiano Ribeiro Luz & Brás & Rua Visconde de Parnaíba & Arruamento & 1928 & 185 & S.I. & - & - & 16 casas populares +6 aptos. \\
\hline 2 & Belli \& CIA & Brás & Rua Rangel Pestana e Campos Sales & Arruamento & 1930 & 234 & $1950 \mathrm{~m}^{2}$ & $\bullet$ & $\bullet$ & 57 casas populares \\
\hline 3 & Antônio Dias Grilo & Brás & Rua Visconde de Parnaíba, 1750 (*) & Passagem & 1954 & 492 & $2282 \mathrm{~m}^{2}$ & - & - & 24 casas em vila \\
\hline 4 & Francisco e Afonso Graffine & Brás & Rua Frei Gaspar, 733 & Passagem & 1942 & 193 & $1600 \mathrm{~m}^{2}$ & - & - & 16 casas em vila \\
\hline 6 & C.F de Lacerda & Mooca & Rua da Mooca & Arruamento & 1916 & 07 & S.I. & - & 57 Lotes & - \\
\hline 7 & Desconhecido & Mooca & Rua Coronel Cintra e outras & Arruamento & 1925 & 112 & S.I. & - & - & 76 casas populares térreas \\
\hline 8 & João Dente & Mooca & $\begin{array}{l}\text { Rua Agostinho Figueiredo (depois } \\
\text { Rua Conselheiro João Alfredo) }\end{array}$ & Arruamento & 1924 & 88 & S.I. & S.I. & S.I. & S.I. \\
\hline 9 & Mahfruz e Irmãos & Mooca & Rua Almeida Lima com Rua da Mooca & Arruamento & 1938 & 218 & $23840,88 \mathrm{~m}^{2}$ & $\bullet$ & $\begin{array}{l}30 \text { Lotes de } \\
220 \text { a } 570 \mathrm{~m}^{2}\end{array}$ & $\bullet$ \\
\hline 10 & Herdeiros de Dr. S.A. da Rocha Camargo & Mooca & $\begin{array}{l}\text { Rua Almirante Brasil; Rua dos Tri- } \\
\text { Ihos e Rua Conselheiro Lafayete }\end{array}$ & Arruamento & 1937 & 311 & $28762 \mathrm{~m}^{2}$ & - & 58 Lotes & - \\
\hline 11 & Pedro Aniz & Mooca & Rua Barra do Turvo & Arruamento & 1940 & 163 & $18100 \mathrm{~m}^{2}$ & 01 & 36 Lotes & - \\
\hline 12 & $\begin{array}{l}\text { Caixa de Aposentadoria e Pensões } \\
\text { dos Ferroviários da SP Railway }\end{array}$ & Mooca & Rua João Caetano e Rua dos Trilhos & Arruamento & 1939 & 352 & S.I. & $\bullet$ & $\bullet$ & S.I. \\
\hline 13 & Desconhecido & Mooca & Rua Itajaú e Rua Bresser & Arruamento & 1930 & 174 & S.I. & - & - & S.I. \\
\hline 14 & Desconhecido & Mooca & Rua do Hipódromo s/n & Arruamento & 1936 & 251 & S.I. & - & - & S.I. \\
\hline 15 & Barão de Arary e Outros & Mooca & Rua da Mooca & Arruamento & 1892 & 161 & S.I. & - & - & S.I. \\
\hline 16 & Desconhecido & Mooca & Rua Odorico Mendes, $\mathrm{n}^{\circ} \mathrm{IOI}$ & Passagem & 1938 & 3 & S.I. & - & - & S.I. \\
\hline 17 & Joaquim Ferreira Filho & Mooca & Rua Ana Nery, nº 379 & Passagem & 1941 & 163 & $1034 \mathrm{~m}^{2}$ & - & - & 16 Casas de $81,7 \mathrm{~m}^{2}$ aproximadamente \\
\hline 18 & Comendador José Giorge & Mooca & Av. do Estado $\times$ Rua Ananeri & Passagem & 1940 & 97 & S.I. & - & - & 22 Casas Populares +2 Armazéns \\
\hline 19 & Emília de Costa Ferreira & Mooca & Av. Presidente Wilson, 14 & Passagem & 1939 & 34 & S.I. & - & - & 36 Casas populares de $65 \mathrm{~m}^{2}$ \\
\hline 20 & Elias Dib Schwery & Mooca & Rua João Caetano s/n & Passagem & 1939 & 57 & S.I. & - & - & 14 Casas de $70 \mathrm{~m}^{2}$ cada \\
\hline 21 & Nazario L. Checa & Mooca & Rua João Caetano I47// 55 & Passagem & 1940 & 85 & $595 \mathrm{~m}^{2}$ & - & - & 4 Casas de $85 \mathrm{~m}^{2}$ cada \\
\hline 22 & Luis Rossi & Mooca & Rua João Caetano, n 322 & Passagem & 1955 & 545 & $2437 \mathrm{~m}^{2}$ & $\bullet$ & $\bullet$ & $\begin{array}{l}15 \text { Casas de aproximada- } \\
\text { mente } 70 \mathrm{~m}^{2} \text { cada }\end{array}$ \\
\hline 23 & Desconhecido & Mooca & Rua Guaratinguetá, s/n & Passagem & sem data & 115 & S.I. & - & - & S.I. \\
\hline 24 & Orlando Benedetti & Mooca & Rua Olímpio Portugal & Passagem & 1942 & 185 & S.I. & - & - & 4 Casas \\
\hline 25 & Desconhecido & Mooca & Rua Orville Derby & Arruamento & sem data & 215 & S.I. & - & - & - \\
\hline 26 & Desconhecido & Mooca & Rua Orville Derby & Arruamento & sem data & 69 & S.I. & - & - & - \\
\hline 27 & Desconhecido & Mooca & Sem Informaçōes & Arruamento & sem data & 287 & S.I. & \multicolumn{3}{|c|}{$\begin{array}{l}\text { Grande loteamento na região mais alta da Mooca, em torno da } \\
\text { Avenida Paes de Barros, Madre de Deus, Padre Raposo e Visconde } \\
\text { de Inhomerim, Rua Tabajaras, Rua Camé, Rua Canuto Saraiva, etc. }\end{array}$} \\
\hline 28 & Desconhecido & Mooca & Rua Araribóía e Rua Pedro de Lucena & Arruamento & sem data & 227 & S.I. & - & - & S.I. \\
\hline
\end{tabular}

As informações foram obtidas através de certidões de filiação e de origem solicitadas junto aos Cartórios de Registro de Imóveis que abrangem os distritos que abrigam a área estudada. Foram solicitadas certidões a partir de uma prévia seleção, escolhendo-se endereços de imóveis inseridos nos arruamentos aprovados na prefeitura municipal com maior importância em relação às dimensões e à localização. As certidões recolhidas levaram ao conhecimento do atual proprietário do imóvel, residência ou galpão industrial ocioso, apartamento ou casa de vila até o primeiro loteador da gleba. A partir da análise das certidões foi possível montar os organogramas de propriedades e seu fracionamento e, com isso, conhecer os nomes dos grandes loteadores da Mooca e Brás.

No caso da Mooca, a família de Rafael Agenor Paes de Barros foi responsável, em $|88|$, pelo agrupamento de uma grande área chamada Sítio do Pinheiro, a partir da compra em 1810 da Chácara da Glória, que estava localizada entre a Rua da Mooca e a Rua da Glória. Posteriormente, em 1912, a viúva de Rafael Paes de Barros, Francisca A. Paes de Barros e família dispuseram de uma fração de $4.140 .000 \mathrm{~m}^{2}$ da propriedade, já parcelada, e que foi o capital necessário para a criação da Cia. Chácara da Mooca S/A, que desenvolveu a Chácara da Mooca, de traçado viário orgânico em parte. Transparecem em algunas casos nos organogramas as configurações produtivas do espaço, como no exemplo da Avenida Paes de Barros, 70 I, Parque da Mooca, onde o proprietário de grandes glebas faz seu parcelamento, vende parte ou funda empresa incorporadora para lotear e vender. Viúva e órfãos de Julio Rinaldi, comprador de um dos lotes de $1200 \mathrm{~m}^{2}$ onde viviam, se mudam de lá para erguer um edifício residencial vertical, onde voltam a viver num dos apartamentos construídos, de $212 \mathrm{~m}^{2}$. Em 
função do nome do edifício lá erguido ser Edífício Julio Rinaldi, o mesmo nome do comprador original do lote de $1200 \mathrm{~m}^{2}$ de área, pode-se concluir que a família deste desempenhou o papel de promotor imobiliário capitalista na produção de edifício vertical de uso residencial para o mercado, em 1952. O exemplo descrito está representado no organograma I que foi montado a partir do levantamento de certidões de transmissão de propriedade dos imóveis I e 2 apontados na figura 14.

O organograma 2 mostra, a partir de uma residência (imóvel 3) de tamanho médio na Rua Javari, que seu lote remonta ao parcelamento das terras do Barão de Arary, grande investidor em terras que solicitou a aprovação desse arruamento em 1892 à prefeitura sob registro número $|6|$.

Foi possível localizar um segundo grande loteador e proprietário de terras no Brás: o Coronel José Ferreira de Figueiredo, grande acumulador de terras e imóveis por toda a cidade de São Paulo, em bairros como Santa Ifigênia, Avenida Paulista, Vila Mariana, Consolação, Pari e também na Mooca. Neste último, pertenciam a ele pelo menos $15.678 \mathrm{~m}^{2}$ localizados entre as Ruas da Mooca, Barão de Jaguará, Mem de Sá e Visconde de Parnaíba, que foram vendidos para G. Crespi \& Cia. onde seria construída a Fábrica de Tecidos Labor (imóvel 4), até hoje a proprietária deste imóvel, em péssimo estado de conservação e que se encontra subutilizado como estacionamento e casa de eventos. As transmissões de propriedades estão representadas no organograma 3.

Em 1930 pode ter ocorrido uma incorporação que produziu 57 casas populares de $84 \mathrm{~m}^{2}$, contruídas por Belli \& Cia., de acordo com o pedido número 234 do CASE3-PMSP, sobre as terras de José Paulo Queiroz Júnior, tendo sido uma dessas casas (imóvel 5) vendida ao casal Femé e Adélia Catib, em 1953. Queiroz Júnior adquiriu $24.200 \mathrm{~m}^{2}$ do parcelamento das terras "Invernada", que perteceram antes disso ao Capitão Joaquim Fermino Gonçalves, proprietário das terras mencionadas nas Estrada do Caguassú até | 89|. Este exemplo corresponde ao organograma 4.

Observando-se os organogramas a seguir, é possível visualizar as transmissões de propriedade ocorridas desde as chácaras até os pequenos imóveis atualmente existentes nas frações desses terrenos. Os imóveis estão numerados e localizados na figura abaixo.

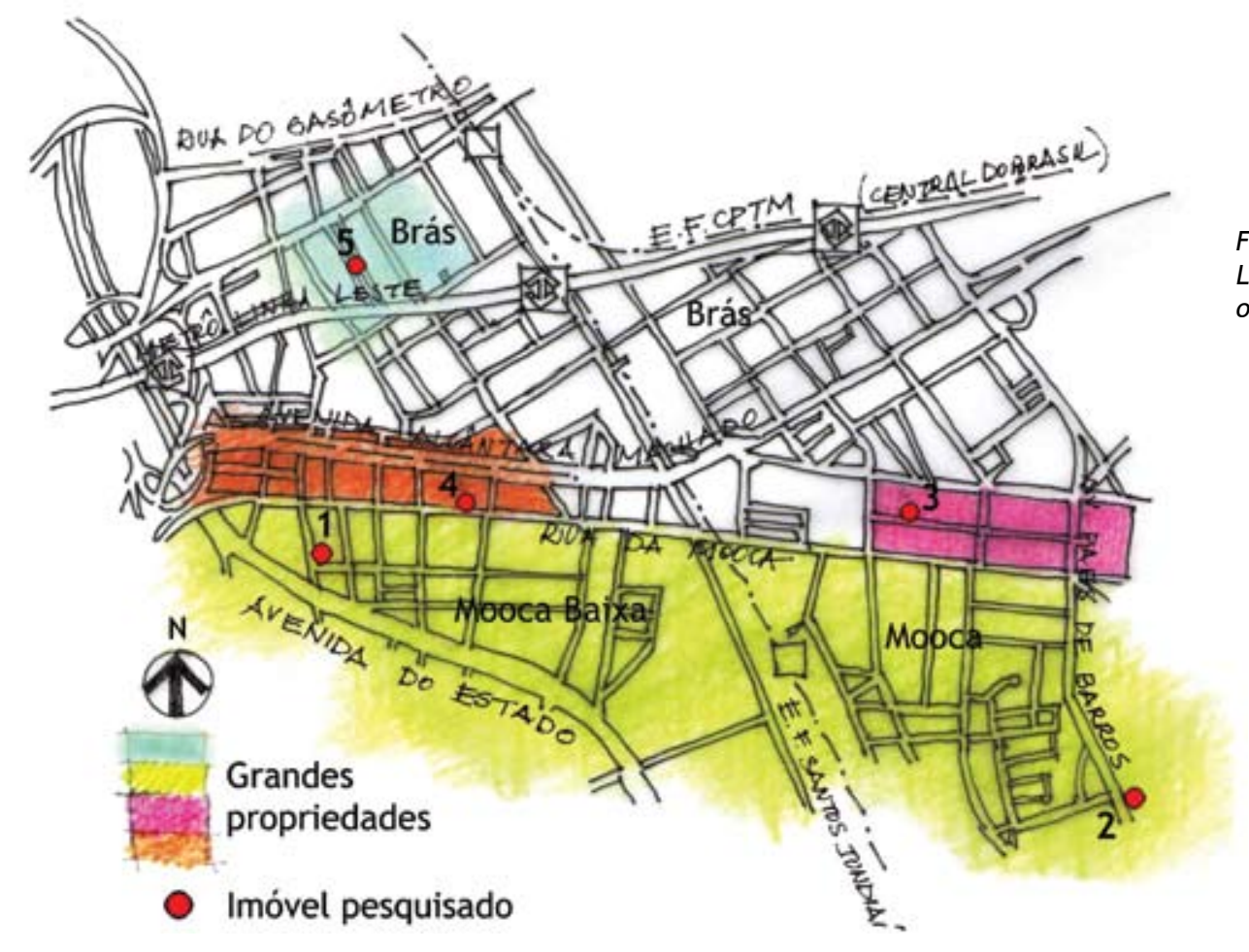




\section{Organograma I}

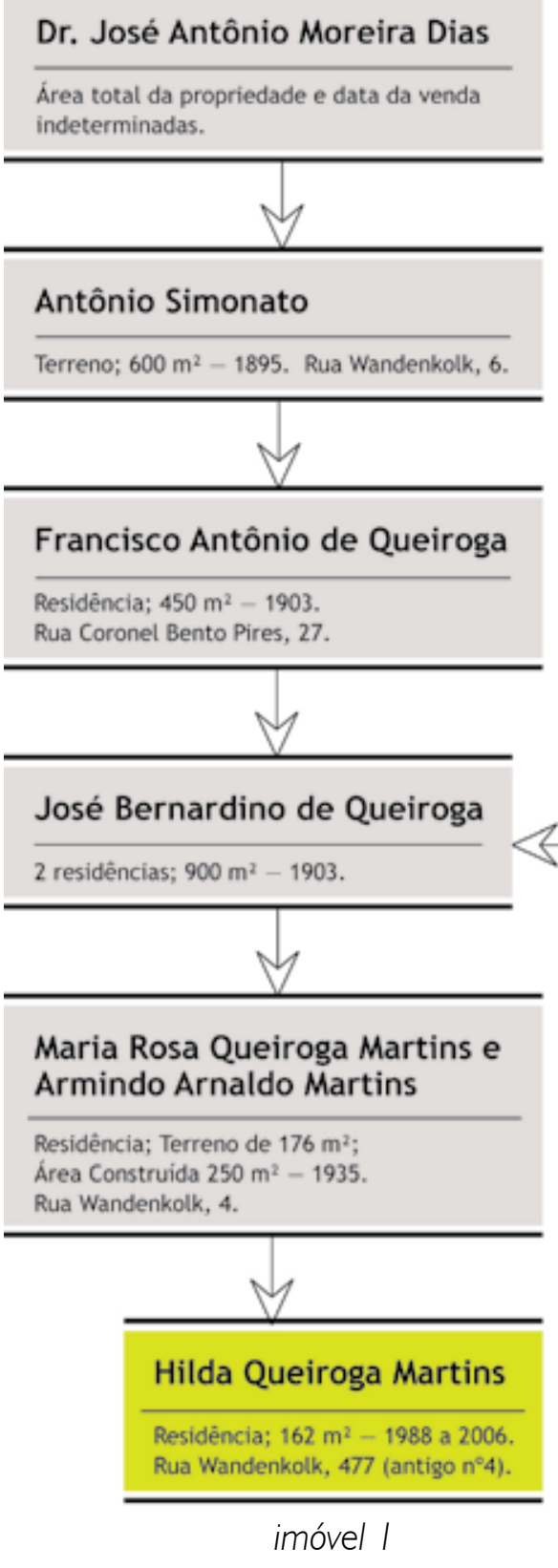

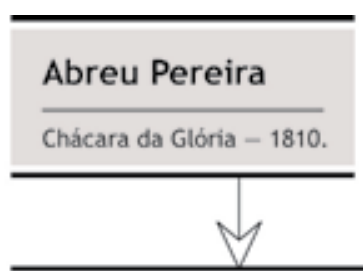

\section{Alferes Francisco} Belizário de Camargo

Chácara da Glória entre as ruas da Mooca e da Glória.
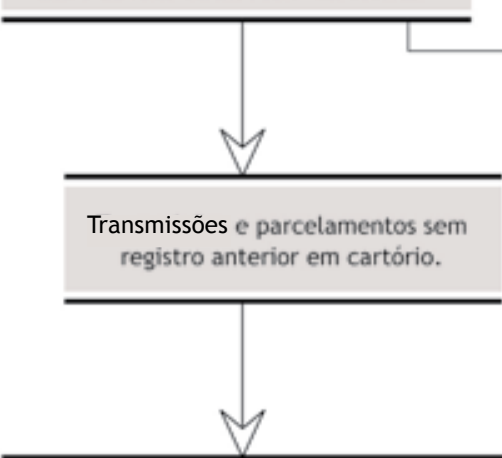

\section{Francisco Antônio de Queiroga}

Terreno; $450 \mathrm{~m}^{2}-1903$. Rua Wandenkolk, 6 .
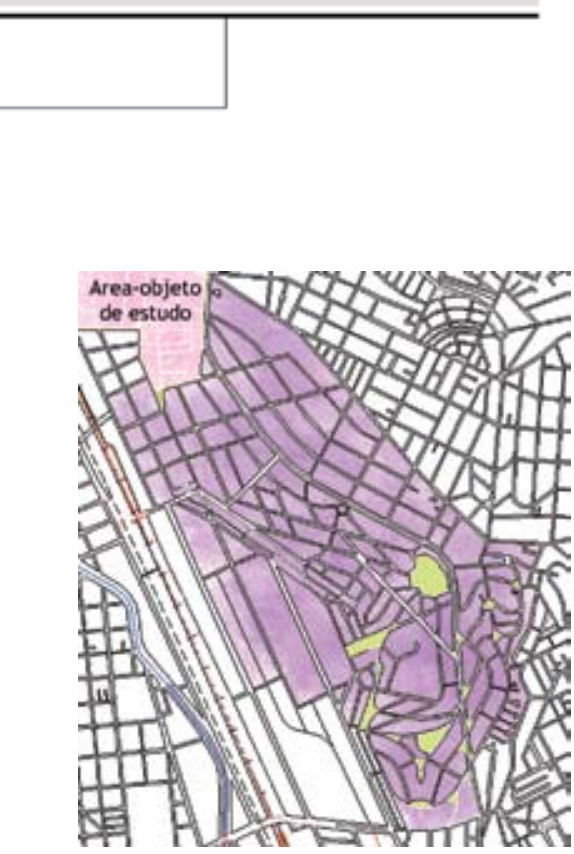

Figura 16

Parque da Mooca, empreendimento da Cia. da Chácara da Mooca, pertencente à família Paes de Barros.
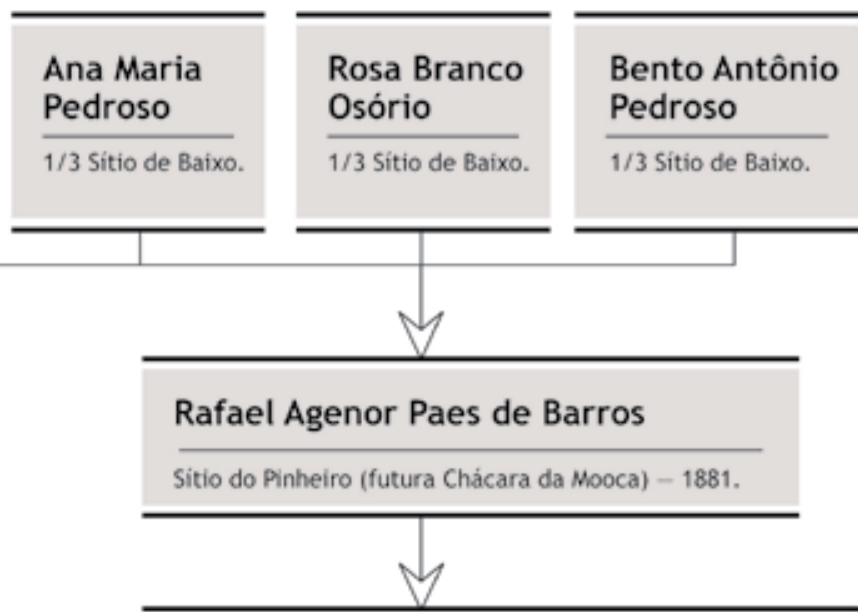

Francisca A. Paes de Barros e familiares (espólio de Rafael Agenor Paes de Barros)

\section{Chácara da Mooca}

(localizada na Freguesia do Brás, distrido da Mooca).

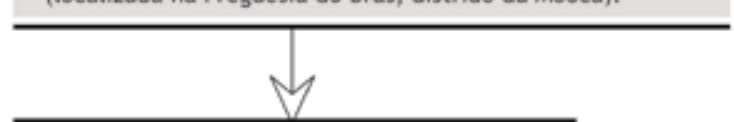

\section{Cia. da Chácara da Mooca S/A.}

Aquisiçăo de parte da Chácara da Mooca; $4140000 \mathrm{~m}^{2}-1912$

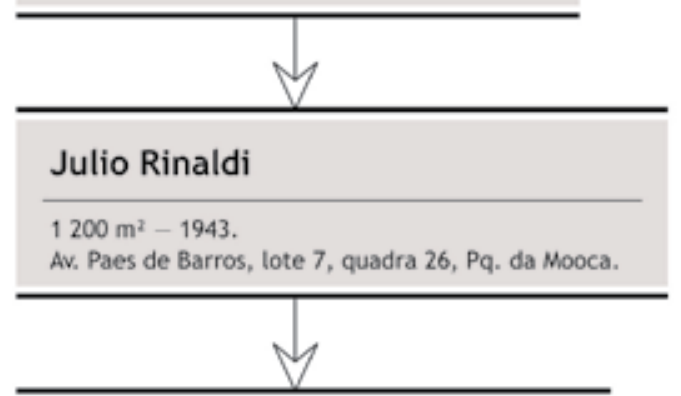

Bruna Romanato Rinaldi e filhos (espólio de Julio Rinaldi)

Casa térrea e terreno; $1200 \mathrm{~m}^{2}-1952$

\begin{tabular}{l}
\hline \\
\hline Bruna Romanato Rinaldi e outros \\
\hline Edificio Julio Rinaldi - Apartamento; \\
$212 \mathrm{~m}^{2}$ - até 2006. \\
Av. Paes de Barros, lote 701, Pq. da Mooca, ap ${ }^{\text {to }} 402$.
\end{tabular}




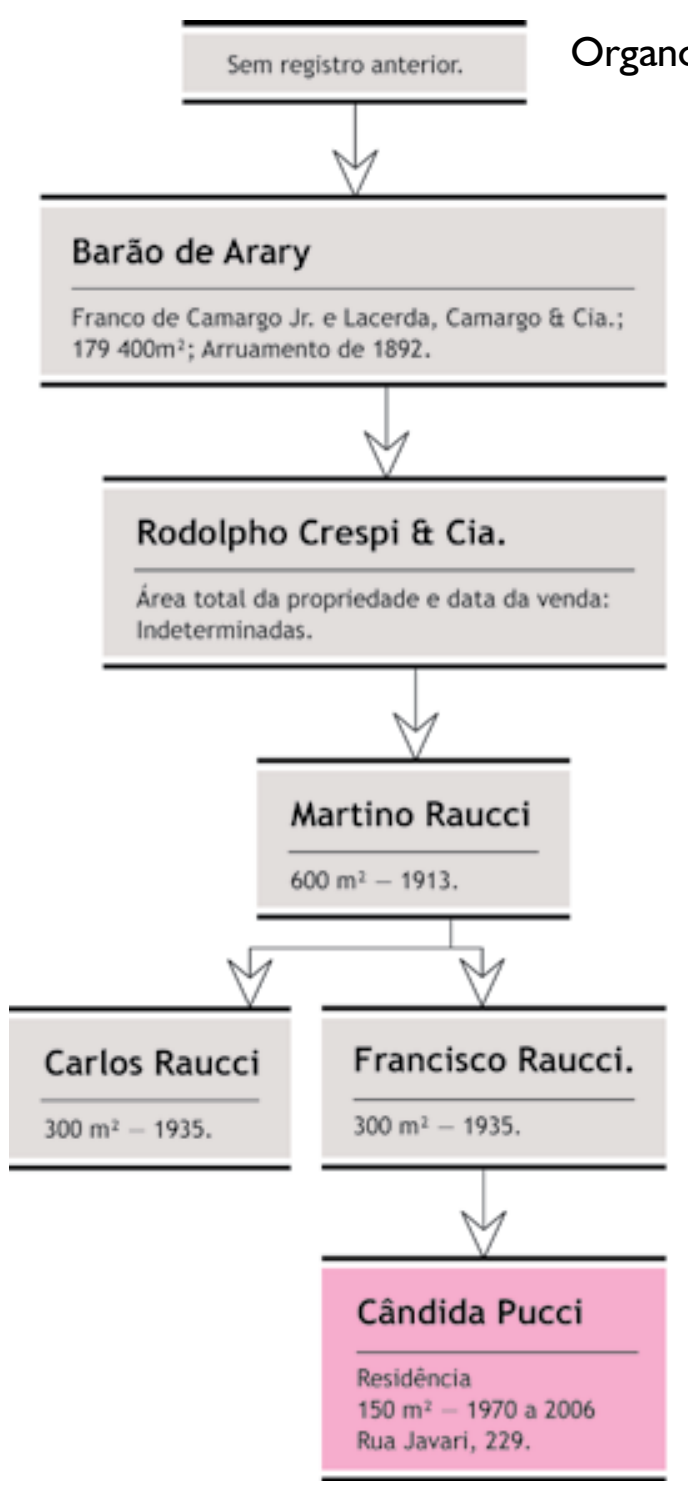

imóvel 3

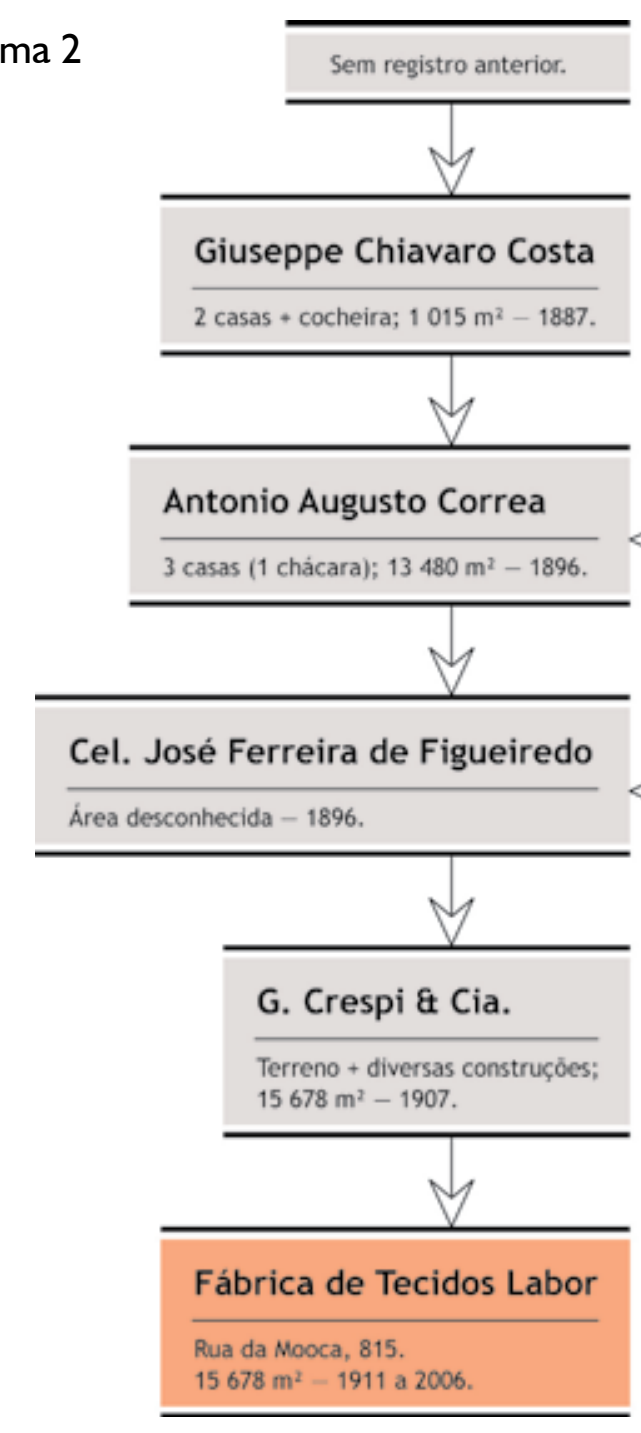

imóvel 4

\section{Organograma 3}

Banco Constructor e Agricola de São Paulo

Chácaras entre as Ruas Piratininga, Mooca e Visconde de Parnaiba. Área desconhecida - proprietário até 1894.

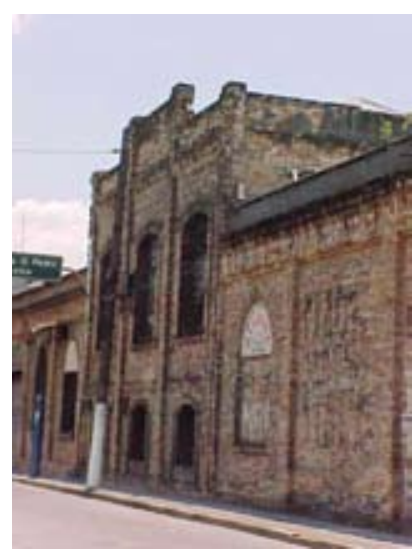




\section{Organograma 4}

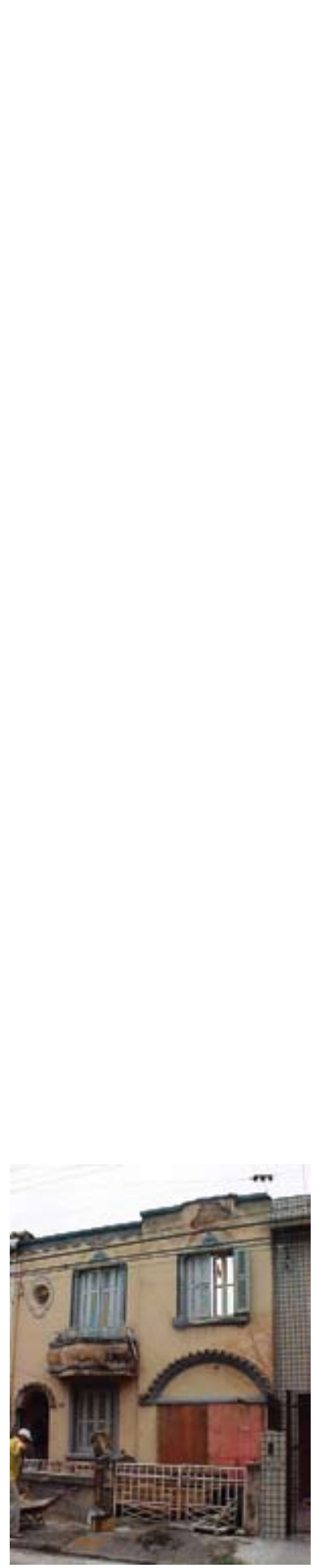

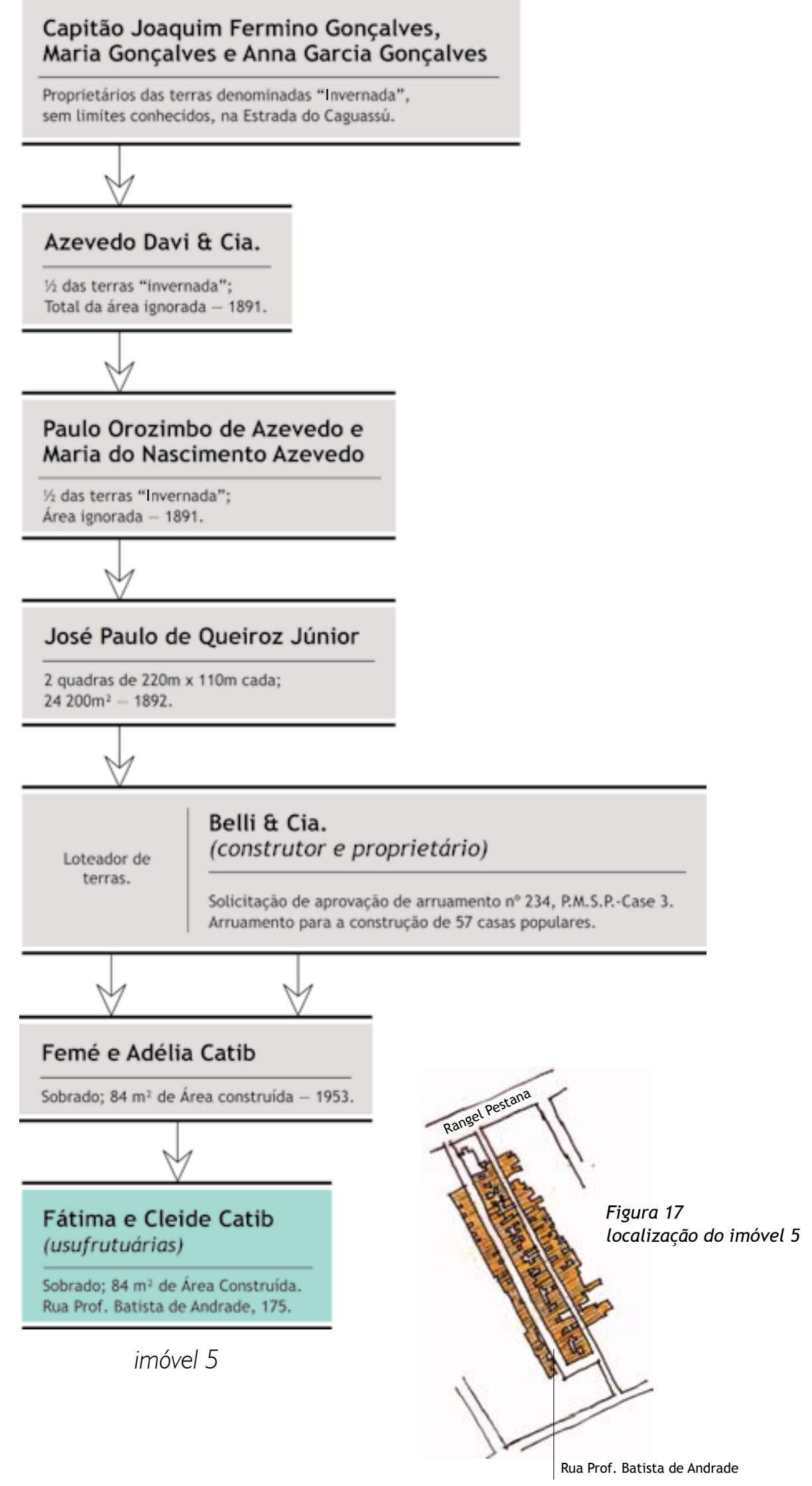

Capitão Joaquim Fermino Gonçalves, Maria Gonçalves e Anna Garcia Gonçalves

Proprietários das terras denominadas "Invernada", sem limites conhecidos, na Estrada do Caguassú.

Paulo Orozimbo de Azevedo Maria do Nascimento Azevedo 


\section{I A produção capitalista do espaço urbano no Brás e Mooca}

Um dos exemplos mais importantes de produção capitalista no Brás e Mooca são as vilas operárias e as vilas residenciais para a classe média, construídas para serem vendidas ou para aluguel, a partir do início do século 20. Outro exemplo, mais recente, são os edifícios residenciais de classe média, construídos a partir da década de 1980, mas que tem pouca representatividade na área até o momento.

No primeiro exemplo, as vilas operárias produzidas para os investidores capitalistas representavam duas formas de renda para estes: o lucro obtido com a venda de residências prontas e a renda anual obtida com o aluguel de galpões industriais e moradias operárias. O rentismo era um importante investimento já que alugar era a única forma de moradia ao alcance da população. Segundo a Planta Geral da Cidade de São Paulo com indicações diversas, de 1914, organizada pela Comissão Geográphica e Geológica e pelo engenheiro João Pedro Cardoso, o rendimento anual dos 43.940 prédios existentes na cidade em 1913 estava oficialmente calculado em $75.419 .002 \$ 000$ (setenta e cinco mil quatrocentos e dezenove contos e dois mil réis), valor que correspondia a $10 \%$ do valor venal estimado desses imóveis: 754. 190.020\$000 (setecentos e cinqüenta e quatro mil cento e noventa contos e vinte mil réis).

Segundo Langenbuch, a cidade apresentava entre 1890 e 1900 uma área arruada mais ou menos contínua da cidade entre a Barra Funda e o Belenzinho, sendo a Mooca um dos extremos desse bloco mais compacto, circundado por extensões não arruadas. Segundo ele, o espraiamento da cidade foi iniciado pelo surgimento de loteamentos novos em áreas isoladas e desconectadas do bloco arruado. Isso levou ao início da especulação imobiliária em São Paulo já em 1890, quando compradores de lotes afastados tinham consciência de que a cidade não tardaria a alcançar o local (1971 , pp.82-83). Langenbuch menciona o "quase total desprezo pelas várzeas e baixos terraços", segundo este sabiamente: "Apenas uma várzea, a do Tamanduateí, já havia sido parcialmente ocupada depois de executadas obras de retificação do rio" (197I, p.84).

A produção capitalista do espaço na forma de moradias começa a partir da década de 1920, no Brás e Mooca, com pedidos de alvará para a construção de casas populares ou operárias nos loteamentos anteriormente executados e detalhados na tabela 5. Em 1928 foi solicitado pedido de alvará para a construção de vila operária com dezesseis casas geminadas e um prédio com seis apartamentos à Rua Visconde de Parnaíba, no Brás, entre as ruas Piratininga e Caetano Pinto, de propriedade de Cristiano Ribeiro Luz. Outro registro interessante encontrado nos arquivos da prefeitura mostra o pedido de alvará de 1939, para construção de 36 casas operárias à Avenida Presidente Wilson, dentro da propriedade da Cervejaria Antárctica. Essas casas tinham $65 \mathrm{~m}^{2}$ de área construída. O número de moradias construídas variava muito e podia ser em lotes de quatro, quinze, vinte e duas ou de trinta e seis casas, como no exemplo da Antárctica.

Em 1955, foi emitido último pedido de alvará que envolveu a construção de uma vila residencial com 15 casas na Rua João Caetano, 322, na Mooca, com dois dormitórios e 70m² de área construída cada uma. No Brás, o último pedido refere-se à construção de vila com 24 casas em renque, à Rua Visconde de Parnaíba, num lote com área total de $2.282 \mathrm{~m}^{2}$.

Segundo Kawai (2000, p. I2), na década de 1930, os terrenos localizados na região do Brás estavam mais valorizados que os terrenos localizados em loteamentos mais recentes, hoje áreas nobres do município de São Paulo, como o Jardim América e Cerqueira César e equiparados a terrenos em áreas como o Centro e Consolação.

Também a construção de cortiços, apesar de ser um tipo de construção ou habitação precária, configura uma forma capitalista de provisão de moradia para o mercado de baixa renda ou a classe trabalhadora, desde a industrialização da cidade até hoje. O surgimento de 
${ }^{47}$ Fonte: Cadastro de valores do Município de São Paulo 1937. 1938 in Célia Seri Kawal, Os loteamentos de traçado orgânico realizados no Município de São Paulo na primeira metade do século 20. Dissertação de Mestrado. Departamento de Geografia - USP. São Paulo, 2000, p. 12.

\section{Figura 18}

Exemplo de projeto para casas operárias na região da Mooca, à Rua João Caetano, incorparado e construído por Elias Dib Schwery em 1939: catorze casas de $70 \mathrm{~m}^{2}$ cada. Fonte: Arquivo CASE 3 - PMSP novos cortiços nunca foi evitado apesar da legislação e da tentativa de controle por parte dos sanitaristas. Continuaram a multiplicar-se inclusive com a subdivisão de casarões no Brás e Mooca e continuam existindo até hoje em maior quantidade na Mooca baixa.

Segundo Rolnik, a cidade de São Paulo teve áreas valorizadas ou não pela condução das leis urbanas pela elite paulistana, a classe dominante, que procurou resguardar seus interesses, criando bairros estritamente residenciais, protegendo-os de quaisquer tipos de "invasões" ao mesmo tempo em que esquecia do resto da cidade, da cidade dos operários e imigrantes, criando assim duas cidades em uma: a cidade legal e a cidade ilegal. Vimos que como conseqüência a cidade de São Paulo foi dividida em muitos pedaços, onde predominam até hoje dois tipos econômicos: a cidade pobre e a cidade rica (1997, pp.46-48).

Em virtude da procura por terrenos de proporções apropriadas para a instalação de edifícios industriais e para a produção capitalista de moradias para a classe operária, na década de 1930, o bairro do Brás aparece como um dos bairros com terrenos mais valorizados da cidade, equiparando-se à Consolação e ao centro e ficando acima de outros bairros como Jardim América e Cerqueira César ${ }^{47}$.

Os pedidos de alvará para abertura de ruas e a posterior construção de casas populares ou operárias e que configuram a produção capitalista de moradias no Brás e Mooca, começaram a partir do início da década de 1920 e perduraram até o ano de 1955. É um bom exemplo o pedido de 1892 para arruamento na área contida entre as ruas Mooca, Trilhos, João Antonio de Oliveira e que avançava à direita da Rua Taquari, num total aproximado de $178.000 \mathrm{~m}^{2}$, onde se implantaria a Rua Javari, a Visconde de Laguna e a R ua Yolanda, passagem de uma vila operária. Outro bom exemplo é o pedido de 1916, também na Mooca, onde se dividiu a área localizada na Rua da Mooca de propriedade de C.F. de Lacerda em 57 lotes residenciais ou possivelmente para outras atividades também.
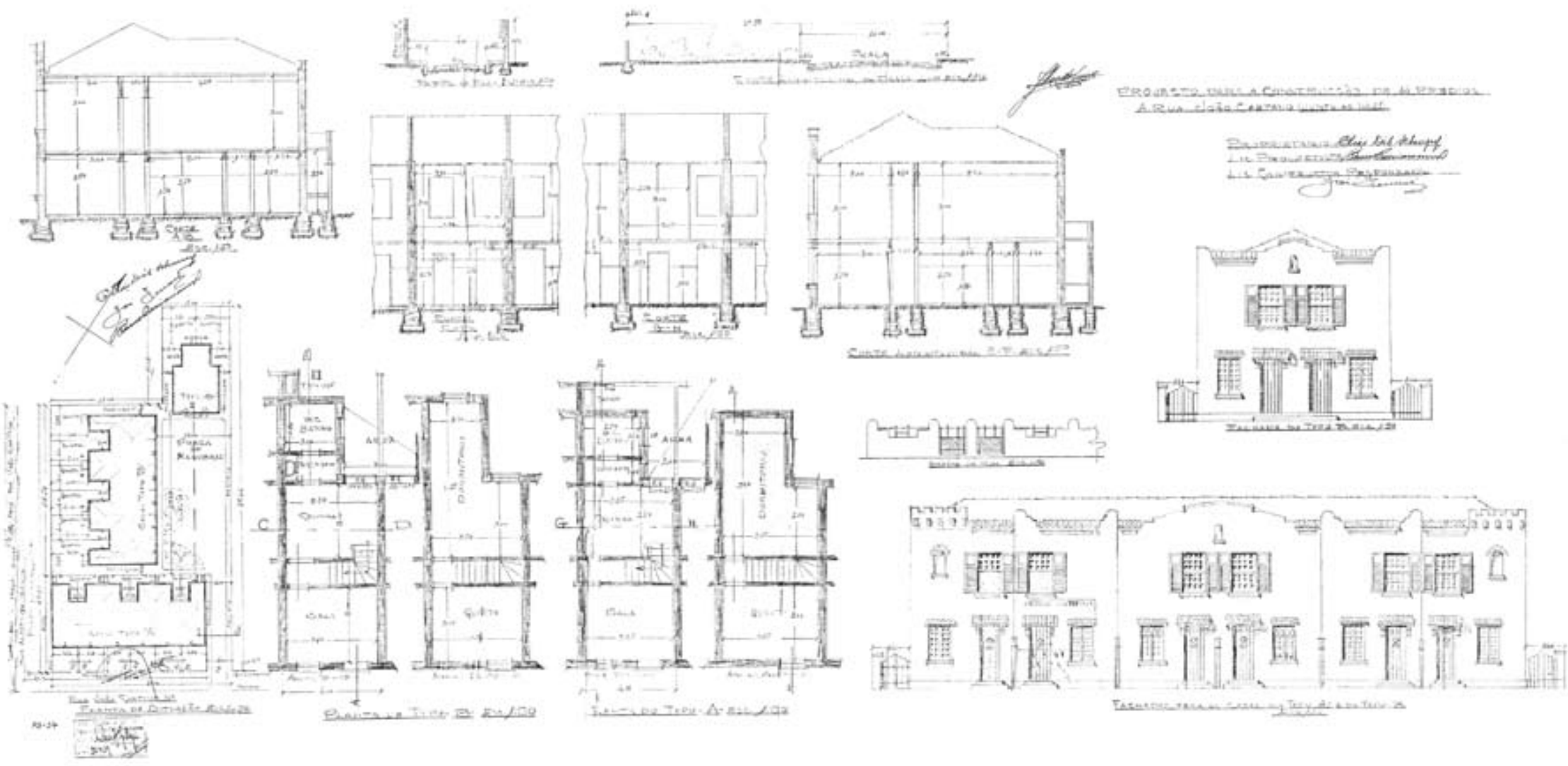


\subsection{A produção estatal do espaço urbano na Mooca e Brás}

São várias as formas de produção estatal do espaço numa metrópole como São Paulo: moradias para as classes de baixa e média renda, instalações institucionais públicas como escolas, postos de saúde, sistemas viários, instalações esportivas, instalações culturais como museus, teatros e outros espaços culturais e até mesmo a própria legislação que regula a produção do espaço urbano, como planos diretores, leis de uso e ocupação do solo e mais recentemente os planos diretores regionais das subprefeituras e os planos de bairro. Em relação aos dois últimos, serão melhor detalhados no Capítulo VI.

A partir da década de 1920 "os investimentos privados se desinteressaram da construção de cidades, seja na infra-estrutura urbana, seja em vilas operárias, em virtude da fome de capitais na industrialização em ascensão" (Campos Filho, 1989).

Em 1920, Anhaia Mello defendia a regulamentação, por parte do Estado, dos serviços públicos de forma que sua distribuição tivesse uma função social ${ }^{48}$.

Pouco a pouco o estado passa a assumir parcelas dos investimentos urbanos, criando condições gerais exigidas pela industrialização, principalmente o transporte ferroviário, essencial para os trabalhadores pobres e o transporte urbano por ônibus (década de 40). Essa crescente estatização dos meios coletivos de produção e consumo foi provocada pelo interesse do capital em aumentar seus lucros e manter os salários dos trabalhadores achatados, o que deixava os trabalhadores sem condições de comprar serviços urbanos produzidos pela iniciativa privada, o que exige o subsídio estatal. Na década de 1960, uma maior soma de recursos que o Estado passou a centralizar, e a euforia desenvolvimentista, geraram um crescimento de obras e serviços públicos de alto custo, denominados faraônicos (Campos Filho, 1989).

Apesar da média nacional nos anos 50, quando a cobertura de área urbana com saneamento básico era de $40 \%$ para água e $25 \%$ para esgoto, os bairros do Brás já dispunha, em 1900, de 50\% de cobertura com iluminação pública e 50\% para água encanada e esgoto em sua área urbanizada; em 1928, a cobertura para água e esgoto sobre a área urbanizada era de 100\% no Brás e de 80\% aproximadamente na Mooca (Rolnik, 1997, Mapas 15, 16, 17, 18 e 19).

Além das obras de saneamento básico, as principais ações do Estado na área resumemse às implantações dos sistemas viários Metrô Leste e Avenida Radial Leste e, a produção de moradias para média renda, nas décadas de 1980, 1990 e 2000.

$\mathrm{Na}$ cidade de São Paulo, dois órgãos públicos ${ }^{49}$ atuaram e atuam na área de habitação provendo moradias para a população de baixa e média renda: a COHAB - Companhia Metropolitana de habitação de São Paulo, e a CDHU - Companhia de Desenvolvimento Habitacional do Estado de São Paulo. A COHAB foi criada em 1965 e a CDHU iniciou suas atividades em 1949. A COHAB passou a atuar na área específica do Brás a partir do final da década de 1980 e a CDHU ao final da década de 1990 com empreendimentos no Brás e Mooca.

Hoje a COHAB agrupa vários programas de atendimento à população de baixa renda, como Morar no Centro, PAR, Bolsa Aluguel, Locação Social e os mutirões organizados para a autoconstrução. A CDHU, órgão da esfera do governo estadual participa com programas de produção de habitação para população de baixa renda em quase todas as cidades do estado de São Paulo, além da capital. A CDHU tem atuado eficazmente na realocação da população moradora de cortiços, através do PAC - Programa de Atuação em Cortiços.

A produção estatal na provisão de moradias para a classe de baixa renda na área-objeto de estudo está representada pelos edifícios construídos pela $\mathrm{COHAB}$ e $\mathrm{CDHU}$, localizados no Brás. O primeiro empreendimento habitacional para a população de baixa renda, construído pelo Estado no Brás, através da COHAB, ocorre somente em 1989 no fim da crise dos anos 80. $\mathrm{Na}$ área da Mooca baixa dentro da área-objeto deste estudo, não existe nenhum empreendimento construído por esse órgão até hoje. A produção estatal na provisão de mo-
48 Philip GunN e Ricardo Toledo. Notas tomadas durante aula ministrada na disciplina AUH582 I - Estado Capitalista e a Questão Urbana, PG-FAUUSP, I semestre de 2004

${ }^{49} \mathrm{COHAB}$ - Companhia Metropolitana de Habitação de São Paulo, sociedade anônima de economia mista, foi criada sob a Lei n 6738 de 16/1 I/1965 e tem a Prefeitura do Município de São Paulo como sócia-majoritária, com 99\% das ações;

CDHU - Companhia de Desenvolvimento Habitacional e Urbano do Estado de São Paulo, foi fundada em 1949 com o nome de CECAP - Companhia Estadual de Casas Populares; passou a CODESPAULO - Companhia de Desenvolvimento Habitacional de São Paulo em 1981; em 1984 passa a ser chamada de CDH - Companhia de Desenvolvimento Habitacional de São Paulo e em 1989 recebe o seu atual nome. A nova estatal absorve o DOP - Departamento de Obras Públicas e a CONESP - Companhia de Construções Escolares. Fontes: sítio oficial da CDHU e COHAB na internet: www.cdhu.sp.gov e www.prefeitura.sp.gov.br/empresas autarquias/cohab/organização 
radias para a classe baixa e média está também representada pelos edifícios construídos pela CDHU.

A proposta da CDHU é o atendimento exclusivo da população de baixa renda ( I a 10 salários mínimos). Sua produção é basicamente formada por edifícios verticais com cerca 754 unidades já entregues ou em fase de finalização, até 2005 aproximadamente, somente no distrito do Brás. Não há registros de empreendimentos no trecho Mooca da área-objeto deste estudo. A CDHU conta também com o PAC - Programa de Atuação em Cortiços, que transfere moradores de cortiços presentes em áreas degradadas dentro do município de São Paulo para imóveis novos do CDHU na região original de residência dessa população. O PAC da $\mathrm{CDHU}$, tem atuado na área com a seguinte estratégia:

A estratégia do Programa PAC tem como procedimento inicial da elaboração do plano no SBIBrás foi à confirmação e retificação do cadastro de imóveis encortiçados realizado pela SEADE, através de trabalho de campo que, em paralelo, verificou in-loco outras informações relativas a aspectos urbanísticos apontados naquele trabalho.

Neste primeiro momento procurou-se também, através do estudo da história de sua formação, recuperar os motivos determinantes para a atual configuração física do setor e buscar elementos que auxiliassem na compreensão de sua dinâmica urbana. Ao mesmo tempo foram pesquisados os imóveis de valor histórico tombados, a legislação pertinente e seus reflexos no setor com a determinação das respectivas áreas envoltórias. Além disto, nesta primeira etapa, iniciou-se a análise e a sistematização dos diversos aspectos, que farão parte da elaboração final do diagnóstico que integra o Projeto Setorial. A saber:

- Aspectos Urbanísticos - Formação do bairro, uso e ocupação do solo, tamanho dos lotes, gabaritos das edificações, terrenos vagos, imóveis públicos;

- Aspectos de preservação - Z8-200, tombamentos e edificações de importância histórica;

- Aspectos legais - Plano Diretor Estratégico, zoneamento, ZEIS 3, PRIH, Operações Urbanas;

- Infra-estrutura, equipamentos públicos e investimentos previstos;

- Pesquisa imobiliária;

- Identificação das concentrações de cortiços.

Todas as informações atualizadas foram acrescentadas ao Banco de Dados Georeferenciado CDHU-SEADE, o que possibilitou a geração dos mapas temáticos necessários para a formulação do diagnóstico final (CDHU, Relatório PAC-Brás, 2004, p.4).

Os sistemas viários são outra forma de produção estatal e está representada na áreaobjeto deste estudo pelo sistema viário local construído ao longo do desenvolvimento urbano da área e associado à construção de sistemas viários regionais mais recentes como a Avenida Alcântara Machado ou Radial Leste, a partir do fim da década de 1950; a implantação da Linha Leste do Metrô, a partir da década de 1980 e as ferrovias, inicialmente construídas a partir de investimentos privados no fim do século 19, mas que foram posteriormente encampadas pelo poder público e por este foram expandidas. Os sistemas viários serão vistos mais detalhadamente no item 5 deste capítulo. 


\subsection{As demandas habitacionais no Brás e Mooca}

Para avaliar as reais necessidades de provisão de moradias no Brás e Mooca, foi necessário conhecer a sua população efetiva além dos tipos de domicílio existentes na região. Para isso, foi de grande valia a consulta de dados realizada no sítio da Fundação SEADE na internet para conhecimento das quantidades e tipos de domicílio ${ }^{50}$.

Os números relativos ao distrito do Cambuci foram considerados nesta tabela em função da Mooca baixa fazer parte do distrito do Cambuci pela administração pública. As lacunas indicam que do período em questão não existem registros ou levantamentos.

Assim como no restante da cidade de São Paulo, os habitantes do Brás e Mooca foram duramente atingidos pela recessão dos anos 81 a 83 e pela perda de empregos com a saída das indústrias da região metropolitana. Muitas famílias foram obrigadas a mudar-se para regiões mais distantes em busca de aluguéis mais baratos, principal atração das periferias. $\bigcirc$ grau de adensamento da área-objeto de estudo pode ser considerado muito baixo se comparar-se os índices de densidade demográfica dos distritos Mooca, Brás e Cambuci a outros distritos da metrópole.

A Tabela 6 demonstra a evolução da população por padrão e tipo de domicílio na ocasião dos dois últimos Censos Demográficos realizados pelo IBGE, nos três distritos em questão: Brás, Mooca e Cambuci (que inclui a área da Mooca baixa).

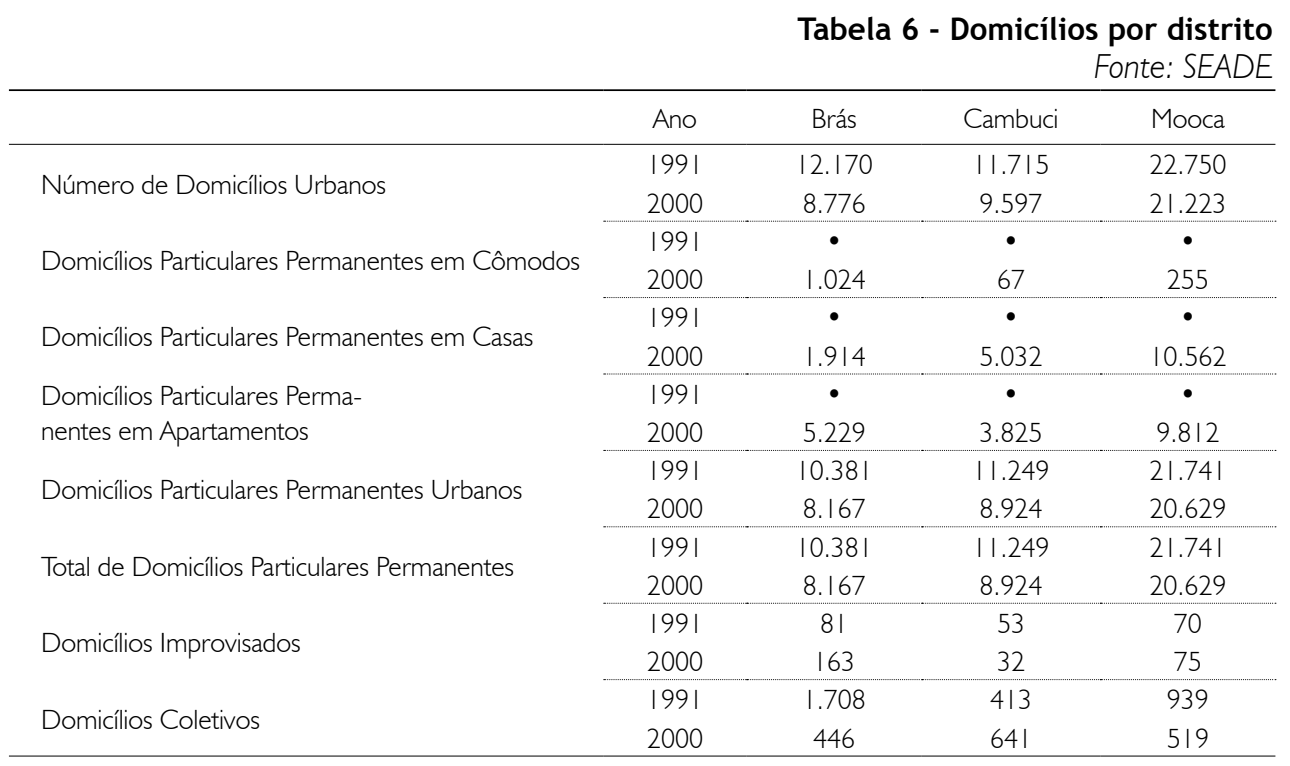

Depreende-se dessa tabela que entre os Censos Demográficos de |99| e de 2000, os três distritos tiveram diminuição no número total de domićílios, sendo o Brás o distrito que mais perdeu (cerca de 27\%). Nos três distritos há um número significativo de moradores de domićlío do tipo cômodos, improvisados e coletivos e que deverão ser incluídos em programas de realocação ou de provisão de moradias dignas por parte do Estado.

Segundo dados do Censo Demográfico de 2000 do IBGE, a população do Brás era de I 4.893 habitantes naquele ano, sendo que 2.798 moradores de cortiços ( 28 cortiços segundo SEADE 200 I); na Mooca a população era de 48.050 habitantes com 2.096 pessoas morando em cortiços ( I I cortiços segundo SEADE 200 I). No Cambuci, que inclui a área aqui chamada de Mooca baixa, a população era de 19.280 habitantes, sendo 2.960 moradores de cortiços ( 63 cortiços segundo SEADE 200 I). Segundo uma pesquisa mais recente
50 Ver a classificação das varáveis desta tabela no verbete domicílio do Anexo I - Glossário. 
${ }^{51}$ Favela: Construções precárias em terrenos públicos invadidos em número superior a 50 habitações. Yvonne MAUTNER. Notas de aula durante disciplina AUH 5706 Economia política na formação urbana de São Paulo, PG-FAUUSP, 2003.

52 Lei Municipal n 8328, de 02 de dezembro de 1975 in Maria Cecília CARDoso, O Metrô e a Urbanização de São Paulo. Dissertação de Mestrado, FAUUSP, I 983.

${ }^{53}$ Idem. realizada pela CDHU, no ano de 2004 existiam 196 cortiços no Brás, 69 cortiços na Mooca e I 3 cortiços no Cambuci. A diferença de número de cortiços entre a pesquisa SEADE e a realizada pela $\mathrm{CDHU}$ podem retratar um aumento de cortiços no Brás entre os anos de 2000 e 2004 e diminuição do número de cortiços nos distritos Mooca e Cambuci.

Além da população moradora de cortiços locais, também existe a demanda por parte da população de baixa e média renda dos já moradores não proprietários e de outros que possam migrar das periferias para essa região central, no caso de ocorrerem políticas e ações públicas de provisão estatal de moradias com conseqüente atração de moradores para uma área urbana requalificada.

Não há atualmente a presença de favelas na região e historicamente não houve referências na bibliografia estudada. A análise dos mapas e documentos históricos comprova que o tecido urbano desses dois bairros já estava praticamente consolidado na década de 1930, muito antes das grandes migrações de populações rurais em direção à cidade de São Paulo ${ }^{51}$. Estão presentes na área casas de quintal ou cortiços antigos construídos com o objetivo de lucrar com sua locação a operários e habitantes locais de baixa renda. Hoje, sem manutenção, esses imóveis se encontram degradados e subdivididos em pequenos espaços.

\section{A legislação urbana no Brás e Mooca}

"Em 1971, a lei 7670 cria a Empresa de Urbanização [EMURB] para desenvolver projetos urbanos na cidade de São Paulo e com a implantação do Metrô, leis municipais são criadas para atender às demandas urbanísticas que este acarretaria" ${ }^{22}$.

\footnotetext{
Art. 22. Fica criada a Zona Metrô-Leste, ZML, destinada à implantação do sistema de Metrô, do sistema viário, terminais de ônibus, estações de transferência de passageiros, remanejamento de rede ferroviária e obras complementares, integradas em plano de urbanização, compreendendo também a construção de equipamento comunitário, áreas verdes, unidades habitacionais e comerciais $^{53}$ (Cardoso, 1983, p.2).
}

Conforme se pode observar no Mapa |4, a Lei de Uso e Ocupação do Solo de 1972 estipulou para a região objeto de nosso estudo, áreas de Z2, Z3 e ZI2, todas zonas de uso predominantemente residencial, Z4, de uso misto e uma pequena área Z6, de uso predominantemente industrial no bairro do Brás, em plena Radial Leste, esta com zoneamento específico: Z8.

O Plano Diretor datado de 1985 e produzido pela SEMPLA, Secretaria Municipal de Planejamento, na gestão de Jânio Quadros, previa um forte crescimento da cidade em direção à Zona Leste e ao longo das Marginais. No capítulo "Intervenção na Rede Viária", na relação das vias a sofrerem algum tipo de melhoria, não há menção à Avenida Radial Leste, no trecho entre Avenida do Estado e Viaduto Bresser.

No entanto não veio com a implantação da linha Leste do Metrô em 1979 a valorização da área, como teriam desejado os proprietários de imóveis da região e como ocorrido em outros bairros que tiveram esse sistema de transporte de massa instalado. Ao contrário, o que se viu e se vê é a franca degradação em que se encontra a região, principalmente a Avenida Radial Leste.

Segundo Rolnik (1997), ocorreu na cidade de São Paulo, o fenômeno da valorização do vetor sudoeste, que situou de forma positiva e permanente no mercado imobiliário da cidade, bairros como Higienópolis, Jardins e Moema, criando salvo exceções, grandes diferenças no valor de imóveis semelhantes em virtude de sua localização. 
Por ocasião da instituição da LUOS - Lei de Uso e Ocupação do Solo de 1972, o parcelamento do solo na área-objeto de estudo já era uma realidade difícil de alterar uma vez que, como visto a partir dos mapas de 1930, 1950 e 1972, tratava-se de tecido urbano totalmente consolidado. A figura abaixo, recorte ampliado de trecho do bairro do Brás, a partir do Mapa Gegran de 1972, demonstra a variedade de formas e dimensões de terrenos e sua ocupação, na maioria dos casos, sem recuo frontal e muitas vezes sem recuo lateral.
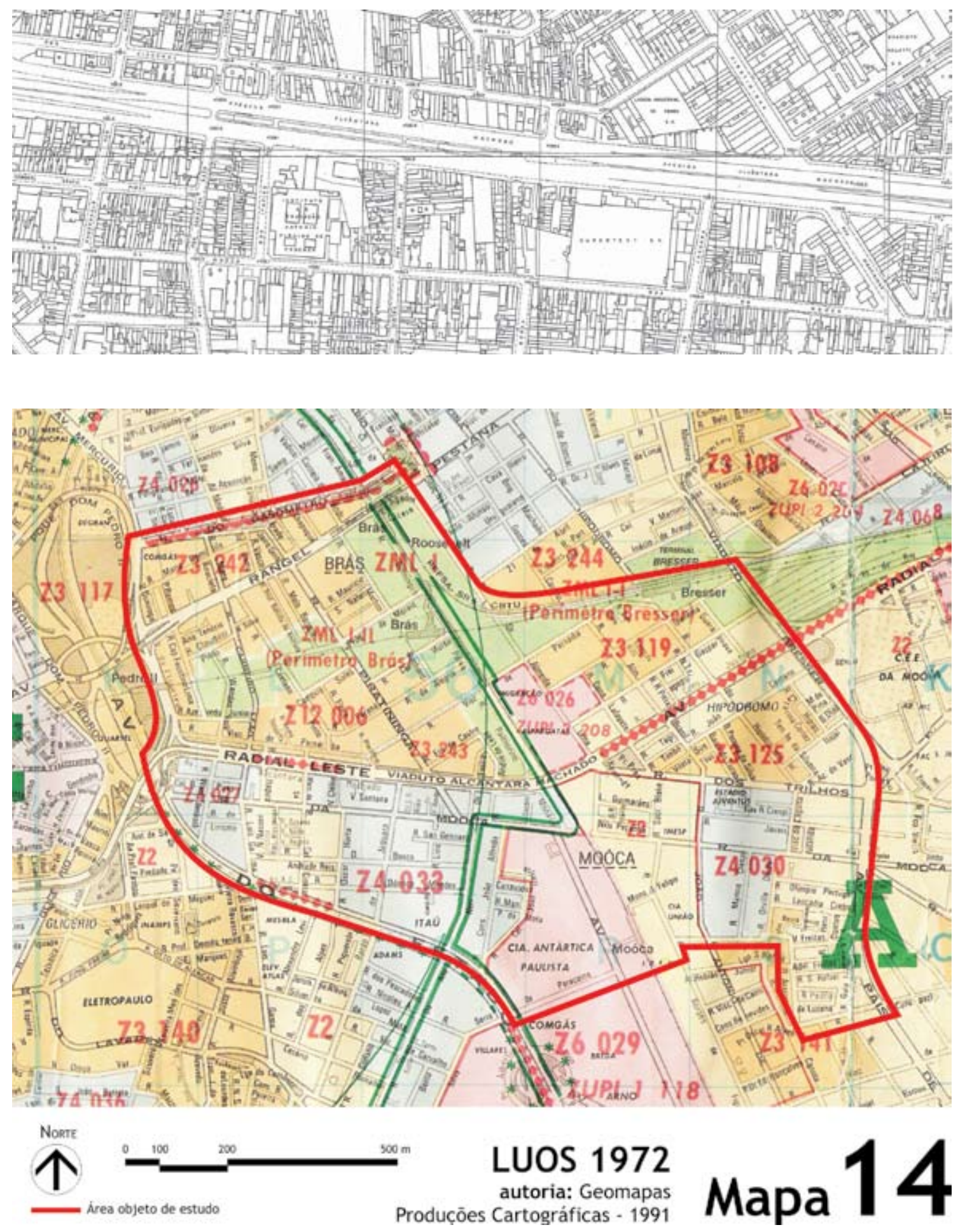

No item 2.2 do Capítulo VI faz-se uma comparação entre as Leis de Uso e Ocupação do solo de 1972 e a atual, de 2002, contida nos Planos Diretores Regionais das Subprefeituras Sé e Mooca. 
Para a década de 1970 e 1980, o planejamento em torno da implantação da Linha Leste do Metrô de São Paulo, elaborado à época pela COGEP - Coordenadoria Geral de Planejamento da Prefeitura do Município de São Paulo e durante a gestão de Olavo Egydio Setúbal como prefeito nomeado, previa uma reestruturação ao longo da nova linha a ser implantada: a ZML - Zona Metrô Leste, como demonstrado no Mapa I5.

Os limites de recorte de aplicação da ZML não incluíram a área da Mooca baixa, apesar da proximidade, o que poderia ter sido benéfico, caso as diretrizes da ZML tivessem sido aplicadas na sua íntegra. A não consideração dessa área nas diretrizes propostas endossa o isolamento a que se destinou esse pedaço da Mooca, localizado entre duas avenidas de alto tráfego e uma ferrovia - Radial Leste e Avenida do Estado e Ferrovia da CPTM, antiga SantosJundiaí - que tem características de barreiras urbanas que afetam a mobilidade e acessibilidade local. A população tem dificuldade de acesso ao meio de transporte mais rápido que é a metrovia, apesar da proximidade dela.

Analisando-se o Mapa 15, produzido pela COGEP em 1979, pode-se observar que, na área onde posteriormente se implantaria a Linha Leste do Metrô, uma grande mancha que corresponde a quase todo o trecho Brás da área-objeto de estudo era classificada como Z2; pequena área estava classificada como Z3 entre as ruas Frei Gaspar e Ipanema; a área em azul representa as áreas desapropriadas para a implantação da Linha Leste do Metrô e onde se construiriam os empreendimentos da COHAB Brás I a X e Bresser I a III; a área em vermelho e que representa Z6, parte do Brás em pequeno trecho, ampliando-se sobre a área da Mooca, onde se localiza o distrito industrial da Mooca e também sobre o Cambuci; toda a área da Mooca baixa exceto pela propriedade pertencente à Companhia Antárctica Paulista.

O Mapa 16, também produzido pela COGEP em 1979, apresenta a estrutura proposta para a ZML - Zona do Metrô Leste, onde o zoneamento foi alterado ao longo de toda a extensão dessa linha. No trecho Brás da área-objeto de estudo, a área foi dividida em uma grande parte de Zona de Renovação Urbana, outra de dimensões similares como Zona de Comércio Especializado (máquinas, couros e plásticos) ao longo da rua Piratininga, Avenida Rangel Pestana, rua Visconde de Parnaíba, Avenida Alcântara Machado e Rua do Gasômetro; quatro trechos delimitam as Principais Indústrias: Papéis Madi S/A, à Rua Palmorino Mônaco; Metalúrgica Matarazzo, à Rua Caetano Pinto; NCR do Brasil, à Rua da Figueira e a quadra entre as Ruas Domingos Paiva, Coronel Mursa e Prudente de Morais, contendo a Açolan, a Speary do Brasil e a Cummins Diesel do Brasil. Ao leste da Ferrovia Santos-Jundiaí, uma grande área chamada Zona de Comércio Diversificado, de frente para a Radial Leste onde se mesclam quadras também contendo Principais Indústrias e uma grande área também destinada a Zona de Renovação Urbana. Como demonstrado no mapa 16, na Mooca não se planejou ou se estimou nenhum resultado urbanístico a ser colhido em relação à implantação da Linha Leste do Metrô.

A ZML considerava como proposta estrutural para implantação da Linha Leste do Metrô os seguintes usos e áreas de aplicação:

- Zona de renovação urbana englobando um polígono número I, configurado pelas ruas Visconde de Parnaíba, Rua da Figueira, Avenida Rangel Pestana e Rua Domingos Paiva. Esse polígono exclui a faixa da Rua Piratininga, com forte comércio especializado em maquinário. O segundo polígono de Zona de renovação urbana abrange a área compreendida dentro das ruas Uruguaiana, Hipódromo, Coronel Antonio Marcelo, Bresser, Ipanema, Hipódromo, Frei Gaspar e fechando na Rua Almeida Lima;

- Áreas verdes - manutenção das já existentes - Parque Municipal da Mooca - sem prever a criação de novas na área de nosso objeto de estudo;

- Zona residencial de alta densidade (fora da nossa área objeto de estudo);

- Zona residencial de densidade média (fora do limite da área objeto deste estudo);

- Zona de comércio especializado (manutenção das já existentes); 


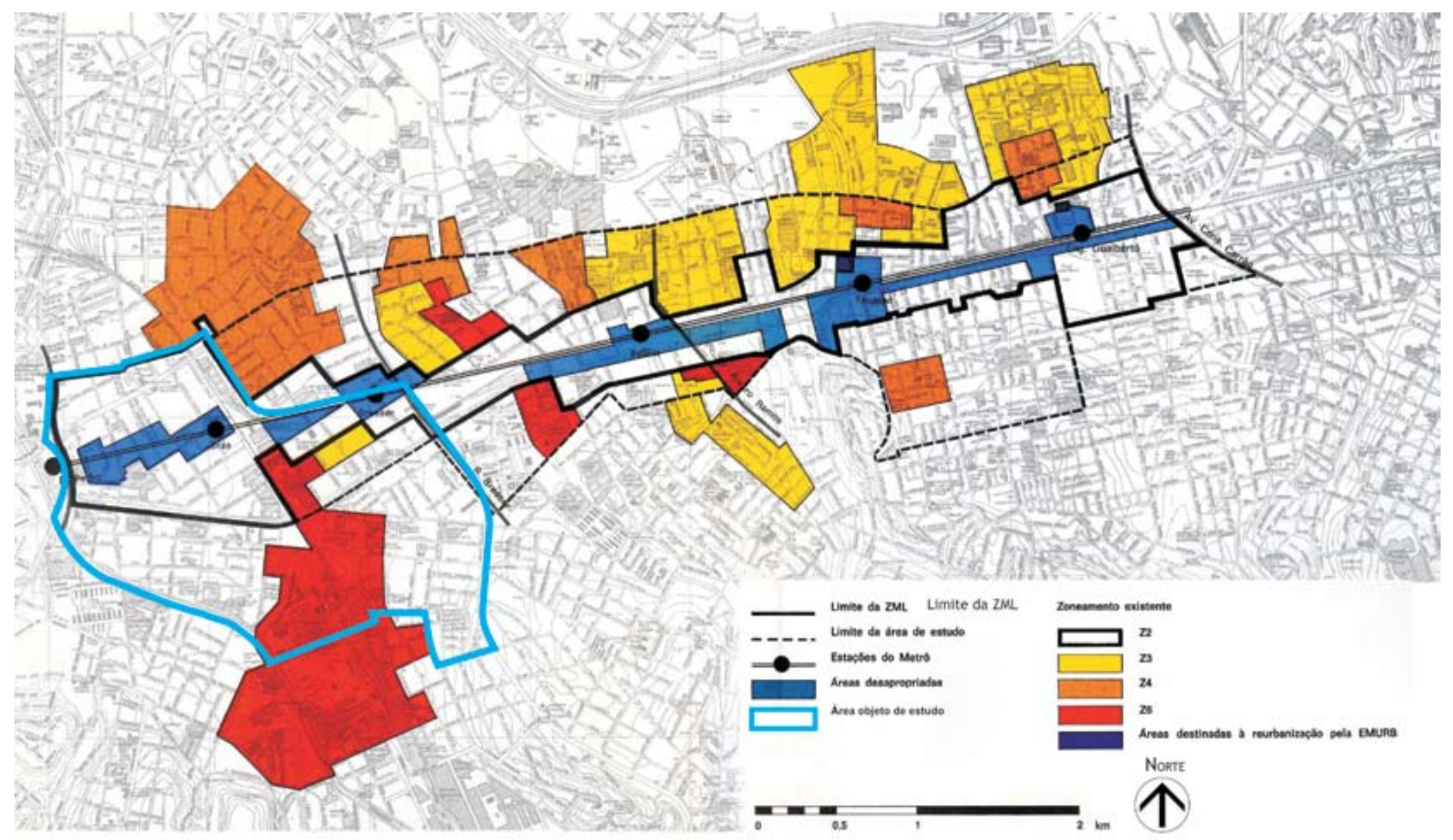

Situação e delimitação do zoneamento à epoca antes da implantação da ZML - 1979 autoria: COGEP - PMSP
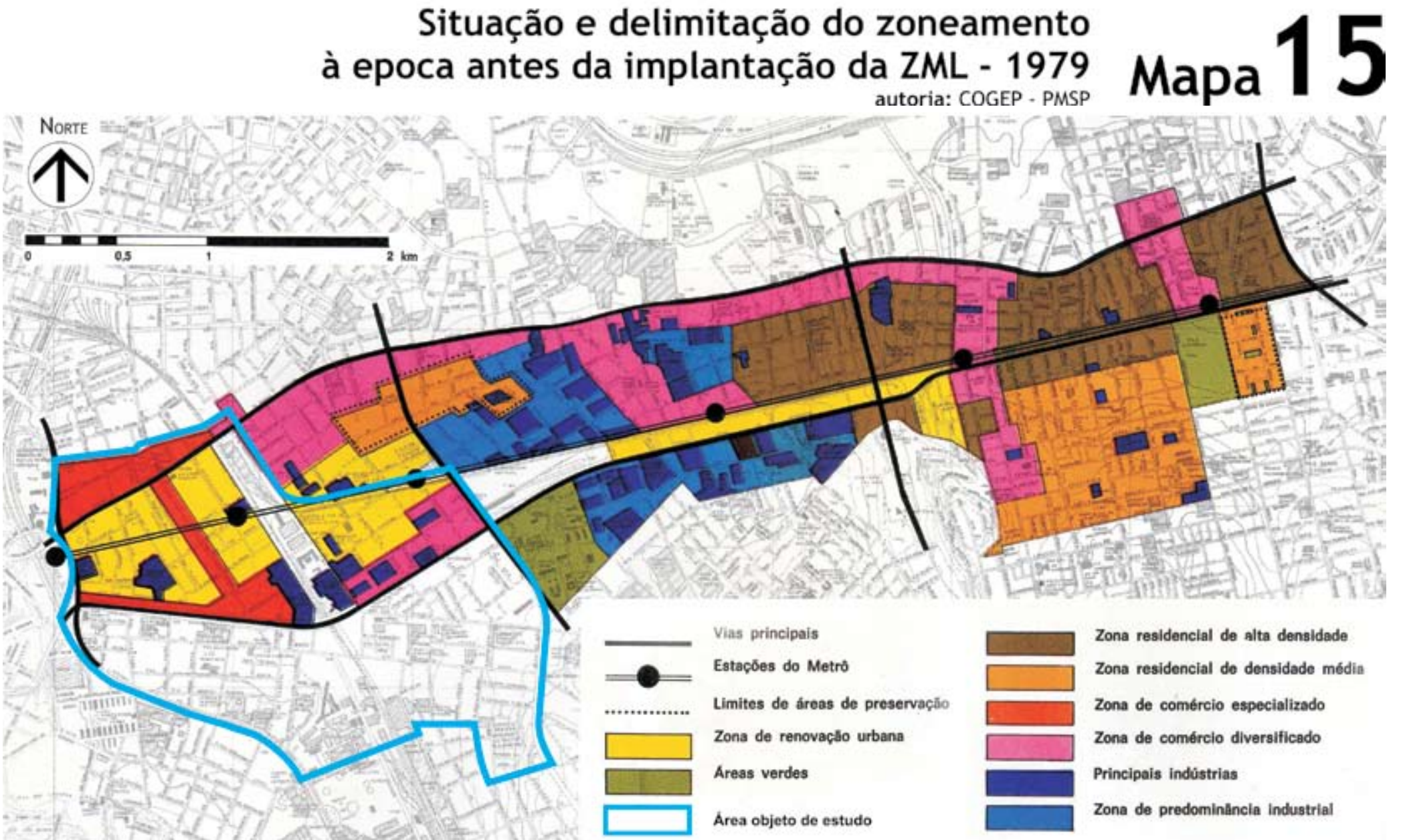

Estrutura proposta para a ZML - 1979

мара 16 
- Manutenção das principais indústrias e

- Zona de predominância industrial.

\title{
5. A estruturação viária no Brás e Mooca
}

\section{I As ferrovias Santos-Jundiaí e Estrada de Ferro Central do Brasil}

As primeiras aglomerações urbanas do Brás surgiram antes da ferrovia Central do Brasil, na área de várzea do Rio Tamanduateí, em fins do século 18, mas com a formação do tecido urbano ao longo do trajeto ferroviário na área próxima ao perímetro urbano da cidade, era inevitável que a linha férrea viesse futuramente a se constituir em uma barreira urbana à ligação entre os bairros formados marginais a esta, cuja única possibilidade de conexão eram as porteiras existentes na época. Posteriormente foram construídos viadutos sobre as ferrovias: Viaduto Alberto Marinho, sobre a ferrovia Santos-Jundiaí e Central do Brasil, atualmente CPTM, à continuação da Avenida Celso Garcia e, o Viaduto Alcântara Machado, continuação da Avenida de mesmo nome, transpondo a ferrovia Santos-Jundiaí, hoje também CPTM.

\begin{abstract}
Com efeito, dois eventos de grande importância, quer por si mesmos, quer pelas repercussões - imediatas ou a longo prazo - que trazem, ocorrem na mencionada década. Um deles é a conclusão da estrutura básica da rede ferroviária extra-regional do Planalto Paulistano. Isto se dá em 1875, com a entrega ao tráfego dos trechos iniciais da Sorocabana e da ferrovia em demanda do Rio de Janeiro (Langenbuch, 197I, p.78).
\end{abstract}

Langenbuch ressalta que, antes do início da industrialização, a tendência de escolha de Obras no cruzamento de Linhas de bonde no Largo do Brás, na Avenida Rangel Pestana, esquina das Ruas Piratininga e Jair Góes, antiga travessa do Brás. Ao fundo, grupo escolar do Brás. Autor: Gaesly, Guilherme, 1903.

Fonte: Fundação Energia e Saneamento

Em 1939, o número de trens diários de 16; 23 em 1949; 43 em 1960 e trens diários em direção à variante de Poá, que era de 6 em 1939; 10 em 1949, 25 em 1960 e passou a 29 em 1965 (Langenbuch, 197I, p. 189).

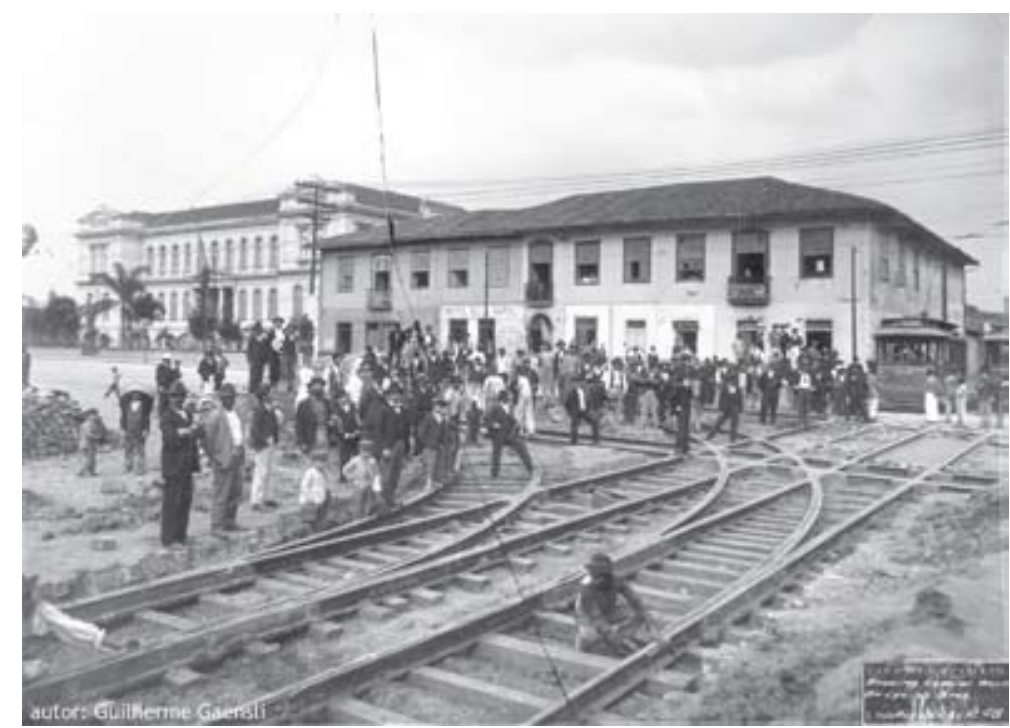

sítios às margens da ferrovia já existia, apesar das várzeas (Langenbuch, 197I , pp.85-87). Isso se explica pelo poder indutor de crescimento urbano das mesmas. Com a chegada das indústrias essa preferência se confirma.

A Estação Roosevelt, localizada no Brás e atendendo às duas ferrovias, Santos-Jundiaí e Central do Brasil, teve o número de viagens de trens suburbanos partindo dessa estação em dias úteis triplicado entre 1939 e 1965 em direção à linha-tronco e quintuplicado em direção à variante de Poá ${ }^{54}$.

Esse forte crescimento demonstra a demanda por parte dos novos habitantes da cidade, migrantes que tem como única opção morar nas crescentes periferias, mesmo trabalhando em bairros mais centrais, principalmente na indústria.

Apesar do fato da ferrovia ser um sistema viário indutor do crescimento urbano, em São Paulo esta não consegue acompanhar o ritmo do desenvolvimento urbano por ela gerado e até a década de 1970, as estradas de ferro não tomaram medidas para possibilitar a sua expansão, chegando inclusive a suprimir a linha dupla de ligação regional entre Mauá e Campo Grande. Os trens de subúrbio passam a viajar com superlotação nos horários de pico e os passageiros que sobravam passaram gradativamente a viajar de ônibus (Langenbuch, I97I, p. 191). 
A despeito de seu rebaixamento de perímetro urbano para perímetro suburbano, o Brás - assim como os outros bairros localizados no perímetro urbano - foi pioneiro em relação aos transportes urbanos já que em 1901 já circulavam bondes elétricos pela Avenida Intendência, antigo Caminho da Penha, hoje chamada de Avenida Celso Garcia e Avenida Rangel Pestana (Rolnik, 2003, p. 12 I e Mapa I I p.35).

As linhas de bonde eram exploradas por empresas privadas e rapidamente atingiram o bairro da Mooca. Em 1914 o trajeto instalado circundava e atendia de forma confortável os habitantes do Brás e Mooca, considerando-se trajetos intra-urbanos e trajetos até o centro histórico da cidade.

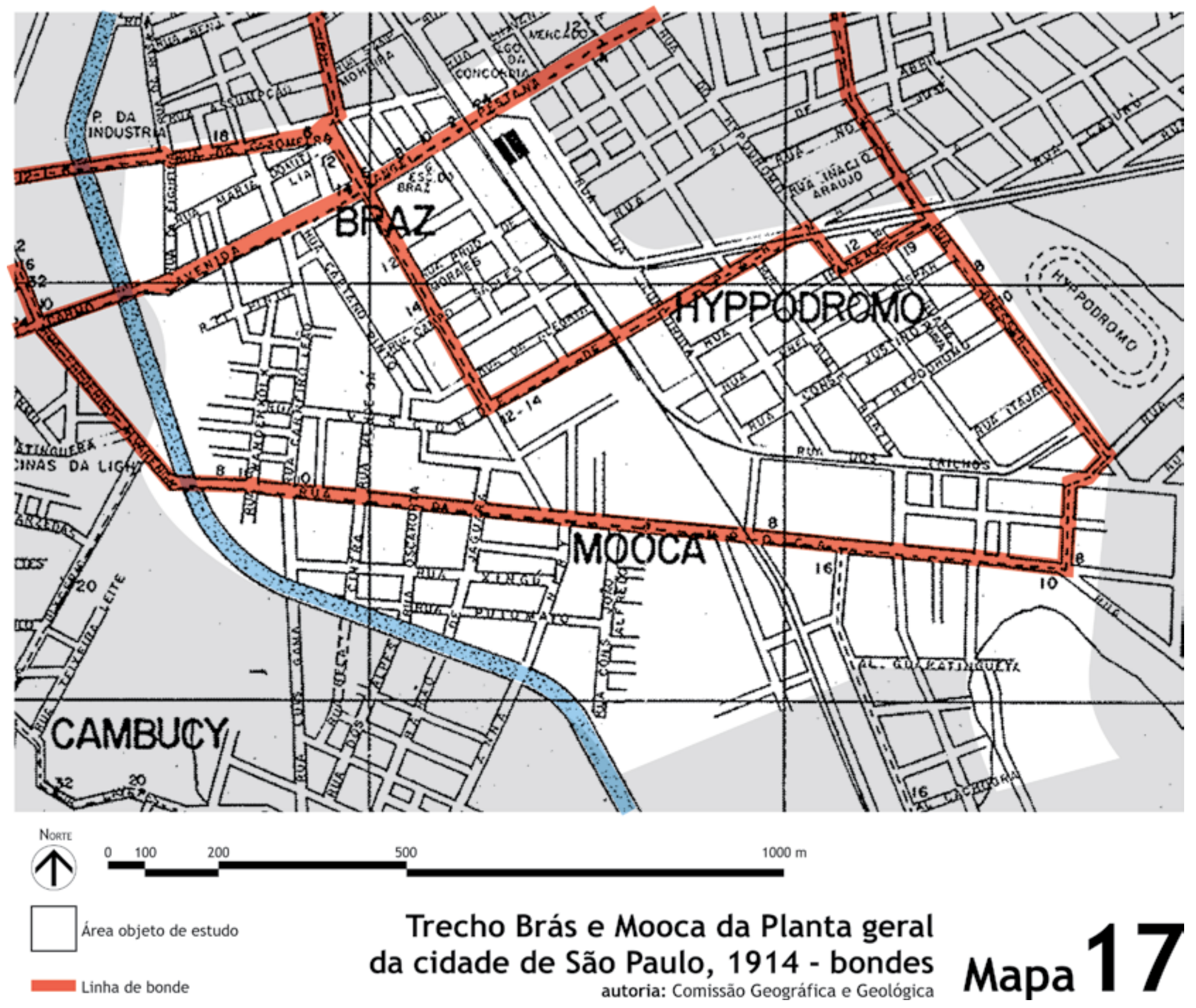




\subsection{A Avenida Radial Leste e as outras vias estruturadoras}

Segundo Langenbuch, as estradas de província de São Paulo eram de um modo geral, bastante precárias, com escassos trechos calçados. Apesar disso, a circulação não foi afetada pois, o uso era intenso e aumentava a medida que a cidade crescia. Essas estradas sofreram alterações em seu traçado local, corrigindo-se a desnecessária sinuosidade original. Além de circulação, as estradas tiveram um papel significativo no processo de povoamento, que teria sido mais importante se não houvessem ocorrido tantas alterações de traçado.

Dentro das estradas de província mais importantes até o advento ferroviário, Langenbuch cita a Rua do Brás, hoje Avenida Rangel Pestana: "Estrada demandando o Rio de Janeiro (ou a 'Corte', com se dizia) passando pelas freguesias do Brás, Penha e pela Vila de Mogi das Cruzes" (I97|, p.30).

Langenbuch classifica hierarquicamente as vias como:

I- circulação local, entre diferentes porções dos próprios arredores;

II- circulação entre os arredores e a cidade de São Paulo;

III- circulação entre áreas mais afastadas (Interior) e São Paulo ( 197|, p. 3 I).

São Paulo à época já gozava da invejável posição de centro irradiador do sistema de circulação da província e nessas estradas também se desenvolveram atividades a ela relacionadas, como o pouso de tropas com pastagem para os animais e pernoite para os viajantes (Langenbuch, pp.29-38).

A estrada do Rio contava com dois pousos: um no Brás e outro na Penha. Além do pouso de tropas, a estrada São Paulo-Rio contava com o albergue e estabelecimento comercial de José Braz, português ali radicado em 1730 (Langenbuch, p.4I).

\footnotetext{
Entre os pousos há a distinguir aqueles situados na vizinhança imediata da cidade (no cinturão das chácaras) que constituíam um deslocamento da função de hospedagem da cidade para o seu exterior, daqueles sítios a maiores distâncias, no "cinturão caipira", relacionadas às interrupções de viagem (Langenbuch, p.75).
}

A Avenida Radial Leste ou Avenida Alcântara Machado representa um segundo nível de intervenção viária nos bairros do Brás e da Mooca, depois da ferrovia, mas diferentemente da primeira, que polarizou o crescimento urbano ao longo das linhas, a Avenida se interpôs entre os dois bairros, alterando o traçado viário e conseqüentemente o tecido urbano consolidado anterior à sua construção, de forma drástica.

Surgida para promover as ligações entre bairros e o centro, no sentido leste-oeste da cidade de São Paulo, esta Avenida já fazia parte do Estudo do Plano de Avenidas de Francisco Prestes Maia, dentro do seu famoso esquema de vias radiais e perimetrais, concebido entre as décadas de 20 e 30 (Leme, pp. 168-169).

O projeto de abertura de uma via expressa, em direção leste da cidade, foi aprovado em 1955 durante a gestão de Adhemar de Barros como prefeito e José Carlos de Figueiredo Ferraz como secretário de obras (Rolnik, 2003, p. 198).

Décio Amadio, em sua tese de doutoramento (2005, p. I36), fez um levantamento histórico da evolução da estruturação viária planejada no Estudo do Plano de Avenidas, que inclui a Avenida Radial Leste: 
Avenida Central do Brasil: Projeto de via semi-rápida que foi substituída pela atual Avenida Alcântara Machado, ou Radial Leste, contando com as sub-radiais Bresser, Siqueira Bueno, Álvaro Ramos, Salles Leme e Tatuapé. A função dessa radial seria a de desafogar as avenidas Rangel Pestana Celso Garcia, Visconde de Parnaíba e Mooca, contando os bairros [sic] do Brás, Mooca, Tatuapé e Penha. No projeto original estava prevista uma largura de 60 metros, que receberia uma linha central de alta velocidade.

Batizada de Avenida Alcântara Machado, possuía uma extensão prevista de 10.400 metros, com dupla via e um viaduto sobre as linhas férreas. Na gestão municipal de Faria Lima, Luis Gomes Cardim Sangirardi, funcionário do Departamento de Urbanismo, criou diretrizes para a realização de projeto complementar, que tinha como objetivo dar vazão ao tráfego de veículos na direção da zona oeste à zona leste, passando pelo centro da cidade e pela áreaobjeto de estudo, que resultou no Elevado Costa e Silva e que faz parte do conjunto da Radial Leste-Oeste, contribuindo com o alto tráfego de veículos na Avenida (Martins, 1997, p.9). O Elevado afeta a cidade com seu forte impacto estético, através de suas laterais de concreto que impossibilitam a circulação de pedestres na extremidade que desemboca na Avenida Radial Leste, junto à Avenida do Estado. A análise desse impacto pode interferir na tomada de decisões na proposição de diretrizes para a reurbanização da Radial Leste.

O Elevado Costa e Silva foi projetado durante a gestão de Faria Lima e seu ano de construção foi 1970, durante a gestão municipal do engenheiro Paulo Salim Maluf, tendo como Diretor de obras o engenheiro Octávio Camillo. A obra ocorreu durante o período do autoritarismo pós-ditadura militar, quando o planejamento urbano pasou a ser importante. (Martins, 1997)

As outras vias de circulação de veículos existentes na área que devem ser consideradas para a análise do tecido urbano da região são a Avenida Rangel Pestana e a Rua da Mooca.

No levantamento histórico da evolução da estruturação viária planejada no Estudo do Plano de Avenidas realizado por Décio Amadio, em sua tese de doutoramento (2005, p. 136), foram também incluídas as importantes vias a seguir:

Rangel Pestana: considerada a principal radial do vetor leste, para a qual se preconizava o seu alargamento no sentido Belenzinho e a solução ap problema apresentado pela travessia em nível das ferrovias, juntamente ao Largo da Concórdia, que se constituía no centro comercial do Brás. Em igual situação se encontrava também a Avenida do Gasômetro.

Rua da Mooca: Considerada principal pelas ligações e circulação, encontrava obstáculos para o alargamento devido a densidade das suas construções e o preço dos terrenos. No estudo inicial seria o início da Avenida Central do Brasil e interligava-se com vias secundárias como a Oratório, duplicada até o alto da Mooca pela Avenida Paes de Barros, início da ligação com São Caetano e São Bernardo, já considerados subúrbios industriais.

O mapa 18 demonstra a hierarquia viária das vias que compõe a área, classificadas como Nível I, Nível 3, vias coletoras e vias locais, segundo o Plano Diretor de São Paulo. Apresenta também os sistemas viários das ferrovias e metrovias. 

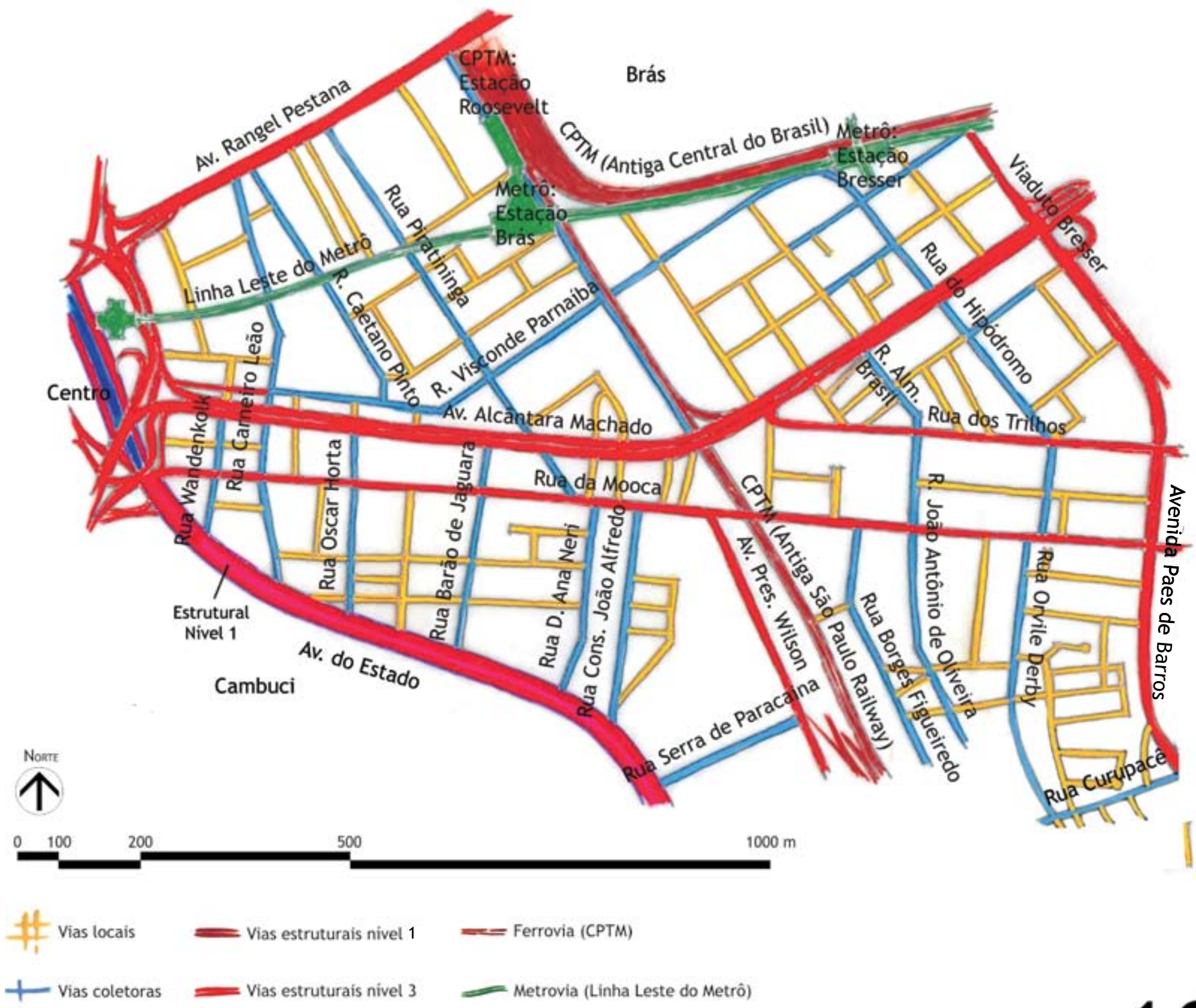

Hierarquia viária / acessos

autoria: Maria Elizabet Paez Rodriguez sobre GEGRAN 1972 


\subsection{A Linha Leste do Metrô de São Paulo}

Com seu primeiro trecho inaugurado em 1981, a Linha Leste do Metrô, segunda linha implantada na cidade, no sentido Leste-Oeste, passa a oferecer transporte público de massa mais moderno, mais confortável e mais veloz e o maior beneficiado a princípio foi o Brás, seguido da Mooca, pela proximidade entre os bairros. Financiado pelo Estado com capital privado, fora planejado para ser a primeira linha a ser construída, baseado no forte crescimento da mancha urbana em direção ao leste. Apesar disso, foi preterida em relação à construção da linha NorteSul. Foi implantada ao longo da linha férrea existente, a Central do Brasil (CBTU, hoje CPTM), e significou um terceiro nível de intervenções viárias na região do Brás e da Mooca, somando-se à linha ferroviária e a Avenida Radial Leste, representando um terceiro corte na malha urbana.

Linha Leste, ou Linha Vermelha do Metrô está inserida numa rede metropolitana de trens com 60,2 km de extensão e 52 estações, divididas em 5 linhas: Linha Azul, Linha Verde, Linha Vermelha, Linha Amarela e Linha Lilás. Essas 5 linhas transportam 2,7 milhões de passageiros por dia. É um dos principais elementos de ligação do distrito do Brás com o restante do município, uma vez que somente nesse distrito existem três estações: D.Pedro II, Brás e Bresser, cujas principais características estão comparadas no quadro abaixo:

Quadro 2 - Estações de Metrô na área-objeto de estudo Fonte: www.metro.sp.gov.br

\begin{tabular}{|c|c|c|c|}
\hline & Dom Pedro II & Brás & Bresser \\
\hline \multirow{4}{*}{$\begin{array}{c}\text { endereço } \\
\text { passageiros/hora/pico } \\
\text { inauguração } \\
\text { área construída }\end{array}$} & Rua da Figueira, s/n & Rua Domingos Paiva, s/n & Rua do Hipódromo, s/n \\
\hline & 20.000 & 60.000 & 20.000 \\
\hline & 10.mar. 1979 & 10.mar. 1979 & 205.mai. 1981 \\
\hline & $9.353 \mathrm{~m}^{2}$ & $23.350 \mathrm{~m}^{2}$ & $10.375 \mathrm{~m}^{2}$ \\
\hline
\end{tabular}

No Capítulo IV, Diagnóstico, o item 3 trata mais detidamente a questão do impacto da implantação desse sistema viário no tecido urbano consolidado e da alteração na mobilidade intra-urbana no Brás.

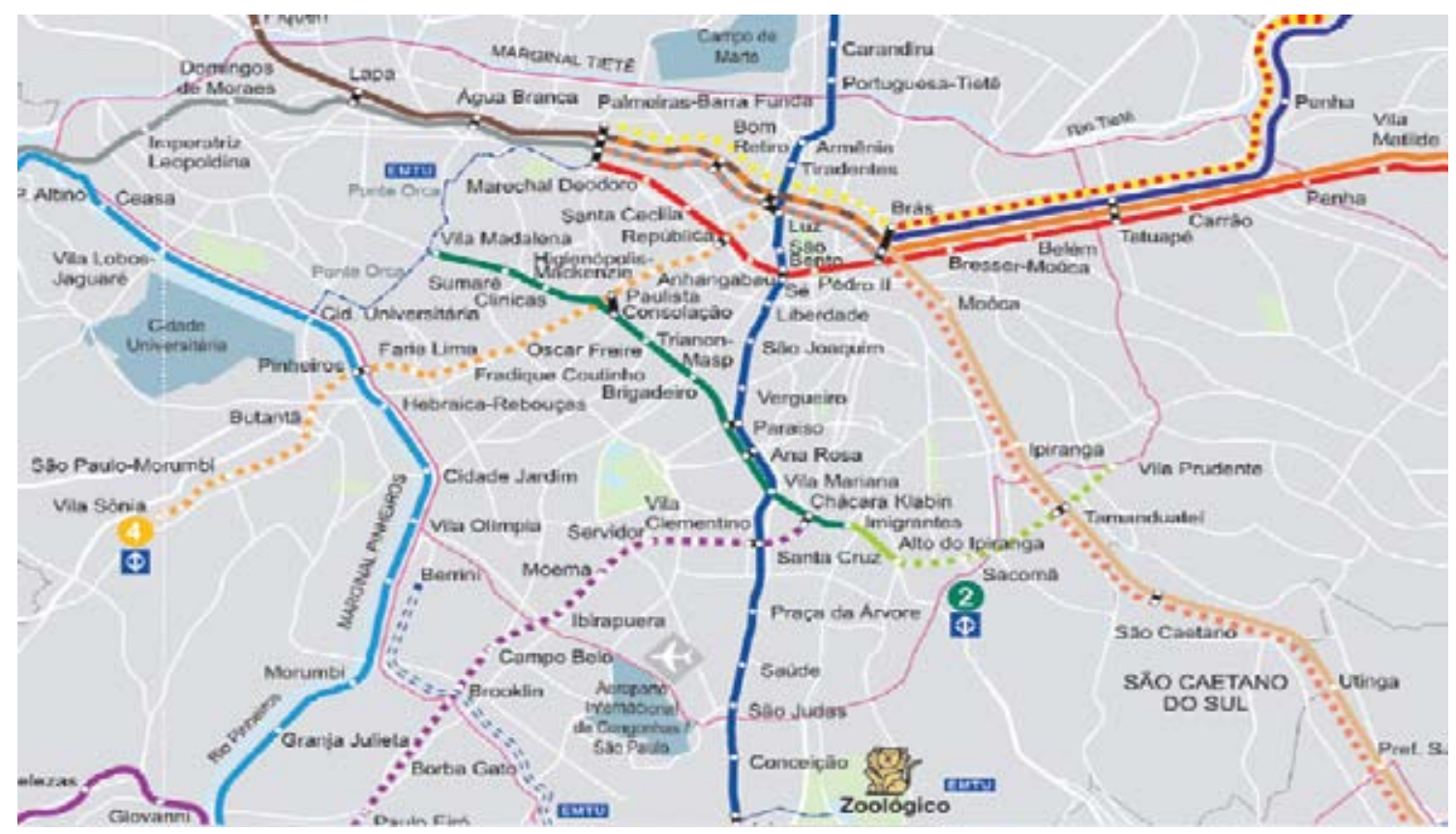

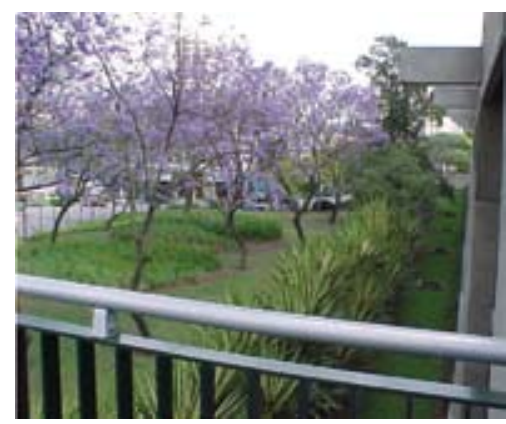
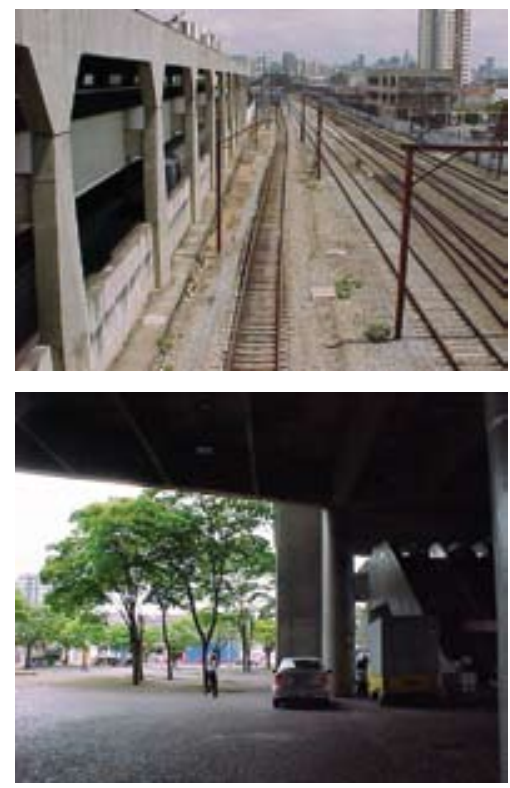

Acima e ao centro

Estação Bresser do Metrô Leste Arquivo pessoal, 2003

Abaixo

Estação Brás do Metrô Leste

Arquivo pessoal, 2003

Figura 19

Rede de Metrô do Município de São

Paulo

Fonte: www.metro.com.br 


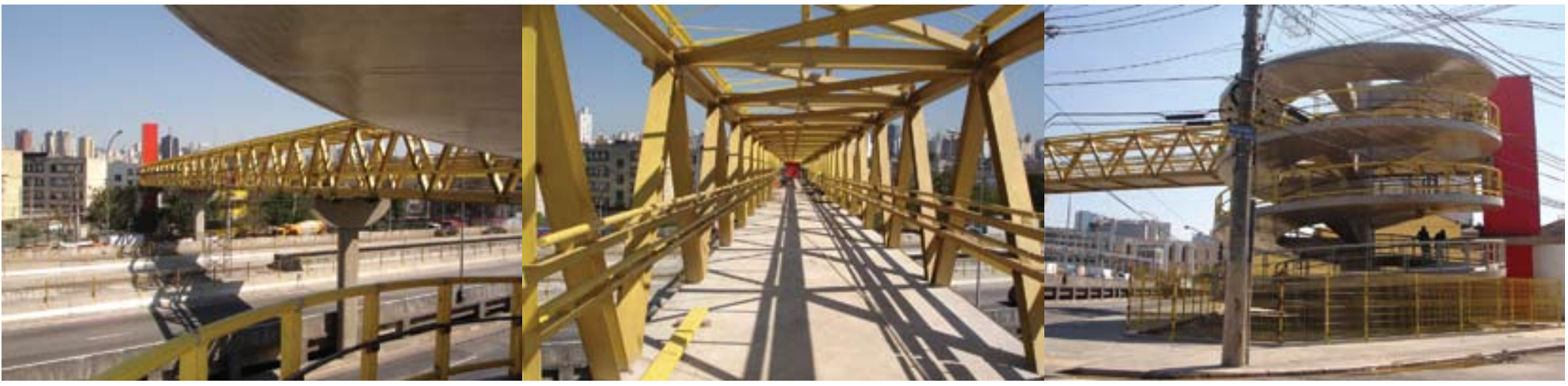

Estacão Luis Gama do Expresso Tiradentes na Mooca baixa, em fase de finalização.

Arquivo pessoal, 2006

\subsection{O Expresso Tiradentes: VLP - Veículo Leve sobre Pneus}

O VLP - Veículo Leve sobre Pneus, teve o início de sua implantação na gestão municipal de 1996, na ocasião batizado de Fura-Fila, com previsão de conclusão de seu primeiro trecho em 1998, o que não ocorreu e ainda encontra-se em fase de finalização. Projetado a princípio para deslocar-se sobre canaletas-guia, seus veículos teriam duas articulações, som ambiente e ar condicionado. Após 10 anos do início de implantação, o custo de seu quilômetro já chegou a $80 \%$ do custo do quilômetro de metrovia subterrânea. Em função dos altos custos, fol reformulado e seus veículos, simples, serão movidos a gás, diesel ou com motor híbrido, e conduzidos por motoristas de forma convencional - sem as canaletas-guia. Também não terão obrigatoriamente ar condicionado e som ambiente. $O$ primeiro trecho foi construído com pistas elevadas sobre pilares de concreto sobre a cobertura de concreto do rio Tamanduateí, no trecho onde este foi canalizado.

A primeira fase de sua implantação prevê três estações na área-objeto de estudo: Rangel Pestana (no Brás), Luis Gama e Ana Neri (ambas na Mooca baixa), conforme nos mostra a figura 20. O ponto de partida é a estação Parque Dom Pedro II, passando pelas três estações mencionadas anteriormente e seguindo até o Terminal Sacomã, na zona sul do município. A proposta atual é que esse sistema de transporte público de massa chegue até Cidade Tiradentes, no extremo leste do município.

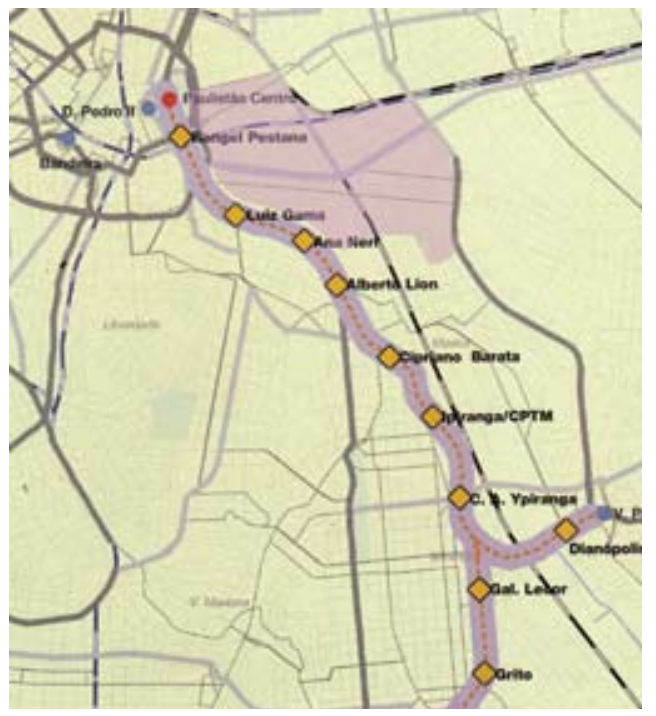

Via exclusiva para ônibus - Paulistão

Ponto de parada

Terminal municipal existente até 2001

Terminal municipal previsto para 2005 a 2008

Figura 20

Linha em fase de execução do VLP. Fonte: São Paulo Interligado: Plano de Transporte Público Urbano - SMT, 2004, p. 246. 


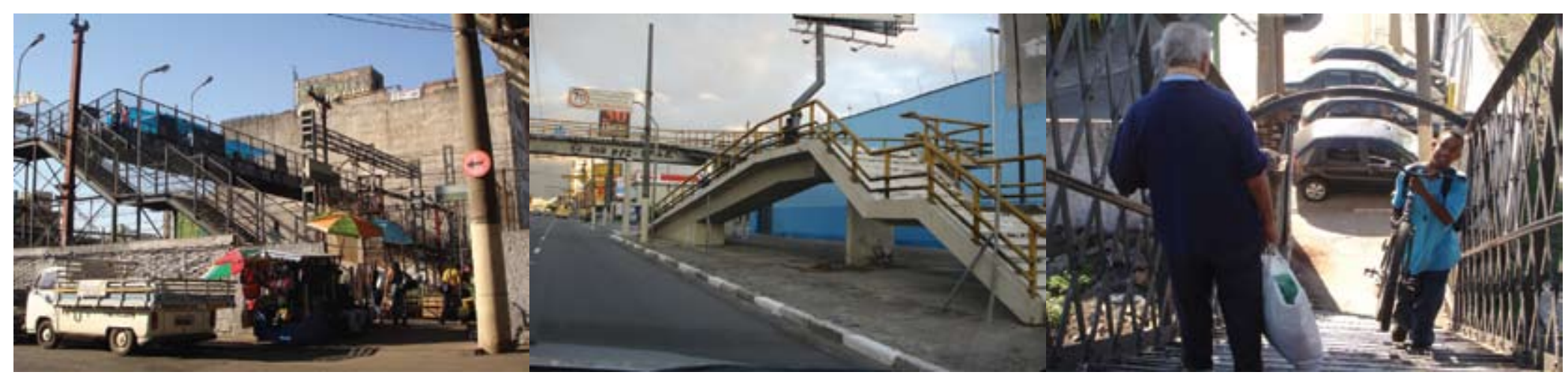

\subsection{Os fluxos de pedestres e veículos}

Brás: circulando-se pelo Brás, percebe-se uma grande diferença em seu fragmentado espaço. No trecho do Brás entre as ruas Bresser, Oriente, Celso Garcia, o forte comércio de confecções e calçados atrai multidões diariamente, atacadistas e varejistas que somados aos camelôs nas calçadas e aos veículos que por ali circulam com grande dificuldade, num espaço caótico.

No trecho compreendido entre Avenidas Celso Garcia, Alcântara Machado, Rua da Figueira e Ferrovia Santos-Jundiaí, apesar do comércio especializado em máquinas, Estação Brás do Metrô com terminal de ônibus e todos os outros usos que ali existem, o fluxo de pessoas e veículos é bem menos caótico que no outro trecho mencionado, viável até.

Entre ambos os trechos o problema mais grave é a falta de mobilidade entre os diferentes setores a que o bairro foi reduzido e com isso a dificuldade na acessibilidade ao que um trecho oferece em relação ao outro.

Os pontos de transposição das ferrovias e metrovia e até mesmo da Avenida são poucos e muitas vezes pouco convidativos, como a passarela sobre a ferrovia Santos-Jundiaí, próxima à estação Brás do Metrô, localizada numa rua erma com um paredão ao longo da ferrovia.

No caso dos veículos, a maioria das ruas do Brás próximas às linhas de trem e de metrô não tem saída e acabam em paredões, dificultando a saída do bairro em direção ao centro, ou seja, pela Radial Leste.

Mooca: $O$ Trecho da Mooca em estudo dispõe de acessos e saídas do bairro mais fáceis que o Brás, inclusive pelo formato, longitudinal e sem ruas sem saída.

Seus habitantes têm maior facilidade no ir e vir, caminhando pelas ruas, que geralmente são menos congestionadas de veículos.

Em relação ao transporte público, as estações de metrô (três ao todo: Pedro I, Brás, Bresser), estão muito distantes e a dificuldade de cruzar a Avenida Radial Leste (exceto em raros pontos como as passarelas junto à Rua Wandenkolk e Praça Kennedy), aumentam o isolamento. Dependem somente das linhas de ônibus coletivos que circulam pela Rua da Mooca e Avenida do Estado.

O Mapa 19 demonstra os fluxos de acesso aos dois bairros, bem como os locais onde são possíveis as transposições dos sistemas viários que se comportam como barreiras urbanas, tanto na escala humana como em relação aos veículos automotores. Esses pontos são chamados aqui de Transposições Viárias, tanto sobre ferrovias como para transpor a metrovia e a via de alto tráfego objeto deste estudo, a Radial Leste. As setas representam as alternativas de acesso à área-objeto de estudo a partir de outros distritos do município ou de outros trechos dos próprios distritos da Mooca e Brás.
À esquerda

Passarela sobre a Radial Leste, entre Mooca e Brás.

Ao centro

passarela sobre ferrovias no Brás, Rua Visconde de Parnaíba.

À direita

Passarela sobre ferrovias no Brás, Rua do Gasômetro.

Arquivo pessoal, 2006. 

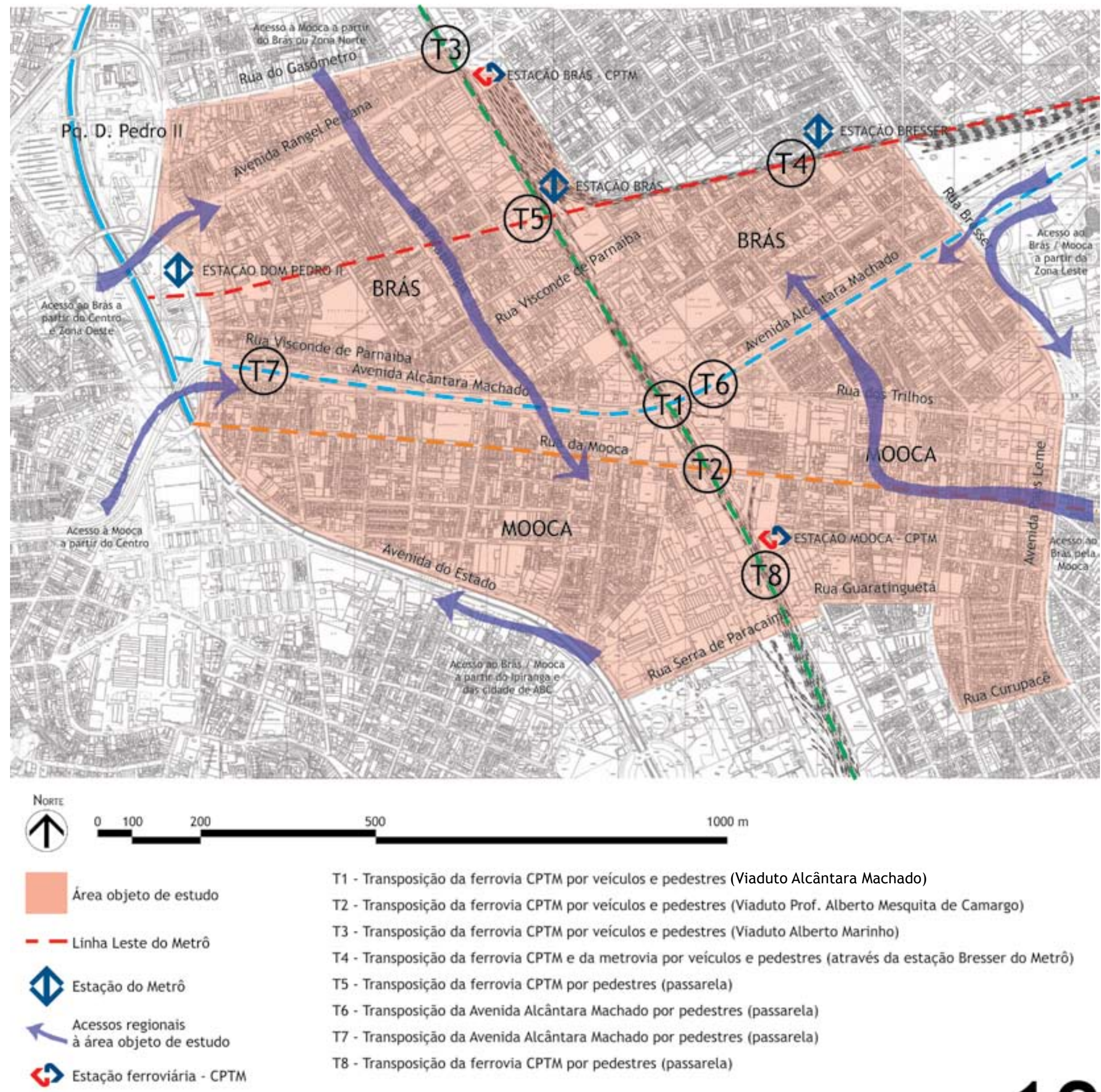

T1 - Transposiçăo da ferrovia CPTM por veículos e pedestres (Viaduto Alcântara Machado)

T2 - Transposição da ferrovia CPTM por veículos e pedestres (Viaduto Prof. Alberto Mesquita de Camargo)

T3 - Transposição da ferrovia CPTM por veículos e pedestres (Viaduto Alberto Marinho)

T4 - Transposição da ferrovia CPTM e da metrovia por veículos e pedestres (através da estaçāo Bresser do Metrô)

T5 - Transposiçāo da ferrovia CPTM por pedestres (passarela)

T6 - Transposição da Avenida Alcântara Machado por pedestres (passarela)

T7 - Transposiçāo da Avenida Alcântara Machado por pedestres (passarela)

T8 - Transposição da ferrovia CPTM por pedestres (passarela)

\section{Transposições viárias} autoria: Maria Elizabet Paez Rodriguez sobre GEGRAN 1972

Mapa 19 


\subsection{Transporte público}

Os mapas 20 e 21 representam o plano de tranporte público urbano implantado na gestão de 200 I a 2004 e demonstram a disponibilidade de tranporte público de massa na área-objeto de estudo.

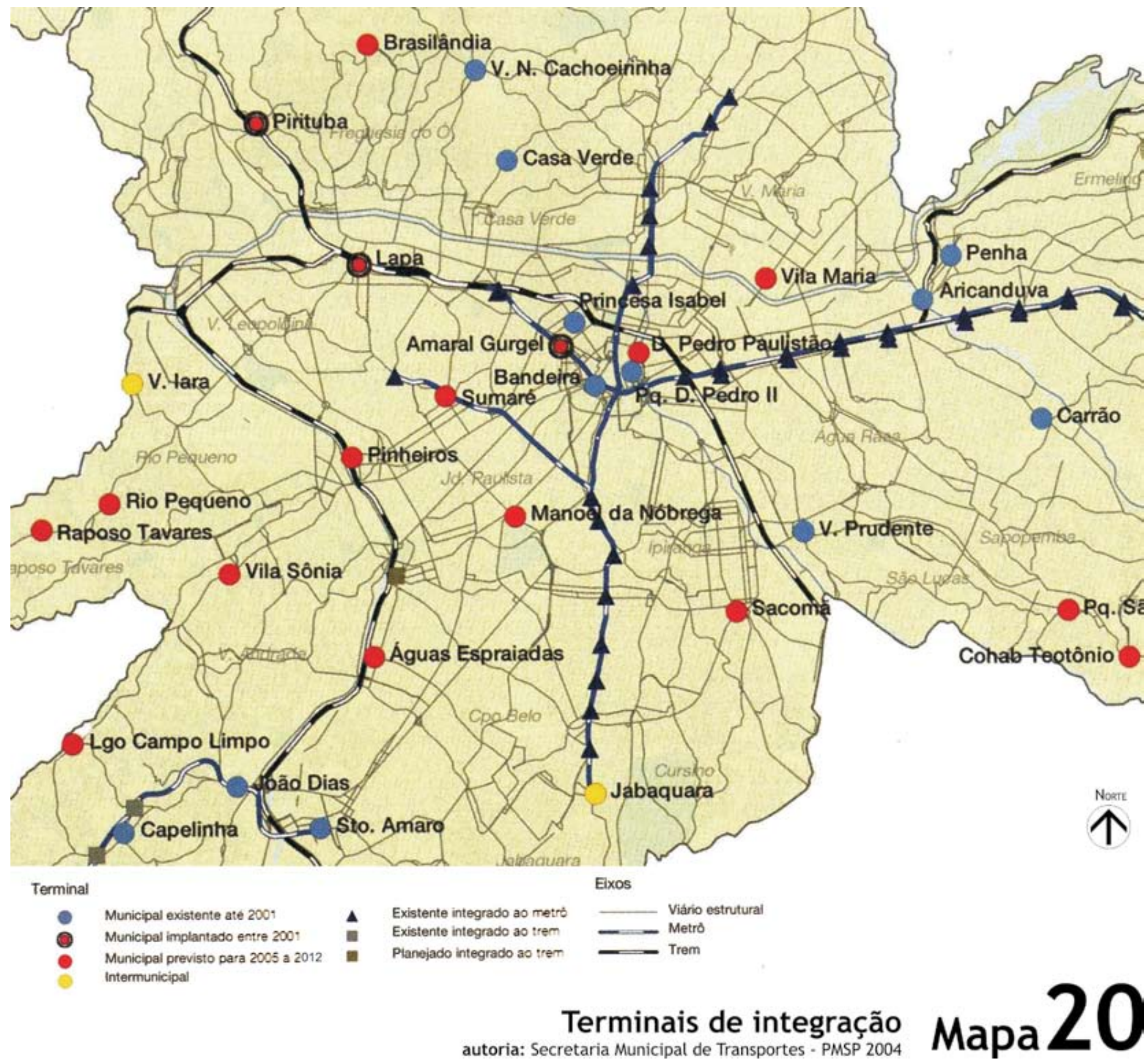


Observando-se os mapas 19 e 20, conclui-se que a área objeto de estudo é plenamente atendida por vários sistemas de transporte públicos de massa.

Como a rede de metrô de São Paulo está ainda muito aquém da necessidade, em determinados horários do dia, as composições já chegam lotadas nas estações localizadas no Brás e Bresser, tornando mais lento um sistema de transporte rápido, em função do tempo de espera para embarque.

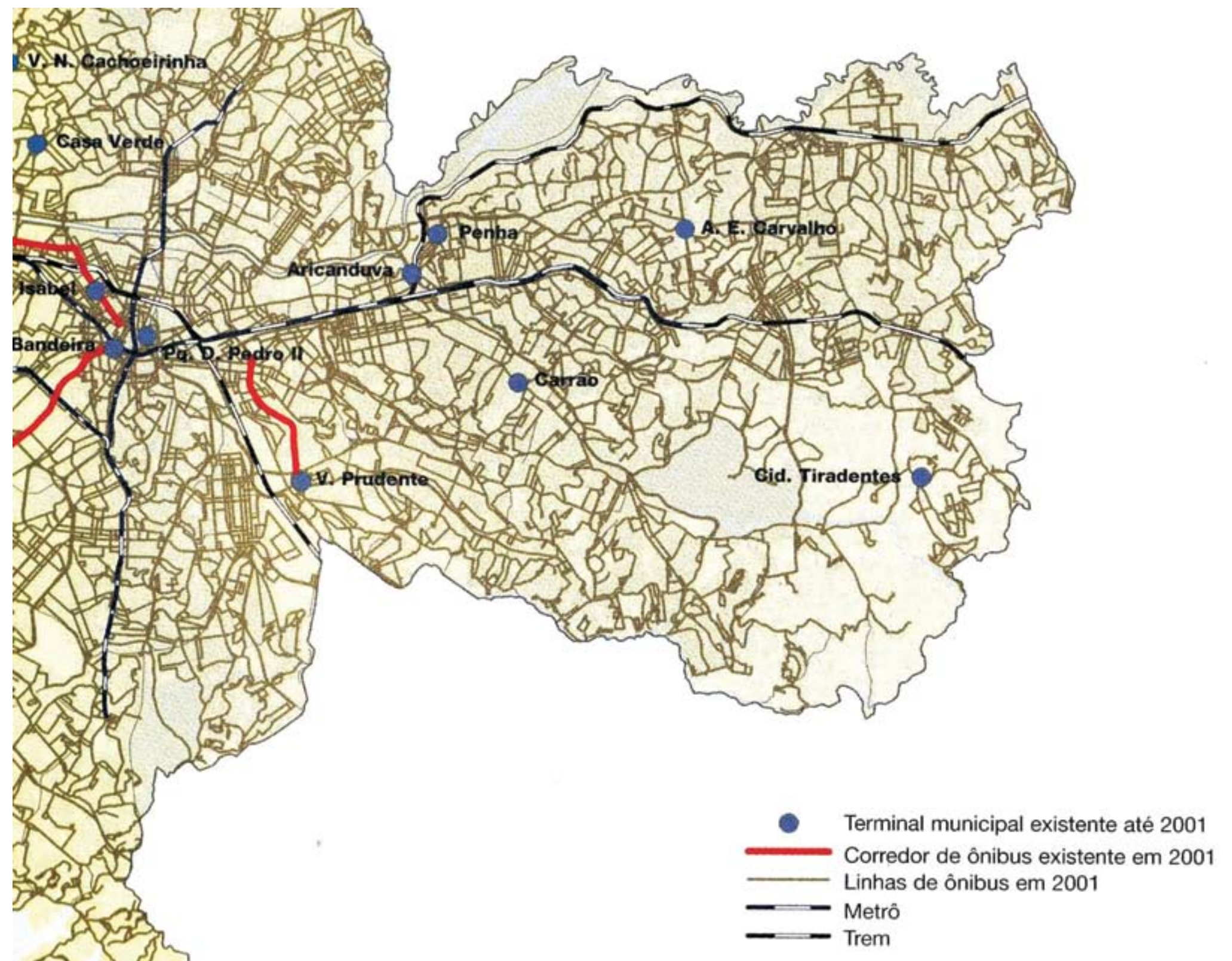

Sistema de transporte público autoria: Secretaria Municipal de Transportes - PMSP 2004
Mapa 21 


\section{Equipamentos urbanos públicos e áreas verdes}

\section{I Unidades de ensino público}

Unidades da rede pública de ensino localizadas na área-objeto de estudo e em funcionamento:

- Creche Divina Providência (conveniada com a prefeitura), na Rua da Mooca, nI I3, Mooca baixa;

- Creche Municipal José de Moura, na Rua Dona Ana Nery, no I57, Mooca baixa;

- Creche Municipal Nazir Miguel, na Rua Prudente de Moraes, n 210 , Brás;

- EMEl Almirante Tamandaré, no Largo. São Rafael, n I85, Mooca;

- EMEl João Mendonça Falcão, na Rua Coronel Mursa, nº Brás;

- EE Prof. Antônio Firmino de Proença, na Rua da Mooca, nº 363, Mooca baixa;

- EE Gianfrancesco Guarnieri, na Rua Itapira, n 183, Mooca baixa;

- EE Romão Puigari, Avenida Rangel Pestana, n |482, Brás;

- Classes Provisórias Padre Anchieta - FEBEM - UIP-6, na Rua Domingos Paiva, n 6I 8, Brás;

- Classes Provisórias Romão Puigari - FEBEM - UIP-6, na Rua Domingos Paiva, n 618, Brás;

- Classes Provisórias Rio Nilo - FEBEM - UIP- I0, na Rua Piratininga, n 85, Brás;

- Classes Provisórias Padre Anchieta - FEBEM - UIP-7, 8, 9, 34, 35 e 36, na Rua Cel. Mursa, n 270, Brás.

- Classes Provisórias Romão Puigari - FEBEM - UIP-9, 34, 35 e 36, na Rua Cel. Mursa, n²70, Brás.

Unidades da rede pública de Ensino localizadas fora da área-objeto de estudo mas próximas o suficiente para poder atender aos moradores da área-objeto de estudo:

- Creche Municipal Antônia Muotri Lamberga, na Rua Inácio de Araújo, n 232, Brás;

- Creche São Vito (conveniada com a prefeitura), na Rua Polignano a Mare, n 255, Brás;

- EMEF Dr. Fábio da silva Prado, na Rua Taquari, no 459, Mooca;

- EMEE Profa. Neusa Basseto, na Rua Taquari, nº 459, Mooca;

- EE Padre Anchieta, na Rua Visconde de Abaeté, n I54, Brás;

- EE Domingos Faustino Sarmiento, na Rua 21 de abril, no 970, Brás;

- EE Pandia Calogeras, na Avenida Paes de Barros, n 1025, Mooca;

- ET Prof. Camargo Aranha.

Além das unidades educacionais públicas listadas acima, um importante centro educacional privada já se implantou na área: A Universidade Anhembi-Morumbi, com suas instalações locais em constante crescimento.
À esquerda

Prédio da FEBEM na Rua Piratininga, $n^{\circ} 85$, Brás.

\section{À direita}

Prédio da Universidade AnhembiMorumbi, na esquina da Rua Dr. Almeida Lima com a Avenida Alcântara Machado.

Arquivo pessoal, 2006.

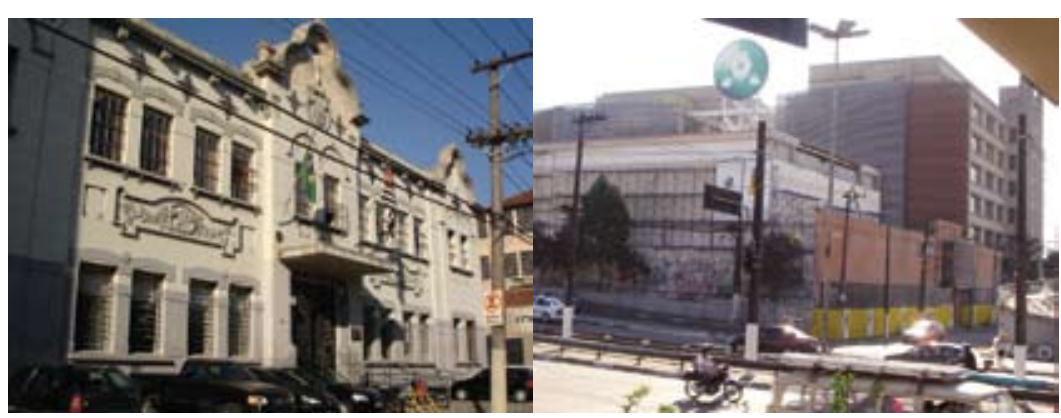


Creche Municipal

1- Divina Providência

2. São Vito

3- Nazir Miguel

4. José de Moura

5. Antonia M. Lamberga

- Escola Municipal de

Ensino Infantil - EMEI

1. Joăo Mendonza Falcão

2-Almirante Tamandaré

- Escola Municipal de Ensino Fundamental - EMEF 1- Dr. Fábio da Silva Prado

- Escola Municipal de Educação Especial - EMEE (portadores de deficiència) 1. Profa. Neuza Basseto

- Escola Estadual - EE

1. Gianfrancesco Guarnieri

2- Prof. Antonio Firmino de Proença

3. Romão Puigari

4. Padre Anchieta

5. Pandia Calógeras

- Escola Técnica - ET 1. Prof. Camargo Aranha

- Classes Provisórias (FEBEM) 1- Rio Nilo

2- Padre Anchieta

-- - Área objeto de estudo

-- Área objeto de estudo

Ambulatório de

Especialidades - AE

1. AE Dr. Ítalo Domingos Le Vocci

Centro de Atenção Psicossocial álcool e drodas - CAPS ad 1. CAPS ad Mooca

Centro de Convivência e Cooperativa - CECCO 1. CECCO Mooca

Centro de Atençăo Psicossocial - CAPS 1. CAPS infantil Mooca

Unidade Básica de Saúde - UBS 1. UBS Mooca I

- - Linha Leste do Metrô

(1) Estação do Metrô

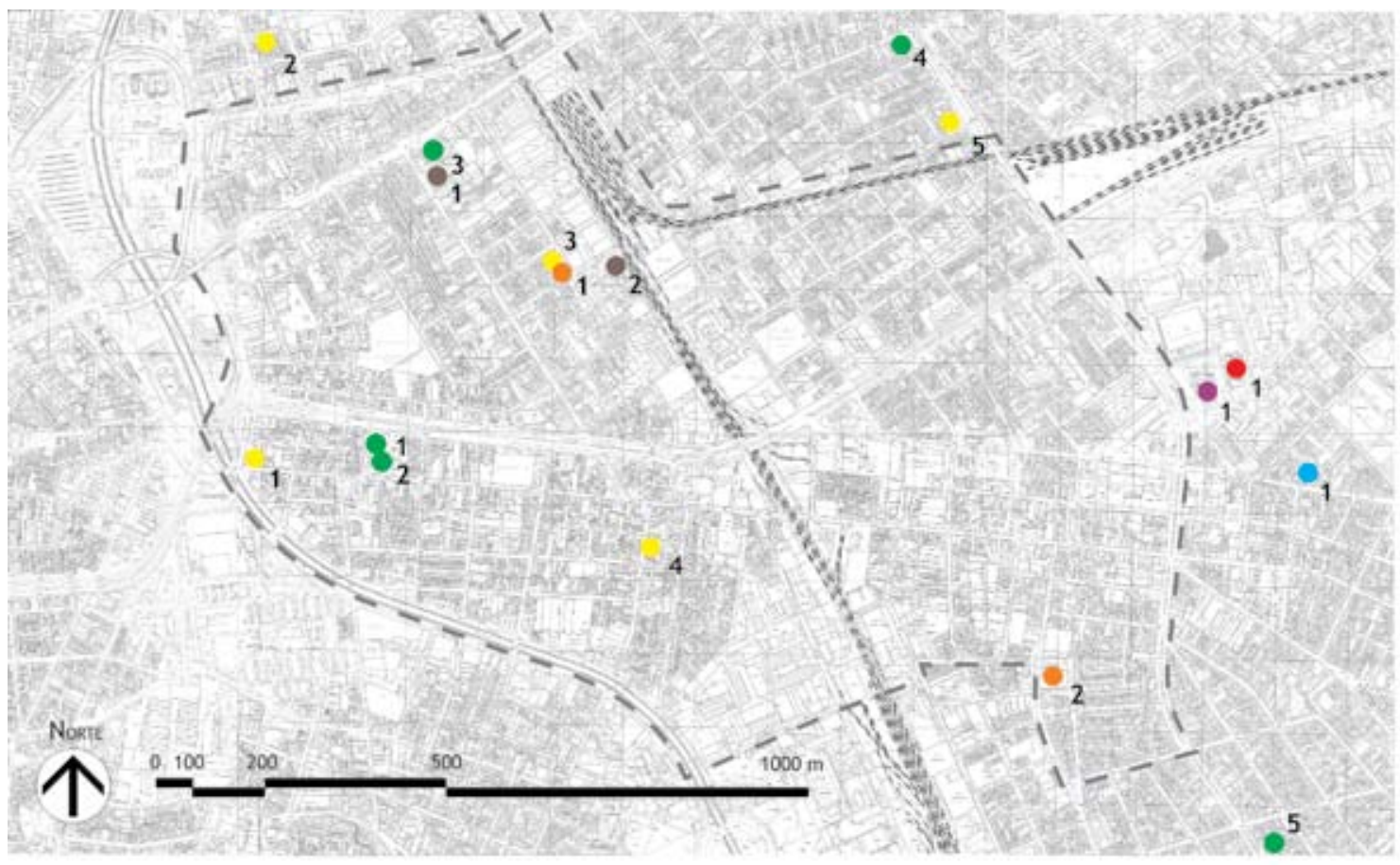

\section{Escolas públicas existentes}

autoria: Maria Elizabet Paez Rodriguez sobre GEGRAN 1972
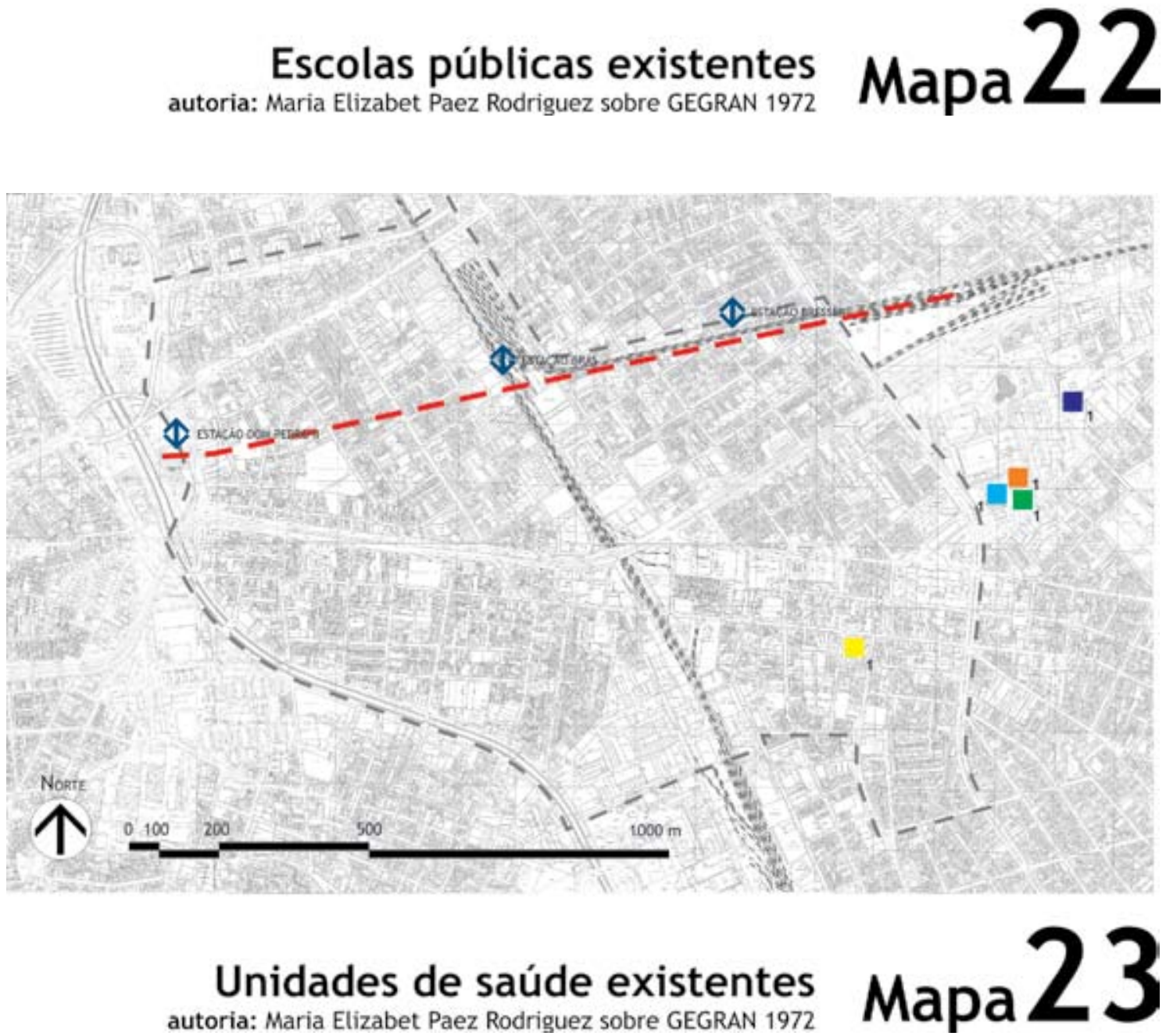


\subsection{Saúde pública}

$\mathrm{Na}$ área-objeto de estudo existe em funcionamento uma única unidades da rede pública de saúde: o Ambulatório de Especialidades (AE) Dr. Ítalo Domingos Levocci, na Rua Marina Crespi, no 91, Mooca.

As seguintes unidades da rede pública de saúde estão localizadas fora da área-objeto de estudo mas, pela sua proximidade, podem atender aos moradores dessa área:

- CECCO Mooca, Rua Taquari, n 549, Mooca;

- UBS Mooca, Rua Taquari, no 549, Mooca.

\subsection{Referências culturais}

$\mathrm{Na}$ área-objeto de estudo existem em funcionamento as seguintes unidades culturais da rede pública:

- Casa das Retortas, na Rua da Figueira, n 77, Mooca; atualmente abriga a sede da Secretaria de Governo Municipal;

- Museu da Imigração, na Rua Visconde de Parnaíba, no I3 I6, Mooca;

- Teatros e Centros Culturais: inexistentes, exceto pelo Teatro Arthur de Azevedo, localizado na Avenida Paes de Barros, n 955, Mooca, próximo à área objeto de estudo, que atende essa população.

\section{4 Áreas verdes}

O trecho Brás daárea-objeto de estudo não dispõe de nenhuma praça exceto os terrenos remanescentes da implantação das obras do Metrô Leste, localizados em "pontas" de quadra e sem vegetação ou pavimentação adequadas ou qualquer outro atrativo como brinquedos infantis. Junto à estação Brás do Metrô existe a praça ao lado da Creche Municipal Nazir Miguel, localizada à Rua Prudente de Moraes $n^{\circ} 210$, a requalificar.

Já na Mooca baixa, existe um triângulo gramado localizado na Avenida do Estado e a confluência das ruas Odorico Mendes e Cel. Cintra, chamado Praça Álvaro Cardozo de Moura, hoje habitado por pessoas em situação de rua e constantemente utilizado pelos moradores da região para despejo de lixo. Já o trecho Mooca da área-objeto de estudo dispõe da Praça Kennedy (entre a Avenida Alcântara Machado, a Rua dos Trilhos e a Rua Dr. Almeida Lima).

- Clubes municipais: O bairro da Mooca possui o Centro Educacional Municipal da Mooca, complexo educacional e esportivo onde está situada também a Subprefeitura Mooca. Dispõe de quadras esportivas, piscinas, creche, biblioteca, dentre outros. Por estar localizado na confluência da Avenida Alcântara Machado com o Viaduto Bresser, o Parque Municipal da Mooca atende à toda a região. Apesar disso, a existência de um conjunto de equipamentos públicos de abrangência regional não elimina a necessidade de equipamentos públicos locais, implantados em vários pontos dentro de uma área da cidade;

- Quadras esportivas públicas: inexistentes.
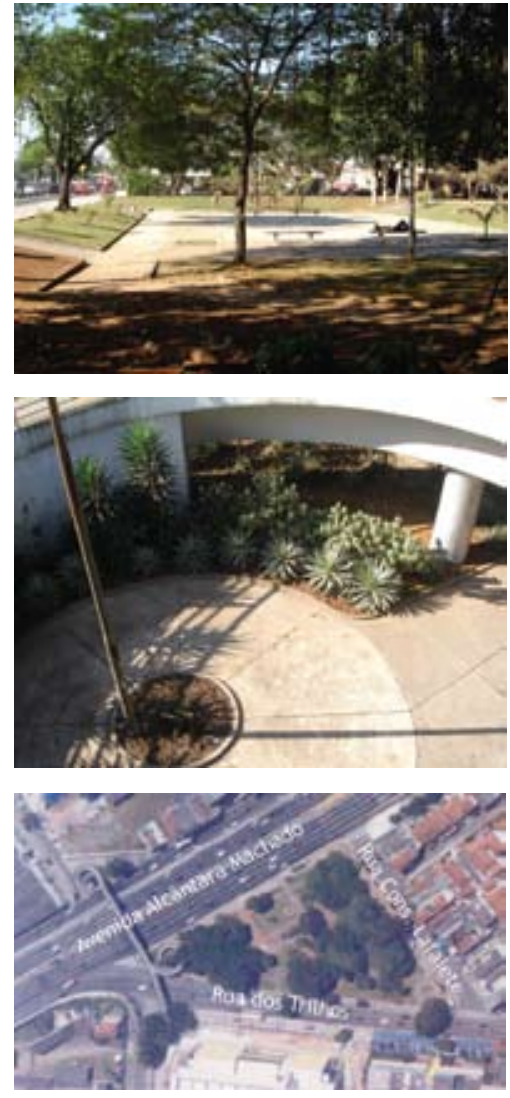

Acima

Praça Kennedy: fotos in loco (arquivo pessoal, 2006) e vista aérea (Google Earth, 2006)

\section{Abaixo}

Centro Educacional Municipal da Mooca (Google Earth, 2006)

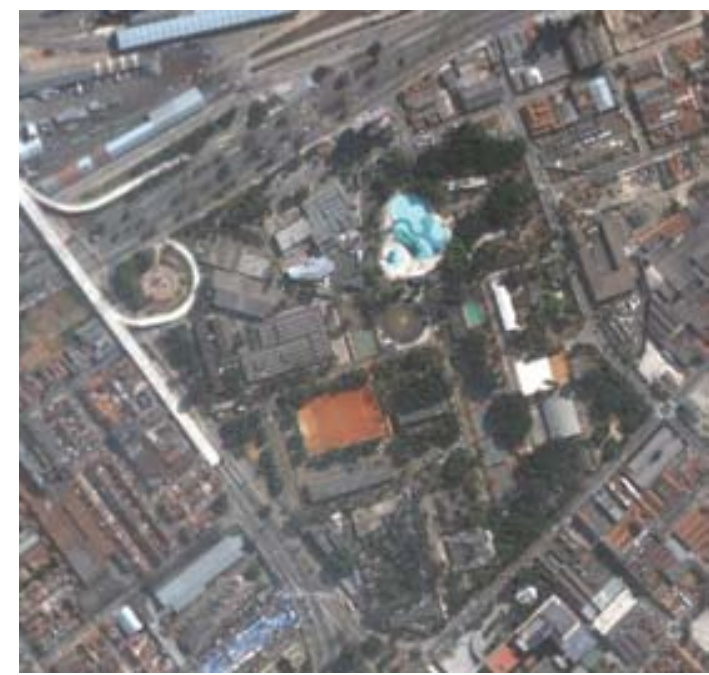




\section{Capítulo III \\ O tecido urbano \\ do Brás e Mooca}

Por tecido urbano entende-se um conjunto de elementos que juntos o compõem: traçado viário aliado ao uso e ocupação do solo, à morfologia, à topografia e à tipologia das construções efetivamente encontrados numa determinada área urbanizada. Por isso, fez-se um levantamento completo in loco, lote a lote, dos atuais uso e ocupação do solo nesses dois bairros, ou seja, na área-objeto de estudo desta dissertação. Com esse levantamento foi possível também determinar o grau de adensamento urbano e de verticalização das construções. Esse adensamento e verticalização estão demonstrados nas imagens elaboradas por computação gráica e que apresentam os usos atuais das construções.

\section{Delimitação da área-objeto de estudo}

O processo de definição da área-objeto de estudo que apresentasse a problemática que se decidiu estudar passou por duas etapas. Primeiramente, a escolha foi a revitalização da Avenida Radial Leste, via de alto tráfego transformada basicamente num local de passagem, com raras exceções. O trecho da Avenida selecionado nesse momento fica entre a Avenida do Estado e a Rua Bresser. Brás e Mooca baixa estão localizados a aproximadamente 2 quilômetros do Centro Histórico do Município de São Paulo, na Macrometróple de São Paulo ${ }^{55}$.

Considerou-se como medida inicial para definição da área a ser estudada, uma marcação de 500 metros à direita e 500 metros à esquerda da avenida, aproximadamente, chegando-se até ruas de importância local ou regional como a Avenida Rangel Pestana, Rua do Gasômetro, Rua Piratininga, Rua Visconde de Parnaíba, Rua Bresser, Avenida Presidente Wilson, Rua da Mooca e Avenida do Estado. Outros fatores foram considerados para a delimitação final da área como a inserção das quadras que hoje apresentam uso estritamente residencial localizadas na Mooca. A área total resultante e que representa a área objeto de estudo é de 3.683. $188 \mathrm{~m}^{2}$

Como metodologia para a análise do tecido urbano definimos duas áreas de recorte:

- Recorte I: contém as áreas mais antigas dos dois bairros limitadas, no caso da Mooca baixa pelas avenidas do Estado, Alcântara Machado ou Radial Leste, Rua Presidente Wilson, paralela à ferrovia Santos-Jundiaí, antiga São Paulo Railway e hoje pertencente à CPTM e, no caso do Brás, pela Avenida Radial Leste, Rua da Figueira, Rua do Gasômetro e Rua Domingos Paiva, paralela à Antiga Estrada de Ferro Central do Brasil, hoje pertencente à CPTM - Companhia Paulista de Trens Metropolitanos, no caso do Brás.

Metropolitano Expandido compreende as regiões metropolitanas de São Paulo, de Campinas, da Baixada Santisita, parte do Vale do Paraíba e a região de Sorocaba. A população da Macrometrópole aproxima-se de 24 milhões, sendo que apenas na região metropolitana de São Paulo vivem 17,8 milhões de habitantes. Fonte: SEMPLA - Secretaria Municipal de Planejamento, 2001 .

- Recorte 2: o Recorte 2 contém a área do Recorte I e configura a área total da área-objeto de estudo, cuja delimitação é finalmente formada pelas vias Avenida do Estado, Rua da Figueira, Rua do Gasômetro, Rua Domingos Paiva, Ferrovia Central do Brasil (CPTM), Rua Bresser, Rua Taquari, Avenida Paes de Barros, Rua Curupacê, Rua Canuto Saraiva, Rua Guaratinguetá e pela rua lateral à propriedade da fábrica da Antárctica Paulista, a Rua Serra de Paracaima.

A área-objeto de estudo desta dissertação está demonstrada no mapa 24. 

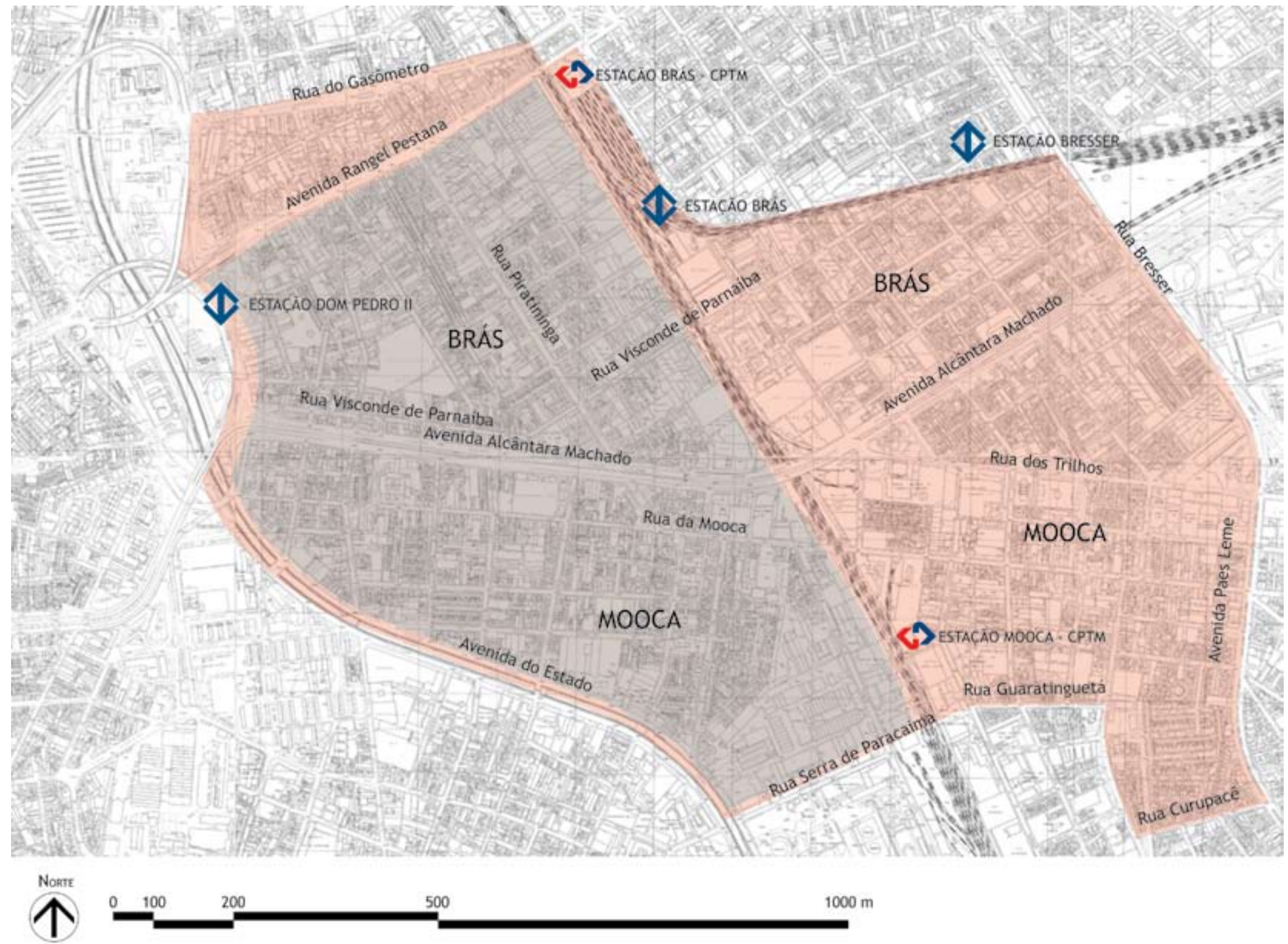
O Recorte I está inserido na área do recorte 2 e representa a área onde se fez o levantamento de uso e ocupação do solo e tipologias arquitetônicas in loco e lote a lote, principal dado para a análise do tecido urbano.

O Recorte 2 representa a área-objeto de estudo em sua totalidade e para ela encontrase no Capítulo VI desta dissertação a proposta do conjunto de diretrizes para reurbanização dos dois bairros proposta no Capítulo VII.

Os trechos ao oeste e ao leste da Ferrovia Santos-Jundiaí apresentam características muito similares e, por esse motivo, somente na área do Recorte I é que foram levantados dados in loco sobre a morfologia urbana, como uso e ocupação do solo, equipamentos públicos, tipologia das construções, demonstrando a complexidade dos usos atuais dos imóveis que ali se encontram: comércio diversificado e especializado, uso residencial, uso industrial e serviços. Fluxos de pedestres e de veículos e marcos referenciais, áreas verdes, equipamentos públicos, espaços livres e de lazer, também foram levantados, determinando os padrões ali existentes para localizá-los cronologicamente e determinar possibilidades de mudança de uso.

As duas áreas - ao leste e ao oeste da Ferrovia Santos-Jundiaí - têm em comum uma importante característica: são fortemente afetadas pelos mesmos sistemas viários abaixo listados, fator importante de similaridade, que resulta na diminuição da mobilidade e acessibilidade intra-urbana dos fragmentados bairros do Brás e Mooca.

- Ferrovias da CPTM: antiga Estrada de Ferro Central do Brasil e a antiga São Paulo Railway, hoje Santos-Jundiaí;

- Linha Leste do Metrô;

- Av. Alcântara Machado ou Avenida Radial Leste, via de ligação regional com alto tráfego de veículos automotores de pequeno, médio e grande porte.

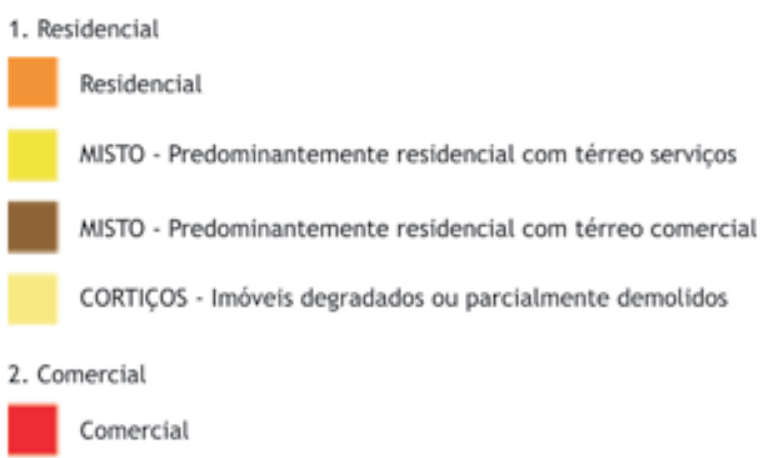

Comercial

3. Serviços
SERVIÇOS
MISTO - térreo comercial / superior serviços
MISTO - térreo industrial / superior serviços
ESTACIONAMENTO
RECICLAGEM - coleta e transformação
4. Industrial
INDÚSTRIA - galpăo industrial
INDÚSTRIA - galpão industrial vazio /
abandonado / uso indefinido

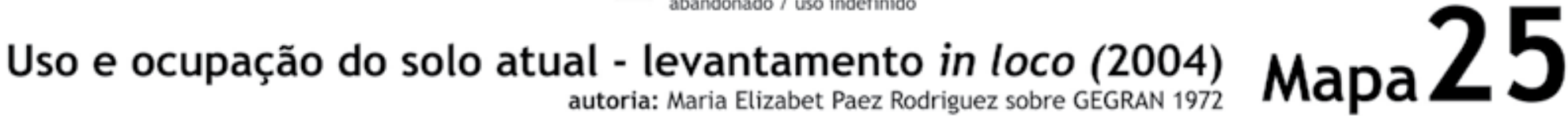




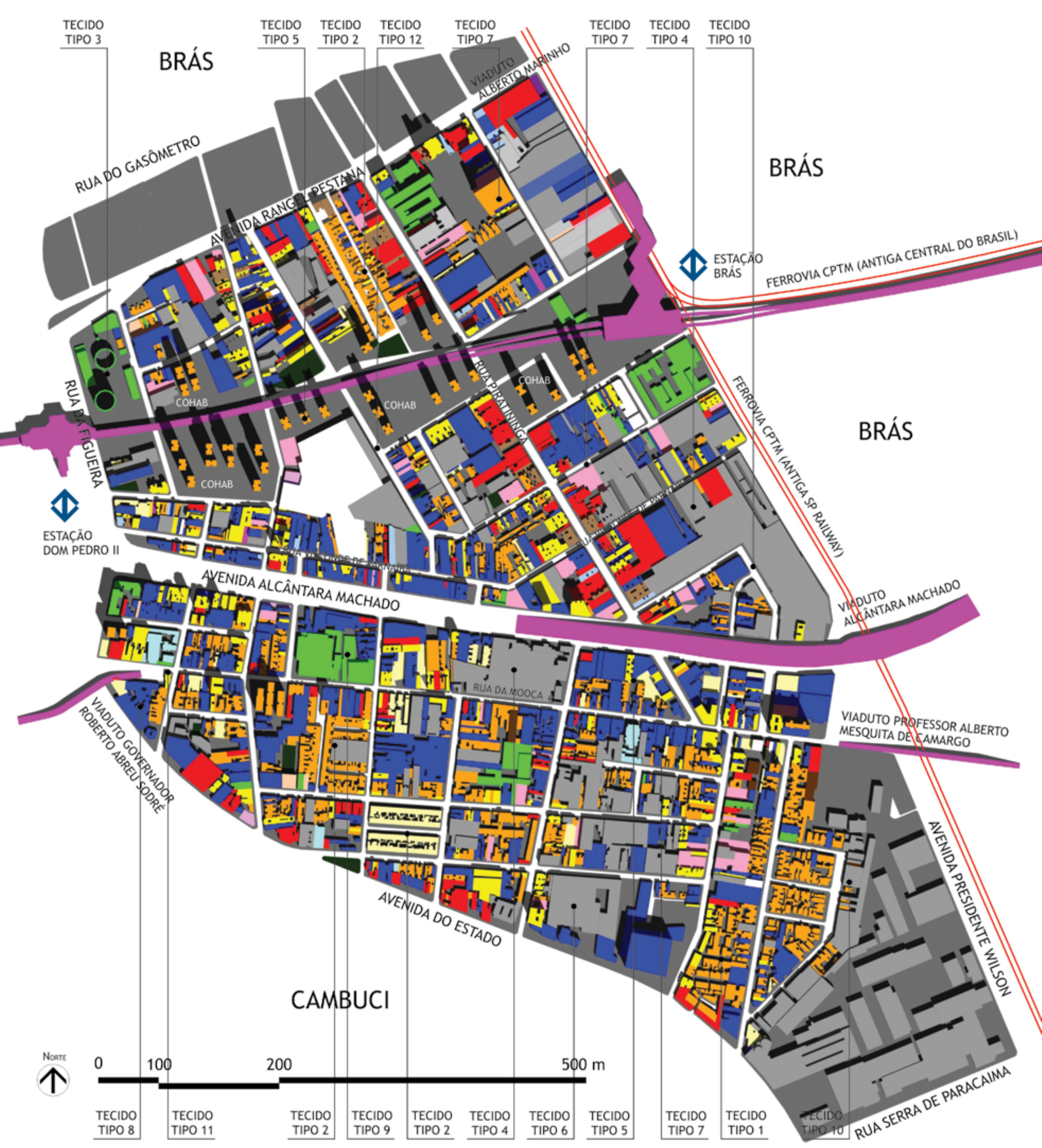




\section{Categorias de uso e ocupação do solo no Brás e Mooca}

Basicamente são cinco as categorias de uso e ocupação do solo da legislação que vigorou por 30 anos, de 1972 a 2002 (LUOS), no Município de São Paulo: residencial, serviços, comercial, institucional e industrial.

Para ilustrar a grande quantidade de usos encontrados na área-objeto de estudo durante os levantamentos in loco, foi necessário fazer um desdobramento desses usos para melhor elucidar a abordagem desejada. Foram consideradas categorias como uso misto num mesmo edifício, vazios urbanos, cortiços, estacionamentos (considerados por muitos planejadores como vazios urbanos à espera de valorização com o objetivo de especular), áreas públicas ociosas, áreas remanescentes de obras públicas etc.

A congregação de dados de uso e ocupação do solo levantados in loco resultou no Mapa 25. A partir desse mapa foram geradas elevações e vistas em perspectivas da área, para visualizar melhor outros fatores importantes do tecido urbano local: verticalização das construções que por si só dão a real dimensão do baixo adensamento populacional local e o enquadramento causado pelos sistemas viários regionais ali presentes. Através da análise do Mapa 25 pode-se observar que ambos os bairros apresentam uso misto complexo nos imóveis que compõem seu tecido urbano.

O bairro do Brás apresenta usos comercial e serviços diversificados e especializados de forma bem concentrada como, por exemplo, o comércio na Rua Piratininga e Avenida Rangel Pestana. O bairro da Mooca baixa conta também com grande diversidade de usos, mas a predominância residencial em algumas quadras é mais presente que no Brás. Os usos comercial e serviços é bem diversificado, mas de forma mais dispersa que no Brás. Nos dois bairros o comércio e serviço de âmbito local ocorrem de forma dispersa, sem centralidades. Em ambos os bairros, a presença de galpões industriais ainda é forte, mas a grande maioria deles teve seu uso alterado para serviço ou para depósitos logísticos de apoio ao comércio especializado de couros, plásticos e máquinas operatrizes.

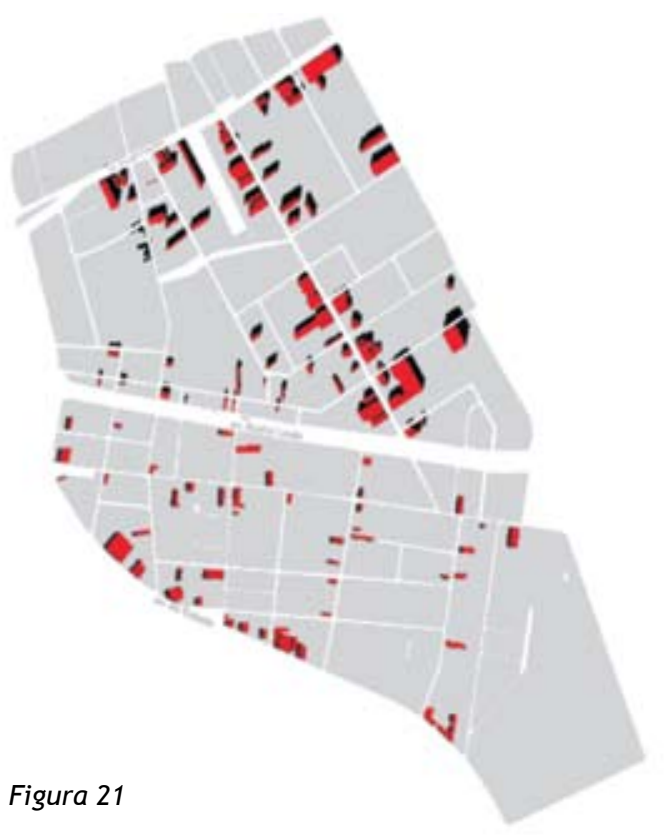

COMERCIAL

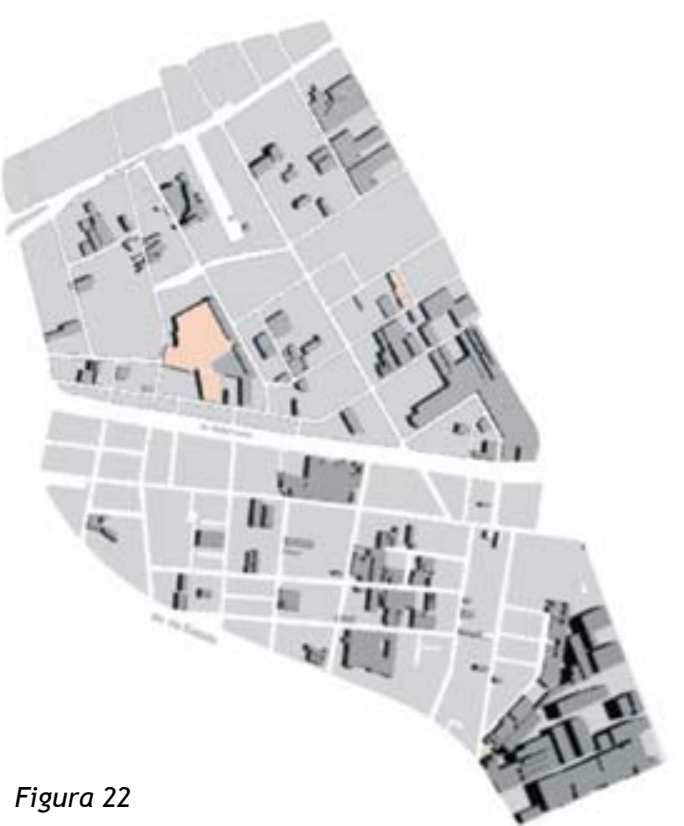

INDÚSTRIA - galpăo industrial

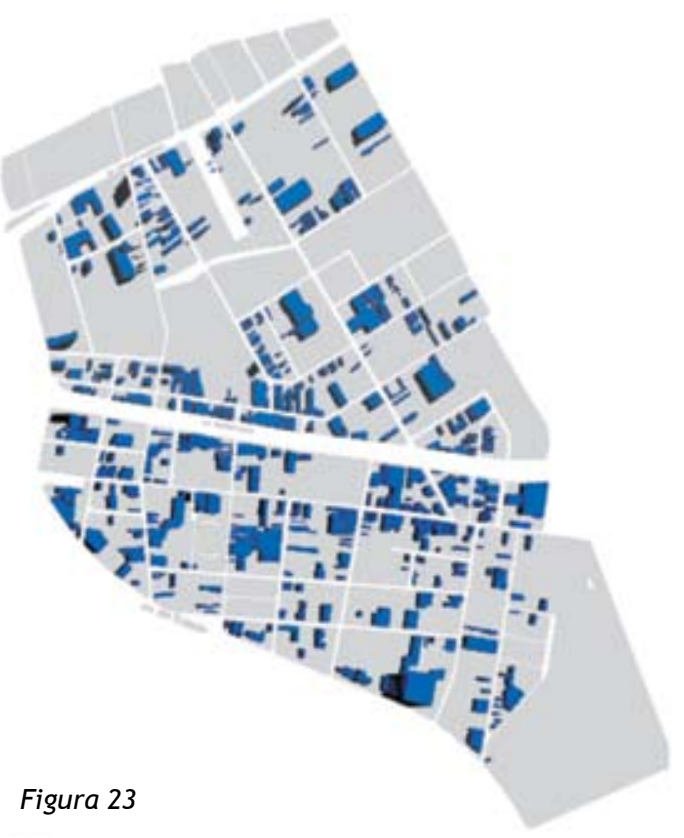

SERVIÇOS

INDÚSTRIA - galpão industrial vazio / abandonado $\%$ uso indefinido 


\section{I. Análise dos usos do solo no Brás e Mooca}

Na figura 21, que demonstra o uso comércio, fica claro que essa atividade é mais forte no Brás que na Mooca baixa. Nas visitas in loco foi possível avaliar também que o comércio local e diversificado na Mooca baixa tem padrão de qualidade mais baixo que no Brás, onde a população tem poder aquisitivo mais alto. Ao longo da Avenida do Estado, na Mooca baixa, o comércio predominante é o de móveis de segunda mão. No caso do Brás, é forte o comércio de máquinas ao longo da Rua Piratininga e o de couros e plásticos ao longo da Avenida Rangel Pestana. Note-se a dispersão dos pontos comerciais nos dois bairros.

No caso do uso industrial, demonstrado na figura 22, pode-se observar que em ambos os bairros uma grande quantidade de galpões industriais ainda abriga esse tipo de atividade, mas muitos deles hoje abrigam o uso serviços ou servem como depósito. A planta industrial da antiga fábrica de cerveja da Cervejaria Antárctica Paulista, hoje do grupo AMBEV e localizada na Mooca baixa, já não mantém atividades de fabricação no local, funcionando apenas como centro de distribuição. Com isso, um grande número de galpões, dentro dos limites da antiga fábrica, entre a Avenida Presidente Wilson e a Ferrovia Santos-Jundiaí, está desativado. A fábrica mantém, no entanto, a fabricação de outros produtos na área entre a Avenida Presidente Wilson, Rua Serra de Paracaima e Coronel João Dente, mas já em fase de desativação. A cor rosa na figura onde se demonstra o uso industrial corresponde ao antigo prédio da Metalúrgica Matarazzo, totalmente ocioso e que será alvo de desapropriação para implantação de um CEU - Centro Educacional Unificado, como será visto nas diretrizes do Capítulo VII.

No caso do uso serviços, demonstrado na figura 23, este ocorre com mais freqüência se comparado ao uso comércio, nos dois bairros, sendo mais freqüente na Mooca baixa que no Brás e um pouco mais concentrado que o uso comercial, no caso do Brás. Na Mooca, o setor de serviços, ainda que de baixa qualidade, conforme constatado nas visitas ao local - pequenos salóes de cabeleireiro, barbearias, quitandas, pequenas lojas e armarinhos, pequenas copiadoras, chaveiros, bares e pequenos restaurantes - é responsável pela maioria dos negócios locais. Ou seja, o uso serviços na Mooca baixa está mais voltado para o âmbito local que para o diversificado.

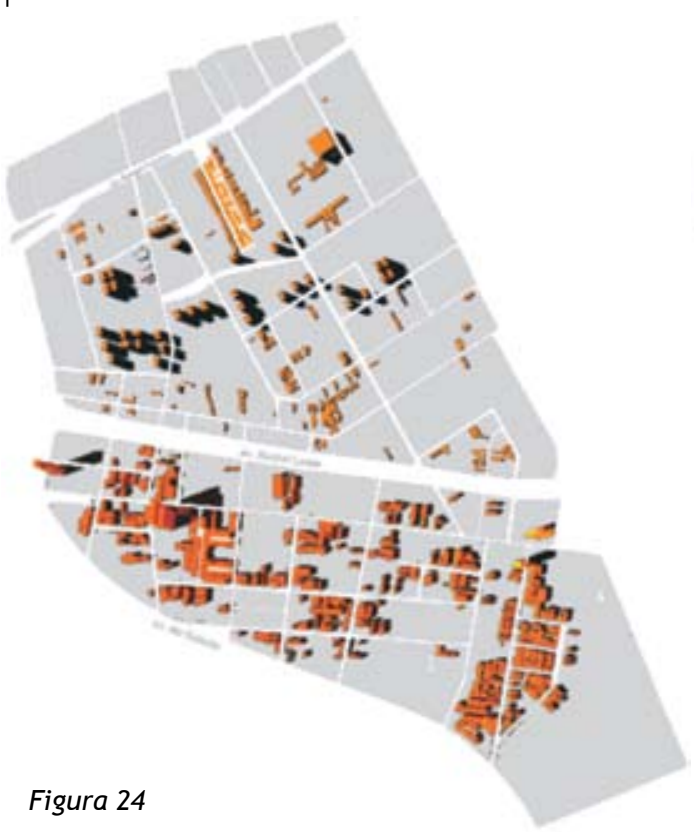

RESIDENCIAL

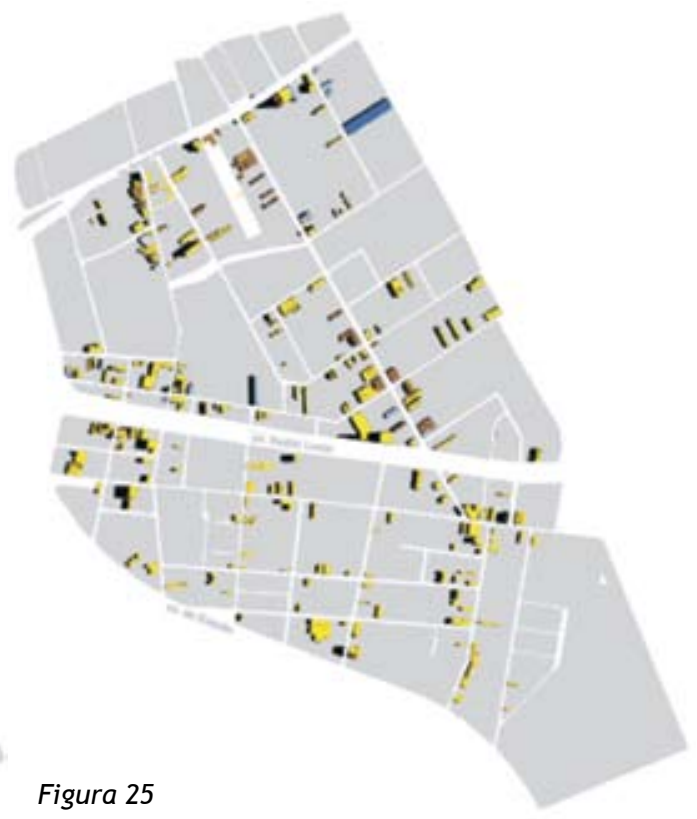

MISTO - Predominantemente residencial com térreo serviços

MISTO - Predominantemente residencial com térreo comercial

CORTIÇOS - Imóveis degradados ou parcialmente demolidos

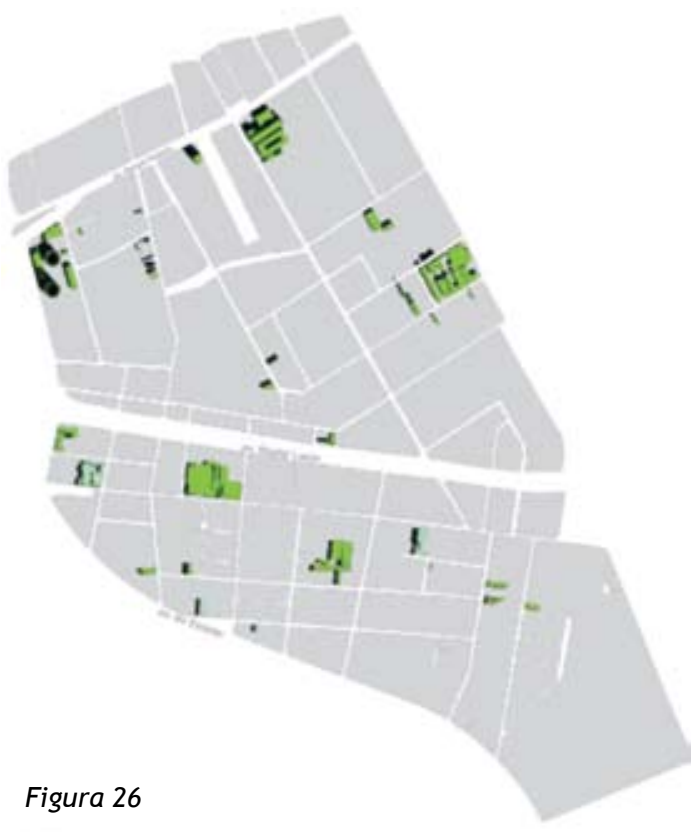

INSTITUCIONAL / escola pública

INSTITUCIONAL / edificio religioso 
Observando-se a figura 24, com a distribuição dos imóveis com uso exclusivamente residencial, conclui-se que esse uso é muito mais intenso na Mooca baixa que no Brás. Por outro lado, é no Brás que se encontram os dez condomínios residenciais verticais produzidos pela COHAB na década de 1980, chamados de Brás I a Brás X, com edifícios de 13, I4, I 8 ou 19 andares-tipo com 4 apartamentos por andar cada um (ver detalhamento no item 5 deste capítulo). Já no trecho Mooca onde não se fez o levantamento in loco, as visitas freqüentes para observação mostram que o uso predominante é o residencial, com alguns edifícios residências de produção capitalista para o mercado. No trecho Brás localizado entre a Avenida Radial Leste, a metrovia e a Ferrovia Central do Brasil, estão os três condomínios verticais produzidos pela COHAB e chamados Bresser I, Bresser II e Bresser III, com I 8 andares-tipo e 4 apartamentos por andar. Na Mooca baixa, a verticalização é rarefeita, representada por alguns edifícios de produção capitalista para o mercado e localizados à Rua da Mooca e Rua Coronel Bento Pires, próximos à Rua Wandenkolk. Exceto pela produção estatal de moradias por parte da $\mathrm{COHAB}$ e $\mathrm{CDHU}$, o restante dos imóveis residenciais existentes no local datam do período entre a década de 1920 e a década de 1950, resultantes em sua grande maioria da produção capitalista e uma pequena parte produzidos por encomenda para uso próprio ou para renda.

Analisando-se a figura 25 com a distribuição dos imóveis com uso misto - térreo com salão para prestação de serviços ou armazém utilizado como comércio e andares superiores com uso residencial na forma de apartamentos em vários andares ou simplesmente uma ou duas residências no andar superior - observa-se que esse tipo de uso é tão freqüente na Mooca baixa quanto no Brás. A maioria dos imóveis de uso misto com andar térreo e um ou dois andares superiores foi construída entre durante a década de 1930 ou pouco depois. Atendiam às necessidades dos pequenos industriais ou comerciantes que trabalhavam e moravam com suas famílias no mesmo local.

Na figura 26 fica clara a pouca quantidade de edifícios institucionais, públicos ou particulares, para os usos educacional, saúde e cultura, nos trechos Brás e Mooca baixa da área-objeto de estudo, como se descreveu e demonstrou no item 6 do Capítulo II desta dissertação.

\section{I.I. Adensamento e verticalização}

As imagens montadas por computação gráfica demonstram claramente o grau de verticalização de cada trecho da área-objeto de estudo onde se realizou o levantamento in loco do uso e ocupação do solo. Também fica demonstrada a complexidade da mistura de usos em toda a área.

A figura 27, uma elevação transversal, mostra as diferenças no adensamento entre Brás, à direita do desenho e mais verticalizado, e Mooca, à esquerda e com adensamento ainda por ser explorado.

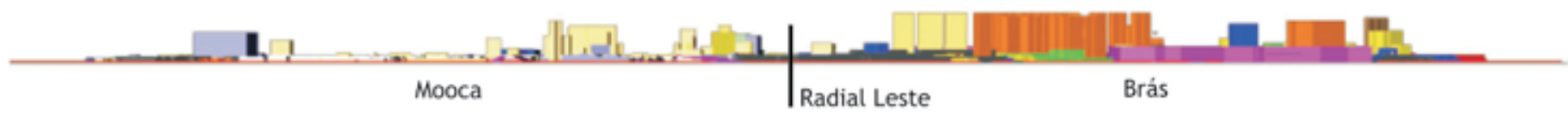

Figura 27 VISTA DA MOOCA E DO BRÁS A PARTIR DA LINHA FÉRREA EM DIREÇÃO A OESTE

$A$ vista $\mathrm{VI}$ nos mostra a baixa verticalização e o conseqüente baixo adensamento urbano desse bairro. As vistas V2, V3 e V4 mostram vistas aéreas da Mooca com os Viadutos Alcântara Machado na Radial Leste e o Viaduto da Rua da Mooca, em destaque. A baixa altura das construções é geral exceto por alguns poucos edifícios residenciais. 
O mapa do trecho Brás mostra a sua divisão pela Linha Leste do Metrô e a mistura de usos: comercial, serviços, residencial, industrial e institucional. A elevação acima mostra a verticalização no Brás representada pelos edifícios residenciais produzidos pela $\mathrm{COHAB}$ no fim da década de 1980, localizados ao longo da linha do metrô.
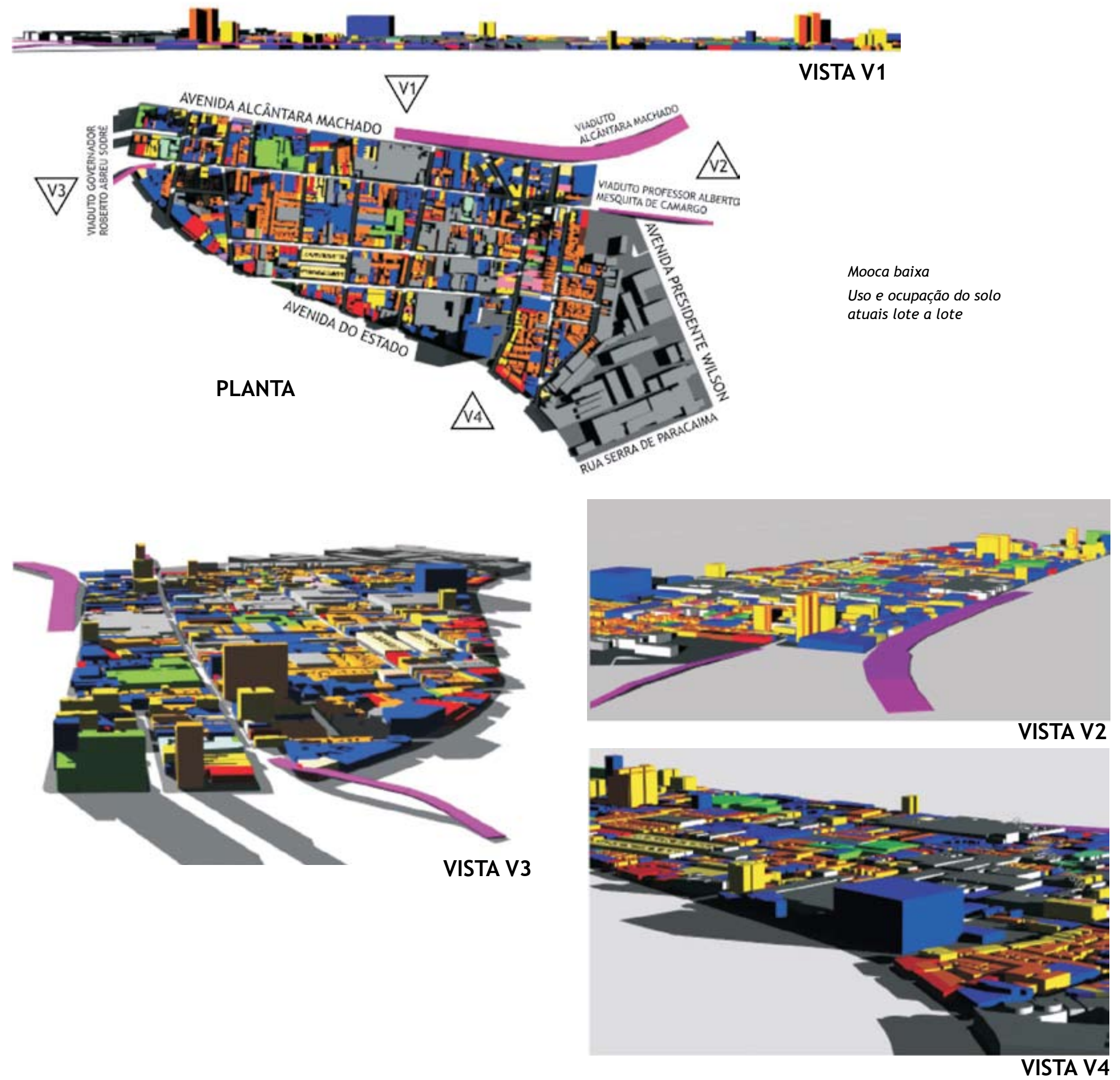
As vistas V5, V6, V7 e V8 mostram vistas aéreas do Brás com a Linha Leste do Metrô (de superfície) em destaque.
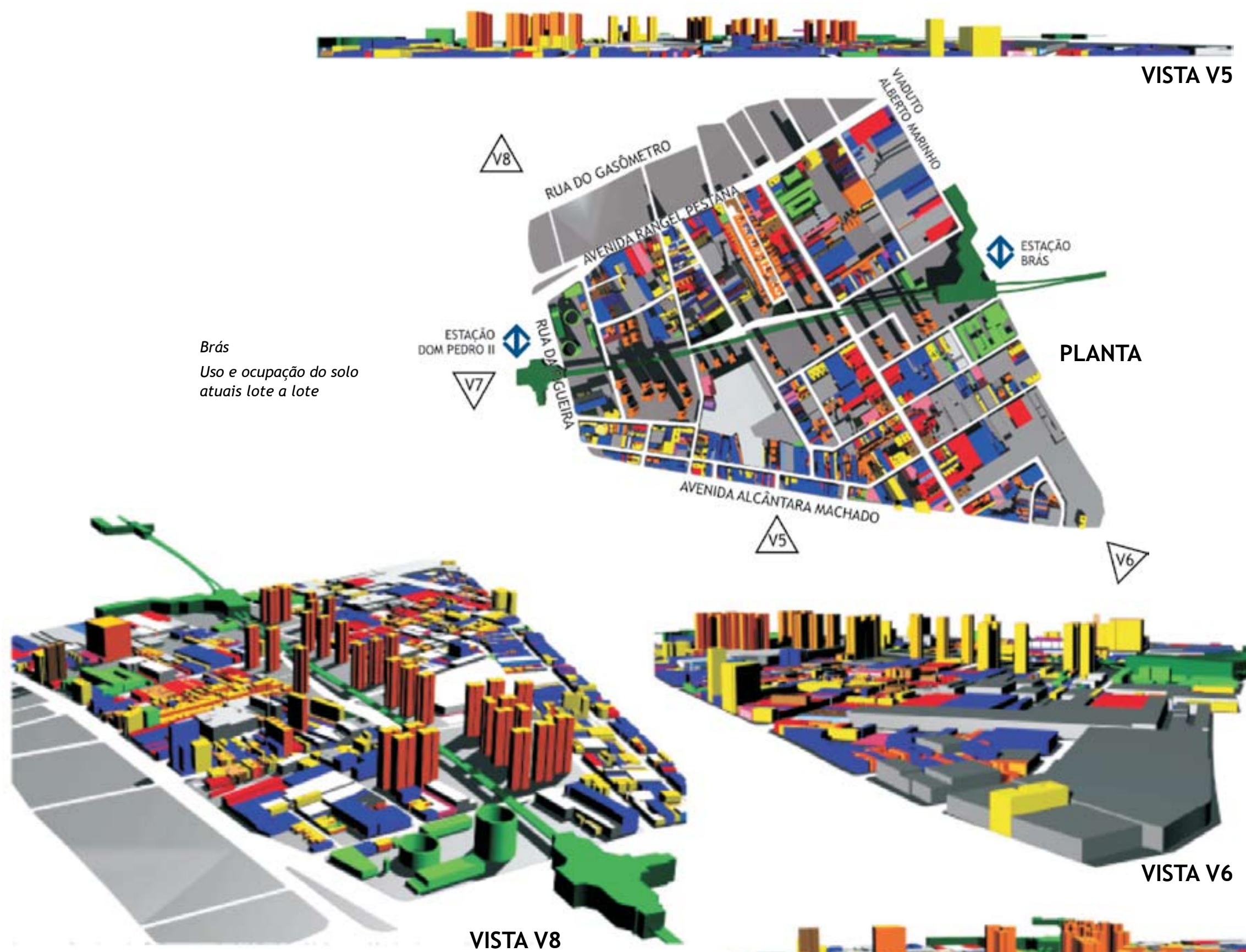

会
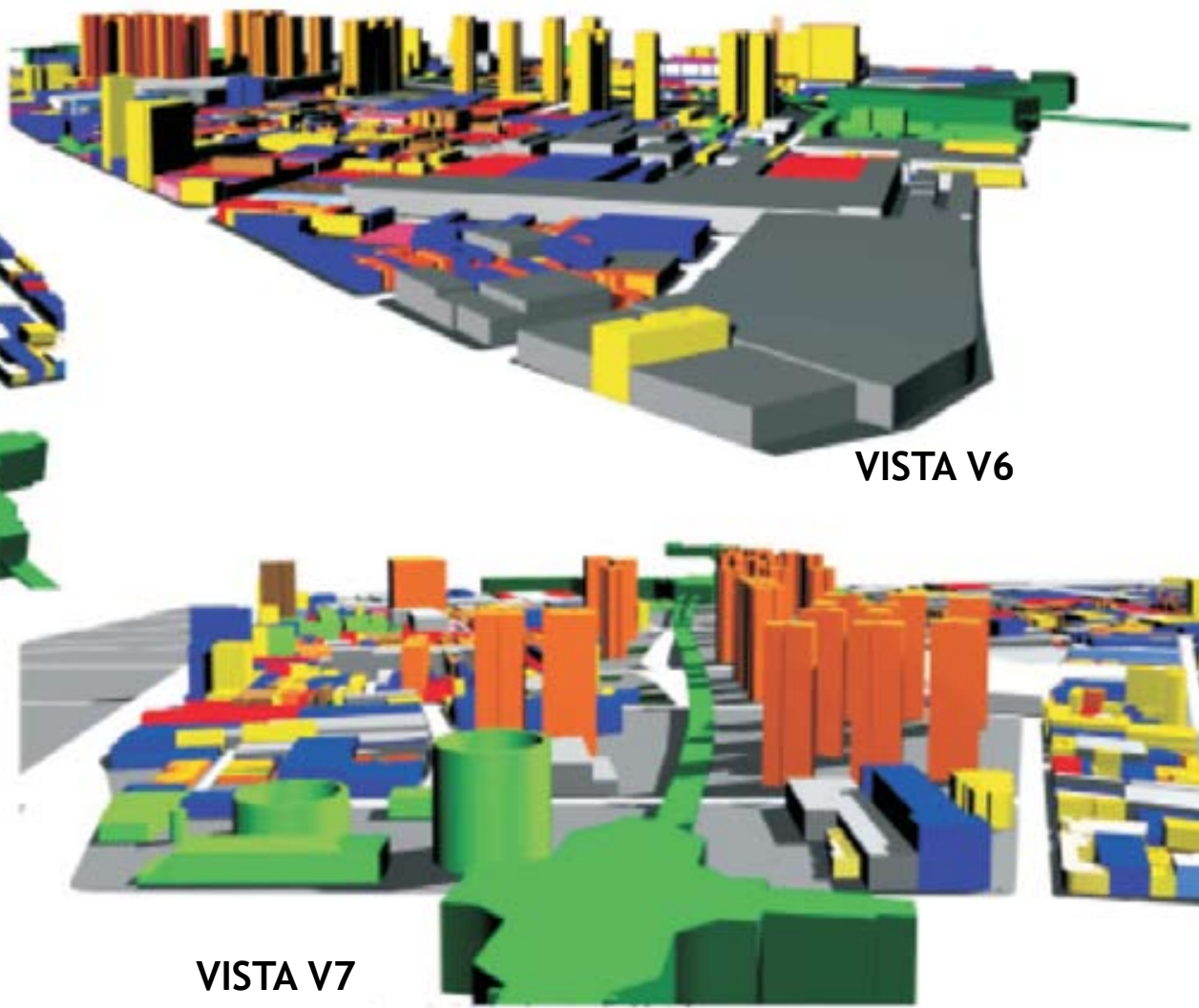


\section{A morfologia urbana}

\section{1. A topografia}

A topografia da região (Mapa 26 a seguir) é composta por áreas de várzea entre os rios Tietê e Tamanduateí, sujeita às cheias constantes desses rios. Apresenta a menor declividade do município de São Paulo, com índice de 0 a 5\% segundo o Atlas Ambiental, publicado pela Secretaria do Verde e Meio Ambiente da Prefeitura de São Paulo ${ }^{56}$.

A área confinada entre a Ferrovia Santos Jundiaí, atual CPTM, caracteriza-se por solo de depósitos aluviais. Nesse tipo de solo estão assentados o trecho em estudo do Brás e boa parte da Mooca baixa. Outro tipo de solo, onde se encontram os trechos da Mooca e Parque da Mooca, aqui considerados, é do tipo planície aluvial de rios entrelaçados (lamitos, arenitos e conglomerados $)^{57}$.

A topografia do Brás e Mooca passou por algumas alterações desde meados do século 19, quando ocorreu a retificação do Rio Tamanduateí. A área era formada por grande várzea entre as margens dos rios Tietê e Tamanduateí, sujeitas a enchentes (Mapa 26) durante muitos anos, antes das polêmicas obras de canalização do Rio Tamanduateí, entre as décadas de 1980 e 1990, quando as grandes enchentes foram finalmente debeladas, apesar do impacto estético e ambiental causado pelo encaixotamento desse rio. Hoje, poucos são os pontos apontados pela população residente como alagáveis. Ocorrem no início da Avenida Alcântara Machado, ao longo da Rua do Gasômetro no Brás, no final do Viaduto Alcântara Machado, na confluência com a Rua dos Trilhos e Rua Dr. Almeida Lima e na Rua do Hipódromo com a Avenida Alcântara Machado, na Mooca.

\subsection{O traçado viário}

Como visto anteriormente no item 2.2 do Capítulo II, o espaço urbano do Brás e Mooca, localizado ao leste da margem do rio Tamanduateí, começa a ser delimitado pela implantação das linhas férreas São Paulo Railway e Central do Brasil, indutores do crescimento em seu entorno. Antes disso, a Avenida Rangel Pestana, a antiga Rua do Braz, ligando as chácaras ao centro pela ponte do Carmo.

Pode-se começar a descrever o traçado viário da área de recorte delimitando a área em estudo pelo Rio Tamanduateí a oeste; pela Rua e Viaduto Bresser de forma quase paralela ao traçado do rio no pequeno trecho junto ao início da Avenida Alcântara Machado, a leste. Ao norte, a Avenida Rangel Pestana traça uma ortogonal com a Rua Bresser e com a via férrea Santos-Jundiaí, de onde parte a princípio paralela e posteriormente volta-se à direita em ângulo de $45^{\circ}$ aproximadamente. Ao sul, fica mais difícil encontrar linhas paralelas, pela irregularidade da malha viária, mas pode-se considerar a Rua Serra de Paracaima lateral à propriedade da Cervejaria Antárctica, paralela à Avenida Rangel Pestana.

Nos trechos formados entre esses sistemas viários, observa-se um traçado viário ortogonal irregular, com quadras de diversas dimensões. No trecho do Brás deste estudo, o paralelismo das ruas se dá a partir da Rua Piratininga em relação à via férrea São Paulo Railway e em direção ao oeste, sintoma da indução de crescimento a partir desse sistema viário.

Os croquis abaixo demonstram claramente que a implantação da Avenida Radial Leste acontece paralelamente à Rua da Mooca neste trecho inicial, ou seja, dentro da área do Recorte I. Analisando-se os mapas e plantas anteriores à sua implantação, verifica-se que ela não obedeceu outro critério senão o de rasgar o tecido consolidado existente, criando interrupções em várias ruas locais que quase transformavam os dois bairros em um só, levando o observador a tratar esse paralelismo como mera coincidência.
${ }^{56}$ Fonte: Atlas Ambiental do Município de São Paulo. Secretaria Municipal do Verde e Meio Ambiente. Mapa 15 - Declividade. São Paulo: SVMA, 2004.

${ }^{57}$ Fonte: Atlas Ambiental do Município de São Paulo. Secretaria Municipal do Verde e Meio Ambiente. Mapa 14 - Geologia. São Paulo: SVMA, 2004 

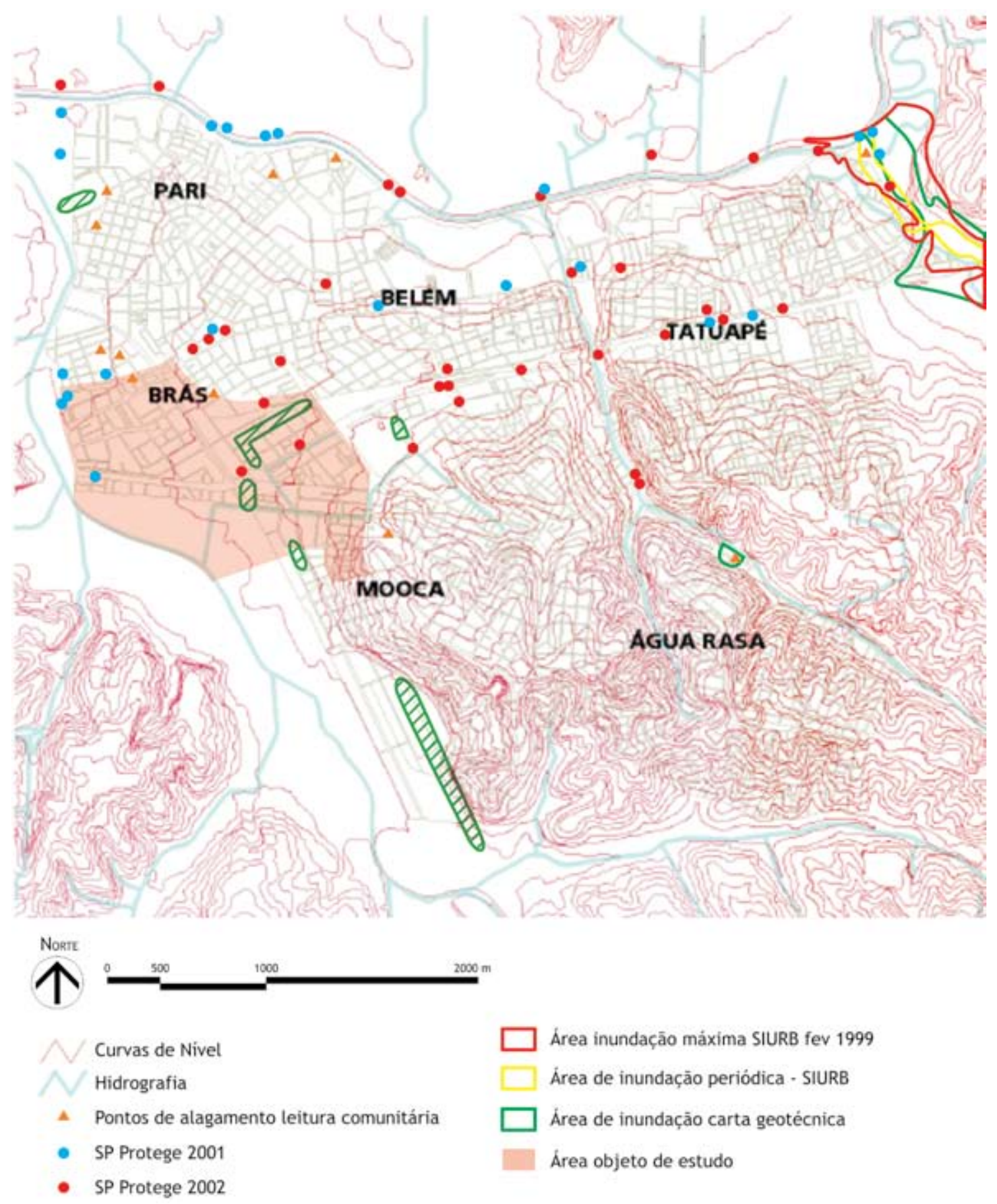

Topografia e fundos de vale

Mapa 26 

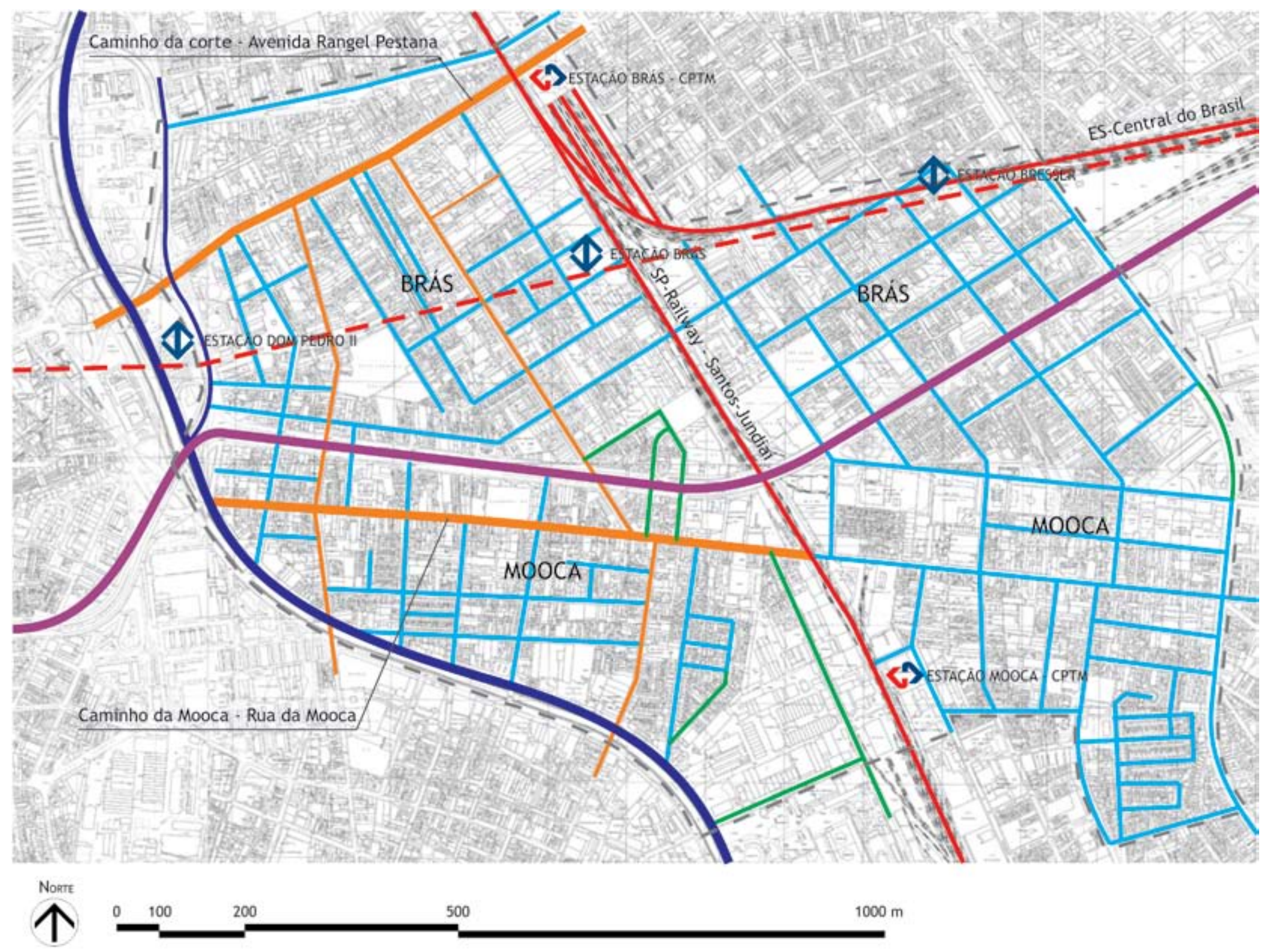

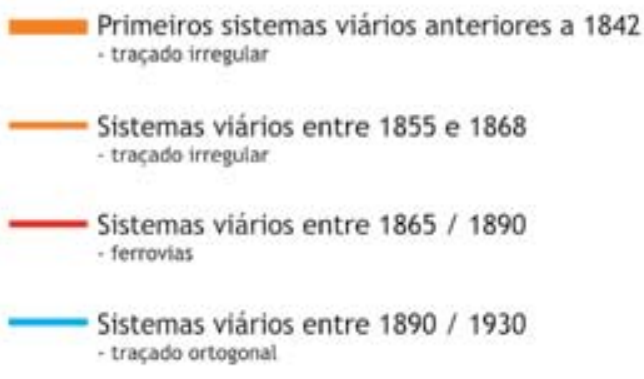
Sistemas viários entre 1915 e 1924 traçado irregular
— Sistemas viários entre 1930 / 1950 - traçado irregular
Sistemas viários entre 1950 / 1960 Avenida Alcântara Machads
- Sistemas viários entre 1979 / 1980 -Metrô Leste - 1 "Trecho

Traçado viário - etapas de surgimento autoria: Maria Elizabet Paez Rodriguez sobre GEGRAN 1972
Mapa 27 


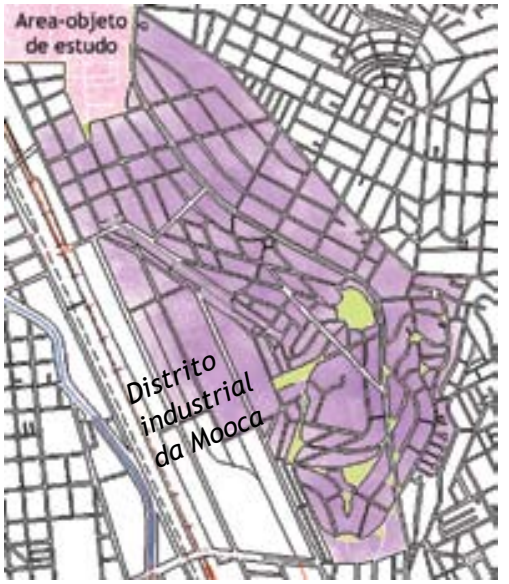

Figura 28

Planta Parque da Mooca, antiga Chácara da Mooca, com traçado viário orgânico e contíguo ao traçado ortogonal do distrito industrial, que fez parte do mesmo loteamento.
Observando-se o Mapa 27, com as etapas de surgimento das vias na área-objeto de estudo, obtém-se uma leitura de como o traçado viário da região em estudo foi sendo implantado. Esse mapa foi preparado sobre a planta GEGRAN e demonstra as etapas seqüenciais das grandes alterações viárias e da subdivisão das terras.

Na segunda metade do século 19, Brás e Mooca contavam com ruas principais como Rua da Mooca, Rua do Brás, entre outras, e as ferrovias Central do Brasil e São Paulo Railway.

Primeiramente procurou-se demonstrar o início da subdivisão das chácaras e grandes glebas. Supõe-se que, estando a ferrovia implantada e por ser este sistema viário indutor do crescimento urbano, tenham os primeiros loteadores iniciado os traçados de ruas paralelamente à ferrovia Inglesa. Conforme a análise de evolução urbana feita a partir dos mapas e documentos históricos utilizados no Capítulo II ficou claro que o desenvolvimento urbano da Mooca foi mais tardio que o do Brás. Na Mooca, o paralelismo das ruas se inicia a partir da Rua da Mooca, antigo Caminho da Mooca, na época das chácaras e propriedades rurais, no século 19, provavelmente já representando uma acanhada centralidade. Ruas secundárias completam a malha ortogonal. Pode-se concluir que a subdivisão das chácaras em glebas e depois em loteamentos utiliza a já implantada ferrovia citada como ponto de partida juntamente com a Rua do Brás, hoje Rangel Pestana, que lhe é ortogonal. Essa primeira grande área loteada em malha ortogonal se engancha no traçado viário irregular anterior formado pela Rua do Gasômetro, Carneiro Leão e Rua da Mooca, formando polígonos irregulares que encerram novas glebas.

Este mapa apresenta os traçados ortogonal e irregular do tecido urbano da área histórica e industrializada do Brás e Mooca, já alterados pela implantação da Avenida Radial Leste (década de 1960) e da Linha Leste do Metrô (décadas de 1970-80).

Como dito anteriormente, a Mooca e o Brás são bairros que ainda preservam muitas das vilas operárias ali construídas para a classe operária durante a industrialização da cidade. As vilas eram aprovadas junto à municipalidade com o nome "passagens" e os loteamentos

\section{Figura 29}

Traçado viário com a continuidade das vias antes da implantação da Radial Leste. Croquis da autora, 2003.

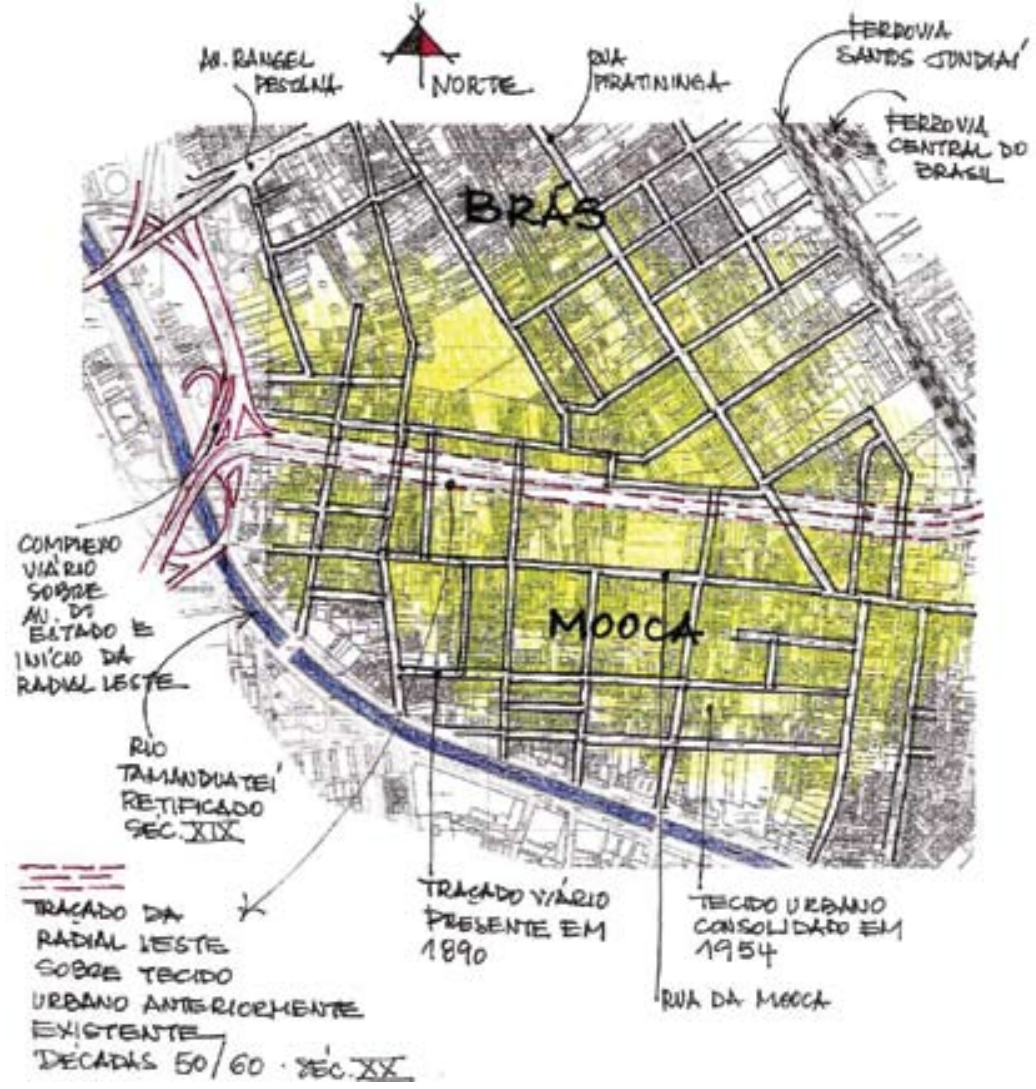
como "arruamentos" ou seja, fazem parte do traçado urbano, pois as vilas não necessariamente são ruas sem saída. Isso pode ser observado no Mapa 12 do Capítulo II, tanto no Brás como na Mooca.

A partir da década de 1980 a morfologia urbana passa a ser ditada pelas construções em concreto aparente das obras viárias e de engenharia, como viadutos e canalização do rio Tamanduateí. Elas alteraram o tecido urbano e diminuíram a acessibilidade e a mobilidade dos habitantes locais, com suas alças para o acesso dos veículos e suas passagens tão estreitas que expõem tanto os pedestres que acabam por desestimular o seu uso por estes.

Analisando-se a planta final do Parque da Mooca no projeto da figura 28 e na planta oficial atual da cidade, é possível observar que o polígono entre as ruas Araribóia, Rua dos Bancários, Rua Leocádia Cintra Jr., Avenida Paes de Barros e Curupacê não foi incluído no projeto de 1922, mas foi também subdivido em lotes individuais onde hoje ainda sobrevivem aprazíveis ruas estreitas e sobrados bem conservados, com uso do solo atual exclusivamente residencial, mimetizando o tecido urbano do projeto Parque da Mooca. É uma área que contém aproximadamente oito ruas internas e aproximadamente 320 casas de dois pavimentos. A rua dos 
Bancários, que chega a uma pequena e simpática praça, com uma frondosa árvore ao centro, é freqüentada por crianças e adultos.

\subsection{As tipologias do tecido urbano no Brás e Mooca}

Considerou-se aqui adotar parte da metodologia de leitura e análise do tecido urbano do urbanista Cândido Malta. Por serem bairros centrais, Brás e Mooca já dispõem dos três níveis de comércio e serviços, que podem melhorar em relação a tipo, qualidade e localização de forma espontânea, a partir da requalificação urbana desses bairros, ou seja, um projeto de requalificação urbana que promova o adensamento populacional dentro dos limites da infra-estrutura urbana instalada poderá levar ao surgimento de novos estabelecimentos para atender às novas demandas, ficando inclusive mais próximos do consumidor.

Lançando-se mão da classificação dos tipos básicos criada pelo urbanista Campos Filho, podemos concluir que a área do Brás e Mooca, em sua gênese, apresentam primeiramente o tecido urbano tipo I: o Caminho da Mooca e a Rua do Brás como vias principais no século 17 para a passagem de tropeiros vindos das localidades ao leste e como ligação das chácaras com o centro histórico. No século I 8, estas vias permanecem como tecido tipo I ao longo do tempo, em função das centralidades em que elas se transformaram, concentrando ali pontos comerciais e de prestação de serviços. No século 19, essas duas vias se cruzam com outras vias que também possuíam comércio forte, como a Rua Piratininga. Esse cruzamento de ruas com forte comércio e serviços diversificados gera uma centralidade polar levando ao tecido tipo 2. O tipo 4 de tecido urbano toma corpo quando as vias locais recebem cada vez mais tráfego de veículos, transformando-se em vias coletoras e posteriormente em vias de ligação regional, o que atrai mais visitantes e consumidores, que atraem mais pontos comerciais e por fim vão transformando o comércio e serviços locais em diversificados e estes em especializados.

O Quadro 3 demonstra as etapas de transformação do tecido urbano do Brás e Mooca entre os séculos 18 e 20, aplicando-se a metodologia de Campos Filho.

Quadro 3 - Evolução da tipologia do tecido urbano associado ao sistema viário

\begin{tabular}{|c|c|c|c|c|}
\hline & Tipo 1 & Tipo 2 & Tipo 3 & Tipo 4 \\
\hline Séc. 18 & $\begin{array}{c}\text { Rua do Brás } \\
\text { Caminho da Mooca }\end{array}$ & - & - & - \\
\hline Séc. 19 & $\begin{array}{c}\text { Rua do Brás } \\
\text { Caminho da Mooca }\end{array}$ & $\begin{array}{l}\text { Rua Piratininga com } \\
\text { Rua da Mooca }\end{array}$ & - & - \\
\hline $\begin{array}{l}1^{\mathrm{a}} \text { metade } \\
\text { séc. } 20\end{array}$ & $\begin{array}{l}\text { Bairro do Brás } \\
\text { Bairro da Mooca }\end{array}$ & $\begin{array}{l}\text { Bairro do Brás } \\
\text { Bairro da Mooca }\end{array}$ & - & $\bullet$ \\
\hline $\begin{array}{l}2^{\mathrm{a}} \text { metade } \\
\text { séc. } 20\end{array}$ & $\begin{array}{c}\text { Bairro do Brás } \\
\text { Bairro da Mooca }\end{array}$ & $\begin{array}{c}\text { Bairro do Brás } \\
\text { Bairro da Mooca }\end{array}$ & Parque da Mooca & $\begin{array}{c}\text { Bairro do Brás } \\
\text { Bairro da Mooca }\end{array}$ \\
\hline
\end{tabular}

Dos quatro tipos básicos considerados por Campos Filho (2003, p.60) como base para análise do tecido urbano, vistos no item 4. I do Capítulo I, pode-se concluir que basicamente os bairros do Brás e Mooca dispõem na maioria dos casos de quadras com tecido urbano tipo 4, cortado por vias de ligação inter-bairros ou regionais e os usos comercial e serviços são de âmbito local e diversificados, mas dispersos, sem gerar centralidades claras, exceto por algumas vias com comércio especializado em forma de centralidades polares ou lineares. Um exemplo é o encontro da Rua Piratininga e Rua Visconde de Parnaíba, com forte comércio especializado em máquinas. O levantamento in loco não focou definir o grau de diversificação do comércio que caracteriza o tipo 4, da classificação de Campos Filho. 
No caso do tipo 3, segundo a classificação de Campos Filho, essa tipologia é encontrada somente no loteamento Chácara da Mooca, ao sul da área-objeto de estudo desta dissertação, onde as ruas de uma determinada área tem uso exclusivamente residencial e não é cortada por vias de tráfego regional, apenas local. Nesse caso, a centralidade É formada por pontos de comércio e serviços locais ou diversificados concentrados e fica adjacente à área residencial. A figura 28 da página 96 apresenta a planta final da Chácara da Mooca, mencionada acima, com sua principal Avenida, a Paes de Barros, centralidade linear que concentra comércio e serviços de âmbito local e diversificados.

A partir do levantamento do uso do solo da região, in loco e lote a lote (Mapa 25), foi possível identificar e classificar 13 diferentes tipos de tecido urbano considerando-se a combinação de vários fatores: forma de traçado viário, uso e ocupação do solo, densidade demográfica e gabarito. O levantamento foi feito tendo a quadra como foco e não o uso do sistema viário.

Os trechos a seguir foram destacados do Mapa 25, com os reais usos e a real ocupação do solo da área-objeto de estudo, no ano do levantamento: 2004.

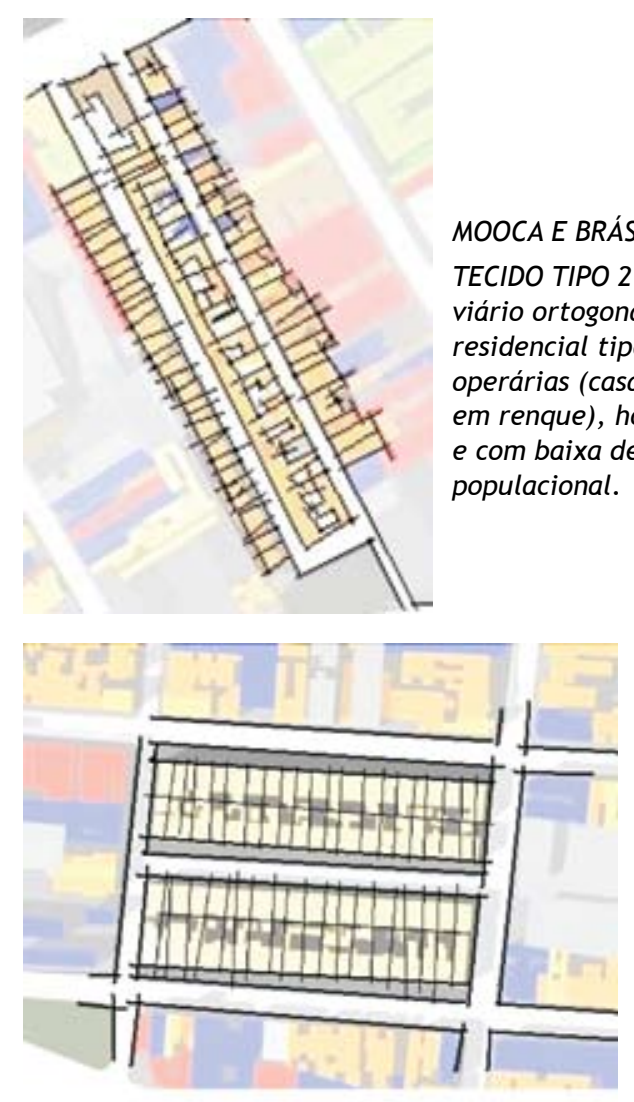

\section{MOOCA E BRÁS}

tipo

residencial tipo vilas

em renque), horizontalizado

e com baixa densidade

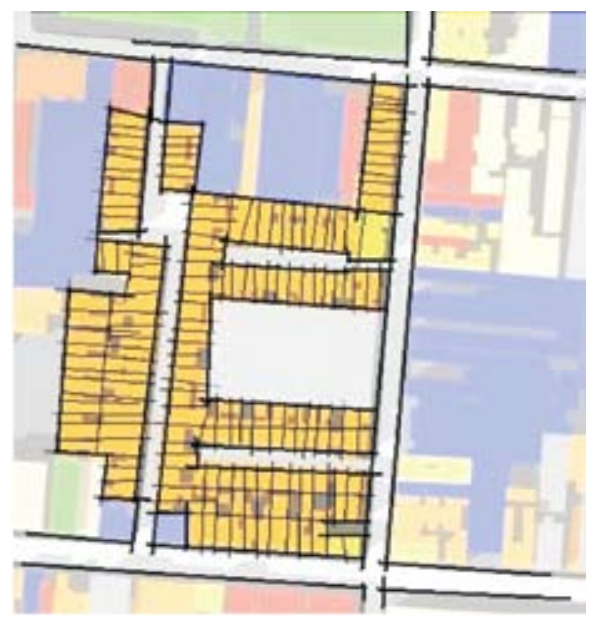

MOOCA

TECIDO TIPO 1: traçado viário

irregular, uso residencial,

horizontalizado e com baixa

densidade; lotes pequenos e médios

e uso misto, predominantemente

residencial

\section{MOOCA}

TECIDO TIPO 3: traçado viário ortogonal, uso institucional, horizontalizado e baixa densidade populacional, com lote único de grandes dimensões.

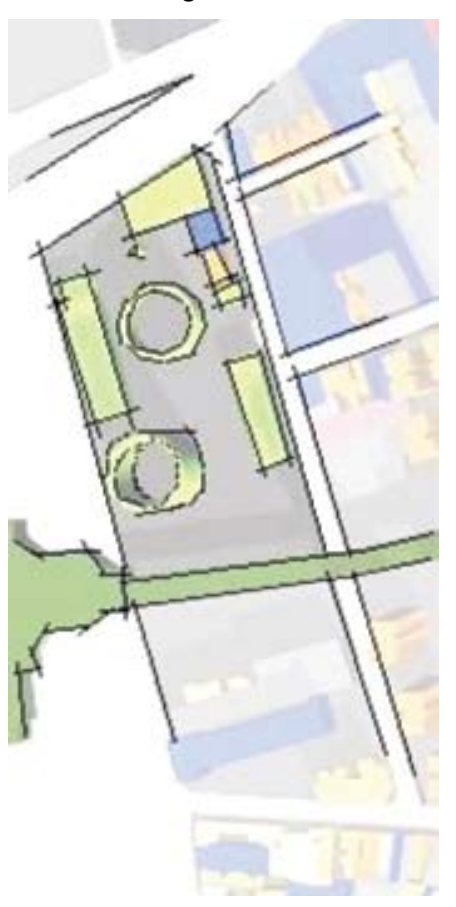




\section{MOOCA E BRÁS}

TECIDO TIPO 4: traçado viário ortogonal, uso misto com comércio e serviços locais e diversificados dispersos; os usos industrial e residencial também são presentes; o tecido é horizontalizado e com baixa densidade populacional; os lotes são irregulares e de tamanhos variados.
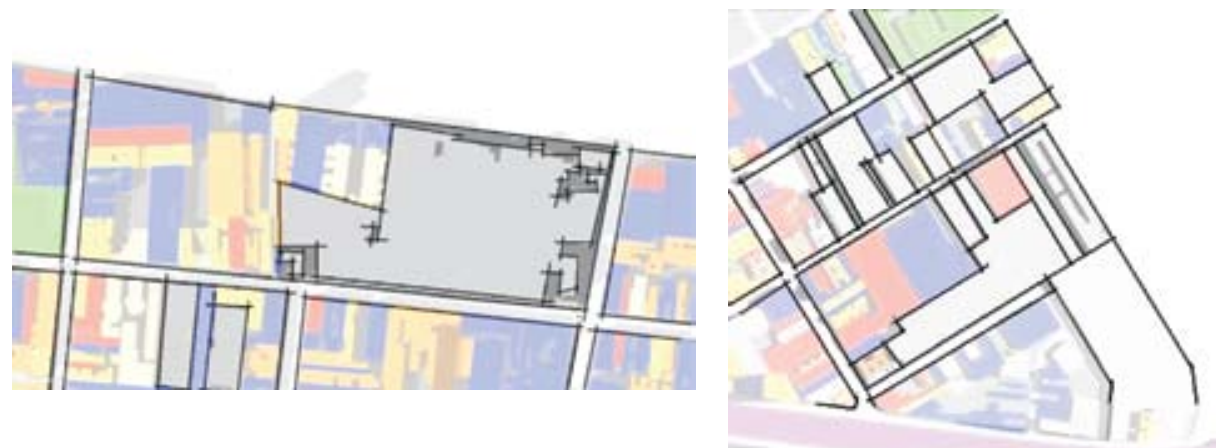

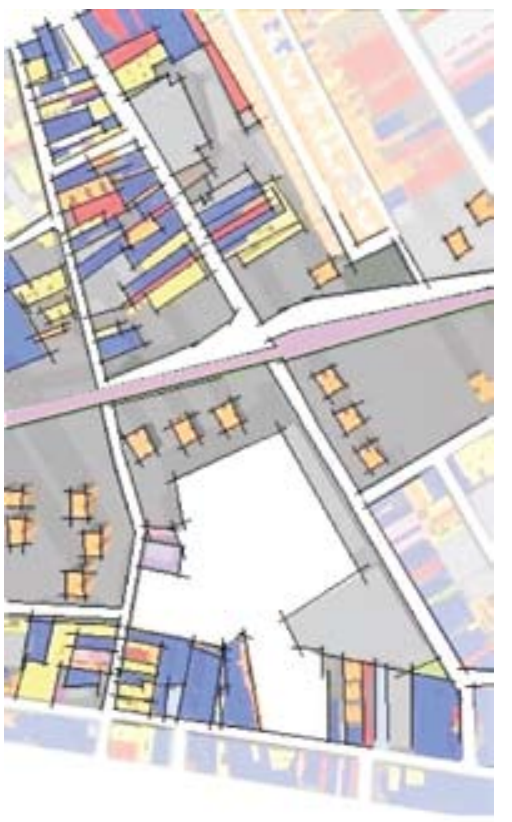

BRÁS

TECIDO TIPO 5: traçado viário irregular, uso misto com comércio e serviços locais e diversificados mas dispersos; predominantemente horizontalizado, com baixa densidade populacional e lotes irregulares de diversas dimensões.

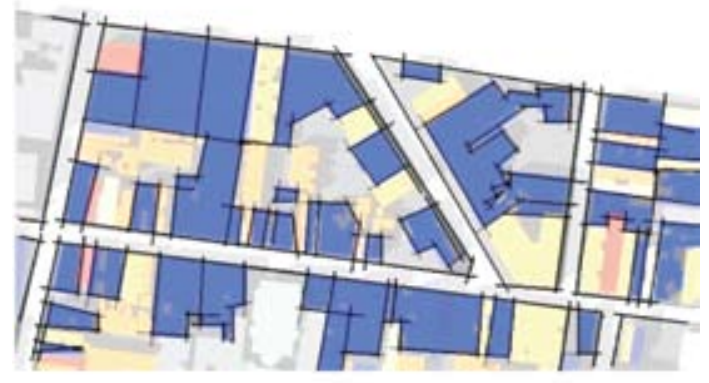

BRÁS

MOOCA

TECIDO TIPO 7: traçado viário ortogonal, uso misto, horizontalizado e baixa densidade populacional, com lotes pequenos com diversas dimensões.
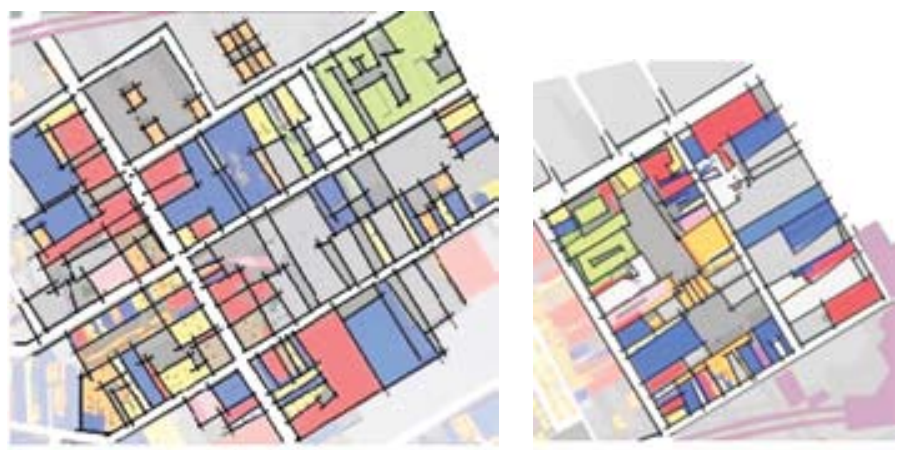

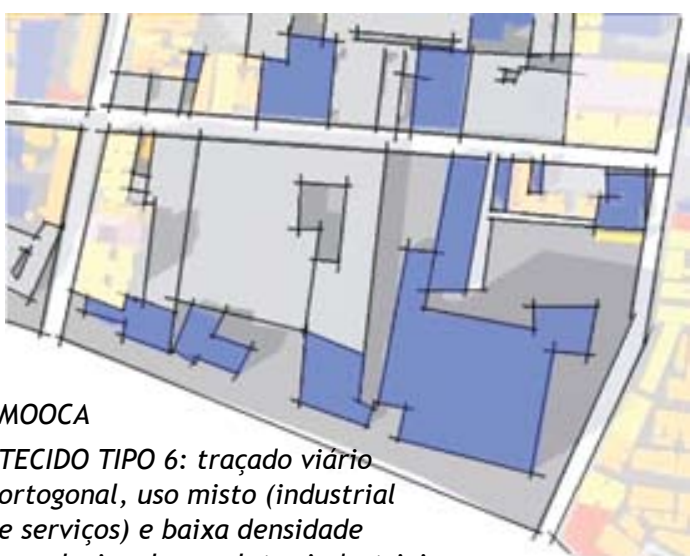

e serviços) e baixa densidade populacional, com lotes industriais de tamanho médio.
TECIDO TIPO 8:

traçado viário

irregular, misto (predominantemente residencial),

verticalizado e média densidade, com lotes irregulares e de dimensões variadas.

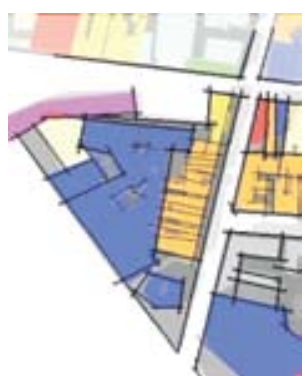

MOOCA

TECIDO TIPO 9: traçado viário ortogonal, uso misto (institucional e servicos), horizontalizado e baixa densidade populacional, com lotes irregulares de tamanho médio.

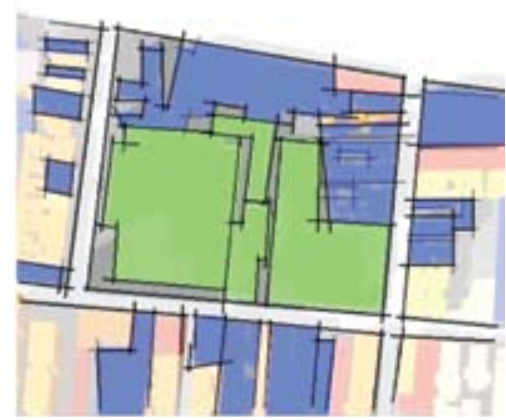




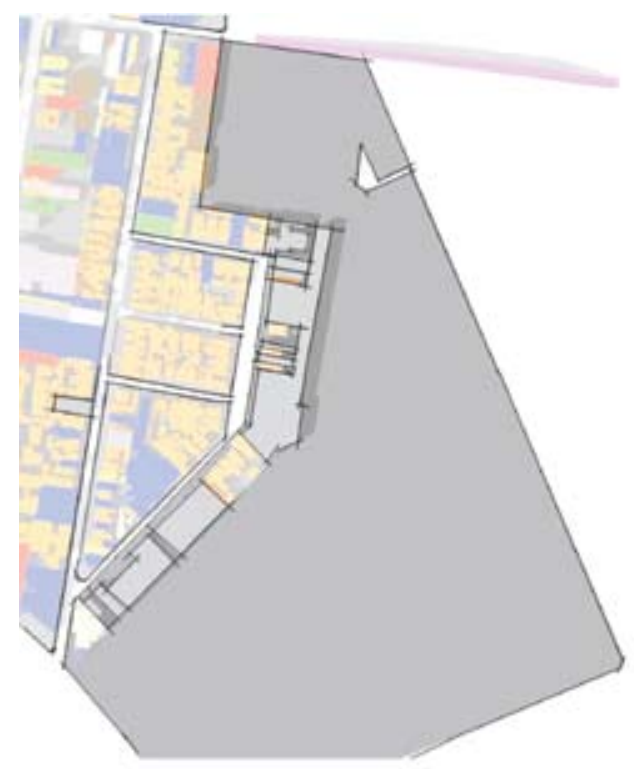

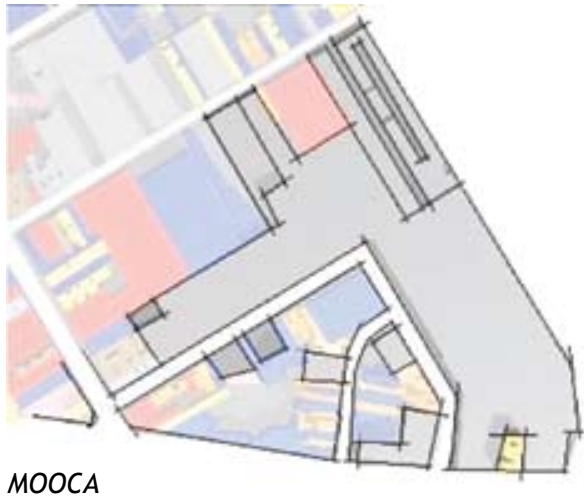

TECIDO TIPO 10: traçado viário irregular, uso predominantemente industrial, horizontal $e$ baixa densidade populacional com terrenos de médio e grande porte.

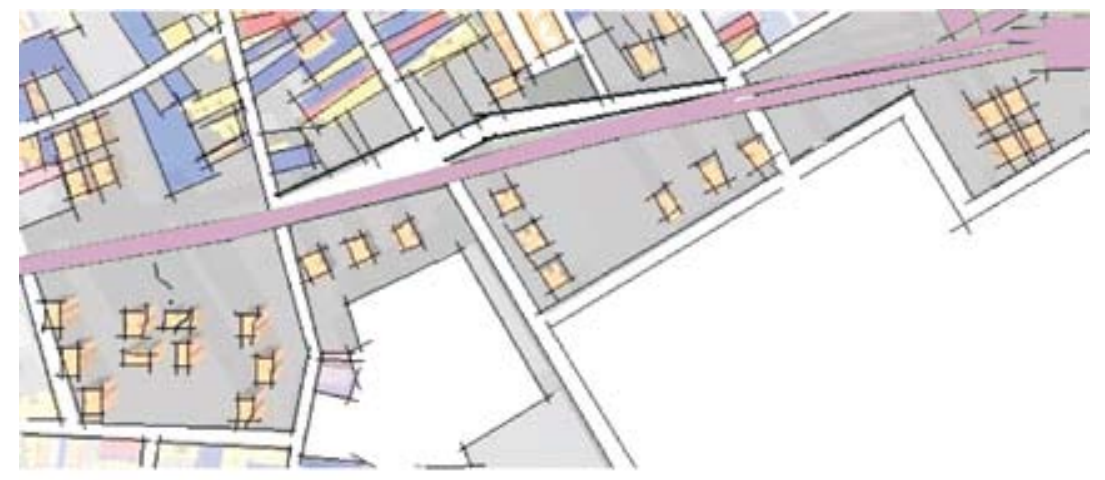

BRÁS

TECIDO TIPO 12: traçado viário irregular, uso exclusivamente residencial, verticalizado apenas em função dos edifícios residenciais de 20 andares; média densidade populacional e lotes grandes e irregulares com áreas variando entre 3.082 e $11.234 \mathrm{~m}^{2}$.

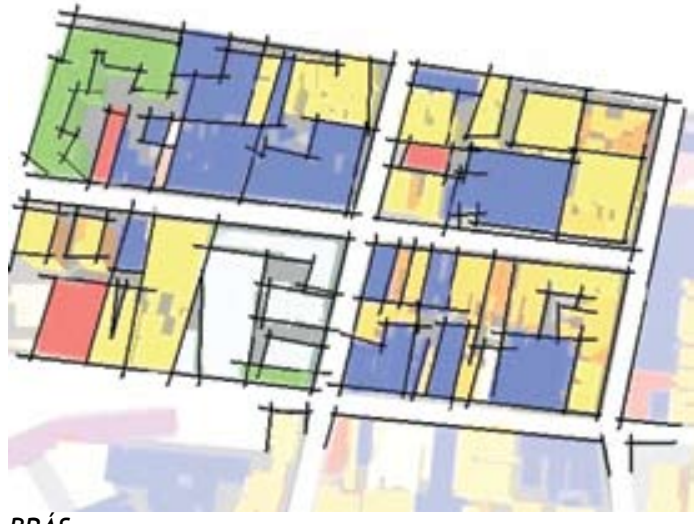

BRÁS

TECIDO TIPO 11: traçado viário ortogonal, uso misto, predominantemente horizontal com alguns edifícios residenciais; baixa densidade populacional e lotes irregulares de tamanhos variados.

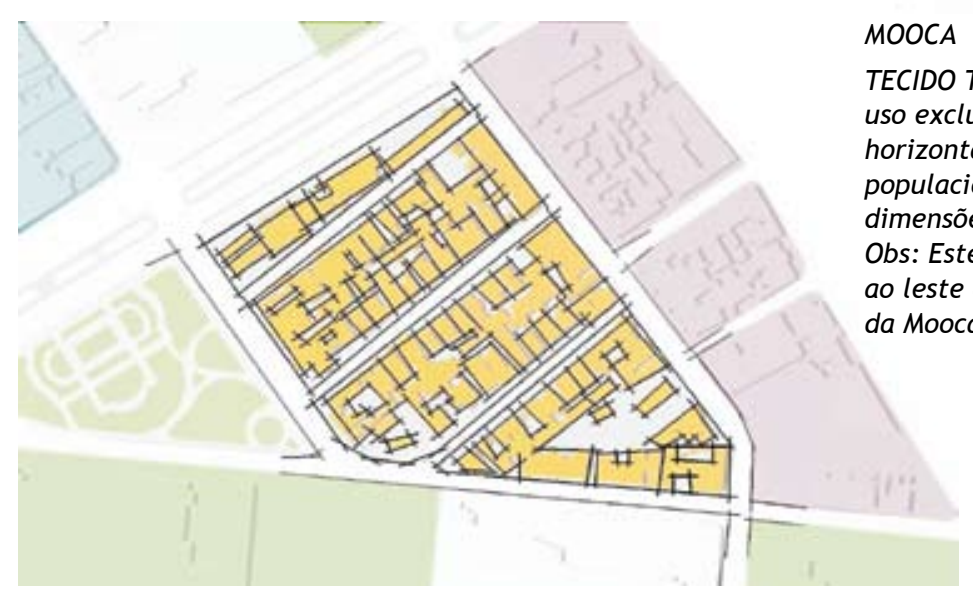




\subsection{Os vazios urbanos}

Existem na região vários espaços, vazios ou de certa forma subutilizados que podem ter seus usos alterados para outros que melhor atendam as demandas das comunidades locais. Como exemplo, pode-se citar edifícios e galpões industriais que se encontram ociosos, terrenos vazios e edifícios residenciais de dois ou três pavimentos também ociosos.

Existe também na região, uma grande quantidade de terrenos utilizados como estacionamentos. Apesar de polêmica, a classificação deste tipo de imóvel atrelado a esse uso não é consenso como "vazio urbano" entre os urbanistas e planejadores públicos.

Áreas remanescentes das desapropriações ocorridas para a implantação da Linha Leste do Metrô podem ter alguma destinação já que se encontram ociosas, apesar de terem dimensões significativas.

Foram encontradas quatro áreas ociosas ou remanescentes após as desapropriações para a implantação da Linha Leste do Metrô. São elas:

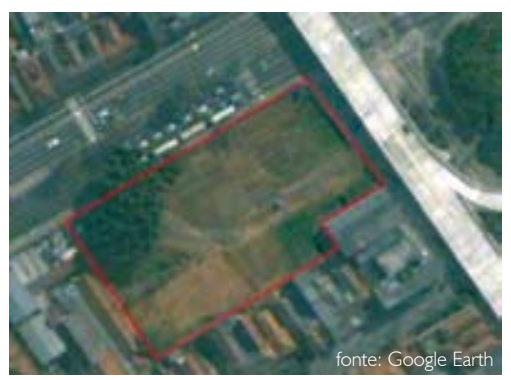

Área remanescente I:

Terreno de propriedade da prefeitura municipal de São Paulo localizado na Avenida Radial Leste, esquina com o Viaduto Bresser.

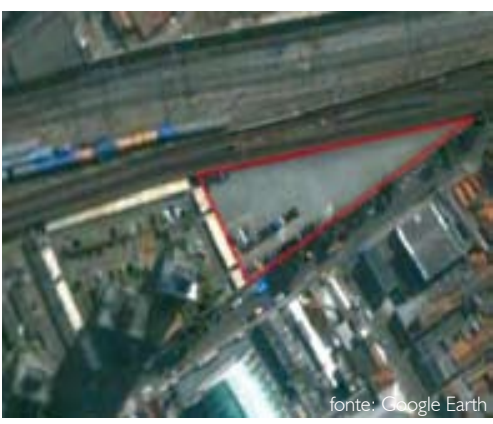

Área remanescente 3:

Trata-se de sobras de terreno em função da implantação da Linha Leste do Metrô, junto à estação Brás. Entre as duas áreas assinaladas na foto aérea existe uma creche municipal.

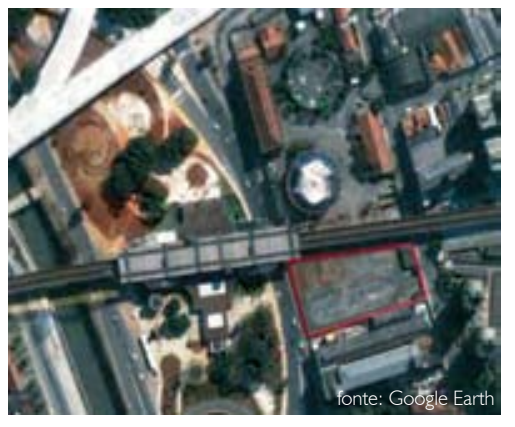

Área remanescente 2:

Localizada entre a Linha Leste do Metrô, ao lado do antigo Gasômetro, esta área trata-se de sobra de terreno em função da implantação do Metrô Leste. Pelas grandes dimensões e por estar localizado ao lado de área institucional, poderá abrigar um equipamento urbano público para o qual haja demanda.

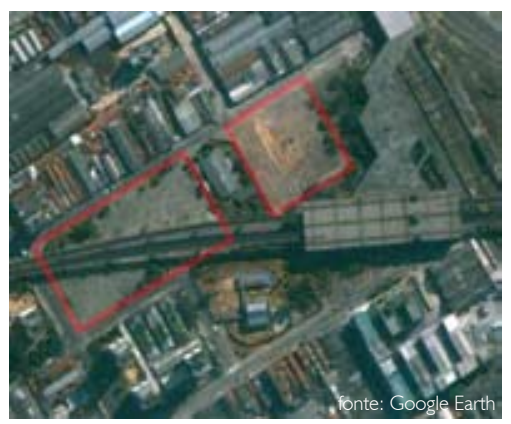

Área remanescente 4:

Localizada entre a via férrea da CPTM (antiga Central do Brasil), com frente para Rua Visconde de Parnaíba e ao lado de um empreendimento da COHAB-Bresser, a área já vem sendo estudada por esse órgão para acomodar mais um condomínio residencial vertical. 


\subsection{As centralidades}

Baseada na metodologia de análise desenvolvida pelo urbanista Cândido Malta Campos FiIho em seu livro Reinvente seu bairro, procurou-se localizar os usos predominantes quadra a quadra e foram identificadas as centralidades formadas pelo agrupamento de comércio ou serviços diversificados nas principais vias que formam centralidades polares. Mooca.

O Mapa 28 demonstra a localização e o tipo de centralidaes que existe no Brás e

O corredor Radial Leste apresenta, em ambos os lados, comércio diversificado regional de freqüência média ou baixa. A esta via se junta a Rua Piratininga com denso comércio diversificado e especializado em máquinas. Complentando-se o conjunto com a Rua da Mooca e seu comércio e serviços diversificados, obtém-se uma "centralidade de serviços e comércio diversificados polarizados" (Campos Filho, 2003, p.25).

O mesmo ocorre no encontro das Ruas Piratininga e Avenida Rangel Pestana, onde o comércio especializado em couros e revestimentos plásticos atrai consumidores de toda a cidade. A Avenida do Estado foi aqui considerada como centralidade de comércio especializado em mobiliário, além de outros serviços.

Exceto por algumas quadras de uso exclusivamente residencial tanto na Mooca como no Brás, o restante delas apresenta uso misto de comércio, serviços, áreas institucionais, saúde e educação, tanto do tipo local como do tipo diversificado. Algumas áreas de dimensões razoáveis ainda mantêm atividades industriais.

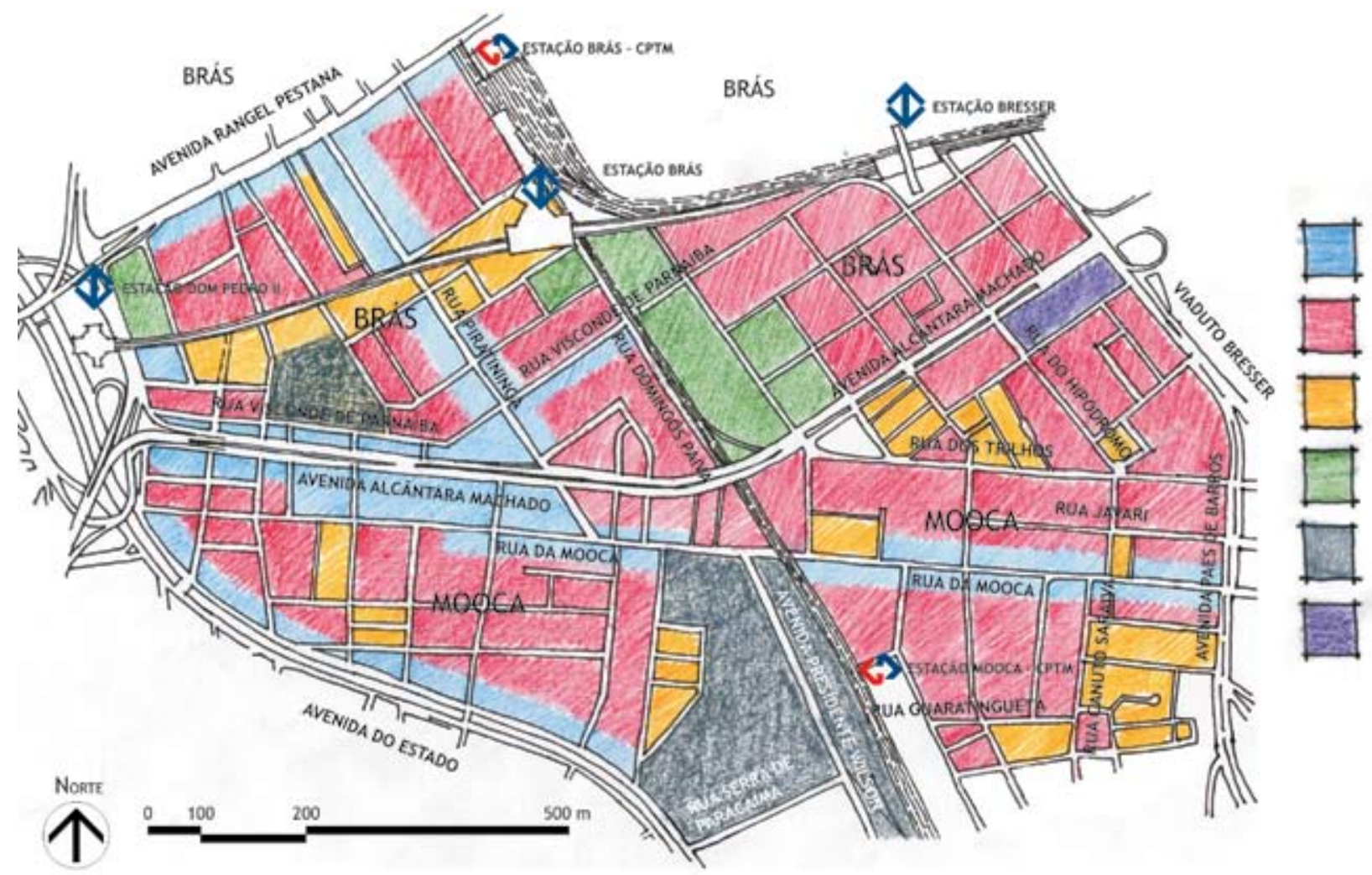

Comércio e servicos diversificados polarizados Uso predominantemente comercial Uso predominantemente residencia Insitucional

Indústria ociosa ou com parte ociosa Área pública ociosa

Centralidades com comércio e serviços autoria: Maria Elizabet Paez Rodriguez sobre GEGRAN 1972 


\subsection{Os marcos referenciais e o Patrimônio Histórico}

Podemos citar como marcos referenciais o Museu da Imigração e a Estação Ferroviária do Brás, que serve a antiga Estrada de Ferro Central do Brasil, hoje pertencente à CPTM.

Esses são dois importantes exemplos de conservação e recuperação de patrimônio histórico para a cidade, atendendo a população funcional e culturalmente.

\section{Bens tombados pelo CONDEPHAAT no Brás}

(Fonte: CDHU, 2004, p. II):

- Acervo arquivístico da Hospedaria dos Imigrantes

Rua Visconde de Parnaíba, 1316

Resolução SC-26, de 06.05.1982;

- Hospedaria dos Imigrantes

Rua Visconde de Parnaíba, 1316

Resolução SC-27, de 06.05.1982;

- E.E. Padre Anchieta

Rua Visconde de Abaeté, 154

Resolução SC-30, de 17.06.1988;

- Estação do Brás

Rua Domingos Paiva s $/ n^{\circ}$ e Praça Agente Cícero s/n

Resolução SC-22, de 03 de maio de 1982.

\section{Bens tombados pelo CONPRESP no Bairro do Brás}

(Fonte: CDHU - Relatório PAC-Brás, p. I I):

- Hospedaria dos Imigrantes

Rua Visconde de Parnaíba, 1316;

- EE Padre Anchieta

Rua Visconde de Abaeté, I 54;

- Estação do Brás

Rua Domingos Paiva s/n e Praça Agente Cícero s/n;

- Teatro Oberdan

Rua Brigadeiro Machado n 71 .

\section{Bens tombados pelo CONPRESP no Bairro da Mooca baixa} (Fonte: CDHU - relatório PAC-Cambuci, p. 18):

- Sobrado de autoria do Arq. Gregory Warchavchik

Rua Barão de Jaguara ns 312 a 394

Resolução I4/CONPRESP/90;

- Teatro Arthur de Azevedo

Rua Paes de Barros no 955

Resolução CONPRESP 29/92.

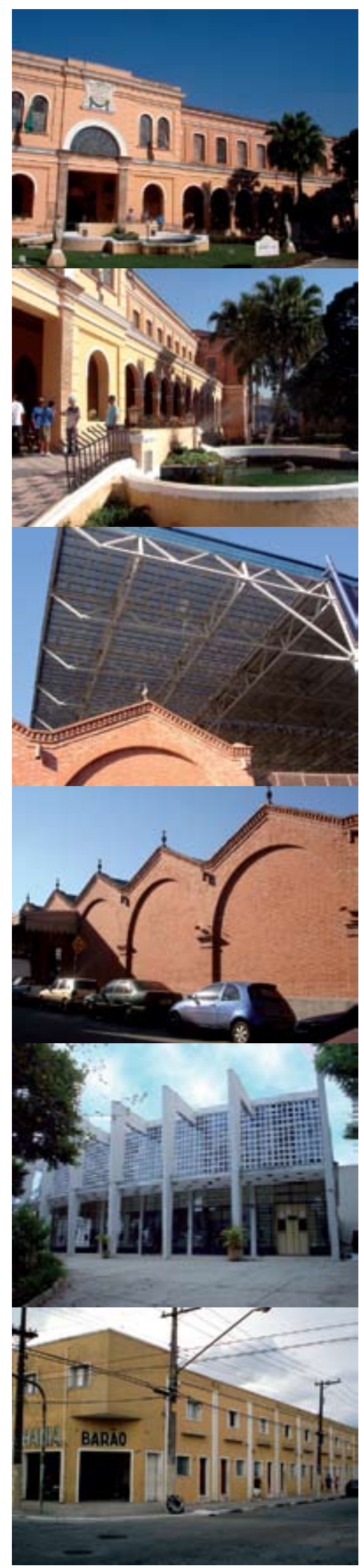


58 Marly Rodriguews é doutora e historiadora do Condephaat.

\section{Da esquerda para a direita:} Fachada preservada do Cotonifício Crespi, à rua Javari, Mooca, 2006; Edifício recuperado por órgãounicipal, à Rua Uruguaiana, Brás, 2006; Estação da Mooca (CPTM) departamento gráfico, 2003; Residência à Rua da Mooca, 825, 2003; Fábrica de Tecidos Labor,

à Rua da Mooca, 815, desativada, 2003.
A Hospedaria dos Imigrantes, hoje Museu da Imigração, está situada à Rua Visconde de Parnaíba, n 13 |6, no Brás. Este imóvel, construído em 1866 em tijolos e com capacidade para 1200 pessoas, foi projetado por Mateus Haüssler e contava com ambulatórios, cozinha, lavanderia e posto dentário.

A Estação do Brás fica na antiga São Paulo Railway, ferrovia construída pelos ingleses e conhecida como Santos-Jundiaí, hoje pertencente à CPTM. Foi projetada por James Fjord em | 897, substituindo a antiga parada, construída em 1867, época da construção da ferrovia. A nova estação foi construída em tijolos e estrutura metálica.

É por meio do tombamento que alguns artefatos são destacados de outros da mesma espécie e oficialmente reconhecidos como portadores de representação cultural, isto é, de qualidades materiais e simbólicas, o que confere aos bens materiais, um novo valor, o de serem parte do patrimônio social (Marly Rodrigues ${ }^{58}$ in Patrimônio cultural paulista, p. I3).

Alguns imóveis com valor arquitetônico e histórico já começam a chamar a atenção da população, empresários e órgãos públicos, que estão providenciando sua recuperação. A foto abaixo à esquerda mostra um edifício localizado na Rua Uruguaiana no Brás, antes da recente revitalização realizada pela prefeitura municipal para abrigar um dos órgãos de seus quadros. A foto à direita mostra o mesmo imóvel após a reforma sofrida.

Além desses exemplos muitos outros imóveis podem e devem ser tombados pelo DPH, em prol da recuperação e preservação de nossa memória histórica e arquitetônica. São eles a Fábrica de Tecidos Labor e o Cotonifício Crespi. Também deve ser considerado o tombamento da residência ao lado da Labor, à Rua da Mooca, 825, na Mooca baixa e o edifício que abriga a gráfica da Estação Mooca da Ferrovia da CPTM, antiga Santos-Jundiaí.

As fotos abaixo mostram o Cotonifício Crespi, única fachada preservada voltada para a Rua Javari, tendo sido o edifício totalmente demolido.

antigo gasômetro pode ser considerado também como um marco histórico popularmente muito importante, mas como referência à industrialização da cidade. Deve-se considerar a requalificação do antigo gasômetro para uso cultural.

Arquivo Pessoal.
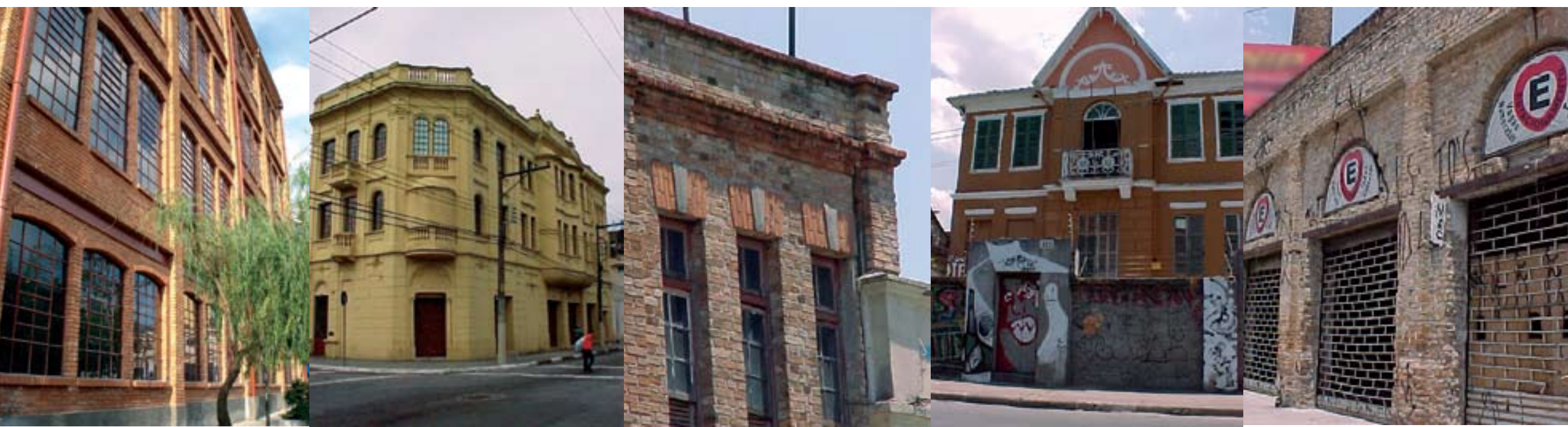


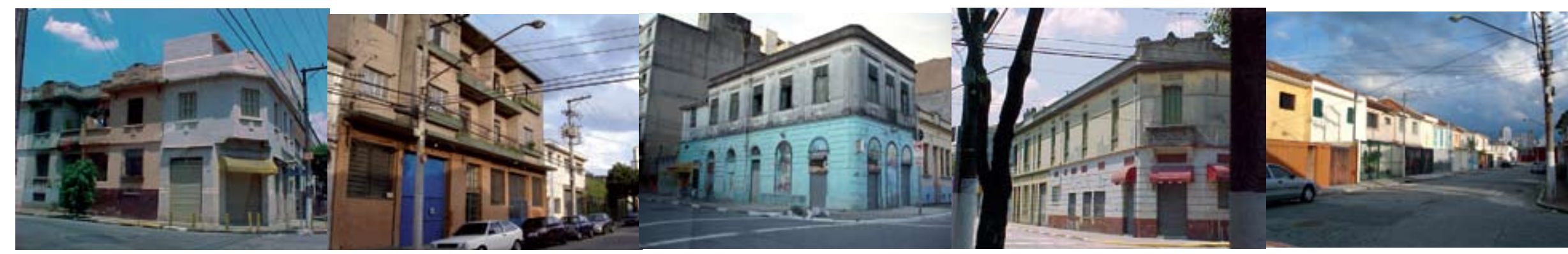

\section{As tipologias arquitetônicas predominantes}

Os dois bairros mantém até hoje, em boa parte das edificações ali existentes, a tipologia típica trazida pelos italianos: sobrados e prédios de 2 ou 3 andares, multifamiliares ou com uso misto, com lojas no térreo e moradias no andar superior.

As construções atraem pela arquitetura - trazida pelos capomastri59 italianos - dos casarões de uso misto do início do século: moradia e trabalho. São casarões, simpáticas casas operárias em renque e até prédios de três andares com belas portas, frisos e relevos aplicados às fachadas, o que lhes atribui certo refinamento arquitetônico, apesar de terem sido construídos para a população operária.

Abaixo, algumas fotos de edifícios na região, com tipologias arquitetônicas da época da industrialização da cidade.

Há também um bom exemplo de arquitetura modernista do período de industrialização: a vila operária projetada por Gregori Warchavichik à Rua Barão de Jaguara, na Mooca.

Existem também edifícios térreos para uso industrial e para comércio e serviços, de dois e três pavimentos, com e sem recuos frontais e laterais, de diversas dimensões e áreas.
${ }^{59}$ Capomastri: imigrante italiano
que exercia a atividade de mestre
de obras ou construtor.

Acima, prédios de uso misto, com armazém no térreo e residência no pavimento superior, no Brás e Mooca Acima à direita, rua típica da Mooca com casas de classe média.

\section{Abaixo,}

Da esquerda para a direita

Edifício residencial de produção capitalista na Mooca baixa

Vista dos edifícios residenciais de produção estatal (COHAB) no Brás Edifícios residenciais de produção capitalista na Mooca

Edifício de empresa de tecnologia com vila operária à frente, na Mooca baixa.

Arquivo pessoal, 2006.
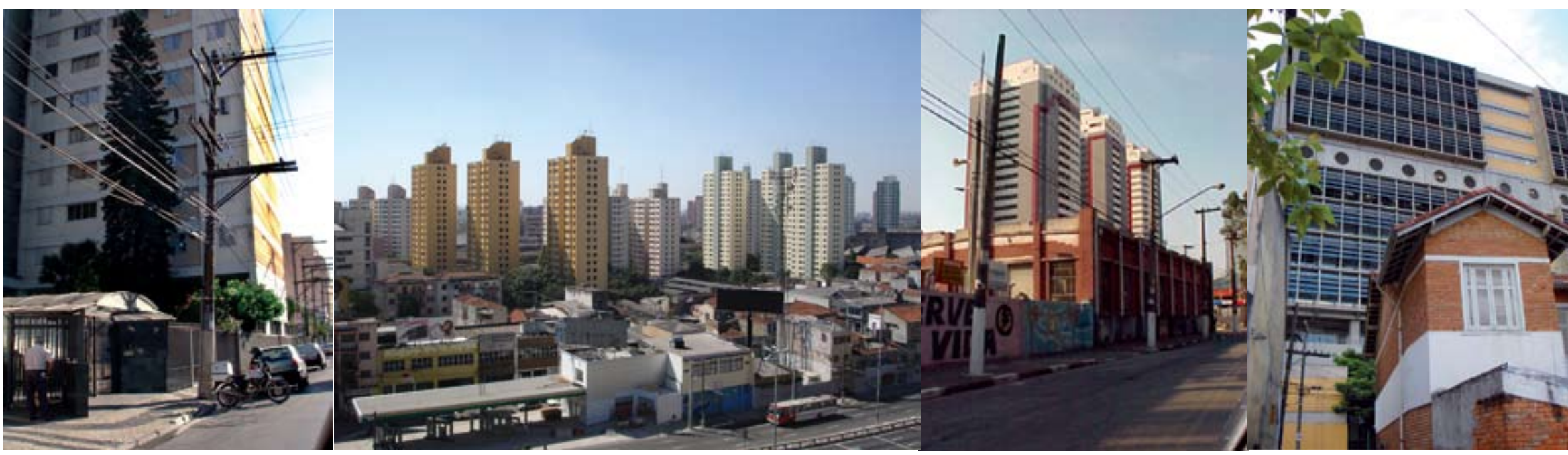


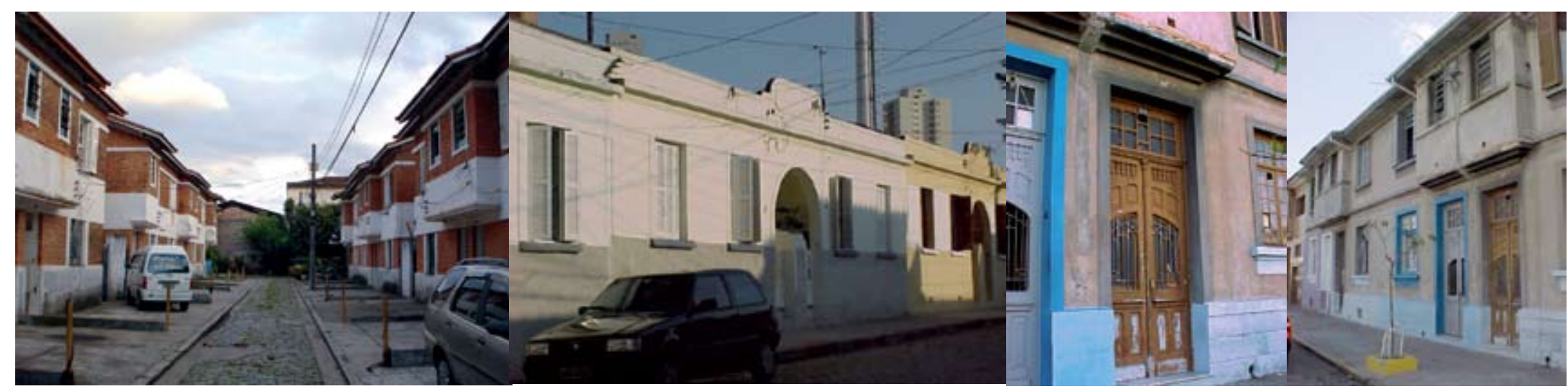

Da esquerda para a direita

Vila operária na rua Ana Nery, Mooca baixa;

Vila operária na Rua Henrique Dantas, Mooca;

Vila operária no Brás e detalhe de fachada da mesma vila.

Arquivo pessoal, 2003.

\section{À direita}

Casas em renque com uso misto, sendo térreo para armazéns e pavimento superior para residencias para aluguel, na Mooca, 2003

\section{À esquerda}

Residência para aluguel no Brás, 2006

Arquivo pessoal.

\section{I. As vilas operárias}

A partir da década de 1910, Brás e Mooca foram escolhidos, em função das atividades industriais que ali se concentravam e se desenvolviam, como local de investimentos na produção de moradias operárias, tanto por parte dos próprios industriais como de outros investidores. Grande parte dessa produção tinha como destino o aluguel das residências aos operários como forma de rendimento e para que vivessem próximos aos locais de trabalho.

Traçando-se um retrato dos projetos de arquitetura para vilas ou passagens encontrados nos registros do CASE 3, na Prefeitura Municipal de São Paulo, pode-se confirmar a predisposição de construir ali vilas operárias ou para a população de classe média, durante o período entre 1928 e 1955.

As casas eram compostas em I00\% dos casos por sala, cozinha, banheiro e dois dormitórios. Raramente possuíam duas salas e área para o tanque. O banheiro, que era um só, não apresentava detalhamento, mostrando os equipamentos que o compunham.

Muitas dessas construções ainda existem, com a grande maioria conservando a arquitetura original. Podem ter de 55 a 85 metros quadrados aproximadamente e são assobradadas e geminadas, ou seja, em renque. As ruas internas das vilas registradas invariavelmente apresentam pequenas áreas destinadas a jardins e a grande maioria uma área no fim da rua em forma de coul-de-sac. Abaixo, alguns exemplos de projetos para vilas operárias:

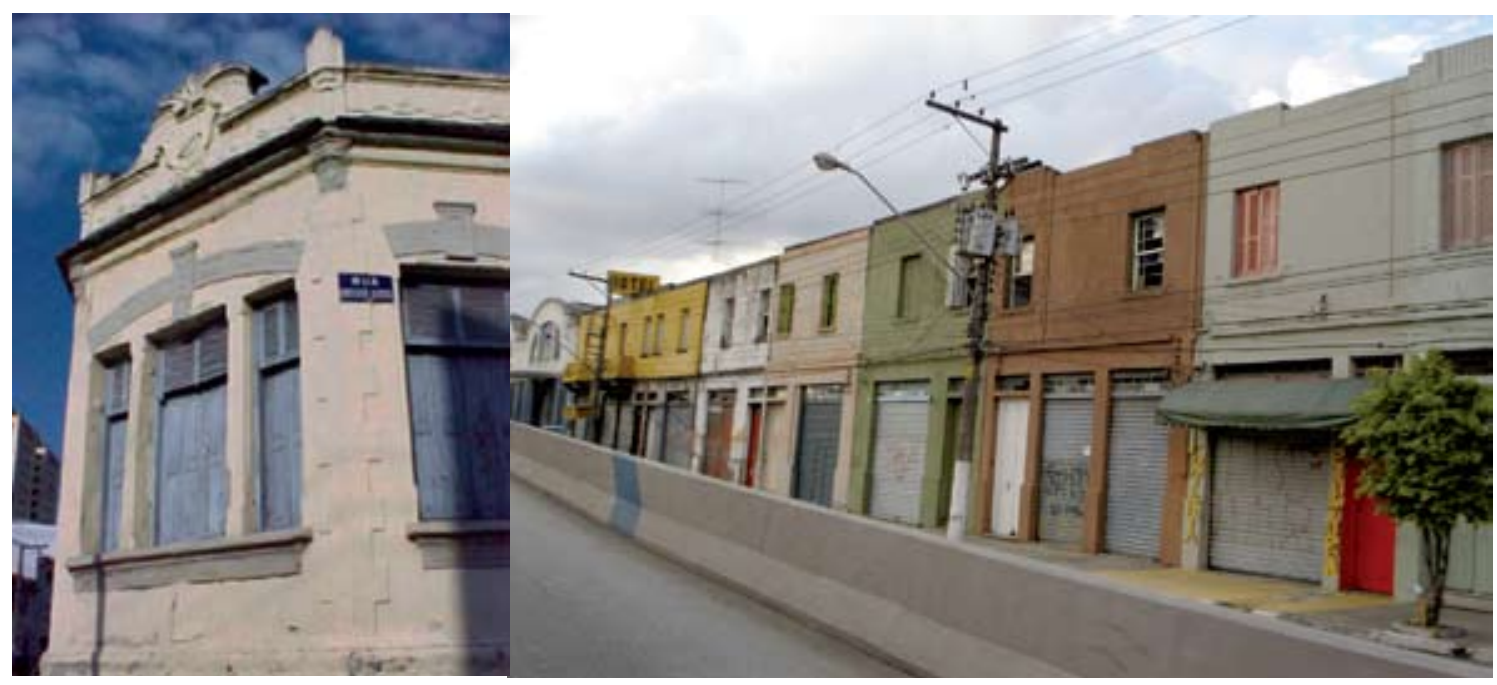




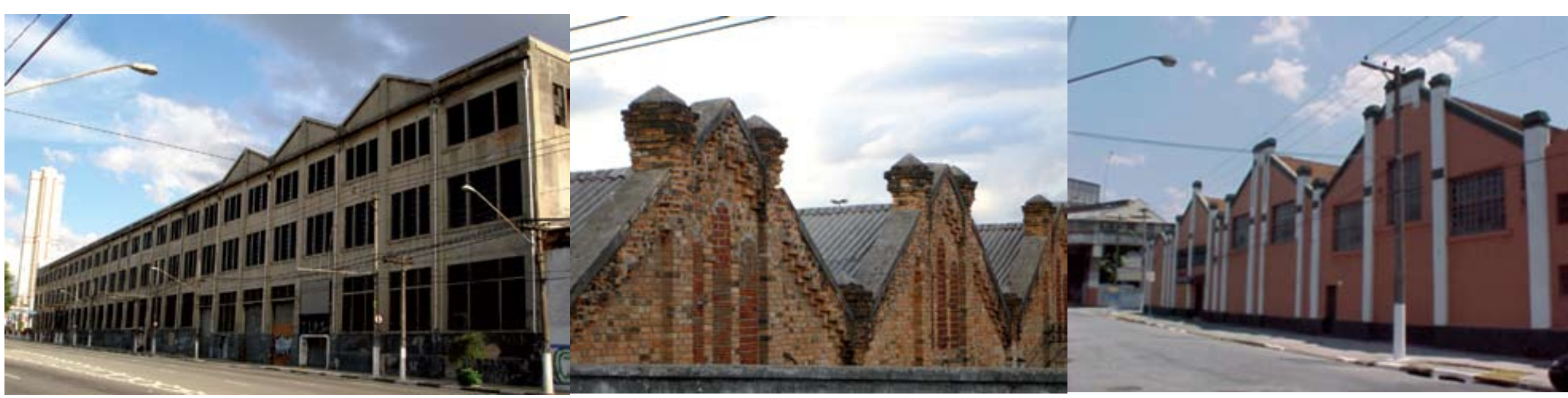

\subsection{Os galpões industriais}

Existem na Mooca e Brás muitos galpões industriais de várias dimensões e tipologias arquitetônicas, com vários usos e ocupações: uso industrial, uso logístico (depósito de apoio ao comércio especializado local), uso para serviços como retífica de peças, reciclagem de materiais, oficinas mecânicas e estacionamentos e também muitos galpões ociosos.

Este trabalho propõe, no conjunto de diretrizes do capítulo VII desta dissertação, a reutilização desses galpões ociosos ou subutilizados para usos mais democráticos como oficinas profissionalizantes ou centros de lazer. Vale lembrar que alguns edifícios industriais já foram requalificados pela iniciativa privada e que possuem agora usos educacional e de entretenimento.

Os galpões existentes no Brás e Mooca têm tipologias muito distintas, variando de simples construções até grandes indústrias. As construções mais simples têm pé-direito baixo e área muito pequena, ocupando totalmente pequenos lotes; já as grandes indústrias são geralmente implantadas em grandes terrenos e possuem tipologia mais nobre, portando fachadas de tijolos aparentes e cobertura em shed ou "lanternins" para iluminação e grandes janelas envidraçadas, que se assemelham aos galpões industriais requalificados no Antíguo Puerto Madero. As diferentes tipologias dão aos bairros uma identidade arquitetônica e um papel importante dentro da memória paulistana. Além dos antigos galpões, existem no Brás e Mooca, instalações industriais contemporâneas, muitas delas com tipologia arquitetônica e construção esmeradas.

\subsection{As estações Brás e Bresser da Linha Leste do Metrô}

Fazendo-se uma observação in loco do espaço urbano em torno das estações Brás e Bresser do Metrô, pode-se concluir que as duas estações têm partidos arquitetônicos bem diferentes no que se refere ao impacto urbano causado no bairro. Na estação Bresser a linha do Metrô foi implantada paralela à linha de trem CBTU (Central do Brasil), com o trem metropolitano trafegando no mesmo nível da rua. Entre as duas linhas, metrô e trem, existem muros de proteção.

O acesso ao outro lado do bairro do Brás é feito pelas rampas da estação e através da estação, sobre as linhas férrea do metrô e do trem, ou seja, a estação Bresser incorpora o único local de acesso ao outro trecho do bairro. Observando-se o conjunto por cima, de dentro da estação, vê-se o número de bloqueios físicos construídos quando os dois sistemas acabaram lado a lado. No caso da estação Brás, a linha do Metrô foi implantada em nível bem
À esquerda

Galpão antigo em atividade, na Rua dos Trilhos, 2006

Ao centro,

Galpão em área industrial junto aos trilhos da ferrovia Santos-Jundiaí, na Mooca baixa, 2006.

\section{À direita}

Galpão industrial em uso, na Rua Dr. Almeida Lima, Mooca, 2003.

Arquivo pessoal. 
superior ao da rua, o que permite que os pedestres circulem livremente sob ela, não interferindo na acessibilidade de um lado ao outro do bairro. A área é ajardinada e apresenta uma qualidade ambiental muito superior à da estação Bresser.

Vemos, portanto, que apesar do crescimento urbano ter acontecido ao longo e em função da ferrovia, esta, associada à linha Leste do Metrô, acabou condenando ao isolamento alguns trechos deste bairro, visto a dificuldade de transposição da barreira representada por sistemas de transporte, potencializada quando estes estão conjugados.

As estações do metrô são formadas por construções de concreto aparente, representantes da arquitetura brutalista da década de 1980, e a morfologia urbana também é modificada pelas construções de apoio à implantação do Metrô Leste, como rampas de acesso para pedestres.

\section{Abaixo}

Estação Brás do Metrô Leste, elevada em relação ao nível da rua.

Arquivo pessoal.

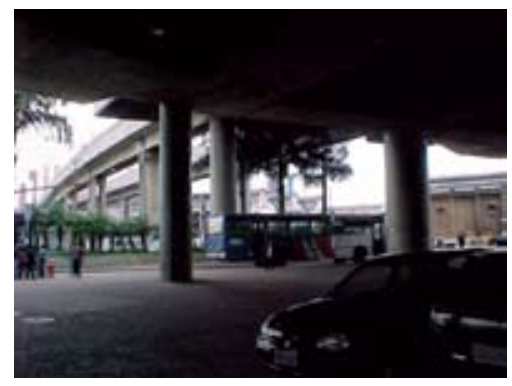

À direita e abaixo

Fotos externa e interna da Estação

Bresser do Metrô Leste.

Arquivo pessoal.
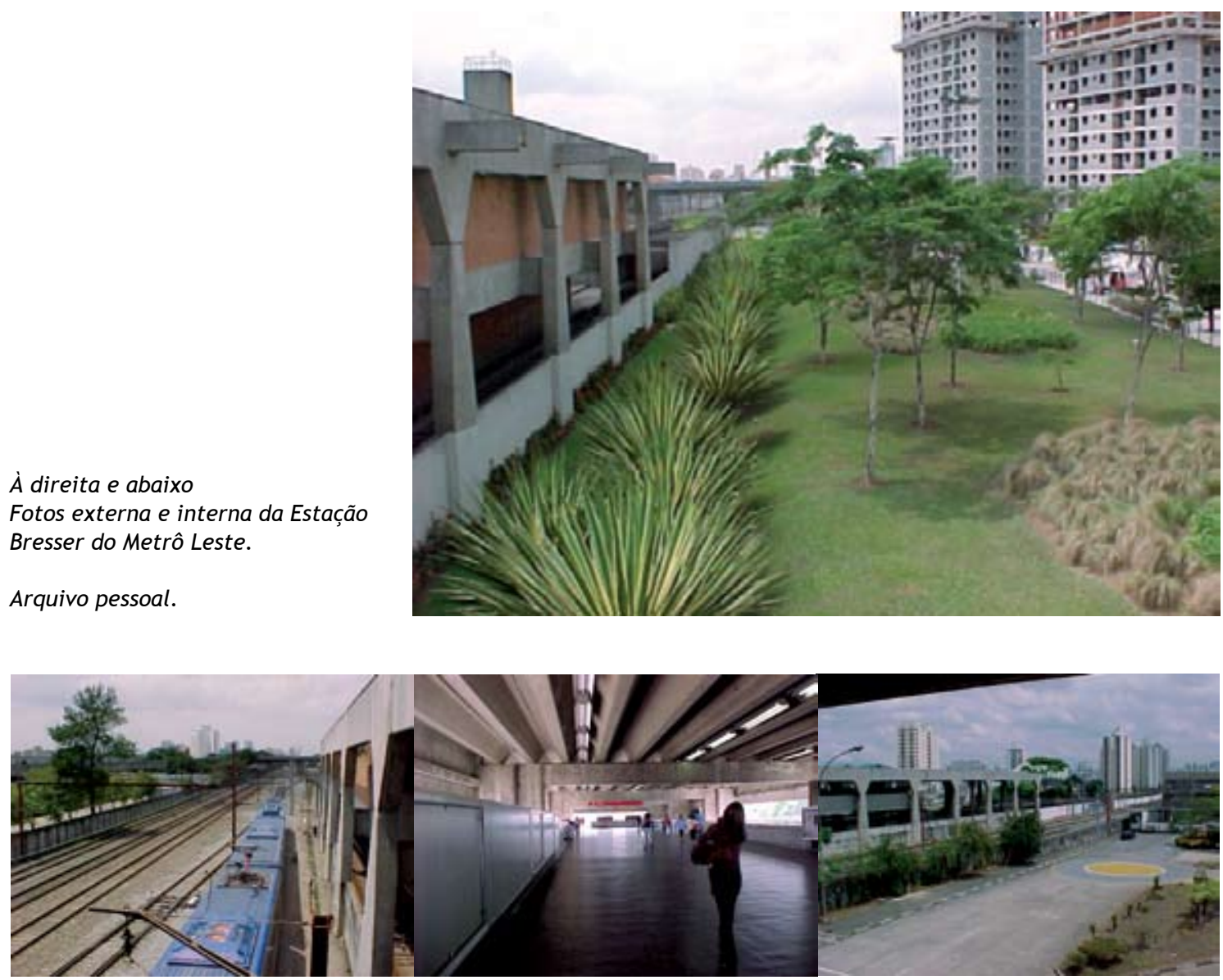


\section{Conclusão do Capítulo III}

Após a análise e observação in loco do tecido urbano da área em estudo, foi possível concluir que o tecido está totalmente consolidado, tendo passado por pelo menos duas etapas de urbanização: a primeira com a construção de imóveis, em geral durante a evolução urbana da área, e uma segunda ao longo do tempo, quando muitos imóveis foram demolidos para dar lugar a novas construções. Como exemplo podemos citar as tantas vilas operárias que já deram lugar a galpões industriais, que hoje são apenas terrenos vagos como a vila de aproximadamente 80 casas, demolida após ação judicial de 2005 de retomada de imóveis dos inquilinos - localizada entre as ruas Dom Bosco, Oscar Horta, Odorico Mendes e Coronel Cintra, na Mooca baixa - ou para dar lugar a estacionamentos - como a vila localizada junto à Cervejaria Antárctica Paulista e a Vila Hilda, localizada na rua Coronel Cintra, ambas na Mooca e já demolidas. Faz-se lembrar Toledo, quando se refere às mudanças sofridas pela cidade de São Paulo em seu tecido urbano:

A cidade é um palimpsesto - um imenso pergaminho cuja escrita é raspada de tempos em tempos, para receber outra nova, de qualidade literária inferior, no geral. Uma cidade reconstruída duas vezes sobre si mesma, no século XIX (I98I, p.77).

Por estar o tecido totalmente consolidado, foi difícil encontrar vazios urbanos na áreaobjeto de estudo, exceto por áreas remanescentes das desapropriações necessárias para a implantação da Linha Leste do Metrô, um terreno de propriedade da Prefeitura Municipal e alguns imóveis ociosos, de boas dimensões para acomodar instalações para atendimento da população local, como a antiga Metalúrgica Matarazzo, a Fábrica de Tecidos Labor e a Discos Continental.

O resultado mais importante dessa leitura e análise do tecido urbano foi concluir que os terrenos utilizados pela COHAB para implantar 13 condomínios verticais para moradores de média renda foram sub-aproveitados, existindo áreas adensáveis dentro dos próprios terrenos dos empreendimentos construídos entre os anos de 1989 e 1992. Seus terrenos tiveram aproximadamente $50 \%$ da área destinados ao estacionamento de automóveis dos moradores, na proporção de uma vaga de estacionamento por unidade habitacional, em função da classificação dos imóveis para a faixa salarial média renda alta, da própria COHAB.

Os croquis abaixo apresentam a implantação dos edifícios e das vagas de estacionamento, dos condomínios Brás I, II, II, IV, V, VI, VII, VIII, IX e X e dos condomínios Bresser I, II e III. O desperdício de área é visível, como demonstrado na tabela de Análise das Áreas Adensáveis da COHAB.

Uma das soluções para o adensamento populacional na área-objeto de estudo pode ser construir novos blocos dentro dos terrenos que já contém edifícios construídos pela $\mathrm{COHAB}$, juntamente com subsolos de dois andares para acomodação das vagas atuais mais as vagas de garagem necessárias aos moradores dos novos blocos. Os terrenos têm dimensões suficientes para que os subsolos sejam construídos fora da projeção dos edifícios e, portanto, de suas atuais fundações.

O potencial construtivo diluído nesses empreendimentos passou despercebido nas disposições do Plano Diretor Regional da Subprefeitura Mooca, aprovado segundo a lei 13.885 de 25 de agosto de 2004. 
A partir da comparação dos coeficientes de aproveitamento das leis de 1972 e de 2002, - quadro Análise das áreas ocupadas a seguir demonstra e compara os Coeficientes de Aproveitamento alcançados na ocasião da construção dos empreendimentos da $\mathrm{COHAB}$ e simula o adensamento possível a partir do Coeficiente de Aproveitamento Básico da localização de cada empreendimento. Onde o número de unidades habitacionais resulta baixo demais se calculado pelo C.A. básico, fez-se uma simulação que compreende a construção de 0 I bloco por empreendimento com 76 unidades habitacionais, com pagamento de outorga onerosa (Brás IV e VI e Bresser I, II, III).

Dessa forma, é possível construir pelo menos 13 edifícios de 18 pavimentos, com 04 apartamentos de 02 dormitórios por andar, na mesma tipologia dos edifícios existentes, totalizando 936 unidades habitacionais ou, mais de 3000 moradores.

As áreas remanescentes das obras de instalação do metrô, na área do antigo Gasômetro, hoje pertencente à COMGÁS, podem ser destinadas à implantação de edifício público de porte suficiente para acomodar um hospital, por exemplo (ver fotos das áreas remanescentes no item 3.3 deste capítulo).

Pelos cálculos da Tabela 7 e demonstração gráfica nas figuras 30 e 3 I a seguir, dentro da nova legislação e do Coeficiente de Aproveitamento máximo para ZEIS 3, determinado em 4 vezes a área do terreno e, seguindo outros fatores determinantes de ocupação do solo, é possível acrescentar 83 blocos nos treze condomínios existentes, com número de pavimentos entre 17 e 24 e 4 apartamentos de dois dormitórios por andar, totalizando 3.448 apartamentos com projetos iguais aos implantados em cada um dos condomínios. Considerando uma média máxima de quatro moradores por apartamento, pode-se concluir que mais 13.792 moradores poderão residir num bairro central que teve queda constante em sua população residente e que deve ser requalificado. 
Tabela 7- Análise do Coeficiente de Aproveitamento (CA) e Taxa de Ocupação (TO) - COHABs Brás e Bresser

\begin{tabular}{|c|c|c|c|c|c|c|c|c|c|c|c|c|c|c|}
\hline & Empreendimento & $\begin{array}{c}\text { Brás } \\
\text { I }\end{array}$ & $\begin{array}{c}\text { Brás } \\
\text { II }\end{array}$ & $\begin{array}{c}\text { Brás } \\
\text { III }\end{array}$ & $\begin{array}{l}\text { Brás } \\
\text { IV }\end{array}$ & $\begin{array}{c}\text { Brás } \\
\text { V }\end{array}$ & $\begin{array}{c}\text { Brás } \\
\text { VI }\end{array}$ & $\begin{array}{l}\text { Brás } \\
\text { VII }\end{array}$ & $\begin{array}{l}\text { Brás } \\
\text { VIII }\end{array}$ & $\begin{array}{l}\text { Brás } \\
\text { IX }\end{array}$ & $\begin{array}{c}\text { Brás } \\
X\end{array}$ & $\begin{array}{c}\text { Bresser } \\
\text { I }\end{array}$ & $\begin{array}{c}\text { Bresser } \\
\text { II }\end{array}$ & $\begin{array}{c}\text { Bresser } \\
\text { III }\end{array}$ \\
\hline \multirow{10}{*}{ 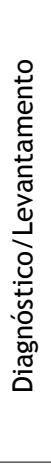 } & Ano da Construção & 1990 & 1992 & 1989 & 1989 & 1990 & 1990 & 1989 & 1990 & 1992 & 1989 & 1989 & 1989 & 1989 \\
\hline & Área do terreno $\left(\mathrm{m}^{2}\right)$ & 8297 & 8319 & 8478 & 6324 & 8650 & 3082 & 6069 & 11234 & 10450 & 6879 & 7333 & 7294 & 4680 \\
\hline & Área construída computável $\left(\mathrm{m}^{2}\right)$ & 11624 & 12631 & 12658 & 12228 & 9329 & 4367 & 8228 & 12130 & 12588 & 12005 & 12425 & 13306 & 8824 \\
\hline & Área para estacionamento $\left(\mathrm{m}^{2}\right)$ & 4346 & 4193 & 4114 & 3103 & 4409 & 1922 & 2340 & 1935 & 4400 & 3622 & 3960 & 3610 & 2407 \\
\hline & $\mathrm{N}^{\circ}$ de unidades habitacionais & 216 & 216 & 256 & 216 & 228 & 76 & 152 & 228 & 228 & 216 & 216 & 216 & 144 \\
\hline & $\mathrm{N}^{\circ}$ de andares & 13,5 & 13,5 & 19 & 18 & 19 & 19 & 19 & 19 & 19 & 18 & 18 & 18 & 18 \\
\hline & $\mathrm{N}^{0}$ de vagas & 216 & 217 & 256 & 216 & 228 & 76 & 152 & 229 & 228 & 216 & 216 & 216 & 144 \\
\hline & C.A. alcançado & 1,40 & 1,52 & 1,49 & 1,93 & 1,08 & 1,42 & 1,36 & 1,08 & 1,20 & 1,75 & ।,83 & 1,85 & 1,89 \\
\hline & T.O. alcançado (\%) & 11,64 & 11,25 & 7,86 & 10,74 & 5,68 & 7,46 & 7,14 & 5,68 & 6,34 & 10,20 & 9,50 & 9,00 & 9,00 \\
\hline & $\begin{array}{r}\text { C.A. básico pelo PRE Mooca } \\
\text { para a antiga ZML-1 }\end{array}$ & 2 & 2 & 2 & 2 & 2 & 2 & 2 & 2 & 2 & 2 & 2 & 2 & 2 \\
\hline \multirow{11}{*}{ 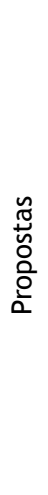 } & T.O. máxima pelo PRE Mooca (\%) & 70 & 70 & 70 & 70 & 70 & 70 & 70 & 70 & 70 & 70 & 50 & 50 & 50 \\
\hline & Novo Zoneamento & $\mathrm{ZCPb}$ & $\mathrm{ZCPb}$ & $\mathrm{ZCPb}$ & $\mathrm{ZCPb}$ & $\mathrm{ZCPb}$ & $\mathrm{ZCPb}$ & $\mathrm{ZCPb}$ & $\mathrm{ZCPb}$ & $\mathrm{ZCPb}$ & $\mathrm{ZCPb}$ & ZC3b & ZC3b & ZC3b \\
\hline & Potencial construtivo pelo C.A. máximo & 3318 & 33276 & 33912 & 25296 & 34600 & 12328 & 24276 & 44936 & 41800 & 27516 & 29332 & 29176 & 18720 \\
\hline & $\mathrm{N}^{\circ}$ de unidades total possíveis & 603 & 605 & 616 & 460 & 629 & 224 & 441 & 817 & 760 & 500 & 533 & 530 & 340 \\
\hline & Total de unid. hab. existentes & 387 & 389 & 360 & 244 & 401 & 148 & 289 & 589 & 532 & 284 & 317 & 314 & 196 \\
\hline & Blocos Novos máximo & 5 & 5 & 5 & 3 & 5 & 2 & 4 & 8 & 7 & 4 & 4 & 4 & 2 \\
\hline & Pavimentos por bloco novo & 19 & 19 & 18 & 20 & 20 & 18 & 18 & $18 / 19$ & 19 & $17 / 18$ & $19 / 20$ & $19 / 20$ & 24 \\
\hline & Unidades novas & 380 & 380 & 360 & 240 & 400 & 144 & 288 & 576 & 532 & 284 & 316 & 312 & 192 \\
\hline & $\begin{array}{r}\text { Total adotado de blocos } \\
\text { novos mais existentes }\end{array}$ & 8 & 8 & 7 & 6 & 5 & 3 & 6 & 9 & 9 & 6 & 6 & 5 & 4 \\
\hline & Somatória da projeção das lajes $\left(\mathrm{m}^{2}\right)$ & 1980 & 1980 & 1760 & 1320 & 1760 & 660 & 1320 & 2420 & 2200 & 1540 & 1540 & 1540 & 1540 \\
\hline & T.O. alcançada com o adensamento (\%) & 23,8 & 23,8 & 20,3 & 21,7 & 20,3 & 21,4 & 21,7 & 21,5 & 21 & 22,3 & 21 & 21,1 & 32,9 \\
\hline
\end{tabular}

Fontes: Lei de Zoneamento do Município de São Paulo, de 1972; Plano Diretor Regional da Subprefeitura Mooca, de 2002, Plantas de aprovação dos empreendimentos habitacionais na Prefeitura Municipal de São Paulo - arquivo da COHAB. Cálculos de Maria Elizabet Paez Rodriguez, 2006.

A seguir, nas figuras 30 e 31 , uma simulação de adensamento através da implantação de novos blocos de apartamentos nos terrenos da COHAB Brás I a $X$ e nos terrenos da COHAB Bresser I a III, segundo os cálculos demonstrados na tabela acima. 


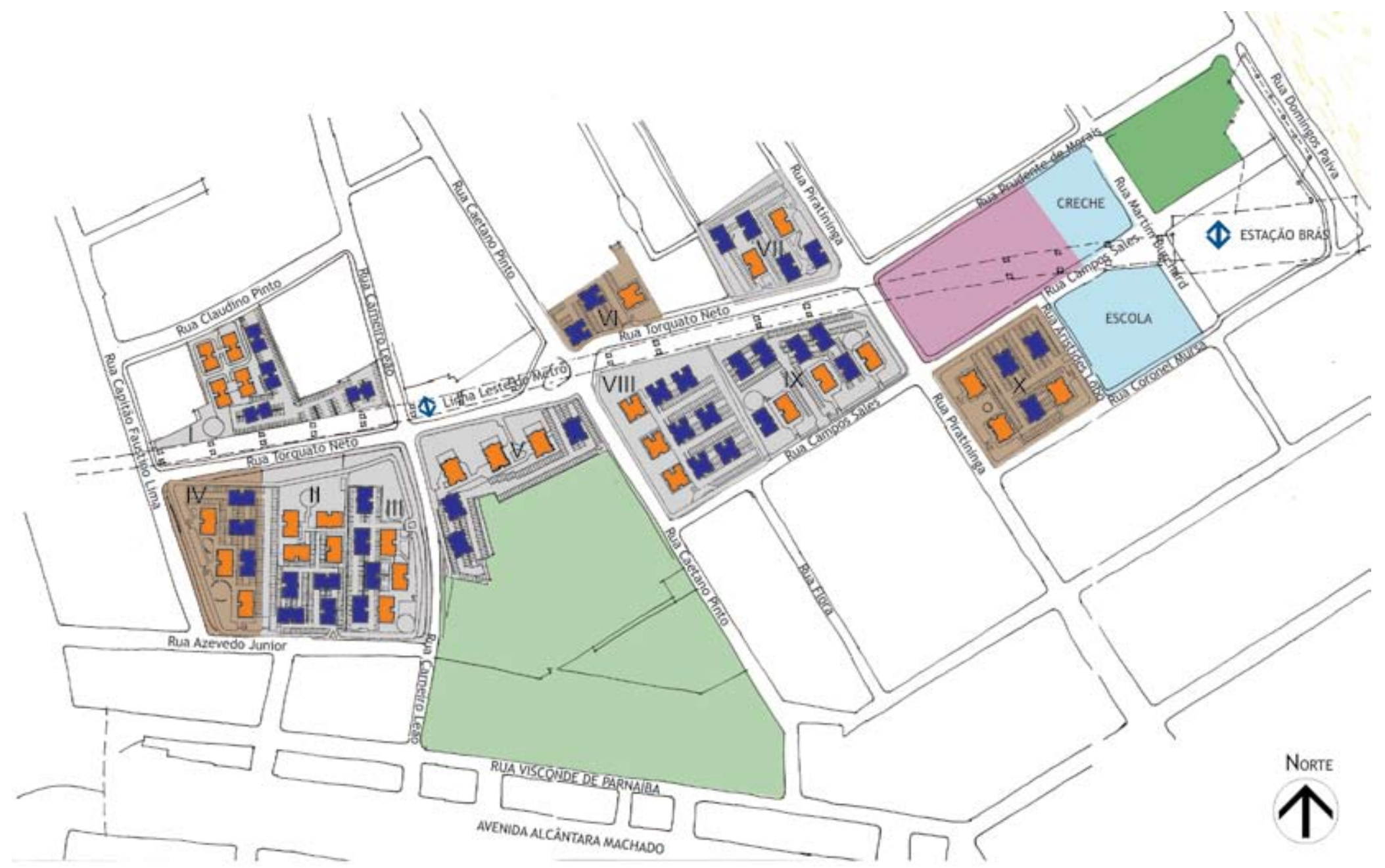

Figura 30

IMPLANTAÇÃO DOS CONDOMÍNIOS RESIDENCIAIS COHAB BRÁS I A X AO LONGO DA LINHA LESTE DO METRÔ NO BRÁS

DESAPROPRIAÇĀO DE INDÚSTRIA DESATIVADA PARA INSTALAÇĀO DE CEU - CENTRO EDUCACIONAL UNIFICADO - E UBS - UNIDADE BäSICA DE SAÚdE

ÁrEA PULMÃo PARA ESTACIONAMENTO PROVISÓRIO OU CANTEIRO DE OBRAS

ÁREA VERDE

ÁREA INSTITUCIONAL

ADENSAMENTO PELO C.A. MÁXIMO $=4$

ADENSAMENTO PELO C.A. MÁXIMO $=4$

[D. EDIFICIOS EXISTENTES PRODUZIDOS PELA COHAB

NOVOS EDIFICIOS PRODUZIDOS PELA COHAB - ADENSAMENTO 


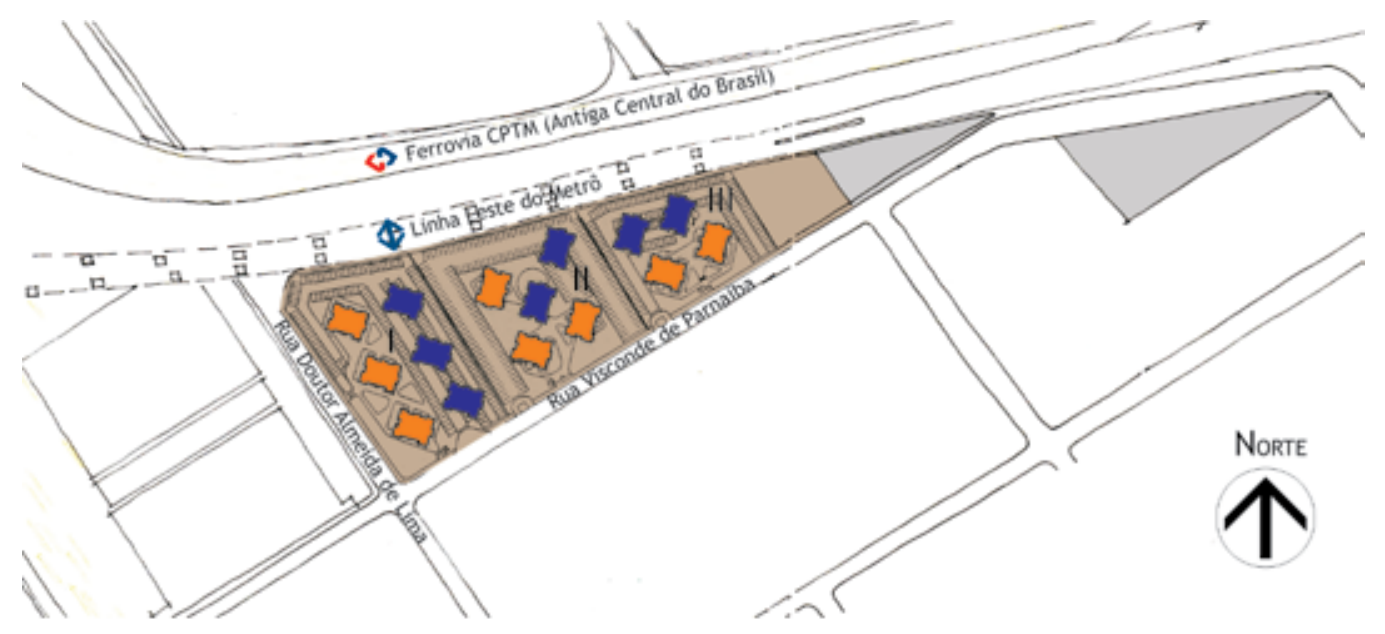

Figura 31

IMPLANTAÇÃO DOS CONDOMÍNIOS RESIDENCIAIS

COHAB BRESSER I A III AO LONGO DA LINHA

\section{LESTE DO METRÔ NO BRÁS}

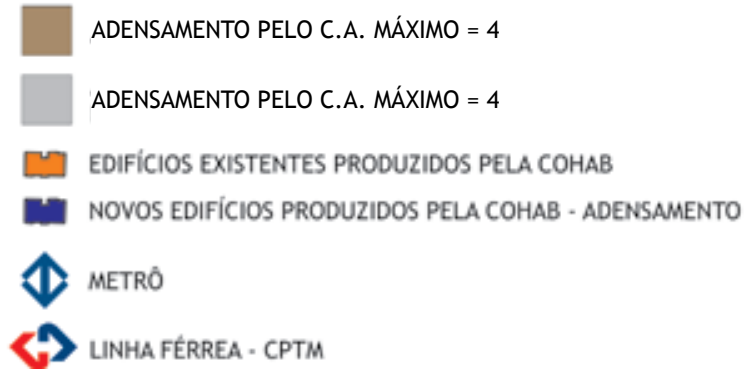




\section{Capítulo IV \\ Diagnóstico}

\footnotetext{
60 Adotou-se a expressão

"congelamento urbano" no sentido positivo para demonstrar que no período em que os dois bairros se mantiveram sem alterações significativas no tecido urbano foi possível a eles manter as suas características básicas.

${ }^{61}$ Fonte: Fundação SEADE.
}

A metodologia utilizada para preparar o diagnóstico geral e com isso determinar demandas e necessidades, foi a detecção de aspectos negativos e positivos encontrados durante toda a análise do desenvolvimento urbano do Brás e Mooca. Durante a análise histórica e geral dos dois bairros apresentada neste capítulo, abordaram-se temas como habitação, sistema viário, Infra-estrutura básica, saúde, esporte e lazer, áreas verdes e qualidade de vida, educação e cultura, comércio e senviços, nível de empregabilidade, indicadores socioeconômicos, marcos referenciais e patrimônio histórico e arquitetônico, planejamento urbano, vazios urbanos e áreas disponíveis. A partir da abordagem desses temas, foi possível vislumbrar a qualidade desses bairros, o que se pretende preservar e os pontos que exigem atenção do estado na requalificação do Brás e Mooca.

O diagnóstico sobre temas de grande importância na organização da cidade como habitação, estruturação viária e qualidade ambiental foram tratados de forma mais detalhada. Por serem as grandes obras viárias, e as interferências causadas por sua implantação, as causas mais importantes do comprometimento da mobilidade e acessibilidade local ou intra-urbana e da qualidade ambiental pelas quais passam Brás e Mooca, a estruturação viária foi propositalmente tratada separadamente tanto quando se discorreu sobre a evolução urbana no Capítulo II ou quando se analisou o tecido urbano no Capítulo III e na proposição de diretrizes no Capítulo V.

\section{Aspectos urbanos positivos}

Exceto pela inauguração da Linha Leste do Metrô em 1979, a partir da década de 1960 acontece uma espécie de congelamento imobiliário ${ }^{60}$, que perdurou por mais de três décadas no desenvolvimento urbano nos bairros do Brás e Mooca, até que o Estado começou a prover habitações de interesse social, no fim da década de 1980, através da COHAB-SP e a partir do início do século 21 , através da CDHU.

Esse congelamento pôde representar um benefício para a região, que não atraiu o mercado imobiliário capitalista e, em conseqüência disso, não sofreu com a especulação imobiliária através da excessiva valorização de imóveis. Conseqüentemente, a área-objeto de estudo apresenta ainda em alguns trechos ruas mais tranqüilas sem grande tráfego de automóveis e outros veículos, onde muitas moradias construídas para atender a população da classe operária das primeiras décadas do século 20, hoje habitadas por moradores de classe média, ainda resistem.

O adensamento populacional é baixo e pode ser aumentado, dentro da capacidade da infra-estrutura básica instalada, que é completa, principalmente em relação ao saneamento básico e ao transporte público. $\bigcirc$ abastecimento de água e de energia e a rede de esgotos estão presentes na área desde o início do século 20 - no caso do Brás e pouco tempo depois na Mooca - hoje está presente em $100 \%$ das residências nos dois bairros ${ }^{61}$.

Na questão do transporte público, além das duas estações Brás e Bresser do Metrô dentro da área-objeto deste estudo, a estação Dom Pedro ll também pode atender aos habitantes desses bairros, principalmente os moradores do Brás. As linhas de transporte público 
sobre rodas são muitas na Radial Leste e outras vias estruturais e coletoras participantes do sistema viário da região, ou seja, a oferta de transporte público de âmbito local e regional é grande, fazendo parte de todo um sistema de ligação regional (avenida de alto tráfego + linhas de ônibus + metrovias).

A proximidade com o Centro Histórico, tanto caminhando, como utilizando o abundante transporte público, pode ser considerado um dos pontos fortes do Brás e Mooca, que atualmente voltaram a ser considerados distritos centrais. Essa proximidade propicia aos seus moradores fácil acesso a comércio e serviços diversificados que não estejam presentes nos seus bairros; fácil acessibilidade ao pólo de empregos representado pelo centro histórico; acesso a eventos culturais como cinemas, teatros e bibliotecas e acesso a escolas públicas. Esta é a justificativa para o estímulo dados pelas últimas gestões municipais aos programas do tipo Morar no Centro, que abrange o distrito do Brás e a Mooca baixa.

De acordo com dados do SEADE, Mooca e Brás são exemplos de distritos com grande oferta de emprego e que, em função disso, atraem trabalhadores de vários outros bairros do município ${ }^{62}$.

Existe nesses dois bairros, uma grande quantidade de construções e outros elementos arquitetônicos e históricos que podem e devem ser recuperados, com o objetivo de resgatar a história neles impregnada, absorvida a partir e durante o desenvolvimento urbano e social da cidade de São Paulo, desde sua condição de vila de parada de tropeiros, dada a antiguidade do Brás, com focos de urbanização partir de fins do século 18 até a importante participação de Brás e Mooca no processo de industrialização.

Sem dúvida, existem muitos aspectos positivos que poderiam ainda ser aqui relacionados, mas um importante fator pode ser considerado como ponto positivo que agrega valor aos dois bairros: em função da vinda de imigrantes de várias partes do mundo e posteriormente dos migrantes mineiros e nordestinos que adotaram São Paulo como moradia definitiva, juntando-se aos primeiros paulistanos, o perfil social da região tem como principal característica a grande riqueza cultural resultante da mistura de tantas nacionalidades e procedências de dentro da nação brasileira, evitando a perniciosa homogeneização das faixas da sociedade formada por habitantes com perfis muito similares. Resta apenas oferecer e aplicar mais organização e qualidade de vida ao tecido urbano e à vida de seus habitantes.

\section{Aspectos urbanos negativos}

Analisando-se plantas e mapas que nos mostram em detalhes a delimitação e os elementos viários que compõem a área do Brás e Mooca, vê-se que hoje esses distritos têm suas áreas fracionadas pelo conjunto de sistemas viários composto pelas duas linhas ferroviárias, linhas de trens metropolitanos e pela Radial Leste, por si só um elemento de ligação regional que na realidade se torna uma barreira urbana à acessibilidade local, já que dificulta o ir e vir entre os dois bairros. A presença desta avenida - que não tem nenhuma identificação com estes bairros, pois desde sua criação serve para ligar o Centro Histórico e o Centro Expandido ao extremo leste da cidade - contribuiu para o afastamento dos pedestres das ruas e para a dificuldade de circulação local nestes bairros, reafirmando mais uma vez o isolamento desta área da cidade e conseqüentemente contribuindo também para a degradação do entorno.

Um importante elemento degradador do espaço urbano nas grandes metrópoles a ser considerado atentamente é a proliferação de cortiços, o que tem ocorrido no Brás e Mooca, conforme números apresentados no Capítulo II e nos parágrafos a seguir, retirados da pesquisa realizada pela CDHU:

\footnotetext{
${ }^{62}$ Como visto no Capítulo III, as centralidades de comércio e serviços concentrados ofertam grande quantidade de empregos nos estabelecimentos existentes nas Ruas Piratininga, Visconde de Parnaíba, Radial Leste e Rua da Mooca, dentre outras. Além do comércio especializado e diversificado no Brás e Mooca, serviços de implantação de sistemas prestados por uma empresa de um grande banco, universidades e faculdades já estão presentes na região, empregando professores que são moradores de outros distritos do município.
} 
Segundo dados da CDHU, são as seguintes, as condições físicas dos imóveis atuando como cortiços na região Brás, Mooca e Cambuci:

Segundo o levantamento da SEADE mais da metade dos imóveis encortiçados no Brás possui unidades habitacionais desocupadas (52,3\%), o equivalente a 70 imóveis. Aliás, o número de moradores corrobora a exigüidade dos cortiços: $46,4 \%$ dos imóveis (59 unidades) abrigam até I 5 moradores, mas quase um terço das edificações (33, I \% ou 42 unidades) são ocupados por mais de 20 pessoas. Isto representa a maior percentagem registrada pela pesquisa para os oito setores de intervenção. Assim, 46 imóveis (36\%) possuíam de uma a 5 moradias vagas e 21 (16\%) tinham mais de 5 moradias vagas. Como a média é de 9,83 domićlios por imóvel, o potencial habitacional do setor é de 1260 domićlios, 46 dentre esses podendo atender a necessidade do "pulmão", isto é, a mudança provisória de famílias cuja moradia está sendo reabilitada.

Para um melhor entendimento das condições habitacionais atuais nos cortiços do setor, parece conveniente citar alguns dados revelados pela Pesquisa CDHU-2002. Assim, uma proporção de $73,5 \%$ dos imóveis do setor Brás se encontram deteriorados ou muito deteriorados. As suas condições de conservação se revelaram dentre as mais precárias: somente |4\% dos imóveis não apresenta problemas relacionados ao revestimento deteriorado das fachadas, janelas quebradas, instalações elétricas improvisadas, iluminação precária ou ainda uma ventilação inadequada. A grande maioria (90\%) dos imóveis encortiçados do Brás é inserida isoladamente na quadra, o que agiliza a resolução de problemas ligados à ventilação, insolação e luz natural. Os porões estão presentes em $14 \%$ das edificações ( 8 em número absoluto).

No caso do Cambuci, que inclui a Mooca baixa, uma proporção de $64,5 \%$ dos imóveis do setor encontram-se deteriorados ou muito deteriorados e somente $35,6 \%$ dos imóveis não apresentam problemas relacionados ao revestimento das fachadas, janelas quebradas, instalações elétricas improvisadas, iluminação precária ou ainda ventilação inadequada. A grande maioria dos imóveis encortiçados do Cambuci (66,3\%) está inserida de forma isolada na quadra, o que agiliza a solução de problemas ligados à ventilação, insolação e luz natural. Entretanto, existem 53 edificações $(32,5 \%)$ geminadas e $2(1,2 \%)$ são agrupadas em conjunto. Os porões que são utilizados como moradias em 13,5\% das edificações (22 em número absoluto), colaboram para aumentar o grau de insalubridade dessas unidades.

Corticos na Mooca baixa. Arquivo pessoal, 2006.

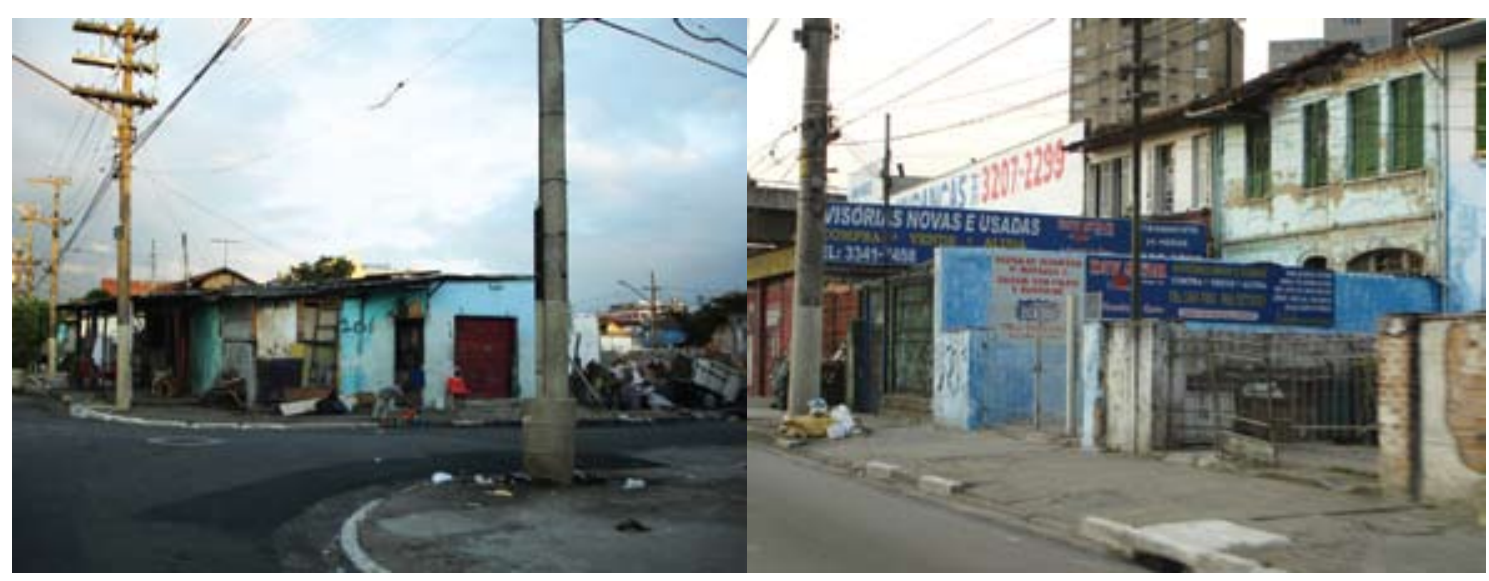


No setor Brás (classificação da CDHU), mais um indicador do grau de insalubridade dos cortiços diz respeito ao número de banheiros e tanques por imóvel, embora seja necessário substituílos. Três imóveis não possuem banheiro nenhum. Levando em conta o número de famílias por imóvel, 64\% dos domicílios divide um ou dois banheiros: ou seja, 24 imóveis contam um só banheiro e 58 cortiços dispõem de dois banheiros. Os mais privilegiados dividem cinco ou mais banheiros em 12 imóveis $(9,4 \%)$. O número de tanques de uso coletivo também é limitado nos cortiços, 28 imóveis (22\%) dispõem apenas de um tanque e 50 cortiços (40\%) têm dois deles. Para o conjunto do setor Brás, quase $90 \%$ dos imóveis possuem de um a 4 tanques de lavar roupa. Porém, 13 imóveis dispõem de 5 tanques ou mais.

A implantação dos cortiços na quadra ocorre quase sempre de forma isolada: I I 5 imóveis (90\%) respondem a essa configuração, enquanto II edificações (8,6\%) se encontram geminadas e apenas duas ( $1,6 \%)$ são agrupadas em conjunto. $O$ uso de uma cozinha coletiva é raro ( $15,6 \%)$, considerando que, segundo estudo CDHU-2002, nos cortiços, a preparação de alimentos ocorre em espaços privativos. Esses últimos, porém, não permitem muitas acomodações, considerando a exigüidade dos domićlilios em cortiços. Quase todos estes (83,6\%) constituem um espaço único para uma família inteira. Aqueles que dispõem de dois cômodos representam 10,4\% das famílias, enquanto apenas 6\% de domićlios contam com três cômodos ou mais (CDHU Relatório PAC, 2004, p. 17),

No setor Cambuci (classificação CDHU, que inclui a Mooca baixa), outro indicador do grau de insalubridade dos cortiços diz respeito ao número de banheiros e tanques por imóvel. Seis imóveis não possuem banheiro nenhum. Levando em conta o número de famílias por imóvel, 78,9\% dos domicílios, compartilham um ou dois banheiros, ou seja, 68 imóveis contam com apenas um banheiro e $6 \mathrm{I}$ cortiços dispõem de dois. $\bigcirc$ número de tanques de uso coletivo também é limitado nos cortiços, 75 imóveis (45,6\%) dispõem apenas de um tanque e 48 cortiços $(29,4 \%)$ têm dois deles. Para o conjunto do setor Cambuci, apenas I,3\% dos imóveis possuem 6 tanques ou mais.

O uso de cozinha coletiva é raro ( I I,7\%), segundo estudo CDHU/SEADE-2002, nos cortiços, a preparação de alimentos ocorre em espaços privativos. Estes últimos, porém, não permitem nenhuma comodidade, considerando a exigüidade dos domicílios em cortiços.
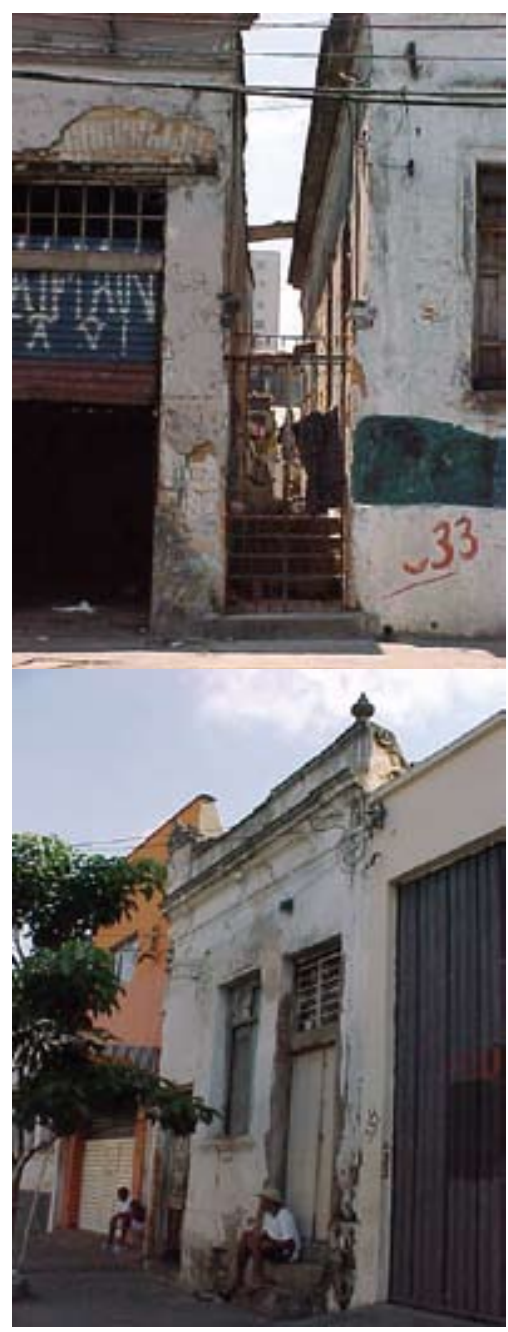

Acima

Cortiço na Mooca.

Abaixo

Cortiço no Brás.

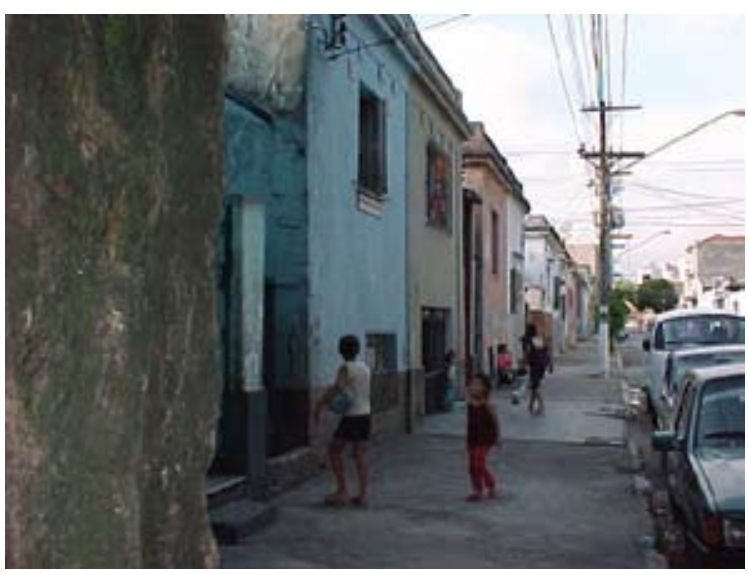

As fotos desta página e da página anterior demonstram as precárias condições de habitabilidade dos cortiços no Brás e Mooca, como esta rua com várias casas operárias em renque transformadas em cortiços lado a lado na Mooca baixa, próximo à Avenida do Estado.

Arquivo pessoal, 2003. 


\section{A estruturação viária fragmentadora do espaço}

Metrovias e avenidas de alto tráfego podem provocar a fragmentação do espaço intra-urbano e dificultar a acessibilidade entre as partes resultantes.

Na cidade de São Paulo, entre as décadas de 1950 e 1980, as ações urbanas promovidas pelo Estado não eram planejadas com o objetivo de mitigar o impacto urbano e ambiental. Exemplos disso são: o resultado da implantação da Avenida Alcântara Machado ou Radial Leste e da Linha Leste do Metrô no tecido urbano consolidado existente nos bairros históricos Brás e Mooca.

Brás e Mooca são dois bairros contíguos, antigamente ligados por várias vias como as ruas Wandenkolk, Carneiro Leão, Mem de Sá e Piratininga, que iam de um bairro ao outro, o que facilitava a relação entre seus habitantes e intercâmbio de serviços e comércio entre ambos (ver figura 29, p.96). Hoje, em função dos sistemas viários citados que atuam como barreiras urbanas à acessibilidade local, convivem com a fragmentação de suas áreas e conseqüente diminuição na acessibilidade e mobilidade local.

Esses sistemas viários interromperam e dificultaram também os fluxos locais de veículos, indispensáveis numa cidade planejada desde a década de 1930 para deslocar-se "sobre quatro rodas".

Iniciando com o caso da ferrovia, indutora do crescimento após sua implantação, teoricamente esta só se transforma em barreira quando o intervalo de tempo entre uma composição e outra é baixo, comum em transporte de passageiros. A alta freqüência dos trens faz necessária a presença de muros ao longo dos trilhos para evitar o perigoso cruzamento de pedestres e veículos. A baixa freqüência de trens de carga não implica necessariamente na construção de muros, pois estes podem parar em cruzamentos com cancelas. Este é o caso da ferrovia Santos-Jundiaí, antiga São Paulo Railway, hoje pertencente à CPTM, mas não é o caso da antiga Estrada de Ferro Central do Brasil, também da rede CPTM, pois, mesmo que transportasse carga (esta transporta passageiros), corre paralela à linha leste do metrô de superfície, que já se coloca como barreira dependente de muros, dada sua alta freqüência de passagem e velocidade.

A ferrovia Central do Brasil que passa pelo bairro do Brás - primeiramente paralela à antiga São Paulo Railway, hoje Santos-Jundiaí da rede CPTM, e posteriormente ao longo da Avenida Radial Leste - separa o bairro do Brás em três trechos.

Processo similar ao ocorrido com o Brás aconteceu com o distrito da Mooca, com re-

Abaixo,

Linha Leste do Metrô e trilhos das ferrovias CPTM, ladeados de muros de proteção que impedem a circulção de pedestres e veículos.

Arquivo pessoal, 2006 lação à linha Santos-Jundiaí, que o divide ao meio: Mooca baixa e Alto da Mooca. Até meados da década de 1960 era a porteira da Rua da Mooca que proporcionava a acessibilidade de automóveis e pedestres de um lado ao outro, função posteriormente exercida pelo Viaduto Alcântara Machado sobre a linha de trem, construído com a expansão da Avenida Radial Leste.

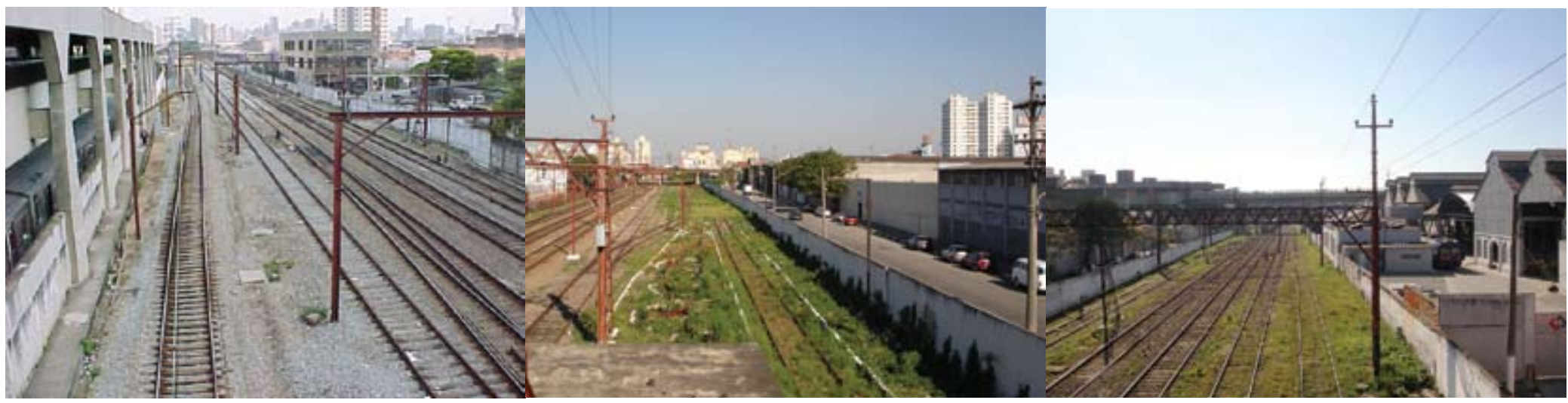




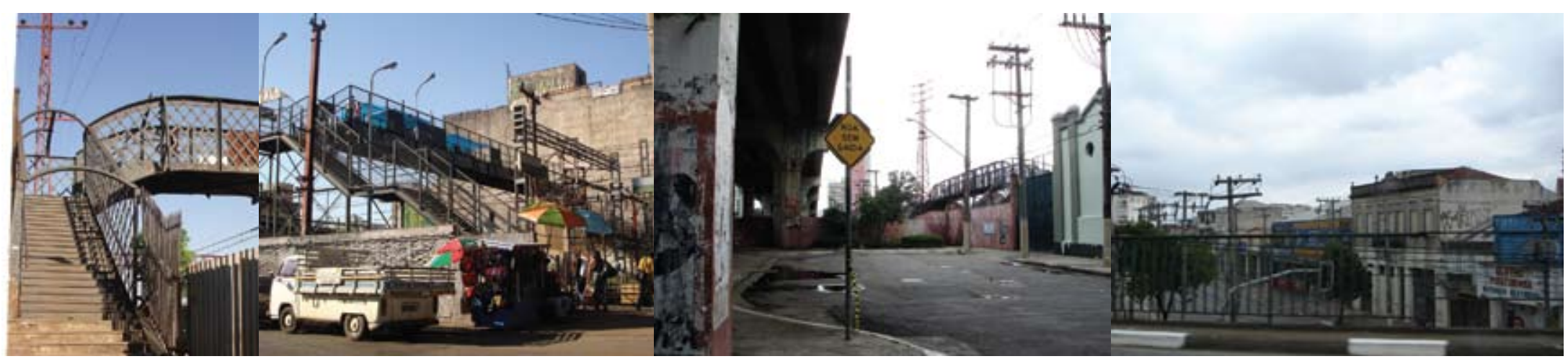

Os pedestres dos dois bairros dispõem até hoje de passarelas metálicas sobre as ferrovias: uma sobre a ferrovia Santos-Jundiaí, servindo de conexão entre os dois trechos da Rua Visconde de Parnaíba, ao leste e ao oeste da ferrovia. Essa passarela, em péssimo estado de conservação, é um ponto de acesso ao Museu da Imigração para pedestres. Outra passarela, também no Brás, está localizada junto à Rua do Gasômetro. Na Mooca, a passarela de pedestres sobre a Santos-Jundiaí está localizada ao lado da Rua da Mooca, onde antigamente existia a porteira da Mooca. A mobilidade dos habitantes com dificuldade de locomoção fica totalmente inviável e dependente de outro tipo de solução pessoal.

No bairro do Brás, a transposição da Estrada de Ferro Santos-Jundiaí é feita por meio do Viaduto Alberto Marinho, construído em 1968 durante a administração de Faria Lima (Torres, 1981, p. 194), que tem até hoje a missão de prover acessibilidade local aos pedestres, mas na prática se restringe quase unicamente aos automóveis.

Finalmente, a canalização do Rio Tamanduateí em muito contribui para a piora da qualidade ambiental do entorno, pela forma que tomou após ter as margens canalizadas e posteriormente receber uma pista de alto tráfego para veículos particulares e, finalmente, a implantação do sistema VLP - Veículo Leve sobre Pneus, em via elevada. O conjunto todo cria uma barreira que na escala humana fica impossível transpor, a menos que o número de passarelas e a segurança para o transeunte sejam ampliados consideravelmente. Na pista que contorna o bairro da Mooca baixa, as vilas operárias foram transformadas em cortiços, na maioria das vezes com o recuo frontal transformado em lojas para revenda de móveis usados. $\bigcirc$ aspecto visual do Rio Tamanduateí, totalmente envolto em caixa de concreto, no trecho ao longo da Mooca baixa é dos piores, como mostram as fotos abaixo.

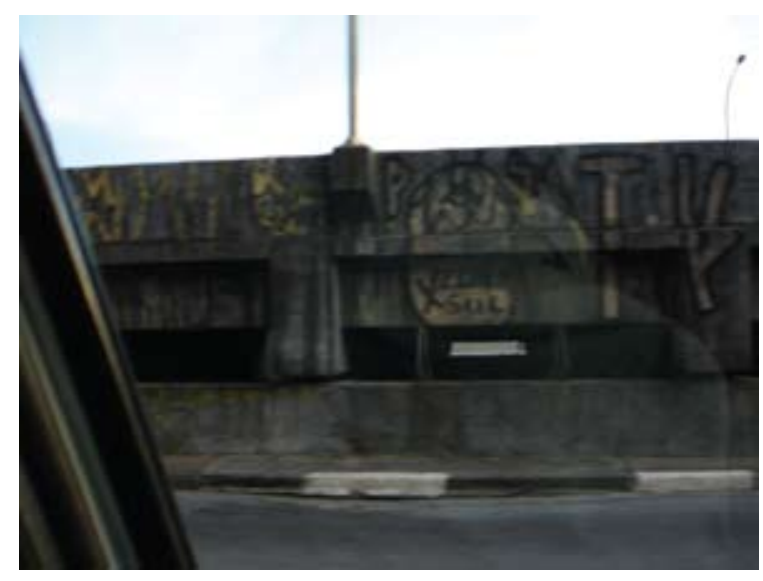

À esquerda

detalhes da canalização do Rio

Tamanduateí.

Arquivo pessoal, 2006.

\section{$\dot{A}$ direita}

foto aérea da Avenida do Estado durante a implantação do VLP - Veículo Leve sobre Pneus.

Fonte: São Paulo Interligado Secretaria Municipal de Transportes, 2004, p.247.
Acima à esquerda

Passarela de pedestres sobre as Ferrovias CPTM na Rua Visconde de Parnaíba e na Rua do Gasômetro.

\section{Ao centro}

Barreira criada pelos muros de proteção na ferrovia Santos Jundia onde antigamente se encontrava a porteira da Mooca, no cruzamento da rua da Mooca com a ferrovia.

Acima, à direita

Viaduto Alcântara Machado sobre a Rua Piratininga, ligação entre Brás e Mooca.

Arquivo pessoal, 2006.

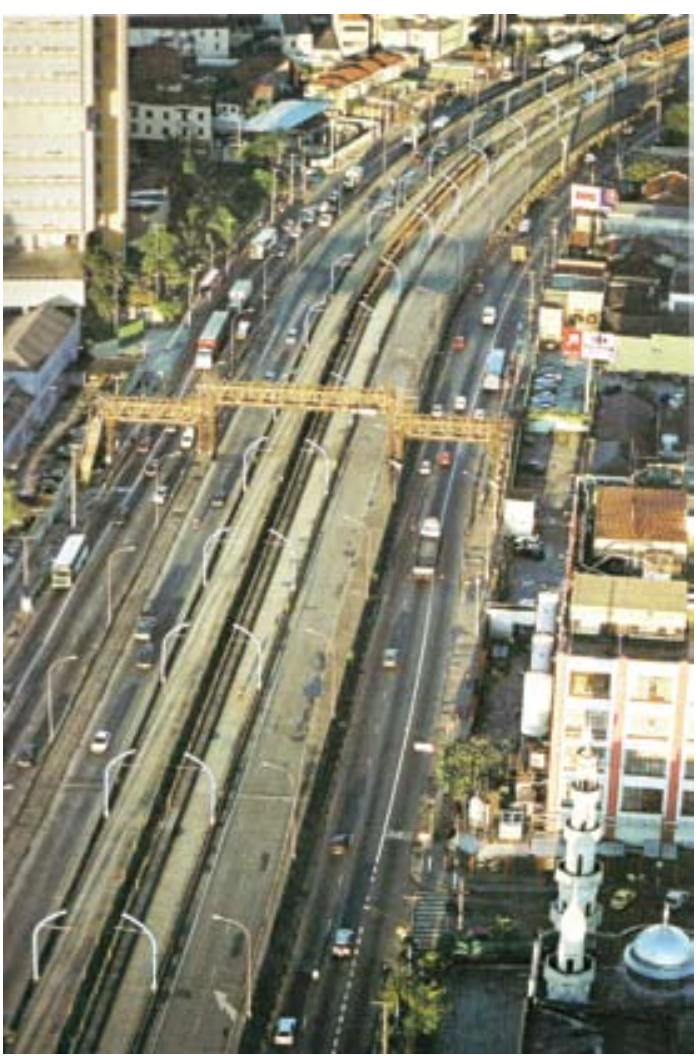




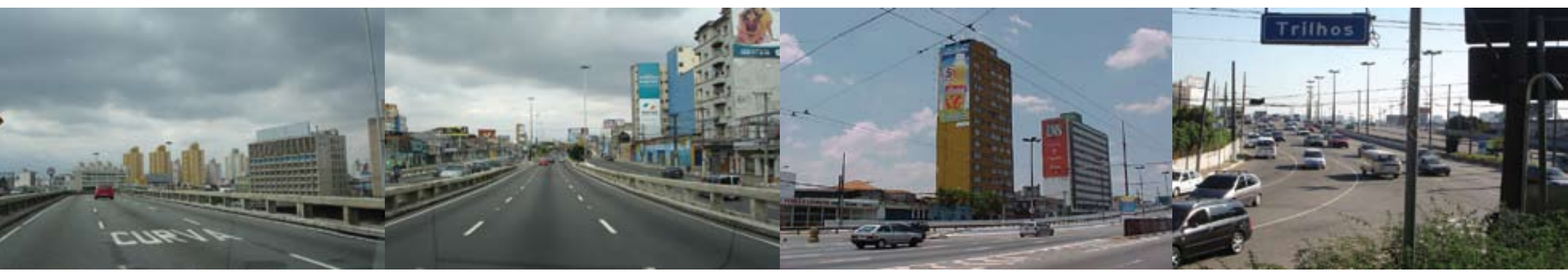

Acima

Fotos da Radial Leste sentido Elevado costa e Silva até Rua dos Trilhos Arquivo pessoal, 2006
Abaixo

Fotos Avenida Alcântara Machado ou Radial Leste com acesso pela Avenida do Estado em direção à Mooca. Arquivo pessoal, 2003
É difícil a comunicabilidade física entre os dois bairros tanto para pedestres como para veículos, pela falta de cruzamentos na Avenida Alcântara Machado, a Radial Leste. Esta avenida de alto tráfego, pode-se concluir, se tornou uma barreira urbana de difícil transposição. Os pedestes contam com apenas duas passarelas pouco convidativas: uma sobre a Rua Itapira e a outra junto à Praça Kennedy. A passarela de pedestres junto à Praça Kennedy favorece os estudantes da Universidade localizada na Radial Leste sentido bairrocentro na questão do transporte público, mas infelizmente não existe em nenhum dos dois lados dessa avenida qualquer tipo de centralidade que ofereça serviços ou comércio de âmbito local ou diversificado, apesar da existência, há muitos anos, dessa universidade em franca expansão de seu espaço físico e conseqüentemente do número de alunos. Os estudantes dispõem, apesar disso, do espaço da praça como lazer em seus intervalos de estudo. No caso desta passarela, seus acessos são em forma de rampa, o que não impede o seu uso por pessoas com dificuldade de locomoção.

A construção da Linha Leste do Metrô em I98I, em grande parte paralelamente e em nível com os trilhos da ferrovia, não provocou a valorização que normalmente ocorre em bairros onde esse tipo de sistema viário é implantado. Esses sistemas viários de superfície, em conjunto, podem ser uma das principais causas da degradação ambiental ocorrida na região, em virtude das dificuldades geradas em sua transposição, na escala humana e mesmo por veículos automotores.

Os efeitos observados em áreas urbanas fracionadas nos levam a refletir sobre o papel do poder público como principal agente das transformaç̧̃es urbanas ocorridas em uma metrópole como São Paulo, diante de intervenções viárias destas dimensões, no sentido de considerar a prévia organização da malha intra-urbana e planejar um traçado viário, minimizando os impactos negativos produzidos no entorno por estes sistemas viários regionais e evitando assim a desestruturação intra-urbana (Marly Namur et al, 2004, p.2).

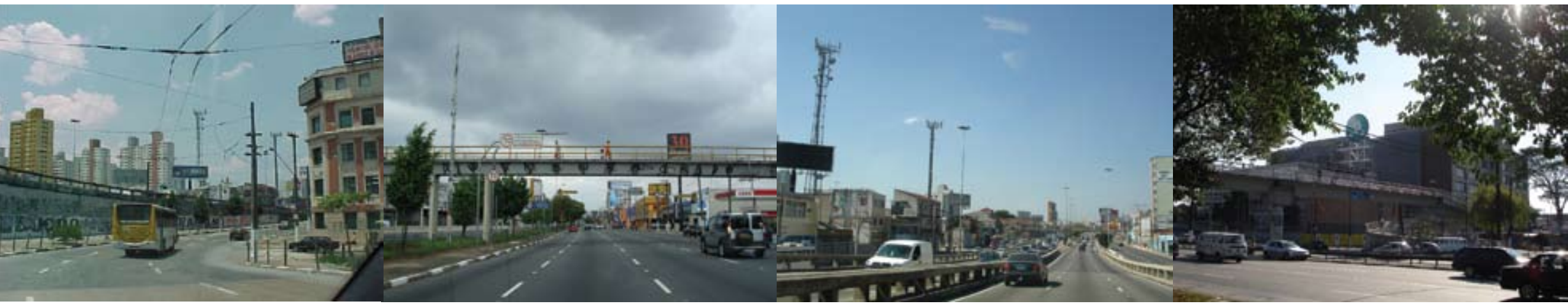




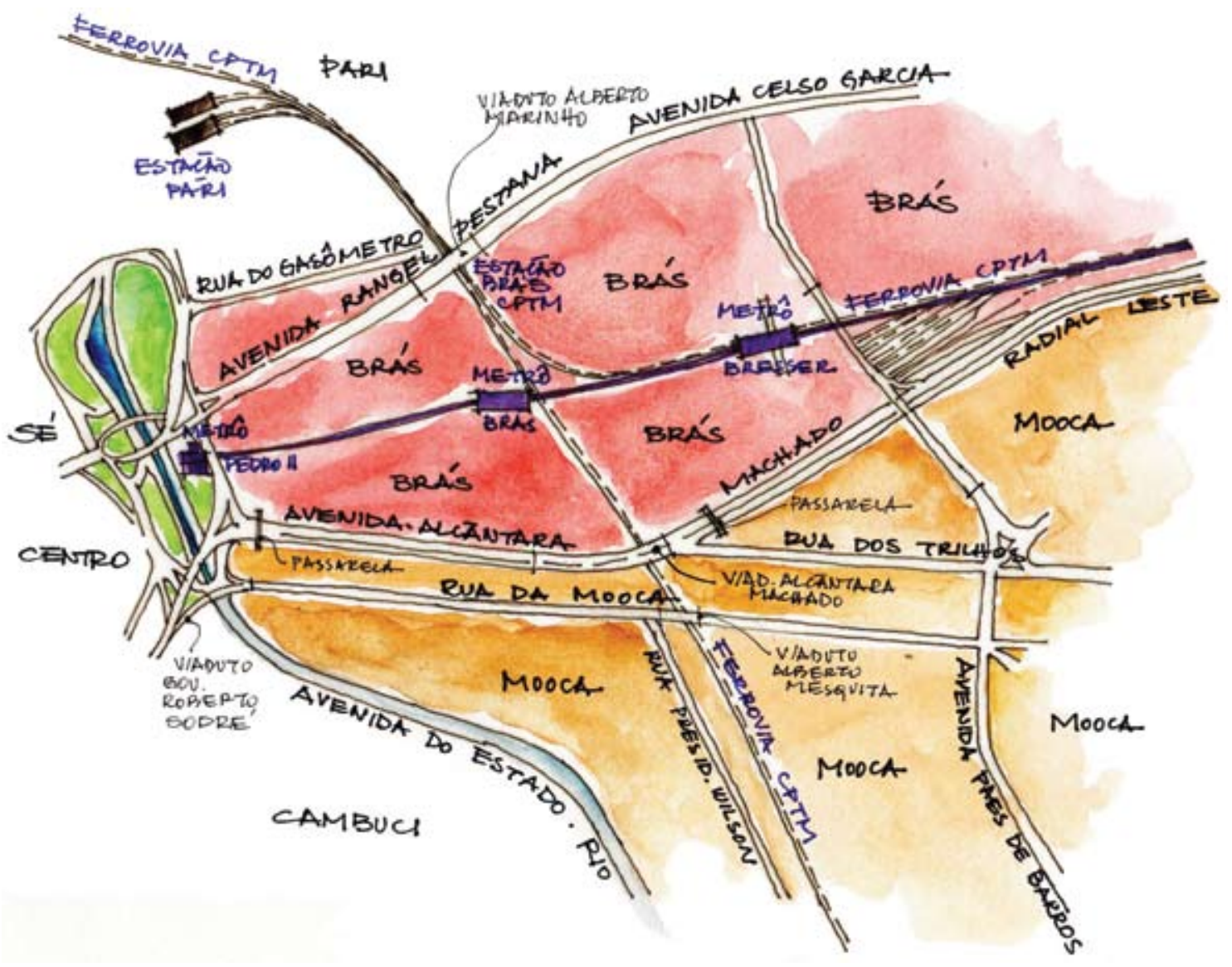

\section{Educação e saúde pública}

O levantamento do número de unidades de ensino, junto à Secretaria da Educação e do número de unidades de saúde, junto à Secretaria da Saúde possibilitou conhecer a área de abrangência de cada uma dessas unidades dentro da área-objeto de estudo e chegar à conclusão de que em relação a alguns tipos de escola municipal como ensino infantil, fundamental e creches e também no caso das escolas estaduais, alguns trechos, tanto no Brás como na Mooca não estão incluídos dentro da área de abrangência de nenhuma escola, determinada como área de conforto para se chegar caminhando, segundo conceito de Campos Filho: um raio de 800 metros. Os mapas 29 a 34 demonstram a localização das unidades educacionais e sua área de abrangência e a área que deverá ser coberta por novas unidades a serem implantadas e que foram propostas no Capítulo VII desta dissertação.

O levantamento do número de unidades existentes para saúde pública possibilitou concluir que, tanto no trecho Brás como no trecho Mooca da área-objeto de estudo, o atendimento à população local é muito deficiente, em virtude do baixo número de unidades, totalmente insuficientes para prestar um bom atendimento. $\bigcirc$ Mapa 23 apresenta as unidades existentes dentro da área-objeto de estudo: apenas um AE - Ambulatório de Especialidades, localizado à Rua Marina Crespi na Mooca. Novas unidades da rede pública de saúde foram propostas no Capítulo VII desta dissertação.
Figura 32

Fracionamento dos bairros Brás e Mooca, na área-objeto de estudo, em virtude da implantação de três sistemas viários importantes: avenida de tráfego intenso, metrovia e ferrovia.

Croquis da autora sobre base Geomapas (1991). 


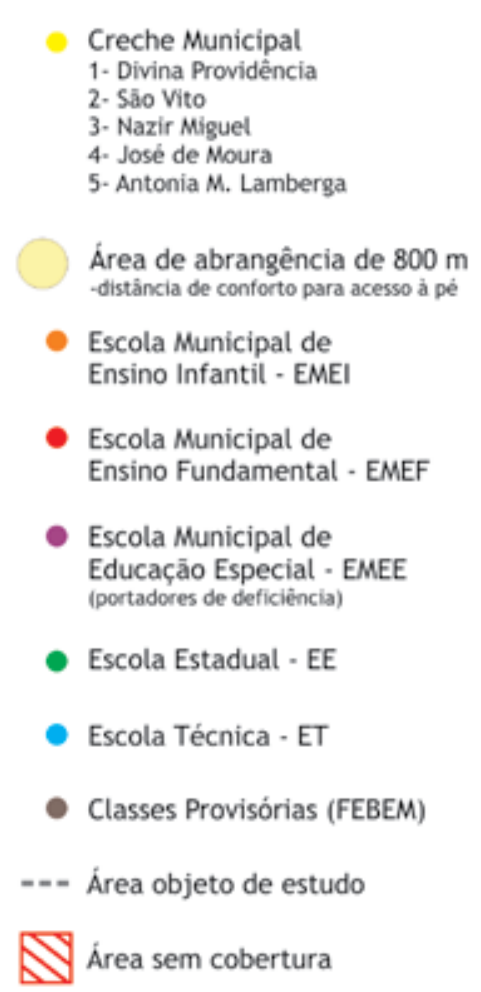

Creche Municipal

- Escola Municipal de Ensino Infantil - EMEI

1. Joăo Mendonza Falcă̊

2. Almirante Tamandaré

Área de abrangência de $800 \mathrm{~m}$ -distância de conforto para acesso à pe

- Escola Municipal de Ensino Fundamental - EMEF

- Escola Municipal de Educaçāo Especial - EMEE (portadores de deficiència)

- Escola Estadual - EE

- Escola Técnica - ET

- Classes Provisórias (FEBEM)

- - - Área objeto de estudo

Área sem cobertura

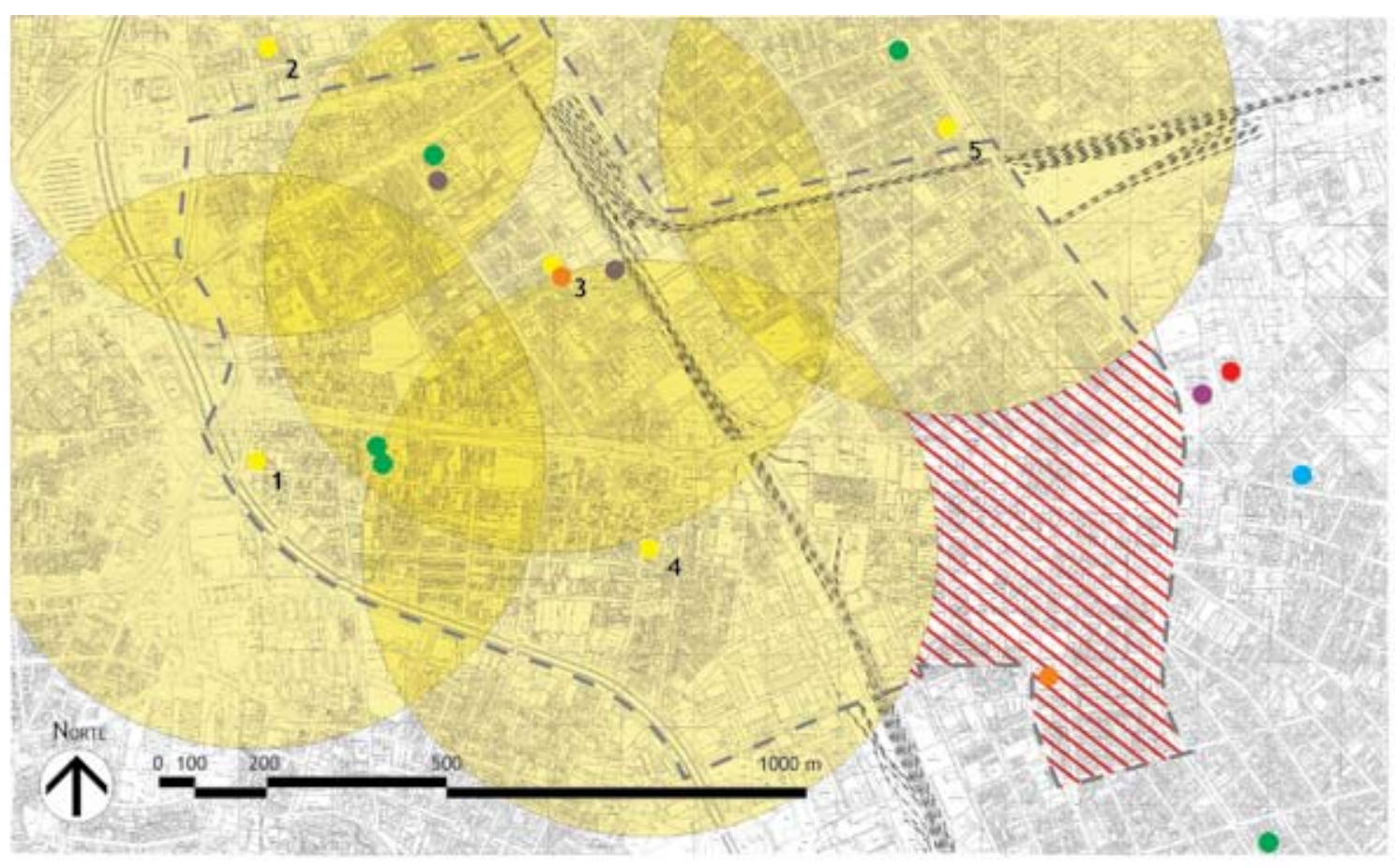

\section{Área de abrangência de Creche Municipal \\ Mapa 29}

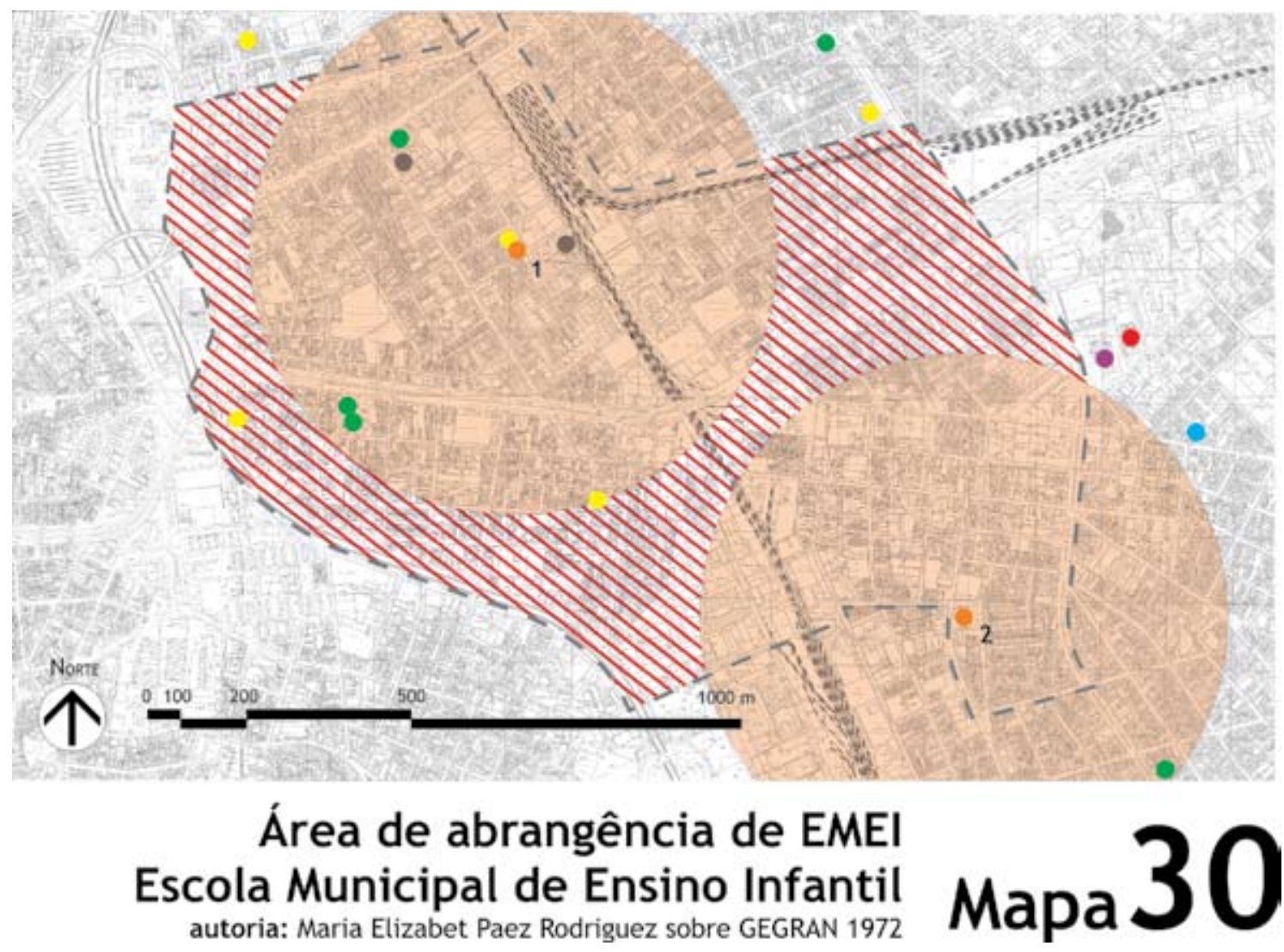




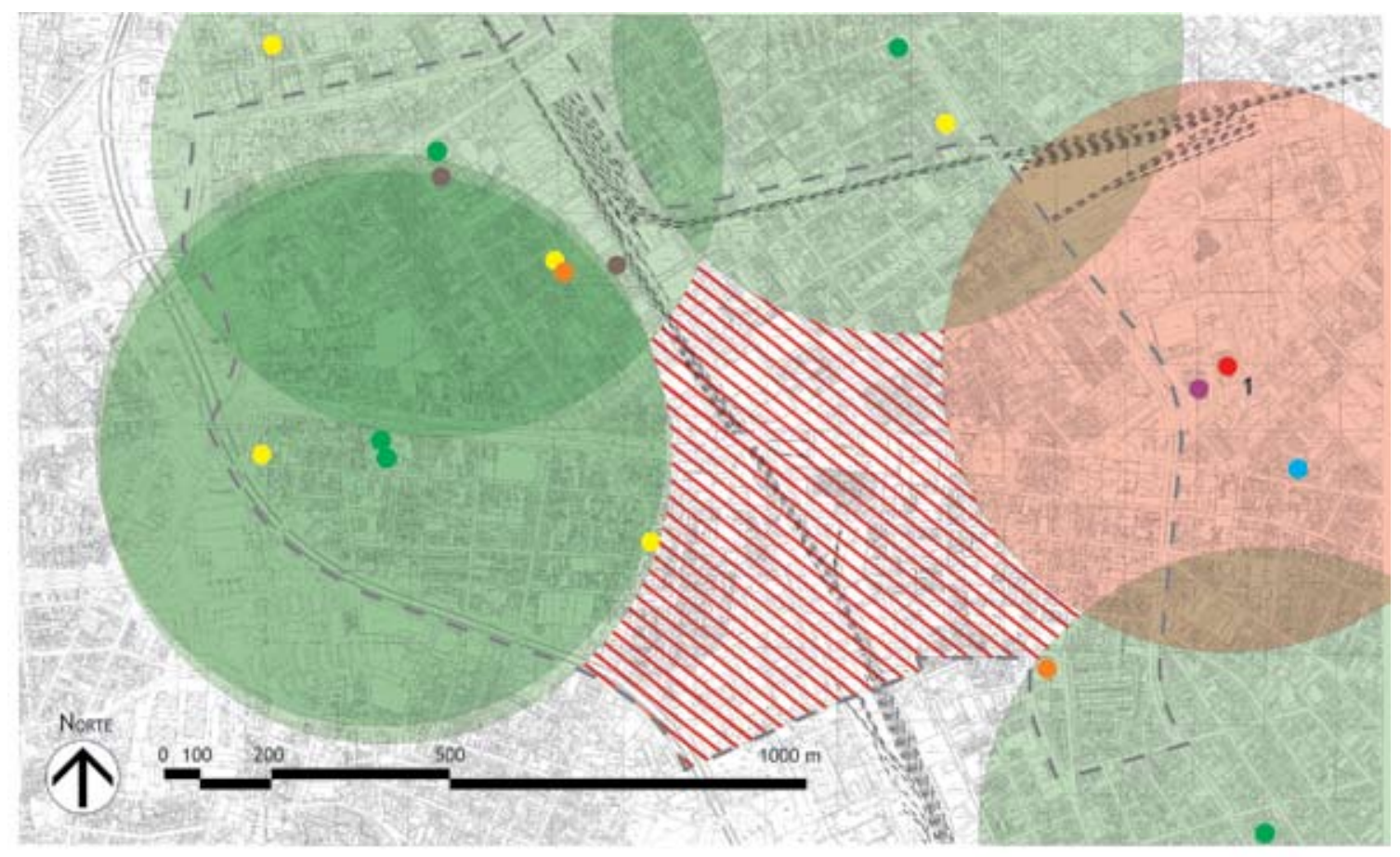

\section{Área de abrangência de EMEF Escola Municipal de Ensino Fundamental autoria: Maria Elizabet Paez Rodriguez sobre GEGRAN 1972}

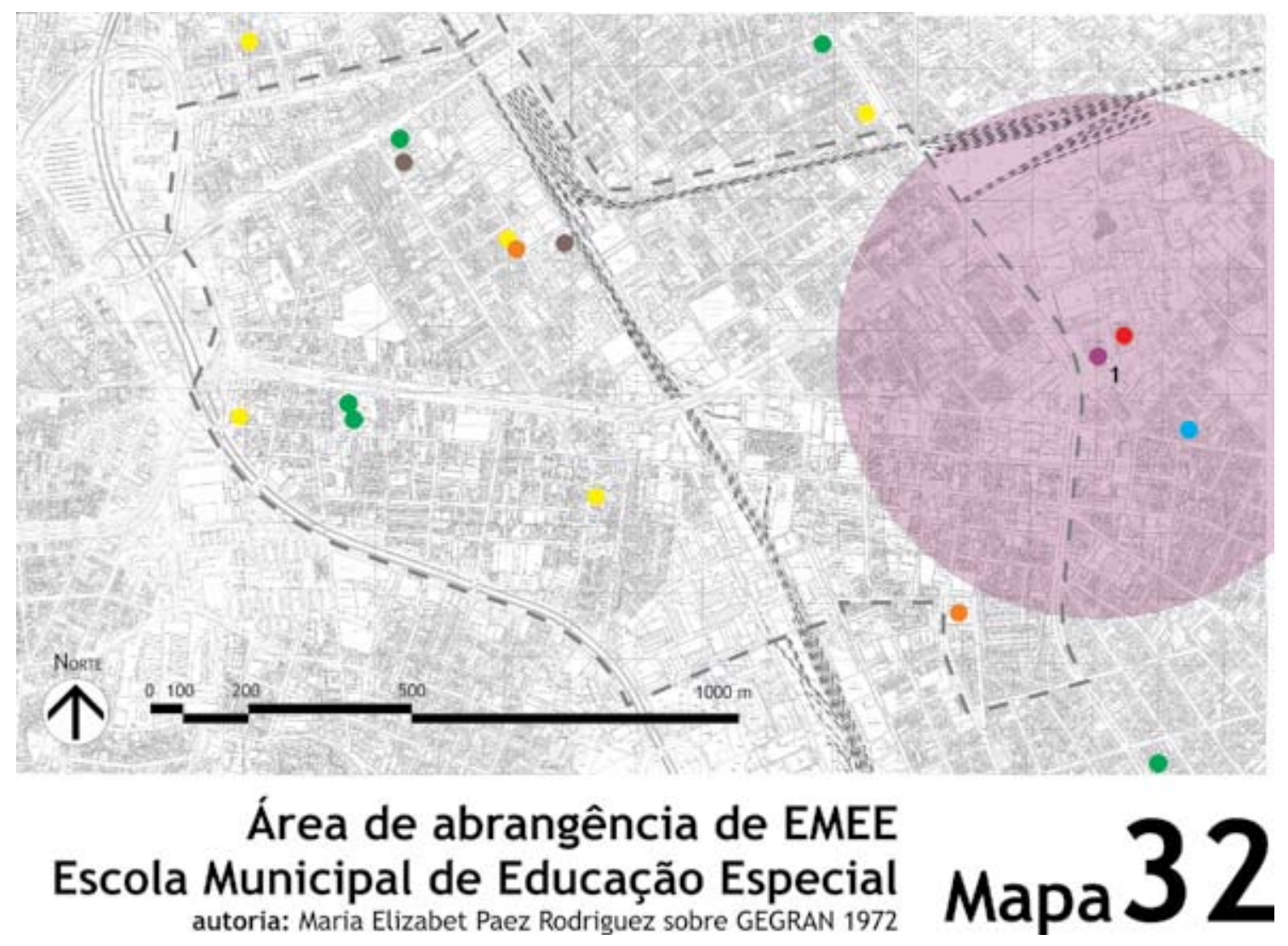

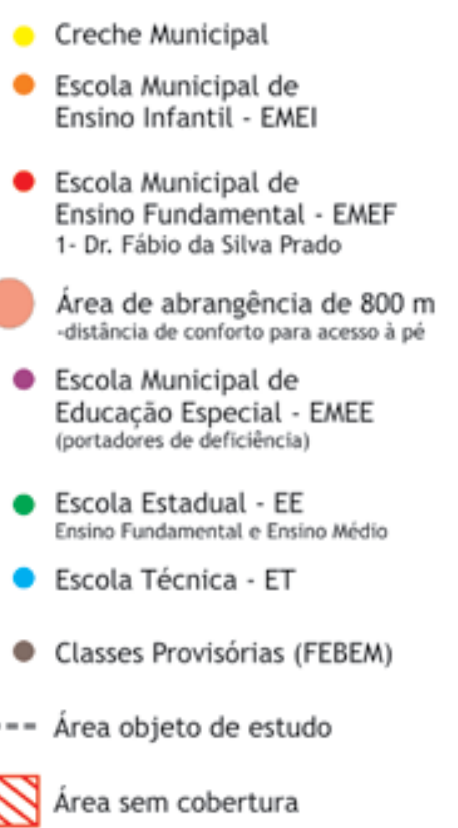

Obs.: Este mapa representa as áreas de abrangência tanto das EMEF quanto das EE, pois ambas atendem a estudantes do ensino fundamental. 


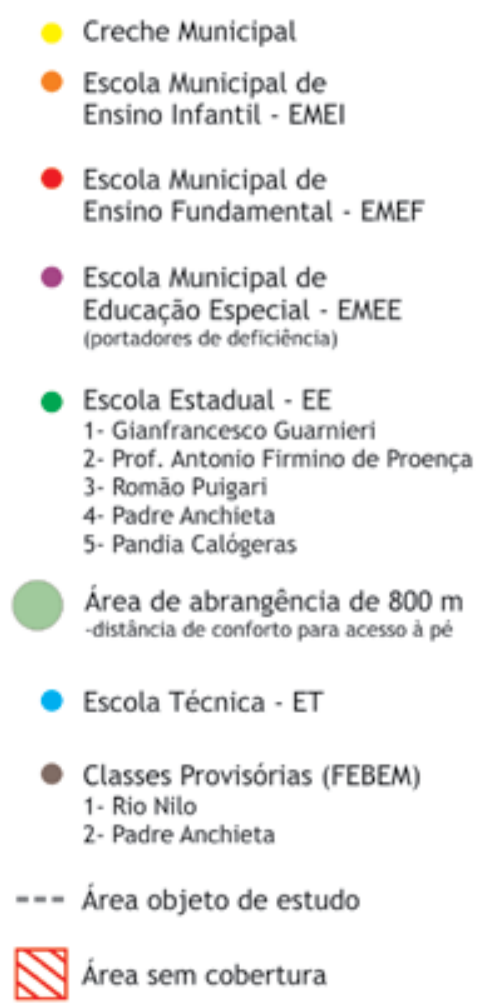

Área sem cobertura

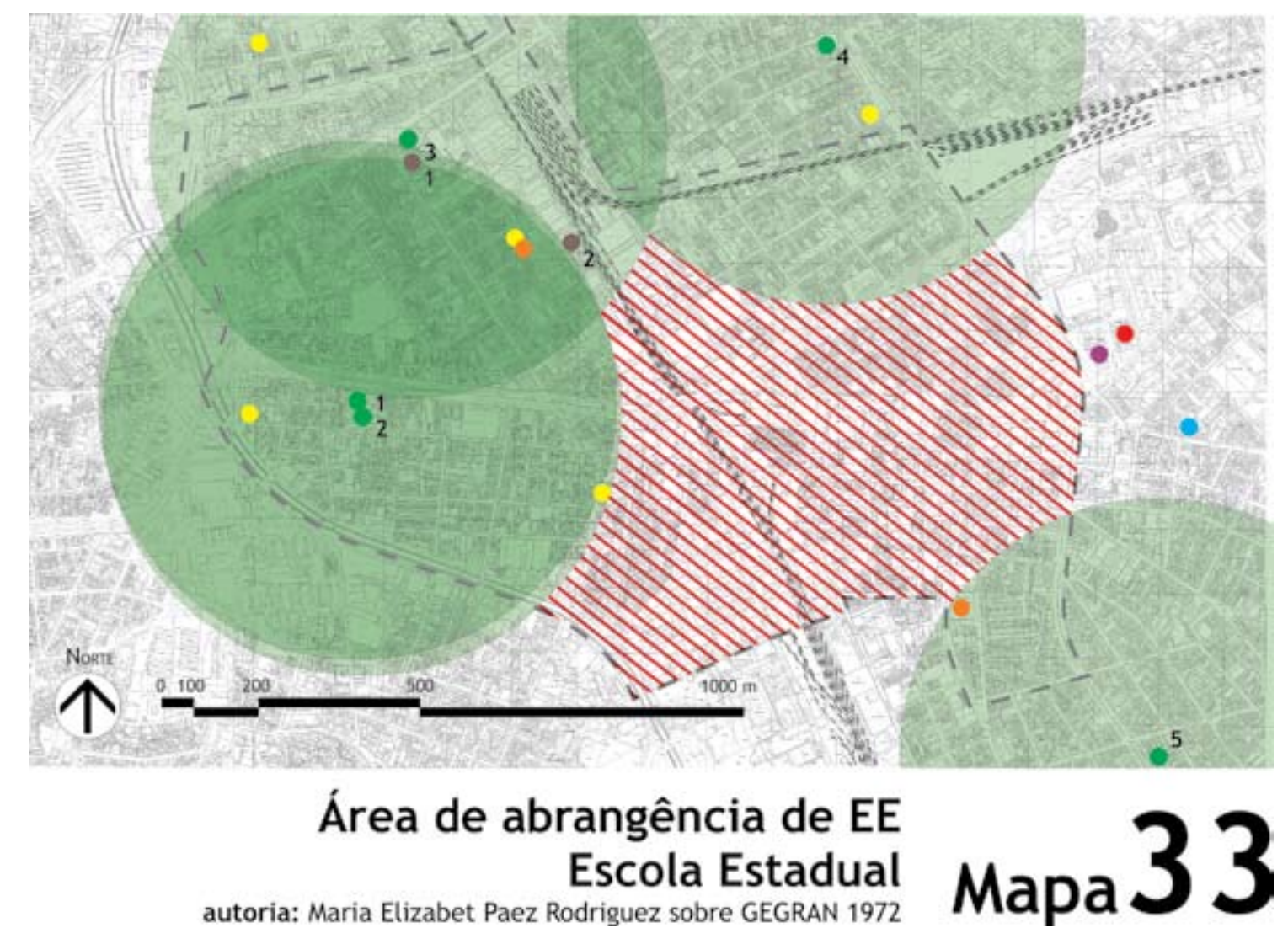

Creche Municipal

- Escola Municipal de Ensino Infantil - EMEI

- Escola Municipal de Ensino Fundamental - EMEF

- Escola Municipal de Educação Especial - EMEE (portadores de deficiência)

- Escola Estadual - EE

- Escola Técnica - ET 1. Prof. Camargo Aranha

Área de abrangência de $800 \mathrm{~m}$ -distância de conforto para acesso à pé

- Classes Provisórias (FEBEM)

-n- Área objeto de estudo

Obs.: A área de abrangência da ET foi representada com o raio de 800 metros apenas para auxiliar o entendimento da escala territorial e não representa necessariamente critério técnico.

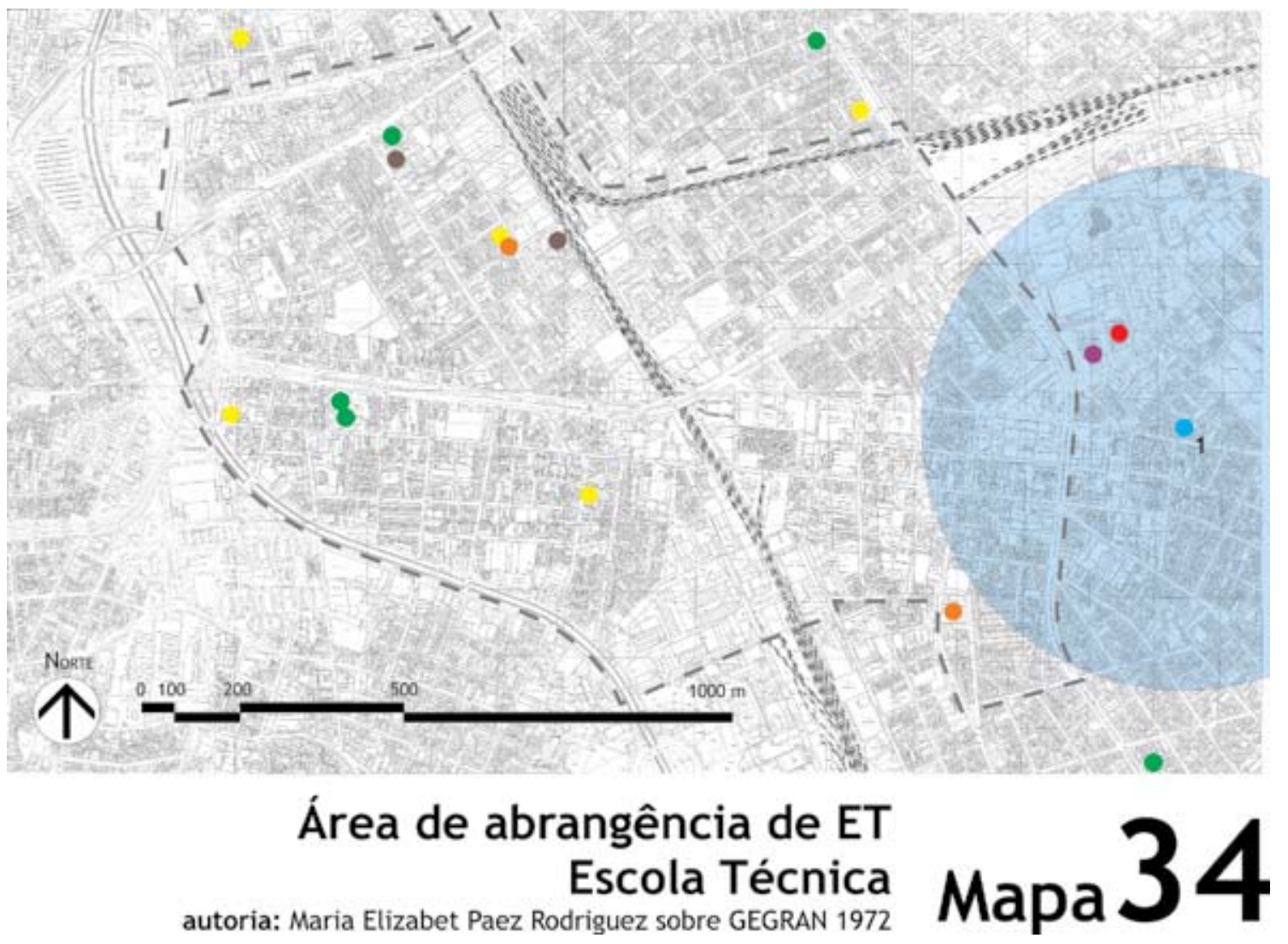




\section{5. Áreas verdes, praças e espaços para lazer}

Os dois bairros históricos em questão são totalmente deficientes em áreas verdes ou espaços abertos.

As ruas do Brás e Mooca têm vida aos domingos, mas o lazer é precário, pois não existem áreas livres arborizadas para a prática de esportes ou para a simples contemplação. Não existem quadras de esportes, clubes municipais ou piscinas públicas em toda a extensão da área-objeto de estudo e as crianças têm como única opção brincar na rua - hábito saudável desde que existam outras opções de lazer e que não haja riscos como tráfego intenso de veículos particulares ou de grande porte, como caminhões.

O trecho Brás da área-objeto de estudo não dispõe de nenhuma praça, exceto pelos terrenos remanescentes da implantação das obras do Metrô Leste, localizados em "pontas" de quadra e sem vegetação, pavimentação adequadas ou qualquer outro atrativo como brinquedos infantis. Junto à estação Brás do Metrô existe uma área remanescente de quadra desapropriada para a implantação dessa linha, mas que não apresenta ajardinamento em boas condições. A praça ao lado da Creche Municipal Nazir Miguel, localizada à Rua Prudente de Moraes, 210, faz parte de um conjunto que inclui uma praça, mas pavimentada e não ajardinada, sem equipamentos como brinquedos infantis ou bancos de descanso.

$\mathrm{Na}$ Mooca baixa, existe uma praça triangular com gramado localizada na Avenida do Estado e na confluência das ruas Odorico Mendes e Oscar Horta, a praça Álvaro Cardozo de Moura, hoje habitada por pessoas em situação de rua e constantemente utilizada pelos moradores da região para despejo de lixo.

Já o trecho Mooca da área-objeto de estudo dispõe da Praça Kennedy localizada na Avenida Alcântara Machado e na confluência das Ruas Dr. Almeida Lima e Trilhos. É uma praça de boas dimensões, bastante agradável, com desenho clássico, árvores frondosas e bancos. É um espaço freqüentado pelos habitantes locais e passantes.

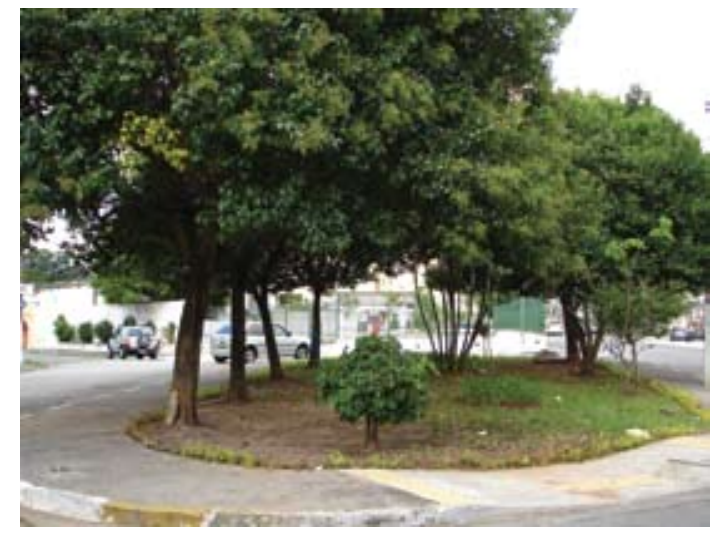

Acima

Praça Sebastião Grandini, na

Mooca.

Arquivo pessoal, 2006.
Abaixo

Praça Álvaro Cardozo de Moura,

na Mooca baixa.

Arquivo pessoal, 2006.

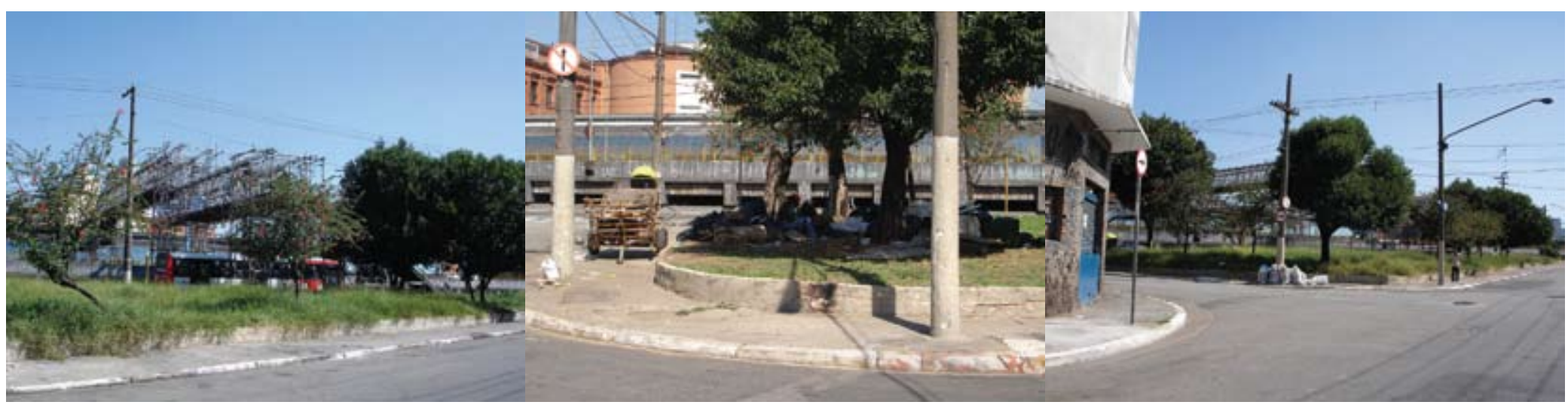




\section{Qualidade ambiental e urbana no Brás e Mooca}

O mapa de temperatura aparente (Mapa 35) indica uma clara associação entre os microclimas existentes e a presença de vegetação e tipo de uso do solo. As maiores temperaturas aparentes foram observadas nas regiões situadas no centro-leste (distritos do Belém, Brás, Mooca e Pari, com temperaturas de $31,5^{\circ} \mathrm{C}$ a $32^{\circ} \mathrm{C}$ ); oeste (distritos da Lapa e Barra Funda, com temperaturas de $30,5^{\circ} \mathrm{C}$ a $31^{\circ} \mathrm{C}$ ); norte (distritos de Vila Guilherme e Vila Medeiros, com temperaturas de $30,5^{\circ} \mathrm{C}$ a $31^{\circ} \mathrm{C}$ ); e leste (distritos de Vila Formosa e São Mateus, com temperaturas de $30,5^{\circ} \mathrm{C}$ a $31^{\circ} \mathrm{C}$ ). Em todas as áreas, tem-se escassa cobertura vegetal, com tipo de ocupação variando entre o residencial de baixo padrão, incluindo favelas e grandes galpões industriais e transportadoras.

mapa de temperatura aparente revela ainda que a clássica idéia de que as áreas centrais das grandes cidades são ilhas de calor deve ser tomada com ressalvas, já que foram observadas, localmente, áreas mais frias, dentro da massa com urbanização consolidada. Tal fenômeno pode ser justificado pela concentração de áreas com ocupação predominantemente vertical. Essa verticalização seria responsável pela atenuação da temperatura, pois são áreas fortemente sombreadas, com presença de canyons urbanos, que constituem microclimas insalubres. Não é o caso do Brás e Mooca, onde a verticalização é rara e insuficiente para gerar esse fenômeno (Atlas Ambiental, 1993, p. 124)

O índice de cobertura vegetal no Brás e Mooca é zero, conforme o Mapa 36. A cidade tem hoje um déficit significativo de espaços públicos e de vegetação, em um quadro de difícil reversão, considerando que, nas regiões de urbanização consolidada, não existem mais áreas públicas para a implantação de novos parques, como já detectavam os estudos realizados pela Secretaria Municipal de Planejamento Urbano (Sempla), em 1984, para a elaboração do Plano Diretor (Kliass, 1993 in Atlas Ambiental, p.7I).

O mapa de cobertura vegetal (Mapa 36) mostra que 48\% do território apresenta carência significativa de cobertura vegetal de qualquer tipo, seja ela na forma de maciços vegetais significativos, arborização viária ou áreas verdes (parque e praças). Por outro lado, 33\% do município é coberto por maciços florestais em diversos estágios de sucessão ecológica, sendo que os distritos de Parelheiros, Marsilac, Grajaú, Jardim Ângela, Jaçanã-Tremembé e Perus, submetidos à intensa pressão para a ocupação, concentram 75\% desse tipo de cobertura vegetal.

63 Secretaria do Verde e Meio Ambiente da Prefeitura Municipal de São Paulo - SVMA.

${ }^{64}$ L.O. Sılvio. Subsídios para a formulação de uma política para as áreas verdes no município de São Paulo in R. PHILLIP JÚNIOR, etal (Eds.) A questão ambiental urbana. Cidade de São Paulo. São Paulo, 1993, pp.425-449.

${ }^{65}$ Lei Municipal $n^{\circ} 261$ । de 20/06/1923.

66 Programa de Melhoramentos Públicos para a cidade de São Paulo.

${ }^{67}$ Lei no 6766/79 - Lei Lehman, alterada pela Lei 9785/99.

Segundo a SVMA ${ }^{63}$, apenas $16,36 \%$ do município é ocupada por área verde, sendo 10,24\% na zona urbana e 6, $12 \%$ na zona rural ${ }^{64}$.

Em 1923, sob influência de City de São Paulo Improvments and Free Hold Land Co. LTD, aprova-se uma lei que exige do loteador de áreas urbanas iguais ou superiores a $40.000 \mathrm{~m}^{2}$, $20 \%$ para vias de circulação e 5\% para espaço livre ajardinado (Atlas Ambiental, p. 98 ) $^{65}$.

Relacionando essa lei com Brás e Mooca naquele período, o loteamento Chácara da Mooca pode ter sido afetado por essa lei, já que as terras foram adquiridas pela Cia. Chácara da Mooca Sociedade Anônima da família Paes de Barros, em 1912, com o objetivo de criar o hoje chamado Parque da Mooca.

Na década de 1950, o Relatório Moses ${ }^{66}$ apresentava recomendações sobre parques e praças, considerando pouca a desativação de $10 \%$ para áreas verdes das glebas a lotear e questionando a localização, geralmente em ilhas do sistema viário (Atlas Ambiental, p.98).

Atualmente é a Lei Municipal no 94/3/89 que disciplina o parcelamento do solo do município com o objetivo de fomentar o estoque público de áreas verdes através de doação de áreas por ocasião do parcelamento, também previsto pela Lei Lehman (Atlas Ambien- 


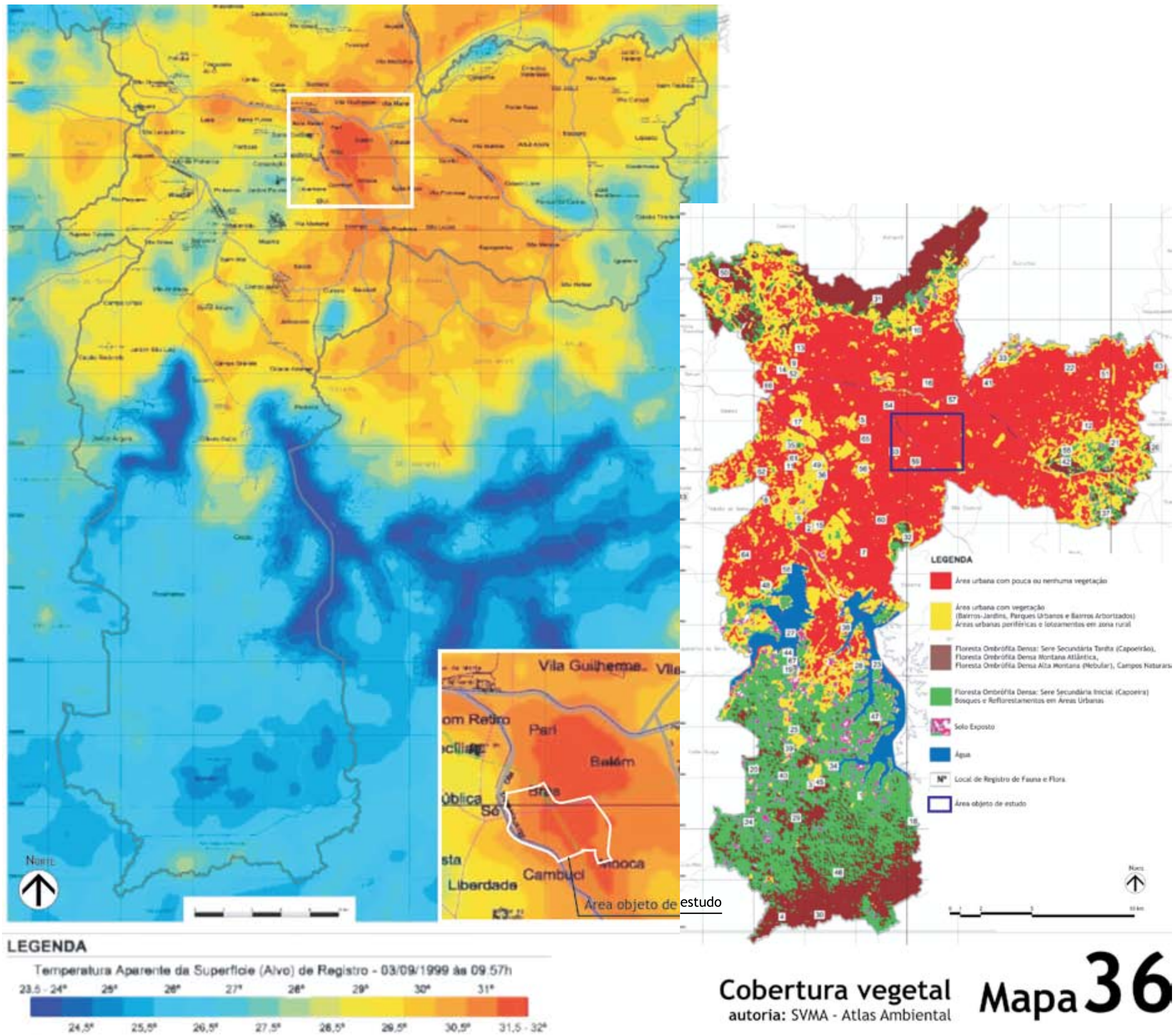

\section{Temperatura aparente da superfície alvo de registro autoria: SVMA - Atlas Ambiental


tal, p.99) $)^{67}$

- Praças: Em toda a área-objeto de estudo existem apenas as sobras de terrenos decorrentes da implantação do Metrô Leste no Brás, revestidas com gramados sem manutenção adequada;

- Áreas verdes e espaços abertos: Assim como no caso das praças, não existem espaços livres abertos para lazer ou contemplação na área estudada. Os dois tipos de espaços públicos são vitais para garantir a qualidade da população de 60 anos ou mais e da população de zero a 19 anos, que têm mais tempo ocioso e representam, respectivamente, I5,8\% e $26,6 \%$ da população total contida na área.

Observando-se o Mapa 35 da temperatura aparente da superfície, vê-se que Brás e Mooca apresentam as temperaturas mais altas da cidade em virtude da falta de arborização, da extensa área de solo impermeabilizado e da poluição atmosférica, esta gerada pela emissão de gases pelos veículos automotores e outras fontes emissoras de poluentes e de calor, comprometendo mais ainda a qualidade de vida da população local.

Confrontado-se o Mapa 35 com o Mapa 36, pode-se observar ainda que a qualidade de vida do Brás e Mooca é uma das piores da cidade, pois congrega uma série de fatores que o predispõem a isso. As áreas verdes são inexistentes nas duas áreas estudadas, exceto pelos pequenos ajardinamentos da Estação Bresser do Metrô. No entorno da Estação Brás, não existe verde adequado. Não existem praças no Brás e Mooca, sendo que nos trechos em questão e arborização é quase inexistente. No lugar de um rio com margens ajardinadas, temos um canal de concreto, com um rio encarcerado, que não contribui com a boa ventilação e refrescamento da área.

O Rio Tamanduateí, que até a primeira metade do século 19 proporcionou aos habitantes das chácaras e outras propriedades a ligação com a natureza, se encontra hoje canalizado e sem vida no trecho entre o Ipiranga e a Rua da Figueira. A canalização desse rio foi feita sem a mínima observação de critérios estéticos ou ambientais e novamente alvo de projetos eleitoreiros, será a base para a implantação de novo sistema de transporte público rápido de massa, em lento processo de construção. O impacto urbano resultante sobre o tecido urbano existente e a população residente será o de barreira urbana potencializada, uma vez que o Rio Tamanduateí sempre foi uma barreira natural.

Miranda, em sua tese de doutoramento, coloca como grande fator de deterioração do distrito da Mooca a "drenagem urbana sobre o Rio Tamanduateí junto à Avenida do Estado, a qual dificultou a ligação entre os bairros vizinhos, principalmente para os moradores e pedestres que circulam pela região" (2002, p. I75).

\section{I Início da degradação urbana}

Degradação significa deterioração, decadência, declínio. Degradação urbana e ambiental significa a decadência da cidade, de seu meio-ambiente e meio social. A cidade apresenta sinais de degradação urbana quando a rua se transforma em moradia para uns, em espaço livre para a delinqüência para outros e "não lugar" para muitos. Esses elementos combinados levam a o espaço urbano degradado por pessoas em situação de rua, lixo depositado nas ruas, poluição visual e ambiental, tráfego intenso mesmo em ruas locais e a violência urbana que afasta o habitante local e, conseqüentemente, a vida saudável da rua. Brás e Mooca baixa, local de moradia de pessoas de baixa e média renda, já a começa a apresentar esses sinais que devem 


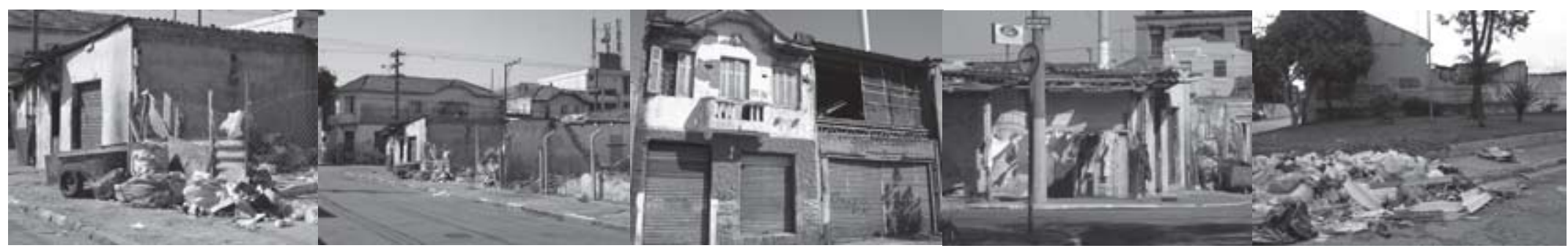

ser combatidos no início desse processo, pelo poder público.

Atualmente, a população residente vem sendo complementada pela presença cada vez maior de imigrantes latinos vivendo e trabalhando em situação irregular, muitas vezes em regime de semi-escravidão. À falta de informações oficiais sobre esse tipo de imigração, observações feitas in loco, mostram que essa parte da população local vive em cortiços, moradias de baixíssima qualidade ambiental, insalubres pela falta de ventilação e insolação mínimas. Muitos deles, por serem imigrantes clandestinos, não conseguem provavelmente ser incluídos nos programas de realocação de encortiçados dos governos estadual e municipal.

Recentemente, em função da retomada de posse por via judicial, um conjunto residencial de aproximadamente 80 casas operárias em estilo neoclássico na Mooca, construídas em 1925 dentro do polígono compreendido pelas ruas Dom Bosco, Oscar Horta, Coronel Cintra e Odorico Mendes, foi prontamente demolido pelo proprietário, restando apenas 4 ou 5 casas, ainda ocupadas pelos últimos inquilinos. Já se vê um foco de favelização no local.

A área-objeto de estudo tem uma significativa parte da população vivendo em péssimas condições. Essa população e os imóveis transformados em cortiços continuam aumentando de número, segundo dados do SEADE e CDHU (Relatório PAC-Brás, 2004, p.68).

Pessoas em situação de rua vêm aumentando gradativamente, principalmente na Mooca baixa. Sua sobrevivência depende muitas vezes, conforme observações in loco, da coleta de materiais recicláveis, que são separados nas próprias calçadas e no meio fio das ruas do bairro e armazenados nos cortiços onde residem, possibilitando a proliferação de roedores e insetos nocivos à saúde humana. Isso vem gerando acúmulo de lixo nas ruas, constituindo focos de degradação urbana. Apesar da proximidade com o Centro Histórico e seus serviços e comércio, a população residente do Brás e Mooca teve significativo decréscimo nos últimos 20 anos, baixando o índice de adensamento ainda mais, a despeito da infra-estrutura instalada. Esses podem ser alguns dos indícios de falta de planejamento específico em bairros tão centrais e com fácil acesso ao centro histórico da cidade ${ }^{68}$. Começa a ocorrer o acúmulo de lixo sob o viaduto da Radial Leste, junto à Avenida do Estado como mostrado na foto abaixo, à esquerda.

A questão do transporte público, apesar da grande oferta local desses serviços, não contempla de forma ideal a população residente na Mooca baixa que, tendo duas estações de
Acima

Moradias precárias, semi-demolidas e lixo depositado em área remanescente gramada à Rua dos Trilhos, Mooca. Arquivo pessoal, 2006.

${ }^{68}$ Conforme dados do IBGE, entre os Censos Demográficos de 1980 e 2000, o Brás perdeu cerca de $35 \%$ e a Mooca cerca de $25 \%$ de seus habitantes.

Abaixo

Pessoas em situacão de rua, catadores de materiasi recicláveis e ciranças vivendo em situação de risco sob viadutos.

Arquivo pessoal, 2006.

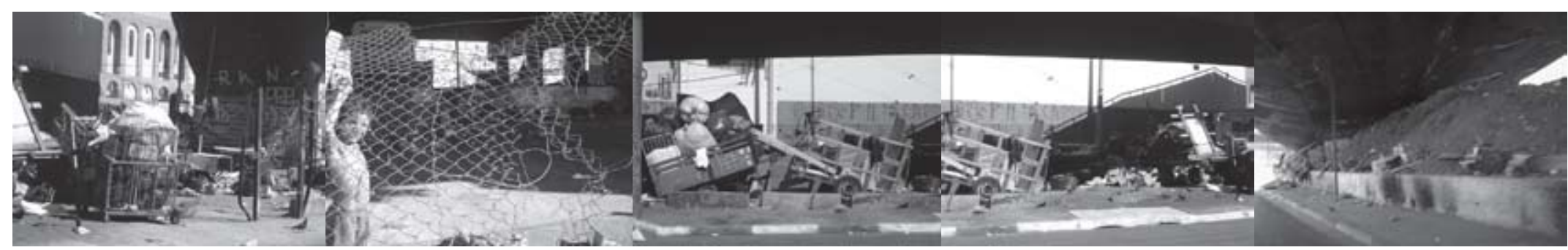


${ }^{69}$ Andreas Marker. Especialista em descontaminação de brownfields. Seminário Revitalização de Areas Contaminadas e Requalificação Urbana: Estudo de Caso Operação Diagonal Sul apresentado em dezembro de 2005

70 Instituto Ekos Brasil.

Abaixo

A esquerda e à direita

Galpões industriais abandonados e ocupados por pessoas em situação de rua.

\section{Centro}

Area industrial com galpões desativados vista a partir do Viaduto Alcântara Machado.

Arquivo pessoal, 2006 metrô tão próximas, tem que lidar com a difícil transposição da Radial Leste.

Um dos pontos fortes da proposta contida na Operação Urbana Diagonal Sul é a reconversão de glebas industriais onde estiveram instaladas por décadas grandes indústrias multinacionais como Esso, Antárctica e Ford. O complexo industrial da Ford, localizado no Viaduto Pacheco Chaves, hoje se encontra totalmente desativado, fato ocorrido a partir da saída da indústria que se instalou no Estado da Bahia nos últimos anos do século 20. A Esso, indústria de combustíveis, por sua vez ocupou gleba com área superior a 100 mil metros quadrados até a sua desativação ou transferência no fim do século 20, quando a empresa, seguindo a tendência mundial, tomou a iniciativa de descontaminar o solo de sua extensa propriedade; caso contrário, não poderá obter o alto valor esperado no mercado imobiliário. A Cervejaria Antárctica - Companhia Antárctica Paulista - já desativou parte de seus galpões e teve parte do terreno classificado como ZEIS 3 na atual legislação, o que garante a produção de moradias HIS ou HMP em número significativo.

A contaminação do solo por metais pesados, provocada pelas indústrias locais, também representa um obstáculo a ser vencido na reutilização desses terrenos. A descontaminação de solos é um tipo de ação iniciada na década de 1980 na Europa e Estados Unidos da América, em metrópoles que contém áreas industriais degradadas chamadas brownfields, áreas que dispõem de propriedades abandonadas ou subutilizadas cuja reutilização implica em sua descontaminação e na responsabilidade pela contaminação que representa risco aos habitantes e à vegetação ${ }^{69}$. Segundo levantamento em andamento realizado pela equipe de consultores especialistas em descontaminação, contratada pela Prefeitura do Município de São Paulo, estão contaminadas as áreas industriais da Companhia Antárctica Paulista, na Mooca baixa; a área da Supertest S/A (antiga Tecelagem e Metalúrgica Pado), localizada à Rua da Mooca; a área da Esso, à Rua Barão de Montesanto, no distrito industrial da Mooca e a Discos Continental, localizada à Rua do Lirismo na Mooca baixa e onde funcionou anteriormente uma fábrica de móveis de aço ${ }^{70}$.

A saída das grandes indústrias deixou para trás áreas ociosas ou envolvidas em processos judiciais trabalhistas ou em inventários. É o caso da Metalúrgica Matarazzo, na Rua Caetano Pinto, desativada há muitos anos estando seu edifício de dimensões importantes, totalmente ocioso; da Fábrica de Tecidos Labor, na Rua da Mooca, desativada e com seu imóvel de mais de $12.000 \mathrm{~m}^{2}$ subutilizado como estacionamento e, mais grave, a lenta desativação ou mudança da Cervejaria Companhia Antárctica Paulista, que já tem grande parte de sua imensa área desativada.

Além dos galpões, muitos ramais de trilhos das ferrovias que levavam os vagões de carga até o pátio dessas, estão hoje desativados, mantendo grandes áreas de terra ociosa em torno dos trilhos.

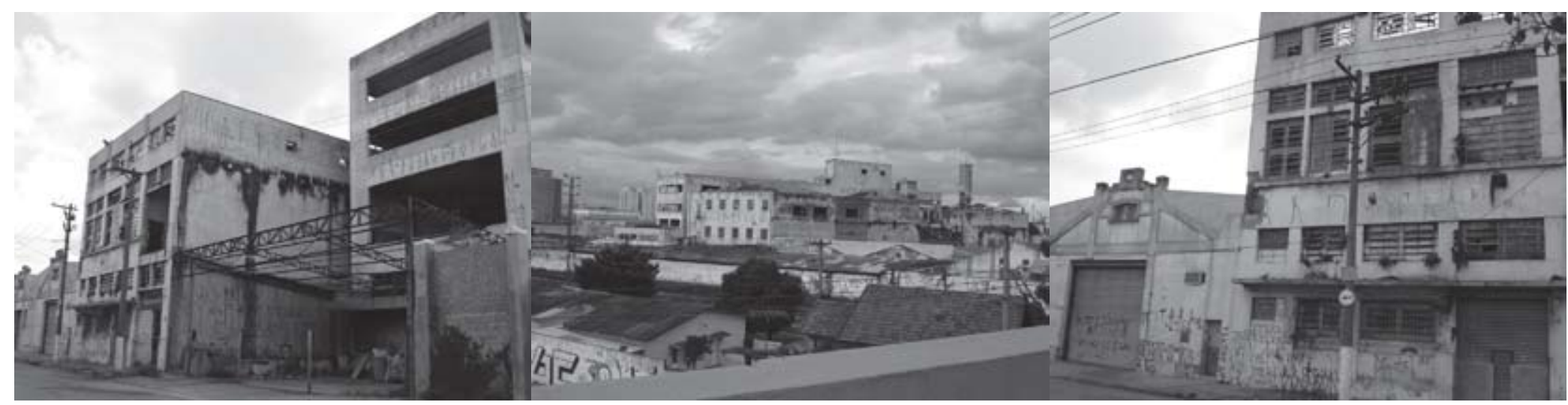


Tanto Mooca quanto Brás detêm um estoque valioso de construções com variados estilos arquitetônicos e valor histórico passíveis de tombamento e preservação, contribuindo com o Patrimônio Histórico do município, como mostrado no item 3.4 do Capítulo III. Infelizmente a maior parte deles ou está em processo de degradação ou são constantemente desconfigurados, chegando até mesmo a ser demolidos.

São poucos os vazios urbanos encontrados nessas áreas, mas eles existem e com dimensões suficientes para acomodar os equipamentos públicos tão necessários. São áreas aproveitáveis remanescentes de desapropriações para obras públicas ou estão localizadas ao longo das ferrovias, ociosas e sem nenhum tratamento paisagístico. Alguns são imóveis subutilizados e alguns poucos são pequenos trechos de terreno onde estão acomodados elementos de apoio a obras viárias.

Como no restante da cidade, a falta de segurança nas ruas impede que estas possam ter vida, afastando as pessoas delas. O Brás tem um dos índices mais altos de violência do município de São Paulo ${ }^{71}$.

Circulando pela Avenida Radial Leste, é notório ao observador que ela passa por um início de processo de degradação urbana. Ao longo desta, um grande número de imóveis estão desocupados, à venda ou disponíveis para locação. Por se tratar de sistema viário de abrangência regional, o prolongamento da Avenida Alcântara Machado, ou Radial Leste, com o objetivo de facilitar o acesso à Zona Leste a partir do centro da metrópole, afetou a região no entorno de seu trecho inicial, na forma de aumento do carregamento de veículos e, consequentemente, do grau de poluição ambiental, nível de ruído e dificuldade de transposição pelos pedestres.

Entrando nos bairros do Brás e Mooca, é possível encontrar focos de degradação urbana, mas menos imóveis desocupados e uso residencial mais intenso que na Radial Leste. Praças ainda que minúsculas, são elementos inexistentes no contexto urbano da área.

Como conseqüência de todos os aspectos negativos aqui apontados, a desvalorização imobiliária pode ser maior que o patamar aceitável. A degradação urbana que pode estar em curso na Avenida Radial Leste e região não é um fato isolado. Ela ocorreu e ocorre em outros pontos da cidade de São Paulo e em outras cidades industrializadas do Brasil e do mundo.

A Avenida Rangel Pestana tem características atuais muito semelhantes às características da Avenida Alcântara Machado, mas a grande diferença é a sua época de surgimento como via de importância regional: a partir do século 18.

Espera-se que esta análise crítica dos bairros históricos Brás e Mooca tenha sido suficiente para mostrar um retrato bem próximo da atual realidade e situação em que se encontram esses bairros, para um melhor entendimento das diretrizes para requalificação urbana propostas no Capítulo VII desta dissertação.

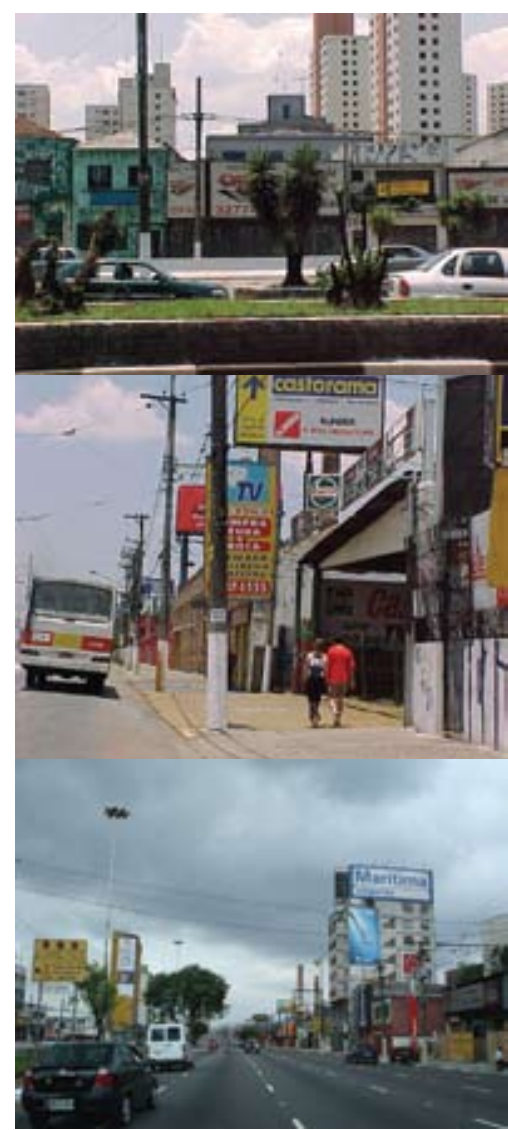

Acima

Poluição visual na Avenida alcântara Machado ou Radial Leste. Arquivo pessoal, 2003.

${ }^{7 \mid}$ Fundação SEADE.

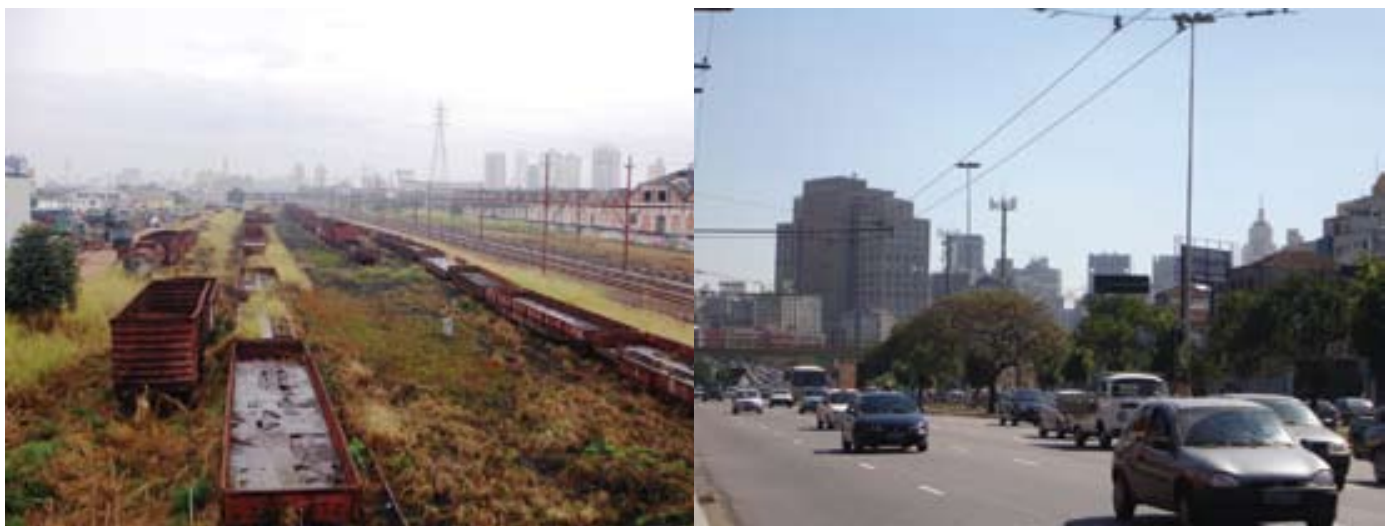

\section{À esquerda}

vagões e trilhos de ramais de carga desativados e abandonados na Ferrovia Santos-Jundiaí, no distrito industrial da Mooca.

Arquivo pessoal, 2006.

\section{À direita}

Vista da Avenida Rangel Pestana, com o Centro Histórico da cidade ao fundo. Arquivo pessoal, 2006. 
72 O índice atribuído ao Brás é de -0,50 a $-0,0$ l, nível médio em relação ao resto da cidade; o índice atribuído à Mooca baixa está classificada com o índice de 0,00 a 0,99, o $2^{\circ}$ melhor da cidade na classificação geral. Paulo: www6.prefeitura.sp.gov. $\mathrm{br} / \mathrm{sec}$ retarias/planejamento/ sp_em_numeros/000 I.
73 Site da Prefeitura Municipal de São

\subsection{O perfil sócio-ambiental}

O perfil sócio-ambiental é o resultado de um cruzamento dos fatores socioeconômicos e ambientais de um distrito que quantifica e qualifica as condições ambientais e sociais existentes no território da metrópole paulistana, com dados referentes à vegetação e clima urbanos.

A correlação dos dados ambientais e socioeconômicos justifica-se pelo caráter essencialmente urbano da cidade e pelo seu padrão desordenado de ocupação urbana, uso indevido de recursos naturais e extrema desigualdade social (Atlas Ambiental do Município de São Paulo, p.232).

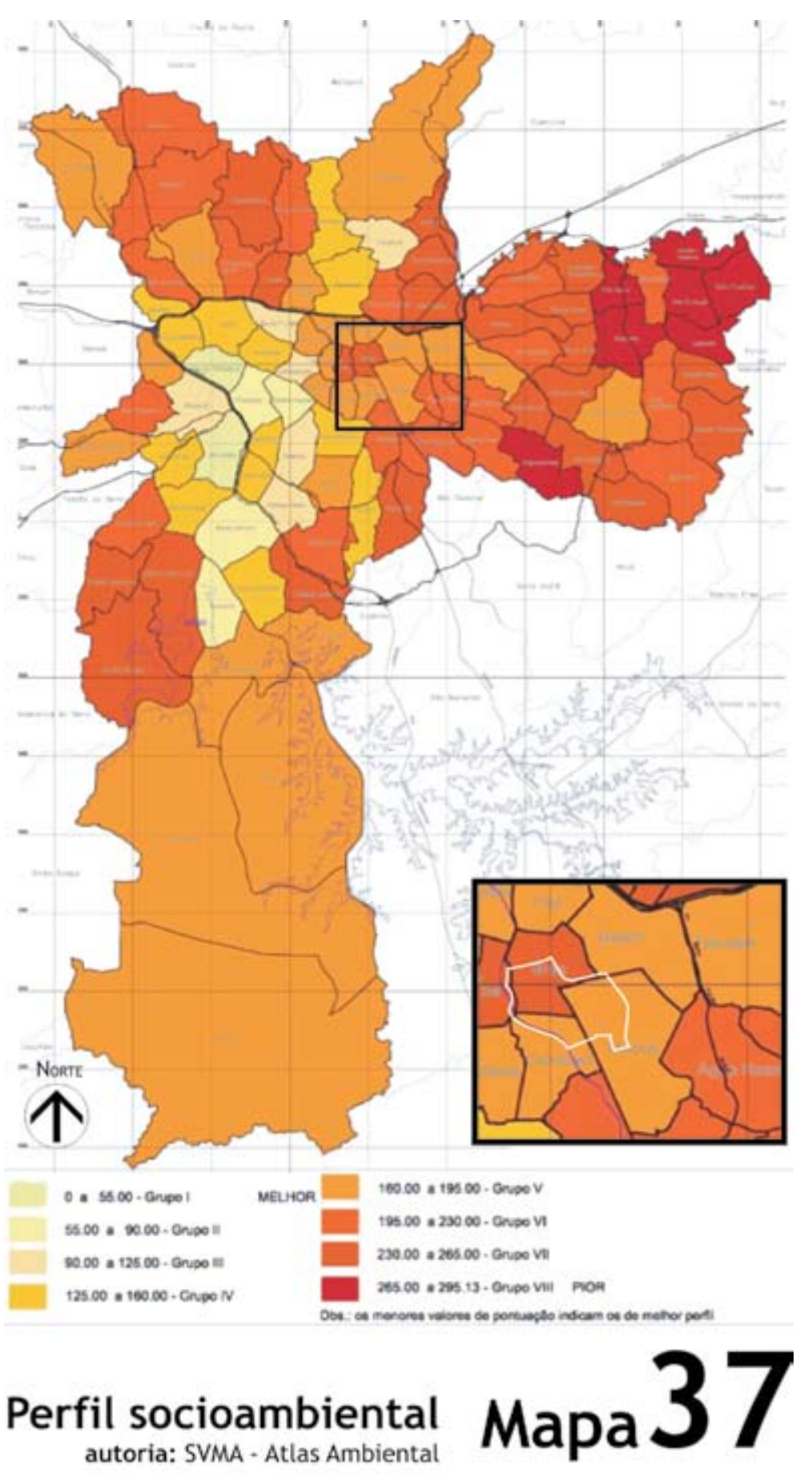

132
O mapa do perfil sócio-ambiental do Atlas da SVMA, publicado pela Prefeitura de São Paulo em 2002, nos mostra que as populações do Brás e Mooca estão classificadas em $7^{\circ}$ (grupo VII) e $5^{\circ}$ (grupo V) lugares respectivamente, na classificação de um ranking com oito posições, sendo que a melhor posição fica para a população de bairros de alta renda e com alta qualidade ambiental (bem arborizados e ventilados), como Alto de Pinheiros e Morumbi ${ }^{72}$.

Em $8^{\circ}$ lugar estão bairros como Sapopemba e Itaquera, na pior classificação da área urbana do município. Com essa baixa qualidade ambiental e, consequentemente, baixa qualidade de vida, os moradores com um pouco mais de mobilidade financeira para escolha de melhores lugares para morar contribuíram para a diminuição da população original dos bairros.

Como mencionado anteriormente, ambos os bairros tiveram decréscimo importante em seu número de habitantes, em torno de $25 \%$, nos últimos 20 anos $^{73}$. 


\section{Recuperação e tombamento de imóveis}

Após análise foram selecionados imóveis ociosos subutilizados que apresentaram potencial arquitetônico que justificasse sua recuperação e preservação combinada com a alteração de uso. Estes imóveis ou foram selecionados por possuírem valor arquitetônico ou porque apresentam qualidade estrutural ou porque apresentam área para expansão. Um exemplo disso é o edifício fabril e edifício de escritórios da metalúrgica Matarazzo, localizada à Rua Caetano Pinto, que está totalmente ocioso e que apresenta boa construção e área para ampliação de instalação para a implantação de alguma instituição púlbica.

Os imóveis selecionados (os números entre parênteses correspondem à localização destes imóveis no mapa 44) para requalificação e tombamento são:

- Edifício comercial ( I ) com área para novas consruções, Rua Dr. Almeida Lima, 1290;

- Recuperação e Requalificação com alteração de uso das Indústrias Metalúrgicas Matarazzo (2);

- Fábrica de Tecidos Labor (3 - à esquerda), Rua da Mooca, 8I 5;

- Residência (3 - à direita), Rua da Mooca, 825;

- Recuperação e tombamento com alteração de uso do edifício da Gráfica da Estação da Mooca (4), à Rua Mosenhor João Felipo.

- Recuperação sem alteração de uso da Estação da Mooca (4, sem foto), Rua Presidente Wilson;

- Cotonifício Crespi (5), fachada na Rua Javari;

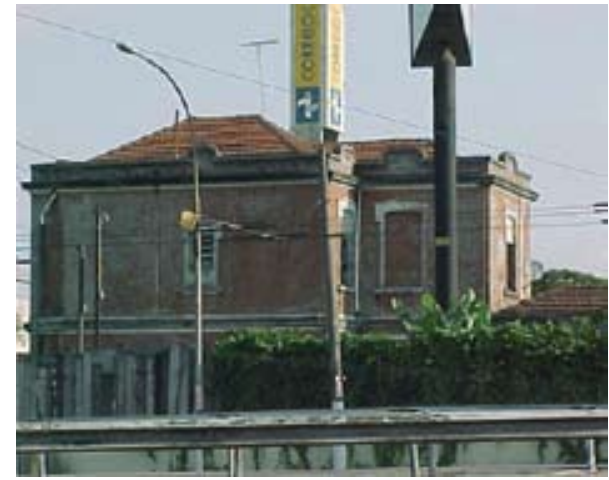

(1)

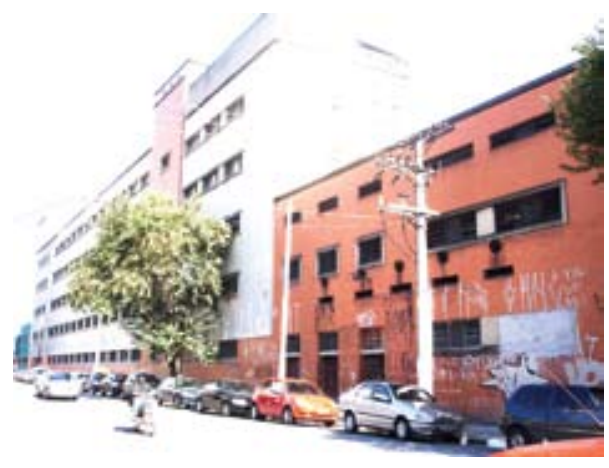

(2)

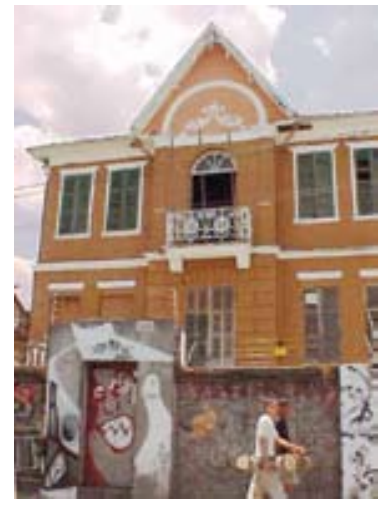

(3)

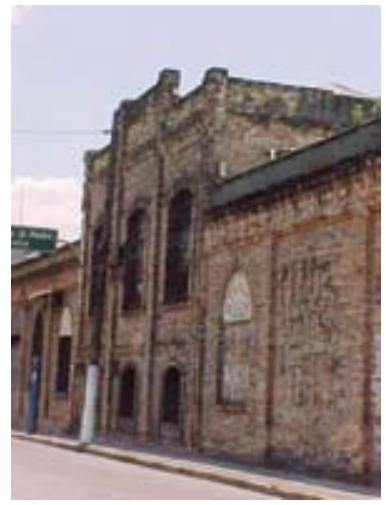

(3)

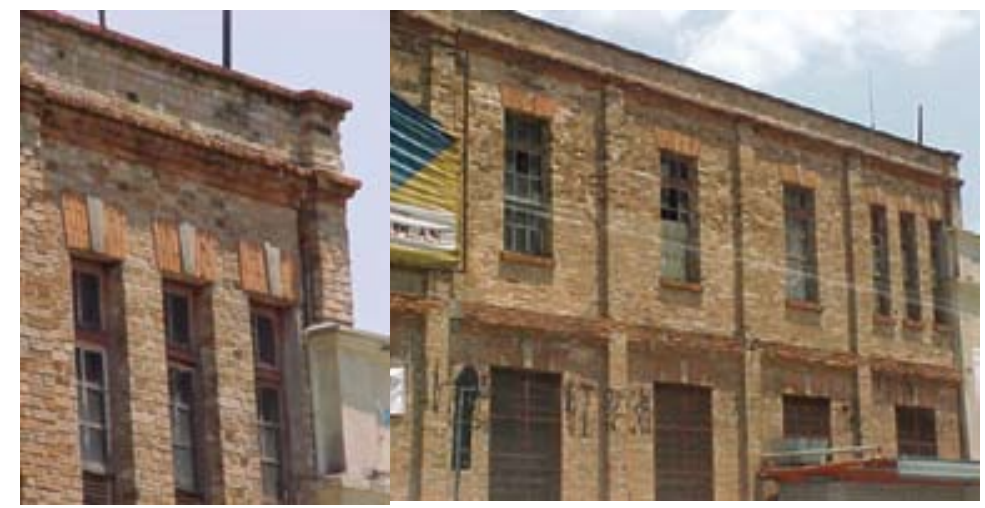

(4) 


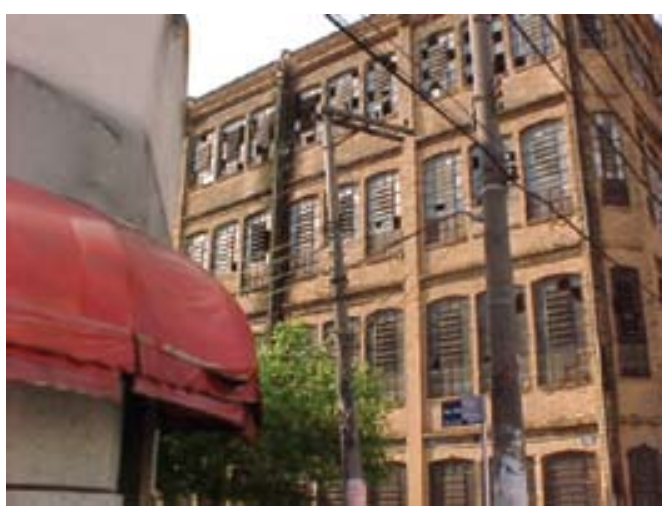

(5)

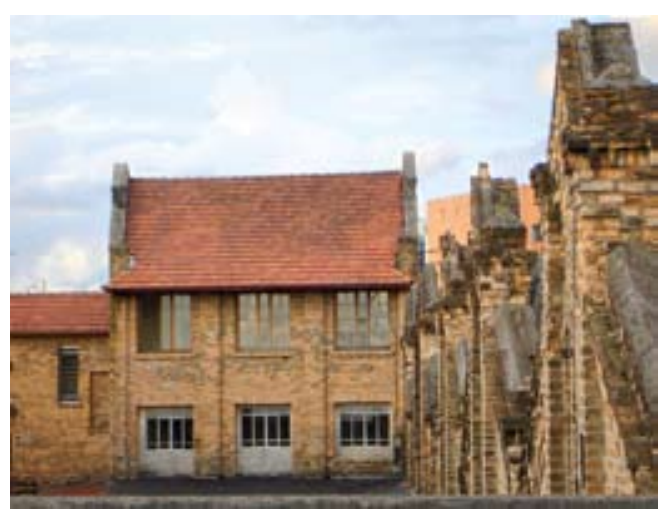

(7)

- Recuperação e tombamento para requalificação e alteração de uso de galpões industriais do fim do século do século 18 (7), à Rua da Mooca, n 7;

- Recuperação e tombamento da passarela metálica (8) para pedestres sobre a ferrovia, à Rua Visconde de Parnaíba;

- Requalificação, tombamento pelo patrimônio histórico e alteração de uso dos edifícios

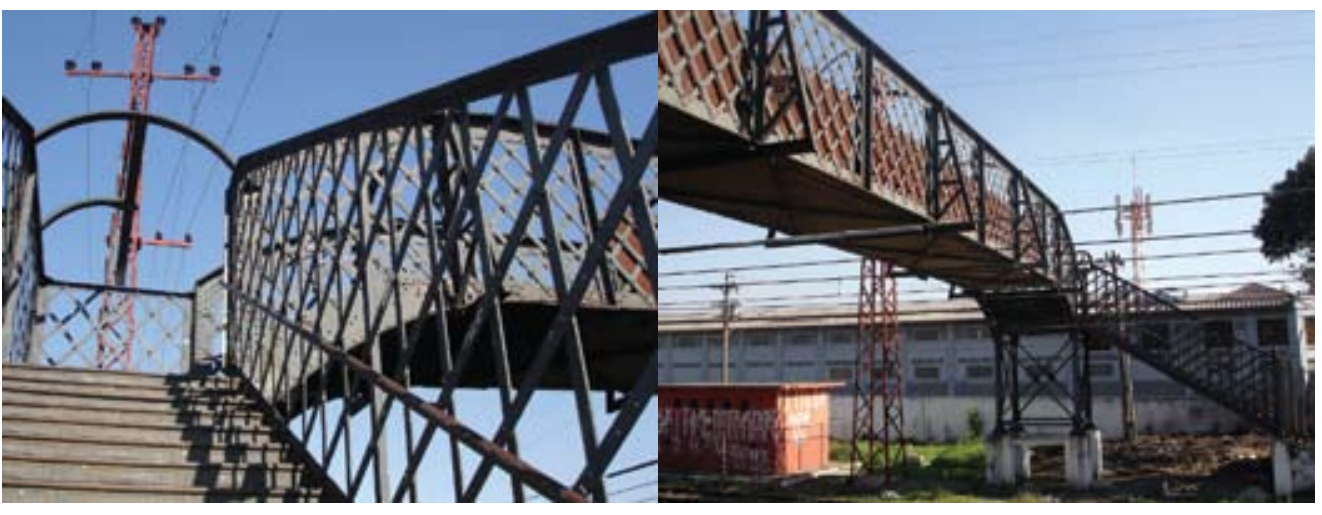

(8)

da antiga fábrica de cerveja da Cia. Antárctica (I I ), à Rua da Mooca;

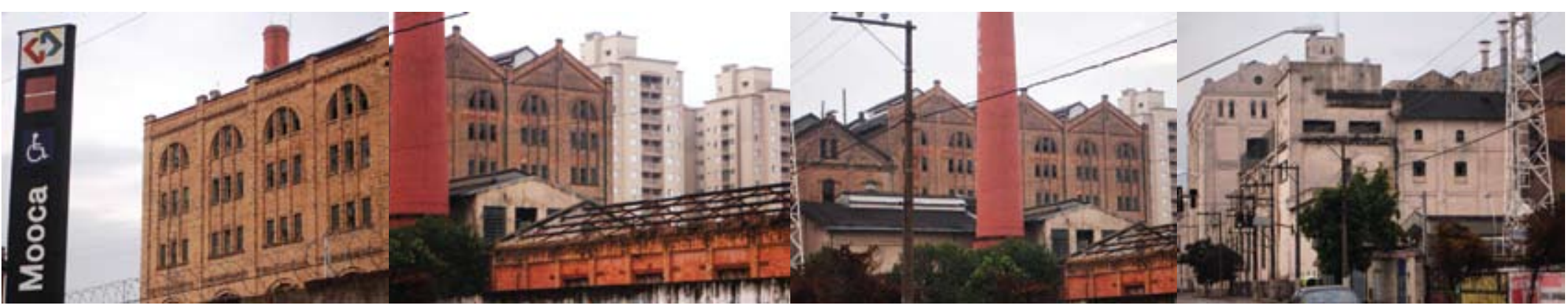




\section{Capítulo V \\ Experiências em requalificação urbana ocorridas pelo mundo}

O processo de desindustrialização das cidades deixou para trás espaços abandonados pelas indústrias, gerando desemprego e cenários de áreas decadentes com galpões industriais obsoletos ou abandonados que podem ser requalificados para novos usos, como tem acontecido em várias cidades pelo mundo.

A pesquisa para conhecimento de conceitos de desenho urbano e de experiências realizadas em processos de requalificação urbana, no panorama nacional e internacional, foi feita através de leituras e análises de casos e experiências ocorridas no Brasil e no exterior, comparando as questões urbanas abordadas para a realização desses projetos com as questões urbanas dos bairros paulistanos Brás e Mooca. No Brasil, até o momento, contamos apenas com pequenas requalifacações urbanas que, em virtude de não terem provocado alterações significativas no traçado viário e na estrutura urbana, tiveram pouco impacto no tecido urbano. Um exemplo é a requalificação do Pelourinho, em Salvador, Bahia.

Na década de 1980, surge no Reino Unido e nos EUA o urbanismo de planejamento simplificado, com áreas de desenvolvimento urbano para usos específicos, como por exemplo, para a instalação de corporações. São as Enterprise Zones (zonas empresariais), Simplified Planning Zones (zonas de planejamento simplificado), Urban Development Areas (áreas de desenvolvimento urbano), Urban Development Corporations (corporações para desenvolvimento urbano), no Reino Unido e, as DDA's - Downtown Development Authority (Comissão para desenvolvimento do centro), EDC's - Economic Development Corporations (corporações para desenvolvimento econômico), LDC's -Local Development Companies (companhias para desenvolvimento local), nos EUA. O objetivo é reverter o processo de decadência econômica em função do êxodo de atividades industriais e de atrair investimentos.

Um exemplo é o projeto Battery Park City, ao sul da ilha de Manhattan, em Nova lorque, complexo urbano formado por hotéis, edifícios corporativos, museus, parques, áreas residenciais de alto padrão e marinas, numa antiga área de docas desativadas.

Foram também analisados o projeto Antiguo Puerto Madero em Buenos Aires e a recuperação do bairro do Chiado em Lisboa, Portugal, além dos projetos London Docklands, na Inglaterra e a Vila Olímpica, em Barcelona.

$\mathrm{Na}$ maioria dos casos, trata-se de requalificação de áreas à beira do mar ou de rios, mas a similaridade destas com a área-objeto de estudo desta pesquisa está na característica de serem áreas industriais obsoletas ou degradadas. Áreas decadentes deram lugar a grandes complexos imobiliários, que representam novas centralidades urbanas dentro de uma política urbana de renovação de cunho neoliberal, com grande injeção de capital por parte do Estado.

À exceção da recuperação do Chiado em Lisboa, em todos os casos comparados se dá o fenômeno gentrification, quando a requalificação das áreas acarreta na valorização no mercado de seus imóveis e conseqüentemente acaba por ter o perfil dos moradores alterado para uma população de poder aquisitivo mais alto, fruto da prática do urbanismo de planejamento estratégico. Segundo Somek e Campos, o planejamento estratégico apresenta limitações, principalmente em relação à questão habitacional:

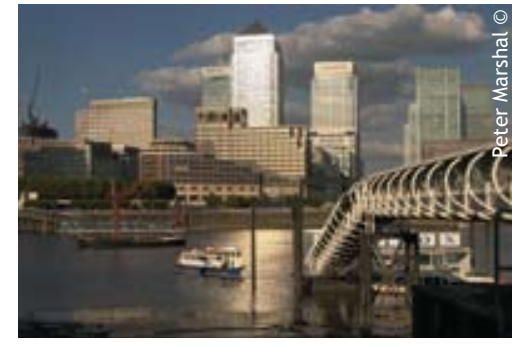

Acima

London Docklands: panorama atual. 
BATTERY PARK CITY

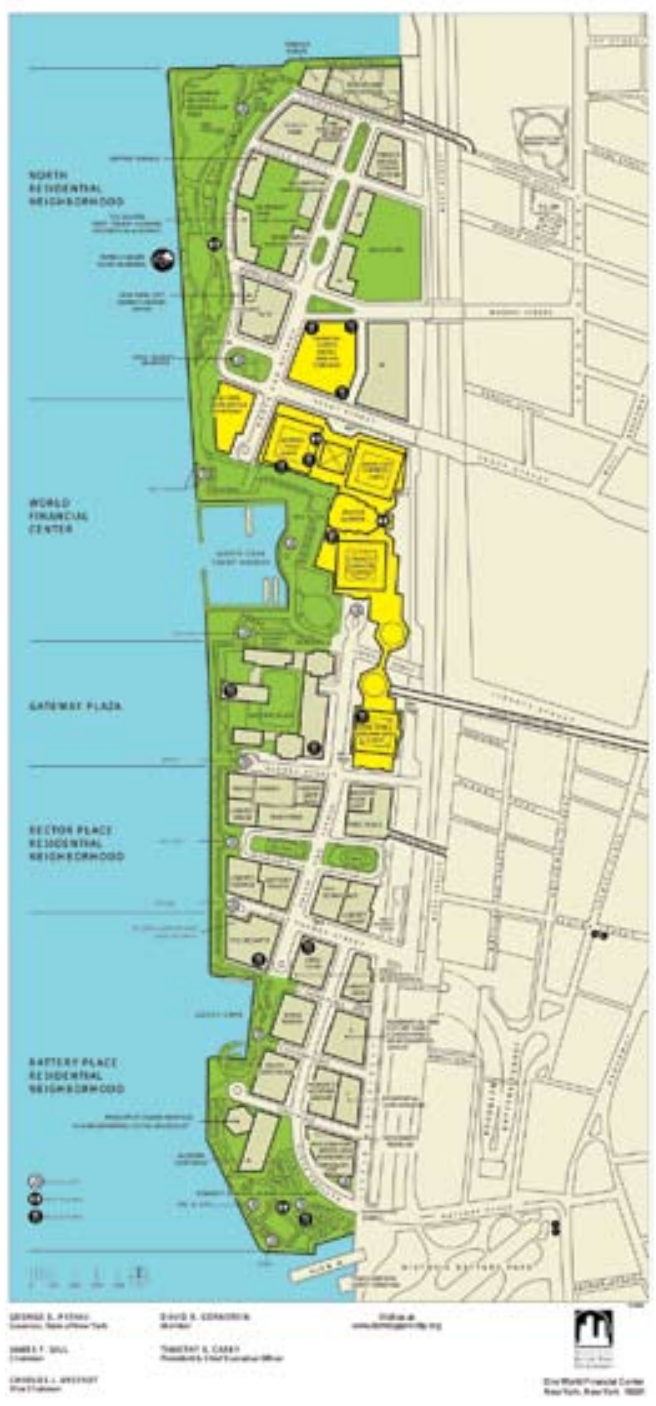

Figura 33

Masterplan.

Fonte: www.bateryparkcity.org

\begin{abstract}
No entanto, após duas décadas de grandes projetos de renovação urbana inseridos nos cenários do planejamento estratégico, evidenciam-se os limites desse modelo no que se refere a algumas das questões cruciais que haviam motivado o recurso às novas abordagens urbanísticas. Além de passar ao largo das carências habitacionais, de infra-estrutura e de serviços sociais que continuam comprometendo as regiões metropolitanas, particularmente no Terceiro Mundo, os projetos estratégicos parecem constituir uma faca de dois gumes no que se refere aos problemas da integração econômica, do desemprego e do combate à exclusão social (Nádia Somek, Cândido M. Campos Neto, 2005. Arquitextos - Vitruvius).
\end{abstract}

\section{Battery Park City - Nova lorque}

Em 1968, cria-se a Battery Park City Authority para gerenciar a recuperação das áreas degradadas nas docas de Nova lorque seu desenvolvimento urbano, numa área total de 92 acres. Em 1980, é finalizado o primeiro empreendimento residencial e, em 1985, um outro grande complexo de edifícios corporativos também, o Word Financial Center. Toda a infra-estrutura urbana necessária para o empreendimento é financiada pelo poder público.

O autor do projeto, Cooper-Eckstutt, adota os critérios de Jane Jacobs (Morte e vida das grandes cidades, 1961), como alta densidade, uso misto e pequenos parques.

\section{a. Descrição do projeto, categorias de uso e principais características}

Battery Park City está composto por setores residenciais, comerciais, culturais e por parques e áreas verdes. Uma das características do projeto é ter preservado o traçado viário das ruas que tinham acesso às docas, costurando o novo traçado ao antigo.

\section{- Uso residencial}

Battery Park City possui cinco setores de edifícios exclusivamente residenciais. Os empreendimentos residenciais são de alto padrão, com vista para o mar e dotados de dispositivos e os mais recentes contam com um conjunto de normas ecológicas próprio, as Green Guidelines (diretrizes ecológicas). Um dos complexos residenciais foi destinado para habitantes da terceira idade, com projeto adequado a esse tipo de morador.

\section{- Comercial}

O complexo Word Financial Center é o principal conjunto de edifícios comerciais. As construções foram finalizadas em 1986 e ocupadas por grandes multinacionais. Outros edifícios comerciais e de serviços continuam a surgir. Além dos edifícios de usos exclusivamente corporativos ou residenciais, são construídos também edifícios de uso misto com acessos independentes.

\section{- Museus, parques e áreas verdes}

A legislação própria do projeto estabeleceu que 30\% da área total fosse reservada para áreas verdes ou livres, sem possibilidade de futuras construções. Dentro da área do Battery Park City existem I 4 parques e playgrounds públicos, num total de 32 acres, mantidos por empresa privada sem fins lucrativos desde 1988. A manutenção das áreas livres é custeada pelos empreendedores imobiliários, pelos residentes e pelos condomínios residenciais e comerciais, sem custos para a municipalidade. Os parques de Battery Park City fazem parte da rede oficial de parques e playgrounds de Nova lorque. Além de vários museus, a programação cultural dos parques e áreas livres ocorre durante o ano todo para habitantes de todas as idades. 


\section{London Docklands}

Uma grande área de docas e instalações portuárias, ao longo do Rio Tamisa na cidade de Londres, Inglaterra, foi objeto de grande processo de requalificação urbana em decorrência de grave degradação urbana, ambiental e econômica em função da desindustrialização ocorrida em várias cidades pelo mundo. $O$ fechamento das docas na década de 1970 foi o fator principal dentro do processo de decadência urbana.

Em meados da década de 1930, as Docklands estavam em seu auge, com um fluxo de manipulação de carga anual de mais de 35 milhões da toneladas, transportadas por 55 mil viagens de navio e empregando mais de 30 mil trabalhadores.

Por uma série de razões como, mercado, administração e tecnologia, a prosperidade do porto caiu em dramático declínio, quando o governo começou a considerar as implicações e conseqüências de seu possível fechamento.

Em 1962, um comitê liderado pelo Visconde Rochdale conduziu uma pesquisa sobre a eficiência dos portos da Gran Bretanha (Commission for the New Towns. Initiating Urban Change - London Docklands Before the LDDC. Monografia LDDC Publications, 1997. English Partnerships copyright).

Entre os anos de 197| e 1981, a população de Londres caiu 20\% e entre 1978 e 1983, mais de 12 mil postos de trabalho foram perdidos chegando a um índice de desemprego de 17,8\%. Nesse mesmo ano, 60\% da área e imóveis de Docklands estavam abandonados, vazios ou subutilizados. Esses fatos e o fechamento das docas atingiram a economia de Londres. O perfil profissional da população local não era apropriado para que essa mão-de-obra pudesse ser absorvida pelas outras áreas de economia crescente em Londres e a difícil ligação entre Docklands e o resto de Londres e do país trazia custos adicionais aos empregadores (Commission for the New Towns: Regeneration Statement. Monografia LDDC Publications, 1998. English Partnerships copyright).

Em 1980, um decreto determina a criação de um órgão de desenvolvimento para assegurar a recuperação dessa área, dando às áreas e construções abandonadas, ou seja, os vazios urbanos, efetivo uso. A recuperação da área de 8,5 milhas quadradas no setor leste de Londres passa a ser responsabilidade da empresa LDDC - London Docklands Development Corporation, uma empresa autônoma de desenvolvimento urbano, criada pela Secretaria de Estado para o Meio Ambiente. O objetivo era assegurar a recuperação urbana da área para combater a grande queda na economia da região a partir do progressivo fechamento das docas a partir da década de 1960 (Commission for the New Towns: A strategy for regeneration. Monografia. LDCC Publications, 1997. English Partnerships copyright).

Os fatores abaixo, ou a combinação deles, estimularam a criação da empresa London Docklands Development Corporation:

Uma grande parte da área era de propriedade de organismos públicos, que não tinham nem intenção nem verba para promover sua requalificação, e não despertava interesse do mercado imobiliário;

O grau de abandono em determinadas áreas de Docklands era tão grave, que os altos custos para reurbanização desencorajava os investidores e foi necessário uma intervenção externa para buscar recursos para viabilizar a recuperação e estimular promotores imobiliários;

Muitas áreas não possuíam boa rede de infra-estrutura de serviços, essencial para seu desenvolvimento. A atuação isolada do mercado imobiliário não tinha condições de prover controle ambiental ou infra-estrutura urbana, essenciais para reverter a imagem decadente e tornar o local atrativo para viver e implantar negócios;

A quase completa ausência de residências particulares na área durante anos dificultava a avaliação, por parte dos promotores imobiliários, do potencial de retorno financeiro

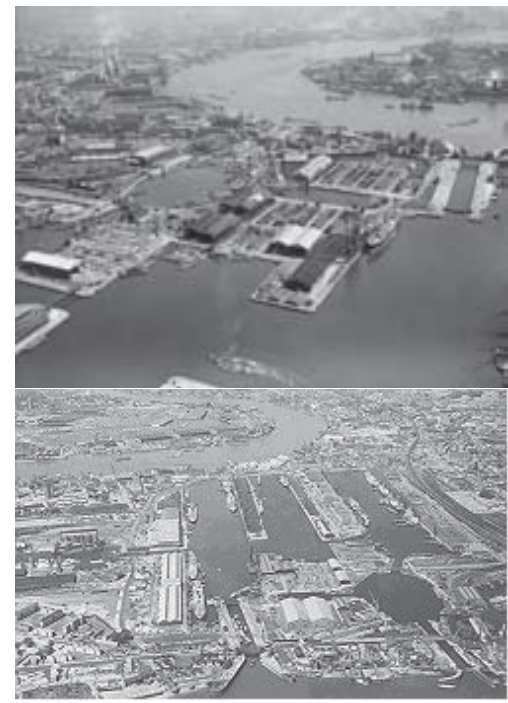

West India Docks,

Superior, em 1956

Acima, em 1967

Abaixo

Upper docks lookins east, 1966.

Fonte: www.lddc-history.org.uk

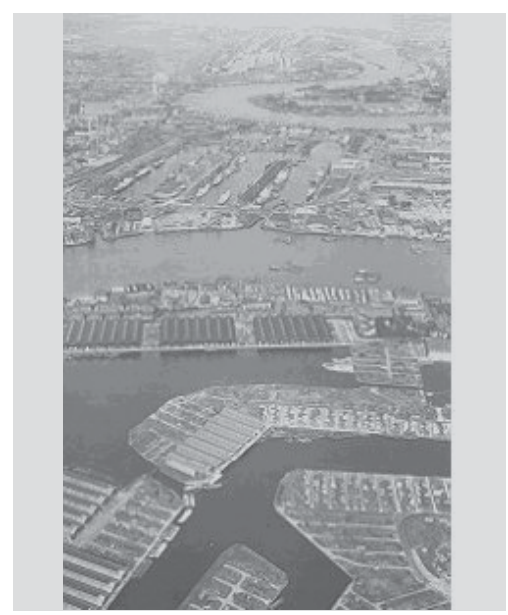


Figura 34

Áreas abandonadas e superfície de água em 1981.

Fonte: Commission for the New Towns: A strategy for regeneration.

Fonte: Monografia. LDDC Publications, 1997, English Partnerships copyright.

\section{Figura 35}

Áreas objetos de reurbanização em

London Docklands.

Fonte: www.lddc-history.org.

uk - copyright of Stuart Innes of IJP Community Regeneration.

Figura 36

The royals - Desenvolvimento estrutural.

Fonte: www.lddc-history.org.uk das novas incorporações imobiliárias, aumentando o grau de risco dos investidores (Commission for the New Towns: A strategy for regeneration - Monografia Londres, LDCC, 1997)

\section{a. Descrição e principais características do projeto}

Os sete setores que compõem a área total de London Docklands estão localizados às margens do Rio Tamisa, intercalados pelos meandros desse rio. A área total é de $22 \mathrm{~km}^{2}$. O maior desses setores é Isle of Dogs e o menor, Bermondsey Riverside. A área total de terrenos e superfície de água chega a 879 hectares e está subdividida em 168 hectares de superfície de água, 222 hectares de áreas comuns para sistemas viários e áreas verdes e 489 hectares de área vendida para desenvolvimento.

A reurbanização completa de London Docklands levou 12 anos e foi iniciada em 1982, com a requalificação do setor Limehouse e finalizada em 1994, com a requalificação de Isle of Dogs.

\section{b. O traçado viário e estrutura urbana}

Observando-se a foto ao lado, pode-se concluir que o traçado viário dos setores de Docklands antes da reurbanização era formado por vias de acesso às docas, basicamente. O tecido urbano é complementado e caracterizado pelas grandes áreas e lotes, com galpões e instalações portuárias, entremeados de água. Algumas vezes as vias formam traçado ortogonal em pequenas áreas, com uma via central e lotes à esquerda e à direita. Os 7 setores que compõem as London Docklands não dispunham de acessibilidade nem transporte público entre eles e com o centro ou o resto da cidade de Londres.

\section{c. Propostas para a reurbanização}

Foram selecionados três exemplos de propostas para a reurbanização das London Docklands: Isle of Dogs, Royal Docks e Limehouse, onde ocorreram várias intervenções viárias, tendo sido necessário desapropriar as residências de habitantes locais, que foram realocados em moradias reformadas.

\section{- The Royal Docks}

A figura ao lado mostra o mapa de usos que fez parte do projeto de reurbanização de Royal Docks, onde está localizado o aeroporto. A proposta determina a localização das áreas residenciais existentes e propostas, as áreas de recreação, os espaços abertos, equipamentos e instalações urbanas, os setores industriais e comerciais e as zonas de desenvolvimento urbano.
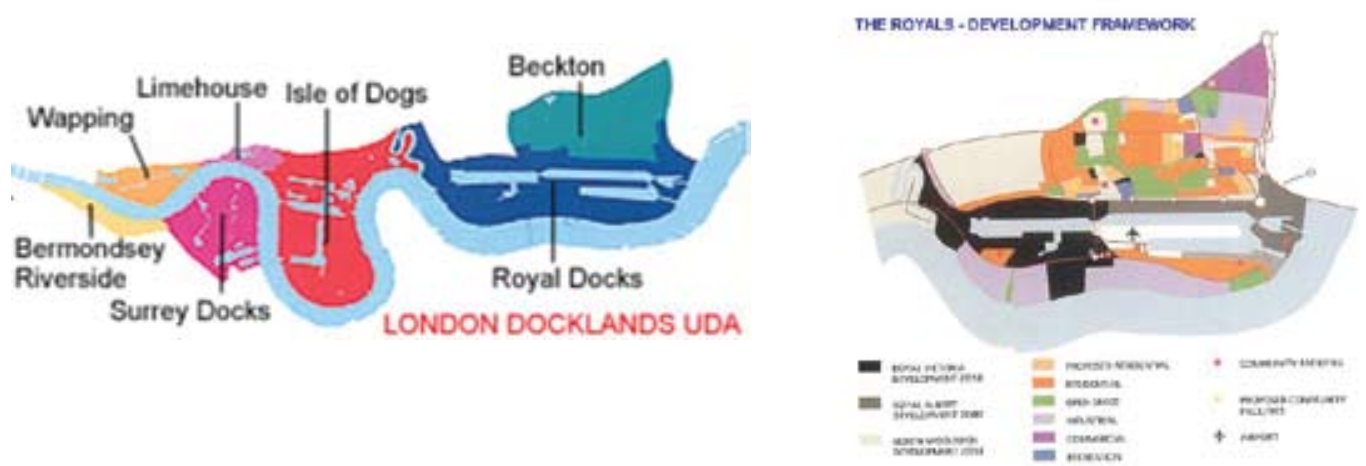

Figura 36

Figura 35

Figura 34 
- Isle of Dogs

Isle of Dogs é uma península, cujo solo original era formado por brejos que foram drenados no século XIII, habitada então por uma comunidade de pequenos agricultores. Em I448, o aterro que separava a terra do rio foi rompido abruptamente e a terra voltou a ser brejo, comprometendo o meio de vida dos habitantes.

A proposta de desenho urbano não altera radicalmente o traçado viário irregular em /s/e of Dogs e propõe muitos pontos com vista atrativa, perspectivas longitudinais amplas das docas e da superfície de água entre elas e eixos de vista panorâmica.

\section{- Limehouse}

No setor de Limehouse, a malha urbana de traçado irregular é mantida em parte da área. São abertos e reformulados acessos, vias para automóveis e vias para pedestres aumentando a mobilidade entre os sete setores de Docklands. São criados marcos referenciais, vistas panorâmicas e duas novas centralidades locais. São propostas áreas de conservação, bem como espaços abertos temporários até futuras ocupações.

\section{d. Sistemas viários em Docklands}

Onde há 17 anos havia somente uma via de alto tráfego, existe hoje uma rede composta por vias de 4 pistas, vias existentes reformuladas, uma via expressa principal, dois túneis cruzando o rio Tamisa, trem metropolitano aéreo (DLR - Docklands Ligth Railway), um aeroporto localizado em Royal Docks e redes de ônibus. Os vários modais viários permitem hoje que 85.000 pessoas trabalhem na região.

\section{e. Preservação}

Entre os anos de 1960 e 1970, a herança arquitetônica representada por muitos edifícios do início e meados do século 19 foi ignorada em virtude da demolição sumária desses edifícios. Essa era a política do pós-guerra que, junto com programas habitacionais para eliminar moradias precárias, atuava ignorando qualquer tipo de continuidade ou contexto do tecido urbano existente. Somente no fim da década de 1960 é que o erro começa a ser reparado com a criação de uma legislação que passou a reconhecer e valorizar a importância da preservação dos imóveis com valor arquitetônico e da provisão de moradia (Commission for the New Towns: A strategy for regeneration. Monografia. LDDC Publications, 1997. English Partnerships copyright).

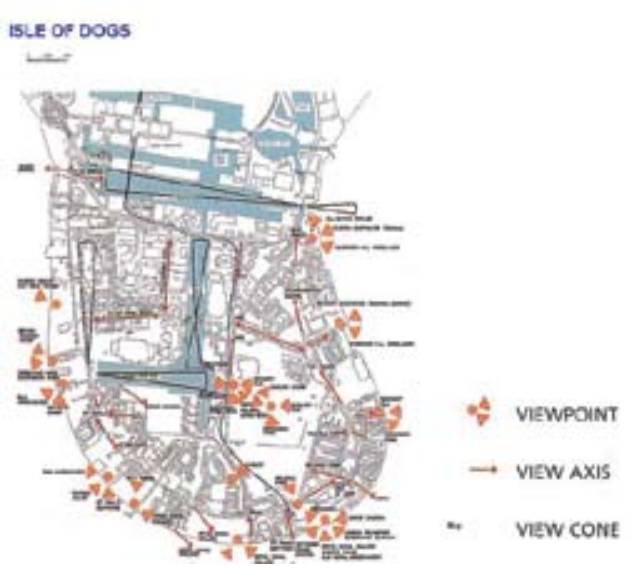

Figura 36

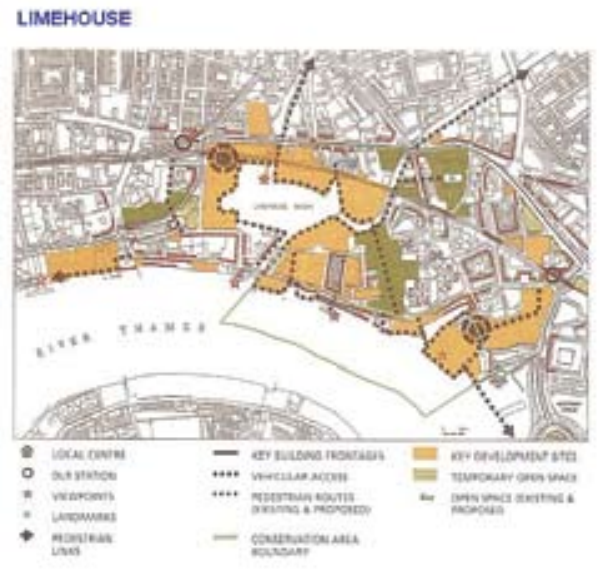

Figura 37

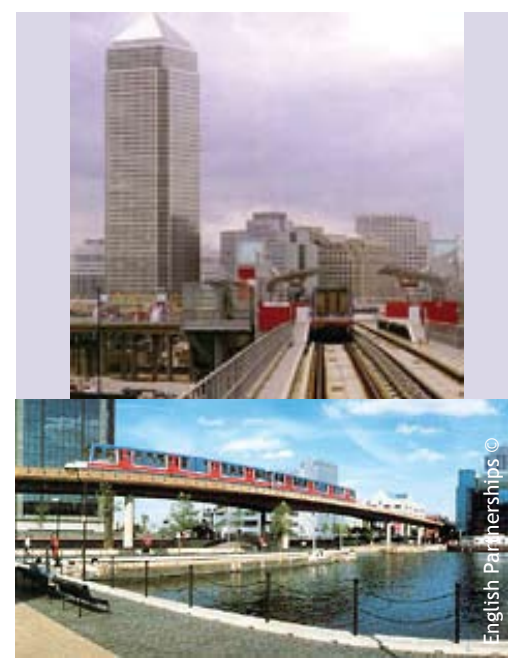

Acima

DLR - Docklands Light Railway, Trem aéreo, em 1982, na inauguração, e em 1997.

Fonte: LDDC Publications, 1997.

\section{Abaixo}

South Quay Footbridge

Fonte: Commission for the New

Towns: Isle of Dogs. Monografia. LDDC Publications, 1997.

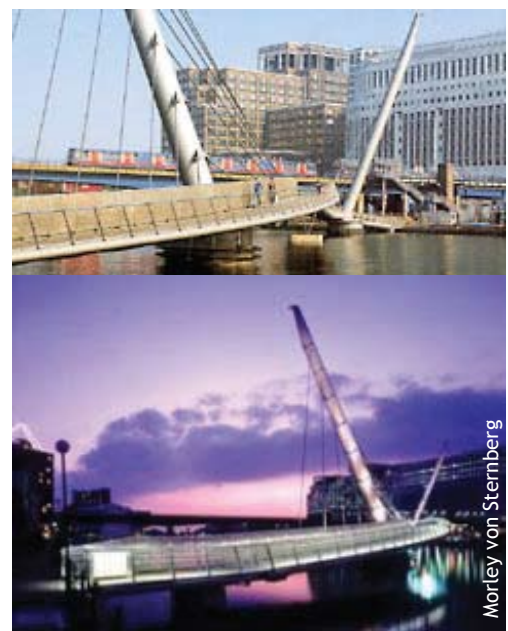

Figura 37

Isle of Dogs.

Figura 38

Ilustração da posição do setor Limehouse.

Fonte: Commission for the New Towns: A strategy for regeneration. Monografia. LDDC Publications, 1997, English Partnerships copyright. 


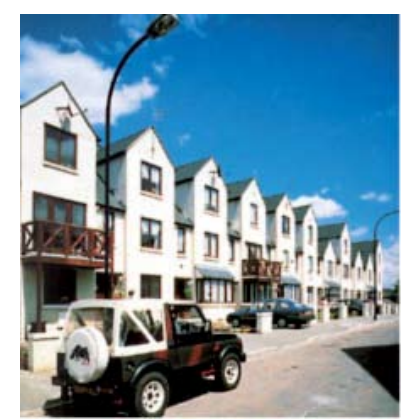

À esquerda

Residências unifamiliares de dois pavimentos.

\section{Ao centro}

Habitações sociais em Surrey Docks antes e depois da reforma.

\section{À direita}

Edifício residencial Surrey Docks antes e depois da recuperação.

Fonte: Commission for the New Towns: A strategy for regeneration. Monografia. LDDC Publications, 1997, English Partnerships copyright.
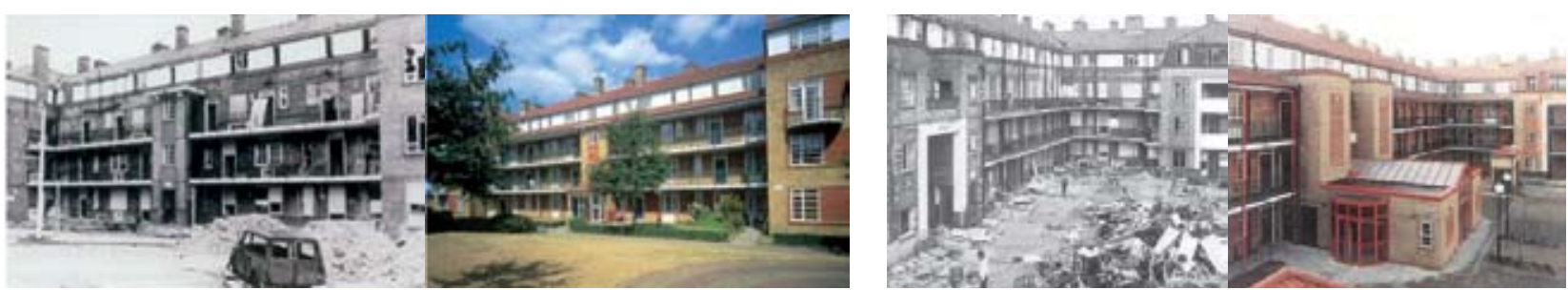

Em 1982, a LDDC solicitou à Secretaria de Estado um cadastramento dos edifícios existentes em Docklands, o que resultou em mais 1 I 6 edifícios adicionados à lista anterior de 210. Iniciou-se então um intenso programa de recuperação desse patrimônio, adicionando mais 18 áreas oficiais de conservação às 10 anteriores.

\section{f. Usos e ocupação do solo}

- Residencial

Em 198I a oferta de moradia na área ficava abaixo da demanda e era de baixa qualidade, sendo que $9.1 \%$ das moradias estavam superlotadas, $20 \%$ eram consideradas inabitáveis, $95 \%$ de moradias eram alugadas e $5 \%$ de casas próprias.

O estoque de moradias em 198I era de 15.000 unidades e, em 1998, mais de 24 mil moradias haviam sido entregues, sendo 17.700 ocupadas pelos proprietários, 5.300 para associações e 1.000 para as autoridades locais. Foram construídas mais de 2.000 moradias sociais e 8.000 moradias existentes foram reformadas.

A proporção de proprietários residenciais passou de $5 \%$ para $45 \%$, ainda abaixo da média londrina (Commission for the New Towns: Regeneration Statement. Monografia. LDDC Publications, 1998).

Segundo dados da LDDC, entre 198 I e 1998 foram construídas 2029 e reformadas 7973 habitações sociais. Considerando-se a população total da área de 83.000 habitantes e uma média de quatro pessoas por família, o total de habitações sociais novas e reformadas juntas atendeu a quase $50 \%$ da demanda por habitação.

- Comércio e Serviços

A destinação de 195 hectares na ilha Dogs como zona comercial isenta de pagamento de impostos por 10 anos, entre 1982 e 1992, foi o estímulo necessário para a criação de mercado imobiliário de 0 I milhão de metros quadrados de escritórios em Docklands. Isso atraiu investimentos e negócios internacionais e formou um novo bairro de negócios em Londres, tendo o empreendimento Canary Warf como peça central, com total de 0,8 milhões de metros quadrados de área construída.

- Cultural, institucional e lazer

Antes da requalificação urbana não havia cinemas na área, apenas pequenos centros comerciais. A vida comunitária se resumia, em grande parte, à freqüência de igrejas, centros comunitários, escolas e a um grande número de pubs.

Segundo o relatório Travers Morgan de 1973 e o Plano Estratégico para Docklands, de 1976, preparado pelo DJC (Docklands Joint Commitee), a área necessitava de espaços abertos, centros de compras e de entretenimento, campos para prática de esportes e acesso ao rio.

Das verbas de investimento, 7\% foram destinados para infra-estrutura e equipamentos comunitários. Desse total de investimentos, aproximadamente 50\% foram aplicados em educação e treinamento e o restante em saúde e outras atividades. Foram instaladas na área duas escolas de nível superior, 12 escolas de ensino elementar, ampliação e modernização de outras 17 escolas, construção de duas novas escolas de ensino médio, construção de 5 
centros de saúde e a reforma de outros 6 já existentes, mais creches e outras instalações de uso social (Commission for the New Towns: Regeneration Statement. Monografia. LDDC Publications, 1998 - English Partners copyright).

\section{g. Tipologias arquitetônicas em Docklands}

Além das igrejas preservadas do século 17 e os edifícios comerciais de arquitetura vanguardista de Canary Warfh, muitas tipologias diferentes compõem o panorama arquitetônico dos diversos setores de Docklands. Altos edifícios residenciais pós-modernos e conjuntos residenciais compostos por moradias de dois pavimentos com fachadas de tijolos escuros aparentes, tipicamente inglesas, demonstram o grande contraste tipológico e morfológico surgidos em conseqüência da reurbanização da área.

Especificamente em Isle of Dogs, o empreendimento de serviços Canary Warth, uma torre envidraçada de escritórios de arquitetura arrojada, se contrapõem à construção também de uso comercial ao seu lado, bem mais baixa e com indecifrável fachada de arquitetura eclética.

\section{h. Meio ambiente}

Os espaços vazios entre as docas foram transformados em áreas livres abertas ao público. Os $6 \mathrm{~km}$ de fachada para a água em 198I se transformaram em $59 \mathrm{~km}$ em 1998, minimizando o efeito barreira anterior com passeios elegantes e instalações náuticas em todas as docas. Também foi criado um parque ecológico e um santuário de aves selvagens, dentro da política de prover habitats de vida selvagem. Foram plantadas 160.000 árvores (Commission for the New Towns. Regeneration statement. Monografia. LDDC Publications, 1998 - English Partnerships copyright).

\section{i. Perfil sócio-econômico}

Antes da reurbanização, 95\% dos habitantes viviam em casas alugadas e aproximadamente dois terços desses habitantes não possuía automóvel. A proporção de trabalhadores semiespecializados e não especializados, de $36 \%$ sobre o total, era mais alta que no resto de Londres, de $11 \%$. O índice de desemprego entre trabalhadores do sexo masculino era de 20\%, com uma perda de 8.500 empregos nos cinco anos até 1981 .

A região tinha uma grande concentração de minorias étnicas, formada por paquistaneses, caribenhos, africanos e indianos, chegando a 42\% da população em Newham e a 36\% em Tower Hamlet (Commission for the New Towns: Learning to live and work together. Monografia. LDDC Publications, 1998. English Partnerships copyright).

Com o crescimento do nível de empregabilidade, a população aumentou de 39.400 habitantes em 1981 para 83.000 em 1998, sendo que 85.000 pessoas trabalham em London Docklands. (Commission for the New Towns: Regeneration Statement. Monografia. LDDC Publications, 1998 - English Partnerships copyright).

\section{j. Críticas}

Sem dúvida, a qualidade urbanística resultante da requalificação urbana de London Docklands, com ressalvas a algumas novas tipologias arquitetônicas ali inseridas, mostra um saldo positivo no balanço entre o que era em | 981, uma imensa área totalmente abandonada e vazia e, a transformação ocorrida até 1998.
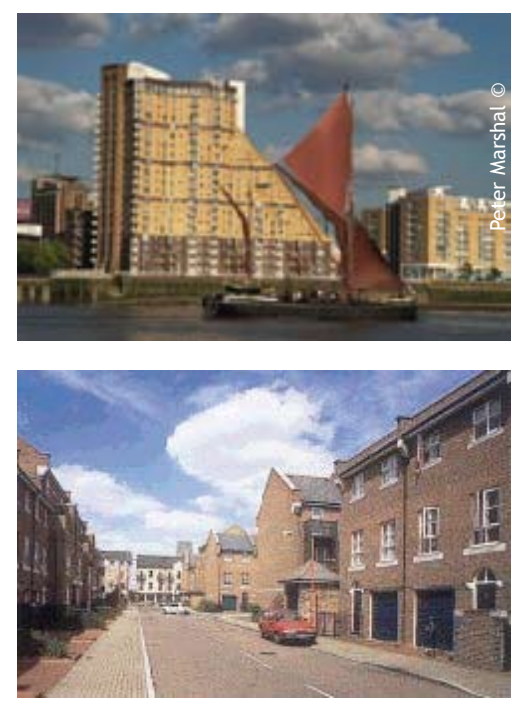

Acima

Cascades: novo edifício residêncial.

Abaixo

Residências unifamiliares para

realocação de famílias desapropriadas em Limehouse.

Fonte: LDDC Publications, 1998 


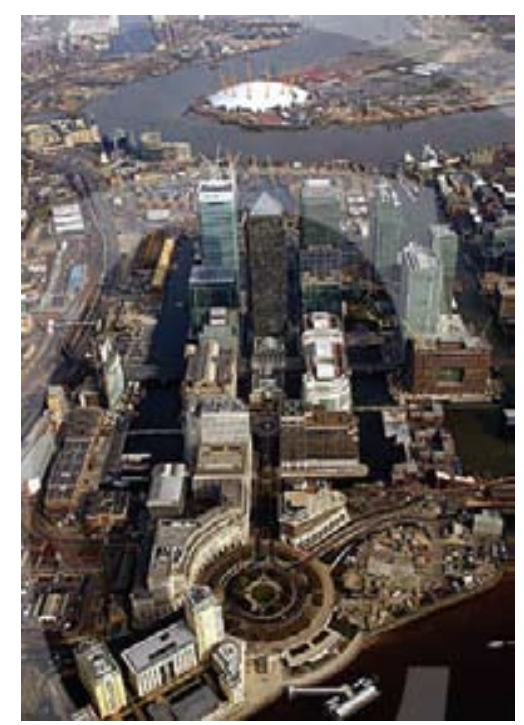

Abaixo

Vista aérea de Canary Wharf (Isle of dogs).

Fonte: LDDC Publications, 2003.
Mas, a inevitável "gentrificação" (do inglês, gentrification), a supervalorização imobiliária que triplicou os preços dos imóveis residenciais existentes e reformados, pode ser considerada saldo positivo nesse balanço? Onde estão os antigos moradores de várias etnias como indianos, paquistaneses, caribenhos e africanos?

Segundo George Nicholson (1989), existe pouco para comemorar em London Docklands, nas áreas de habitação, geração de emprego e democracia, até mesmo para os proprietários de terras. Segundo o autor, a demanda na área era principalmente por pequenas residências públicas para aluguel, tornando necessária a construção de novas unidades, não somente a modernização das existentes. O plano estratégico previa a construção de 23.000 novas moradias, subdivididas em $50 \%$ para locação, $20 \%$ a serem ocupados pelos proprietários e $30 \%$ a serem divididas equitativamente.

Contrariando o plano estratégico e, baseados na inexistência de um órgão oficial incumbido da produção de moradias, a administração da LDDC alterou esse objetivo radicalmente e $80 \%$ das casas construídas foram postas à venda. Conseqüentemente, os moradores não tiveram condições econômicas para adquirir as novas residências. Em função de não ter sido considerado o perfil do morador da região e sim um modelo nacional, existia em 1989 uma grande oferta de pequenas moradias e escassez de habitações familiares. A solução apontada seria ocupar as áreas hoje ocupadas pela água para gerar terrenos onde construir moradias populares e atender à demanda (Nicholson, 1989).

Até 1989, o índice de desemprego em Docklands ainda era um dos mais altos de Londres (I $5 \%)$ e as diretrizes propostas para a manutenção da indústria e comércio existentes foram também negligenciadas. $\bigcirc$ estímulo à construção de novos empreendimentos para escritórios tinha prioridade "3", mas na prática ocorreu o contrário: as indústrias existentes, classificadas como "em processo de extinção" foram encorajadas a deixar as Docklands ou foram fechadas e tiveram seus imóveis colocados à disposição do mercado imobiliário, para especulação e posterior construção de empreendimentos residenciais, principalmente. Até 1987, 7.877 postos de trabalho foram criados na área da LDDC, dos quais, 5.059 foram transferidos de outras regiões e 2.838, novos postos. Não somente as casas estavam sendo ocupadas por pessoas de outras regiões, como os empregos também (Nicholson, 1989).

Ainda segundo Nicholson, atipicamente para um país europeu, a democracia também ficou à margem, em função da LDDC tomar decisões "a portas fechadas" quanto aos destinos e decisões em respeito aos problemas e demandas das Docklands, apesar das muitas reivindicações da população local, sem levar a nenhum resultado ou mudanças de comportamento por parte da LDDC.

Também os proprietários de terras foram lesados quando suas terras foram compradas pelo valor de 20 mil libras o acre e revendidas por um valor quase 100 vezes mais para a construção de condomínios de casas de alto luxo, o que os fez sentirem-se à margem do lucro e da especulação (Nicholson, 1989).

A LDDC e a zona empresarial receberam subsídios públicos no valor de 700 milhões de libras esterlinas de 1981 a 1989, enquanto que no mesmo período, as associações de bairro e conselhos locais tiveram suas verbas públicas drasticamente cortadas, gerando atraso em manutenção e infra-estrutura básica e serviços sociais. O nível das verbas públicas, disponibilizadas para a LDDC excederam em muito o inicialmente disponível para as autoridades locais e permitiu à LDDC oferecer um leque de incentivos e subsídios para o desenvolvimento, incluindo terra barata e provisão de infra-estrutura. Um bom exemplo disso foi a zona empresarial de Isle of Dogs, onde a área total de escritórios do empreendimento Canary Wharf, de aproximadamente I,4 milhão de metros quadrados, custou ao governo bem acima de 500 milhões de libras esterlinas em subsídios (Nicholson, 1989).

Nicholson considera que o sucesso da LDDC tem sido superficial, com ganhadores e perdedores, obviamente. 
Provavelmente, os antigos moradores das diversas etnias ainda se encontrem, em parte, residindo em Docklands, mas muitos deles terão se mudado em busca de moradia mais barata.

\section{Vila Olímpica de Barcelona}

A cidade de Barcelona, capital da Província da Catalunha, Espanha, foi laboratório de reurbanização de seu espaço a partir de três eventos de importância internacional:

- Exposição Universal de 1888, que promoveu a consolidação do setor leste da cidade do Ensanche de Cerdá;

- Exposição Internacional de 1929, que expandiu a cidade em direção oeste e,

- Os Jogos Olímpicos de 1992, que devolveram à cidade sua fachada marítima, anteriormente bloqueada pela zona industrial ali instalada, formada por galpões e linhas férreas.

Na década de 1980, são iniciadas em Barcelona algumas obras pontuais de reurbanização, como resultado da opção pelo urbanismo estratégico adotado pelo arquiteto Oriol Bohigas, responsável pelo departamento de urbanismo da cidade. Essas ações eram focos de recuperação expansiva, numa estratégia de redefinição do âmbito coletivo a partir do espaço

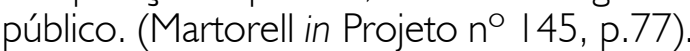

Em 1986, a nova redação do Plano Geral Metropolitano, de autoria do arquiteto Luis Cantallops, incorpora o Plano Especial de Ordenação da Fachada do Mar, dos arquitetos Martorell, Bohigas, Mackay e Puigdomenèch. A proposta visa a urbanização de aproximadamente I 30 ha, dos quais 46,7 correspondem à Vila Olímpica (Projeto n |45, p.30).

O alto grau de complexidade dessa operação urbanística, aliado à exigüidade de tempo, implicou a criação de uma estrutura intrincada que viabilizasse a gestão do plano. Para isso são utilizados os aportes técnico, gerencial e financeiro de empresas públicas dos diversos níveis governamentais, empresas mistas e privadas, em uma distribuição de competência até então inédita na Espanha. (Zein, in. Projeto no 145, p.28).

Para que o plano da nova frente marítima de Barcelona pudesse ser implementado foi criada a Vila Olímpica S/A, empresa privada com capital municipal encarregada de atuar com a agilidade de qualquer empresa privada tanto na gestão do projeto quanto na busca de financiamento para as obras de infra-estrutura. (Martorell in Projeto n 145, p.79).

\section{a. Diretrizes de projeto para a Vila Olímpica de Barcelona}

Para assegurar a configuração do espaço público e as diretrizes conceituais da forma arquitetônica, a organização do bairro se dá com a subdivisão do espaço em 34 "unidades de projeto", incluindo os blocos residenciais, os edifícios para serviços, comércio e lazer e os grandes eixos de espaços públicos.

O plano distingue três níveis de controle sobre os futuros projetos resultantes: os elementos a serem projetados de acordo com as propostas do plano; os cinco edifícios portais, destacados como marcos ou portais de acesso aos recintos interiores das superquadras, sem demasiadas limitações normativas e o restante dos edifícios, que formam um fundo neutro que permite destacar os elementos mais representativos, com normas mais restritas, levando uma arquitetura plana com sistemática repetição (Zein, in Projeto n I45, pp.27-28).

Os projetos, divididos em blocos perimetrais, edificações de interior de quadra e uma série de edifícios para usos terciários, são desenvolvidos por arquitetos catalães premiados com o Foment de les Arts Decoratives (FAD), criado em 1988. Também apresentam projetos 


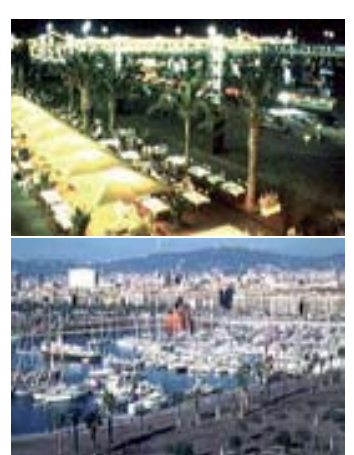

Vistas do Porto de Barcelona após a reurbanização.

Fonte: www.bcn.es/turisme/catala/ turisme/llocs/02.htm para outros edifícios específicos, SOM-Squidimore, Owings \& Merril e Álvaro Siza, entre outros (Projeto n |45, p.31).

\section{b. O tecido urbano na Vila Olímpica}

A demolição de velhos galpões industriais impõe uma arrasadora lógica nova sobre o tecido urbano consolidado ao mesmo tempo que tenta honrar a tradição dos quarteirões quadrados e fechados do Plano Cerdá (Zein in Projeto n 145, p.26).

Para criar e viabilizar a nova fachada para o mar, foram eliminadas as duas vias férreas, consideradas barreiras na acessibilidade ao restante da cidade e ao mar. Os terrenos liberados pela via férrea paralela à costa são reutilizados pela municipalidade como amplos espaços livres e representam a união cidade-praia e a outra via passa a ser subterrânea no primeiro trecho (Martorell in Projeto $n^{\circ}$ |45, p.78).

O setor residencial de Nova Icária é composto por faixas paralelas, formando áreas interligadas. Uma alameda à beira-mar com 30 metros de largura e mais de I quilômetro de comprimento, margeia as praias e as docas. Para eliminar a barreira entre a cidade e o mar, as autopistas de tráfego intenso foram transformadas em avenidas-parque com semáforos, para serem utilizadas como vias urbanas locais (Martorell, in. Projeto $n^{\circ}$ |45, p.78).

Do ponto de vista do desenho, alguns detratores do plano insistem em apontar sua incapacidade de obter uma continuidade equilibrada com a trama Cerdà. E, em decorrência, ele permitiria o surgimento e o acúmulo de soluções particulares que tendem a exaltar a singularidade de cada projeto, valorizando a multiplicação de efeitos visuais em detrimento de uma definição, através de regras claras, do espaço de uso habitacional (Projeto n 145, p.31).

\section{c. Tipologias arquitetônicas, usos e morfologia urbana}

Na Vila Olímpica de Barcelona, a questão residencial teve muita importância, onde mesmo após as extensas demolições, o alinhamento, as quadras fechadas e a volumetria, trazidos do Plano Cerdà, são uma limitação e conceito auto impostos, a título de continuidade, resultando na escolha de uma cidade nem tradicional, nem moderna (Zein in. Projeto n I45, p.28).

\begin{abstract}
O bairro residencial foi projetado como uma continuidade dos tecidos urbanos tradicionais do Ensanche do século XIV, abordando um problema crucial na reconstrução ou projetação de bairros novos: manter a morfologia urbana tradicional utilizando em contrapartida as modernas tipologias residências que garantem mais condições de habitabilidade. Para isso, estruturaram-se as superquadras com edificações alinhadas ao longo da rua, enquanto os espaços interiores se articulam com maior autonomia, permitindo o uso de tipologias inexistentes nos centros históricos (Martorell in Projeto n 145 , pp.78-79).
\end{abstract}

A isso se acrescenta a crítica à superposição dos aportes morfológicos advindos de condicionantes de extração típica do Movimento Moderno, mesclados à clássica solução das quadras fechadas da cidade tradicional. O mesmo ocorre com certos traços preservados da ocupação anterior, no mínimo subjetivos e que acarretam difícil leitura e compreensão do conjunto, devido à grande quantidade de rotatórias, esquinas e encontros irregulares dos diversos volumes construídos (Projeto $n^{\circ} \mid 45$, p.3I).

- Uso Residencial

O parque industrial degradado, por onde passavam duas vias férreas, foi o local escolhido para a construção de um novo bairro à beira mar, o Nova Icária, onde as praias, inacessíveis em 
função da barreira urbana na forma de vias férreas, estavam poluídas por detritos industriais. A decisão inédita de utilizar o bairro como Vila Olímpica para os Jogos de 1992 viabilizou a imediata execução, mas também propiciou a integração da área ao resto da cidade (Martorell in Projeto $n^{\circ}$ 145, pp.77-78).

Segundo Bohigas, as unidades habitacionais que a princípio serviram aos atletas dos jogos olímpicos, seriam vendidas posteriormente. Essas unidades estão em superquadras compostas por blocos periféricos de pouca profundidade definindo ruas quase corredor e quadras quase fechadas. Dentro das superquadras se situam as diversas soluções residenciais, em forma de torres ou de casas em fita, somando 2.500 habitações.

\section{- Uso Comercial e Serviços}

Foram implantados entre a Avenida do Litoral e o Paseo Marítimo, uma série de edifícios isolados, destinados a hotéis, comércio, serviço e lazer, mas de forma a que não constituam barreiras visuais (Martorell in Projeto no 145, p.78).

- Lazer e áreas verdes

Além das avenidas-parque onde antes estavam as auto-pistas, a transformação do primeiro trecho da via férrea em subterrânea promove um novo acesso ao parque da Ciutadella, que deixa de estar de costas para esse setor. Uma série de terraços contínuos ao nível térreo dos edifícios comerciais forma a nova fachada voltada para o mar de Barcelona. No centro foi construída uma plataforma para amarra das embarcações, resultado das exigências olímpicas para competições à vela. "Todo o conjunto é articulado sobre espaços verdes de grandes dimensões responsáveis pela unidade e identificação global do novo bairro" (Martorell in Projeto n० |45, pp.78-79).

\section{Bairro do Chiado, Lisboa}

Este texto trata da recuperação, no fim da década de 1980, de parte do bairro do Chiado, no centro histórico de Lisboa, Portugal, mais precisamente a recuperação de 18 edifícios que foram destruídos por um incêndio em agosto de 1988. Álvaro Siza foi o arquiteto responsável pelo projeto de recuperação.

\begin{abstract}
"Na noite de 28 de agosto de 1988 o Chiado ardeu!" O tom dramático da afirmação com a qual Álvaro Siza iniciou sua aula talvez passasse despercebido para a maior parte dos brasileiros. Ignora-se que, além de constituir um conjunto arquitetônico significativo, com edifícios da época pombalina, conventos, uma grande loja do início do século, o Chiado é parte integrante da memória e da cultura portuguesas, mas principalmente lisboeta (Projeto $n^{\circ} \mid 45$, p. 3 I)
\end{abstract}

O bairro do Chiado está localizado entre a Baixa Pombalina e o Bairro Alto, com vista para o Rio Tejo. Após o terremoto do século I8, implantou-se em Lisboa um plano de traçado viário ortogonal de autoria do Marquês de Pombal, sobreposto sobre a área desconsiderando totalmente o traçado original, irregular.

Segundo Siza, não havia entre o chiado e o resto da cidade de Lisboa, em fase de modernização, elo mais forte além do romântico, já que o bairro contava com armazéns prestes a fechar, dentre suas construções.

O primeiro desafio foi decidir "pela reconstituição dos edifícios queimados ou a total reformulação da área, do uso às construções (...), entre 'integral recuperação científica' ou, ao contrário, oportunidade para introduzir no centro de Lisboa a moderna arquitetura" (Projeto $n^{\circ} \mid 45$, p.31).

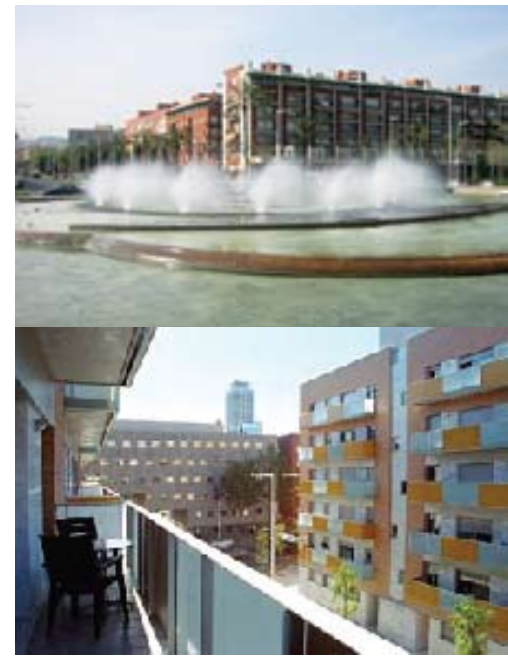

Fotos da Vila Olímpica de Barcelona. Fonte: www.bcn.es/turisme/catala/ turisme/llocs/02.htm
Figura 39

Desenho da reconstrução dos Grandes Armazéns do Chiado a partir do Castelo de São Jorge. Fonte: Boletim Lisboa Urbanismo n' 5, 1999.

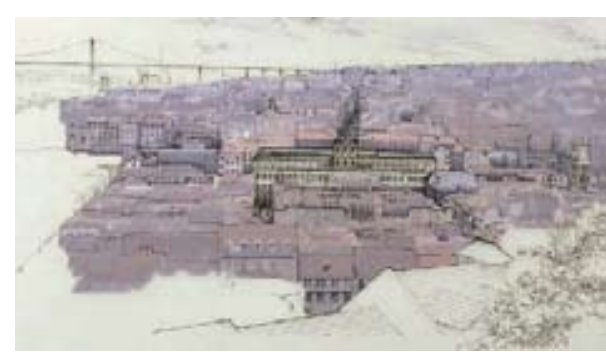




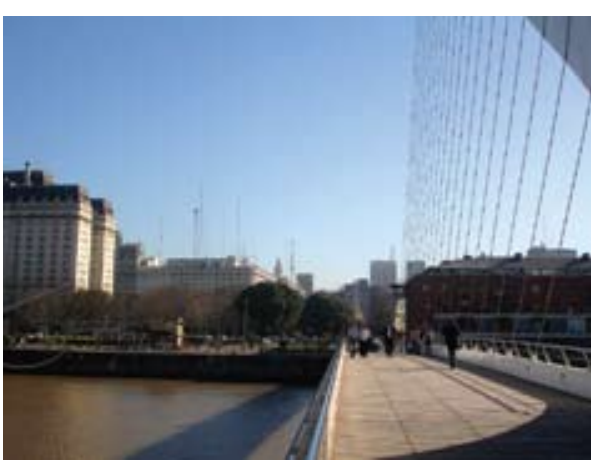

Puerto Madeiro, 2006. Arquivo Pessoal.

Por se tratar apenas da recuperação de dezoito edifícios, o que não justificaria uma transformação radical produzindo um agrupamento de edifícios de arquitetura de vanguarda no centro histórico, Siza optou pela recuperação dos edifícios o que poderia ser o início da recuperação do bairro como um todo. Também os variados usos foram mantidos: comércio, escritórios, habitação. A recuperação do bairro contou com outro importante elemento: a inclusão de novo trecho do metrô, a apenas uma quadra da área em recuperação.

\title{
5. Antíguo Puerto Madero, Buenos Aires
}

Trata-se da recuperação urbana de trecho da orla fluvial de Buenos Aires na Argentina, chamado de Antíguo Puerto Madero, num total de 170 hectares, localizado no estuário do Rio de La Plata.

\begin{abstract}
O resgate e a re-funcionalização dos antigos armazéns de Puerto Madero, situados ao longo do centro da cidade, foi uma benéfica operação de reafirmação da continuidade e valorização do espaço público na malha tradicional. Esta iniciativa foi promovida pelo governo do presidente Menem, à procura de uma renovação urbana associada às políticas de rentabilidade econômica, de marketing e da concorrência entre as cidades "mundiais". Constituiu o maior empreendimento de intervenção na cidade de América Latina - com um investimento público e privado de aproximadamente 2000 milhões de dólares provenientes do Estado e do sistema financeiro internacional (Soros, Eurnekián, Chab-Terrab) - identificado com o "modelo Barcelona" (26) e com as iniciativas portuárias inglesas desenvolvidas em Liverpool e nos Dockland de Londres (Segre, 2005).
\end{abstract}

Em 1929, Le Corbusier apresenta uma proposta urbanística que propõe o conceito de centro de negócios, que toma corpo a partir da aprovação do Plano Diretor de 1940, para a cidade de Buenos Aires. Entre as propostas do plano de 1940 para a cidade se destacam a formação de centros monumentais com edifícios administrativos e públicos, sistema contínuo de avenidas arborizadas conectando espaços urbanos de expressão, a criação da Avenida Costanera, acompanhada por uma ampla franja de parques, criando bairros residenciais escalonados até o limite do município em direção ao norte, I. I 70 hectares de áreas verdes e um impulso ao Bairro Sul, esquecido ante a evolução progressista de todos os demais bairros. Já se cogitava na época da aprovação do Plano Diretor, a recuperação da zona às margens do Rio de La Plata.

Em relação à área de Puerto Madero, o plano de 1940 propunha a continuação dos jardins frontais da Casa do Governo até os diques do porto, suprimir os galpões paralelos ao rio, substituindo-os por edifícios perpendiculares ao porto e a formação de uma praça monumental, como marco importante de uma das entradas da cidade.

\section{a. A recuperação da fachada fluvial}

O governo militar (1976-1983) adotou um projeto com nome de "Ampliação da Área Central". Os dois principais propósitos da Ampliação eram oferecer novas áreas de alta centralidade e criar um grande parque para a área sul da cidade. Nem a Ampliação nem o parque se realizaram e o preenchimento do novo território ficou incompleto. Enquanto no resto da área continuavam se arrefecendo as atividades humanas, nesse novo território surgiram salgueiros, juncos, pássaros, lontras, cobras, patos e garças e todas as espécies animais e vegetais que 0 rio traz do coração das selvas das regiões subtropicais nas quais nasce.

Na década de 1980, a área de Puerto Madero começou a interessar a duas das novas forças culturais que se expandiam nesse momento por todo o planeta: a da revalorização, 
recuperação e reciclagem do patrimônio histórico urbano e a da ecologia. A ação de ambas as forças recuperou para esta zona a visibilidade pública que com seu ocaso havia pouco a pouco perdido. (Liernour, 2004).

Através de uma cooperação técnica entre Buenos Aires e Barcelona, com o patrocínio da Prefeitura de Barcelona, do Porto autônomo de Barcelona, da Prefeitura de Buenos Aires e da Corporação Antíguo Puerto Madero, empresa autônoma criada em 1989, o projeto foi viabilizado pelo alto grau de obsolescência em que se encontrava o porto e pela criação de órgão específico como controlador, da mesma forma como vimos em Londres (London Docklands Development Corporation) e em Nova lorque (Battery Park City Authority).

Em 1989, através da parceria Buenos Aires-Barcelona, o urbanista espanhol Joan Busquets e o economista Joan Alemany, são encarregados de apresentar o plano estratégico para reurbanização da área. Para dar sustentabilidade ao plano, foram estudadas as condições gerais e as estruturas de 20 portos urbanos pelo mundo.

A recuperação de Puerto Madero, iniciada em 1990, quando da aprovação do "Plano Estratégico de Antíguo Puerto Madero", seguiu a tendência de reurbanização de portos urbanos em muitas cidades do mundo (e que deverá prosseguir nas próximas décadas), e poderá levar automaticamente à recuperação do centro de Buenos Aires, como etapa seguinte.

\section{b. Conceituação e diretrizes básicas do projeto}

O texto a seguir está baseado no Plan Estratégico de Antíguo Puerto Madero, apresentado por Consultores Europeus Asociados, como conjunto de diretrizes para nortear o plano de reurbanização, coordenado pelo urbanista Joan Busquets em 1990.

\begin{abstract}
O plano aqui apresentado pretende estabelecer critérios de desenho na transformação de Puerto Madero a partir das condições atuais. Entre elas destaca-se por um lado, a existência de uma corporação específica para impulsionar o desenvolvimento e por outro, as dificuldades óbvias do setor público de iniciar por si mesmo uma operação deste tipo. Deverá pensar-se num processo que evite que estas condições sejam contraditórias, porque as grandes operações de transformação (ex.: Docklands e Kop van Zuid) tiveram um bom investimento público em sua arrancada. Por outro lado, o próprio setor tem um grande potencial de médio prazo, mas deve ser estabelecido um novo limiar que modifique as condições de acesso e aproveitamento de uma imagem de futuro e inovação que no momento, absolutamente não dispõe (Plan Estratégico, 1990).
\end{abstract}

\section{c. O tecido urbano em Antíguo Puerto Madero}

- O traçado viário original

O traçado viário da área de Puerto Madero é composto por faixas no sentido norte-sul, bem definidas: a Costanera, os diques, os galpões e as instalações portuárias, complementadas pela auto-pista que ocupa o espaço livre e longitudinal entre a cidade e o alinhamento de galpões. Essa faixa de 50 a 70 m de largura compõe juntamente com a faixa dos galpões e dos diques, o que se pode chamar de separação entre a cidade consolidada e a nova expansão. Ortogonalmente, existem cinco molhes de acesso ao porto, com uma distância entre eles de 650 a 770 m e que configuram os únicos elementos físicos e visuais, através dos quais o traçado atual de Buenos Aires penetra no setor (Plan Estratégico, 1990).

\section{- Traçado viário após a reurbanização}

A extensão da rede viária de Puerto Madero se realizou levando em conta a evolução das áreas em construção. Por esse motivo a primeira área a ser trabalhada foi a correspondente ao Oeste, prolongando a trama viária urbana. A Avenida Alicia Moreau de Justo, com extensão

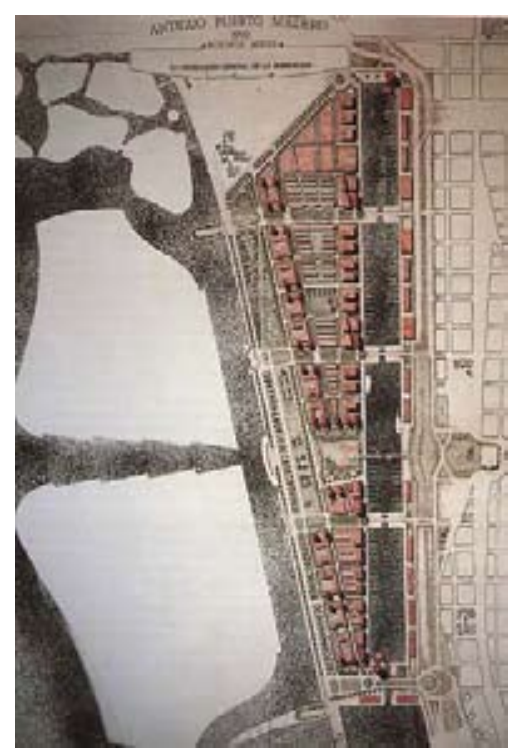

Figura 40

Masterplan de Antíguo Puerto Madero apresentado por Consultores Europeus Asociados.

Fonte: Jorge Francisco LIERNUR.

Buenos Aires e seu rio: de porto de barro ao bairro globalizado. Arquitextos - Vitruvius. Publicação original: Il Porto di Buenos Aires, Casabella, $n^{\circ}$ 723. Milão, jul. 2004, pp.60-65. 
de três quilômetros, foi a primeira artéria importante a concretizar-se e serviu para vincular o bairro de norte a sul, dotando de unidade o conglomerado emergente. $O$ setor Leste se desenvolveu numa segunda etapa, a partir de 1998 aproximadamente. A Corporación Antiguo Puerto Madero S.A. executou esses trabalhos em etapas, priorizando as artérias de comunicação entre o leste e o oeste e a Avenida Juana Manso, que corre paralela à linha dos diques. A rede viária total compreende I 5 ruas, 4 bulevares, 2 avenidas e 2 calçadões pra pedestres.

\section{- As tipologias arquitetônicas}

Por ocasião da proposta de Consultores Europeus Asociados, existiam originalmente na área três grupamentos de tipologias arquitetônicas de destaque: galpões e silos industriais de esmerada construção do século 19, formando séries de edificações estruturadas a partir dos diques, em intervalos regulares, de valor histórico tanto pelo uso portuário como por compor durante um século a fachada fluvial da cidade e que se pretende conservar; mobiliário urbano de alta qualidade, localizado no conjunto do parque e dos jardins da Avenida Costanera, recuperados a partir do relançamento do uso cívico dos espaços e, o terceiro grande grupo de construções que compõem as instalações portuárias, com alguns silos e galpões, estes em condições precárias de conservação (Plan Estratégico, 1990).

- Preservação da memória histórica

Como citado anteriormente, os galpões e silos de Antíguo Puerto Madero são edificações muito conhecidas e que tem valor histórico e arquitetônico. A proposta urbanística era preservar ao máximo esses edifícios. Muitos galpões de fachadas "européias" foram transformados e requalificados para uso comercial, levando a instalarem-se lá muitos escritórios de empresas. "Na área das instalações portuárias, os silos e galpões se encontram muito deteriorados e sua preservação deverá ser estudada caso a caso" (Plan Estratégico, 1990).

- Uso e ocupação do solo

A seqüência de faixas alterna usos privados com públicos.

A ocupação da estrutura linear de 25 quarteirões formada pelos armazéns construídos em tijolos e estrutura metálica - pertencentes à functional tradition industrial do século 19 - por escritórios, restaurantes, universidades, centros de lazer e cultura e lofts residenciais foram acompanhados pela construção de novas torres empresariais, hotéis, torres de apartamentos e a reciclagem de silos, também adaptados para moradias de luxo, distribuídos nos terrenos livres existentes na superfície de 175 hectares (Segre, 2005).

Puerto Madeiro, 2006. Vista sobre Rio da Prata. Arquivo Pessoal.

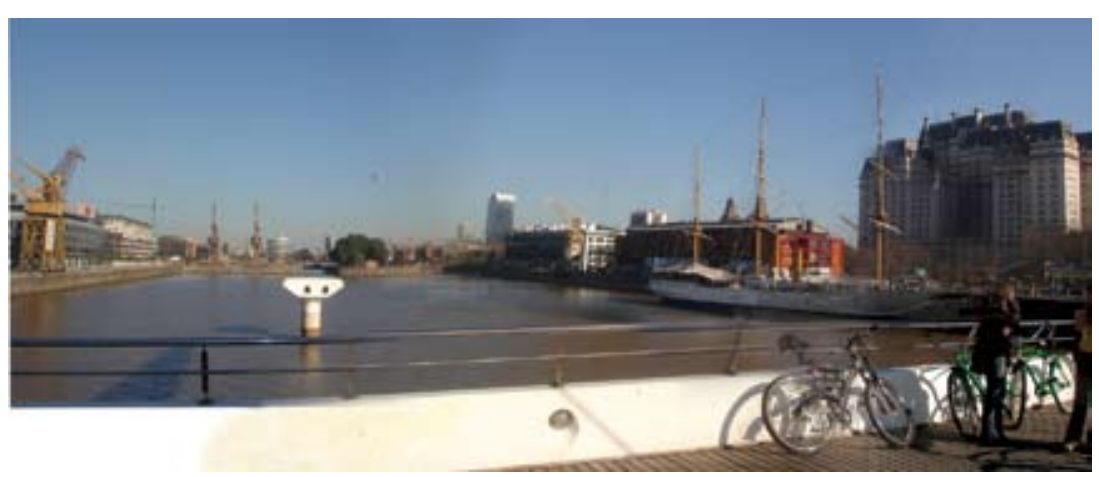

O uso cultural está representado por museus, cinemas, um anfiteatro e o Pavilhão das Artes. Um campo de esportes, áreas de jogos e um iate clube são as opções para lazer e prática de esportes.

A Reserva Ecológica representa uma importante área verde, criada a partir da ilha artificial na frente da Costanera Sur, criada nos anos 1970 pelos militares para conter um centro de negócios e com o objetivo de especular com esses terrenos. O museu Fortabat de Rafael Viñoly e a ponte de pedestres de Santiago Calatrava completaram a sua identificação publicitária e cenográfica, apoiadas nas obras dos profissionais do star system internacional (Segre, 2005). 


\section{d. Críticas}

Segundo informações do órgão público oficial Corporación Antiguo Puerto Madero, a avaliação geral é de um projeto bem sucedido, que conseguiu reativar as atividades na zona do Antiguo Puerto Madero depois de várias tentativas frustradas desde 1925. Os principais resultados relativos aos objetivos são: a reurbanização de uma área central para a cidade de Buenos Aires com a revitalização da antiga Costanera Sur; a obtenção de uma norma urbanística de preservação dos edifícios, a incorporação do uso misto na área, a criação de áreas públicas e de recreação, criação de novos espaços de trabalho e de residência centrais, 56 hectares de áreas verdes com mobiliário urbano; aumento da arrecadação de impostos para a municipalidade e a criação de postos de trabalho.

Segundo Jorge Moscato, esta intervenção exclusiva e gentrificada, foi benéfica para a cidade. Primeiro, porque possibilitou que as corporações internacionais e a camada mais rica da população não abandonassem a cidade tradicional, evitando assim a sua decadência com a criação das novas centralidades comerciais e financeiras no subúrbio distante. Segundo, porque reverteu o processo de privatização da costa de Buenos Aires que esteve em andamento com o governo de Menem, reafirmando a existência de uma faixa de espaços públicos que unem os contrapostos bairros das zonas sul e norte na frente do rio, único pulmão paisagístico da cidade, separado dela pelas abandonadas estruturas portuárias. A política de valorização da costa do Rio de la Plata, ao longo da Capital Federal e do Grande Buenos Aires, foi um dos principais objetivos do Plan Urbano Ambiental (1998) do governo da cidade, concretizado nas intervenções da Prefeitura em novos parques, áreas de lazer, mobiliário urbano e infra-estruturas esportivas. Por último, foi também importante a participação dos melhores escritórios de profissionais argentinos nos projetos realizados - Baudizzone, Lestard, Varas; Dujovne \& Hirsch; Juan Carlos López; Manteola, Sánchez Gómez, Santos, Solsona; Hampton \& Rivoira; Mario Roberto Alvarez, e outros -, que garantiram a qualidade arquitetônica e urbanística do conjunto" (Segre, 2005).

\footnotetext{
Sem dúvida não pode ser ignorada que a eficácia política e econômica da operação-desconsiderando seus numerosos aspectos discutíveis ou duvidosos - não são condizentes com seus resultados sociais e culturais. Em relação ao primeiro aspecto, porque mesmo sendo um espaço público, a área constitui hoje um assentamento para os setores mais privilegiados e nenhum dos recursos potenciais ou efetivamente gerados por ela foram empregados para favorecer de forma eqüitativa, outros setores necessitados (Liernur, 2004).
}

No caso da requalificação urbana de bairros ou áreas degradados em cidades do Primeiro Mundo, há que se lembrar que muitas delas, como Londres, Nova lorque e Barcelona, dispuseram de grandes verbas provenientes de consórcios ou até mesmo da esfera pública que viabilizaram dentro de uma política econômica neo-liberal, grandes investimentos que resultaram em requalificações urbanas de grande efeito sobre o cidadão, pois este, muitas vezes acabou por ter que habitar em regiões mais distantes que a sua de origem, em função da especulação imobiliária e conseqüente valorização dos imóveis e aluguéis, advindas dessas polêmicas interferências urbanas.
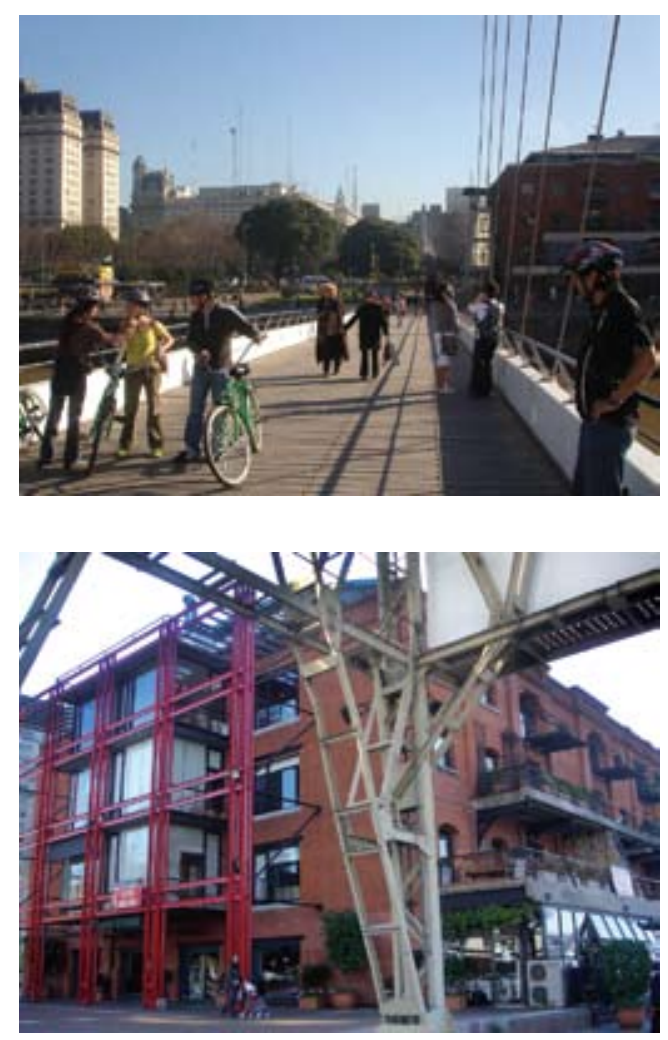

Puerto Madeiro, 2006. Arquivo Pessoal. 


\title{
6. Análise comparativa do estudo de experiências ocorridas em relação à área-objeto deste estudo
}

Em várias cidades pelo mundo, em países desenvolvidos ou em desenvolvimento, não só as áreas industriais obsoletas e abandonadas configuram a degradação urbana. Cidades ricas com centros urbanos modernos possuem bairros segregados em relação ao restante da cidade, com muitos vazios urbanos e quase nenhuma vida nas ruas. Analisando-se os projetos de reurbanização ocorridos em várias cidades de países desenvolvidos a partir da década de 1980, pode-se concluir que a implantação de sistemas viários pode causar essa segregação na forma de fragmentação do espaço. Como resultado, há o comprometimento da mobilidade e da acessibilidade local, ou seja, dentro do espaço intra-urbano.

\begin{abstract}
Para melhor compreender o processo de transformações espaciais no ambiente intra-urbano ocasionado pelas intervenções viárias, é necessário observar duas situações diferenciadas: primeiramente nos referimos aos sistemas viários criados com o objetivo de interligar uma aglomeração central a uma área remota, quando o crescimento do tecido urbano é formado em função de seu surgimento. Neste contexto, pode-se considerar as transformações urbanas geradas pela ferrovia, rodovia e via de trânsito rápido, aeroporto etc. e, na segunda situação, ao tecido urbano consolidado, que é transformado quando nele se fazem interferências de melhorias viárias, cortando a malha urbana existente. É o caso de vias elevadas e sobrepostas, criadas com o objetivo de permitir maior vazão a um tráfego já existente; da implantação de linhas metroviárias aéreas, sobrepondo-se ao tecido urbano existente; das ampliações aeroportuárias em sítios já envolvidos pela malha urbana e ainda, das vias criadas sobre fundo de vales, decorrentes da canalização de córregos (Namur, et al. 2004, p.2).
\end{abstract}

A evolução econômica das cidades está associada às condições de locomoção e transporte, na medida em que possibilita a ligação entre o local da produção de bens aos centros de comercialização e consumo, e os mesmos fatores que teriam promovido o desenvolvimento das cidades se tornaram hoje os seus maiores problemas. Estas estruturas viárias, necessárias à acessibilidade regional, se transformam muitas vezes em barreiras à acessibilidade local no momento em que são envolvidas pela malha urbana e atuam como elemento separador e desagregador do entorno (Namur, et al. 2004, p.2).

\begin{abstract}
A ferrovia funcionou como instrumento da mencionada reorganização. Antes de tudo provocou o colapso do antigo sistema de transporte e das atividades a ele relacionadas. Por seguir trajetos diferentes das antigas estradas "ordinárias" provocou uma relativa desvalorização de áreas beneficiadas por aquelas, desvalorização esta que abrangeu grande número dos aglomerados preexistentes. Pelo mesmo motivo, a ferrovia ocasionou um desvio de rotas, valorizando estradas "ordinárias" transversais. Valorizou as áreas que passou a servir. Os "povoadosestação" cresciam enquanto os aglomerados apartados da linha, de um modo geral, estagnavam (Langenbuch, 1971, p. 129).
\end{abstract}

Comparando-se os elementos existentes nos projetos de renovação urbana estudados, observamos que os bairros Brás e Mooca apresentam similaridades importantes em relação às áreas onde ocorreram esses casos de requalificação urbana. A principal similaridade é a ocorrência do processo de desindustrialização das cidades na década de 1970, deixando grandes galpões industriais e instalações portuárias obsoletas ou abandonadas e áreas urbanizadas que entraram em processo de degradação ambiental.

As linhas férreas existentes no Brás e Mooca e que dividem essas áreas em vários fragmentos dificultando a mobilidade local de seus habitantes podem ser comparadas com as duas linhas férreas que havia em Barcelona entre o centro da cidade e a praia inacessível e poluída, reunificadas ao resto da cidade após a intervenção urbana. 
Apesar do projeto de Barcelona não ter preservado os galpões industriais na área do porto, essa condição foi adotada no projeto de requalificação urbana de Antíguo Puerto Madero, em Buenos Aires, onde os galpões de aparência européia foram transformados em edifícios de escritórios. No Brás e na Mooca existem edifícios antigos construídos com tijolos importados que têm valor histórico e identidade arquitetônica e que devem ser recuperados. Além desses galpões, o patrimônio arquitetônico e histórico também é representado pelas tantas vilas operárias, construídas na primeira metade do século 20 e comparáveis às residências unifamiliares de dois pavimentos originais agrupadas horizontalmente, vistas em London Docklands.

Em relação aos projetos de Docklands e Battery Park City, as similaridades são poucas: Brás e Mooca não têm frentes para a água, já que o Rio Tamanduateí foi canalizado naquele trecho, envolvido numa caixa de concreto, sem nenhum atrativo estético ou ambiental. Provavelmente os níveis de investimentos públicos envolvidos serão muitíssimo mais baixos. O desafio está em não repetir o processo de expulsão dos moradores que não poderão acompanhar o preço da valorização imobiliária decorrente de todo e qualquer processo de requalificação urbana, como o que aconteceu em London Docklands.

O fator mais importante a ser apreendido com a reurbanização da área portuária de Barcelona é a reurbanização integrada com o centro da cidade, criando uma nova centralidade que atraia visitantes do restante da cidade. Para isso é fundamental um alto grau de melhoria da mobilidade e acessibilidade na região e, sem dúvida, a melhoria ambiental.

A mobilidade é o que faz a cidade ser democrática, mas é a centralidade para todos que faz haver cidadãos. Esta dialética entre centralidade e mobilidade é o que garante, se me permitem a expressão um pouco marxista, a reprodução ampliada da cidade (Borja, 2004).

Diferentemente do ocorrido no Chiado em Portugal - onde Álvaro Siza optou corretamente por reconstruir os edifícios incendiados na mesma tipologia arquitetônica original para não criar um miolo com tipologias modernas que seriam conflitantes no histórico bairro - observa-se nos bairros paulistanos em questão, outras tipologias como o brutalismo do concreto à vista das estações de metrô do fim da década de 1970. A comparação com os exemplos citados mostra que em função de sua atual condição urbana, Brás, Mooca e Avenida Radial Leste devem ser incluídos em planos municipais de requalificação que levem à sua reinserção no panorama econômico, cultural e social da cidade de forma democrática, contemplando principalmente os atuais moradores e atraindo novos habitantes de classe média e baixa renda. Numa última comparação com as cidades onde ocorreram os casos estudados, à exceção de Buenos Aires, são cidades mais ricas que as metrópoles brasileiras e puderam dispor de verbas públicas vultosas para realizar seus projetos de requalificação urbana.

No caso de Barcelona, os custos com a implantação da Vila Olímpica foram amortizados em menos tempo do que se supunha. A administração pública do município de São Paulo, assim como outras metrópoles brasileiras, tem muitas prioridades e urgências, o que dificulta mais ainda a obtenção de verbas para a requalificação urbana de bairros ou distritos. 


\section{Capítulo VI \\ Subprefeituras Sé \\ e Mooca: análise comparativa dos Planos Regionais}

\footnotetext{
${ }^{74}$ Ver:

Planta da capital do Estado de São Paulo e seus arrabaldes - 1890"; Autoria: Jules Martin; Coleção São Paulo antigo - Plantas da cidade.

Fonte: Comissão do IV centenário da cidade de São Paulo, 1954; Arquivo: Biblioteca Mário de Andrade; Microfilmes dos mapas digitalizados pelo CEDIP - PUC;

Mapa da expansão da área arruada da cidade de São Paulo entre I88। e 1914.

Fonte: Silveira Brito, Mônica. Dissertação de Mestrado, 1999.

Planta geral da cidade de São Paulo, 1914 - morfologia.

Fonte: Comissão geografia e geológica - Eng. Chefe: João Pedro Cardoso in, encarte da Reconstituição da Memória Estatística da Grande São Paulo; Organização: Governo do Estado de São Paulo;

Mapa topográfico do município de São Paulo - 1930".

Fonte: Empresa Sara Brasil,

Engenheiro Arthur Saboya;

Arquivo do DPH - Departamento de Patrimônio Histórico.
}

Antes de iniciar a proposição das diretrizes para requalificação urbana do Brás, Mooca e Radial Leste, foram necessárias a leitura e análise comparativa das diretrizes apresentadas pelos Planos Regionais da Sé e Mooca, incumbidas da administração das duas áreas que compõem a região objeto deste estudo. Ambos os Planos foram desenvolvidos a partir das diretrizes do Plano Diretor Estratégico de São Paulo e também a partir das demandas de cada um dos bairros. Apesar das especificidades de cada bairro, existem muitas similaridades nas propostas dos dois Planos Regionais.

A metodologia utilizada foi a compilação e análise da Lei dos Planos Regionais Estratégicos das Subprefeituras Mooca e Sé e a fusão dos textos dos dois planos. Artigos, quadros e tabelas foram resumidos e fundidos, listando-se apenas os objetivos ou projetos que estão inseridos na área de recorte em estudo nesta dissertação. $\bigcirc$ texto resultante da compilação dos dois planos encontra-se no Anexo 3 desta dissertação.

$\mathrm{Na}$ compilação desses Planos Diretores Regionais foram inseridos segmentos dos mapas oficiais mostrando a área-objeto em análise, junto ao item onde são mencionados, com o objetivo de facilitar a compreensão do texto.

\section{Situação político-administrativa da área-objeto de estudo}

É necessário um rápido comentário a respeito das mudanças na administração pública do Brás e Mooca. Hoje, todo o território do Brás é administrado pela Subprefeitura da Mooca e a Mooca baixa, rebatizada nas plantas e mapas oficiais de Cambuci, desde 1992, apesar de toda a identidade histórica do bairro com o nome Mooca, marcada principalmente pela tradicional Rua da Mooca (antigo Caminho da Mooca, na época em que o bairro era formado por chácaras, desde o fim do século 18), é administrada pela Subprefeitura da Sé. Mooca, em tupi, significa "lugar de fazer casa" segundo Rosa Miranda em sua tese de doutorado apresentada à FAUUSP. Esta também ainda denomina a nova área doada ao Cambuci como Mooca. Historicamente, o Cambuci é um bairro localizado a oeste do Rio Tamanduateí, entre os bairros Ipiranga e Liberdade. Os mapas históricos utilizados para análise da evolução urbana, no período de 1890 a 1950, nomeiam a área à direita do Tamanduateí e entre a Rua da Mooca e a Ferrovia Santos Jundiaí como Mooca e, como Cambuci, a área à esquerda do Rio ${ }^{74}$.

As 3 I Subprefeituras existentes no município de São Paulo foram homologadas a partir da aprovação da Lei $n^{\circ}$ 13.399, de $1^{\circ}$ de agosto de 2002, durante a gestão da prefeita Marta Suplicy, quando o poder executivo municipal passa a ser exercido pelo prefeito, auxiliado diretamente pelos secretários municipais e subprefeitos (Capítulo I, artigos $\mathrm{I}^{\circ}$ e $2^{\circ}$ ). Às subprefeituras cabe a administração municipal no âmbito das subprefeituras e aos subprefeitos cabe a decisão, gestão e controle dos assuntos municipais em nível local, respeitada a legislação vigente e observadas as prioridades estabelecidas pelo Poder Executivo Municipal (Capítulo II, seção I, artigo $3^{\circ}$ ). 
A principal atribuição das Subprefeituras, a partir da aprovação do novo Plano Diretor Estratégico para o Município de São Paulo, foi coordenar o Plano Diretor Regional e Plano de Bairro, de acordo com as diretrizes estabelecidas pelo plano estratégico da cidade (Capítulo II, Artigo $5^{\circ}$ - item IV).

A Subprefeitura Sé está constituída pelos distritos da Consolação, Santa Cecília, Bom Retiro, República, Sé, Bela Vista, Liberdade e Cambuci e a Subprefeitura Mooca, pelos distritos do Brás, Água Rasa, Mooca, Pari, Belém e Tatuapé (Capítulo II - Seção II: Limites territoriais, Art. $7^{\circ}$ )

Com a aprovação do Plano Diretor Estratégico para o Município de São Paulo, sob a lei $n^{\circ} 13.430$ de 13 de setembro de 2002, onde se estabelece que cada subprefeitura deveria apresentar um Plano Regional Estratégico, foi também aprovada a lei n 13.885 de 25 de agosto de 2004, que estabelece normas complementares ao Plano Diretor Estratégico, institui os Planos Regionais Estratégicos das Subprefeituras, dispõe sobre o parcelamento, disciplina e ordena o Uso e Ocupação do solo do Município de São Paulo.

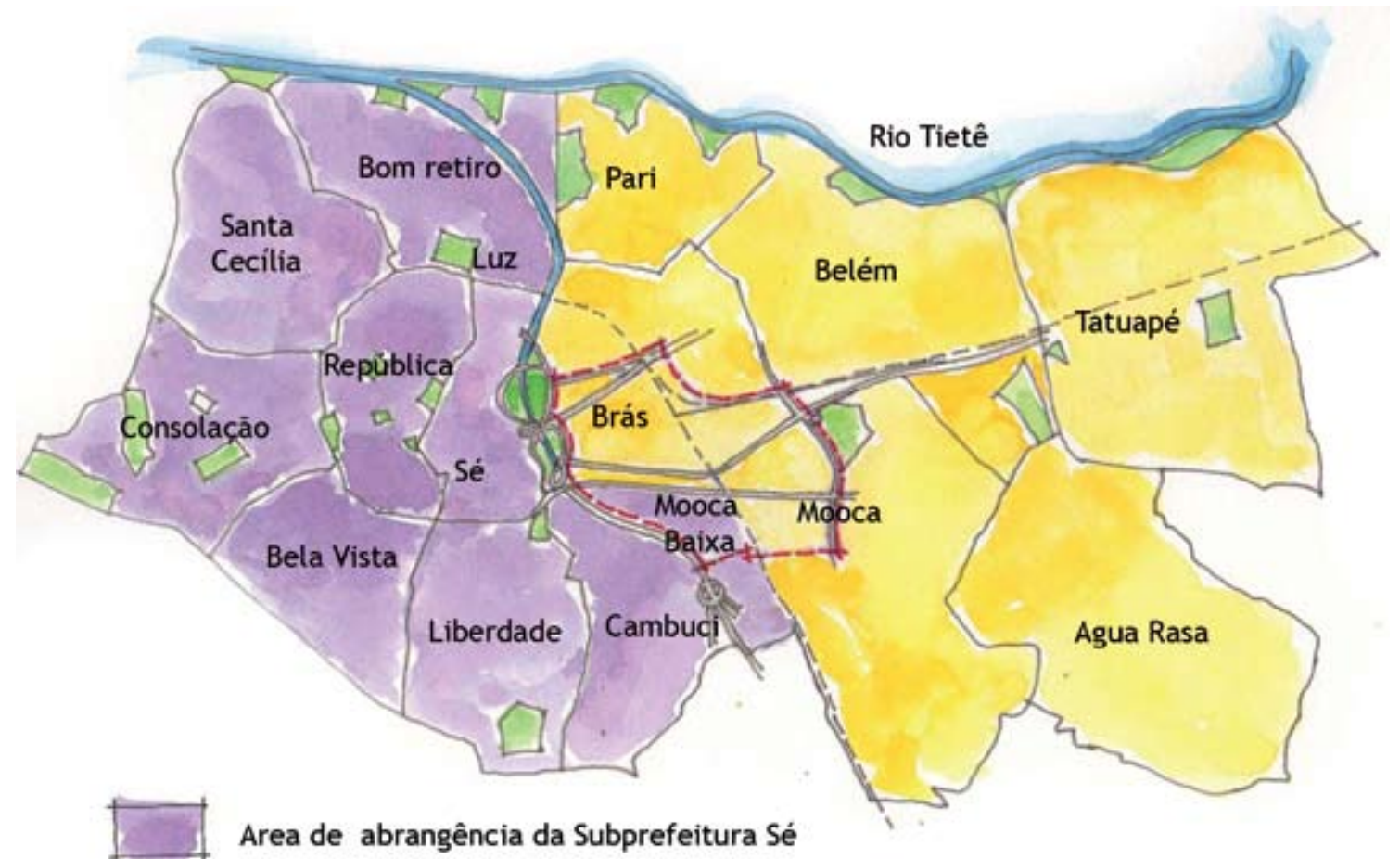

Area de abrangência da Subprefeitura Sé

Area de abrangência da Subprefeitura Mooca

t_ Area-recorte da dissertação
Figura 41

Abrangência das

Subprefeituras Mooca e Sé. Croquis da autora, 2006. 


\section{Análise comparativa dos Planos Diretores Regionais das Subprefeituras Mooca e Sé: diretrizes e propostas}

As análises das respectivas áreas do Brás e Mooca, dentro da abrangência destas duas subprefeituras, foram realizadas pelas equipes de planejamento das subprefeituras levando em conta a aprovação de Lei Municipal n 13.430, de 13 de setembro de 2002, instituição do novo Plano Diretor Estratégico do Município de São Paulo.

A Subprefeitura Mooca elaborou um diagnóstico do quadro situacional através de um processo participativo junto às comunidades e suas representações locais envolvendo uma equipe técnica da subprefeitura auxiliada por plano metodológico desenvolvido pela equipe de assessoria do Instituto Pólis. Além da SEMPLA, diversas instituições colaboraram para o levantamento de dados sobre a região ${ }^{75}$.

Na proposição de diretrizes, a Subprefeitura Mooca estabelece os quatro eixos temáticos abaixo (PRE Mooca, pp.20-22):

I. Diversidade de uso e diversidade social;

2. Qualidade ambiental;

3. Patrimônio histórico;

4. Habitação.

A Subprefeitura Sé, que tem a seu cargo a administração da Mooca baixa, também contou com a assessoria do Instituto Pólis e de órgãos como EMURB e Pró-Centro.

A análise realizada pela equipe da Subprefeitura Sé foi norteada pela construção de Estratégia de Regulação de Uso e Ocupação do Solo, tendo sido o processo desenvolvido por duas linhas de trabalho:

- Reunião de diagnósticos setoriais, dados secundários e informações dispersas já existentes em diferentes instâncias do governo municipal, centros de pesquisas e nos bancos de dados do Instituto Pólis;

- Convocação de grupos sociais que atuam, vivem e possuem interesses nas áreas centrais para constituírem mapeamentos das situações de uso e ocupação do solo na área de abrangência da Subprefeitura Sé.

O processo de análise urbana dos territórios da Subprefeitura Sé priorizou subsídios para a elaboração de uma Estratégia de Regulação do Uso e Ocupação do Solo que dê sustentação aos programas, propostas e ação já definidos para a região, a partir do conteúdo mínimo dos Planos Diretores Regionais, definido genericamente na lei do Plano Diretor Estratégico do Município de São Paulo.

Os objetivos específicos que se inserem nesse escopo são:

I. Definição de diretrizes para mudanças de zoneamento no centro;

2. Detalhamento de critérios de subutilização e não utilização de imóveis e levantamento de áreas passíveis de utilização desse instrumento;

75 Secretaria Municipal de Planejamento de São Paulo - SEMPLA,

Secretaria de Habitação de São Paulo - HABI-Centro, Pró-Centro, EMURB, DEINFO, Secretaria de Transportes de São Paulo, CDHU, Companhia Paulista de Trens Metropolitanos - CPTM, Centro das Indústrias do Estado de São Paulo - CIESP Zona Leste.

76 Mapas 3 a 19 - Centro de Estudos da Metrópole - CEBRAP, 2000. in Plano Diretor Regional da Subprefeitura Sé, pp.26-42.

3. Revisão das áreas delimitadas como Zonas Especiais de Interesse Social;

4. Definição de diretrizes para a revisão da Operação Urbana Centro e diretrizes para elaboração de Operação Urbana Diagonal Sul;

5. Definição de áreas de preservação histórica e ambiental para aplicação da transferência do direito de construir;

6. Definição sobre a destinação das áreas públicas da subprefeitura (PRE SÉ, p. I0).

Como foi possível depreender da análise dos mapas constantes no item diagnóstico do Caderno Leitura Técnica e Participativa, esses mapeamentos foram feitos informalmente pelas comunidades e sem detalhamento técnico suficiente para elaboração de diagnóstico preciso.

O relatório do quadro situacional da Subprefeitura Sé apresenta uma série de mapas elaborados pelo Centro de Estudos da Metrópole - CEBRAP em 2000, demonstrando a distribuição de atividades comerciais, culturais e de serviços por toda sua área de abrangência ${ }^{76}$. 
Analisando-se esses mapas observa-se que na área da Mooca baixa e Brás as atividades acima são rarefeitas, quase inexistentes, à exceção de lojas de revenda de automóveis e outros veículos, peças automotivas e atividades de organizações associativas. A atividade mais presente é a indústria de transformação, na Mooca baixa. O setor hoteleiro não foi mencionado na área objeto deste estudo nem no restante dos distritos do Brás, Mooca e Cambuci e deverá ser contemplado na proposição de diretrizes desta dissertação, no Capítulo VII.

\section{I. Propostas e solicitações das comunidades}

Dentro desta área-objeto de estudo, trechos Brás e Mooca, o resultado das pesquisas feitas pela Subprefeitura Mooca junto à população apresentou as seguintes e principais demandas:

- Criação de áreas verdes;

- Preservação e manutenção do patrimônio histórico;

- Revisão do zoneamento e regularização de usos;

- Temor ante a implantação de ZEIS como forma de "institucionalizar o cortiço";

- Diagnóstico do subsolo;

- Contemplação de todas as classes sociais pelo plano diretor regional77.

A partir dessa pesquisa, a comunidade da Mooca apresentou as seguintes propostas:

\section{Sobre as alterações de zoneamento:}

- Permissão para o uso comercial e de serviços 24 horas ao longo do perímetro compreendido entre as Ruas Taquari, Mooca, Visconde de Laguna e Javari, próximo à Faculdade;

- Criação de um corredor Z8 ao longo da Avenida Radial Leste, ou inserção da Avenida na operação urbana, visando atrair novos investidores e empreendedores, freando o processo de degradação;

- Retirar a ZEIS 1 - 55, devido ao uso quase estritamente residencial do entorno;

- Diminuir a quantidade de áreas Z6 industriais e mudar o zoneamento Z2, Z4, e Z6 para Z3.

\section{Sobre o transporte:}

- Prolongar a Avenida Henry Ford, visando reduzir o tráfego na Avenida Paes de Barros, melhorando a qualidade dos que moram ao redor, estimulando novos investimentos na área do entorno;

- Terminar as obras de canalização do córrego Oratório, que causam alagamentos na região.

\section{Sobre as áreas verdes:}

- Criação do Parque Ecológico da Mooca ao longo da Avenida Presidente Wilson entre o Viaduto São Carlos e a Estação da Mooca, revitalizando os gal pões situados ao longo desse trecho;

- Requalificação da área da Subprefeitura, hoje degradada e mal cuidada;

- Reintegração à comunidade do Centro Desportivo Mooca, no Parque da Mooca, com um campo de futebol, através da revisão do comodato de 99 anos.

\footnotetext{
${ }^{77}$ Plano Regional Estratégico da Subprefeitura Mooca - Relatório Final volume I - Quadro Situacional, p. I0.
} 
No atual projeto de lei do Plano Diretor Estratégico para São Paulo ${ }^{78}$, a questão da vegetação é abordada destacando:

- "o conceito de sistema de Áreas Verdes como um dos quatro elementos integradores de urbanização de território";

- "a introdução de figura do direito de preempção para a implantação de novos parques";

- "a proposta dos parques lineares contínuos e os caminhos verdes, implantadas a partir do Programa de Recuperação Ambiental de curso de água e fundos de vale":

- "a incorporação dos conceitos estabelecidos no Sistemas Nacional de Unidades de Conservação (SNVC) na definição do Sintoma de Áreas Verdes" (Atlas Ambiental, p.99).

\section{Sobre o desenvolvimento econômico:}

- Criação do Varejão da Mooca na área ocupada pela feira confinada.

\section{Sobre as áreas a serem preservadas:}

- Pizzaria São Pedro - Rua Javari esquina com Visconde de Laguna;

- Antiga tecelagem à Rua da Mooca com Avenida Alcântara Machado - hoje possui alguns galpões vazios, um estacionamento e a boate Fábrica 5 (uso que conservou o local);

- Estádio de Futebol do Clube Atlético Juventus (Estádio Conde Rodolfo Crespi), à Rua Javari, Mooca.

Filtrando-se as propostas acima fica clara a preocupação com a revitalização da Avenida Radial Leste como eixo concentrador de comércio e serviços; a preocupação com o excesso de ZEIS 3 que no caso do trecho Brás dentro da área-objeto de estudo equivale a aproximadamente $40 \%$ de sua área total; o anseio por áreas verdes e equipamentos públicos para lazer e esportes; a preservação do patrimônio histórico cultural e a redução do tráfego.

Nas propostas apresentadas pela comunidade da Mooca destaca-se a preocupação de alterar o uso das áreas, por ocasião dos debates, de Z2, Z4 e Z6 para Z3, utilizando ainda como referência a antiga Lei de Zoneamento, de 1972.

Isso pode traduzir-se em influência do mercado imobiliário que, até aquele momento de março de 2003, garantia maior retorno financeiro para seus empreendimentos imobiliários se implantados em Z3. Daí o interesse do mercado imobiliário em garantir os estoques de terrenos e do potencial construtivo.

Os industriais do pólo industrial localizado ao sul da Mooca, que concentra tanto indústrias poluentes como indústrias limpas, de médio e grande porte, manifestaram a necessidade de revitalização das ruas dessa área, pois pretendem manter suas plantas ativas no mesmo local, próximos às rodovias e à grande maioria de sua clientela, num raio de 120 km em São Caetano e São Bernardo. Apesar da intenção de permanecer na Mooca, essas indústrias têm dificuldade em beneficiar-se da atual logística oferecida pelo transporte ferroviário das linhas da CPTM vindas de Santos e a Leste, de Minas Gerais e Rio de Janeiro, na forma de horários noturnos, cruzamento de linhas etc ${ }^{79}$.

No caso do Brás, a leitura comunitária destaca os conflitos urbanos, como congestionade setembro/2002.

79 Plano Regional Estratégico da Subprefeitura Mooca - Relatório Final volume I - Quadro Situacional, p.34. mento das vias, dificuldade de estacionamento de carros e ônibus que transportam compradores de produtos do comércio atacadista (área do distrito do Brás que não está contida dentro da área-objeto deste estudo); dificuldade de travessia das ferrovias que cortam a região; 
conflitos entre comerciantes e ambulantes, que muitas vezes vendem a mesma mercadoria que as lojas e congestionam a calçada dificultando o trânsito de pedestres; presença de pessoas em situaçãa de rua, catadores de lixo que aproveitam para reciclar o lixo gerado pelas pequenas indústrias; conflitos de zoneamento, como por exemplo, indústrias em zonas mistas que não conseguem regularização, portanto não fazem melhorias no imóvel permitindo a sua deterioração ou mesmo conflitos de densidade proposta pelo zoneamento, ou seja, zonas adensáveis que são pouco densas e o contrário (PRE Mooca, p.39).

A comunidade do Brás apresentou como principal proposta estimular o uso comercial especializado já existente, requalificar corredores comerciais como a Avenida Rangel Pestana e desestimular o retorno de indústrias que possam comprometer a qualidade ambiental da região.

\subsection{Uso e ocupação do solo}

Entre as leis de uso e ocupação do solo de 1972 e de 2002, muitas e significativas alterações ocorreram e devem ser analisadas.

Para melhor entender as alterações ocorridas com a nova Lei de Uso e Ocupação do Solo, o quadro a seguir faz uma comparação, das Leis de 1972 e 2002 setor a setor, considerando características, coeficientes de aproveitamento e taxas de ocupação. Esta análise limitou-se à área de estudo desta dissertação. As fontes utilizadas para montar esta tabela foram: o mapa com a LUOS de 1972 - lei de uso e ocupação do solo publicado pela empresa Geomapas, Mapa 38 - e o novo Mapa de Uso e Ocupação do Solo do Município de São

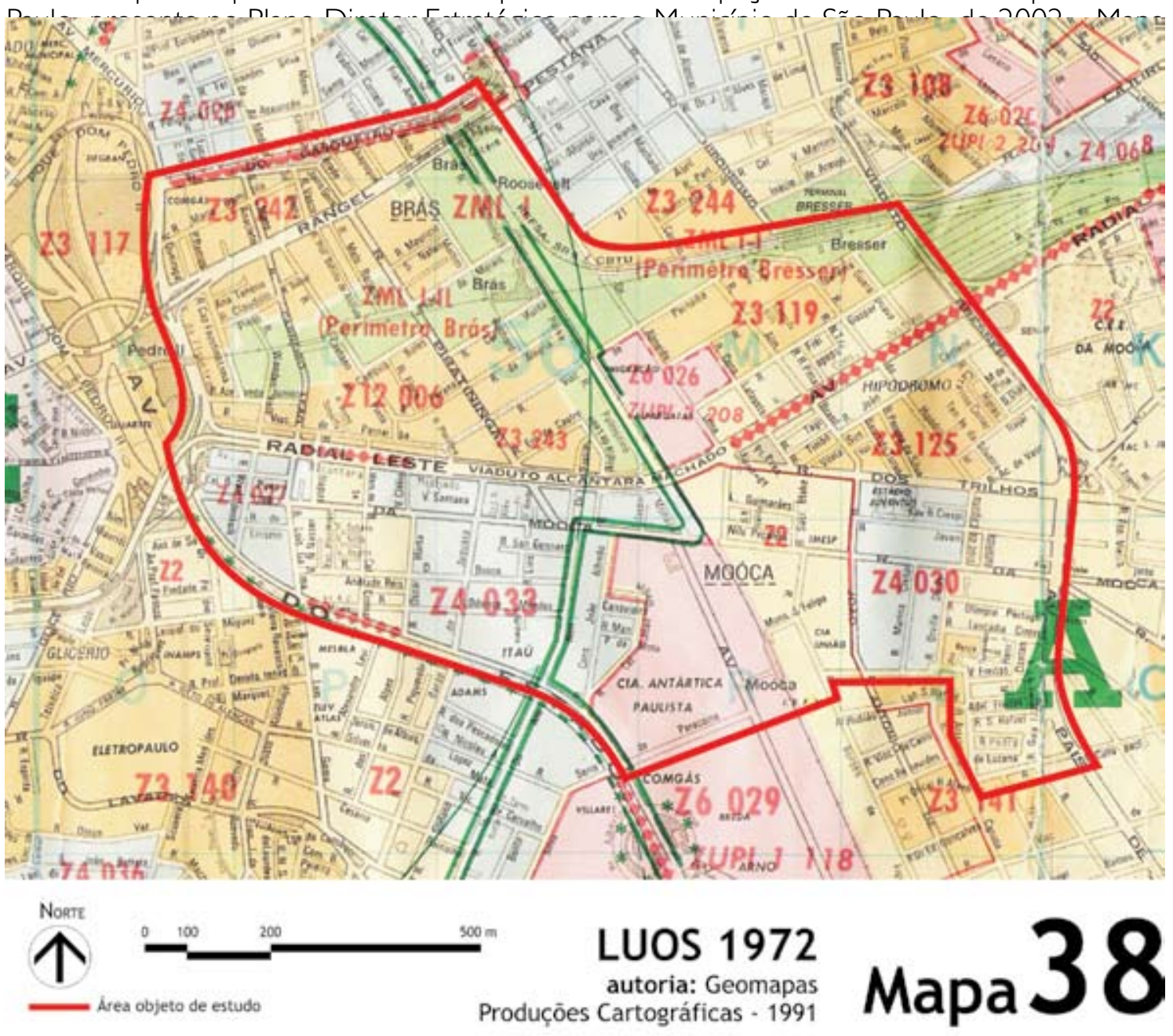


LEGENDA

\begin{tabular}{|c|c|}
\hline$\ldots$ & 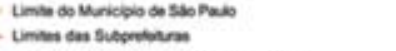 \\
\hline & 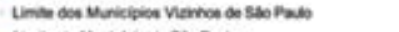 \\
\hline & 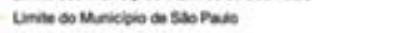 \\
\hline- & 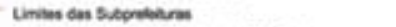 \\
\hline & 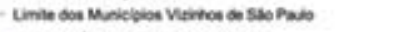 \\
\hline & 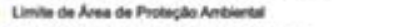 \\
\hline 0000 & 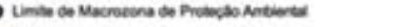 \\
\hline & Rowanes \\
\hline & 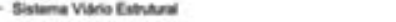 \\
\hline & Fenovis \\
\hline & mopiso \\
\hline & 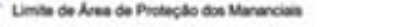 \\
\hline sastem & A DE AREUS VERDES DO WUNAChNo \\
\hline & 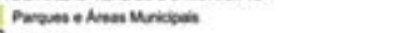 \\
\hline$(\pi+\infty)$ & Conteno \\
\hline bea & ace Eapontos Social \\
\hline 60 & $\operatorname{los} \infty \cos \infty$ \\
\hline menom & 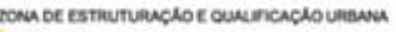 \\
\hline zan & 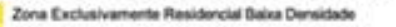 \\
\hline $\operatorname{ans}$ & 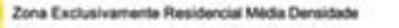 \\
\hline ans & 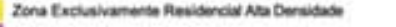 \\
\hline$m$ & 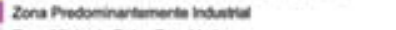 \\
\hline ans & 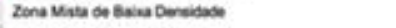 \\
\hline neas & 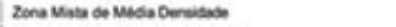 \\
\hline ans & 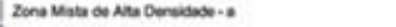 \\
\hline Des & 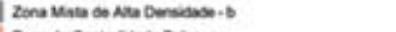 \\
\hline 200. & 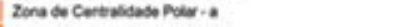 \\
\hline 20:- & 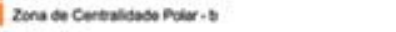 \\
\hline zonuse & Especus \\
\hline Q203 & 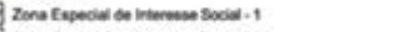 \\
\hline & 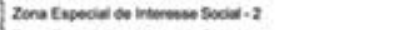 \\
\hline ERT & 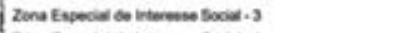 \\
\hline & 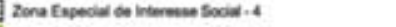 \\
\hline mow & 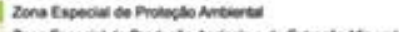 \\
\hline$m \rightarrow \infty$ & 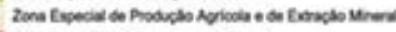 \\
\hline fore: & 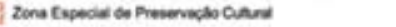 \\
\hline e & 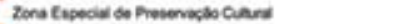 \\
\hline no & 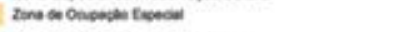 \\
\hline wachos & ZONU DE FWOTECLO MEEENTN \\
\hline$x=$ & 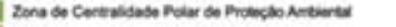 \\
\hline Dat & 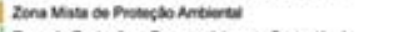 \\
\hline$\infty$ & 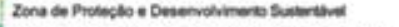 \\
\hline ans. & 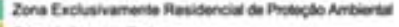 \\
\hline at & L Leter o the \\
\hline & Zona Eapeciel do \\
\hline
\end{tabular}

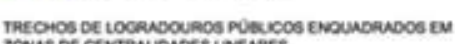

0000 zana do Centraldaso Unew - a paclal

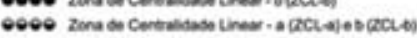

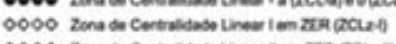

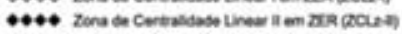

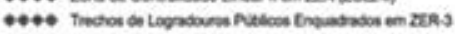

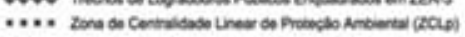

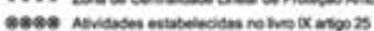

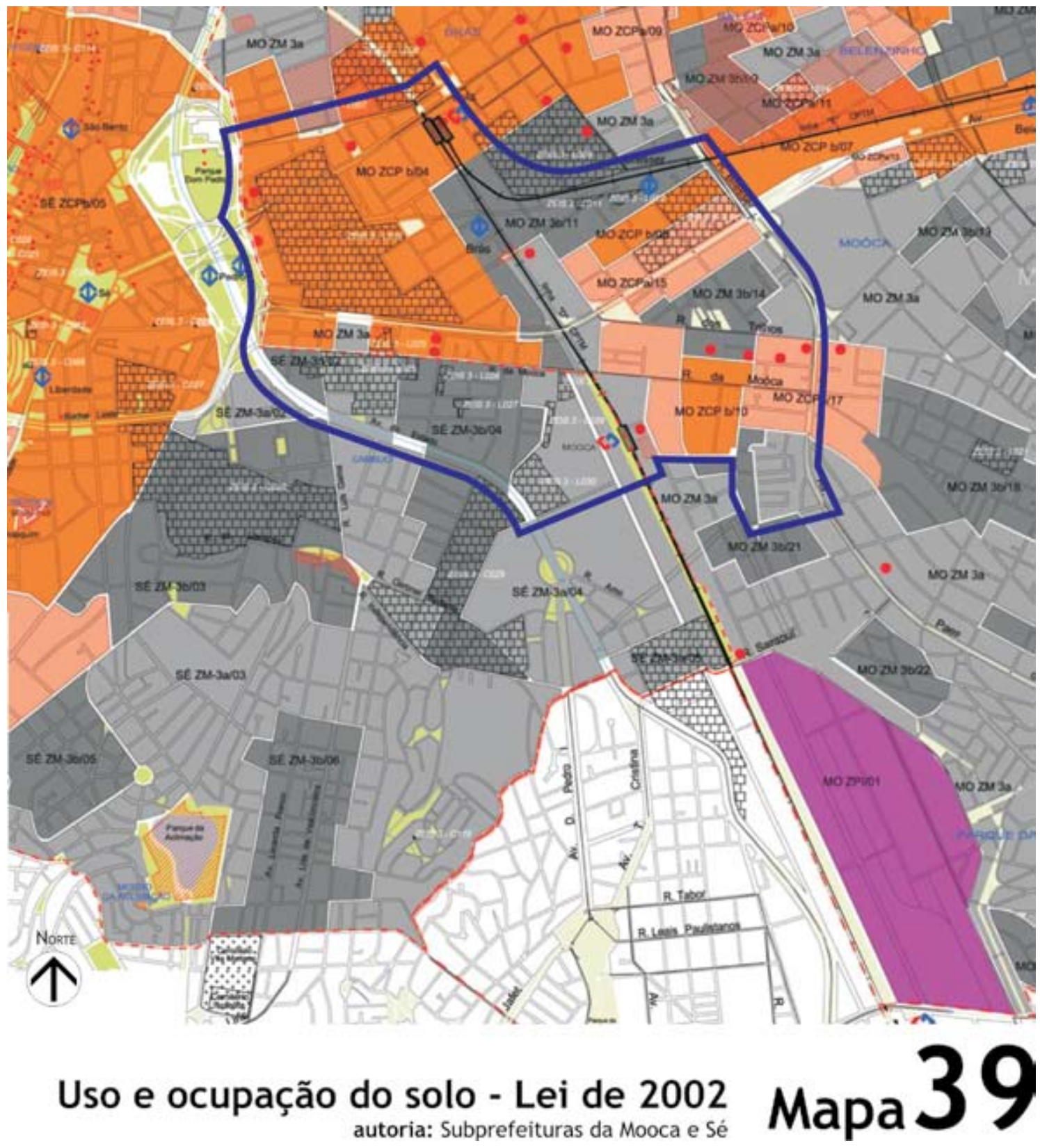


Quadro 4 - Leis de Uso e Ocupação do Solo comparadas: 1972 e 2004

\begin{tabular}{|c|c|c|c|c|c|c|c|c|c|c|}
\hline \multicolumn{11}{|c|}{ Área de abrangência: área-objeto de estudo da dissertação } \\
\hline $\begin{array}{l}\text { Lei de } \\
1972\end{array}$ & $\begin{array}{l}\text { Bairro de } \\
\text { incidência }\end{array}$ & $\begin{array}{c}\text { Características da } \\
\text { zona de uso anterior }\end{array}$ & $\begin{array}{c}\text { Uso real segundo } \\
\text { levantamento in loco }\end{array}$ & $\begin{array}{l}\text { Lei de } \\
2004\end{array}$ & $\begin{array}{l}\text { Incidência } \\
\text { de ZEIS } 3^{*}\end{array}$ & $\begin{array}{l}\text { Descrição sintética } \\
\text { do novo uso }\end{array}$ & $\begin{array}{l}\text { C.A. } \\
\text { básico }\end{array}$ & $\begin{array}{c}\text { C.A. } \\
\text { máximo }\end{array}$ & $\begin{array}{c}\text { T.O. } \\
\text { máximo }\end{array}$ & $\begin{array}{c}\text { Taxa de permeabilidade } \\
\text { mínima }\end{array}$ \\
\hline ZMLI & Brás & Zona Metrô Leste & $\begin{array}{c}\text { Predominantemente Residencial } \\
\text { (CDHU); } \\
\text { alta densidade }\end{array}$ & $\frac{\text { MO-ZCPb }}{\text { MO-ZM3b }}$ & incide & $\begin{array}{l}\text { Zona de Centralidade Polar + } \\
\text { Zona Mista de Alta Densidade }\end{array}$ & 2 & $\frac{4}{3}$ & $\begin{array}{l}0,7 \\
0,5\end{array}$ & 0,15 \\
\hline Z2 & Mooca & $\begin{array}{l}\text { Predominantemente residencial } \\
\text { baixa densidade }\end{array}$ & $\begin{array}{l}\text { Misto: predominantemente serviços } \\
\text { e industrial; } \\
\text { média densidade }\end{array}$ & MO-ZM3а & incide & Zona Mista de Alta Densidade & I & 2,5 & 0,5 & 0,15 \\
\hline Z3 & Mooca/Brás & $\begin{array}{l}\text { Predominantemente residencial } \\
\text { média densidade }\end{array}$ & $\begin{array}{l}\text { Misto: predominantemente comércio } \\
\text { e serviços; } \\
\text { média densidade }\end{array}$ & $\mathrm{MO}-\mathrm{ZCPb}$ & incide & Zona de Centralidade Polar & 2 & 4 & 0,7 & 0,15 \\
\hline Z4 & Mooca & $\begin{array}{c}\text { Misto } \\
\text { densidade demográfica média alta }\end{array}$ & $\begin{array}{l}\text { Misto: predominantemente serviços; } \\
\text { média densidade }\end{array}$ & SE-ZM3b & incide & Zona Mista de Alta Densidade & 2 & 3 & 0,5 & 0,15 \\
\hline ZZ6- & Mooca/Brás & Predominantemente industrial & $\begin{array}{l}\text { Misto: predominantemente industrial; } \\
\text { baixa densidade }\end{array}$ & $\frac{\text { MO-ZM3b }}{\text { SE-ZM3a }}$ & incide & Zona Mista de Alta Densidade & $\frac{2}{1}$ & $\frac{3}{2,5}$ & 0,5 & 0,15 \\
\hline $\mathrm{ZI2}$ & Brás & $\begin{array}{l}\text { Predominantemente residencial } \\
\text { média densidade }\end{array}$ & $\begin{array}{c}\text { Misto: predominantemente comércio } \\
\text { e serviços: } \\
\text { média densidade }\end{array}$ & $\mathrm{MO}-\mathrm{ZCPb}$ & incide & Zona de Centralidade Polar b & 2 & 4 & 0,7 & 0,15 \\
\hline Z8 CRIIII & $\begin{array}{l}\text { Av. Radial Leste / } \\
\text { Av. do Estado }\end{array}$ & $\begin{array}{l}\text { Misto } \\
\text { densidade demográfica média alta }\end{array}$ & $\begin{array}{l}\text { Misto: Comércio e Serviços Diversifi- } \\
\text { cados polarizados } \\
\text { média densidade }\end{array}$ & $\frac{\text { MO-ZCPb }}{\text { MO-ZM3a }}$ & incide & Zona de Centralidade Polar b & 2 & 4 & 0,7 & 0,15 \\
\hline Obs. 01 & \multicolumn{10}{|c|}{$\begin{array}{l}\text { O uso ZPI - Zona predominantemente industrial, que substitui o Z6-ZUP2 somente está } \\
\text { prevista na área sul da Mooca baixa, sob administração da Subprefeitura Sé, fora da área-objeto deste estudo }\end{array}$} \\
\hline Obs. 02 & \multicolumn{10}{|c|}{ O Coeficiente de aproveitamento máximo para a implantação de ZEIS 3 é 4 vezes a área do terreno. acrescentar mais uma linha. } \\
\hline & & & & & & & & \multicolumn{3}{|c|}{$\begin{array}{l}\text { novembro de 1972; } \\
\text { 2002: lei Municipal n' } 13.430 \\
\text { de } 13 \text { de setembro de } 2002 \text {. }\end{array}$} \\
\hline
\end{tabular}

$39^{80}$.

\subsection{Habitação}

O Plano Diretor Estratégico para o Município de São Paulo previu, junto a outros dispositivos urbanos para a requalificação urbana de áreas, a delimitação de ZEIS - Zonas Especiais de Interesse Social, prioritariamente para a produção de Habitações de Interesse Social - HIS e de Habitações para o Mercado Popular - HMP. Inclui também a recuperação de imóveis degradados, a provisão de equipamentos sociais e culturais, espaços públicos, serviços e comércio de caráter local (PDE de São Paulo, Capítulo II, Seção IV, Art. I7I).

$\mathrm{Na}$ área-objeto deste estudo estão delimitadas áreas de ZEIS 3:

ZEIS 3 são áreas com predominância de terrenos ou edificações subutilizados situados em áreas dotadas de infra-estrutura, serviços urbanos e oferta de empregos, ou que estejam recebendo investimentos desta natureza, ou haja interesse público, expresso por meio desta lei, dos planos regionais ou de lei específica, em promover ou ampliar o uso por Habitação de Interesse Social - HIS ou de Mercado Popular - HMP, e melhorar as condições habitacionais da população moradora local (PDE de São Paulo, Capítulo II, Seção IV, Art. I7I, inciso III).

Sendo a questão da habitação um importante assunto considerado pelo Plano Diretor Estratégico de São Paulo, de 2002, torna-se importante analisar e discutir a proporção e a localização das áreas de ZEIS 3 propostas pelas Subprefeituras Sé e Mooca e por isso pareceu importante dedicar um item para tratar-se dele ${ }^{81}$.

A planta de uso e ocupação do solo preparada pela Subprefeitura Mooca propõe, dentro da área total do trecho Brás, uma área delimitada como ZEIS 3 correspondnte a aproximadamente $50 \%$ de seu território, muito concentrada em área consolidada de uso misto

${ }^{81}$ As ZEIS 3 - Zonas Especiais de Interesse Social, tipo 3 - foram delimitadas no Plano Diretor Estratégico abrangendo um grande número de quadras e imóveis isolados nos bairros centrais. Entre as regras desta zona está a obrigatoriedade de destinação para habitação socia (HIS) de no mínimo 50\% da área construída, podendo o restante ser destinado a qualquer outro uso compatível (habitação para outras faixas de renda, comércio, serviços, indústrias não-incômodas etc). (SEHAB - Secretaria da Habitação, Programa Morar no Centro). 
${ }^{82}$ HIS - Habitação de Interesse Social: destina-se a famílias com renda igual ou inferior a 06 (seis) salários mínimos, de promoção pública ou a ela vinculada, com padrão de unidade habitacional com um sanitário, até uma vaga de garagem e área útil de no máximo $50 \mathrm{~m}^{2}$, com possibilidade de ampliação quando as famílias beneficiadas estiverem envolvidas diretamente na produção das moradias;

HMP - Habitação para o Mercado Popular: destina-se a famílias com renda igual ou inferior a 16 (dezesseis) salários mínimos ou capacidade de pagamento a ser definida em lei específica, de promoção privada, com padrão de unidade habitacional com até dois sanitários, até uma vaga de garagem e área útil de no máximo $70 \mathrm{~m}^{2}$.

Fonte: PDE de São Paulo, Capítulo II, Seção I, artigo I46, inciso XIII e XIV.

83 PRE Subprefeitura Mooca. Relatório final, volume 2 . Quadro propositivo, p.8. comercial e serviços diversificados e especializados, o que torna caros os imóveis onde funcionam esses estabelecimentos comerciais e dificulta a compra desses terrenos para a construção de habitações populares.

No caso do trecho Brás deste estudo, são duas as áreas ZEIS 3 propostas pelo PRE da Subprefeitura Mooca e que estão representadas no Mapa 43, no Capítulo VII desta dissertação:

- Trecho 01: trata-se de uma grande área que faz frente para a Avenida Radial Leste, chegando até a Rua Maria Domitila, no sentido Norte. Está delimitada ao Oeste pela Rua Capitão Faustino de Lima e pela Rua Wandenkolk e, ao Leste, a delimitação é feita pelas ruas Piratininga, Flora, Paraná, Campos Salles, Piratininga novamente, Torquato Neto, Professor Batista de Andrade e Vasco da Gama.

Além da questão do tamanho da área definida como ZEIS 3, existe também a questão da localização desta e sobre quais áreas do tecido consolidado ela incide. A primeira crítica a ser feita é que parte dessa grande mancha de ZEIS 3 é cortada pela Rua Visconde de Parnaíba, importante corredor de comércio e serviços diversificados da área. Essa rua paralela à Radial Leste, outro corredor de comércio e serviços diversificados, e separada desta apenas pela quadra existente entre as duas vias, acaba por confinar uma estreita faixa de ZEIS 3 com duas frentes: uma para a Radial Leste e outra para a Visconde de Parnaíba. Analisando-se criticamente a localização desta faixa de ZEIS 3 e tentando vislumbrar o que pode acontecer no futuro, mediante um hipotético cenário montado a partir da construção de habitações populares nessa faixa, pode-se imaginar que os construtores ou promotores imobiliários decidam voltar as entradas dos futuros condomínios de edifícios residenciais para a Rua Visconde de Parnaíba e os fundos para Avenida Radial Leste, o que poderá criar um imenso paredão no nível da rua voltado para esta via, importante para o comércio e prestação de serviços regional, o que em nada contribuirá para a melhoria do seu atual aspecto. Além da questão estética, a classificação dentro da ZEIS 3 dos imóveis com atual uso comercial ali existentes e que hoje são responsáveis por inúmeras vagas no mercado de trabalho do município, altera definitivamente seu destino dentro do mercado imobiliário. Continuando a análise do trecho 0I área ZEIS 3 do trecho Brás, encontra-se outra vez a incidência desse tipo de uso sobre quadras consolidadas com comércio e serviços diversificados, mais especificamente comércio de couros e plásticos, entre as ruas Maria Domitila, Vasco da Gama, Avenida Rangel Pestana, fechando o recorte à esquerda por entre os lotes da última quadra, deixando fora da ZEIS 3 uma vila de casas geminadas, que teriam a ganhar se tivessem sido incluídas pois seriam preservados os imóveis e seu uso, já que não há sentido em demolir uma vila residencial operária antiga ou uma vila de classe média para construir-se outro tipo de habitação popular, do padrão HIS ou HMP82.

- Trecho 02: formado por sete quadras, quatro delas defronte à Avenida Alcântara Machado - Radial Leste, onde o uso atual é misto com considerável presença do residencial, mas que agrupa também, dentro dessa mistura de usos, o uso industrial.

A proposta desta dissertação é diminuir a área ZEIS 3 contida no trecho Brás da áreaobjeto desta dissertação, mantendo o uso comercial e serviços no corredor Radial Leste, no caso do Trecho 0I e manter o polígono proposto pelo PRE Mooca no trecho 02, o que possibilitará o adensamento populacional nesse local.

Outro objetivo proposto pela Subprefeitura Mooca no tocante ao uso residencial e HIS - Habitação de Interesse Social, é que se estimule "os proprietários de cortiços a fazerem intervenções para melhorar a qualidade habitacional das mesmas", encorajados a promover a reforma do cortiço recebendo potencial construtivo por isso ${ }^{83}$. O que se vê no Brás e Mooca, são cortiços a partir de pequenas residências térreas com porões que são subdivididos em pequenos compartimentos, comprometendo totalmente a ventilação e iluminação naturais, gerando ambientes insalubres que acomodam famílias inteiras em apenas um cômodo. Na 
verdade, deveria proibir-se a prática e não oficializá-la. A CDHU - Companhia de Desenvolvimento Habitacional e Urbano do Estado de São Paulo, tem plano melhor para abordar a questão da acomodação definitiva e digna de moradores de cortiços: comprar o imóvel, demoli-lo - desde que não tenha características arquitetônicas importantes para o Patrimônio Histórico - e construir prédios de 4 andares para acomodar os antigos moradores do cortiço. A Subprefeitura Mooca também propõe a reforma dos imóveis ociosos ou abandonados pelo poder público para acomodar moradores de baixa renda.

As áreas de ZEIS 3 delimitadas dentro do trecho Mooca da área-objeto deste estudo são seis, localizadas da seguinte forma (ver Mapa 43 com a representação gráfica das principais diretrizes propostas pelas Subprefeituras Sé e Mooca, no Capítulo VII desta dissertação).

- Trecho 01: é o maior trecho; é delimitado pelas ruas Oscar Horta, Odorico Mendes, Coronel Cintra, Dom Bosco, Luis Gama, Rua da Mooca e se expande quadras a dentro à esquerda, à direita e acima desse perímetro, selecionando somente parte dos imóveis pertencentes a essas quadras; percebe-se a provável intenção por parte da Subprefeitura Sé em preservar o uso residencial de muitos dos imóveis, de padrão classe média, existentes no trecho 01 de ZEIS 3, pois esse trecho inclui várias vilas construídas nas primeiras décadas do século 20 ; infelizmente duas vilas foram demolidas recentemente: uma formada por aproximadamente 80 casas operárias em estilo arquitetônico neoclássico e construídas em 1925, com frentes para as ruas Dom Bosco, Odorico Mendes e Andrade Reis e a Vila Hilda, localizada na Rua Coronel Cintra;

- Trecho 02: localizado à Rua Barão de Jaguara esquina com Rua Dom Bosco, preserva imóveis residenciais, uma vila residencial e outros imóveis com vários usos, mas surpreendentemente não inclui a vila operária projetada por Gregori Warchavchi, localizada na outra esquina formada pelas ruas Barão de Jaguara e Dom Bosco;

- Trecho 03: essa mancha está inserida no meio da quadra formada pelas ruas Odorico Mendes, Barão de Jaguara, Dom Bosco e Dona Ana Nery; alterará no futuro caso haja interesse imobiliário, galpões com uso atual industrial em ZEIS 3;

- Trecho 04: em forma de triângulo e localizado de frente à Avenida Presidente Wilson, preservaria o uso da vila operária existente ao lado da cervejaria Companhia Antárctica Paulista, caso esta ainda existisse, mas foi demolida, dando lugar a um estacionamento; restringe o futuro uso a HIS ou HMP;

- Trecho 05: o segundo maior trecho da Mooca baixa, delimitado pela Rua Coronel João Dente, Avenida do Estado, Rua Serra de Paracaima e segue por dentro do terreno de propriedade da Companhia Antárctica Paulista, numa clara intenção de regular a requalificação de parte dessa grande propriedade;

- Trecho 06: sendo praticamente uma continuação do trecho 05, preservará o uso residencial dos imóveis voltados para a Rua Coronel João Dente; também é limitado à direita pela propriedade da Antárctica.

Surpreende a exclusão de área residencial localizada na mesma rua que os trechos 4 , 5 e 6, formada por três quadras com sobrados de classe média, construídos provavelmente a partir da metade do século 20 e que mantém, até o momento, o uso residencial. Essas quadras estão delimitadas pelas as ruas Conselheiro João Alfredo, Conselheiro João Dente, Canavieiras e Manoel Mota. Essas quadras são objeto de proposta representada no Mapa 44, no Capítulo VII desta dissertação.

Propõe-se nesta dissertação que a área ZEIS 3 contida no trecho 02, descrita acima, seja ampliada de forma a abranger a vila operária de Gregori Warchavchik.

As delimitações de ZEIS 3 propostas por esta dissertação estão presentes no Mapa 44 com a representação gráfica das diretrizes para requalificação urbana do Brás e Mooca. 


\title{
3. As Operações Urbanas no Brás e Mooca
}

Brás e Mooca estão ambos incluídos em Operações Urbanas: a Operação Urbana Centro inclui o trecho Brás da área-objeto de estudo e a Operação Urbana Diagonal Sul inclui os trechos Mooca, Mooca baixa e Brás ao leste da Ferrovia Santos-Jundiaí, além de outras áreas ou distritos, ao sul e ao norte das áreas-objeto deste estudo (Mapa 40).

O perímetro da área abrangida pelo projeto da Operação Urbana Centro engloba a área que vai das ferrovias Santos-Jundiaí e Sorocabana a partir da Avenida Alcântara Machado passando pelo Largo da Concórdia e pela Luz e chegando até a Praça Júlio Prestes. O limite ao oeste abrange o eixo de grandes avenidas: Duque de Caxias, Amaral Gurgel e contorna a Praça Roosevelt até a Rua Caio Prado. Ao sul é delimitado pela Ligação Leste-Oeste chegando novamente à Radial Leste e por fim fechando o polígono junto à ferrovia Santos-Jundiaí.

\begin{abstract}
As Operações Urbanas Consorciadas são o conjunto de medidas coordenadas pelo Município com a participação dos proprietários, moradores, usuários permanentes e investidores privados, com o objetivo de alcançar transformações urbanísticas estruturais, melhorias sociais e a valorização ambiental, notadamente ampliando os espaços públicos, organizando o transporte coletivo, implantando programas habitacionais de interesse social e de melhorias de infra-estrutura e sistema viário, num determinado período (Plano Diretor Estratégico para o Município de São Paulo, Capítulo III, Seção VII, Art. 225).
\end{abstract}

O texto a seguir foi retirado de palestra apresentada pelo arquiteto e urbanista José Eduardo de Assis Lefévre a respeito do instrumento urbanístico Operação Urbana Centro, de cuja estruturação foi coordenador ${ }^{84}$ :

\begin{abstract}
Esta Operação Urbana é o resultado de desdobramentos de uma série de experiências trabalhadas por nós na EMURB desde 1989 como uma forma de obter recursos a partir da iniciativa privada em forma de investimentos na área central. Essa obtenção de recursos usaria o mecanismo que já vinha sendo usado em São Paulo pela chamada Operação Interligada, que previa a possibilidade de ultrapassar os limites estabelecidos pelo zoneamento, mediante o pagamento de uma contrapartida financeira, destinada exclusivamente à construção de habitações de interesse social com desvinculação na lei de Operações Interligadas entre o local da compra do potencial construtivo, onde se fará esse acréscimo acima do que estabelece a lei de zoneamento - e o local da aplicação destes recursos. Posteriormente se percebeu a necessidade de se ter uma ação muito mais abrangente voltada para esta área, principalmente para a recuperação de sua imagem, com atração de empresas de porte para a área. Do ponto de vista da posição de uma cidade - de uma metrópole como São Paulo - face os eventos da globalização, da concorrência entre as cidades, é um contra-senso que em São Paulo não se invista na qualidade de vida da cidade. Espera-se que a Operação Urbana Centro atue positivamente no quadro de perspectiva de resultados para a realização de investimentos no Centro, revertendo um quadro de fuga de atividades e deterioração das edificações e da qualidade ambiental.
\end{abstract}

Em relação aos sistemas viários, a Diagonal Sul privilegia a transformação da SantosJundiaí associada a uma via tangente para alternativa do tráfego de veículos da Avenida do Estado, já sobrecarregada, modernizando as estações de parada e embarque de passageiros - Largo da Concórdia, localizada no Brás; Estação Ipiranga, Estação Tamanduateí, localizada entre o município de São Caetano e o distrito do Ipiranga em São Paulo e a Estação da Mooca, localizada na Rua Monsenhor João Felipo, cujo edifício merece ser tombado pelo Patrimônio Histórico como proposto no item 5 do Capítulo VII.

A Operação Urbana Diagonal Sul propõe área verde linear ao longo da ferrovia - atuais Parques Lineares presentes nas diretrizes do Plano Diretor Estratégico para o Município de São Paulo - em fragmentos, incluindo parte da área onde hoje ainda existem galpões da Cervejaria Antárctica. 
Através de financiamento do projeto Ação Centro, essa operação urbana contará com a aplicação do PRIOU - Plano de Referência de Intervenção e Ordenação Urbanística - com o mapeamento de áreas com contaminação de solo e água e estudos para a melhoria da água do Tamanduateí.

A Operação Urbana Diagonal Sul propõe também uma análise imobiliária da região com inventário de bens culturais geo-referenciados. Partindo de um projeto referência, os idealizadores dessa operação urbana pretendem induzir projetos de requalificação urbana na região em parceria com a iniciativa privada.

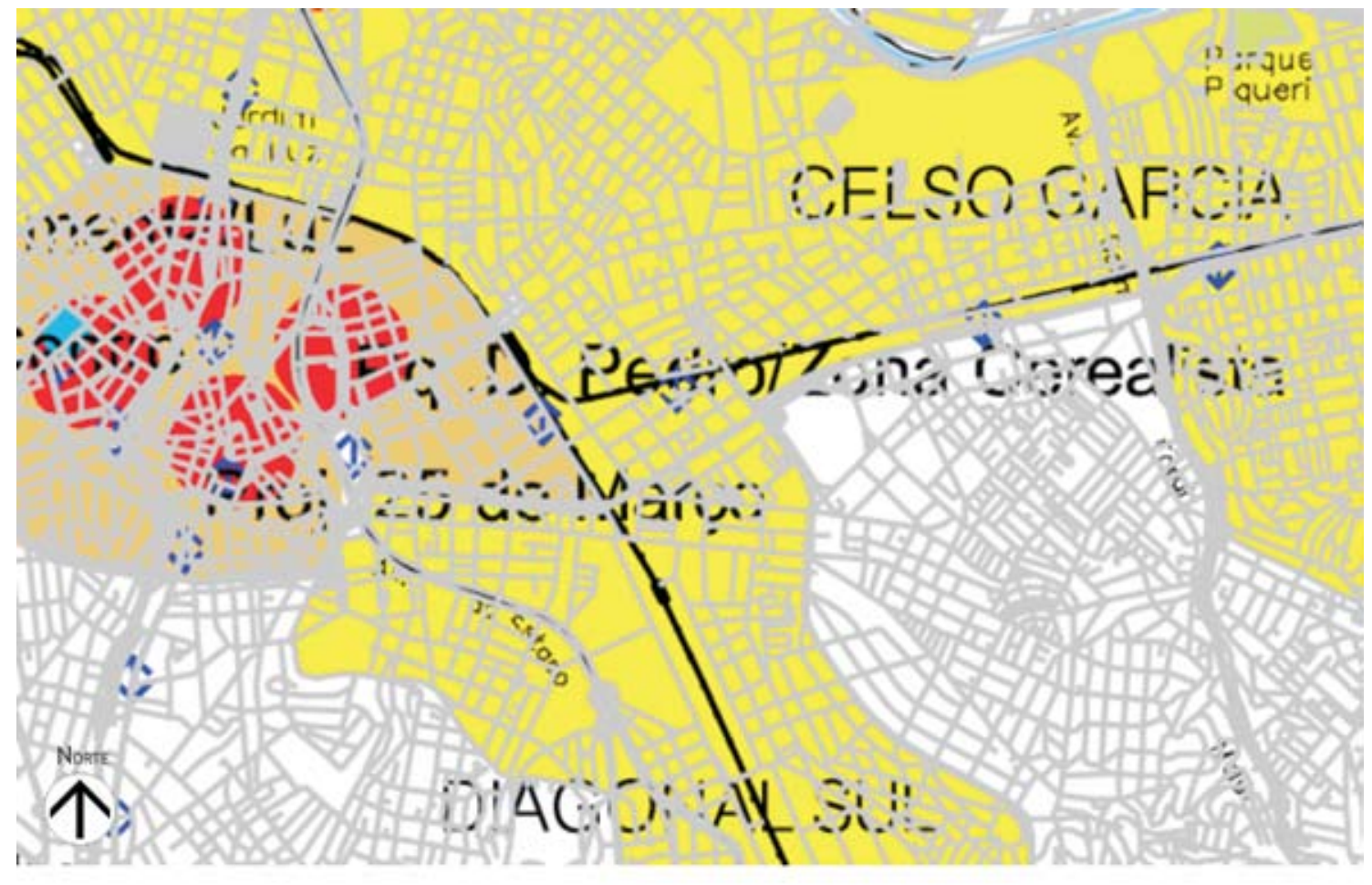

\section{Operações urbanas \\ Mapa40}

Na página a seguir, o Mapa 4I representa graficamente a reunião das principais diretrizes propostas pelos PREs das Subprefeituras Sé e Mooca para a área-objeto de estudo.

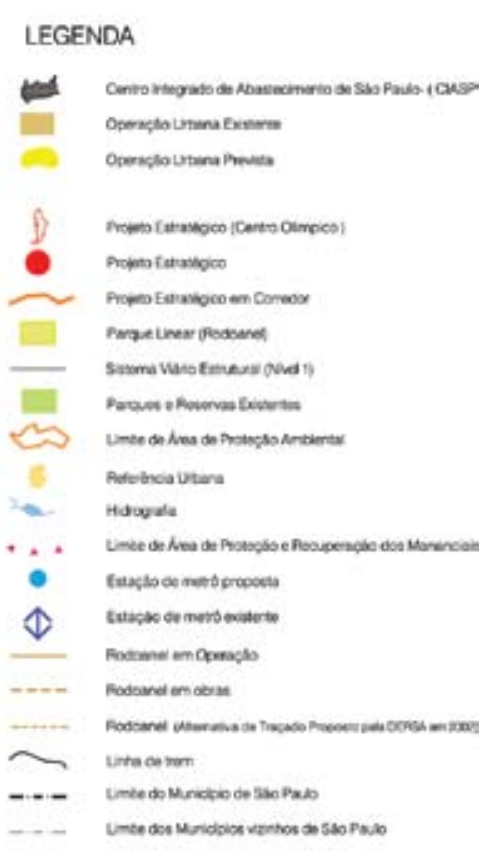




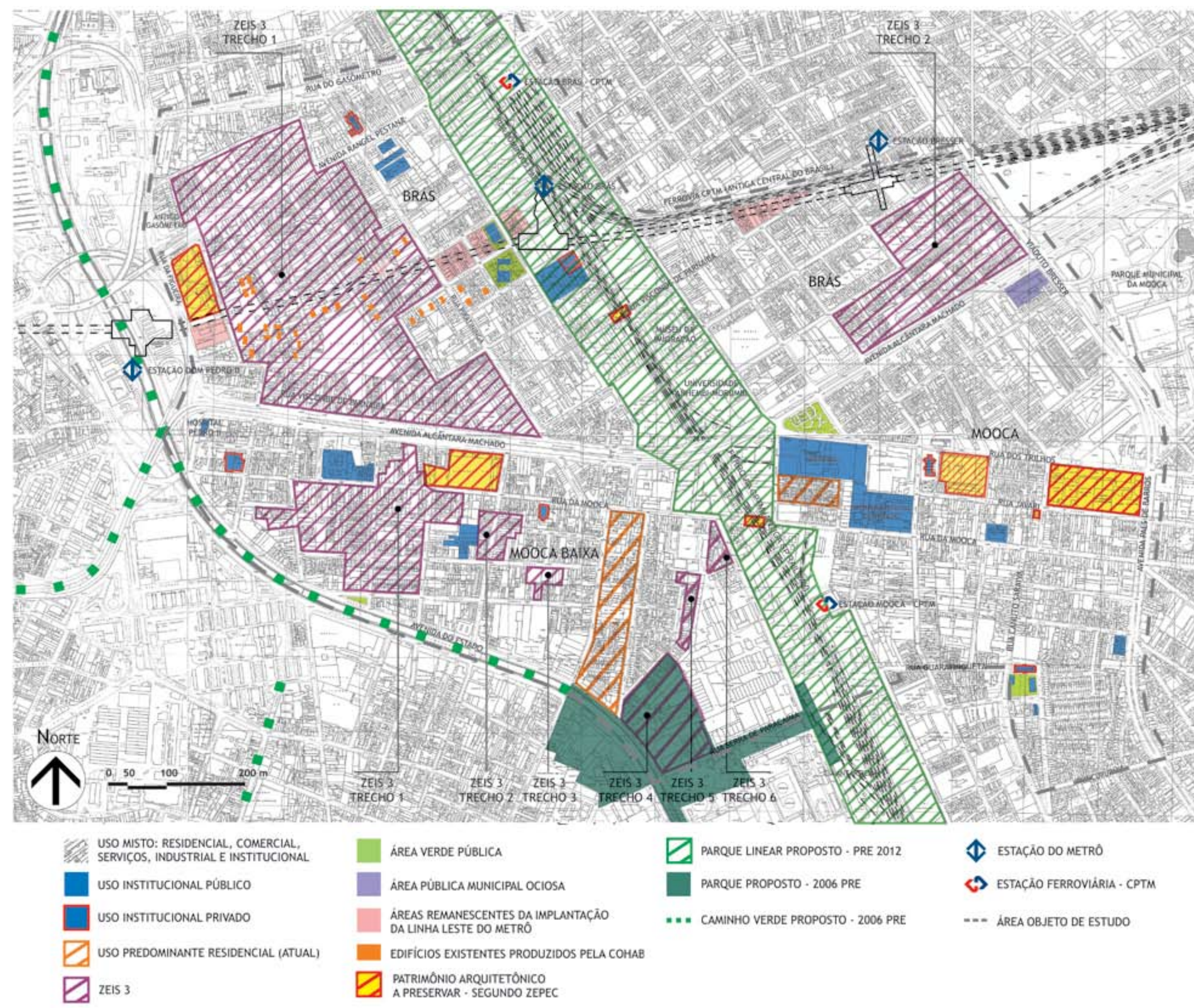

Planos Regionais Estratégicos das subprefeituras Sé e Mooca Representação gráfica dos principais elementos autoria: Maria Elizabet Paez Rodriguez sobre GEGRAN 1972

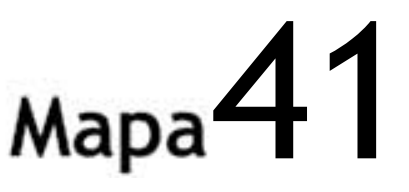




\section{Capítulo VII \\ Radial Leste, Brás e Mooca: diretrizes para a requalificação urbana}

O quadro de diretrizes aqui propostas baseou-se primeiramente na observação in loco e nos levantamentos de dados históricos na análise crítica das diretrizes contidas nos Planos Diretores Regionais apresentados pelas Subprefeituras Sé e Mooca, o que resultou em diretrizes mais específicas para a área em estudo, alterando perímetros de áreas ZEIS 3 pré-estabelecidos pelos PRE's e criando áreas ZER - Zonas Estritamente Residenciais, com objetivo de proteger conjuntos de residências de padrão classe média localizados em ruas de qualidade urbana, cercadas por quadras de uso misto com comércio e serviços de âmbito local e diversificado.

As diretrizes para a requalificação urbana do Brás, Mooca e Radial Leste foram agrupadas em Diretrizes Gerais, Uso e Ocupação do Solo, Reestruturação Viária, Equipamentos Sociais, Qualidade Ambiental e Recuperação do Patrimônio Histórico. As diretrizes propostas a seguir foram agrupadas segundo os critérios acima. Ao fim da apresentação deste conjunto de diretrizes estão o Mapa 41 - Representação Gráfica das Diretrizes das Subprefeituras Sé e Mooca e Mapa 44 - Representação Gráfica das Diretrizes para Requalificação Urbana do Brás e Mooca.

\section{Diretrizes gerais para a requalificação urbana do Brás e Mooca}

Algumas diretrizes gerais tiveram como pano de fundo conceitos adotados dos PREs das Subprefeituras Sé e Mooca.

- Reversão da desvalorização imobiliária e recuperação da função residencial;

- Implantação de usos diversificados, como o cultural, educacional, saúde, hoteleiro e o habitacional, cuja prioridade deve ser dada para a HIS e HMP;

- Estimular o uso habitacional, atividades culturais e de lazer e a diversidade social incentivando a diversidade de usos;

- Garantir os usos adequados de espaços públicos e privados a todos os habitantes, inclusive aos portadores de qualquer tipo de necessidade especial;

- Resgatar o espaço público para a apropriação coletiva;

- Recuperar áreas degradadas, em especial aquelas ocupadas por habitações precárias;

- Intervir em áreas desocupadas ou ocupadas por usos inadequados;

- Melhorar a gestão e o ordenamento dos espaços públicos nas principais ruas comerciais através de programas específicos para isso;

- Estimular o desenvolvimento econômico local, através da permanência de atividades de médio e pequeno porte, geradoras de empregos que utilizem insumos produzidos na região;

- Transformação do perfil econômico e social, por meio de ações de fomento da pluralidade econômica, da inclusão social, da segurança urbana e da cultura; 
- Reconhecer, na logística das atividades, a existência de grupos organizados marginalizados, tais como ambulantes ou catadores de lixo;

- Criação de conjunto de parâmetros para fiscalização e controle de imóveis com usos conflitantes;

- Garantir a despoluição ambiental e a descontaminação de solos;

- Criação e aplicação de conjunto de normas e ações de forma a implantar áreas verdes ou espaços abertos para lazer e contemplação.

\section{Uso e ocupação do solo}

O comércio e serviços diversificados se beneficiam da alta acessibilidade das vias movimentadas, mas deve o poder público distinguir claramente as atividades que delas se beneficiam das que são prejudicadas por tal localização nos planos de nível local, de bairro ou por Operações Urbanas (Campos Filho, 2003, p.22).

Da mesma forma que nas Diretrizes Gerais, adotou-se aqui ações e diretrizes baseadas nos PRE's. São as seguintes as diretrizes destinadas ao controle do uso e ocupação do solo na área-objeto de estudo desta dissertação:

- Estimular a regularização de uso das edificações existentes;

- Reconversão de uso de áreas industriais com consulta aos órgãos ambientais competentes, para averiguar a sua possível contaminação pelo uso industrial anterior, certificando-se da possibilidade de utilização das mesmas;

- Estimular a localização de empreendimentos de maior porte com alteração de uso em antigos edifícios fabris de importância histórica e cultural.

Com o objetivo de disciplinar e ordenar o uso e ocupação do solo, bem como a taxa de permeabilidade de forma convergente ao conjunto de diretrizes apresentadas, a tabela 8 seguir define o Coeficiente de aproveitamento do Solo e a Taxa de ocupação do solo de cada tipo de empreendimento, a seguir:

Tabela 8 - Coeficiente de Aproveitamento (CA) e Taxa de Ocupação (TO) propostos

\begin{tabular}{ccccccc}
\hline & hotel & teatro & HM & $\begin{array}{c}\text { polo com. } \\
\text { e serviços }\end{array}$ & ZEIS & uso misto \\
\hline CA & 4 & 4 & 6 & 6 & 4 & 2 \\
TO & 0,7 & 0,7 & 0,7 & 0,7 & 0,7 & 0,5 \\
$\begin{array}{c}\text { taxa de } \\
\begin{array}{c}\text { impermeabilidade } \\
\text { gabarito }\end{array}\end{array}$ & $15 \%$ & $15 \%$ & $15 \%$ & $15 \%$ & $15 \%$ & $15 \%$ \\
\hline
\end{tabular}

\subsection{Uso residencial}

Este conjunto de diretrizes propõe o adensamento populacional voltado para a produção de moradias que atenda desde às classes de baixa renda, na forma de HIS (Habitação de Interesse Social), até a classe média, na forma de HMP (Habitação para Mercado Popular). 
Conjugando-se a baixa densidade demográfica, pode-se afirmar que a construção de moradias do tipo HIS (Habitação de Interesse Social), nas áreas ZEIS 3 já delimitadas dentro da área-objeto de estudo, e do tipo HMP (Habitação para o Mercado Popular) podem materializar as diretrizes estipuladas no Plano Diretor Estratégico para São Paulo. Adicionando-se a isso a significativa diminuição na população de ambos os bairros nos últimos vinte anos, obtém-se o panorama adequado para atrair novos moradores.

Como visto no diagnóstico geral apresentado nos Capítulos III e IV desta dissertação, os projetos de implantação dos edifícios produzidos pela COHAB destinaram mais de 50\% da área dos terrenos para estacionamento dos veículos dos moradores, gerando subutilização de áreas apropriadas à construção de edifícios residenciais ou equipamentos sociais públicos.

A produção de moradias por parte do Estado poderá atrair o interesse da iniciativa privada na produção capitalista de residências de padrão médio.

São estas as diretrizes para promover-se o adensamento populacional na área-objeto de estudo desta dissertação:

- Promover o adensamento populacional de forma controlada em função da capacidade instalada em infra-estrutura;

- Ampliar a oferta de habitação de interesse social, estimulando a produção privada de moradia para baixa e média renda;

- Estimular a produção de novas unidades habitacionais para diferentes faixas de renda, destinadas às diferentes composições familiares: habitações unifamiliares, habitações multifamiliares e requalificação de moradias precárias;

- Assegurar o direito à moradia digna para a população que vive em cortiços, favelas e ocupações irregulares existentes no território sob administração das Subprefeituras Sé e Mooca;

- Atrair moradores das classes de média e baixa renda;

- Dar condições para mescla de classes sociais próximas (classe média e classe popular);

- Realocação de moradores de cortiços na própria região onde já vivem, através dos programas governamentais na esfera dos governos municipal e estadual;

- Controle do adensamento e verticalização evitando a sobrecarga na infra-estrutura instalada caso esta não possa ser incrementada;

- Criação de "llhas de Tranqüilidade Grau I", segundo conceito de Campos Filho, através da proposição de áreas ZER em quadras já consolidadas onde o uso é estritamente residencial, são cortadas somente por vias locais e estão envoltas por quadras de uso misto predominantemente residencial; essas quadras de uso misto de âmbito local e predominantemente residencial serão classificadas em "Ilhas de Tranqüilidade Grau 2", fazendo-se um desdobramento do conceito de Campos Filho;

- Criação de "Ilhas de Tranqüilidade grau 2", delimitando quadras de uso misto predominantemente residencial; deverá ser promovida a revitalização dessas quadras de uso predominantemente residencial e misto de comércio e serviços de âmbito local, através da recuperação ambiental, garantia da segurança pública e qualidade das ruas e passeios, acrescentadas de arborização.

As aplicações destas diretrizes estão voltadas para a implantação das seguintes áreas com uso habitacional: 


\section{Habitação ZEIS 3 - COHAB:}

Construção de até 83 novos edifícios residenciais padrão média renda de até 24 andares, com quatro apartamentos por andar com planta e área total similares aos apartamentos já existentes, distribuídos dentro dos condomínios existentes nas COHAB Brás I a X e Bresser I a III, conforme projeto arquitetônico de acomodação. As vagas de estacionamento hoje existentes no pavimento térreo deverão ser realocadas para subsolos sob os novos edifícios a serem construídos e devem ter capacidade suficiente para atender aos novos e atuais moradores, na proporção de I vaga por apartamento (ver tabela de cálculo do potencial construtivo no item 5, Conclusão do Capítulo III).

- Processo de viabilização: através dos trâmites inter-poderes do governo municipal.

- Localização no Mapa 44 - ao longo da linha Leste do Metrô

\section{Habitação ZEIS 3 - Antárctica:}

Figura 42

Simulação por maquete eletrônica de implantação de condomínios

residencias com habitações do tipo HIS e HMP nas áreas ZEIS 3 propostas por esta dissertação para a propriedade da Cervejaria Antárctica Paulista.

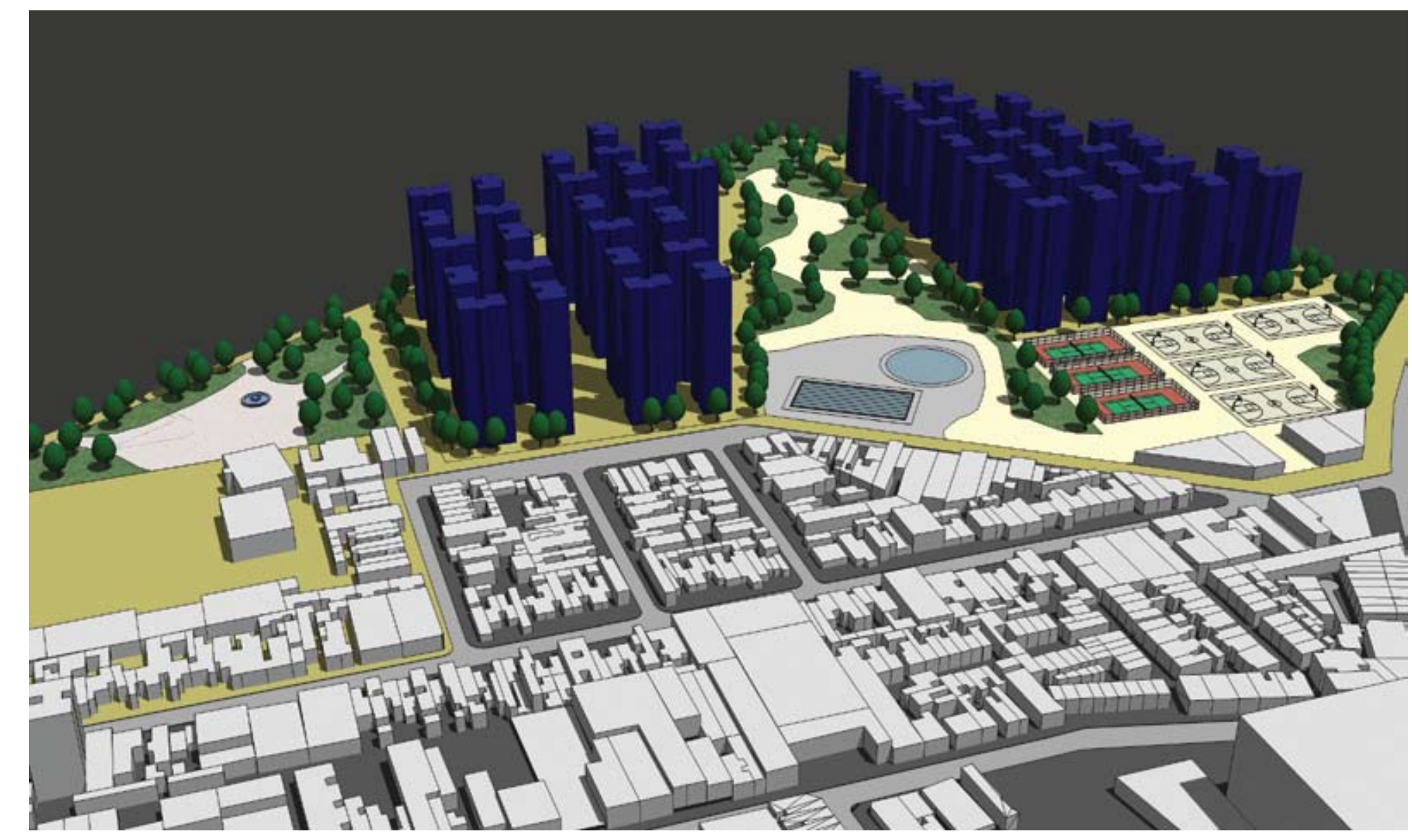

Definição de dois trechos de área ZEIS 3 dentro da propriedade da AMBEV, cujas instalações fabris estão em fase de desativação, localizados à Avenida Presidente Wilson, na Mooca baixa, juntamente com destinação de parte da área para área verde.

- Processo de viabilização: Promoção estatal de moradias ou produção capitalista pela iniciativa privada.

- $\quad$ Localização no Mapa 44 - Trechos ZEIS 3 n 6 e n 7. 


\section{Criação de 05 setores de ZER - Zona Estritamente Residencial na Mooca}

Trechos 1,2,3,4 e 5, com o seguinte objetivo: Criação de áreas ZER - Ilhas de Tranqüilidade grau I: zonas de uso estritamente residencial no trecho Mooca baixa, trecho Mooca e trecho Brás da área-objeto deste estudo.

- Localização no Mapa 44: ZER n I, 2, 3, 4 e 5.

\section{Criação de OI setor de ZER - Zona Estritamente Residencial no Brás}

Trecho I, com o seguinte objetivo: Criação de áreas ZER - Ilhas de tranqüilidade grau I: zonas de uso estritamente residencial no trecho Brás da área-objeto deste estudo.

- Localização no Mapa 44 - ZER n I.

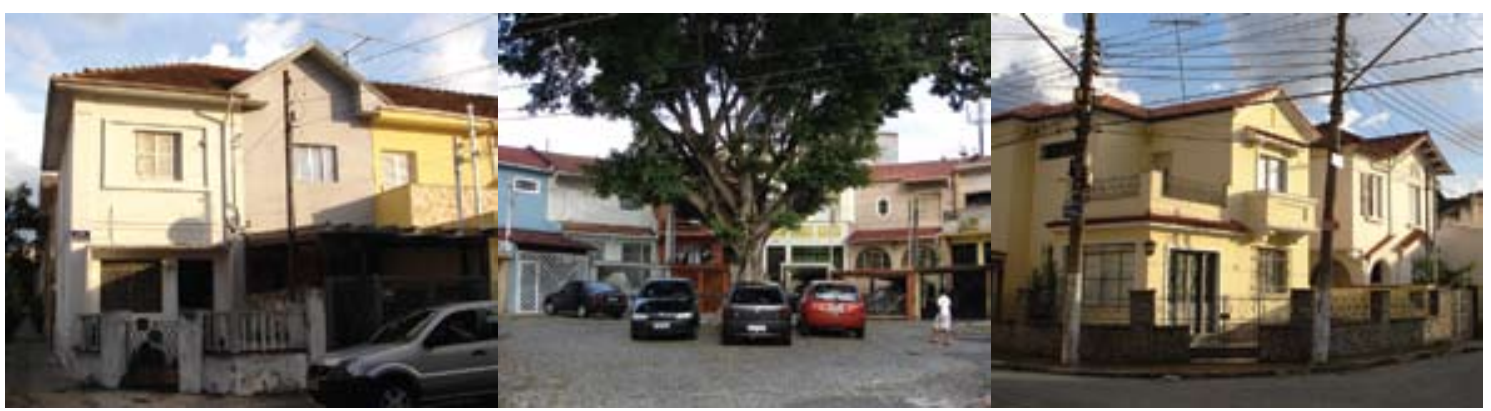

As fotos de satélite abaixo delimitam as áreas de uso real estritamente residencial existentes na Mooca e também no Brás, que devem ter este uso preservado. Acima algumas fotos que mostram a tranqülildade das ruas locais e seus conservados imóveis residenciais de classe média.
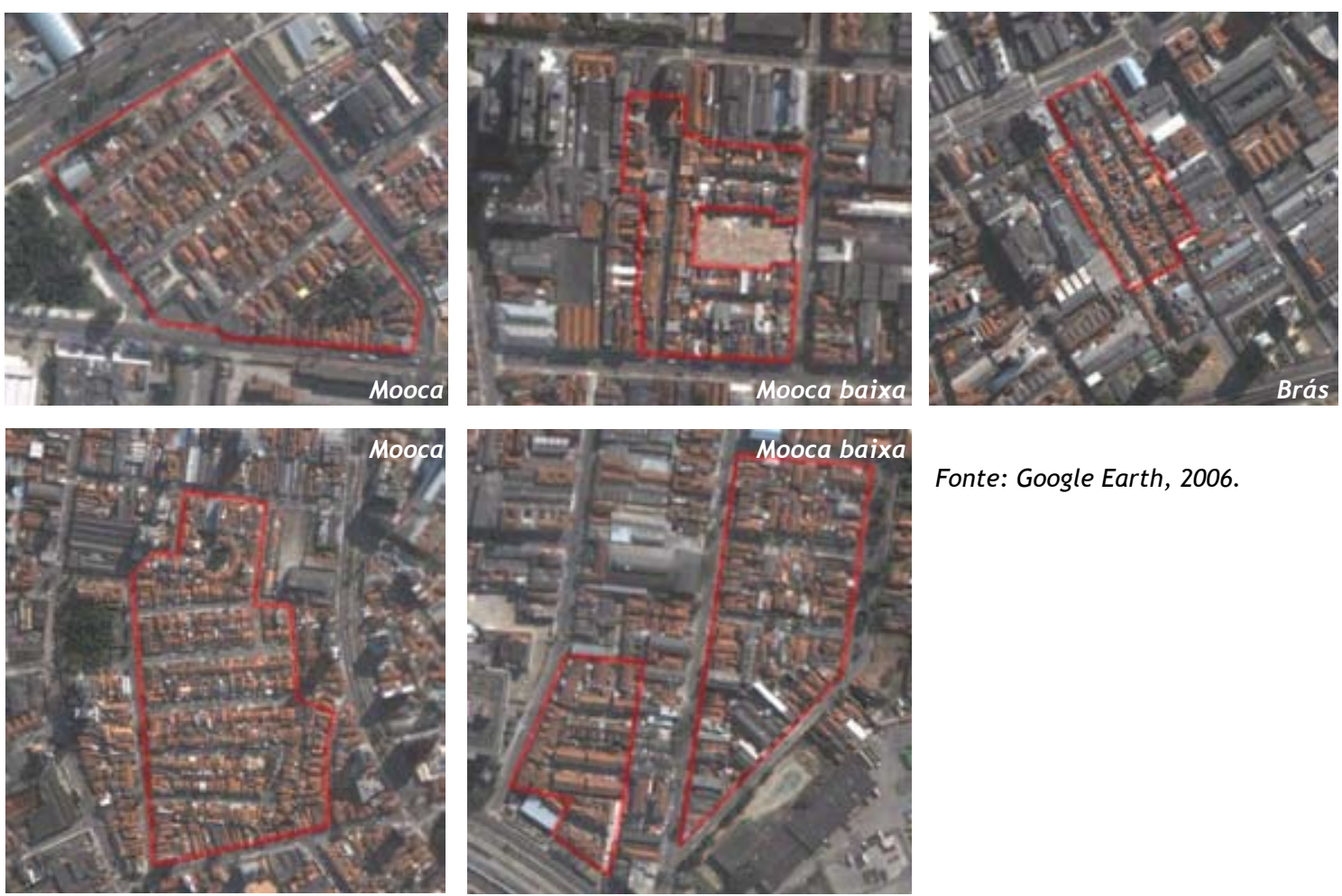

Fonte: Google Earth, 2006. 


\subsection{Uso comercial e uso serviços}

São as seguintes as diretrizes destinadas aos imóveis de uso comercial e serviços nos trechos Brás e Mooca da área-objeto de estudo:

- Estimular a concentração de pontos de comércio e serviços de âmbito local;

- Estimular instalação de empreendimentos pequenos e médios de uso comercial e de serviços;

- Estimular as funções turísticas de hotelaria, entretenimento, lazer, cultura e negócios;

- Desenvolver planos e programas para a revitalização de pontos e áreas de comércio e serviços diversificados e também especializados, para que estes adquiram qualidade ambiental e paisagística, com fácil acessibilidade e que não sejam incompatíveis com os imóveis residenciais próximos; esses planos deverão considerar a melhoria visual das ruas, fiscalizando a propaganda irregular e excessiva, e providenciar a adaptação de passeios e acesso às lojas tornando-os totalmente acessíveis às pessoas com dificuldades visuais e de locomoção.

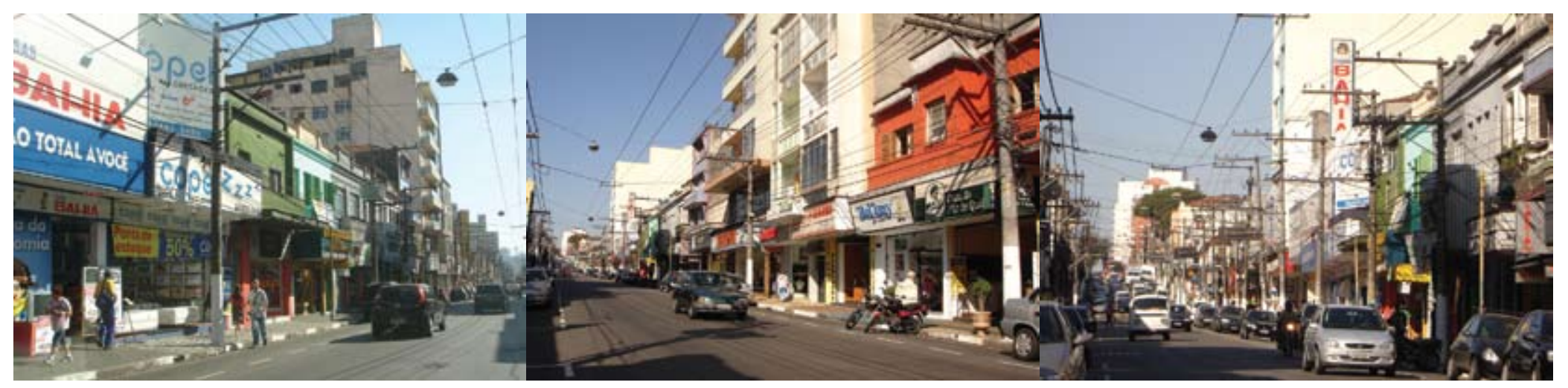

As aplicações destas diretrizes estão voltadas para a implantação das seguintes áreas com uso comercial e serviços:

\section{Pólo de comércio e serviços: Antiga Fábrica da Cervejaria Antárctica Paulista}

Aplicação de política pública de incentivos fiscais que estimulem a criação de centralidade comercial e de serviços de âmbito local e diversificado, formado por lojas diversas, cafés, restaurantes, livraria e outros, em conjunto com a instalação de hotel e centro de convenções para atendimento à demanda gerada pelas atividades comerciais e industriais do Brás (confecções, couros, máquinas, plásticos, atacadistas cerealistas) combinada com a recuperação e posterior tombamento pelo Patrimônio Histórico dos antigos edifícios da cervejaria, preservando a memória local em relação à implantação dessa fábrica e a história entre ela e as comunidades locais.

- Processo de viabilização: Iniciativa privada;

- Localização no Mapa 44: II - área a requalificar com preservação e recuperação da tipologia arquitetônica com alteração de uso e tombamento pelo Departamento de Patrimônio Histórico. 


\subsection{Uso institucional}

São as seguintes diretrizes destinadas aos imóveis de uso institucional no Brás e Mooca:

- Aumentar o número de equipamentos urbanos públicos, para atendimento da atual população e das novas demandas em função do adensamento populacional e que apresentem distâncias confortáveis para chegar-se caminhando até eles;

- Criação de espaços públicos abertos, verdes, para o lazer público e gratuito;

- Criação de espaços públicos para lazer, recreação e prática de esportes.

- Complementação dos equipamentos públicos nas áreas de saúde e educação, de forma a suprir as necessidades e deficiências atuais e atender as novas demandas em função do adensamento populacional;

- Aproveitamento de imóveis ociosos para instalação de equipamentos públicos;

- Recuperação de marcos referenciais importantes para a história dos dois bairros. mentos:

As aplicações destas diretrizes estão voltadas para a implantação dos seguintes equipa-

\subsection{Saúde pública}

\section{Hospital Municipal}

A ser implantado em terreno ocioso da PMSP remanescente das desapropriações necessárias para a implantação da Linha Leste do Metrô, localizado à Rua da Figueira esquina com a Rua Azevedo Júnior, combinado com desapropriação dos imóveis entre essa área e a esquina com a Rua Azevedo Júnior, com programa de ocupação de acordo com as normas da Secretaria da Saúde e adequado à demanda local segundo cálculo elaborado por equipe específica.

- Processo: ocupação de área pública e desapropriação de área particular entre essa área ociosa e a Rua Azevedo Júnior, Brás.

- Localização no Mapa 44: 01 - área a desapropriar para instalação de equipamento público + área remanescente de desapropriação anterior para implantação da Linha Leste do Metrô.

\section{Implantação de UBS - Unidade Básica de Saúde Programa Saúde da Família- unidade 0I:}

Localizada dentro do conjunto do Centro Educacional Unificado (CEU) proposto, com o seguinte programa arquitetônico: recepção, arquivo médico, setor administrativo, sala de imunização, sala de sutura e curativo, sala de observação com WC, apoio de enfermagem, sala para inalação, 8 (oito) consultórios para receber 5 (cinco) equipes do Programa Saúde da Família, consultório odontológico com 3 (três) cadeiras e pequena sala com raio-X odontológico, bancada com pias para orientações sobre higiene bucal, sala de coleta de material para exames laboratoriais, sala de expurgo e esterilização, depósito de material de limpeza, dispensário para médicos, almoxarifado, sanitários para pacientes (feminino e masculino), banheiros de funcionários (feminino e masculino) com chuveiros e armários, sala de reuniões e atividades educativas, sala de reuniões para agentes de saúde, copa e lixeira.

- Processo de viabilização: desapropriação dos imóveis particulares localizados à Rua Visconde de Parnaíba, a partir da esquina com a Rua Carneiro Leão, até a esquina com a Rua Caetano Pinto, no Brás, e do edifício abandonado da antiga Metalúrgica Matarazzo, à Rua Caetano Pinto, em conjunto, para a implantação do CEU - Centro Educacional Integrado, em cujo conjunto se incluirá a UBS.

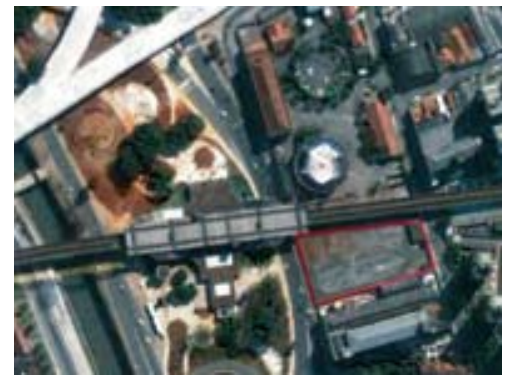

Área remanescente no Brás ao lado da Congás que deverá receber Hospital Municipal. A área ao lado deverá ser desapropriada para complementrtar a superfície necessária para a implantação e para viabilizar as duas entradas necessárias para o funcionamento do hospital. Fonte: Google Earth, 2006. 
- Localização no Mapa 44: 02 - área a desapririar para instalação de equipamento público.

\section{Implantação de UBS - unidade 02:}

Localizada à Rua Odorico Mendes (altura do $\mathrm{n}^{\circ} 60 \mathrm{I}$ ), em trecho previamente selecionado pela PMSP como ZEIS e agora proposto para acomodar esse equipamento social de uso institucional. $O$ programa arquitetônico deverá seguir o mesmo programa da unidade proposta 01 .

- Processo de viabilização: desapropriação de imóveis particulares.

- Localização no Mapa 44: 03 - área a desapropriar para instalação de equipamento público.

\footnotetext{
- - - Área objeto de estudo

Ambulatório de Especialidades - AE 1. AE Dr. Ítalo Domingos Le Vocci

Centro de Atenção Psicossocial álcool e drodas - CAPS ad 1. CAPS ad Mooca

Centro de Convivência e Cooperativa - CECCO

1. CECCO Mooca

Centro de Atençăo Psicossocial - CAPฐ 1. CAPS infantil Mooca

Hospital Municipal proposto - HM

Unidade Básica de Saúde - UBS 1. UBS Mooca I

Unidade Básica de Saúde proposta

m- Linha Leste do Metrô

Estação do Metrô
}

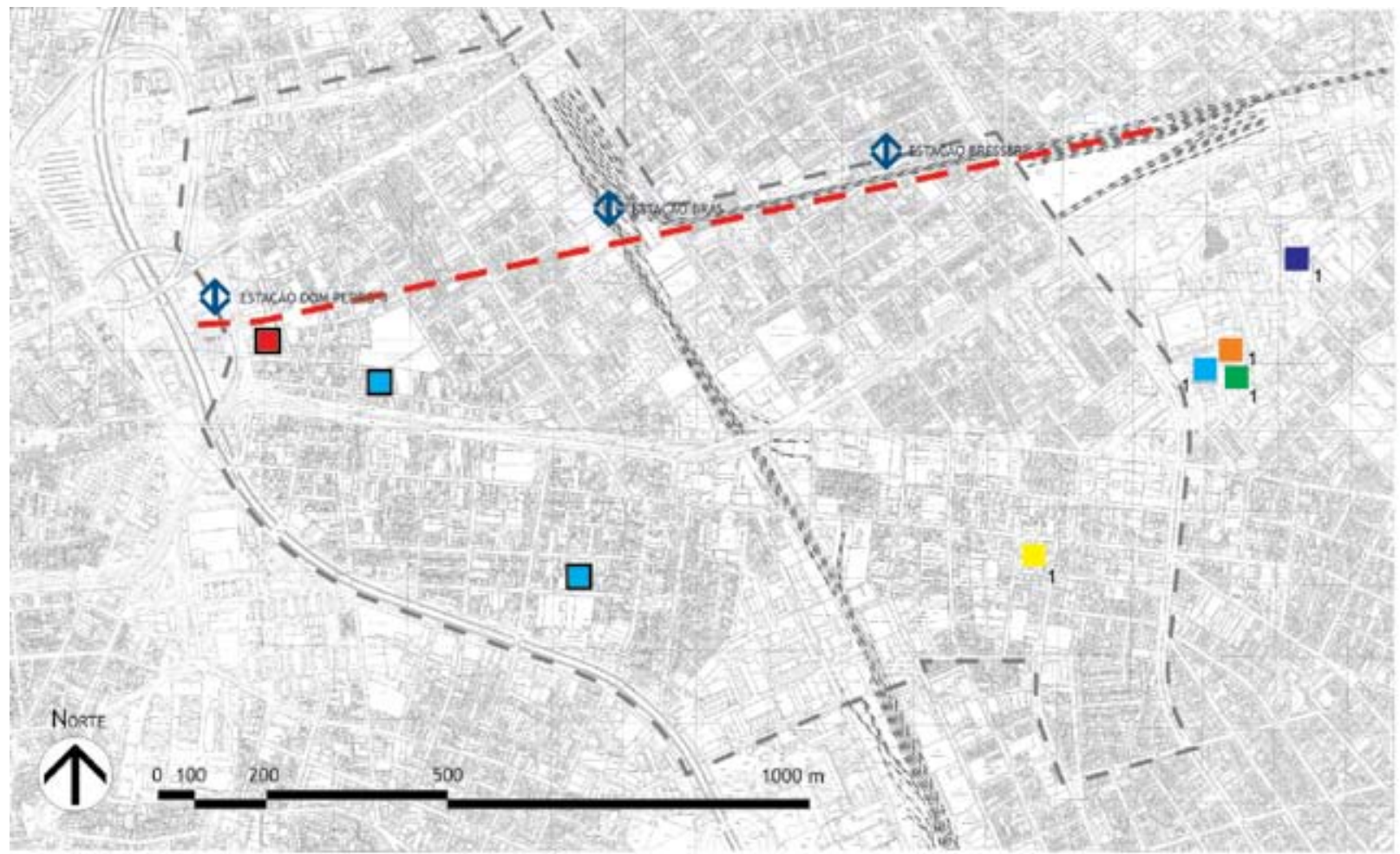

Unidades de saúde públicas propostas autoria: Maria Elizabet Paez Rodriguez sobre GEGRAN 1972
Mapa 42 


\subsubsection{Educação pública - Unidades de ensino}

Conforme visto no Capítulo IV - Diagnóstico, existem áreas não cobertas por unidades de ensino, na área-objeto de estudo. Para suprir essas demandas e contar com novos alunos em função do adensamento populacional que poderá ocorrer, foram propostas novas unidades de âmbito local, adotando uma área de abrangência com raio de $800 \mathrm{~m}$ como zona de conforto para acesso caminhando às escolas de ensino infantil - EMEI, ensino fundamental EMEF e creches. No caso das escolas técnicas e das escolas do tipo EMEE - Escola Municipal de Ensino Especial, por se tratarem de abrangência regional, não foi aqui proposta nenhuma unidade, em virtude do grau de especialização e dificuldade na análise da demanda. As EE - Escolas Estaduais atendem as faixas de ensino fundamental e ensino médio, mas não atendem ao ensino infantil ou creches.

Além das escolas municipais e estaduais existentes na área-objeto de estudo, existem também as Classes Provisórias - FEBEM, em dois endereços diferentes no Brás, mas não foi proposta nenhuma unidade nova na área.

Algumas escolas estaduais, apesar de não estarem localizadas na área-objeto deste estudo têm área de abrangência, segundo o critério do raio de 800 metros adotado da metodologia de Campos Filho, que atende parte da área em estudo e por isso sua área de abrangência foi considerada na proposição de novas unidades.

O Mapa 4I demonstra as unidades existentes por tipo de escola e faixa de ensino e também as unidades educacionais propostas por esta dissertação.

São propostas as seguintes novas unidades educacionais:

\section{Implantação de novo unidade educacional do tipo EE:}

A escola deverá ser implantada em edifício histórico ocioso em estado de abandono, localizado à Rua Dr. Almeida Lima, 1290, Mooca, devendo este ter sua estrutura e arquitetura recuperadas e ser tombado pelo Patrimônio Histórico. O terreno, de grandes dimensões deverá receber construção complementar para abrigar outras atividades necessárias a uma EE.

- Processo de viabilização: desapropriação de propriedade particular por parte do governo estadual.

- Numeração no Mapa 44: 0I - área a requalificar com preservação e recuperação da tipologia arquitetônica e alteração de uso.

\section{Implantação de Creche Municipal:}

A localização da nova creche municipal se dará baseada no imóvel que apresente melhores condições, entre as ruas da Mooca, Guaratinguetá, João Antonio de Oliveira e Orville Derby.

\section{Implantação de EMEl:}

A localização da nova EMEl se dará baseada no imóvel que apresente melhores condições, entre as ruas João Caetano, Hipódromo, Itajaí e Hipiá.. 


\section{Implantação de CEU - Centro Educacional Unificado, para ensino infantil e ensino fundamental:}

Desapropriação do imóvel localizado à Rua Caetano Pinto, $n^{\circ} 454$, de propriedade da Metalúrgica Matarazzo e que se encontra totalmente desocupado, requalificando-o para o uso institucional, devendo conter um Centro Educacional Unificado (CEU), com construções complementares necessárias para incluir: creche, escola de educação infantil, escola de ensino fundamental, playground, centro comunitário, teatro ou cinema, biblioteca, quadra poliesportiva coberta ou descoberta, salão de ginástica e dança, piscinas (semi-olímpica, recreativa e infantil), vestiários, ateliês, estúdios para oficinas de vídeo, TV, rádio e fotografia, telecentro e área verde.

- Processo: desapropriação dos imóveis particulares localizados à Rua Visconde de Parnaíba, a partir da esquina com a Rua Carneiro Leão, até a esquina com a Rua Caetano Pinto, no Brás, e do edifício abandonado da antiga Metalúrgica Matarazzo, à Rua Caetano Pinto, em conjunto, para a implantação do CEU - Centro Educacional Integrado.

Figura 43

- Numeração no Mapa 44: 02 - área a desapropriar para instalação de equipamento urbano público.

Simulação por maquete eletrônica de implantação de CEU - Centro

Unificado de Ensino na área da antiga Metalúrgica Matarazzo.

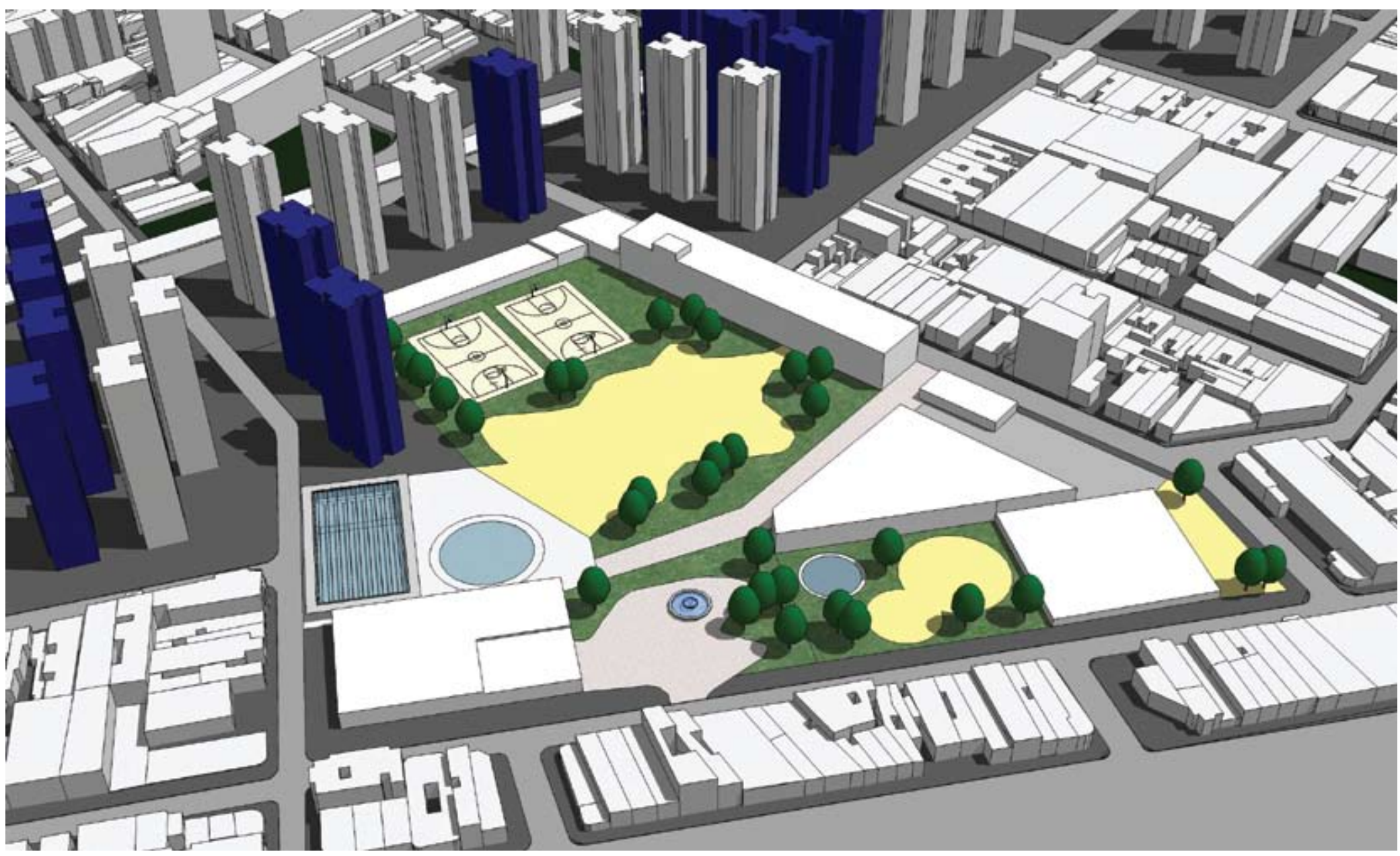


Abaixo

Foto aérea de área a desapropriar

para implantação de CEU
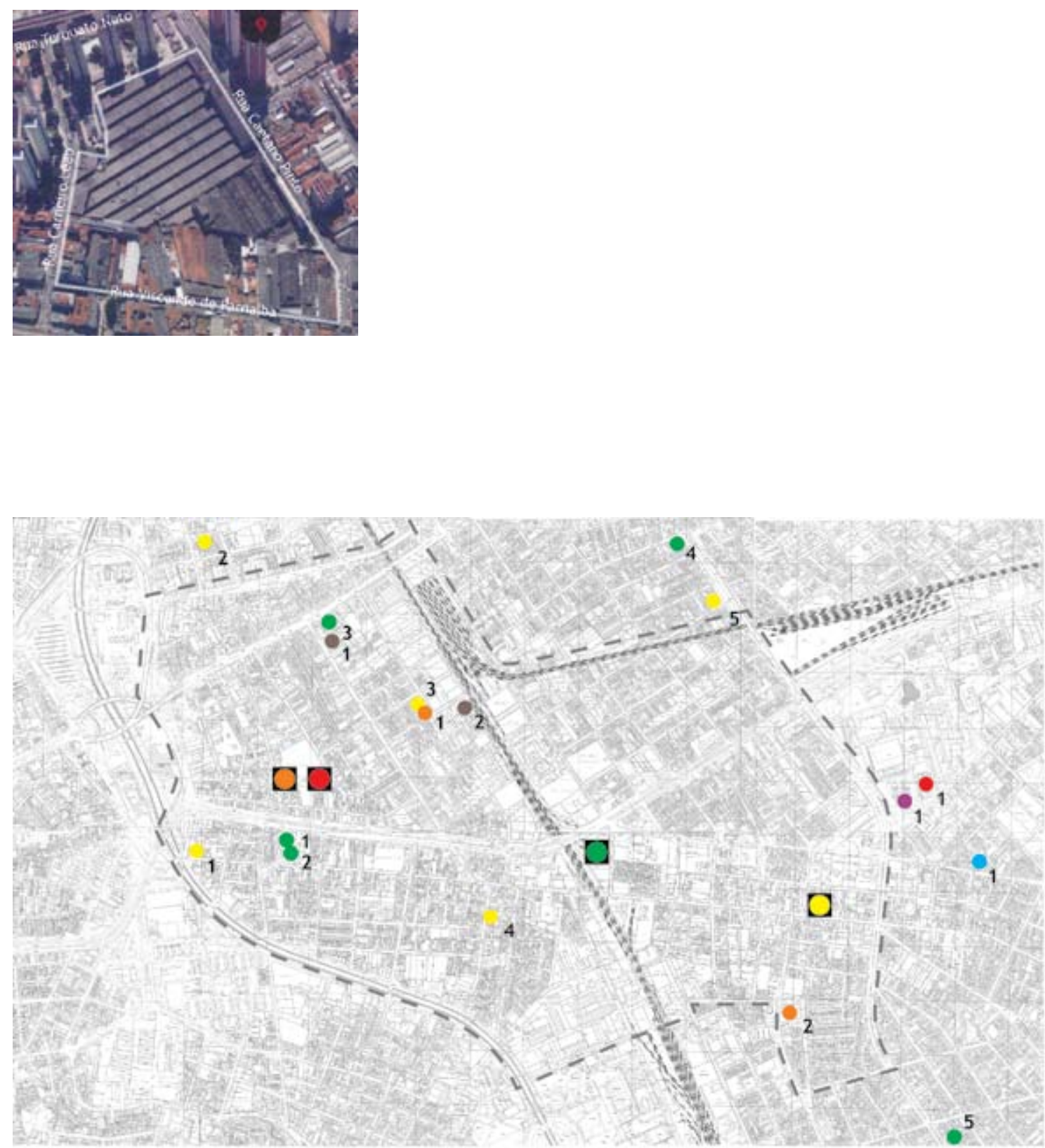

Creche Municipal

1. Divina Providência 2- Săo Vito

3- Nazir Miguel

4. José de Moura

5. Antonia M. Lamberga

- Escola Municipal de Ensino Infantil - EMEI 1- Joăo Mendonza Falcăo 2- Almirante Tamandaré

- Escola Municipal de Ensino Fundamental - EMEF 1- Dr. Fábio da Silva Prado

- Escola Municipal de Educação Especial - EMEE (portadores de deficiencia) 1. Profa. Neuza Basseto

- Escola Estadual - EE 1. Gianfrancesco Guarnieri 2. Prof. Antonio Firmino de Proença 3. Romão Puigari 4. Padre Anchieta 5. Pandia Calógeras

- Escola Técnica - ET 1- Prof. Camargo Aranha

- Classes Provisórias (FEBEM) 1. Rio Nilo

D Unidade de ensino proposta

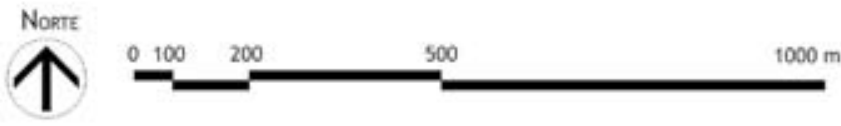

\section{Escolas públicas propostas área-objeto de estudo autoria: Maria Elizabet Paez Rodriguez sobre GEGRAN 1972

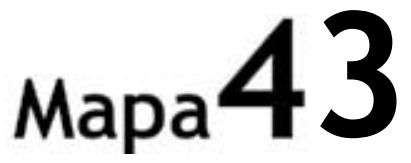




\subsection{3. Áreas verdes, praças e espaços abertos}

\section{Criação de Praça Esportiva - Antárctica:}

Área verde para lazer e prática de esportes localizada entre as duas grandes áreas de ZEIS 3 determinadas dentro da propriedade da Antárctica, provida de equipamentos esportivos que atendam aos moradores dos dois condomínios que se formarão e aos moradores da comunidade já moradora da área. Essa área, com administração municipal, terá as seguintes atividades e funções:

- Servir de área verde para sombreamento e baixa da temperatura local;

- Representar área de solo permeável por estar a área ainda sujeita a alagamentos de menor porte dos que os registrados décadas atrás;

- Criar visual a partir dos futuros edifícios para habitação HIS ou HMP que lá poderão ser construídos em direção ao centro histórico do município;

- Melhorar a qualidade visual e ambiental da área;

- Atender às demandas por áreas de lazer e áreas verdes solicitadas pelas comunidades locais;

- Servir como local de descanso, lazer e prática de esportes aos moradores locais.

A Praça de Esportes Antárctica deverá ser composta por:

- Praça interna;

- Piscina infantil e para adultos;

- Quadras poliesportivas e quadra de tênis;

- Instalações para vestiários, portaria, administração e manutenção;

- Área verde para descanso, provida de bancos de descanso, bebedouros etc.;

- Arborização conforme projeto específico com o objetivo de criar sombreamento;

- Gramados para garantir o nível de permeabilidade do solo mínimo exigido pela lei de uso e ocupação do solo.

\section{Criação de Praça Esportiva - Bresser:}

Área verde para lazer e prática de esportes localizada na confluência da Avenida Alcântara Machado com a Rua Bresser, em terreno de propriedade da Prefeitura de São Paulo, ocioso.

Deverá atender aos moradores da área entorno da praça pública. Com administração municipal, terá as seguintes atividades e funções:

- Servir de área verde para sombreamento e baixa da temperatura local;

- Representar área de solo permeável;

- Melhorar a qualidade visual e ambiental da área;

- Atender à demanda por prática de esportes ao ar livre;

- Atender às demandas por áreas de lazer e áreas verdes solicitadas pelas comunidades locais.

A Praça de Esportes Bresser deverá ser composta por:

- Quadras poliesportivas e quadra de tênis;

- Área verde para descanso, provida de bancos de descanso;

- Deverá ser fechada por alambrado e ter horário estendido de uso no verão. 


\section{Criação de nova praça I:}

Desapropriação de duas quadras contidas entre as ruas Odorico Mendes, Dom Bosco, Oscar Horta e Coronel Cintra para a implantação de praça com mobiliário urbano para lazer e contemplação (playground, bancos de jardim, ajardinamento, mudas de árvores e caminhos internos pavimentados). Por apresentar tráfego de veículos insignificante, a área da rua local Andrade Reis deverá ser absorvida pela área da praça.

\section{Criação de nova praça 2:}

Criação de praça em área remanescente da implantação dos condomínios Bresser I a III, à Rua Visconde de Parnaíba, no Brás.

\section{Criação de nova praça 3:}

Desapropriação de quadra de forma triangular de propriedade da Cervejaria Antárctica, com uso atual para estacionamento instalado em área onde havia vilas operárias que foram demolidas com esse objetivo. Na praça deverá ser instalada pavimentação em parte da área, arborização e ajardinamento e colocação de bancos de descanso.

\section{Recuperação de praça 4:}

Recuperação de praça existente ao lado da Creche Nazir Miguel, à Rua Prudente de Moraes, 210, no Brás, cujo piso é totalmente concretado. Itens para sua recuperação:

- Abertura de $60 \%$ da área do piso de concreto para criação de área permeável;

- Arborização para sombreamento futuro;

- Aplicação de gramado e ajardinamento;

- Instalação de bancos de descanso e equipamentos infantis.

\subsubsection{Cultura:}

\section{Novo teatro municipal Continental - Antiga fábrica da Discos Continental:}

Em função da localização, na Avenida do Estado, esquina com a Rua Luis Gama, junto à parada Luis Gama do Expresso Tiradentes VLP. - Veículo Leve sobre Pneus, propõe-se a instalação de um teatro de administração municipal, no edifício ocioso da antiga Indústria fonográfica Continental, que hoje se encontra subutilizado, em estado precário de conservação, suprindo a grande lacuna existente na área cultural da área-objeto de estudo e região em torno.

- Processo de viabilização: Desapropriação do imóvel por parte da administração pública;

- Localização no Mapa 44: 04.

\section{Novo Centro Cultural Fábrica - Antiga Fábrica de Tecidos Labor:}

Instalação de centro cultural no edifício ocioso da antiga Fábrica de Tecidos Labor, atual proprietária, que hoje se encontra subutilizado, em estado precário de conservação, funcionando como estacionamento e casa de eventos esporádicos, com o objetivo de suprir a grande falta de espaços culturais na área-objeto de estudo e região do entorno. O Centro Cultural Fábrica

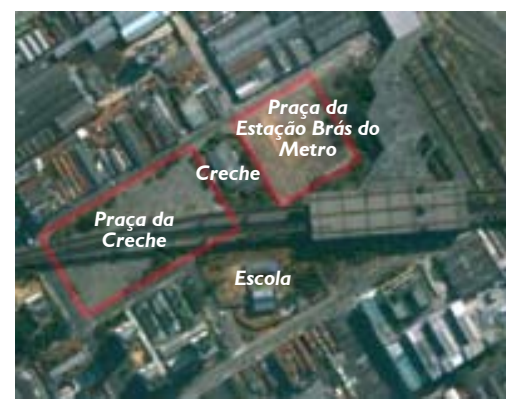

Acima

Foto aérea das praças.

Fonte: Google Earth, 2006. 
deverá ser instalado após a recuperação e tombamento do imóvel pelo Patrimônio Histórico e deverá abrigar as seguintes atividades: oficinas culturais, ateliêrs para cursos de curta duração, atividades para a terceira idade, salas de exposição e estrutura de apoio.

- Processo de viabilização: Desapropriação de imóvel particular e implantação do novo uso através da administração municipal ou através de PPP - Parceria públicoprivado, com recuperação e preservação de sua estrutura arquitetônica e posterior tombamento pelo Patrimônio Histórico.

- Localização no Mapa 44: 03.

\section{Museu da Indústria Paulista:}

Construção de Museu à Rua Dr. Almeida Lima, 1290, junto aos trilhos da Santos-Jundiaí em terreno ocioso, que hoje se encontra subutilizado, funcionando como estacionamento e casa de eventos esporádicos, com o objetivo de homenagear a história da industrialização de São Paulo.

- Processo de viabilização: Iniciativa da administração municipal ou através de PPP - Parceria Público Privado.

- Numeração no Mapa 44: 07 - Área a requalificar com alteração de uso.

\subsection{Uso misto}

São as seguintes as diretrizes destinadas aos imóveis de uso misto no Brás e Mooca:

- Estimular a construção de edifícios com uso misto com uso comercial ou serviços nos pavimentos térreos e uso residencial nos pavimentos acima disso.

\subsection{Uso industrial}

São as seguintes as diretrizes destinadas aos imóveis de uso industrial no Brás e Mooca:

- Manutenção de indústrias limpas existentes na área;

- Readequação de indústrias existentes com inclusão de áreas permeáveis;

- Incentivar a permanência das indústrias existentes em situação regular, que desempenham com qualidade a sua função social;

- Incentivar a instalação de novas pequenas indústrias que não sejam incômodas e que cumpram a sua função social;

- Incentivar a alteração de uso em imóveis industriais desativados sem uso ou considerados subutilizados, com o aproveitamento da arquitetura original de valor histórico;

- Estimular indústrias novas ou existentes a promover o treinamento e a formação profissional de jovens moradores locais;

- Reestruturação das áreas industriais existentes, estimulando a permanência de indústrias não incômodas.

\section{Reestruturação Viária no Brás e Mooca}

A partir da finalização da construção do Rodoanel Viário, obra metropolitana que tem por objetivo desafogar o trânsito nas marginais dos rios Tietê e Pinheiros, antevê-se um redirecionamento de grande parte do volume de veículos pesados de transporte de cargas que hoje trafega na Avenida do Estado e Avenida Radial Leste. Com essa liberação de espaço na marginal Tietê poderá acontecer um redirecionamento parcial, mas significativo, de volume 
de veículos particulares no sentido Centro-Leste e que hoje se serve da Radial Leste para chegar a bairros da Zona Leste da cidade como Penha e Tatuapé. Dessa forma, a diminuição da intensidade e da freqüência dos congestionamentos recorrentes há décadas na Radial Leste devolverá qualidade ambiental à região do Brás e Mooca, em virtude da diminuição de ruído e poluição e, conseqüentemente, do calor gerado pelos veículos. Como resultado, haverá a liberação de duas faixas na Radial Leste para a criação de canteiro arborizado central ou nas calçadas, propiciando o sombreamento do passeio, justa causa do pedestre e morador.

\section{I. Transporte público}

São diretrizes para melhorar e retomar a mobilidade e a acessibilidade intra-urbana:

- Criação de ciclovias para facilitar o deslocamento intra-urbano;

- Reestruturação viária local com o objetivo de minimizar o tráfego regional de veículos, melhorando assim o tráfego local;

- Interligação dos transportes públicos com a criação de linhas de transporte tipo shuttle entre pontos distantes da Mooca às estações do Metrô do Brás.

A Prefeitura Municipal de São Paulo tem em seu plano de transporte público, a implantação de Estações de Transferência, nos seguintes locais (fonte: CDHU - Relatório PACCambuci, p.50):

Para atender às linhas municipais de ônibus:

- Rua da Figueira com Rua Azevedo Junior, com horizonte 2006;

- Rua Apache com Rua Piratininga, com horizonte 2006;

- Avenida Alcântara Machado com Rua Bresser, com horizonte 2006;

- Estações de transferência nos corredores de ônibus (Passa Rápido);

- Avenida do Estado, da Rua da Figueira até a Rua Serra de Paracaima, com horizonte 2006;

- Rua Bresser, da linha 3 - Vermelha do Metrô até a Avenida Alcântara Machado, com horizonte 2012:

- Programa Via Livre com horizonte 2006;

- Rua Apache e Avenida Alcântara Machado, da Rua da Figueira até a Rua Bresser.

A SMT - Secretaria Municipal de Transporte tem em projeto a implantação da Estação de Trasferência da Rua da Mooca com a Rua Taquari e Avenida Paes de Barros, nos mesmos moldes das outras estações de transferências pela cidade. Este conjunto de diretrizes adota este modelo como padrão.

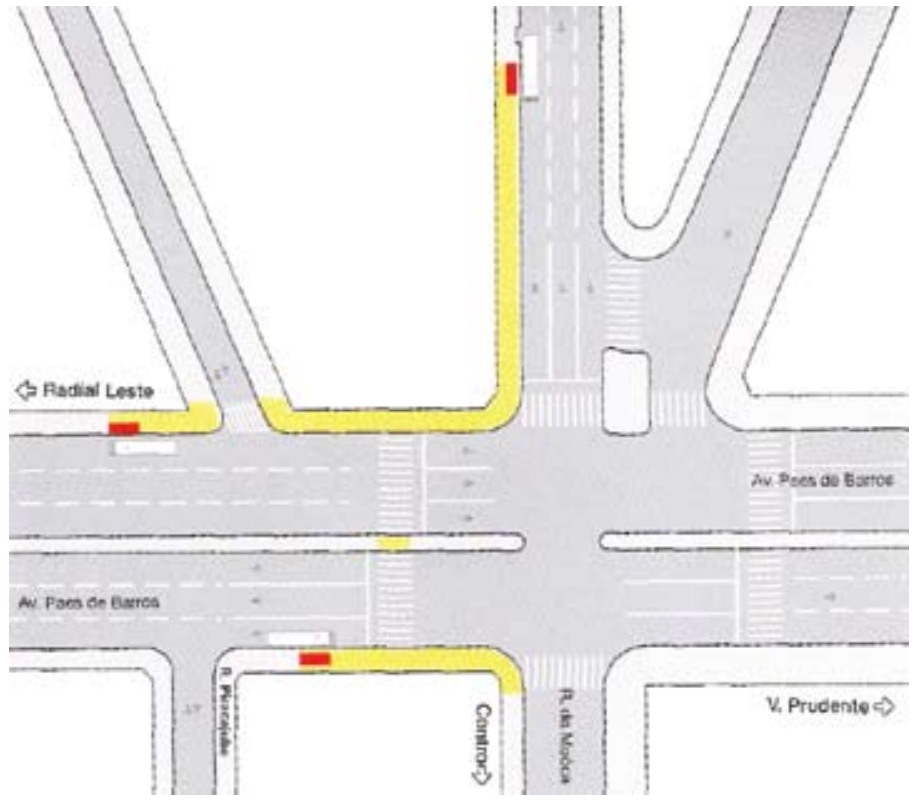

Figura 44

Estação de Transferência da Avenida

Paes de Barros e Rua da Mooca.

Fonte: São Paulo interligado. SMT/ PMSP, 2004, p. 187. 


\subsection{Vias estruturais}

Promover a requalificação das Avenidas Radial Leste, Rangel Pestana e do Estado e reformular o traçado do corredor da Avenida Radial Leste, por meio de projeto urbanístico e paisagístico, compreendendo a reordenação das faixas de rodagem, da sinalização horizontal e vertical, o ordenamento do mobiliário urbano e a melhoria das condições de circulação de pedestres e ciclistas e forte arborização com o objetivo de futuro sombreamento.

\section{Vias coletoras:}

Promover a requalificação das vias coletoras que ligam as Avenidas Radial Leste, Rangel Pestana e Estado de forma a que fiquem adaptadas aos usos em curso nos imóveis existentes no espaço intra-urbano, recuperando suas calçadas, por meio de projeto urbanístico e paisagístico, compreendendo a reordenação da sinalização horizontal e vertical e a fiscalização da publicidade particular, o ordenamento do mobiliário urbano e a melhoria das condições de circulação de pedestres e ciclistas e forte arborização com o objetivo de futuro sombreamento;

\section{Vias locais:}

Requalificar as vias locais de forma a promover sua adaptação à circulação de habitantes com dificuldade de locomoção, adaptá-las aos usos em curso nos imóveis existentes no espaço intra-urbano, recuperando suas calçadas, por meio de projeto urbanístico e paisagístico, compreendendo a reordenação da sinalização horizontal e vertical e a fiscalização da publicidade particular, o ordenamento do mobiliário urbano e a melhoria das condições de circulação de pedestres e ciclistas e forte arborização com o objetivo de futuro sombreamento.

\section{Acessibilidade:}

Construção de duas passarelas cobertas sobre as ferrovias da CPTM, com acesso em ambos os lados por elevadores de passageiros, para atendimento de pessoas com dificuldade de locomoção permanente ou provisória.

- Processo de viabilização: Provisão através da administração pública ou PPP - Parceria público-privada.

- Localização: uma localizada na Estação Mooca da CPTM com um acesso pela Rua Monsenhor João Felipo e outra com acesso pelo novo Pólo de Comércio e Serviços Antárctica

Figura 45

Sugestão de projeto para passarela sobre ferrovias CPTM. Croquis da autora.

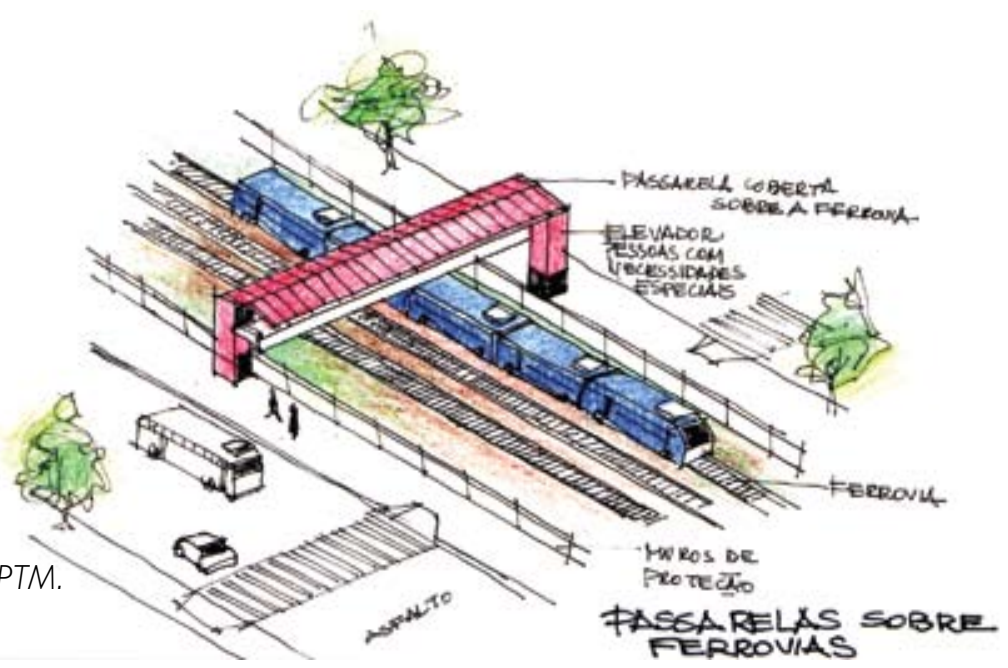




\section{Qualidade ambiental}

As diretrizes a seguir pretendem melhorar a qualidade ambiental, através de:

- Exigir a recuperação de áreas contaminadas através da descontaminação dos solos, subsolos e lençóis freáticos de áreas com antigas fábricas que deixaram para trás solos contaminados, por meio do tratamento de resíduos sólidos recicláveis, promover a recuperação dessas áreas contaminadas e estipular compensações ambientais, através de instrumentos legais existentes ou criados para esse fim;

- Permitir a ocupação de áreas contaminadas somente após a sua recuperação;

- Elaborar um plano de drenagem de águas pluviais incluindo a criação de cisternas para captação de águas pluviais para reuso e minimização do risco de enchentes;

- Aumento significativo de áreas permeáveis através da não ocupação de áreas ociosas nos lotes industriais a requalificar e em outros pontos da área, eliminando os riscos ambientais (inundações, deslizamentos, desabamentos e outros);

- Buscar novas soluções para bacias de contenção, evitando-se a impermeabilização total;

- Criar áreas verdes e aumentar a arborização com o objetivo de obter queda na temperatura de superfície da região e aumento da área de sombreamento;

- Aplicar instrumento de faixa non edificandi do Plano Diretor nas margens dos rios;

- Modernizar e tornar mais eficiente o sistema de iluminação pública.

\section{O patrimônio histórico do Brás e Mooca}

Estando o Brás incluído na Operação Urbana Centro, suas edificações históricas poderão ser tratadas pelos mesmos critérios que os propostos por esse instrumento urbanístico para os imóveis localizados no Centro Histórico.

O conjunto de edifícios que hoje está na área central, em sua maioria - com exceção dos poucos prédios mais recentes - são edifícios mais antigos e apenas uma pequena parte é constituída de edificios novos. A reforma dos edificios antigos é obstaculizada por uma série de fatores: dificuldades na aprovação decorrentes inclusive de uma coisa que foi ultrapassada na lei de Operação Urbana Centro. Por outro lado, há uma quantidade já muito grande de edifícios na área central que estão preservados, tombados e listados para preservação. Isso significa, portanto, uma série de entraves do ponto de vista de aprovação. Além das dificuldades de reformas dos edifícios existentes, da sua antiguidade e dificuldade de aprovação perante os órgãos de preservação, existem outros fatores que também não estimulam a ida ao centro - além daquele fator inicial que é o problema da qualidade ambiental (Lefévre, palestra no Instituto IDEA)

São as seguintes as diretrizes para a requalificação e inclusão de imóveis históricos no Patrimônio Histórico do Município:

- Valorizar e incentivar a preservação do patrimônio histórico, cultural e ambiental urbano, consolidando a identidade das áreas históricas do Brás e Mooca;

- Desenvolver políticas e programas que estimulem o uso de áreas tombadas, dinamizando-as;

- Estimular a implantação de equipamentos públicos nos edifícios identificados como de importância histórica e cultural ou que representem marcos referenciais para a comunidade, restaurando-os, se necessário;

- Recuperar bens tombados em processo de degradação; 
- Recuperação do ambiente urbano, em especial das áreas degradadas, através da requalificação de edifícios de interesse histórico;

- Tombamento pelo Departamento Patrimônio Histórico de todo o complexo de edifícios de propriedade da extinta Fábrica de Tecidos Labor, localizados à Rua da Mooca, 815 :

- Tombamento pelo Departamento Patrimônio Histórico de todo de residência de propriedade da extinta Fábrica de Tecidos Labor, localizados à Rua da Mooca, 825;

- Tombamento do complexo de edifícios do Antigo Gasômetro, localizado à Rua Capitão Faustino de Lima, s/n;

- Tombamento dos edifícios do antigo Cotonifício Crespi, localizados entre as ruas dos Trilhos, Javari, Taquari e Visconde de Laguna;

- Tombamento das duas passarelas para pedestres de transposição das metrovias CPTM e Linha Leste do Metrô;

- Tombamento do campo de futebol e edificações de apoio do Esporte Clube Juventus, à Rua Javari, n 117 ;

- Tombamento da Pizzaria São Pedro à Rua Javari, no 333.

\section{Conclusão}

Com o conjunto de diretrizes aqui proposto pretendeu-se abranger os mais importantes temas envolvidos na reorganização da áreas históricas dos bairros do Brás e Mooca e atender às populações de baixa e média renda que lá residem. Foi grande a preocupação em obter, com a futura aplicação das diretrizes específicas, a qualidade ambiental e a qualidade de vida de seus atuais e novos moradores, juntamente com a complementação de equipamentos públicos necessários para completar o circuito urbano básico formado por moradia, trabalho, educação, saúde, lazer e cultura.

As consultas aos órgãos públicos na busca de documentos históricos, levantamento de dados e de índices, mostraram a riqueza da história dessa megalópole que é São Paulo e realimentou a cada nova consulta o desejo de conhecer mais, desejo esse refreado a certo ponto pela restrição de tempo.

O levantamento do real uso e ocupação do solo, feito in loco, uma das primeiras atividades realizadas para o desenvolvimento desta dissertação, levou ao conhecimento físico da área-objeto de estudo de forma muito rica, seja em relação às edificações, ruas e avenidas, como em relação aos habitantes, tráfego de veículos e outras particularidades que não seria possível obter de qualquer outra forma.

Várias formas foram encontradas para conseguir isso. Uma delas foi criar áreas estritamente residenciais em trechos do tecido urbano onde as moradias de classe média existentes e bem conservadas mostraram o alto valor de uso que esses imóveis tem para seus moradores e a determinação em não deixar o bairro ou o imóvel. Essa criação de ZER voltada para a classe média e não para as classes de alta renda, como sempre foi o habitual nos momentos onde se criaram leis e instrumentos urbanísticos, foi a forma encontrada de preservar essas ilhas de tranqüilidade e protegê-las de especulação imobiliária predatória, quando casas são derrubadas para dar lugar a espigões de apartamentos com valor de venda muito mais elevado que os antigos moradores podem pagar. 
Outra forma de manter os atuais moradores em seus bairros foi a ampliação ou alteração dos polígonos de áreas ZEIS 3, originalmente propostas pelas subprefeituras, só que posicionando ao lado destas alguns equipamentos públicos de porte como um Centro Educacional Unificado no Brás e uma área de esporte e lazer entre dois grandes trechos de ZEIS 3 propostos na área da antiga cervejaria Antárctica Paulista, hoje servindo somente como centro de distribuição. Gerar novas moradias para as classes de baixa e média renda pode trazer de volta antigos moradores que por circunstâncias diversas podem ter deixado o bairro involuntariamente. As novas moradias podem manter no bairro os filhos dos moradores que deixam a residência de seus pais para formar novas famílias sem precisar adquirir imóveis em locais diferentes de onde estão suas raízes.

No caso dos tantos cortiços e outras habitações precárias, os procedimentos de órgãos como a CDHU e COHAB demonstram que os caminhos existem e estão sendo seguidos, mesmo que de forma ainda insuficiente, em função talvez de dificuldades de coordenação de um mesmo assunto por órgãos estaduais e municipais.

A análise dos planos diretores regionais das Subprefeituras Sé e Mooca levou à conclusão de que estes foram elaborados, atendendo a Lei 13.885 de 25 de agosto de 2004 que estabelece normas para a elaboração dos planos regionais, mas com resultados genéricos demais, o que justifica a necessidade de criação de um conjunto de diretrizes mais pontuais para a requalificação urbana de bairros industriais centrais, antes de se passar para a fase de projeto e desenho urbano.

Como proceder para que as idéias aqui propostas venham a ser realizadas e não fiquem apenas no plano acadêmico é um grande desafio. Não é o objetivo desta dissertação discutir uma metodologia ou um conjunto de ações e parcerias entre Estado e iniciativa privada que possa viabilizar a aplicação deste conjunto de diretrizes dando sentido à pesquisa realizada e ao investimento em estudo e análise, além do mais importante: requalificar os bairros históricos do Brás e Mooca.

Conclui-se portanto, que Brás e Mooca têm todas as características urbanas, históricas e sociais, além do potencial demonstrado durante as análises realizadas que justificam a sua requalificação. A pesquisa, os estudos, as observações e as divagações necessárias para a elaboração desta proposta de requalificação urbana estiveram sempre direcionadas a obter um resultado que ofereça a esses dois bairros históricos e centrais, uma mudança sensível de seus ambientes, tanto de moradia como de trabalho, mas sem perdas na forma de expulsão de qualquer tipo, agregando, em primeiro lugar, valor de uso a cada bairro como um todo.

O Mapa 44 a seguir traz a representação das diretrizes propostas nesta dissertação, além de outros elementos elucidativos.

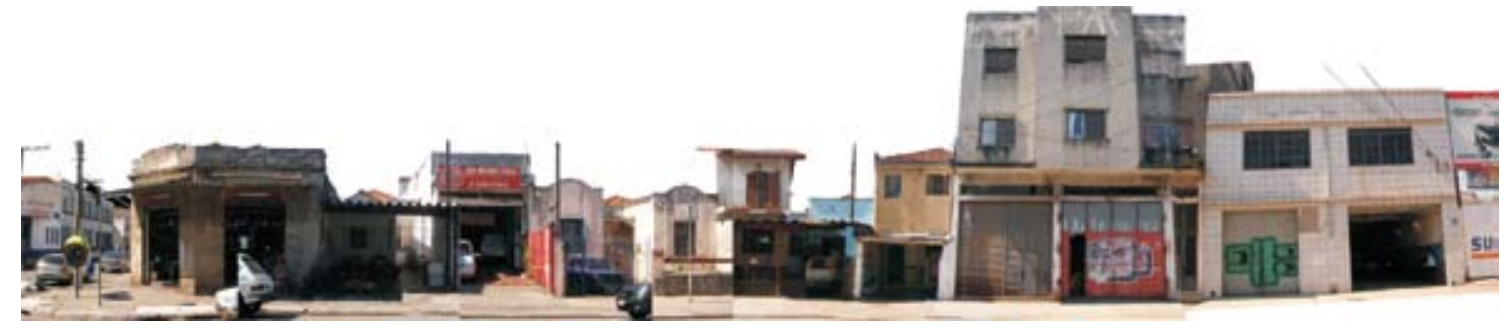

Fachada típica de quadra

na Mooca baixa.

Arquivo pessoal, 2006. 



\section{Bibliografia}

AMADIO, Décio. Desenho urbano e bairros contrais de São Paulo: um estudo sobre a formação e transformação do Brás bom Retiro e Pari. Tese de Doutorado. Pós-graduação FAUUSP. São Paulo, 2004.

AUGÉ, Marc. Não-lugares: introdução a uma antropologia da supermodernidade. Campinas, São Paulo: Papirus, 1994 - $4^{a}$ edição, 2004.

BALL, Michael. O desenvolvimento do capitalismo na produção da habitação. Tradução de Yvonne Mautner. Revista Espaço e Debates nº 36.

BÓGUS, Maria Lucia Machado. (Re) Urbanização: Por Que E Para Quem? Tese de Doutorado. Pós-graduação FAUUSP. São Paulo, 1988.

BORJA, Jordi. Ciudadania y Espacio Publico. Centre de Cultura Contemporania de Barcelona, 1998 (texto mimeografado).

BRESSER, Luis Carlos. Economia Brasileira: Uma Introdução Crítica. São Paulo: Ed. 34, 1998.

CAMPOS FILHO, Cândido Malta. Cidades Brasileiras: Seu Controle Ou O Caos. São Paulo: Ed. Nobel, 1992.

Reinvente seu bairro - caminhos para você participar do planejamento de sua cidade. São Paulo: Editora 34, 2003.

CARDOSO, Maria Cecília. O Metrô e a Urbanização de São Paulo. Dissertação de Mestrado. Pós-graduação FAUUSP. São Paulo, 1983.

CASTRO, José Guilherme Savoy de. Áreas de Resistência: Uma Forma de Morar em São Paulo. Dissertação de Mestrado. Pós-graduação FAUUSP. São Paulo, 1988.

CONSULTORES EUROPEUS ASOCIADOS. Plan Estratégico de Antíguo Puerto Madero. Buenos Aires, 1990.

ECO, Umberto. Como se faz uma tese. $17^{a}$ edição. São Paulo: Perspectiva, 2002.

GAWRYSZEWSKI, Alberto. Agonia de morar: urbanização e habitação na cidade do Rio de Janeiro - 1945 a 1950. Tese de Doutoramento em História Econômica. FFLCH-USP, 1996.

GOSLING, David; Maitland. Barry. Concepts of urban design. London; New York: Academy Eds.: St. Martin's Press, 1984.

GRILLO, Maria Teresa Oliveira. Industrialização e desindustrialização no Município de São Paulo. Dissertação de Mestrado. Pós-graduação FAUỦSP. São Paulo, 1997. 
HATJE, Gerd. Diccionario ilustrado de la arquitectura contemporánea.

Barcelona: Editorial Gustavo Gili, 1970 - 3ª edição, 1980.

JACOBS, Jane. Morte e vida de grandes cidades. São Paulo: Martins Fontes, 2003.

JARAMILLO, Samuel. Las Formas de producción del espacio construído en Bogotá. In PRADILLA, Emilio. (org) Ensayos sobre el problema de la vivienda en México. México: Latina, UNAM, 1982.

JUDD, D. \& Parkinson, M. Oleadership and urban regeneration, Newbury Park Sage publications, 1990.

KAWAI, Célia Seri. Os loteamentos de traçado orgânico realizados no município de São Paulo na primeira metade do século 20. Dissertação de mestrado. FFLCH-USP. São Paulo, 2000.

LANGENBUCH, Juergen R. A estruturação da grande São Paulo. Rio de Janeiro, Instituto Brasileiro de Geografia, Departamento de Documentação e Divulgação Geográfica e Cartográfica, | 971 .

LEME, Maria Cristina da Silva. Revisão do Plano de Avenidas: um estudo sobre planejamento urbano em São Paulo: 1930. Tese de doutoramento. Pós-graduação FAUUSP. São Paulo, 1982.

LIERNUR, Jorge Francisco Liernur. Buenos Aires e seu rio: de porto de barro ao bairro globalizado. In www.vitruvius.com.br/arquitextos. Publicação original: II Porto di Buenos Aires, Casabella nº 723, pp.60-65. Milano, jul. 2004.

MARCILIO, Maria Luiza. História da cidade de São Paulo: a cidade colonial. São Paulo: Paz e Terra, 2004.

MARICATO, Ermínia. As idéias fora do lugar e o lugar fora das idéias. In Cidade do pensamento único. Petrópolis: Editora Vozes, 2002.

MAUTNER, Yvonne. A periferia como fronteira de expansão do capital. In DEAK, Csaba e SCHIFFER, Sueli (org.) O Processo de Urbanização no Brasil. São Paulo: Edusp, FUPAM, 1999.

MARTINS, José de Souza. O poder do Atraso: Ensaios de Sociologia da História Lenta. São Paulo: Hucitec, 1999.

MARTINS, Luciana Bongiovani. Elevado Costa e Silva. Dissertação de mestrado: Pós-graduação FAUUSP, 1997.

MIRANDA, Rosana Helena. Mooca: lugar de fazer casa. Tese de Doutorado. Pós-graduação. São Paulo, 2003.

NAMUR, Marly; LASALVIA, Liliana; RODRIGUEZ, Maria Elizabet P.; BERSIANO, Daniel. Quano os sistemas viários de acesso regional se transformam em barreiras urbanas à acessibilidade local. NUTAU, 2004. 
OLIVEIRA, Francisco de. Crítica à razão dualista: O Ornitorrinco.

I a edição. São Paulo: Bom Tempo, 2003.

PAC - Programa de Atuação em Cortiços - Relatório Brás e Cambuci. São Paulo: CDHU, 2003.

PEREIRA, Luis Carlos Bresser. Economia Brasileira - Uma Introdução Crítica. São Paulo: Ed. 34, 1998 ( ${ }^{a}$ edição, 1982).

PREFEITURA DO MUNICÍPIO DE SÃO PAULO. COORDENADORIA GERAL DE PLANEJAMENTO - COGEP. Política de controle de uso e ocupação do solo; Política de preservação de bens culturais e paisagísticos. 1979.

ROLNIK, Raquel. A cidade e a lei. São Paulo: Studio Nobel: FAPESP, 2003.

RUBIÓ, Manuel De Solá Morales I. Las Formas Del Crecimiento Urbano. Barcelona: UPC, 1997.

SANTOS NETO, Adelino Francisco dos. (Re)Leituras de Santa Ifigênia: Diretrizes de Renovação Urbana. Dissertação de Mestrado. Pós-graduação FAUUSP. São Paulo, 2000.

Secretaria Municipal de Saúde/PMSP. Atribuições de estabelecimentos assistenciais de saúde segundo normas do Ministério da Saúde. Programa Saúde da Família, 2006.

SEGRE, Roberto. Espaço público e democracia: experiências recentes nas cidades de América Hispância. In www.vitruvius.com.br/arquitextos, maio, 2005.

SEVERINO, Antonio Joaquim. Metodologia do trabalho científico. São Paulo: Cortez, 2002.

SINGER, Paul. Desenvolvimento econômico e evolução urbana. São Paulo: Nacional, 1974.

SOMEKH, Nádia; CAMPOS NETO, Cândido Malta. Desenvolvimento local e projetos urbanos - IX Encontro Nacional da ANPUR. Ética, Planejamento e Construção Democrática do Espaço (Tema I: Escalas de poder e novas formas de gestão urbana e regional). In www.vitruvius.com. br/arquitextos, abril, 2005.

TOLEDO, Benedito Lima de. São Paulo: três cidades em um século. São Paulo: Duas Cidades, 1981.

TOPALOV, Christian. La Urbanización Capitalista. México: Edicol, 1979.

TORRES, Maria Celestina Teixeira Mendes. História dos bairros de São Paulo O Bairro do Brás. Monografia vencedora do concurso de monografias do departamento de Cultura da Secretaria de Educação e Cultura, 1985. 
VARGAS, Heliana Comin; CASTILHO, Ana Luisa H. Intervenções em centros urbanos: objetivos, estratégias e resultados. Barueri: Manole, 2006.

VILLAÇA, Flávio. O espaço intra-urbano no Brasil. São Paulo: FAPESP/ Studio Nobel, 1998.

\section{Referências da legislação consultada}

\section{Estatuto da Cidade}

Lei Federal $n^{\circ}$ 10.257, de 10 de julho de 2001 .

Plano Diretor do Município de São Paulo - 1985 a 2000

Lei Municipal n 10.676 de 07// I//985.

Plano Diretor Estratégico de São Paulo - 200 I a 2010

Lei Municipal no. 13.430 de 13/09/2002. Lei dos Planos Regionais Estratégicos - n 13.885 de 25 de agosto de 2004.

Plano Diretor da Subprefeitura da Mooca:

Relatório final - volume 1: Quadro situacional

Relatório final - volume 2: Quadro propositivo

Relatório final - volume 3: Habitação

Relatório final - volume 4: Patrimônio histórico e cultural

Relatório final - volume 5: Levantamento agentes vistores

Plano Diretor Regional da Subprefeitura Sé - São Paulo:

Relatório final - volume I: Quadro situacional

Relatório final - volume 2: Quadro propositivo

Relatório final - volume 3: Habitação

Relatório final - volume 4: Patrimônio histórico e cultural

Relatório final - volume 5: Levantamento agentes vistores 


\section{Órgãos para pesquisa de dados oficiais}

CDHU - Companhia de Desenvolvimento Habitacional e Urbano do Estado de São Paulo

COHAB - Companhia Metropolitana de Habitação de São Paulo

IBGE - Instituto Brasileiro de Geografia e Estatística

SEHAB - Secretaria Municipal de Habitação

METRÔ - Companhia do Metropolitano de São Paulo

SEADE - Fundação Sistema Estadual de Análise de Dados

EMPLASA - Empresa Metroloplitana de Planejamento S/A

FES - Fundação Energia e Saneamento

$1{ }^{\circ}$ Oficial de Registro de Imóveis de São Paulo

$3^{\circ}$ Oficial de Registro de Imóveis de São Paulo

$7^{\circ}$ Oficial de Registro de Imóveis de São Paulo

$9^{\circ}$ Oficial de Registro de Imóveis de São Paulo 


\section{Referências cartográficas}

\section{Capítulo II}

p.25 Mapa I - Planta da cidade de São Paulo - 1810 Autoria: Capitão Engenheiro Rufino Felizardo e Costa

Fonte: Comissão do IV centenário da cidade de São Paulo, 1954.

Coleção São Paulo antigo: Plantas da cidade. Arquivo: Biblioteca Mário de Andrade. Microfilmes dos mapas digitalizados pelo CEDIP - PUC.

p.27 Mapa 2 - Mapa das Chácaras

Fonte: Aroldo de Azevedo. "A Cidade de São Paulo".

Chácaras, sítios e fazendas ao redor do centro, de J. Rufino.

p.30 Mapa 03 - Planta da cidade de São Paulo - 1868

Autoria: Carlos Roth

Fonte: Comissão do IV centenário da cidade de São Paulo, 1954.

Coleção São Paulo antigo: Plantas da cidade. Arquivo: Biblioteca Mário de Andrade. Microfilmes dos mapas digitalizados pelo CEDIP - PUC.

p.32 Mapa 04 - Planta da capital do Estado de São Paulo - 1890

Autoria: Jules Martin

Fonte: Comissão do IV centenário da cidade de São Paulo, 1954.

Coleção São Paulo antigo: Plantas da cidade. Arquivo: Biblioteca Mário de Andrade. Microfilmes dos mapas digitalizados pelo CEDIP - PUC.

p.34 Mapa 05 - Planta geral da capital da cidade de São Paulo - 1897 Autoria: Gomes Cardin

Fonte: Comissão do IV centenário da cidade de São Paulo, 1954.

Coleção São Paulo antigo: Plantas da cidade. Arquivo: Biblioteca Mário de Andrade. Microfilmes dos mapas digitalizados pelo CEDIP - PUC.

p.35 Mapa 06 - Mapa da expansão da área arruada da cidade de São Paulo entre $188 \mid$ e 1914

Fonte: Silveira Brito, Mônica. Dissertação de Mestrado, 1999.

Base: planta da cidade de São Paulo de 19|4.

p.39 Mapa 07 - Planta geral da cidade de São Paulo com indicações diversas, 19/4 Fonte: Comissão Geográfica e Geológica - Eng. Chefe: João Pedro Cardoso in Encarte da Reconstituição da Memória Estatííitica da Grande São Paulo. Organização: Governo do Estado de São Paulo.

p.4I Mapa 08 - Planta Geral da cidade de São Paulo, $19 \mid 4$ - fábricas Fonte: Comissão Geográfica e Geológica - Eng. Chefe: João Pedro Cardoso in Encarte da Reconstituição da Memória Estatííitica da Grande São Paulo. Organização: Governo do Estado de São Paulo.

p.42 Mapa 09 - Mapa topográfico do município de São Paulo, 1930 Fonte: Empresa Sara Brasil, Eng. Arthur Saboya. Arquivo do DPH. 
p.44 Mapa 10 - Planta da cidade de São Paulo e municípios vizinhos, 1950

Autoria: The São Paulo Tramway Light and Power

Fonte: Fundação Energia e Saneamento.

p.45 Mapa II - Mapa Gegran, 1972

Fonte: EMPLASA - Empresa Paulista de Planejamento Metropolitano S/A.

p.54 Mapa 12 - Indicação de arruamentos e passagens/glebas/divisão administração de regional

Base: Mapa Oficial da Cidade de São Paulo - MOC

Fonte: EMPLASA - junho. 1985.

p.55 Mapa 13 - Loteamentos irregulares na cidade de São Paulo

Autoria: RESOLO

Fonte: SEMPLA - Secretaria Municipal de Planejamento da Prefeitura de São Paulo.

p.67 Mapa I4 - Legislação Urbanística - LUOS/Zoneamento de 1972

Fonte: Código GEOMAPAS do Zoneamento.

p.69 Mapa 15 - Situação e delimitação do zoneamento antes da implantação da ZML, 1979 Fonte: COGEP/PMSP. Série Políticas setoriais: controle normativo I: Política de controle de uso e ocupação do solo, mapa I: situação atual.

p.69 Mapa 16 - Situação e delimitação do zoneamento antes da implantação da ZML, 1979 Fonte: COGEP/PMSP - Série Políticas setoriais. Controle normativo I: Política de controle de uso e ocupação do solo, mapa II: estrutura proposta.

p.7I Mapa 17 - Planta Geral da cidade de São Paulo, $19 \mid 4$ - bondes

Fonte: Comissão Geográfica e Geológica - Eng. Chefe: João Pedro Cardoso in Encarte da Reconstituição da Memória Estatísitica da Grande São Paulo. Organização: Governo do Estado de São Paulo.

p.74 Mapa 18 - Hierarquia viária / acessos

Autoria: Maria Elizabet Paez Rodriguez sobre base GEGRAN 1972, 2006.

p.78 Mapa 19 - Transposições viárias

Autoria: Maria Elizabet Paez Rodriguez sobre base GEGRAN 1972, 2006.

p.79 Mapa 20 - Terminais de integração

São Paulo Interligado, SMT - Secretaria Municipal de Transportes, 2004.

p.80 Mapa 21 - Sistema de transporte público

São Paulo Interligado, SMT - Secretaria Municipal de Transportes, 2004.

p.82 Mapa 22 - Escolas públicas existentes

Autoria: Maria Elizabet Paez Rodriguez sobre base GEGRAN 1972, 2006.

p.82 Mapa 23 - Unidades de saúde pública existentes

Autoria: Maria Elizabet Paez Rodriguez sobre base GEGRAN 1972, 2006. 


\section{Capítulo III}

p.85 Mapa 24 - Demonstrativo da área-objeto de estudo Autoria: Maria Elizabet Paez Rodriguez sobre base GEGRAN 1972, 2006.

p.87 Mapa 25 - Uso e ocupação do solo atual - levantamento in loco, 2004 Autoria: Maria Elizabet Paez Rodriguez sobre base GEGRAN 1972, 2006.

p.94 Mapa 26 - Topografia e fundos de vale Autoria: Plano Regional Estratégico da Subprefeitura Mooca.

p.95 Mapa 27 - Traçado viário - etapas de surgimento Autoria: Maria Elizabet Paez Rodriguez sobre base GEGRAN 1972, 2006.

p. 102 Mapa 28 - Centralidades com comércio e serviços Autoria: Maria Elizabet Paez Rodriguez sobre base GEGRAN 1972, 2006.

\section{Capítulo IV}

p. 122 Mapa 29 - Área de abrangência de creche municipal Autoria: Maria Elizabet Paez Rodriguez sobre base GEGRAN 1972, 2006.

p. I 22 Mapa 30 - Área de abrangência de EMEI - Escola Municipal de Ensino Infantil Autoria: Maria Elizabet Paez Rodriguez sobre base GEGRAN 1972, 2006.

p. I 23 Mapa 3 I - Área de abrangência de EMEF - Escola Municipal de Ensino Fundamental Autoria: Maria Elizabet Paez Rodriguez sobre base GEGRAN 1972, 2006.

p. I 23 Mapa 32 - Área de abrangência de EMEE - Escola Municipal de Ensino Especial Autoria: Maria Elizabet Paez Rodriguez sobre base GEGRAN 1972, 2006.

p. 124 Mapa 33 - Área de abrangência de EE - Escola Estadual Autoria: Maria Elizabet Paez Rodriguez sobre base GEGRAN 1972, 2006.

p. 124 Mapa 34 - Área de abrangência de ET - Escola Técnica Autoria: Maria Elizabet Paez Rodriguez sobre base GEGRAN 1972, 2006.

p. 127 Mapa 35 - Temperatura aparente da superfície alvo de registro Fonte: Atlas ambiental do Município de São Paulo.

SVMA - Secretaria do Verde e Meio Ambiente, 2004.

p. 127 Mapa 36 - Cobertura vegetal Fonte: Atlas ambiental do Município de São Paulo.

SVMA - Secretaria do Verde e Meio Ambiente, 2004.

p. I 32 Mapa 37 - Perfil sócio-ambiental Fonte: Atlas ambiental do Município de São Paulo. SVMA - Secretaria do Verde e Meio Ambiente, 2004. 


\section{Capítulo VI}

p. 157 Mapa 38 - Legislação Urbanística - LUOS. Zoneamento de 1972 Fonte: Código GEOMAPAS do Zoneamento.

p. 158 Mapa 39 - Uso e Ocupação do Solo - Lei de 2002 Autoria: Planos Regionais Estratégicos das Subprefeituras Mooca e Sé.

p. 163 Mapa 40 - Operações Urbanas Fonte: Plano diretor Estratégico para o Município de São Paulo, Mapas, 2002.

p. I 64 Mapa 4I - Planos Regionais Estratégicos das Subprefeituras Sé e Mooca. Representação gráfica dos principais elementos Autoria: Maria Elizabet Paez Rodriguez sobre base GEGRAN 1972, 2006.

\section{Capítulo VII}

p. 172 Mapa 42 - Escolas públicas existentes Autoria: Maria Elizabet Paez Rodriguez sobre base GEGRAN 1972, 2006.

p. 175 Mapa 43 - Unidades de saúde pública Autoria: Maria Elizabet Paez Rodriguez sobre base GEGRAN 1972, 2006.

p. 184 Mapa 44 - Representação Gráfica das Diretrizes para Requalificação Urbana do Brás e Mooca Autoria: Maria Elizabet Paez Rodriguez sobre base GEGRAN 1972, 2006. 


\section{Anexo 1 \\ Glossário}

Aldeamento: povoação de índios (Houaiss).

Área rural: área externa ao perímetro urbano (IBGE).

Área urbana: área interna ao perímetro urbano de uma cidade ou vila, definida por lei municipal. Para as cidades ou vilas onde não existe legislação que regulamente essas áreas, deve-se estabelecer um perímetro urbano para fins da coleta censitária do XI Recenseamento Geral, cujos limites devem ser aprovados pelo Prefeito local (IBGE).

Área urbana isolada: área definida por lei municipal e separada da sede municipal ou distrital por área rural ou por um outro limite legal (IBGE).

Arruamento: termo adotado pela PMSP à época nas aprovações de parcelamento de terrenos em lotes residenciais ou industriais.

Bairro: cada uma das partes em que se costuma dividir uma cidade ou vila, para mais precisa orientação das pessoas e mais fácil controle administrativo dos serviços públicos (Aurélio). Segundo IBGE, nem todos os municípios possuem subdistritos e bairros.

Brutalismo: Estilo arquitetônico simples, datado da década de 1950, que deixava à mostra tubulações e outras instalações técnicas. Arquitetos do brutalismo: Kahn e Mies van der Rohe.

Distritos: são unidades administrativas dos municípios. Têm sua criação norteada pelas Leis Orgânicas dos Municípios (IBGE).

Domicílio: domicílio é o local estruturalmente separado e independente que se destina a servir de habitação a uma ou mais pessoas, ou que esteja sendo utilizado como tal (IBGE).

Domincílios Coletivos: o domićlio é considerado coletivo quando a relação entre as pessoas que nele habitam é restrita a normas de subordinação administrativa, como em hotéis, pensões, presídios, cadeias, penitenciárias, quartéis, postos militares, asilos, orfanatos, conventos, hospitais e clínicas (com internação), alojamento de trabalhadores, motéis, camping etc (IBGE).

Domicílios improvisados: domićlio localizado em unidade não-residencial (loja, fábrica etc) que não tinha dependências destinadas exclusivamente à moradia, mas que é ocupado por morador. Os prédios em contrução, vagões de trem, carroças, tendas, barracas, grutas etc, que servem de moradia, também são considerados como domicílios particulares improvisados (IBGE). 
Domicílios Particulares Permanentes: domicílio é o local construído para servir exclusivamente à habitação e tem a finalidade de servir de moradia a uma ou mais pessoas $O$ domicílio é considerado particular quando o relacionamento entre seus ocupantes é ditado por laços de parentesco, de dependência doméstica ou por normas de convivência (IBGE e SEADE).

Domicílios Particulares Permanentes em Apartamentos: domicílio localizado em edifício de um ou mais andares, com mais de um domicílio, servido por espaços comuns (hall de entrada, escadas, corredores, portaria ou outras dependências). O domićlilo localizado em um prédio de dois ou mais andares em que as demais unidades não eram residenciais e, ainda, aquele localizado em edifício de dois ou mais pavimentos com entradas independentes para os andares, foram considerados como apartamentos (IBGE).

Domicílios Particulares Permanentes em Casas: domicílio localizado em uma edificação de um ou mais pavimentos, desde que ocupado integralmente por um único domićlio, com acesso direto a um logradouro (arruamento, vila, avenida, caminho etc), legalizado ou não, independentemente do material utilizado em sua construção (IBGE).

Domicílios Particulares Permanentes em Cômodos: domicílio composto por um ou mais aposentos localizado em uma casa de cômodos, cortiço, cabeça-de-porco etc (IBGE e SEADE).

Domicílios Particulares Permanentes Urbanos: domićlios localizados em áreas urbanizadas ou não, correspondentes às cidades (sedes municipais), às vilas (sedes distritais) ou às áreas urbanas isoladas (IBGE).

Domicílios Urbanos: domicílios localizados em áreas urbanizadas ou não, correspondentes às cidades (sedes municipais), às vilas (sedes distritais) ou às áreas urbanas isoladas (IBGE).

Freguesia: divisão administrativa que evolutivamente passa à vila e posteriormente à cidade (Houaiss).

Municípios: são as unidades de menor hierarquia dentro da organização político-administrativa do Brasil, criadas através de leis ordinárias das Assembléias Legislativas de cada Unidade da Federação e sancionadas pelo Governador (IBGE).

Passagem: termo adotado pela PMSP à época nas aprovações de construção de vilas operacionais ou populares.

Regiões administrativas; Subdistritos e Zonas: são unidades administrativas municipais, normalmente estabelecidas nas grandes cidades, criadas através de leis ordinárias das Câmaras Municipais e sancionadas pelo Prefeito (IBGE). 
Unidades da Federação (Estados, Distrito Federal): são as unidades de maior hierarquia dentro da organização político-administrativa no Brasil, criadas através de leis emanadas do Congresso Nacional e sancionadas pelo Presidente da República (IBGE).

Vila: pequeno povoado; conjunto de casas em beco com uma única saída para rua (Houaiss).

Termos correlatos para Requalificação Urbana

Recuperação: restauração, restituição, reabilitação, reintegração (Houaiss).

Renovação: trocar por mais novo, atualização.

Renovar: tornar novo, modificar para melhor, restaurar (Aurélio); revigorar, refazer, atualizar (Houaiss).

Requalificação: verbete não encontrado.

Qualificar: atribuir qualidade (Aurélio).

Reurbanização: verbete não encontrado.

Urbanizar: civilizar, tornar urbano, embelezar, reformar (Houaiss).

Revitalização: retornar à vida (Houaiss). 
Radial Leste, Brás e Mooca: diretrizes para requalificação urbana 


\section{Anexo 2 \\ Compilação dos \\ Planos Regionais \\ Estratégicos das Subprefeituras \\ Mooca e Sé}

Esta é uma compilação dos Planos Regionais Estratégicos das Subprefeituras Mooca e Sé. Em virtude da área-objeto de estudo ter trecho administrado pela Subprefeitura Mooca (Brás, Alto da Mooca e Parque da Mooca) e trecho administrado pela Subprefeitura Sé (Mooca Baixa), foi necessário encontrar os pontos divergentes e os convergentes entre os dois para facilitar o entendimento das propostas de diretrizes das duas Subprefeituras para a área-objeto de estudo, eliminando os assuntos e mapas não pertinenetes a esta dissertação. A numeração dos mapas foi alterada em relação à dos PRE's para facilitar a compreensão da continuidade e eventuais referências aos mapas aqui apresentados foram adequadas à essa nova numeração.

Vários temas são abordados de forma diferente pelas duas Subprefeituras e por isso os itens foram mantidos em seu texto original; foram sinalizados com símbolo MO, mo, SE e ${ }^{\text {SE }}$, em referência ao PRE que os originou. Os sinalizados com MO/SE referem-se a itens mencionados nos dois planos regionais.

Alguns itens, como requalificação do Parque Dom Pedro II, foram mantidos pela proximidade com o Brás e por representar opção de uso aos seus moradores.

\section{Políticas públicas regionais}

\section{I Objetivos da política de desenvolvimento urbano e ambiental da região}

Ambos os Planos Regionais têm como primeiro princípio de desenvolvimento regional garantir a implementação, em escala distrital e da subprefeitura, dos princípios gerais do PDE, visando à correção dos desequilíbrios sociais e entre distritos, buscando alcançar o desenvolvimento harmônico da região por meio de Projetos Estratégicos, Programas de Requalificação, Áreas de Intervenção Urbana e pela Operação Urbana Centro.

MO/SE - Princípios dos Planos Regionais:

- garantir o acesso aos bens, serviços e políticas sociais à todos;

- garantir o direito à Cidade para todos, baseado na Carta Mundial pelo Direito à Cidade, entendendo Cidade como um conjunto de necessidades dos cidadãos como terra, moradia, transporte, qualidade e insumos ambientais, serviços públicos, trabalho e lazer;

- respeitar as funções sociais da Cidade e da propriedade, traduzindo e detalhando-as para a escala da subprefeitura;

- garantir e fortalecer os espaços de participação da população nos processos de decisão, planejamento e gestão, bem como respeitar, integrar e capacitar os cidadãos para ocupar esses espaços. 
MO/SE - Objetivos do Plano Regional da Mooca e Plano Regional da Sé para o desenvolvimento urbano e ambiental da região:

mo articular projetos e políticas setoriais relacionados com a região;

mo subsidiar a construção de parâmetros de controle de incomodidades;

mo priorizar a oferta de equipamentos setoriais na região;

mo melhorar as condições ambientais por meio:

- da manutenção das áreas verdes existentes;

- da criação de novas áreas verdes;

- da criação de áreas permeáveis, eliminando os riscos ambientais (inundação, deslizamentos, desabamentos e outros);

- da recuperação de áreas contaminadas;

mo/sミ implementar o Programa de Reabilitação da Área Central - Ação Centro - PMSP/BID nos distritos Sé, República, Cambuci/Mooca Baixa, Bela Vista, Consolação, Santa Cecília, Bom Retiro e Liberdade, visando à:

- recuperação do ambiente urbano, em especial das áreas degradadas, por meio do incremento das atividades de zeladoria da Subprefeitura, da requalificação de edifícios de interesse histórico, do controle de inundações e do tratamento de resíduos sólidos recicláveis;

- melhoria da circulação e dos transportes;

- reversão da desvalorização imobiliária e recuperação da função residencial;

- transformação do perfil econômico e social, por meio de ações de fomento da pluralidade econômica, da inclusão social, da segurança urbana e da cultura.

mo/ss estimular o uso habitacional, atividades culturais e de lazer e a diversidade social incentivando a diversidade de usos;

mo/sミ assegurar o direito à moradia digna para a população que vive em cortiços, favelas e ocupações irregulares existentes no território da Subprefeitura;

sE fortalecer as funções turísticas de entretenimento, lazer, cultura e negócios;

ss incentivar a localização de órgãos de administração pública dos três níveis de governo na área central;

sE valorizar e incentivar a preservação do patrimônio histórico, cultural e ambiental urbano, consolidando a identidade do centro metropolitano;

sE garantir o uso adequado de espaços públicos e privados, em especial na planície aluvial dos rios Tamanduateí e Tietê e no entorno da Avenida Tiradentes, promovendo a expansão das atividades do centro histórico até o centro de convenções do Anhembi;

sE intervir em áreas desocupadas ou ocupadas por usos inadequados;

sE recuperar áreas degradadas, em especial aquelas ocupadas por habitações precárias;

sE modernizar e tornar mais eficiente o sistema de iluminação pública no centro, priorizando o pedestre;

sE melhorar a gestão e o ordenamento dos espaços públicos nas principais ruas comerciais através do Programa Ruas Comerciais, Circuito de Compras e Loja Cidade de São Paulo, entre outros.

\section{I.I.I Objetivos para o desenvolvimento econômico e social:}

MO/SE - Objetivos e diretrizes de desenvolvimento econômico e social:

mo incentivar a permanência das indústrias regularmente existentes, que desempenham com qualidade a sua função social;

mo incentivar a instalação de indústrias que não sejam incômodas e que cumpram a sua função social; 
mo incentivar a reconversão de uso nas construções ou reformas com mudança de uso, em áreas sem uso ou consideradas subutilizadas:

- na reutilização das áreas industriais, estimulando o uso misto com indústrias não incômodas;

- com a implantação de usos diversificados, como o habitacional, cuja prioridade deve ser dada para a HIS e HMP, cultural, educacional e de saúde.

mo estimular empreendimentos pequenos e médios de uso comercial e de serviços em toda a região e, principalmente, nas áreas de reconversão de uso;

mo estimular a localização de empreendimentos de maior porte em antigos edifícios fabris de importância histórica e cultural, atribuindo importância e agregando valor à morfologia industrial do começo do século 20 que ainda existe na região;

mo desenvolver planos e programas para a manutenção e o desenvolvimento das áreas de comércio especializado, que concentram-se, principalmente, nos Distritos do Brás e do Pari, para que essas adquiram qualidade ambiental e paisagística, tenham boa acessibilidade e não sejam incompatíveis com os imóveis residenciais próximos;

mo reconhecer, na logística das atividades, a existência de grupos organizados marginalizados, tais como ambulantes ou catadores de lixo;

mo estimular a organização e inserção no mercado e no espaço urbano de agentes econômicos locais que hoje atuam isoladamente, de maneira marginalizada;

mo estimular o desenvolvimento econômico local, através da implantação de atividades de médio e pequeno porte, geradoras de empregos com maior valor agregado, que se utilizem de insumos produzidos na região.

mo - oss Para a reconversão de uso de áreas industriais deverão ser ouvidos os órgãos ambientais competentes, para averiguar a sua possível contaminação pelo uso industrial anterior, certificando-se da possibilidade de utilização das mesmas.

mo - oss Na reconversão de uso por reparcelamento de lote ou quadra deverá ser observado:

- lote máximo de $500 \mathrm{~m}^{2}$ (quinhentos metros quadrados) para uso não residencial;

- área máxima do empreendimento de uso residencial de $10.000 \mathrm{~m}^{2}$ (dez mil metros quadrados).

sE incentivar a multiplicidade de funções, por meio de instrumentos que favoreçam o aproveitamento do estoque imobiliário ocioso;

sE estimular a alteração de uso das edificações existentes para as necessidades específicas, segundo distritos da Subprefeitura;

sE estimular a produção de novas unidades habitacionais para diferentes faixas de renda, destinadas a diferentes composições familiares;

sE resgatar o espaço público para a apropriação coletiva;

sE estimular a abertura de espaços de apropriação coletiva interna e externa dos espaços comerciais e de prestação de serviços;

sE ampliar a oferta de habitação de interesse social;

sE viabilizar parcerias com entidades de classe para o incremento de novos empreendimentos residenciais destinados às faixas de renda média e baixa.

\section{I.I.2 Objetivos para o desenvolvimento humano e qualidade de vida:}

SE - Na Subprefeitura Sé os objetivos para o Desenvolvimento Humano e Qualidade de Vida são:

- assegurar o direito à moradia digna para a população de baixa renda que vive em habitações precárias;

- estimular a reabilitação de imóveis, em especial, daqueles contidos nos Perímetros de Reabilitação Integrada do Habitat $(P R I H)$ e nas zonas especiais de interesse social 
(ZEIS);

- complementar a rede de equipamentos sociais para atendimento das novas famílias;

- criar programas de capacitação e formação profissional, por meio da realização de oficinas-escola de paisagismo, de restauração de monumentos, de reabilitação de edificações, de padrões de manutenção de espaços públicos;

- criar mecanismos de geração de emprego e renda para a população de menor poder aquisitivo residente no território da Subprefeitura;

- readequar os abrigos e albergues públicos existentes na região central, incluindo novas abordagens e metodologias de atendimento;

- readequar a atuação dos ambulantes criando projetos de qualificação profissional;

- reforçar a segurança urbana com a instalação de bases comunitárias de segurança em locais estratégicos nos espaços públicos, envolvendo ação conjunta com a polícia militar e civil.

MO - Segundo o PRE da Subprefeitura Mooca, para alcançar o desenvolvimento humano e qualidade de vida, de que trata o Capítulo II do Título II do PDE, em função das propostas feitas pela comunidade local, ficam estabelecidos no artigo $6^{\circ}$ deste PRE as prioridades para os anos meta 2006 e 2012 , por meio de ação conjunta da subprefeitura com as demais Secretarias pertinentes, visando à priorização das políticas setoriais e das ações estratégicas localizadas, de modo a promover a inclusão social e a reduzir as desigualdades regionais relativas aos diversos setores.

\subsubsection{Objetivos da Subprefeitura Mooca quanto ao ambiente urbano:}

- criar novas áreas verdes;

- propiciar o acesso da população aos equipamentos de lazer e esportes existentes ou a serem criados nas áreas públicas;

- estimular a arborização em toda a região de operação urbana;

- garantir o controle da permeabilidade do solo de modo a evitar os impactos negativos sobre a drenagem urbana;

- buscar novas soluções para bacias de contenção, evitando-se a impermeabilização total;

- exigir a recuperação de áreas contaminadas e estipular compensações ambientais, através de instrumentos legais existentes ou criados para esse fim;

- elaborar um plano de drenagem de águas pluviais;

- estabelecer procedimentos para avaliação de áreas contaminadas, ou com suspeita ou potencial de contaminação, nos termos das disposições desta Lei;

- permitir a ocupação de áreas contaminadas somente após a sua recuperação;

- garantir segurança e bem-estar a todos os cidadãos;

- desenvolver políticas e programas que estimulem o uso de áreas tombadas, dinamizandoas;

- recuperar bens tombados em processo de degradação;

- estimular a implantação de equipamentos nos edifícios identificados como de importância histórica e cultural ou de identidade com a comunidade, restaurando-os se necessário.

\section{1.2.2 Objetivos da Subprefeitura Mooca quanto às áreas públicas:}

- garantir a sua utilização por todos os cidadãos;

- utilizar as áreas remanescentes de traçados viários ou baixos de viadutos por atividades efêmeras de interesse da coletividade;

- elaborar um diagnóstico da demanda por equipamentos na área da subprefeitura que inclua as propostas e necessidades apontadas pela comunidade no Orçamento 
Participativo e neste plano, a fim de priorizar a utilização destas áreas;

- garantir a iluminação de ruas, vias e praças, para gerar a sensação de segurança;

- implementar um sistema informatizado de cadastramento das áreas verdes e áreas públicas em ação conjunta com a Secretaria do Verde e do Meio Ambiente. resse social:

1.1.2.3 Objetivos da Subprefeitura Mooca quanto ao uso residencial e habitação de inte-

- estimular a implantação de novas áreas residenciais em regiões de uso misto;

- evitar o surgimento de grandes áreas que concentrem apenas um uso - residencial - e concentrem também a mesma faixa de renda;

- estimular a produção e oferta de Habitação de Interesse Social (HIS), tanto pelo poder público, como pela iniciativa privada,em toda a região da Subprefeitura;

- garantir que $20 \%$ da área reparcelada em processos de reconversão de uso seja utilizada para a produção de HIS;

- estimular a participação popular na tomada de decisão, elaboração de projetos, elencando prioridades.

\subsubsection{Objetivos da Subprefeitura Mooca quanto aos cortiços:}

- estimular os proprietários de cortiços a fazerem intervenções para melhorar a qualidade habitacional dos mesmos;

- alugar edifícios que estiverem em condições dignas e de acordo com a legislação vigente para atender a população residente em cortiços;

- desenvolver planos e programas para os imóveis a serem reformados pelo Poder Público;

- formar uma base de dados articulada e integrada nos âmbitos municipal e estadual.

\section{I.I.3 Objetivos para o desenvolvimento humano com qualidade ambiental}

MO/SE - São objetivos do desenvolvimento urbano com qualidade ambiental em ambos os PRE:

mo promover a recuperação e melhoria das condições de ocupação do solo, de forma a garantir o controle da permeabilidade;

mo diminuir os graves problemas ambientais de drenagem, poluição atmosférica e sonora, adotando Planos e Programas de Gestão Ambiental;

mo fazer gestões junto às diversas esferas de governo visando à expansão e integração da Rede Estrutural de Transportes e Viária, articulando os diferentes modos para atender às novas demandas;

мo incentivar a dinamização das centralidades existentes;

mo promover a ampliaçã̃o e qualificação das áreas de uso público nas intervenções relacionadas com as centralidades e a implantação dos Terminais de Transporte Público;

mo participar da implantação do Plano Diretor de Resíduos Sólidos em um papel pró-ativo com a ativação do Centro de Triagem do Tatuapé;

mo estimular a implantação de programas, pelos setores público e privado, que tenham como objetivo a recuperação do patrimônio histórico;

mo propor novas ZEPEC a partir do mapeamento do patrimônio histórico existente e de indicações da população.

sE implementar obras de melhoria urbana na área da Subprefeitura;

sE promover a valorização da paisagem urbana e a melhoria da infra-estrutura e de sua qualidade ambiental;

sø permitir a identificação, leitura e apreensão da paisagem, garantindo sempre que possível, a 
continuidade visual dos referenciais históricos do centro da cidade;

SE assegurar a visibilidade dos bens tombados por meio do controle dos anúncios de publicidade e do gabarito das edificações do entorno;

sE promover a gestão integrada dos mobiliários urbanos com os demais órgãos públicos e concessionárias de serviços públicos, visando à segurança e ao conforto do percurso dos pedestres e à melhor qualificação dos espaços públicos;

sE promover a preservação, recuperação e melhoria das condições de ocupação do solo de forma a garantir o controle da permeabilidade, em especial na planície aluvial do rio Tamanduateí;

sE melhorar a qualidade do ambiente urbano por meio de obras de drenagem que minimizem os riscos de alagamento, inundação, desabamento e deslizamento;

sE promover intensas e extensas ações para diminuir os graves problemas ambientais de drenagem, poluição atmosférica, poluição do solo, sonora e de desconforto térmico, adotando planos e programas de gestão ambiental;

sE regulamentar as atividades não residenciais contidas em zonas mistas com predominância residencial, visando à redução dos níveis de incômodos.

\section{Plano urbanístico-ambiental}

\section{I Elementos estruturadores}

\section{I.I Rede Hídrica Ambiental}

MO - Além dos objetivos e diretrizes estabelecidos nos artigos 6I , 62, 64, 65, 67 e 68 da Lei $n^{\circ}$ 13.430, de 13 de setembro de 2002, deverão ser observados os seguintes:

mo minimizar a ocorrência de alagamentos, por meio do estabelecimento de taxa de permeabilidade mínima do solo e preservação dos talvegues de mananciais não canalizados;

мo promover a contenção das águas pluviais, atendendo ao disposto na Lei n 13.276 , de 04 de janeiro de 2002;

mo controlar a ocupação dos fundos de vale, de forma a recuperar a permeabilidade do solo;

мo mitigar o desconforto térmico e a poluição atmosférica, por meio da arborização dos espaços de uso público e preservação das concentrações arbóreas significativas;

mo ampliar as áreas de uso público, as áreas verdes, a arborização e as calçadas;

мо criar um Programa de Proteção das Águas Subterrâneas que garanta:

- que o uso desse potencial aqüífero não provoque o rebaixamento dos níveis d'água;

- que o seu consumo seja controlado;

- que o risco de contaminação dos poços por problemas no saneamento e outros sejam controlados, reduzidos e minimizados;

mo incentivar a arborização em toda a área da subprefeitura;

mo desenvolver um programa de manutenção e criação de árvores junto à comunidade;

mo fomentar o Viveiro da Mooca.

мо - овs As áreas residenciais e as áreas públicas municipais são prioritárias para atender o disposto acima, principalmente nos Distritos da Água Rasa e Mooca.

sE manter a permeabilidade na planície aluvial do rio Tamanduateí, e assegurar os condicionantes para sua ocupação adequada;

sE minimizar a ocorrência de alagamentos por meio do atendimento da taxa de permeabilidade mínima do solo estabelecida por esta lei e por legislação específica; 
sE promover a contenção das águas pluviais atendendo ao disposto na Lei $n^{\circ}$ | 3.276 de 04 de janeiro de 2002;

sE ampliar as superfícies de retenção de águas pluviais na planície aluvial, por meio de tratamento arbóreo e com "superfícies de piso" preponderantemente vegetais ou drenantes;

SE mitigar o desconforto térmico e a poluição atmosférica por meio da arborização dos espaços públicos;

sE ampliar as áreas de uso público, as áreas verdes e a arborização;

sE estimular a ampliação dos espaços públicos e não públicos de apropriação coletiva.

SE - Diretrizes específicas para a planície aluvial do Rio Tamanduateí, para o sistema de drenagem, caminhos verdes, parques e parques lineares:

sE planície aluvial do rio:

- promover a requalificação ambiental, paisagística e funcional da área;

- integrar o equipamento metropolitano a ser implantado no Parque Dom Pedro II ao Parque da Foz do Rio Tamanduateí e ao parque proposto, neste Plano, no Distrito do Cambuci;

- incluir no escopo das intervenções previstas na Operação Urbana Diagonal Sul, conforme estabelecido no inciso II do Artigo 229' do PDE, as ações necessárias ao atendimento das diretrizes mencionadas acima.

se drenagem:

- melhorar a drenagem urbana, por meio de obras de intervenção nos cursos d'água, piscinões e requalificação de galerias de águas pluviais contidas no perímetro da Subprefeitura;

- implantar piscinão na baixada do Glicério, situada na sub-bacia do córrego Moringuinho;

- requalificar a drenagem das 8 (oito) sub-bacias dos córregos Anhangüera, Moringuinho, Saracura, Anhangabaú, Pacaembu, Aclimação, Itororó e Estação da Luz.

sE implantar e ampliar os caminhos verdes;

sE implantar novos parques visando à valorização das praças e áreas verdes públicas, requalificando a arborização e as áreas degradadas existentes;

sE dar tratamento paisagístico adequado ao longo dos rios Tietê e Tamanduateí, criando parque linear com condições ambientais adequadas.

\footnotetext{
' Art. 229 - Cada operação urbana consorciada deverá ser aprovada por lei específica, que conterá, no mínimo: (...) Il. Finalidade da operação. Fonte: Plano Diretor Estratégico de São Paulo. Lei Municipal no 13.430 de setembro de 2002.
} 
Quadro 1 - Rede hídrica ambiental / Caminhos verdes

\begin{tabular}{|c|c|c|}
\hline Subprefeitura Mooca & Origem & Ano Meta \\
\hline $\begin{array}{l}\text { - } \quad \text { Reservatórios de retenção de águas pluviais (piscinões) } \\
\text { Sem previsão }\end{array}$ & N.I. & N.I. \\
\hline $\begin{array}{l}\text { - Caminhos Verdes } \\
\text { Sem previsão }\end{array}$ & N.I. & N.I. \\
\hline $\begin{array}{lr}\text { - } & \text { Parques } \\
\text { Sem previsão }\end{array}$ & N.I. & N.I. \\
\hline $\begin{array}{l}\text { - Parques Lineares } \\
\text { PLI3 }\left(\text { I.503.8I } 3 \mathrm{~m}^{2}\right) \text { - Inicia-se na confluência da Avenida do Estado com rua São } \\
\text { Caetano, rua São Caetano, rua Ministro Andradde, rua Oriente, rua Rodrigues dos } \\
\text { Santos, rua da Juta, rua do Gasômetro, Largo da Concórdia, rua Dr. Almeida Lima, } \\
\text { viaduto Prof. Alberto Mesquita de Camargo, rua Ministro Joãpo felipe, rua Borges de } \\
\text { Figueiredo, rua Sarapui, Avenida Henry Ford, viaduto Cap. Pacheco E. Chaves, Avenida } \\
\text { Preidente Wilson, viaduto Prof. Alberto Mesquita, rua Lúcio Cardim, rua André Leão. } \\
\text { Nos parques lineares da Subprefeitura da Mooca, criados no PDE e no Pla- } \\
\text { no Regional, está incluído um parque linear ao longo da via férrea que deve: } \\
\text { - } \quad \text { funcionar como um eixo de conexão de áreas verdes existen- } \\
\text { tes, que se encontram espalhadas por toda a sua extensão; } \\
\text { - } \quad \text { criar uma ciclovia neste eixo. }\end{array}$ & N.I. & 2012 \\
\hline Subprefeitura Sé & Origem & Ano Meta \\
\hline $\begin{array}{l}\text { - } \quad \text { Reservatórios de retenção de águas pluviais (piscinões) } \\
\text { Córrego Moringuinho - baixada do Glicério }\end{array}$ & PRE & 2012 \\
\hline $\begin{array}{l}\text { Caminhos Verdes } \\
\text { Av. Radial Leste }\end{array}$ & PDE & 2006 \\
\hline $\begin{array}{l}\text { Parques } \\
\text { Parque Dom Pedro II }\end{array}$ & PDE & 2006 \\
\hline $\begin{array}{l}\text { - Parques Lineares } \\
\text { PLOI - Eixo da Ferrovia começando na Avenida do Estado até o viaduto Pacaembu }\end{array}$ & PRE & 2012 \\
\hline
\end{tabular}




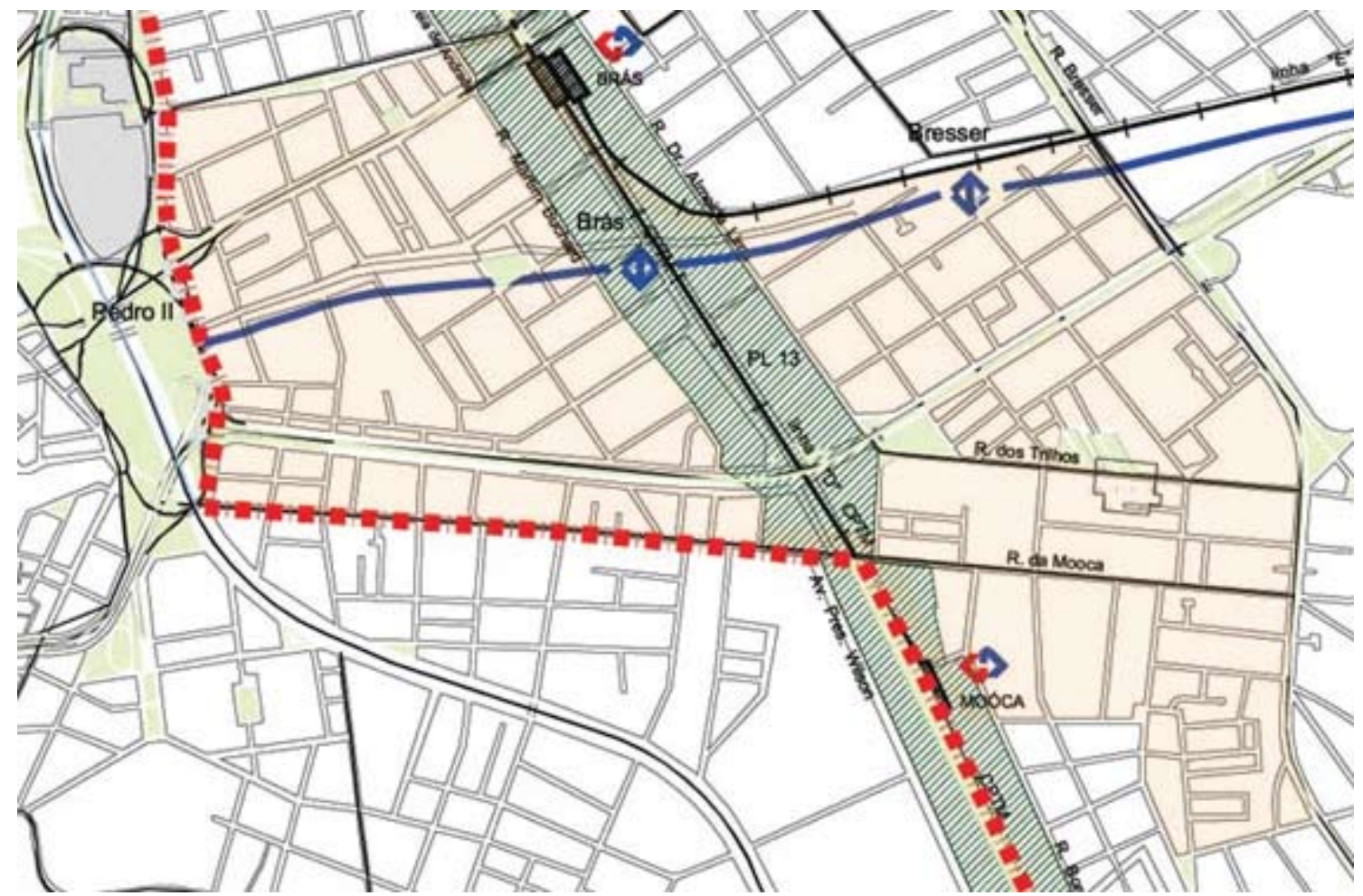

LEGENDA

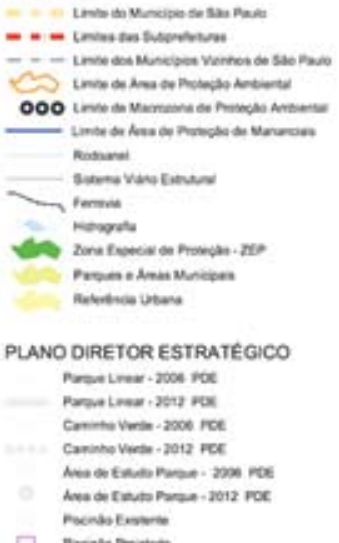

PLANO REGIONAL ESTRATEGICO

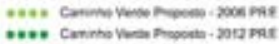

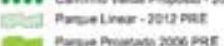

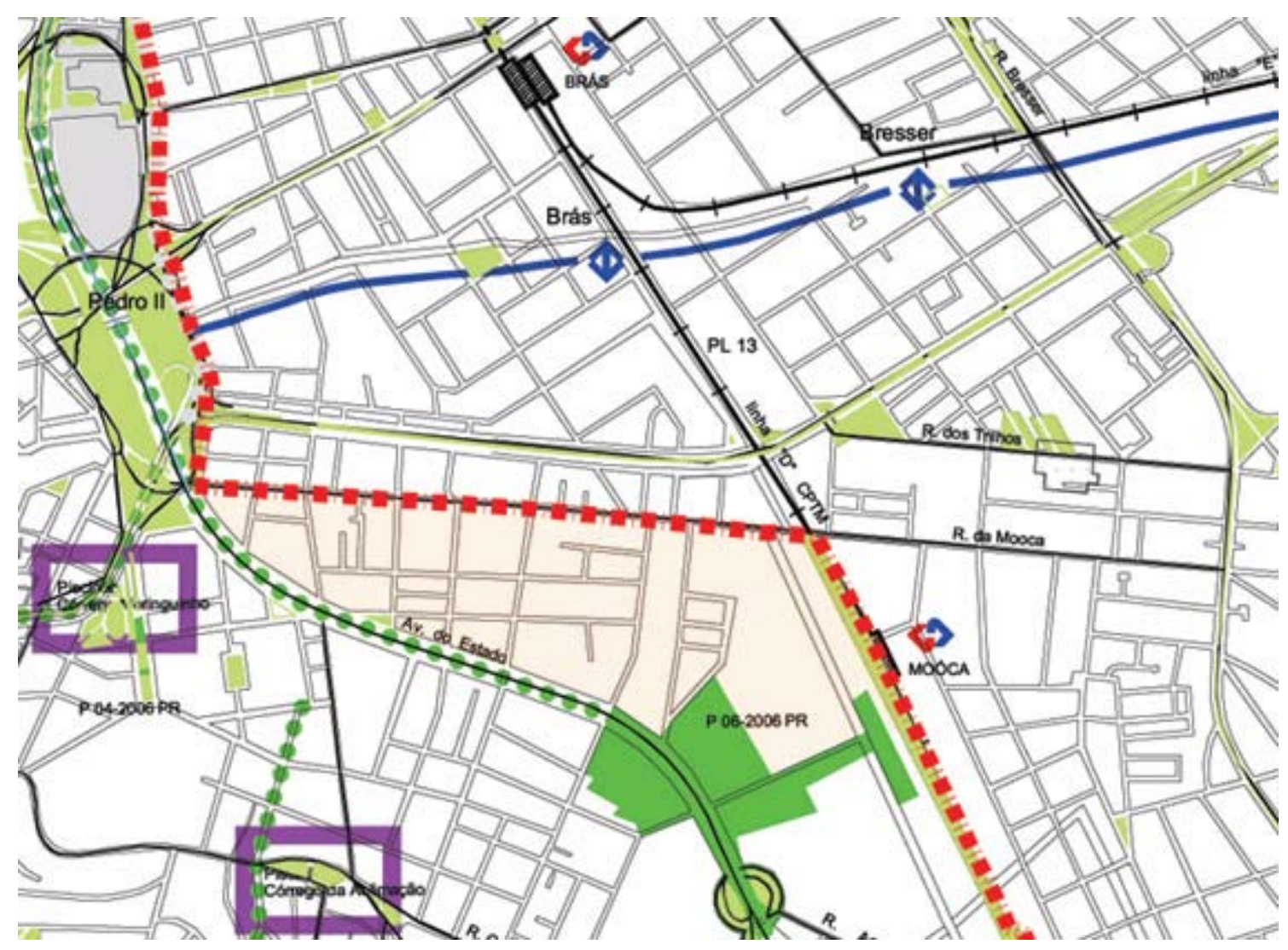

Acima:

Mapa 01-MO - Rede hídrica ambiental no Brás e Mooca.

Fonte: PRE Subprefeitura Mooca, 2004.

\section{Abaixo:}

Mapa 01-SE - Rede hídrica ambiental na Mooca Baixa.

Fonte: PRE Subprefeitura Sé, 2004. 


\subsubsection{Rede Viária Estrutural}

MO - Para a subprefeitura da Mooca, além dos objetivos e diretrizes estabelecidos nos artigos 82 e 83 do Plano Diretor Estratégico para o Município de São Paulo, deverão ser observados os seguintes:

mo requalificar os eixos viários identificados como centralidades;

mo requalificar os corredores de transporte público;

mo elaborar estudos que quantifiquem e qualifiquem o volume de veículos que trafegam pelas vias, adequando o uso do solo do entorno com a capacidade da via;

mo incorporar a escala do pedestre nos projetos de novos sistemas viários e projetos urbanísticos;

mo ofertar estacionamentos e elaborar plano de gestão de vagas ociosas, em áreas que concentrem veículos, principalmente:

- nos pólos e eixos de centralidades;

- nas estações de trem e metrô;

- na região do comércio especializado nos Distritos do Brás e Pari;

mo projetar mini-terminais de turismo ao longo da região do comércio especializado no Brás e Pari, formando anéis de circulação:

- que sejam pontos de chegada de ônibus;

- interligados por vans;

- que incorporem as diretrizes para o projeto urbanístico proposto para essa área; mo prover um número maior de travessias de veículos e pedestres em vias estruturais, principalmente na Avenida Salim Farah Maluf, na região próxima ao Largo da Água Rasa e no Tatuapé, para sobrepor a Avenida Radial Leste, linha de trem e metrô;

mo priorizar os eixos de transporte principais para a implantação de equipamentos públicos; mo permitir que as áreas do entorno da rede viária estrutural proposta, as áreas para implantação da mesma e as estações de transporte público coletivo possam receber o potencial construtivo adicional, através de outorga onerosa ou da transferência de potencial construtivo.

SE - As vias estruturais da Subprefeitura Sé estão previstas no Quadro n 02 do PDE, cabendo a este Plano Regional Estratégico o estabelecimento de melhoramentos viários adequados aos planos urbanísticos e projetos de intervenções estratégicas:

sE melhorar a micro-acessibilidade da área central, garantindo o acesso aos portadores de necessidades especiais e permitindo a seletividade de tráfego.

Obs: Não existem vias a serem melhoradas pelos planos Regionais Sé ou Mooca previstas dentro da área de recorte.

Quadro 2 - Rede viária estrutural e coletora abertura de vias / melhoramento viário

\begin{tabular}{|c|c|c|c|}
\hline \multicolumn{4}{|l|}{ Subprefeitura Mooca } \\
\hline \multicolumn{4}{|c|}{ O Plano Regional da Subprefeitura Mooca não apresentou este quadro } \\
\hline Subprefeitura Sé & Tipo de Intervenção & Origem & Ano Meta \\
\hline
\end{tabular}

Obs: Não foram apresentados nesta compilação os Mapas 02 dos Planos Regionais (numeração dos Planos originais) das Subprefeituras Sé e Mooca por não serem pertinentes à áreaobjeto de estudo. 


\section{I.3 Rede Estrutural de Transporte Público}

MO - Devem ser observados, nos projetos estratégicos em corredores de ônibus, sempre que houver viabilidade técnico-financeira, as seguintes diretrizes:

мо prever a implantação de baias para:

- paradas dos ônibus que trafegam nas vias;

- paradas de veículos particulares;

- paradas de serviços especiais.

мо prever a implantação de faixas especiais para:

- desaceleração;

- acesso aos estabelecimentos dispostos ao longo da via;

мo determinar a implantação de usos não residenciais que:

- $\quad$ isolem os usos residenciais dos incômodos de trânsito, ruído, poluição da via;

- propiciem estacionamento e acesso aos estabelecimentos, de forma a não prejudicar o fluxo de veículos da avenida;

мo priorizar a instalação de equipamentos públicos ao longo dessas vias;

mo estudar o impacto de vizinhança resultante da instalação dos pontos finais das linhas de ônibus em pólos ou eixos de centralidades;

мo determinar que o corredor de ônibus:

- seja arborizado nos padrões de caminhos verdes propostos para a subprefeitura;

- não prejudique o acesso ao comércio e serviços lindeiros a via.

mo $\bigcirc$ proprietário que doar ao Município seu imóvel, ou parte dele, para a realização do projeto estratégico em corredor de ônibus, poderá exercer, em outro local passível de receber potencial construtivo, o direito de construir previsto na legislação de uso e ocupação do solo para o seu imóvel, observado o disposto no artigo 218 do PDE.

mo Nos projetos estratégicos em corredores de ônibus poderão ser utilizados todos os instrumentos previstos na Lei Federal n 10.257, de 10 de julho de 2001 - Estatuto da Cidade.

Executivo Municipal fará gestões junto aos níveis de governo competentes de modo a viabilizar com a CPTM:

мo implantação de baias para a integração dos trens com ônibus e vans, parada de veículos particulares e de veículos especiais;

mo implantação do trecho de trem expresso interligando o Brás como o $A B C$, nos moldes do trem expresso leste já implantado;

мo duplicação do número de usuários do sistema para 2 milhões de pessoas;

mo implantação do trecho de trem parador entre a Estação da Luz e Estação Mooca, atual linha

D do trem;

mo abertura de praças junto às rampas de acesso às estações;

mo recuperação dos galpões ferroviários existentes e destinação para usos de cunho social e comunitário, dentre eles o de habitação de interesse social;

мo implantação de parque linear ao longo da via férrea à medida que as atividades existentes possam ser erradicadas;

mo implantação de novas estações;

mo reforma e reciclagem da Estação Mooca com reabilitação e extensão do acesso subterrâneo, visando evitar a transposição aérea das linhas;

мo implantação do trecho Brás - Aeroporto;

São diretrizes para o sistema de transporte coletivo na Subprefeitura da Mooca:

mo transferir para imóveis mais distantes das áreas centrais as garagens de ônibus, adensando a população destas áreas e dando uma nova função social para as mesmas;

mo utilizar prioritariamente para a implantação de área verde, equipamentos e habitações de interesse social, integradas nas áreas de ZEIS, as grandes glebas de garagem. 
SE - Este Plano Regional Estratégico da Subprefeitura Sé mantém as propostas constantes do PDE, sendo que os principais equipamentos de conexão da estrutura de suas linhas físicas e a logística operacional, entre as diferentes modalidades de transporte, que compõem o Sistema Integrado de Transportes na Subprefeitura Sé estão apresentados no Quadro 3 abaixo e Mapa 02-MO e Mapa 02-SE ao lado.

Quadro 3 - Rede estrutural de transporte público

\begin{tabular}{clcc}
\hline Subprefeitura Mooca & \multicolumn{1}{c}{ Localização } & Mapa & Ano Meta \\
\hline Estação de Transferência & Av. Celso Garcia com a Rua Bresser & MO-0I & 2006 \\
\hline Estação de Transferência & Rua Piratininga com Avenida Alcântara Machado & MO-03 & 2006 \\
\hline Estação de Transferência & Av. Alcântara Machado com a Rua Bresser & MO-05 & 2006 \\
\hline Estação de Transferência & Rua da Mooca com a Rua Taquari & MO-08 & 2006 \\
\hline Estação de Transferência & Av. Rangel Pestana com o Largo da Concórdia & MO-II & 2006 \\
\hline Programa Via Livre & Rua Bresser & MO-30 & 2006 \\
\hline Programa Via Livre & Rua do Gasômetro & MO-37 & 2006 \\
\hline Programa Via Livre & Av. Rangel Pestana & MO-38 & 2006 \\
\hline Programa Via Livre & Av. Celso Garcia & MO-48 & 2006 \\
\hline Programa Via Livre & Av. Alcântara Machado & MO-57 & 2006 \\
\hline Passa Rápido & Rua Bresser/Rua Taquari & MO-620 & 2020 \\
\hline Linhas de Metrô & $\begin{array}{l}\text { Extensão da linha 5 (lilás) até a linha 3 (vermelha): da } \\
\text { estação Chácara Klabin (linha 3) até a linha de trens } \\
\text { metropolitano (entre a estação Brás e Tamanduateí) e } \\
\text { desta até a linha 3 (entre as estações Carrão e Penha). }\end{array}$ & Mapa & Ano Meta \\
\hline Subprefeitura Sé & $\quad$ Localização & SE-06 & 2006 \\
\hline Programa Via Livre & $\begin{array}{l}\text { Trecho Radial Leste - Avenida Alcântara Ma- } \\
\text { chado - Avenida Conde de Frontin }\end{array}$ & &
\end{tabular}

As diferentes modalidades de transporte mencionadas têm suas diretrizes operacionais estabelecidas nos planos setoriais dos órgãos competentes de cada âmbito de Governo, cabendo ao Executivo Municipal:

sE implantar o corredor preferencial exclusivo de ônibus entre a Rua Maria Paula e o início da Avenida Rangel Pestana;

sE vedar a utilização das calçadas para ponto terminal da linha de ônibus ou de transporte coletivo na região interna à contra-rótula viária;

ss implantar as estações de transferência e terminais definidos pelo Sistema Integrado de Transportes de Passageiros (SITP), definido no Plano de Transporte;

sE promover a readequação das calçadas, à época da implantação dos corredores exclusivos de ônibus, compreendendo o ordenamento do mobiliário urbano, a implantação de projeto paisagístico, o ordenamento da sinalização horizontal e vertical e a qualificação da iluminação de forma a adequá-los à circulação de pedestres. 

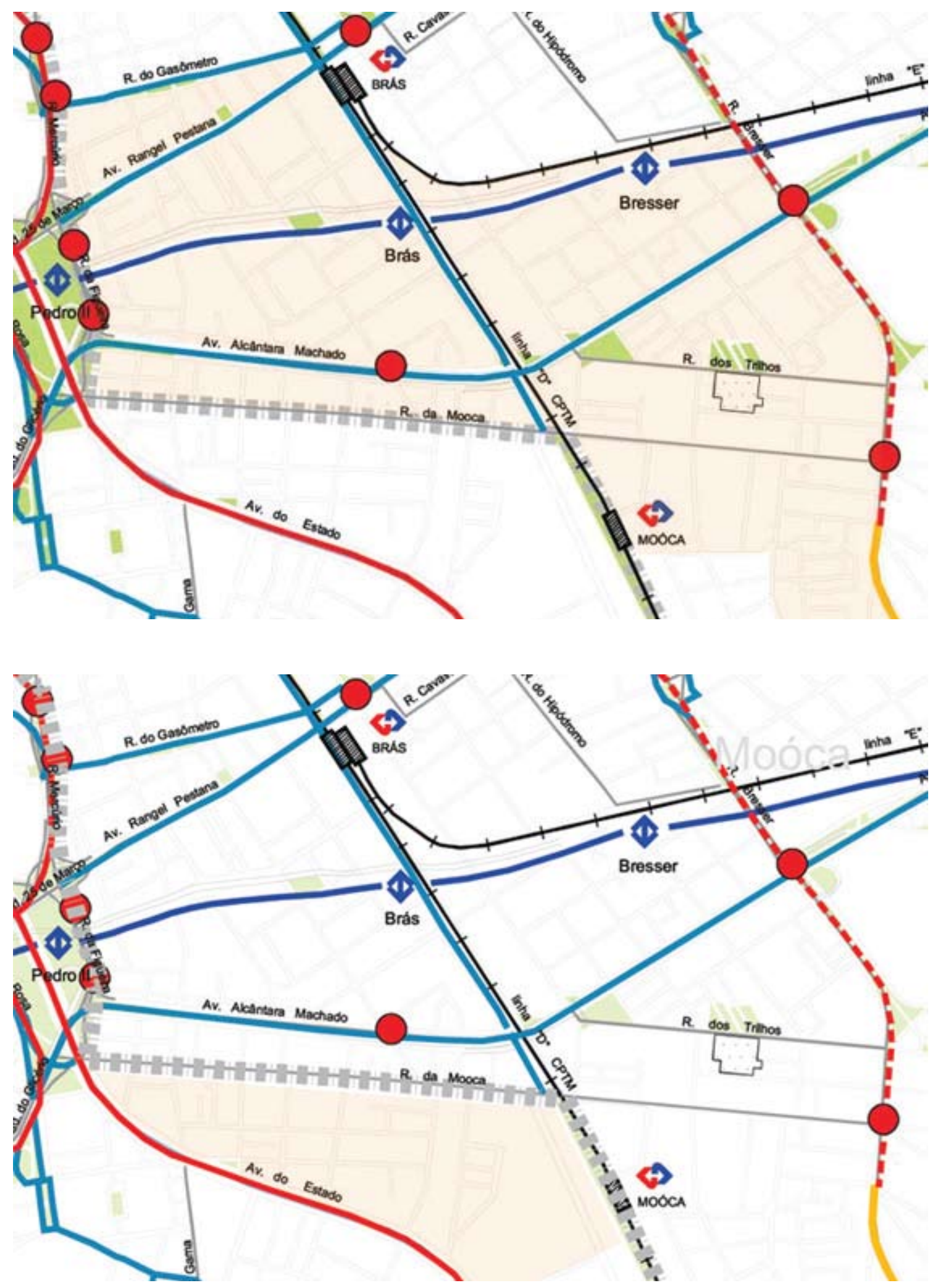

LEGENDA

$$
\begin{aligned}
& \text { " w w w " Linso so Municipo de Sto Pavile } \\
& \text { Limtes das Suconeteiturs }
\end{aligned}
$$

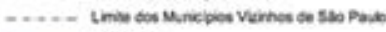

$$
\begin{aligned}
& \text { - Rosomet } \\
& \text { - Selema Vano Earunara } \\
& \text { Ta Forove }
\end{aligned}
$$

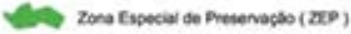

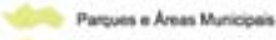

$$
\begin{aligned}
& \text { Restemence Utaras } \\
& \text { nios Cemento } \\
& \text { EHoD Cove Esponvo socid }
\end{aligned}
$$

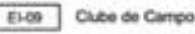

$$
\begin{aligned}
& \Delta \quad \text { Tominar meamodar Entroete } \\
& \text { A Temina mermodas } 2006
\end{aligned}
$$

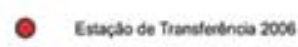

$$
\begin{aligned}
& \text { - Estacso de Trantenencia } 2012 \\
& \text { - } \odot-\text { Esticalo de Meros Existemion } \\
& \text { - }- \text { - Evtacio de Mots } 2012 \\
& \text { \& Teminal Rostowitoso } 2006 \\
& \text { - Teminal Rosoviaro } 2012 \\
& \text { D Etasto CPTM } 2006 \\
& \text { [ Etacilo CPTU } 2012
\end{aligned}
$$

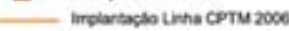

$$
\begin{aligned}
& \text { Conodoe Metopoliano Exidente (EMTU) } \\
& \text { Conede Metropoliano (EMTU) } 2012 \\
& \text { Pansa Resolo Genters } \\
& \text { - . - Pata Rapiso } 2012 \\
& \text { - Drogrma Va Live } 2006
\end{aligned}
$$

\section{Acima:}

Mapa 02-MO - Rede estrutural de transporte público no Brás e Mooca. Fonte: PRE Subprefeitura Mooca, 2004.

Abaixo:

Mapa 02-SE - Rede estrutural de transporte público na Mooca Baixa. Fonte: PRE Subprefeitura Sé, 2004. 


\section{I.4 Rede Estrutural de Eixos e Pólos de Centralidade}

MO - Os eixos e pólos de centralidades deverão ser objeto de projeto urbanístico específico, a ser desenvolvido independentemente da área estar inserida ou não dentro da área de operação urbana. As calçadas e os espaços públicos, nos projetos urbanísticos específicos para os eixos e pólos de centralidades, devem receber tratamento que possibilite a sua utilização pelos portadores de necessidades especiais.

Os pólos de centralidades existentes a reestruturar e qualificar são:

mo Prioridade I - Centralidade Regional:

- Largo da Concórdia;

mo Prioridade 2 - Centralidades dos distritos: nenhum objeto dentro da área deste estudo.

mo Prioridade 3 - Outras centralidades:

- entorno do encontro da Rua da Mooca com a Avenida Paes de Barros.

Os pólos de centralidades existentes a reestruturar e qualificar, sempre que possível, deverão atender as seguintes diretrizes:

mo regulamentar o uso das ruas e calçadas;

мo regulamentar os espaços a serem ocupados por ambulantes, principalmente nas áreas de circulação intensa de pedestres;

мо melhorar a acessibilidade do pedestre;

мo elaborar programa ambiental e paisagístico visando qualificar o ambiente urbano;

mo desenvolver projeto de mobiliário urbano em conformidade com as diretrizes ambientais e paisagísticas;

мo organizar a circulação com novos pontos de chegada de transporte público;

mo criar estacionamentos;

мo recuperar as fachadas e controlar a poluição visual;

мо estimular e qualificar o comércio tradicional da centralidade;

mo equacionar as questões de trânsito.

Os eixos de centralidades existentes a reestruturar e qualificar são:

mo Prioridade I - Eixos regionais:

- Av. Rangel Pestana / Avenida Celso Garcia;

- Av. Alcântara Machado / Avenida Radial Leste.

mo Prioridade I-Eixos comerciais a qualificar:

- Rua do Gasômetro (Brás).

mo Prioridade 2 - Eixos comerciais a qualificar:

- Rua da Mooca (Mooca);

- ruas de comércio especializado no Brás dentro da área de estudo: Rua Monsenhor de Andrade, entre a Rua do Gasômetro e a Avenida Rangel Pestana.

Os eixos de centralidades existentes a reestruturar e qualificar, sempre que possível, deverão atender as seguintes diretrizes:

мо elaborar projeto de desenho urbano da via e do entorno;

mo melhorar a acessibilidade do pedestre;

mo alargar as calçadas;

мо criar espaços para estacionamento de veículos;

мо criar baias para parada de ônibus e veículos de carga/descarga;

мo prover espaço público ajardinado, arborizado e equipado, destinado aos pedestres e usuários da região.

Todas as centralidades da Subprefeitura da Mooca são Áreas de Intervenção Urbana e serão objeto de lei específica. 
Quadro 04 - Eixos e pólos de centralidades

\begin{tabular}{|c|c|}
\hline \multicolumn{2}{|l|}{ Subprefeitura Mooca } \\
\hline Perímetro & Área $\left(\mathrm{m}^{2}\right)$ \\
\hline $\begin{array}{l}\text { RUA DA MOOCA x Avenida PAES DE BARROS - Inicia-se na confluência da Rua dos Trilhos com R. Ju- } \\
\text { venal Parada, segue pela Juvenal Parada, Avenida Paes de Barros, R. Leocádia Cintra, R. da Moo- } \\
\text { ca, R. lolanda, R. Javari, R. Visc. De Laguna, Rua dos Trilhos até o ponto inicial. }\end{array}$ & 288380 \\
\hline Centralidades a Qualificar & Ano Meta \\
\hline $\begin{array}{l}\text { RUA DA MOOCA } \\
\text { Inicia-se na Rua da Mooca com Rua da Figueira, segue pela Rua da Figueira, Avenida Alcântara Machado, Rua Flora, Rua } \\
\text { Melo Barreto, Avenida Rangel Pestana, Rua Aristides Lobo, Viaduto Alcântara Machado, Rua Doutor Almeida Lima, Rua dos } \\
\text { Trilhos, Rua Almirante Brasil, Rua Javari, Rua Taquari, Avenida Paes de Barros, Rua Leocadia Cintra, Rua Orville Derby, Largo } \\
\text { São Rafael, Rua Guaratinguetá, Rua Borges de Figueiredo, Rua Monsenhor João Felipe, Rua Luis Gama até o ponto inicial. }\end{array}$ & 2006 \\
\hline $\begin{array}{l}\text { RUA PIRATININGA } \\
\text { Inicia-se na confluência da Rua Flora com Rua Campos Sales, segue Pela Rua Flora, Rua Melo Barreto, Ave- } \\
\text { nida Rangel Pestana, Rua Aristides Lobo, Viaduto Alcântara Machado, Rua Flora até o ponto inicial. }\end{array}$ & 2006 \\
\hline $\begin{array}{l}\text { AV. RANGEL PESTANA E Avenida CELSO GARCIA } \\
\text { Inicia-se na confluência da Avenida Mercúrio com Rua da Assunção, R. Monsenhor Andrade, R. do Bucolismo, R. Rodrigues dos } \\
\text { Santos, R. Oriente, R. Barão de Ladário, R. Firmino Whitaker, R. Maria Marcolina, R. Visconde de Abaeté, R. Dr. Ricardo Gonçalves, } \\
\text { R. Dr. Manuel Vitorino, R. Dr. Carlos Botelho, R. João Bohemer, R. Santa Clara, R. Cachoeira, R. Santa Rita, R. Paulo Andrighet- } \\
\text { ti, R. Marcos Arruda, R. Valdemar Dória, R. Catumbi, Tr. Cavalheiro, R. Manoel Ramos Paiva, R. Cachoeira, Rua Mores Miguel, } \\
\text { Rua Saturnino de Brito, Rua Iguarucu, Rua Tuiti, Rua Sabatino Nastari, Rua Ururai, Rua Santa Virgínia, Rua Santa Maria, Rua Siria, } \\
\text { Rua Jacinto Jose de Araujo, Rua Vitório Ramalho, Rua Mateus Gomes, Rua Antonio de Barros, Largo São Jose do Maranhão, Rua } \\
\text { Tenente Gelas, Rua Romer Ducasse, Rua Adelino de Almeida Castilho, Rua Igrapiúna, rua Barra Bonita, Rua Antonio de Barros, } \\
\text { Rua Brejal, Rua Cezario Galeno, Rua Evaristo Vaz de Arruda, Rua doutor Miguel Vieira Ferreira, Rua larcai, Rua Souza Breves, Rua } \\
\text { Sargento Oswaldo, Rua Bernardo Rodrigues, Rua Henrique Lindenberg, Rua Teixeira de Melo, Rua Soriano de Souza, Rua Almi- } \\
\text { rante Calheiros, Rua André Vidal, Rua Engenheiro Saturnino de Brito, Rua Conselheiro Cotegipe, Rua Visconde de Parnaíba, Rua } \\
\text { Saldanha Marinho, Rua Doutor Ubaldino do Amaral, Rua São Leopoldo, Rua Vinte Um de Abril, Rua Cesario Alvim, Rua Vinte Um } \\
\text { de Abril, Rua do Hipódromo, Rua Paulo Afonso, Rua Doutor Almeida Lima, Rua Matim Burchard, Rua Mauricio Salomão Nahas, } \\
\text { Rua Jairo Góis, Rua Torquato Neto, Rua Prefeito Batista de Andrade, Avenida Rangel Pestana, Rua da Figueira até o ponto inicial. }\end{array}$ & 2006 \\
\hline $\begin{array}{l}\text { AV. ALCÂNTARA MACHADO (AV. RADIAL LESTE) } \\
\text { Inicia-se na confluêcia da Rua da Figueira com Avenida Alcântara Machado, segue pela Rua da Figueira, Rua Professor Batista de Andra- } \\
\text { de, Rua escola Técnica da Aviação, Rua Mauricio Salomão Nahas, Rua Aristides Lobo, Rua Ernesto de Castro, Rua Ipanema, Viaduto } \\
\text { Bresser, Acesso ao Viaduto Bresser, Rua Visconde de Parnaíba, Rua Major Otaviano, Rua Cajuru, Rua Lopes Coutinho, Rua Visconde } \\
\text { de Parnaíba, Rua Cesário Alvim, Rua Julio de Castilho, Rua Siqueira Bueno, Rua Herval, Rua Doutor Clementino, Rua Toledo Barbosa, } \\
\text { Rua S/N, Rua Engenheiro Balem, Rua Saturnino de Brito, Rua Artur Mendonça, Rua Doutor Corinto Baldoino Costa, Rua Cunha } \\
\text { Abreu, Rua Honório Maia, Rua Jose Epaminondas de Oliveira, Rua Santo Antônio do Pinhal, Rua Ingu, Rua Cirino de Abreu, Acesso } \\
\text { a Via Elevada Aricanduva, Rua Carlos Silva, Rua Acangatara, Rua Pinhalzinho, Rua Pascoal Provenzano, Rua Frei Celso, Rua Ibicaba, } \\
\text { Rua Platina, Rua Platina, Praça Barão de Itaqui, Rua Platina, Praça Santa Terezinha, Rua Platina, Praça Coronel Sandoval de Figuei- } \\
\text { redo, Rua Platina, Rua Domingos Agostin, Rua Caraguatai, Rua Padre Adelino, Praça Barão do Tiete, Rua Doutor Fomm, Rua João } \\
\text { Tobias, Rua Benedito Barbosa, Praça Vicente Mateus, Rua João Caetano, Rua Almirante Brasil, Rua Timbo, Praça Presidente Kennedy, } \\
\text { Rua Doutor Almeida Lima, Viaduto Professor Alberto Mesquita de Carvalho, Rua da Mooca, Rua Da Figueira até o ponto inicial. }\end{array}$ & 2006 \\
\hline Subprefeitura Sé & \\
\hline
\end{tabular}


${ }^{2}$ Art. 126: será estimulada a geração de novas centralidades e dinamizadas as já existentes pela implantação contígua, de agências e repartições da Prefeitura, escolas públicas, pontos de embarque, praças e passeios públicos, equipamentos de serviços públicos, como elementos catalisadores do comércio e serviços privados. $\S 1^{\circ}$ - Ficam definidas como Áreas de Intervenção Urbana as faixas de largura de até 300 (trezentos) metros de cada lado dos eixos de centralidade, visando à inclusão social e à melhoria da qualidade dos centros atuais e futuros.

$\S 2^{\circ}$ - As Áreas de Intervenção Urbana para implantação dos pólos de centralidade serão definidas nas leis dos Planos Regionais.

$\S 3^{\circ}$ - Para a qualificação ou requalificação de eixos e pólos de centralidade poderão ser realizadas parcerias com a iniciativa privada. $\$ 4^{\circ}$ - A Rede Estrutural de Eixos e Pólos de Centralidades, bem como as propostas específicas, constam do Quadro no 08 e Mapa no 04 , integrantes desta lei.

Fonte: Plano Diretor Estratégico de São Paulo. Lei Municipal no 13.430 de setembro de 2002

${ }^{3}$ Art 147 - O território do Município fica divido em duas Macrozonas complementares, delimitadas no Mapa $n^{\circ} 05$, integrante desta Lei:

I. macrozona de proteção ambiental;

II. macrozona de estruturação e qualificação urbana.

$\S 1^{\circ}$ - Ficam enquadradas nas Macrozonas de Proteção Ambiental os perímetros delimitados no Mapa $\mathrm{n}^{\circ} 05$ e Quadro $n^{\circ} 17$ integrantes desta Lei. $\$ 2^{\circ}$ - As áreas restantes, cuja descrição de perímetros não está incluída no parágrafo anterior ficam enquadradas, por exclusão, na Macrozona de Estruturação e Qualificação Urbana. Fonte: Plano Diretor Estratégico de São Paulo. Lei Municipal n 13.430 de setembro de 2002
SE - Nos termos das diretrizes estabelecidas pelo artigo $126^{2}$ do PDE, este Plano Regional Estratégico mantém a centralidade polar do centro histórico e do centro expandido da Avenida Paulista, e cria novas centralidades na região da planície aluvial dos Rios Tietê e Tamanduateí, compreendendo:

sE zona centralidade polar - ZCPa/OI a ZCPa/03;

se zona centralidade polar - ZCPb/0 I a ZCPb/06.

Fica classificada como via comercial incluída no Programa de Intervenções em Ruas Comerciais a Rua Dona Ana Néri, aos cuidados da Subprefeitura da Sé.

\subsection{Elementos integradores}

MO/SE - Deverão ser estabelecidas pela Subprefeitura e pela comunidade local, no Plano de Gestão Ambiental e nos Planos de Distritos, as ações a serem implementadas para os diferentes tipos de espaço de uso público, considerando as diretrizes contidas nestes Planos Regionais Estratégicos. Os espaços de uso público incluem as áreas públicas, as áreas verdes públicas e as áreas abertas para uso público.

\section{Uso e ocupação do solo}

\section{I Macrozonas}

\section{I.I Macrozona de Estruturação e Qualificação Urbana}

MO/SE - De acordo com o artigo $147^{3}$ do PDE, as Subprefeituras Mooca e Sé encontram-se integralmente contidas na Macrozona de Estruturação e Qualificação Urbana, configurando áreas de diferentes graus de consolidação e manutenção, compreendendo as seguintes zonas de uso:

- Zonas Predominantemente Industriais - ZPI;

- Zonas Mistas - ZM:

- Zonas Centralidades - ZC.

SE - São estabelecidos por este PRE para a Macroárea de Reestruturação e Requalificação Urbana, para os distritos: Bela Vista, Bom Retiro, Cambuci, incluindo Mooca Baixa, Liberdade, República, Santa Cecília e Sé, e para a Macroárea de Urbanização Consolidada, em especial, o distrito Consolação os seguintes objetivos, diretrizes e ações estratégicas:

sE objetivos específicos:

- estabelecer em função das especificidades de cada distrito zonas de centralidade polar e zonas mistas de alta densidade com estímulos diferenciados para as atividades terciárias de alta tecnologia, para aquelas relacionadas ao lazer, à cultura, ao turismo e à produção habitacional.

se diretrizes específicas:

- estimular à implantação de atividades comerciais e de prestação de serviços diversificados;

- implementar a Operação Urbana Consorciada Diagonal Sul, proposta pelo PDE, como forma de ampliar as potencialidades das novas centralidades;

- prover habitações de interesse social para famílias de baixa renda; 
- estimular a produção de Habitações de Interesse Social (HIS) nos novos perímetros delimitados como ZEIS 3.

sE ações estratégicas:

- implantar a Trilha Histórica no Centro de São Paulo, como medida de valorização dos logradouros e edifícios de interesse histórico do Município;

- implantar o Projeto "Parque D.Pedro II" com seus projetos complementares;

- implantar Empreendimentos de Habitação de Interesse Social (EHIS) nas áreas denominadas Perímetro de Reabilitação Integrada do Habitat $(\mathrm{PRIH})$.

\subsection{Zoneamento}

MO - As características de dimensionamento, ocupação e aproveitamento dos lotes nas zonas de uso contidas na Subprefeitura da Mooca são as constantes do Quadro 05-MO abaixo.

SE - Este Plano Regional Estratégico estabelece as características de aproveitamento, dimensionamento e ocupação dos lotes no Quadro 05-SE e os perímetros das diferentes zonas de uso inclusive as zonas especiais contidas no perímetro desta Subprefeitura no Mapa 03-SE.

Quadro 05-MO - Características de aproveitamento, dimensionamento e ocupação dos lotes

\begin{tabular}{|c|c|c|c|c|c|c|c|c|c|c|c|c|c|}
\hline \multirow{3}{*}{\multicolumn{2}{|c|}{ Características das Zonas de Uso }} & \multirow{3}{*}{ Zona de uso } & \multicolumn{3}{|c|}{$\begin{array}{l}\text { Coeficiente de } \\
\text { aproveitamento }\end{array}$} & \multicolumn{5}{|c|}{ Caraterísticas de dimensionamento e ocupação dos lotes } & \multirow{2}{*}{\multicolumn{3}{|c|}{$\begin{array}{r}\text { Recuos mínimos }(\mathrm{m}) \\
\text { Fundos e laterais }\end{array}$}} \\
\hline & & & \multirow[b]{2}{*}{ mínimo } & \multirow[b]{2}{*}{ básico } & \multirow[b]{2}{*}{ máximo } & \multirow[b]{2}{*}{$\begin{array}{l}\text { Taxa de } \\
\text { ocupação } \\
\text { máxima }\end{array}$} & \multirow[b]{2}{*}{$\begin{array}{l}\text { Taxa de } \\
\text { permea- } \\
\text { bilidade } \\
\text { mínima }\end{array}$} & \multirow[b]{2}{*}{$\underset{\substack{\text { Lote } \\
\text { mínimo } \\
\left(\mathrm{m}^{2}\right)}}{ }$} & \multirow[b]{2}{*}{$\begin{array}{l}\text { Frente } \\
\text { minima } \\
(\mathrm{m})\end{array}$} & \multirow[b]{2}{*}{$\begin{array}{l}\text { Gabarito } \\
\text { de altura } \\
\text { máximo } \\
(\mathrm{m})\end{array}$} & & & \\
\hline & & & & & & & & & & & Frente & $\begin{array}{c}\text { Altura da } \\
\text { edificação } \\
\text { menor ou igual } \\
\text { a } 6,00 \mathrm{~m}\end{array}$ & $\begin{array}{l}\text { Altura da } \\
\text { edificação } \\
\text { superior a } \\
6,00 \mathrm{~m}\end{array}$ \\
\hline \multirow{3}{*}{ 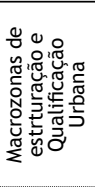 } & $\begin{array}{l}\text { Zona predominan- } \\
\text { temente industrial }\end{array}$ & ZPI & 0,10 & 1,00 & 1,50 & 0,70 & 0,15 & $500 \mathrm{~m}^{2}$ & $15,00 \mathrm{~m}$ & $15,00 \mathrm{~m}$ & $5,00 \mathrm{~m}$ & Não exigido & (c) (d) \\
\hline & $\begin{array}{l}\text { ZM } \\
\text { alta densidade }\end{array}$ & $\begin{array}{l}Z M-3 a \\
Z M-3 b\end{array}$ & 0,20 & $\begin{array}{l}1,00 \\
2,00\end{array}$ & $\begin{array}{l}2,50 \\
3,00\end{array}$ & $0,5(\mathrm{a})$ & 0,15 & $125 \mathrm{~m}^{2}$ & $5,00 \mathrm{~m}$ & Sem limite & $\begin{array}{l}5,00 \mathrm{~m} \\
(\mathrm{~b})\end{array}$ & Não exigido (d) & (c) (d) \\
\hline & $\begin{array}{l}\text { Zona Centralidade } \\
\text { Polar ou Linear }\end{array}$ & $\begin{array}{l}\text { ZCP ou ZCL-a } \\
\text { ZCP ou ZCL-b }\end{array}$ & 0,20 & $\begin{array}{l}1,00 \\
2,00\end{array}$ & $\begin{array}{l}2,50 \\
4,00\end{array}$ & 0,70 & 0,15 & $125 \mathrm{~m}^{2}$ & $5,00 \mathrm{~m}$ & Sem limite & $\begin{array}{c}5,00 \mathrm{~m} \\
\text { (b) }\end{array}$ & Não exigido (d) & (c) (d) \\
\hline \multirow{2}{*}{ 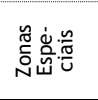 } & $\begin{array}{c}\text { Zona Especial de } \\
\text { Presservação Ambiental }\end{array}$ & ZEPAM & (e) & $0,1(f)$ & $0,1(f)$ & 0,10 & 0,90 & \multicolumn{2}{|c|}{$\begin{array}{l}\text { estudo de cada caso } \\
\text { pelo Executivo }\end{array}$} & 9,00 & \multicolumn{3}{|c|}{ estudo de cada caso pelo Executivo } \\
\hline & $\begin{array}{l}\text { Zona Especial de } \\
\text { Preservação Cultural }\end{array}$ & ZEPEC & \multicolumn{3}{|c|}{$\begin{array}{l}\text { Parâmet } \\
\text { çấo pai }\end{array}$} & $\mathrm{em} \mathrm{q}$ & obe & $\begin{array}{ll}\text { repr } \\
\text { adaa }\end{array}$ & $\begin{array}{l}\text { (BIR } \\
\text { siçõe }\end{array}$ & rea de & ação & $\begin{array}{l}\text { ial (AUE) ou áre } \\
\text { bamento quand }\end{array}$ & \\
\hline
\end{tabular}

Quadro 05-SE - Características de aproveitamento, dimensionamento e ocupação dos lotes

\begin{tabular}{|c|c|c|c|c|c|c|c|c|c|c|c|c|c|}
\hline \multirow{3}{*}{\multicolumn{2}{|c|}{ Características das Zonas de Uso }} & \multirow{3}{*}{ Zona de uso } & \multicolumn{3}{|c|}{$\begin{array}{l}\text { Coeficiente de } \\
\text { aproveitamento }\end{array}$} & \multicolumn{5}{|c|}{ Caraterísticas de dimensionamento e ocupação dos lotes } & \multirow{2}{*}{\multicolumn{3}{|c|}{$\begin{array}{r}\text { Recuos mínimos }(\mathrm{m}) \\
\text { Fundos e laterais }\end{array}$}} \\
\hline & & & \multirow[b]{2}{*}{ mínimo } & \multirow[b]{2}{*}{ básico } & \multirow[b]{2}{*}{ máximo } & \multirow[b]{2}{*}{$\begin{array}{l}\text { Taxa de } \\
\text { ocupação } \\
\text { máxima }\end{array}$} & \multirow[b]{2}{*}{$\begin{array}{l}\text { Taxa de } \\
\text { permea- } \\
\text { bilidade } \\
\text { mínima }\end{array}$} & \multirow[b]{2}{*}{$\underset{\left(\mathrm{m}^{2}\right)}{\substack{\text { Lote } \\
\text { minimo }}}$} & \multirow[b]{2}{*}{$\begin{array}{l}\text { Frente } \\
\text { mínima } \\
(\mathrm{m})\end{array}$} & \multirow[b]{2}{*}{$\begin{array}{l}\text { Gabarito } \\
\text { de altura } \\
\text { máximo } \\
(\mathrm{m})\end{array}$} & & & \\
\hline & & & & & & & & & & & Frente & $\begin{array}{l}\text { Altura da } \\
\text { edificação } \\
\text { menor ou igual } \\
\text { a } 6,00 \mathrm{~m}\end{array}$ & $\begin{array}{c}\text { Altura da } \\
\text { edificação } \\
\text { superior a } \\
6,00 \mathrm{~m}\end{array}$ \\
\hline \multirow{9}{*}{ 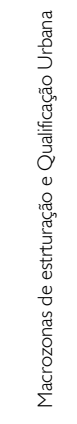 } & ZER baixa densidade & ZERI-0I (j) & 0,05 & 1,00 & 1,00 & 0,50 & 0,30 (i) & $250 \mathrm{~m}^{2}$ & $10,00 \mathrm{~m}$ & $9,00 \mathrm{~m}$ & $5,00 \mathrm{~m}$ & Não exigido (d) & (c) (g) \\
\hline & $\begin{array}{l}\text { Zona Centralidade Linear } \\
\text { interna ou lindeira a ZER }\end{array}$ & $\begin{array}{c}\text { ZCLz-I e } \\
\text { ZCLz-II (h) (j) }\end{array}$ & 0,05 & 1,00 & 1,00 & 0,50 & 0,30 & $250 \mathrm{~m}^{2}$ & $10,00 \mathrm{~m}$ & $9,00 \mathrm{~m}$ & $5,00 \mathrm{~m}$ & Não exigido (d) & (c) (g) \\
\hline & $\begin{array}{l}\text { ZM } \\
\text { baixa densidade }\end{array}$ & $\begin{array}{l}\text { ZMI-0I e } \\
\mathrm{ZMI-02}\end{array}$ & 0,20 & 1,00 & 1,00 & $0,50(a)$ & 0,15 & $125 \mathrm{~m}^{2}$ & $5,00 \mathrm{~m}$ & $9,00 \mathrm{~m}$ & $\begin{array}{l}5,00 \mathrm{~m} \\
(b)\end{array}$ & Não exigido (d) & (c) (g) \\
\hline & $\begin{array}{l}\text { ZM } \\
\text { média densidade }\end{array}$ & $\begin{array}{l}\text { ZM2-0I e } \\
\text { ZM2-02 }\end{array}$ & 0,20 & 1,00 & 2,00 & 0,50 (a) & 0,15 & $125 \mathrm{~m}^{2}$ & $5,00 \mathrm{~m}$ & $25,00 \mathrm{~m}$ & $\begin{array}{l}5,00 \mathrm{~m} \\
\text { (b) }\end{array}$ & Não exigido (d) & (c) (d) \\
\hline & ZM & $\begin{array}{l}\text { ZM3a-0I a } \\
\text { ZM3a-06 }\end{array}$ & \multirow{2}{*}{0,20} & 1,00 & \multirow{2}{*}{2,50} & \multirow{2}{*}{0,5 (a) } & \multirow{2}{*}{0,15} & \multirow{2}{*}{$125 \mathrm{~m}^{2}$} & \multirow{2}{*}{$5,00 \mathrm{~m}$} & \multirow{2}{*}{$\underset{(k)}{\text { Sem limite }}$} & \multirow{2}{*}{$\begin{array}{l}5,00 \mathrm{~m} \\
\text { (b) }\end{array}$} & \multirow{2}{*}{ Não exigido (d) } & \multirow{2}{*}{ (c) (d) } \\
\hline & alta densidade & $\begin{array}{l}\text { ZM3b-0I a } \\
\text { ZM3b-05 }\end{array}$ & & 2,00 & & & & & & & & & \\
\hline & \multirow{2}{*}{ Zona Centralidade Polar } & $\begin{array}{l}\text { ZCPa-OI a } \\
\mathrm{ZCPa}-03\end{array}$ & \multirow{2}{*}{0,20} & 1,00 & 2,50 & \multirow{2}{*}{0,70} & \multirow{2}{*}{0,15} & \multirow{2}{*}{$125 \mathrm{~m}^{2}$} & \multirow{2}{*}{$5,00 \mathrm{~m}$} & \multirow{2}{*}{ Sem limite } & \multirow{2}{*}{$\begin{array}{l}5,00 \mathrm{~m} \\
\text { (b) }\end{array}$} & \multirow{2}{*}{ Não exigido (d) } & \multirow{2}{*}{ (c) (d) } \\
\hline & & $\begin{array}{l}\text { ZCPb-0I a } \\
\mathrm{ZCPb}-06\end{array}$ & & 2,00 & 4,00 & & & & & & & & \\
\hline & Zona Centralidade Linear & ZCLb & 0,20 & 2,00 & 4,00 & 0,70 & 0,15 & $125 \mathrm{~m}^{2}$ & $5,00 \mathrm{~m}$ & Sem limite & $\begin{array}{l}5,00 \mathrm{~m} \\
(\mathrm{~b})\end{array}$ & Não exigido (d) & (c) (d) \\
\hline ZE & $\begin{array}{l}\text { Zona Especial de } \\
\text { Preservação Cultural }\end{array}$ & ZEPEC & \multicolumn{11}{|c|}{$\begin{array}{l}\text { Parâmetros da zona de uso em que se situa o bem imóvel representativo (BIR) ou a área de urbanização especial (AUE) ou área de prote- } \\
\text { çấo paisagística (APP), enquadrado como ZEPEC, observadas as disposiçôes espećficas da Resoluçăo de tombamento quando houver. }\end{array}$} \\
\hline
\end{tabular}
de frente em ZM, ZCP, ZCL de rentee日s 2 ZP

c) ver artigo 185 da Parte III do PDE quanto aos recuos mínimos laterals e de fundos para 6,00 metros

d) ver $\S 1^{\circ}$ e $\$ 2^{\circ}$ do artigo 186 Parte III do PDE quanto aos recuos para atividades indusmento e guarda de bens móveis e oficinas

e) não se aplica o instrumento do PDE da Utilização

f) respeitadas as disposições da
Legislação Ambiental vigente

g) observar as restriçōos constas forem mais exigentes que as definidas neste quadro h) as atividades permitidas do § $1^{\circ}$ do art. 21 do PDE

i) a taxa de permeabilidade mínima de 0,3 aplica-se aos lotes otes contidos no perímetro bairro tombado do Pacaembú

j) o número máximo de habilaçōes por $\mathrm{m}^{2}$ é igual a 0,0042 ZCLZ-II 
LEGENDA

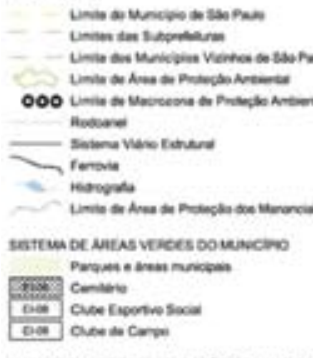

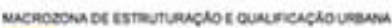

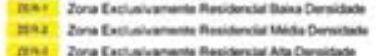

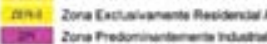

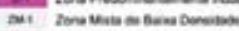

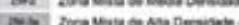

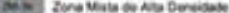

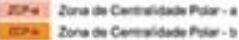

zonus tseccuns

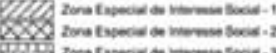

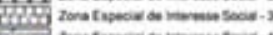

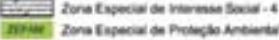

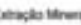

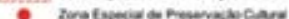

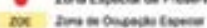

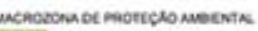

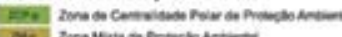

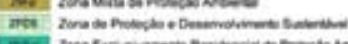

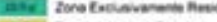

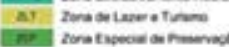

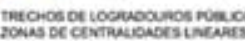

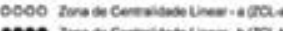

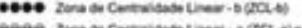

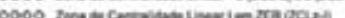

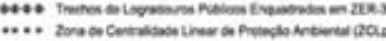

Mapa 03-MO (acima) - Uso e ocupação do Solo no Brás e Mooca.

Fonte: PRE Subprefeitura Mooca, 2004

Mapa 03-SE (abaixo) - Uso e ocupação do Solo na Mooca Baixa.

Fonte: PRE Subprefeitura Sé, 2004.
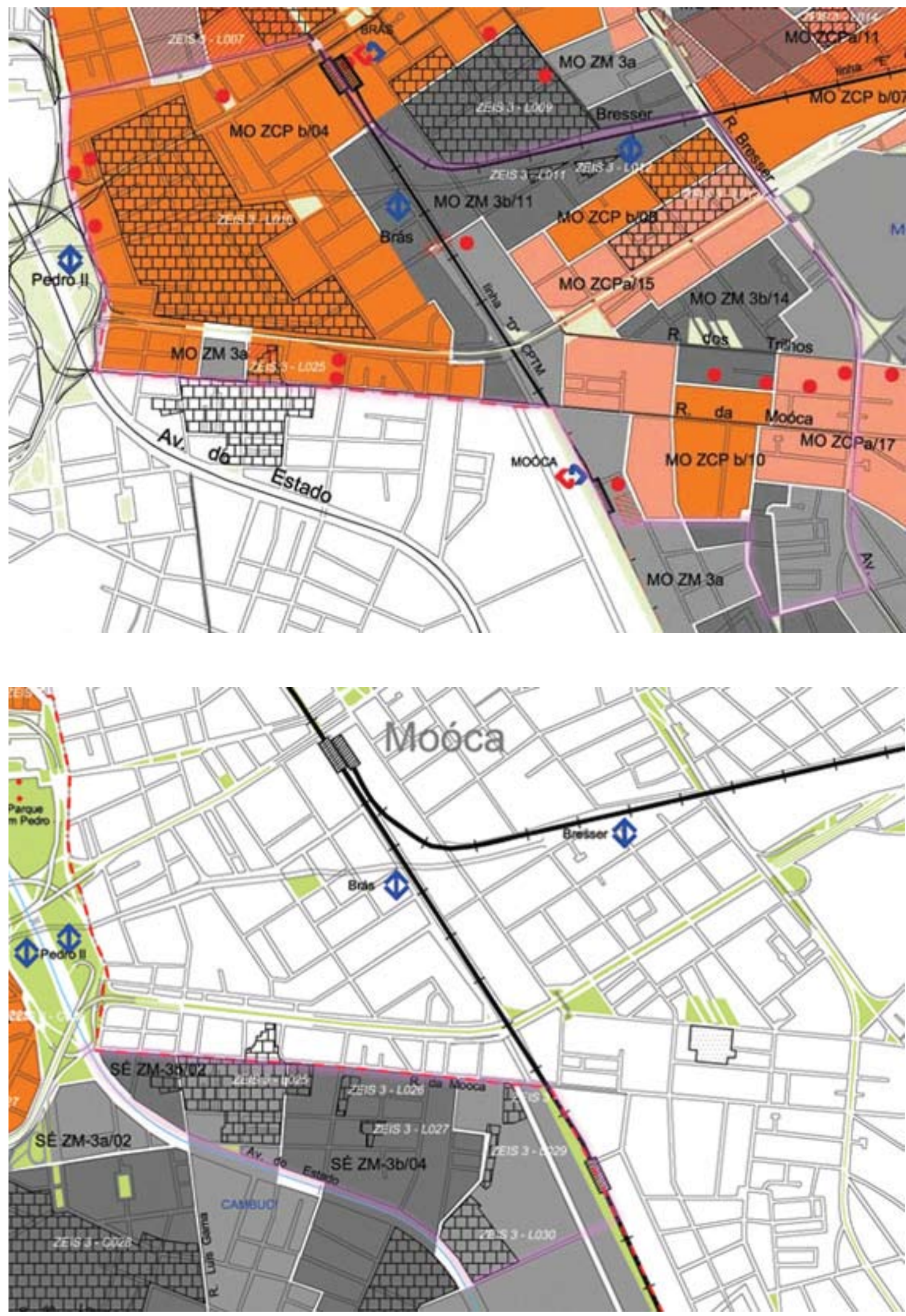


\subsection{Zonas Predominantemente Industriais - ZPI}

MO - Na ZPI da Subprefeitura da Mooca são permitidas uma ou mais unidades industriais por lote ou gleba, com cota mínima de terreno igual a $500 \mathrm{~m}^{2} /$ indústria.

A Zona Predominantemente Industrial (ZPI) da Subprefeitura da Mooca encontra-se integralmente contida na Operação Urbana Consorciada Diagonal Sul.

Os coeficientes de aproveitamento mínimo e máximo e as condições e parâmetros para a instalação de usos definidos para a ZPI, até a aprovação da lei específica da Operação Urbana Consorciada Diagonal Sul, são os estabelecidos no Quadro 05-MO deste Plano Regional Estratégico e nas disposições da Parte III desta lei.

Obs: Tanto na área-recorte da Mooca Baixa quanto na do Brás não se localiza nenhum trecho ZPI previsto pelas Subprefeituras Sé e Mooca, respectivamente.

\subsubsection{Zonas Mistas - ZM}

MO - São Zonas Mistas com densidade demográfica e construtiva alta - ZM3a e ZM3b, aquelas constituídas pelo território da Subprefeitura da Mooca pertencente à Macrozona de Estruturação e Qualificação Urbana, destinadas à implantação de usos residenciais e não residenciais, inclusive no mesmo lote ou edificação, segundo critérios gerais de compatibilidade de incômodo e qualidade ambiental, que têm como referência o uso residencial.

As Zonas Mistas ZM3a são aquelas constituídas pelo território da Subprefeitura da Mooca pertencente à Macrozona de Estruturação e Qualificação Urbana, excluídas as Zonas Mista ZM3b, as Zonas Predominantemente Industriais - ZPI, as Zonas Centralidades Polares com densidade demográfica e construtiva alta - ZCPa, as Zonas Centralidades Polares com densidade demográfica e construtiva alta - ZCPb e as Zonas Especiais.

$\mathrm{Na}$ Subprefeitura da Mooca, as novas construções ou reformas com mudança de uso para usos não residenciais incômodos, compatíveis com o uso residencial, deverão ocorrer preferencialmente no sistema viário estrutural NI, N2, N3; nas vias coletoras e nos eixos e pólos de centralidades.

SE - No território enfocado por este levantamento, incluído nesta Subprefeitura, está contida apenas o seguinte tipo de zona mista:

ss ZM3a-0I a ZM3a-06 - zona mista de alta densidade.

As características de aproveitamento, dimensionamento e ocupação dos lotes são constantes do Quadro 05-SE.

\subsubsection{Zonas Centralidades - ZC}

MO - Segundo a Subprefeitura Mooca são Zonas Centralidades Polares com densidade demográfica e construtiva alta - ZCPa e ZCPb, aquelas destinadas à localização de atividades típicas de áreas centrais ou de subcentros regionais, caracterizada pela coexistência entre os usos não residenciais e habitacionais, porém, com a predominância de usos não residenciais.

As Zonas Centralidades Polares - ZCPa da Subprefeitura da Mooca são Áreas de Intervenção Urbana e serão objeto de lei específica, podendo o coeficiente de aproveitamento máximo ser igual a 4,0 (quatro).

Todas as Zonas Centralidades Polares - ZCPb da Subprefeitura da Mooca são Áreas de Intervenção Urbana e serão objeto de lei específica.

SE - Segundo a Subprefeitura Sé, nas Zonas Mistas e Zonas Centralidades contidas na planície aluvial do rio Tamanduateí será permitida a implantação de edifícios com garagens acima do pavimento térreo, como área construída não computável, para não comprometer o nível do lençol freático. 
Nos perímetros das Zonas Mistas e Zonas Centralidades, inclusive os corredores e circuitos culturais, deve-se compartilhar com a iniciativa privada a manutenção e a segurança dos espaços de apropriação coletiva, públicos e privados.

\subsubsection{Zonas Especiais}

MO/SE - As Zonas Especiais contidas nas Subprefeituras Sé e Mooca são aquelas que ocupam porções do território, com diferentes características ou com destinação específica e normas próprias de uso e ocupação do solo e edilícias, situadas na Macrozona de Estruturação e Qualificação Urbana, compreendendo.

- Zonas Especiais de Preservação Cultural - ZEPEC.;

- Zonas Especiais de Interesse Social - ZEIS;

- Zonas Especiais de Preservação Ambiental - ZEPAM ${ }^{4}$.

\subsubsection{Zonas Especiais de Preservação Cultural - ZEPEC}

MO - Na Subprefeitura Mooca, as áreas ou imóveis constantes do Quadro 06A abaixo e Mapa 03-MO que vierem a ser tombadas ou preservadas pelos órgãos federal, estadual e municipal, estarão sujeitas às disposições estabelecidas por esta lei para as ZEPEC.

A aprovação de novas edificações nos imóveis localizados em ZEPEC ou em sua área envoltória, determinada pelo tombamento, fica sujeita à apreciação dos órgãos de defesa do patrimônio cultural no âmbito do Estado, ao Conselho de Defesa do Patrimônio Histórico, Arqueológico, Artístico e Turístico do Estado (CONDEPHAAT) e, no âmbito do Município, ao Conselho Municipal de Preservação do Patrimônio Histórico, Cultural e Ambiental da Cidade de São Paulo (CONPRESP), os quais deverão observar as diretrizes de ocupação da área envoltória determinadas em seu Tombamento.

Quadro 06A - Zonas especiais de preservação cultural (ZEPEC): imóveis sugeridos para estudo de tombamento

Subprefeitura Mooca

\begin{tabular}{|c|}
\hline Subprefeitura Mooca \\
\hline Gasômetro da Figueira (R. Cap. Faustino de Lima, I34 × R. da Figueira) \\
\hline Cotonifício Crespe (R. Taquari, $173 \times$ R. Trilhos) \\
\hline Antigo Moinho Santo Antonio (R. Borges de Figueiredo, 448 a 5I0) \\
\hline Travessia estrada de ferro (altura Moinho Matarrazzo) \\
\hline Travessia estrada de ferro (altura Museu do Imigrante) \\
\hline Travessia estrada de ferro (altura da estação da Mooca) \\
\hline Conjunto de residências (R. Conselheiro Belisário) \\
\hline Conjunto de residências (travessa Quiroga) \\
\hline Edifício Industrial (atual fábrica 5) - Av. Alcântara Machado x R. Barão de Jaguara \\
\hline Pizzaria São Pedro (R. Javari x R. Vinconde de Laguna) \\
\hline Estádio Conde Rodolfo Crespi (R. Javari, n 101, 107, 169 e 183) \\
\hline Orfanato - antiga casa da roda (R. Barão de Jaguara x R. da Mooca) \\
\hline Edifício Industrial Fábrica Orion (R. Behring × R. Fernão de Magalhães) \\
\hline Edifício na R. Jairo Goes, $n^{\circ} 46 \times$ Av. Rangel Pestana \\
\hline Casa das Retortas \\
\hline Antigo edifício industrial na R. da Mooca, no 815 e 775 \\
\hline Edifício industrial / antigo colégio São Judas, na R. Javari, 403 \\
\hline Subprefeitura Sé \\
\hline $\begin{array}{c}\text { A Subprefeitura Sé não tem em seu quadro de ZEPEC áreas que } \\
\text { se localizem na região de estudo deste trabalho. }\end{array}$ \\
\hline
\end{tabular}




\subsubsection{Zonas Especiais de Interesse Social - ZEIS.}

Os perímetros das ZEIS dentro da área-objeto são os constantes do Quadro 06B e delimitados no Mapa 04 integrantes dos planos regionais e que são parcialmente apresentados nesta compilação.
Quadro 06B - Zonas especiais de interesse social (ZEIS)

\section{Subprefeitura Mooca}

\section{ZEIS 3 - L007 (MO)}

Rua Assunção, n 480, lote 43 da quadra 56 do setor 2 da Planta Genérica de Valores.

ZEIS 3 - LOIO (MO)

Inicia-se na confluência da Rua Maria Domitila com a Rua Vasco da Gama, segue pela Rua Vasco da Gama, Avenida Rangel Pestana, Rua Prof. Batista de Andrade, Rua Torquato Neto, Rua Piratininga, Rua Campos Sales, Rua Flora, Rua Paraná, Rua Piratininga, Avenida Alcântara Machado, Rua Wandenkolk, Rua Azevedo Júnior, Rua Capitão Faustino de Lima, Rua Pires Ramos, Rua Maria Domitila até o ponto inicial. ZEIS 3 - LOII (MO)

Inicia-se na confluência da Rua Visconde de Parnaíba com a Linha Leste-Oeste do Metrô, segue pela Linha Leste-Oeste do Metrô até o ponto 2, segmento 2-3 (divisa dos lotes 323 a 466 com o lote 468 da quadra 87 do setor 27 da Planta Genérica de Valores), Rua Visconde de Parnaíba até o ponto inicial.

ZEIS 3 - LOI 2 (MO)

Inicia-se na confluência da Rua Visconde de Parnaíba com a Rua Dias Grilo, segue pelo segmento I-2 (Linha Leste-Oeste do Metrô), segmento 2-3 (divisa do lote I03 "EMURB" com os lotes I, 5, 6, 7, 8, 9, I0, 30 e 31 da quadra 87 do setor 27 da Planta Genérica de Valores), Rua Dias Grilo até o ponto inicial. ZEIS 3 - LOI3 (MO)

Inicia-se na confluência da Rua Ipanema com a Rua Bresser, segue pela Rua Bresser, Avenida Alcântara Machado, Rua Almirante Brasil, Rua Frei Gaspar, Rua do Hipódromo, Rua Ipanema até o ponto inicial.

ZEIS 3 - L025 (SE/MO) Inicia-se na confluência da Rua Luis Gama com a Rua da Mooca, segue pela Rua da Mooca, Rua Mem de Sá, Avenida Alcântara Machado, Viela dos Cientistas, Rua da Mooca, Rua Oscar Horta, Rua Odorico Mendes, Rua Dom Bosco, Rua Luis Gama, Rua do Lirismo, Rua Luis Gama até o ponto inicial.

\section{Subprefeitura Sé}

ZEIS 3 - C008 (SE)

Rua Baronesa Porto Carreiro, n 169 , lote 29 da quadra 24 do setor 19 da Planta Genérica de Valores. ZEIS 3 - LO25 (SE/MO)

Inicia-se na confluência da Rua Luis Gama com a Rua da Mooca, segue pela Rua da Mooca, Rua Mem de Sá, Avenida Alcântara Machado, Viela dos Cientistas, Rua da Mooca, Rua Oscar Horta, Rua Odorico Mendes, Rua Dom Bosco, Rua Luis Gama, Rua do Lirismo, Rua Luis Gama até o ponto inicial. ZEIS 3 - LO26 (SE)

Inicia-se na confluência da Rua Dom Bosco com a Rua Barão de Jaguará, se-

gue pela Rua Barão de Jaguará, Rua Dom Bosco até o ponto inicial.

ZEIS 3 - LO27 (SE)

Inicia-se na Rua Dom Bosco, segue pela Rua Odorico Mendes, Rua Dom Bosco até o ponto inicial.

ZEIS 3 - L028 (SE)

Inicia-se na confluência do Viaduto Prof. Alberto Mesquita de Camargo com a Avenida Presidente Wilson, segue pela Avenida Presidente Wilson, Viaduto Prof. Alberto Mesquita de Camargo até o ponto inicial. ZEIS 3 - L029 (SE)

Localizada na Rua Coronel João Dente.

ZEIS 3 - L030 (SE)

Inicia-se na confluência da Rua Conselheiro João Alfredo com a Rua Coronel João Dente, segue pela Rua Coronel João Dente, Rua Serra de Paracaina, Avenida do Estado, Rua Conselheiro João Alfredo até o ponto inicial.
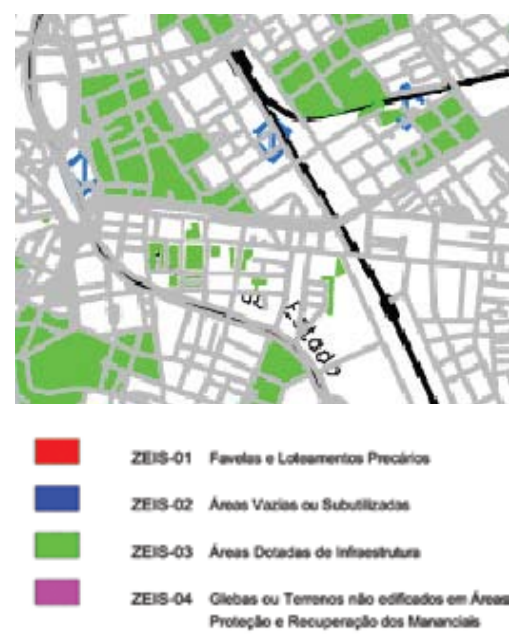

Mapa 04 - Zonas Especiais de Interesse Socil (ZEIS); Brás e Mooca. Fonte: Plano Diretor Estratégico de São Paulo, 2004.

Este mapa foi editado pois nem todas as ZEIS foram originalmente nele representadas. 
${ }^{5}$ Art. 146 - Para os efeitos desta lei, as seguintes expressões ficam assim definidas:

XIII. Habitação de Interesse Social - HIS, é aquela que se destina a famílias com renda igual ou inferior a 6 (seis) salários mínimos, de promoção pública ou a ela, vinculada, com padrão de unidade habitacional com um sanitário, até uma vaga de garagem e área útil de no máximo $50 \mathrm{~m}^{2}$ (cinqüenta metros quadrados), com possibilidade de ampliação quando as famílias beneficiadas estiverem envolvidas diretamente na produção das moradias;

XIV. Habitação de Mercado Popular (HMP), é aquela que se destina a famílias de renda igual ou inferior a 16 (dezesseis) salários mínimos ou capacidade a ser definida em lei específica, de promoção privada, com padrão de unidade habitacional com até dois sanitários, até uma vaga de garagem e área útil de no máximo $70 \mathrm{~m}^{2}$.

${ }^{6}$ Art. 17| - As Zonas Especiais de Interesse Social - ZEIS, são porções do território destinadas, prioritariamente, à recuperação urbanística, à regularização fundiária e produção de Habitações de Interesse Social - HIS ou do Mercado Popular - HMP definidos nos incisos XII e XIV do art. 146 desta lei, incluindo recuperação de imóveis degradados a provisão de equipamentos sociais e culturais, espaços públicos, serviços e comércio de caráter local, compreendendo:

III. ZEIS 3 - áreas com predominância de terrenos ou edificações

subutilizados situados em áreas dotadas de infraestrutura, serviços urbanos e oferta de empregos, ou que estejam recebendo investimentos desta natureza, onde haja interesse público, expresso por meio desta lei, dos planos regionais ou de lei específica, em promover ou ampliar o uso por Habitação de Interesse Social - HIS ou do Mercado Popular - HMP, e melhorar as condições habitacionais da população moradora.

à esq.: Mapa 05-MO - Desenvolvimento urbano no Brás e Mooca.

Fonte: PRE Subprefeitura Mooca, 2004.

à dir.: Mapa 05-SE - Desenvolvimento urbano na Mooca Baixa.

Fonte: PRE Subprefeitura Sé, 2004.
MO - Diretrizes para o plano de urbanização das ZEIS 3 da Subprefeitura Mooca: mo arborizar todas as vias, principalmente nos Distritos do Brás, Mooca e Água Rasa; mo criar áreas verdes nos Distritos do Brás, Mooca e Água Rasa;

mo promover a diversidade de usos e a diversidade social;

mo manter a continuidade do sistema viário, evitando a criação de condomínios fechados;

mo articular o projeto da ZEIS com a área do entorno;

mo reparcelar glebas maiores que I hectare $\left(10.000 \mathrm{~m}^{2}\right)$, de acordo com as diretrizes descritas no $\S 4^{\circ}$ do artigo $4^{\circ}$ do Capítulo II do PRE da Subprefeitura Mooca;

mo propiciar a requalificação de espaços verdes existentes;

mo estimular o proprietário de cortiços a melhorar a qualidade habitacional dos mesmos;

mo demarcar os cortiços que estarão sujeitos ao direito de preempção.

SE - As Zonas Especiais de Interesse Social (ZEIS) são aquelas destinadas, prioritariamente, à recuperação urbanística, à regularização fundiária e à produção de Habitações de Interesse Social (HIS) ou de Mercado Popular (HMP), definidos nos incisos XIII e XIV do artigo I46 do PDE, inclusive à recuperação de imóveis degradados, à provisão de equipamentos sociais e culturais, espaços públicos, serviço e comércio de caráter local, e demais definições desta Lei.

Este Plano Regional Estratégico, tendo por referência as disposições estabelecidas no artigo $\left.17\right|^{6}$ do PDE, em função das necessidades da Subprefeitura Sé, demarca apenas um tipo, a ZEIS 3 .

Os perímetros das ZEIS são os constantes do Quadro 06B Sintetizado e representados no Mapa 04 integrantes desta compilação.

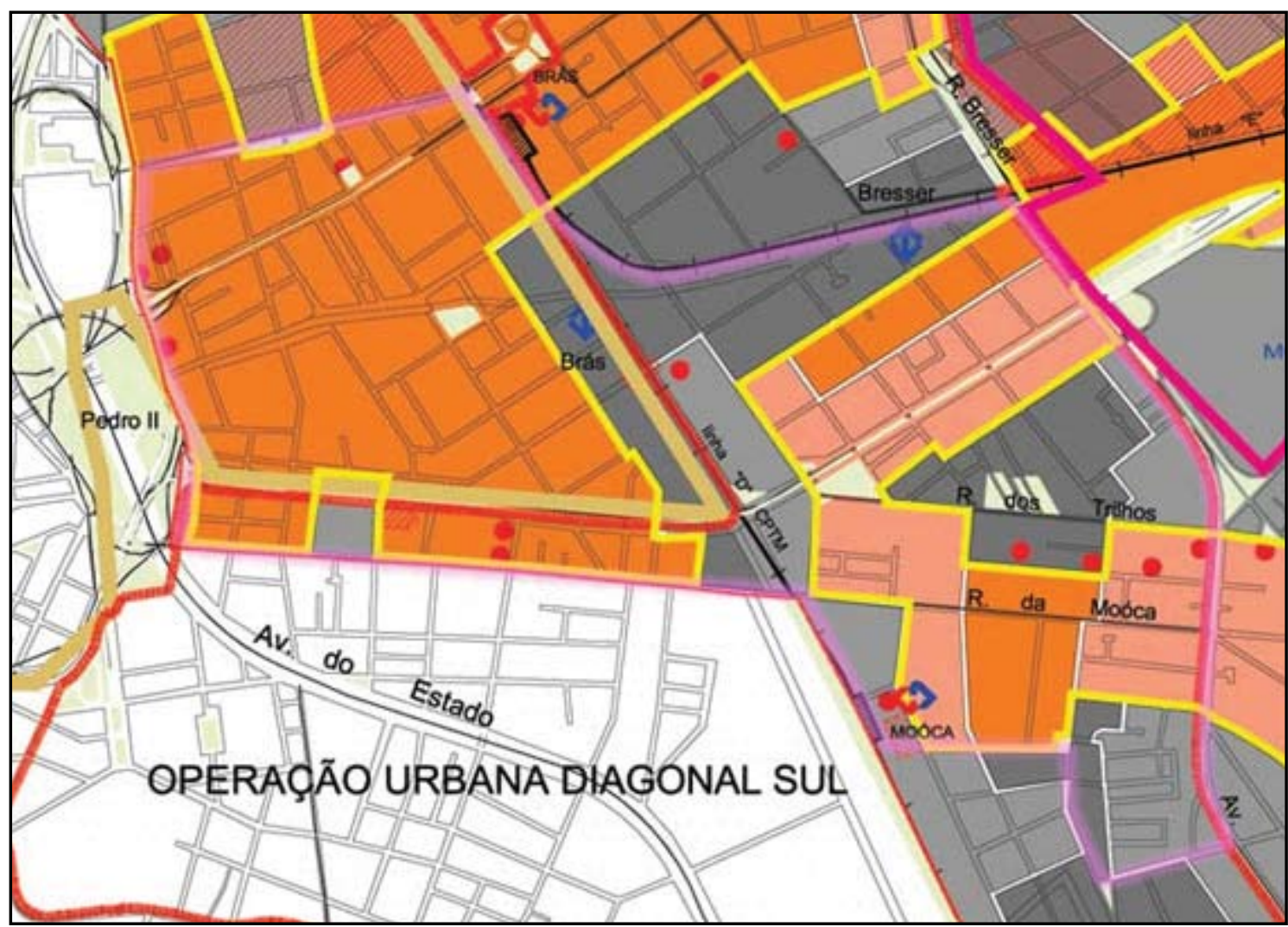




\subsection{Instrumentos de gestão urbana ambiental}

\subsection{Instrumentos Urbanísticos}

MO - Este Plano Regional para o planejamento, controle, gestão e promoção do desenvolvimento urbano ambiental do território da Subprefeitura, faz uso dos instrumentos urbanísticos estabelecidos pelo artigo 198 da Lei $n^{\circ}$ 13.430, de 13 de setembro de 2002, e daqueles constantes da Lei Federal $n^{\circ}$ I 0.257 de 10 de julho de 200 I, observadas as diretrizes contidas na Política Nacional do Meio Ambiente, quando for o caso.

\subsubsection{Instrumentos Indutores do Uso Social da Propriedade}

MO - São passíveis de aplicação do parcelamento, edificação e utilização compulsória todos os imóveis não edificados, subutilizados ou não utilizados localizados no território da Subprefeitura da Mooca, conforme o estabelecido nos artigos 201 e $234^{7}$ do PDE e nas disposições do PRE Mooca, excetuando-se os localizados na ZEIS I, cujo perímetro está delimitado no Quadro 04B desta compilação.

As leis específicas das Operações Urbanas Consorciadas Diagonal Sul e Celso Garcia, para as áreas delimitadas no Mapa 05 abaixo, poderão determinar regras e prazos específicos para a aplicação do Parcelamento, Edificação e Utilização Compulsória, de que trata o artigo $5^{\circ}$ da Lei Federal n 10.257, de 10 de julho de 2001 .

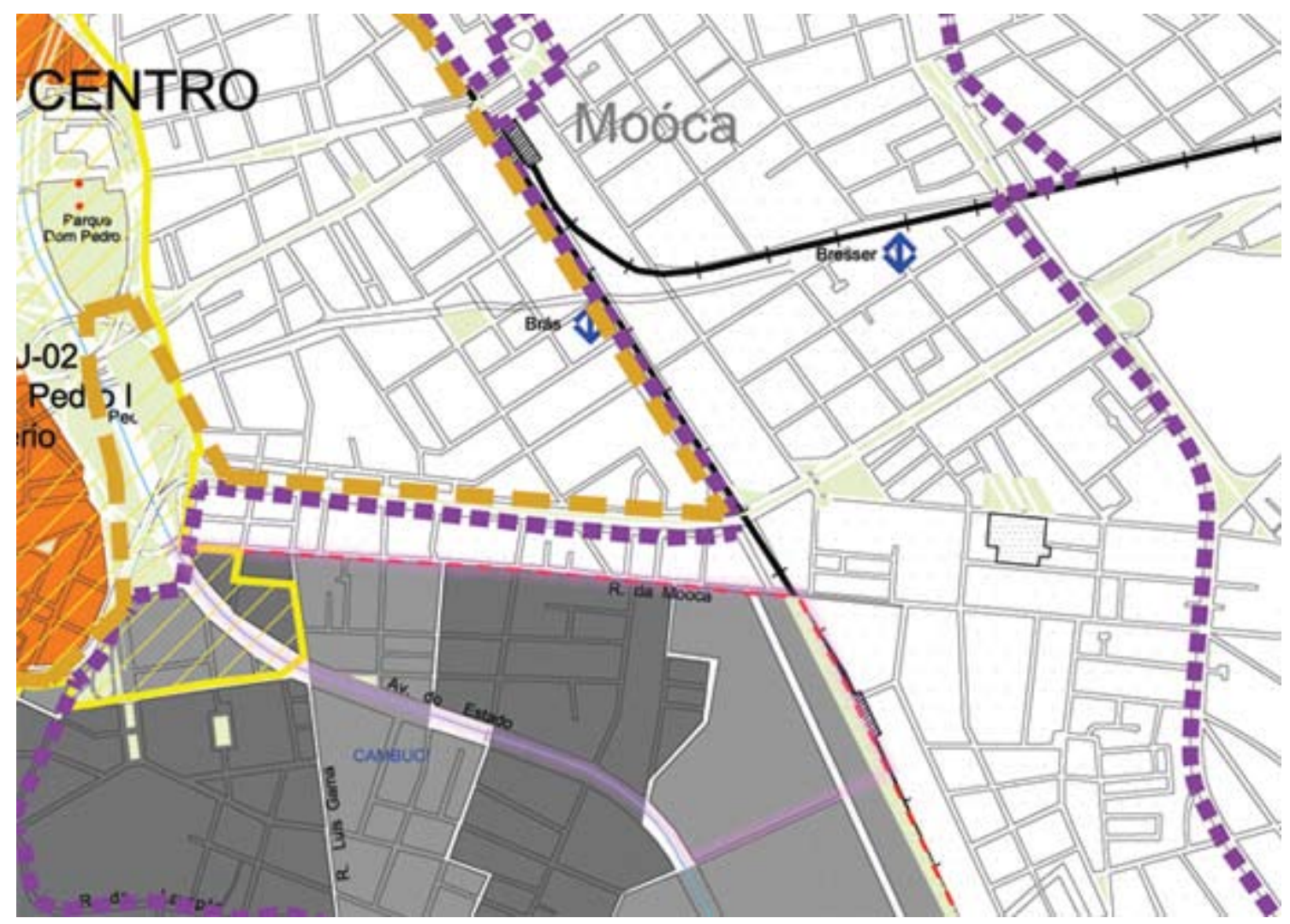

Art. 20I - São consideradas passíveis de parcelamento, edificação e utilização compulsórios os imóveis não edificados, subutilizados, ou não utilizados localizados nas ZEIS 2 e 3, descritas no Quadro no 14 e delimitadas no Mapa no 07 integrantes desta lei, os imóveis incluídos nas áreas de Operações Urbanas consorciadas e Projetos Estratégico os imóveis inseridos nos perímetros dos distritos municipais (...) Brás, (...) Mooca (...)

Art. 234 - Nas áreas localizadas no interior dos perímetros de operações urbanas consorciadas já existentes, a utilização de qualquer dos instrumentos previstos neste Plano Diretor, especificamente nas seções I , II, III, IV, V e VI, Cap. III do Título III, deverão ser obedecidas as regras estabelecidas nas leis específicas. Fonte: Plano Diretor Estratégico de São Paulo. Lei Municipal n 13.430 de setembro de 2002.

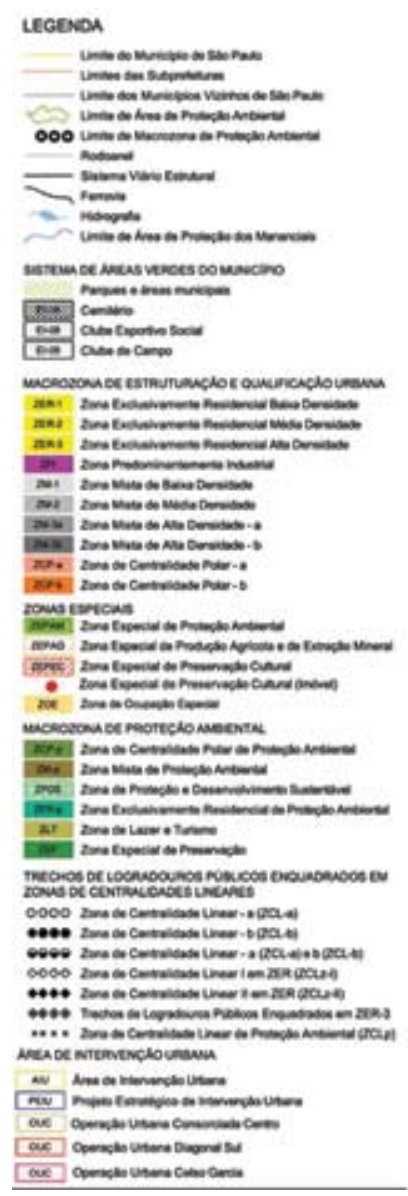


${ }^{8}$ Art. 293 - O Executivo deverá encaminhar à Câmara Municipal o projeto de revisão do Plano Diretor Estratégico em 2006, adequando as Ações Estratégicas nele previstas e acrescentando áreas passíveis de aplicação dos instrumentos previstos na Lei Federal 10.257/200 I - Estatuto da Cidade. Parágrafo Unico - Executivo coordenará e promoverá os estudos necessários para a revisão prevista no "caput" deste artigo. Fonte: Plano Diretor Estratégico de São Paulo. Lei Municipal n | 3.430 de setembro de 2002.

9 caput do Art. 246 - O Poder Executivo poderá receber por transferência imóveis que, a requerimento dos seus proprietários, the sejam oferecidos como forma de viabilização financeira do melhor aproveitamento do imóvel. Fonte: Plano Diretor Estratégico de São Paulo. Lei Municipal no 13.430 de setembro de 2002
Nas Áreas de Intervenção Urbana (AIU) delimitadas nos Mapas 05 dos Planos Regionais das Subprefeituras Mooca e Sé, por ato do Executivo, deverão ser notificados os proprietários de terrenos e edificações subutilizados, nos termos do artigo $5^{\circ}$ da Lei Federal no 10.257 (Estatuto da Cidade), de 10 de julho de 200 I, que não atendam aos objetivos e diretrizes estabelecidas para as transformações urbanísticas que se desejam alcançar nessas áreas.

Os proprietários dos imóveis de que trata o disposto acima poderão propor ao Executivo o estabelecimento de Consórcio Imobiliário, conforme dispõe o artigo 46 da Lei Federal $n^{\circ}$ 10.257, de 10 de julho de 2001 .

São considerados passíveis de Parcelamento, Edificação e Utilização Compulsórios os imóveis não edificados, subutilizados, ou não utilizados que se enquadrem nas disposições dos $\S 1^{\circ}, 2^{\circ}$ e $4^{\circ}$ do artigo 201 do PDE, localizados:

I. nas ZEIS 3 demarcadas no Mapa 05 desta compilação;

II. nas áreas das operações urbanas demarcadas no Mapa 05 desta compilação;

III. nos eixos e centralidades a dinamizar demarcados no Mapa 04 desta compilação;

IV. nas áreas de ZIR demarcadas no Mapa 04 deste PRE.

SE - São passíveis de aplicação do parcelamento, da edificação e da utilização compulsórios os imóveis não edificados, subutilizados ou não utilizados, localizados nos distritos da Sé, República, Bom Retiro, Consolação, Brás, Liberdade, Cambuci, Mooca Baixa, Pari, Santa Cecília e Bela Vista, inclusive nas ZEIS, e que se enquadrem nas seguintes condições:

sE lotes e glebas não edificados com área superior a $250 \mathrm{~m}^{2}$ (duzentos e cinqüenta metros quadrados), cujo coeficiente de aproveitamento seja igual a zero lotes e glebas não edificados ou que contenham edificações de até um pavimento, com área superior a $250 \mathrm{~m}^{2}$ utilizados para o estacionamento de veículos;

sE lotes e glebas com área superior a $250 \mathrm{~m}^{2}$ (duzentos e cinqüenta metros quadrados) cujo coeficiente de aproveitamento seja igual ou inferior ao coeficiente mínimo definido para o lote na zona onde se situam, excetuando-se os postos de abastecimento de veículos e os imóveis integrantes do Sistema de Áreas Verdes do Município;

ss todo tipo de edificação que tenha, no mínimo, 80\% (oitenta por cento) de sua área construída desocupada há mais de cinco anos, ressalvados os casos em que a desocupação decorra de impossibilidades jurídicas ou resultantes de pendências judiciais incidentes sobre o imóvel;

sE conjuntos formados por dois ou mais lotes confrontantes que, isoladamente, tenham área inferior a $250 \mathrm{~m}^{2}$ e que atendam a todas as seguintes condições:

- pertençam ao mesmo proprietário;

- sejam passíveis de remembramento do qual resulte lote com área maior ou igual a $250 \mathrm{~m}^{2}$

- tenham coeficiente de aproveitamento igual ou inferior ao coeficiente mínimo definido para a zona de uso onde se situam.

Estes imóveis, localizados nas ZEIS 3, estão demarcados no Mapa 04 integrante deste Plano Regional.

Estão relacionados no Plano Regional Estratégico Sé os imóveis contidos na área de abrangência desta Subprefeitura que se enquadram nas condições descritas acima e que, portanto, são passíveis da aplicação do parcelamento, edificação e utilização compulsórios. No caso da área objeto de estudo, esta não engloba nenhum imóvel pré-determinado. O Quadro 07 a seguir poderá ser objeto de atualização quando da revisão do Plano Diretor Estratégico, conforme disposições do Artigo $293^{8}$ do PDE. É facultada aos proprietários a transferência à Prefeitura, dos imóveis sujeitos ao parcelamento, à edificação e à utilização compulsórios para efeito de seu aproveitamento nos termos do Artigo $246^{\circ}$ do Plano Diretor Estratégico, para viabilizar a Habitação de Interesse Social. Aplicam-se a esses imóveis as disposições sobre estes instrumentos no primeiro item acima. 


\subsubsection{Direito de Preempção}

\begin{tabular}{|c|c|c|}
\hline \multicolumn{3}{|c|}{ Quadro 07 - Áreas Sujeitas ao Direito de Preempção } \\
\hline \multicolumn{3}{|c|}{ Subprefeitura Mooca } \\
\hline \multicolumn{3}{|c|}{ Não há nenhum imóvel passível de aplicação deste dispositivo dentro da área de abrangência deste estudo. } \\
\hline \multicolumn{3}{|c|}{ Subprefeitura Sé } \\
\hline Setor / Quadra / Lote & Endereço & Finalidade \\
\hline $\begin{array}{l}280460072 \\
280460073 \\
280460074\end{array}$ & $\begin{array}{l}\text { Av. Pres. Wilson, } n^{\circ} 0 \\
\text { Av. Pres. Wilson, } n^{\circ} 1035 \\
\text { Av. Pres. Wilson, } n^{\circ} 1009\end{array}$ & $\begin{array}{l}\text { Requalificação urbana com } \\
\text { uso misto predominan- } \\
\text { temente residencial }\end{array}$ \\
\hline $\begin{array}{l}\text { O quadro do PRE da S } \\
\text { imóvel passível de }\end{array}$ & $\begin{array}{l}\text { ra Sé equivalente ao aqui a } \\
\text { desse dispositivo de lei der }\end{array}$ & $\begin{array}{l}\text { do não apresenta nenhum } \\
\text { rea objeto de estudo. }\end{array}$ \\
\hline
\end{tabular}

MO - Lei baseada nas áreas descritas no Quadro 07 acima e delimitadas no Mapa 06-MO abaixo, indicará os imóveis sujeitos à incidência do Direito de Preempção, necessários à implantação de parques, abertura de vias e melhoramentos viários, equipamentos de transporte coletivo e equipamentos urbanos.

SE - O Plano Regional Estratégico da Suprefeitura Sé não apresenta áreas sujeitas à incidência do Direito de Preempção dentro da área-objeto deste estudo.
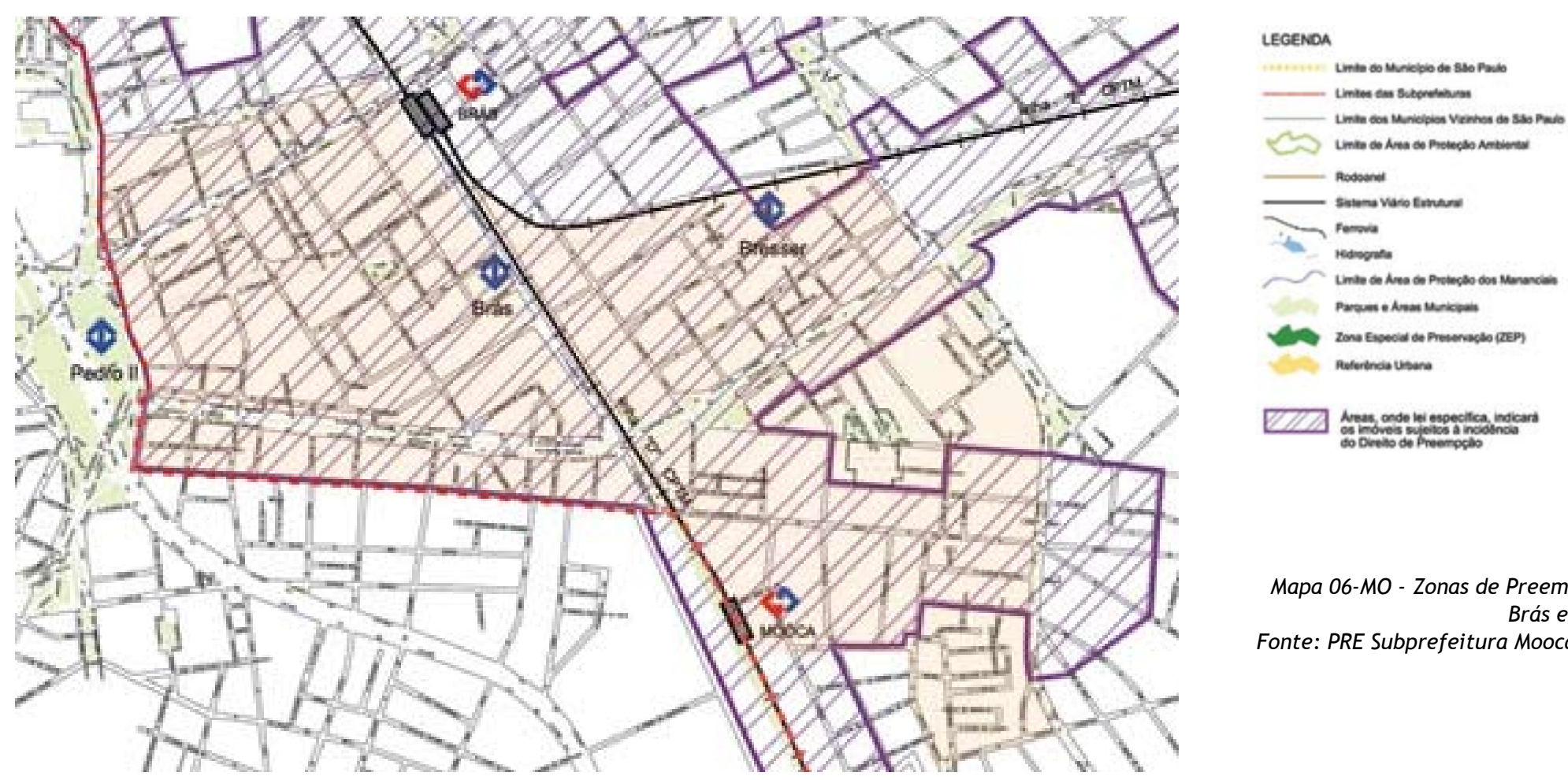

Mapa 06-MO - Zonas de Preempção no Brás e Mooca. Fonte: PRE Subprefeitura Mooca, 2004. 


\subsubsection{Outorga Onerosa do Direito de Construir}

MO - Nas Áreas de Intervenção Urbana (AIU), delimitadas no Mapa 05-MO, enquanto estas não forem regulamentadas por lei, o Executivo Municipal poderá aplicar a Outorga Onerosa do Direito de Construir nos imóveis nelas contidos até o coeficiente de aproveitamento máximo permitido para as zonas nas quais elas estiverem inseridas, respeitados os estoques de potencial construtivo adicional estabelecidos na legislação de uso e ocupação do solo.

MO/SE - Nas Operações Urbanas Consorciadas Diagonal Sul e Celso Garcia, delimitadas no Mapa 05-MO e no Mapa 05-SE, enquanto não regulamentadas por leis específicas, o Executivo Municipal poderá aplicar a outorga onerosa do Direito de Construir nos imóveis nelas contidos até o coeficiente de aproveitamento máximo permitido para as zonas nas quais elas estiverem inseridas, respeitados os estoques de potencial construtivo adicional estabelecidos na legislação de uso e ocupação do solo.

Não se aplica a Outorga Onerosa do Direito de Construir nos imóveis preservados, enquadrados como ZEPEC.

SE - Ficam sujeitos à Outorga Onerosa do Direito de Construir os imóveis particulares localizados nas zonas onde o coeficiente de aproveitamento máximo for maior do que o básico, de acordo com as regras estabelecidas nos artigos 209 a 216 do PDE e da Parte I do PRE da Subprefeitura Sé, e especialmente nas Zonas Mistas, excluindo-se as ZMI-0I e ZMI-02.

${ }^{10}$ Art. 220 - São passíveis de receber o potencial construtivo transferido de outros imóveis os lotes, em que o Coeficiente Básico pode ser ultrapassado, situados nas Areas dos Projetos Estratégicos, nas faixas de até 300 (trezentos) metros ao longo dos eixos de transporte público de massa e situados na área definida por circunferências, com raio de até 600 (seiscentos) metros tendo como centro as estações de transporte metroviário ou ferroviário excluídas das áreas de Operações Urbanas Consorciadas.

Fonte: Plano Diretor Estratégico de São Paulo. Lei Municipal $n^{\circ}$ | 3.430 de setembro de 2002.

II Idem.

12 Ibdem.

\subsubsection{Transferência do Direito de Construir}

MO - A Transferência do Direito de Construir, nos termos dos artigos 217 a 219 do PDE e nas disposições do PRE da Subprefeitura da Mooca, poderá ser realizada somente para as áreas receptoras do direito de construir definidas no artigo $220^{10}$ do PDE. Os procedimentos de implantação das diretrizes estabelecidas para as Áreas de Intervenção Urbana serão regulamentados por lei.

Nos imóveis, lotes ou glebas localizados nas áreas necessárias para a implantação dos parques lineares, poderá ser transferido o seu potencial construtivo para outros imóveis contidos na faixa de $200 \mathrm{~m}$ (duzentos metros) lindeiros ao parque, desde que os proprietários doem ao Município o seu imóvel.

SE - São passiveis de receber o potencial construtivo transferido as áreas indicadas no artigo 220" do PDE.

Ficam estendidos os efeitos do disposto no artigo $6^{\circ}$ da Lei $n^{\circ} 12.349$ de 6 de junho de 1997, para todos os proprietários de imóveis localizados na Subprefeitura Sé que doarem o imóvel para implantação de área verde, observadas as áreas receptoras a que se refere o caput do artigo $220^{12}$ do PDE. 


\subsection{6 Áreas de Intervenções Urbanas}

Quadro 08 - Áreas de intervenção urbana (AIU)

Subprefeitura Mooca

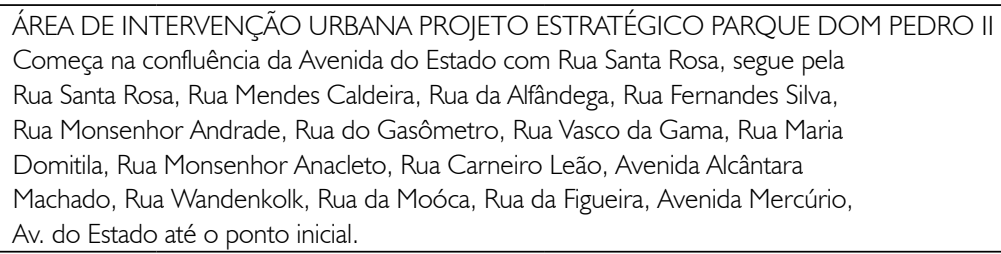

Subprefeitura Sé

\begin{tabular}{|c|c|c|}
\hline AIU & Distrito & Perímetro \\
\hline AIU-02 & $\begin{array}{c}\text { Parque Dom Pedro II } \\
\text { e Glicério } \\
\text { Requalificação Urbana }\end{array}$ & $\begin{array}{l}\text { TRECHO CONTIDO NA SUBPREFEITURA SÉ } \\
\text { Começa na confluência da Rua Paula Sousa com a Avenida do Estado, } \\
\text { segue pela Avenida do Estado, Avenida Mercúrio, Viaduto Mercúrio, Rua da } \\
\text { Figueira, Rua da Mooca, Rua Wandenkolk, Rua do Lirismo, Rua Luís Gama, } \\
\text { segmento I-2, Rua Leopoldo Miguez, Rua Teixeira Leite, Viaduto do Gli- } \\
\text { cério, Rua Glicério, Rua São Paulo, Rua Conselheiro Furtado, Largo Sete } \\
\text { de Setembro, Praça Dr. João Mendes, Praça da Sé, Rua Direita, Praça do } \\
\text { Patriarca, Rua São Bento, Largo São Bento, Rua Florêncio de Abreu, Avenida } \\
\text { Senador Queirós, Rua Barão de Duprat, Rua Paula Sousa até o ponto inicial. }\end{array}$ \\
\hline AIU-04 & $\begin{array}{c}\text { Pari - Brás } \\
\text { Requalificação Urbana }\end{array}$ & $\begin{array}{l}\text { TRECHO CONTIDO NA SUBPREFEITURA SÉ } \\
\text { Começa na confluência da Rua Dr. Jorge de Miranda com a Rua Guilherme } \\
\text { Maw, segue pela Rua Dr. Jorge de Miranda, Praça Odilon Aquino de Oliveira, } \\
\text { Avenida do Estado, Rua Paula Sousa, Rua Antônio Paes, segmento 2- I, Rua } \\
\text { Djalma Dutra, Rua João Teodoro, Rua Guilherme Maw até o ponto inicial. }\end{array}$ \\
\hline
\end{tabular}

MO - As Áreas de Intervenção Urbana da Subprefeitura da Mooca, criadas neste Plano Regional, são aquelas constantes do Quadro 08 acima e do Mapas 05 do PRE têm como diretrizes:

мо implantar parques lineares;

mo implantar áreas verdes de recreação e lazer;

мo viabilizar áreas de retenção de águas pluviais para auxiliar o sistema de drenagem;

mo manter a permeabilidade do solo existente, garantindo as condições de drenagem e absorção das águas pluviais;

mo ampliar as áreas permeáveis nos fundos de vale;

мо valorizar a paisagem, privilegiando espaços de uso público;

мo criar e qualificar espaço de uso público destinado ao lazer da população residente nas imediações dos parques lineares e ZEPAM's;

мо implantar ciclovia;

mo transformar a calçada em caminho verde para pedestres, com complementação da arborização;

мo promover espaços de uso público, viabilizando integração com calçadas e praças para as áreas das estações de metrô;

mo criar e qualificar os espaços públicos no entorno das estações do metrô;

мо revitalizar e manter as praças públicas;

mo manter com tratamento adequado as calçadas, avaliando, inclusive, a arborização existente, visando ao conforto térmico e à atenuação dos ruídos;

мо implantar habitações adequadas para abrigar os moradores da favela e cortiços;

mo implantar habitações de interesse social e seus equipamentos de uso coletivo, permitindo a recuperação das áreas atuais ocupadas por favelas e cortiços.

As Áreas de Intervenção Urbana Projeto Estratégico Pari-Brás e Projeto Estratégico Rua Santa Rita/Avenida Guilherme Cotching não abrangem a área de estudo deste trabalho. 
A Área de Intervenção Urbana Projeto Estratégico Parque Dom Pedro II tem como objetivo uma renovação completa do setor, incluindo a reforma do Mercado Municipal, a reurbanização do Parque Dom Pedro II, a criação do Museu da Cidade no edifício do Palácio das Indústrias, o restauro da Casa das Retortas, a recuperação dos viadutos 25 de Março e do Glicério e as novas diretrizes viárias e de transporte público que atravessam o setor. A Área de Intervenção Urbana Projeto Estratégico Parque Dom Pedro II tem como diretrizes:

mo promover a recuperação dos edifícios e elementos do patrimônio histórico presentes no setor, com a introdução de equipamentos públicos e de uso coletivo, destacando-se o Palácio das Indústrias, a Casa das Retortas e o Quartel do Batalhão de Guardas;

mo estimular a renovação de imóveis, procurando incentivar a presença de população de renda média e baixa, principalmente nas quadras do Glicério e nas quadras do Brás (indicadas para Zeis 3) e das quadras posteriores ao imóvel da Comgás, junto à Rangel Pestana;

mo promover a readequação dos espaços de vendas de rua, principalmente quanto à presença dos ambulantes, criando novos espaços destinados ao comércio de pequeno porte, com a criação de shoppings populares.

SE - Ficam definidas por este Plano Regional Estratégico as seguintes Áreas de Intervenção Urbana (AIU) e Projetos de Intervenção Estratégica, de acordo com o Quadro 08 e Mapa 05 dos PRE Mooca e Sé. O coeficiente de aproveitamento máximo do lote nas AlUs é igual a 4,0, excetuadas as disposições expressas no PRE da Subprefeitura Sé e na Lei 12.349, de 06 de junho de 1997, para os lotes contidos no perímetro da Operação Urbana Centro.

SE - AIU - 02: Parque Dom Pedro ll e Glicério têm por objetivos a recuperação e reabilitação da várzea do Rio Tamanduateí, compreendendo a reurbanização do Parque Dom Pedro II, a criação do Museu da Cidade no edifício do Palácio das Indústrias, o restauro da Casa das Retortas, a recuperação dos viadutos 25 de março e do Glicério, a reforma do Mercado Municipal, a reabilitação dos imóveis destinados ao uso residencial, em especial para a diversificação de unidades habitacionais que atendam demandas das faixas de rendas média, popular e de interesse social, promovendo a requalificação do sistema viário e dos espaços públicos e de uso coletivo da população, promovendo a recuperação de edifícios e de elementos significativos do patrimônio histórico como:

- o Palácio das Indústrias, a Casa das Retortas e o Quartel do Batalhão de Guardas;

- promover a readequação dos espaços públicos, principalmente quanto à presença de ambulantes, criando novos espaços destinados ao comércio de pequeno porte como os shoppings populares:

- reurbanizar a Rua 25 de Março, qualificando os espaços públicos com prioridade aos transeuntes e revendo as rotas de tráfego de carga e descarga;

- ampliar os espaços públicos e de uso coletivo das quadras situadas junto à Praça da Sé e o Páteo do Colégio, visando à harmonização e à integração paisagística dos edifícios públicos e privados;

- aplicar cumulativamente a Lei de Incentivos Seletivos;

- promover gestões junto à Caixa Econômica Federal para fazer uso dos recursos destinados ao Programa de Arrendamento Residencial (PAR) e ao Programa de Locação Social aos Perímetros de Reabilitação Integrada do Habitat (PRIH);

- promover gestões junto às concessionárias de serviços públicos, visando à requalificação das redes existentes de água, coleta de esgoto, fornecimento de energia elétrica, sistema de telefonia, em função do novo potencial construtivo da área;

- instituir fundo especial para estudos de viabilidade técnica e socioeconômica de recuperação de edifícios deteriorados, voltados ao desenvolvimento de tecnologia e de projetos;

- estimular a reabilitação condominial em quadras inteiras, identificando as possibilidades de melhor aproveitamento dos recuos existentes para criação de áreas de apropriação 
coletiva e de viabilização de implantação de equipamentos sociais que se façam necessários;

- adotar o instrumento denominado "Consórcio Imobiliário" para as reabilitações envolvendo proprietários, locatários e investidores.

SE - O coeficiente de aproveitamento máximo do lote nas AlU's de que trata o caput deste artigo é igual a 4,0, excetuadas as disposições expressas neste PRE e na Lei n I2.349, de 06 de junho de 1997, para os lotes contidos no perímetro da Operação Urbana Centro.

Os procedimentos de implantação das diretrizes estabelecidas para as Áreas de Intervenção Urbana (AIU), tratadas pelo PRE Sé, serão regulamentados por ato do Executivo, sendo:

sE estabelecer os termos do edital de licitação;

${ }^{\text {sE }}$ estabelecer a proporção do potencial construtivo total em quotas de terreno por área construída segundo usos residenciais e não residenciais;

se permitir que o Executivo Municipal, por meio de edital de adesão, convoque os proprietários para participar do novo empreendimento, tendo por referência o projeto de desenho urbano a ser implantado;

sE permitir que o Executivo Municipal, mediante edital de chamamento, findo o prazo concedido aos proprietários, receba propostas de participação de locatários e incorporadores que desejem adquirir quotas do empreendimento futuro;

sE conceder, aos proprietários que doarem o terreno para a implantação das obras institucionais públicas, a opção de escolha pela aplicação em quotas do futuro empreendimento ou pela transformação do valor do imóvel doado em potencial construtivo não utilizado, que poderá ser transferido para outro imóvel nos termos do artigo 220 do PDE.

\subsubsection{Operações Urbanas Consorciadas}

MO - As Operações Urbanas Consorciadas Diagonal Sul e Celso Garcia, atendendo as disposições dos artigos 225 a 234 da Lei no 13.430, de 13 de setembro de 2002, deverão ser objeto de lei específica sendo por este Plano Regional estabelecidas alterações nos perímetros demarcados pelo Plano Diretor Estratégico do Município de São Paulo, conforme representado no Mapa 05-MO.

A lei específica da Operação Urbana Consorciada Diagonal Sul deverá observar as seguintes diretrizes:

mo implantar um parque linear ao longo da via férrea;

mo controlar o aumento de áreas impermeabilizadas;

mo promover ocupação que privilegie arborização intensa e adequada para diminuir o desconforto térmico, a poluição atmosférica e sonora;

mo promover a criaçãa de áreas verdes, preferencialmente públicas ou em parceria com a iniciativa privada;

mo reservar áreas de drenagem e contenção, áreas verdes e áreas de uso público, as últimas valorizando, preferencialmente, os terminais de embarque de transporte coletivo existente e previsto, a integração entre eles e com as ruas comerciais e as centralidades;

mo promover parceria com o órgão competente para viabilizar a modernização das estações dos trens da CPTM;

мo promover a integração física das regiões separadas pela via férrea;

mo definir medidas mitigadoras e compensações ambientais para as áreas com solo ou águas subterrâneas contaminadas, nas antigas áreas industriais da operação.

A lei específica da Operação Urbana Consorciada Celso Garcia deverá observar as seguintes diretrizes:

mo implantar Avenida projetada de apoio sul à Marginal Tietê; 
mo implantar um parque linear e uma ciclovia ao longo da Avenida projetada de apoio sul à Marginal Tietê;

mo recuperar e modernizar o corredor de ônibus da Avenida Rangel Pestana e Avenida Celso Garcia;

mo implantar passagens em desnível, para pedestres e veículos, na via férrea;

mo promover ocupação que privilegie arborização intensa e adequada para diminuir o desconforto térmico, a poluição atmosférica e sonora;

mo implantar áreas verdes e áreas de uso público, valorizando os terminais de embarque de transporte coletivo, a integração entre eles e com as ruas comerciais e as centralidades.

SE - As Operações Urbanas Consorciadas, atendendo às disposições dos artigos 225 a 234 do PDE, deverão ser objeto de lei específica, sendo por este Plano Regional Estratégico mantido o perímetro da Operação Urbana Diagonal Sul e o perímetro da Operação Urbano Centro, conforme dispõe a Lei n 12.349 de 06 de junho de 1997 e conforme representado no Mapa 05-SE.

A Subprefeitura da Sé poderá estabelecer critérios e especificações para a execução de intervenções diretas ou conduzidas por particulares em espaços públicos, compreendendo a padronização de pisos de mobiliário urbano, de projetos e obras de paisagismo e de demais elementos constitutivos do espaço público.

\subsubsection{Instrumentos de Gestão Ambiental}

MO - As diretrizes estabelecidas neste Plano Regional, com a finalidade de proteger, recuperar e melhorar a qualidade ambiental do território, compreendido pela Subprefeitura da Mooca, deverão ser observadas pela lei específica de zoneamento ambiental, nos termos dispostos pelos artigos 248 a 255 da Lei n 13.430, de 13 de setembro de 2002, e, em especial, pelas seguintes:

I. a ampliação das áreas arborizadas, constituídas pelos caminhos verdes e parques lineares, que passam a integrar o Sistema de Áreas Verdes;

II. o aumento das áreas permeáveis, em especial, junto às cabeceiras de drenagem;

III. as obras de drenagem necessárias para o controle dos alagamentos;

IV. a recuperação de áreas degradadas ocupadas por favelas, que deverão contar com habitações adequadas e com equipamentos sociais de uso coletivo da população residente nas suas imediações;

V. o controle da poluição do ar, emissões de ruídos e radiação.

SE - O plano regional da Subprefeitura Sé não apresentou instrumentos de gestão ambiental. 